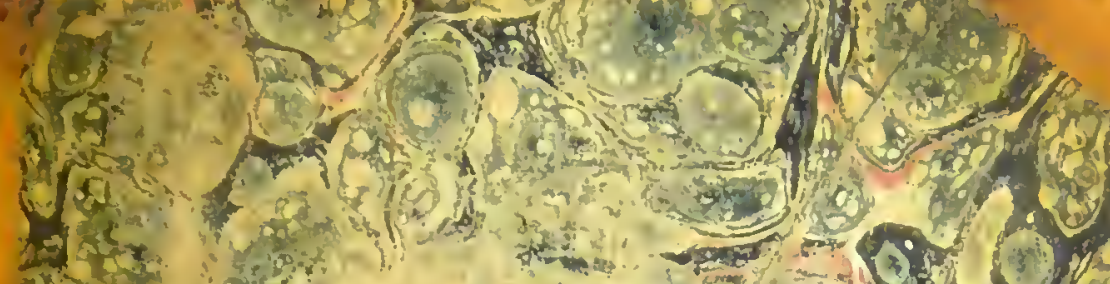

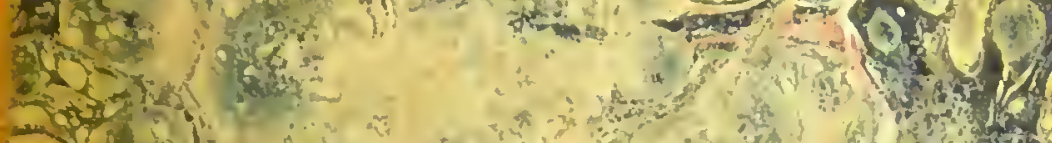

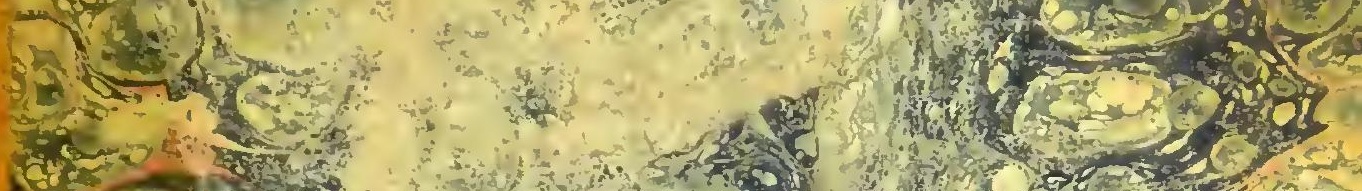

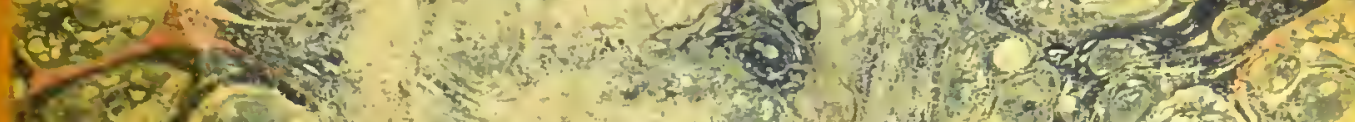

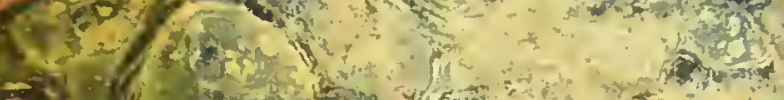

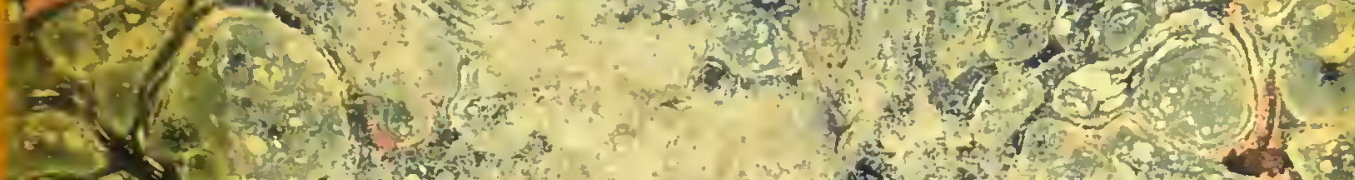

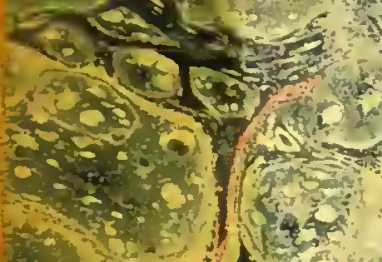

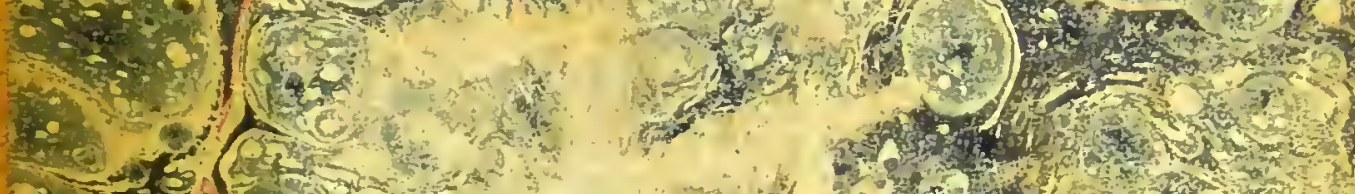
$2+\frac{3}{2}\left(\frac{3}{2}\right)$

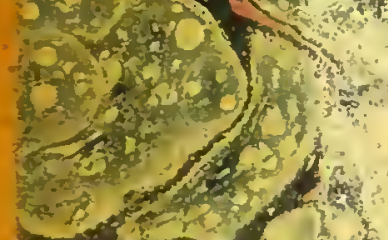

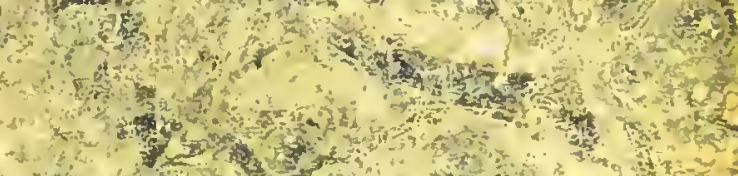

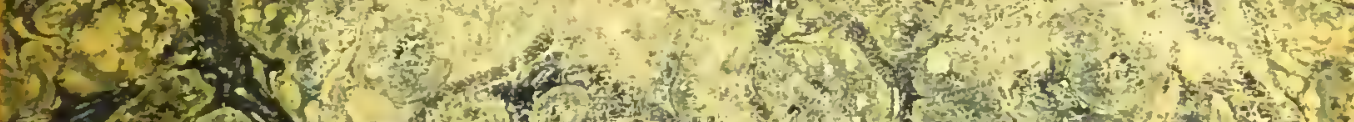

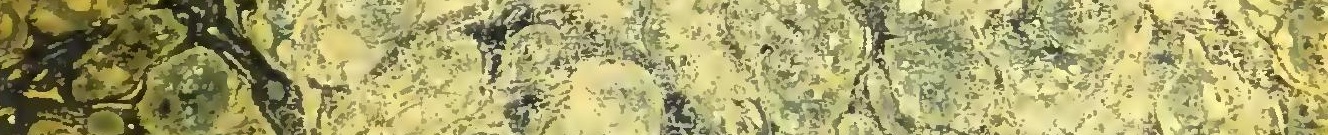

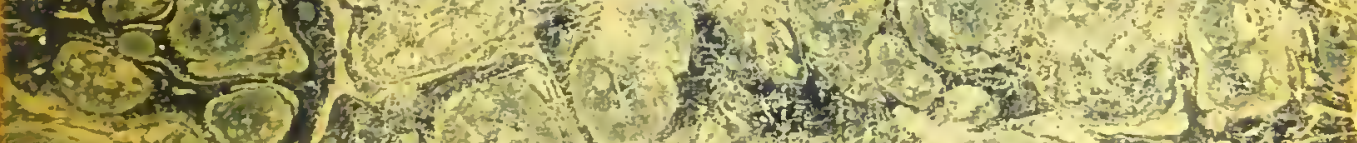

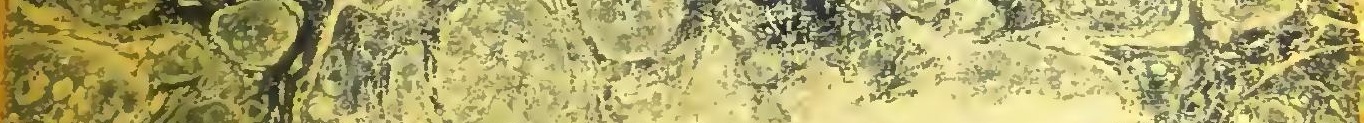

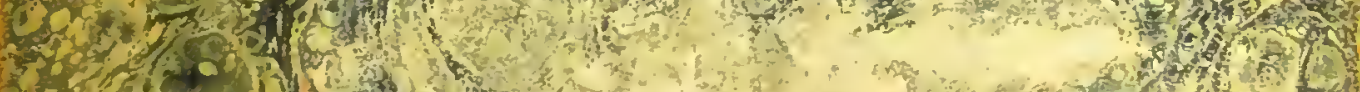

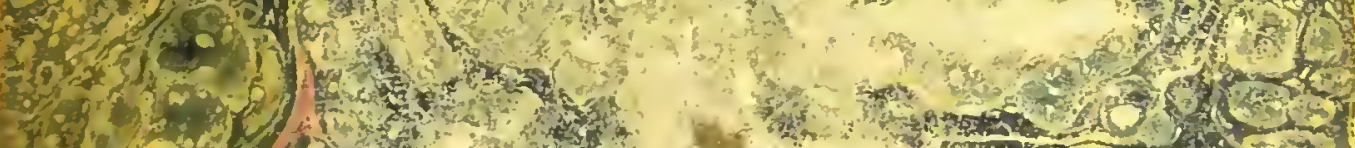

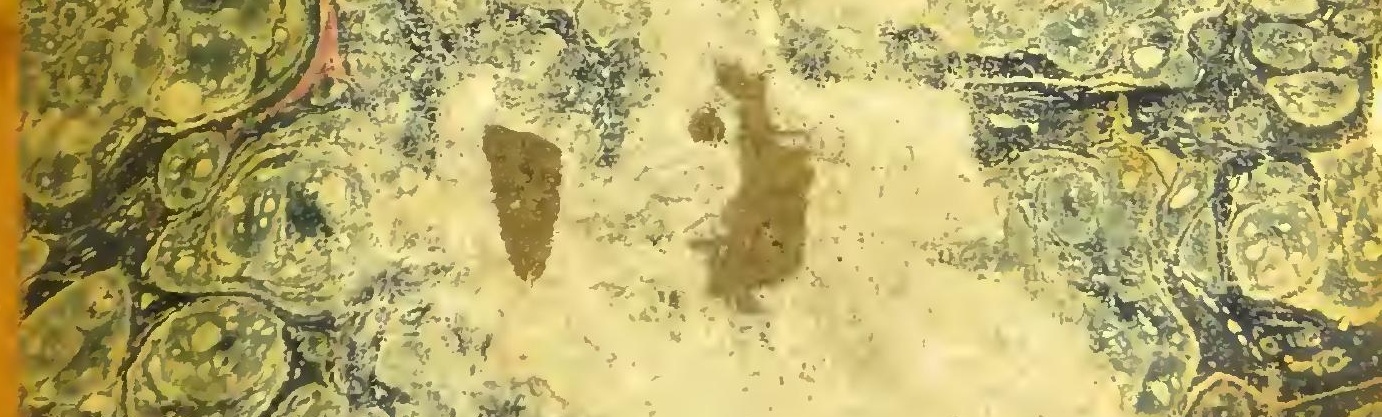

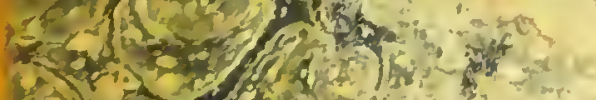

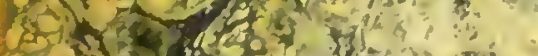

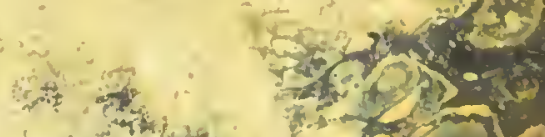

mats

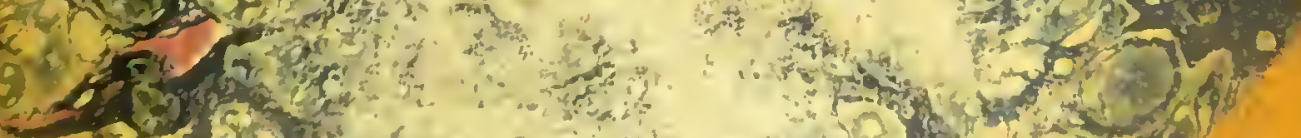

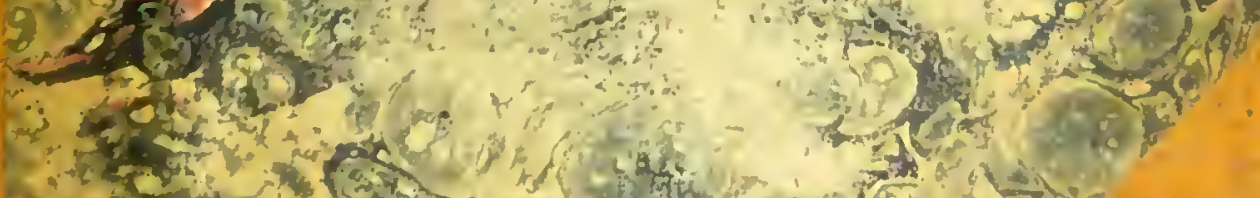

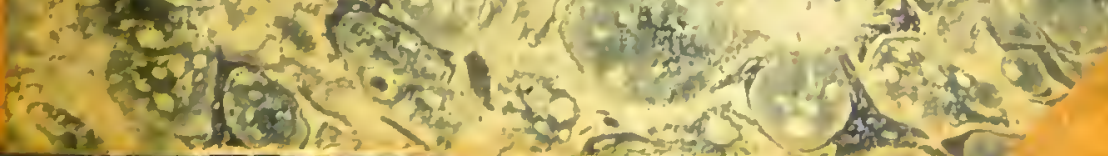


$3 / 5$ 


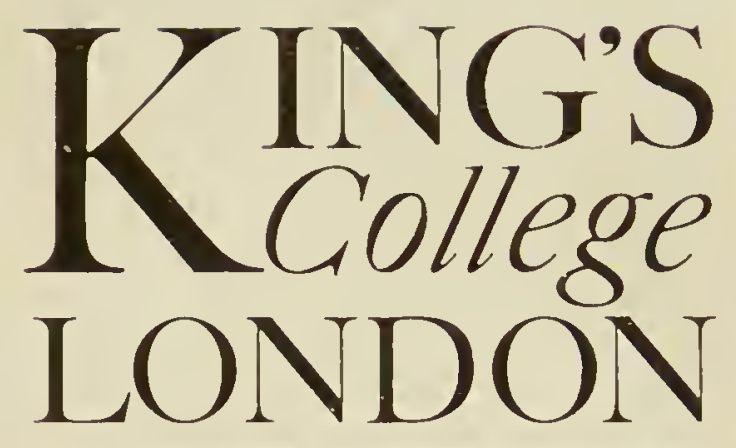

R51 S70

STokes, Libram

a Bo tompent matraca

mences

182

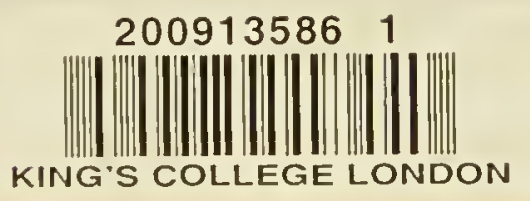




A

\title{
BOTANICAL
}

\section{MATERIA MEDICA,}

CONSISTING OF THE

GENERIC AND SPECIFIC CHARACTERS

\author{
OF THE \\ PLANTS \\ USED IN \\ MEDICINE AND DIET, \\ WITH
}

SYNONYMS,

IND REFERENCES TO MEDICAL AUTHORS,

BY

\section{JONATHAN STOKES M.D.}

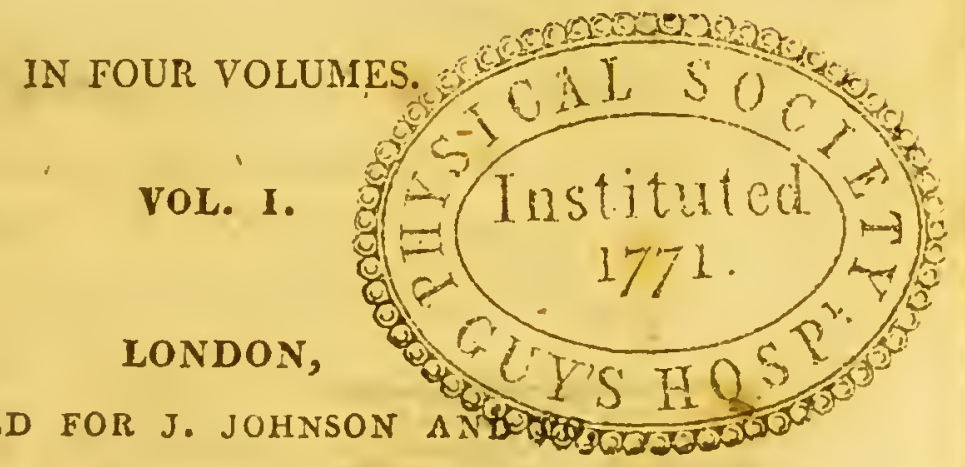

ST. PAULS CHUIRCHYARD.

1812. 
600375

GUYPS

Printed by J. Belcher and Son,

High-street, Birmingbam. 


\section{To}

\section{DR. W RIGHT.}

\section{Dear Sir}

If you make use of this work in the course of your medical or botanical studies, I must beg you to attend to the following circumstances. Let us open the 1st vol. at p. 394. Each species is distinguished by a numeral. The specific character is followed by references to the authors consulted. In the citations the first numeral in roman figures expresses the number of the volume, fasciculus, section, part, or other primary division of the work, unless preceded by the letter $p$. in which case it expresses the page of the preface or introduction. The first numeral in arabic figures expresses the page of the work, but when the letter $n$. is prefixed it implies the number of the species, which in some authors are distinguished by a regular series of numbers, When $t$. is prefixed to an arabic numeral it denotes the number of the plate, but in the authors whose works contain figures cut in wood, as Brunfelsius, Fuchsius, Tragus, Matthiolus, Camerarius, Dodonaeus, Lobel, Clusius, Dalechamp, the Bauhines, Gerard, and 
Parkinson, the arabic numeral refers to the page in which a figure of the plant is found, and when there is only a description it is expressly said that there is no fig.

I have stated what figures are reimpressions and copies of others, that when the reader has turned to one he may save limself the trouble of consulting thosc which are reimpressions or. copies or the original of what he has already examined.

The figures subjoined to botanical observations refer to the numbers of a journal which I have kept ever since I began to investigate plants, my. specimens having corresponding. numbers affixed to them. The benefit I have experienced from this method induces me to recommend it to all students of natural history, advising them to incorporate all other observations which they may commit to writing into the same series, affixing corresponding numbers to specimens of all kinds, and to plants growing in their gardens numbers stamped on plates. of lead by means of steel dies, as practised by. florists. To these observations I haye an index, which consisting of separate papers arranged in. a book, admits of occasional additions withoutthe labour of transcription. 
The numbers subjoined to genera indicate from what species the alterations in the generic character were formed, but when such species are not to be found in the work, the name of the species is given.

I generally add where and by whom the plant or specimen was gathered. When the subject of examination is a dried plant I use the word specimen, when nothing is said the plant was examined in a recent state.

On some occasions I have been led to examine into the native place of plants. The result of such enquiries is placed after the references to botanical authors and observations upon structure, and the authorities will be found in remarks subjoined to the citations of different botanical observers.

To distinguish the medical references I have printed the first of the names used by medical authors in italic capitals, as Belladonna in p. 395 of Vol. 1st. The references which immediately follow the name in italic capitals are generally to pharmacopoeias, but in the latter part of the work, fearful lest it should swell out to too great a size, I have sometimes inserted botanical references distinguishing them from b. 2 
the medical references by a hyphen, as in Sphagnum latifolium, iv. 585, where all the references following Sphagnum palustre and preceeding the hyphen are botanical.

The references which follow those to pharmacopoeias are to the writers of materia medicas and such practical authors as I have been in the habit of reading or consulting, arranged under each pharmaceutical name in alphabetical order that the name of the author whom the reader may wish to consult may be most expeditiously found. But notwithstanding this division of botanical and medical references it may be proper to advertise the reader that he will find accounts of the virtues of plants in many of the authors cited as botanists such as Dodonaeus, Clusius, Lobel, J. Bauhine, Gerard, Parkinson, Rheede, Rumphius, Ray, Gouan -in his flora, Krocker, and Loureiro, and that among the medical references he will meet with accurate descriptions in Bergius's materia medica.

The numerals prefixed to the genera are repeated in the rumning title to afford the investigating botanist an easy reference from the synoptic tables to the body of the work. 
The terms made use of are generally those of Linnaeus, or, formed on his principles, but in the grasses it may be necessary to observe that what Linnaeus calls the calyx I consider as bracteae, and what he terms corolla I regard as the calyx. In describing the calyx I have also substituted the word phyllum for foliolum, confining the use of foliole to the subdivisions of leaves. The compound flowers as they are generally termed, contained in the class Syngenesia I have called anthodia, considering them as collections of flowers analogous to those of Scabiosa and Jasione. And instead of calyx communis and squamae I employ the terms involcurum and bracteae.

I make no apology for these or other deviations from common usage, holding it to be the duty of every writer who publishes, to communicate all he knows on the subject of which he treats. If convinced by others or my own reflexions that such deviations are errors I trust I shall have courage to retrace my steps.

Since I wrote the advertisement prefixed to the 2nd edition of the Botanical arrangement, my opinions respecting trivial names have almost entirely changed. Improvements in nomenclab 3 
ture will kecp pace with increasing knowledge, and where a name is susceptible of amendment, every botanist slould be as ready to suggest a better as tn communicate an improved specific character or description. I do not approve of altering every name which is not good, thinking it better to use the bad one till we discover one which is characteristic. In some genera the difficulty of finding good names is so great, that we must be content with their having names at all. In adopting one of two or more names given to the same plant by contemporary authors we ought always to give a preference to that which is most characteristic.

When the trivial name adopted is not that used by the author from whom the specific character was taken, a hyphen is subjoined to the trivial name, the name of the author of the specific character is added at the end of the specific character, and the name used by the author of the specific character cited at length below. See ii. 386. $n .1$; iii. 139. n. 5. If after the name at the end of the specific character a hyphen is subjoined and a work cited, it implies that the trivial name has been adopted from the last cited author. See ii, 386. n. 1 . 
When I have referred a species to a distinct genus and only one species is found in that genus, I have not followed Linnaeus in endeavouring to discover a characteristic name, but have judged it more adviseable to give it a name expressive of its being the only known species, and a name which must inevitably be changed whenever another shall be referred to the same genus. See ii. 169.

In the course of this work I have been led to distinguish between a variety and what $I$ have sometimes called a variation. When plants are so much alike that one entertains no doubt of their specific sameness, and yet differ in colour size or mode of growth, I am inclined to call those that assume the form or colour which is least usual a variation. When plants are so little alike that we almost begin to suspect them to be specifically different, and yet on a careful examination are not able to fix on sufficient marks of specific distinction; I call that form which is least usual a variety.

Hoping that you will resume your pen and communicate to the world in a work of your own all that you have observed on the plants and dis- 
xii DEDICATION.

eases of the West Indies, I remain with much esteem

\section{Dear Sir}

Your obliged and sincere friend JONATHAN STOKES.

Chesterfield 20 May, 1812.

P. S. Mr. Hunters nursery, late Messrs. Brunton and Hunters at Perry Hill between Birmingham and Hales $\mathrm{O} w e n$, is now at Soho near Birmingham. 


\section{ABBREVIATIONS}

OF

WORDS, TITLES OF BOOKS, AND NAMES OF-

AUTHORS EXPLAINED.

Abù. A bbots flora bedfordiensis. 8vo. 1798.

abr abridged.

Acost. Acosta, Christoval tractade de las drogas. 4 to. 1578.

Acost. a Clus. A Costa historia aromatum, in Clus. exot. p. 253. The figures omitted.

Act. haun. Acta sacietatis medicae hauniensis. Tomi

2. 8vo. 1783.

Adams morb. Adams on morbid poisons. 4to 1807. Adans. fam. Adanson familles des plantes. 2 tomes. 8то. 1759.

Adans. voy. Adansons royage to Senegal. 8vo. 1759. Aik. man. Aikins manual of materia medica. 12mo. 1785.

Aitk. Aitkens midwifery. 8vo. 1786.

Ait. W. T. Delineations of exotic plants, cultivated

in the Kew garden, drawn by $\mathrm{F}$. Bauer and published by W. T. Aiton. fol. 1796.

All. nic. Allionii stirpium littoris et agri Nicaeensis enumeratio. 8vo. 1757.

All. ped. Allionii flora pedemontana. Tomi 3. fol. 1785.

All. rar. Allionii rariorum stirpium Pedemontii specimen. Ato 1755.

Alp. aegypt. Alpinus de plantis aegypti. 4to. 1592. Alp. bals. Alpinus de balsamo, Ato, 1592. 
Alp. cum. Vesl. Alpini historia aegypti naturalis. Tomi 2. 4to. 1735 .

Alp. exot. Alpinus de plantis exoticis. 4to. 1627. Alp. med. aegypt. Alpini medicina aegyptiorum. 4to. 1745.

Alp. rhap. Alpinus de rhapontico. 4to, at the end of Alp. med. aegypt.

Alst. Alstons lectures on the materia medica. 2 vols. 4to. 1770.

Alst. hort. Alston hortus medicus. $12 \mathrm{mo}, 1740$. Alxing. fung. Alxingeri historia fungorum. 8 vo. Alxing. grat. Alxinger de gratiola. Svo.

Amm. Amman stirpium in imperio ruthenico provenientium icones et descriptiones. 4to. 1739. Ann. med. Annals of medicine. 8 vols. 8vo. 1796 . The vols. subsequent to the 5 th. sometimes quoted as lustrum 2 nd.

Ann. bot. Annals of botany by Konig and J. Sims. 2 vols. 8vo. 1805.

Andr. rep. Andrews botanists repository. 4to, 1797. Arbuth. Arbuthnot on aliments. 8vo. 1735. Ard. anim. Arduini animadversionum botanicarum specimen. 4to. 1759 ; alterum. 1763.

Arist. A ristotelis opera ab J. Casaubone. fol. 1590. Arnold on hydroplobia. 8vo. 1793. As. res. Asiatic researches. 7 vols. 8vo. 1798. Asso. Asso synopsis stirpium Aragoniae. 4to. 1779. Aurel. Caelius Aurelianus de morbis acutis et chronicis. 4to. 1755.

Aubl. Aublet histoire des plantes de la Guiane francoise. 4 tomes. Ato. 1775.

Barrel. Barrelicri plantae per Galliam Hispaniam et Italiam observatie. fol. 1714.

Barrere. Barrere histoire naturelle de la France aequinoctiale, $12 \mathrm{mo}, 1741$. 
Barry on the wines of the ancients. Ato. 1775 .

Bart. Bartons materia medica of the United States.

Svo. 1798 .

Bartr. W. W. Bartrams travels through North and

South Carolina Georgia and East and West Flo-

rida. 8vo. 1792.

Bast. Bastcri opuscula subseciva. Tomi 2. 4to. 1762. Batsch. Batsch elenchus fungorum. Fasc. 3. Ato. 1783. Batt. Battara fungorum agri ariminensis bistoria, Ato. 1759.

Battie on madness. 8vo. 1758.

Bauh. Casp. phytop. Bauhinis Caspari, ФrTOMINA $\Xi .4$ to. 1596 .

Bauh. Casp. pin. Bauhini Caspari, MINAZ theatri botanici. 4to. 1623.

Bauh. Casp. prodr. Bauhini Caspari, produromus theatri botanici. Ato. 1671 .

Bauh. Casp. theatr. Bauhini Caspari, theatrum botanicum. fol. 1658.

Baıh.J. Bauhini, Joannis historia plantarum. Tomi 3. 1650. $a$, signifies the 1st part and $b$ the 2nd part of the ist and 3rd volumes.

Bellev. Opuscules de Belleval. Svo. 1785.

Berg. Bergii materia medica. Tomi 2. 87o. 17 i8. Berkeley siris, on the virtues of tar water. 8vo. 1747. Bellon. Bellonii observationes. ful. 1605, in Clus. exot. Besl. hort. Besler, Basil. hortus eystettensis. fol. 1613. Besl. mus. Besler, Basil et Michael musaeum. fol. 1716.

Biss. ess. Bissets medical essays and observations. 8 vo. 1766.

Blaclist. specim. Blackstone specimen botanicum. $12 \mathrm{mo} .1746$.

Blackst. haref. Blackstone fasciculus plantarum circa Harcfield nascentium, $12 \mathrm{mo}, 1737$. 
Blackw. $\Lambda$ curious herbal by Eliz. Blackwell. 2 vols. fol. 1737.

Blair pliarmaco-botanologia. Ato. 1723.

Blair.ess. Blairs botanic essays. 8vo. 1720.

Blane on the diseasas of seamen. 8vo. 1789.

Bligh voyage to the South seas. 4 to.

Bocc. piunte. Boccone museo di piante rare. 4 to. 1697.

Bocc. sic. Bocconi icones et descriptiones plantarum rariorum Siciliae Melitae $\ddagger$ Galliae. 4to. 1674.

Boerh. Boerhaave index alter plantarum quae in horto Lugduno-batavo aluntur. Tomi 2. 4to. 1720.

Boerh. (in the medical references) Boerhaave historia plantarum quae in horto academico Lugduni Batavorum crescunt. Tomi 2. $12 \mathrm{mo} .1731$.

Bolt. fil. Boltous filices britannicae. 4to. 1785.

Bolt. fung. Boltons history of fungusses. 4 vols. Ato. 1788.

Bont. Bontii historia naturalis et medicae indiae orientalis. At the end of Piso ind.

Bont. med. ind. Bontius de medicina indorum. 4to. at the end of Alp. med. aegypt.

Boryde St. Vincents voyage to the African seas, in the 2nd vol. of a collection of voyages printed by Philips. 8vo. 1805.

Bosischen garten. Leipsig. $12 \mathrm{mo} 1738$.

Bot. guide. Turner and Dillwyns botanists guide through England and Wales. 2 vols. 12mo. 1805.

Bot. arr. Botanical arrangement. 2nd cd. 3 vols. 8vo. 1787 ; ed. 1st 2 vols. 1776 ; ed. 4th 4 vols. 1801.

Bot. mag. The continuation of Curt. mag. by J. Sims, beginning at t. 505. $8 \mathrm{ro}, 1801$. 
Bradl. kal. . Bradleys gentlemans and gardeners kalendar. 8vo. 1728.

Bradl. succ. Bradley historia plantarum succulentarum. 4to. 1716.

Breyn. cent. Breynii exoticarum plant. centuria. fol. 1678.

Breyn. ic. The figures with descriptions at the end of Breyn. prodr.

Bryn. prodr. Breynii fasciculi rariorum plantarum. 1 et 2. 4to. 1739.

Brit. herb. British herbal. Ato.

Bromf. Bromfields chirurgical observations and cases. 2 vols. 8 vo. 1778.

Brought. ench. Broughton enchiridion botanicum. $12 \mathrm{mo} .1782$.

Brought. hort. Hortus Eastensis by Arthur Brough. ton M.D. at the end of the 1st rol. of Edwardss west indies.

Brown, $J$. elements of medicine by Beddoes. 2 rols. 8vo. 1795.

Brown, Rob. Prodromus florae novae hollandiae Tom. 1. 8vo. 1810.

Browne, Patr. Natural history of Jamaica. fol. The letterpress is the old edit. with copies of the original plates. 1789.

Bruce. Bruces travels. 5 vols, 4 to. 1790.

Brunf. herb. Brunfelsii herbarium. Tomi 3. 1539.

Brunf. ic. Brunfelsii herbarum eicones. Tomi 2. fol. 1530.

Bry. Bryants flora dietetica. 8vo. 1789.

Burm. J. afr. Rariorum africanarum plantarum decades 10. 4to. 1738.

Burm. J. zeyl. Burmanni thesaurus zcylanicus. Ato. 1737.

Burm. N. ind. Flora indica. 4to. 1769. 
Burs. Burserii institutiones medicinae practicae. Tomi 4. 8vo. 1798.

Buxb. Buxbaumii plantarum minus cognitarum centuriac 5. 4to. 1728.

Cand. by Givs: Camdens britannia by Gibson, fol. 1695. (by Gough ed. 1st I have consulted, but the communications respecting the plaees of growth of plants being anonymous I have not hitherto ventured to quote it.)

Cam. epit. Cámerarii de plantis epitome Mathioli. 4to. 1586.

Cam. hort. Camerarii hortus medicus. 4to. 1588.

Carth. Cartheuser fundamenta materiae medicae. :Toini 4. 12mo. 1769.

Cat. Catesbys natural history of Carolina Florida and the Rahama islands. 2 vols. fol. 1731.

Cat. lond. Catilogus plantarum. A catalogue of trees shrubs plants and flowers propagated near Londón. fol. 17.30.

Chabr. Chabraei stirpium sciagraphia. fol. 1666.

Chalm. Clialmerss' account of the weather and diseases of South Carolina. 2 vols. 8vo. 1776.

Chir.rev. The medical and chirurgical review. 16 vols. 8 vo. 1794.

Chir. tr. Medico-chirurgical transaetions. 8ro. 1809.

Chish. Chisholm on the pestilential fever of the west indian islands. 8ro. 1795.

Chom. Abrege de l'histoire des plantes usuclles, par J. B. Chomel. 3 tomes. $12 \mathrm{~m}$. 1739.

Clark, J. fev. J. Clark on fevers. 8vo. 1792. Clark, J. tong roy. J. Clark on thie diseases of long voyages. 2 vols. 8 vo. 1792.

Clegh. Clenglom on the diseases of Minorca.' Svo. 1779. 
Clus. app. alt. Clusii appendix altera ad rariorum plantarum historiam. At the end of the and edit. of Clus. exot.

Clus. cur. Clusii curae posteriores, in Clus, exot. 2nd edit.

Clus. exot. Clnsii exotica. fol. 1605.

Clus. hist. Clusii rariorum plantarum historia. ful. ed. i. 1601 ; ed: ii. 1633.

Clus. hisp. Clusii rariorum stirp. per hispanias observatarum historia. $12 \mathrm{mo} .1576$.

Clus. pann. Clusii rariorum stirpium per Pannoniam Austriam et vicinas quasdam provincias observatarım historia. 12mo. 1583 .

Cod. med. Codex medicamentarius, seu Pharmacopoeà parisiensis. 4to. 1739.

Collin observationes. Partes 6. 8 vo. 1765.

Col. ecphr. Columnae expparis. Partcs 2. 4to. 1616.

Col. phyt. Columnae Qutoßaravos. Ato. 1592.

Comm. Casp. hort.- Commelini, Casparis hortus amstelodainensis. Tomus II. fol, 170I:

Comm. Casp.prael. Commelini, Casparis praeludia. 4to. 1703.

Comm. Casp.rar. Commelini' Casparis horti amstelodamensis plantae rariores:' Ato. 1706.

Comm. J. hort. Commelini, Joamis hortus amstelodamensis. Tomus I. fol. 1697.

Contril. Contributions to medical knowledge, collected by Beddoes. 8vo. 1799.

Cook 3rd voy. A voyage to the pacific ocean in the years 1776 to 1780 by Captains Cook and King. 4 vols. 8vo. 1784 .

cop. copied.

Cord Valerii Cordi annotationes, historin, \&c. fol. 1561. Corn. Cornuti canadensium plantarum allarumque nondum editarum historia. Ato. 1635. 
Coxe American dispensatory. 8vo. 1806, account from in chir. rev. xiii. 365.

Coyte hort. Coytes hortus botanicus gippovicensis. 4to. 1796.

Coyte ind. Coytes index plantarum. 8vo. 1787.

Crantz. aust. Crantzii stirpium austriacarum partes 6. 4 to. 1769.

Crossf. Crossfields calendar of flora. 8vo. 1810.

Cull. Cullens lectures on the materia medica. 2 vols. 4to. 1789.

Cull. clin. Cullens clinical lectures. 8vo. 1797.

Cull. pract. Cullens first lines of the practice of physic. ed. by Reid. 2 vols. 8vo.

Culp. Culpeppers english physician. 12mo. 1711 .

Cuntira de Nicotiana. 8vo. 1777.

Currie wat. Curric on water. 2 vols. 8vo. 1797.

Curt. lond. Curtiss flora londinensis. fasc. 6. fol. 1776.

Curt. mag. Curtiss botanical magazine. 8vo. 1787. Cutl. An account of the vegetable productions naturally growing in the neighbourbood of Ipswich in New England, by Manasseh Cutler D. D. in the Memoirs of the American acad. i. 396.

Cycl. Cyclopacdia edited by Abr. Rees. D. D. 18 vols. 4to. Many of the botanical articles are by Dr. Smith, the only contributor who affixes a signature to his articles, a practice which if general would add much to the value of the rork, and perhaps to that of the communications. My name was inserted in the prospectus by a deceased friend without my knowledge, but I never wrote any thing in it.

Dale. Dalei pharmacologia. Ato. 1737.

Dalech. Historia generalis plantarum. Tomi 2. fol. Tom. I. 1587. Tom. II. 1586! 
Dalech. plantes. Histoire generale des plantes. Tomi 2. 1615.

Dalib. Dalibard flora parisiensis. 12mo. 1719.

Dariv. Darwins zoonomia. 2 vols. 4to. 1796.

Daws. vheum. Dawson on rheumatism. 8vo. 1781.

Denm. Denmans midwifery. 2 vols. 8vo. 1788.

Dicl.s. Dicksoni plantarum cryptogamicarum Britanniae fasciculi 4. Ato. 1785 .

Dill. giss, Dillenii calalogus plantarum circa Gissam nascentium. Svo. 1719.

Dill. hort. Dillenii hortus elthamensis. fol. 1732. Dill. musc. Dillenii historia muscorum. 4to. 1741 . Diosc. Dioscoridis libri 8, Gr. \& Lat. a Ruellio. $12 \mathrm{mo} .1549$.

Dodart. Memoires pour servir a l'histoire des plantes par M. Dodart. fol. 1676.

Dod. flor. Dodonaci florum \&c. hist. 12mo. 1569.

Dod. and Dod. pempt. Dodonaei stirpium historiae pemptades 6. fol. lst ed. 1583 ; 2nd ed. 1616.

Dod. purg. Dodonaei purgantium historia. $12 \mathrm{mo.}$ 1574.

Donn. Donn hortus cantabrigiensis. ed. 2nd, 4th, 5th. 1800. 1807. 1809.

Duham. arb. Du Hamel des arbres. 2 tomes. 4to. 1755.

Juroi obs. Du Roi observationes botanicae. Ato. 1771. Edin. journ. The Edinburgh medical and surgical journal. 8vo. 1805.

Edinb. tr. Transactions of the royal society of Edinburgh. 4to.

Edro. Bry. History of the West Indies by Bryan Edwards. 2 vols. Ato. 1794.

Edw. dis. Diseases of the human body by G. Edwards M. D. Ato. 
Edw. G. A natural history of birds by G. Edwards. 4 vols. 4to. 1743.

Edw. G. glcan. Gleanings of natural history. 3 vols. 1758.

Ehr. Ehret plantae et papiliones depictac. fol. 1748. Ellis mang. Elliss description of the Mangostan and Breadfruit. 4to. 1775.

Encycl. Encyclopaedia britannica. 20 vols. 4 to. 1797. Eschenb. obs. Eschenbach observationes botanicac. 4 to. 1784.

Evel. by Frunt. Evelyns silva by Hunter. 2nd ed. 2 vols. 1786.

Ferriar. Ferriars medical histories 3 vols. 8vo. 1792.

Ferriar on digitalis purpurea. 12 mo. 1799.

Feuil. Jourual des observations par Fcuille. 3 tomes 4to. 1714 .

Fl. dan. Flora danica ab Oeder Muller et Vahl. fol. 1761.

fol. leaf, the leaves being numbered in some of the earlier printed books.

Fordyce, G. fev. Fordyce, G. on fever. 6 parts. 8 ro. 1794.

Fordyce, G. pract. G. Fordyces practice of physic. 8 vo. 1791.

Fordyce, W. Fev. W. Fordyce on Fevers. Svo. 1777: Fordyce, W. fragm. Eordyce, Gul. fragmenta chirurgica et medica. 8vo. 1784.

Forsk. Forskal flora aegyptiaco-arabica. 4to. 1775.

Forst. G. austrul. Georgii Forsteri florula insularum australium. 8vo. 1786.

Forst. G. esc. Georgii Forsteri plantac esculentae insularum oceani australis. 8vo. 1786.

Forst. J. amer. Forsters flora aniericae septentrio. nalis. Svo. 1771. 
Forst. J. \& G. Forster, J. \& G. characteres generun plantarum. 4to. 1776.

Fotherg. J. sorethr. Fothergill on sore throat. 8vo. 1754.

Fowl. T. tob. Fowler on Tobacco. 8vo. 1788.

Fowl. T. rheum. Fowler on rheumatism. 8vo. 1795.

Freem. Silict specimens of British plants from the drawings of Misses Strickland. 2 numbers. fol. 1797.

Fuchs. Fuchsii historia stirpium. 12mo. 1549 ; fol. ed. 154 ?

Gaerin. Gacrtner de fructibus et seminibus planta. rum. Tomi 2. 4to. 1788.

Garc. a Clus. Garcias ab Horto aromatum historia, iconibus illustrata a Clusio. 12mo. 1574; repr, in Clus. exot.

Garid. Histoire des plantes qui naissent en Provence par M. Garidel. fol. 1715.

Gataker on Solanum. 8vo. 1757.

Gent. mag. Gentlemans magazine. Vol. 1st. 1731 to the prisent time. 8 vo.

Geoff. Geoffroy tractatus de materia medica. Tomi 3. 8 vo. 1741.

Genffr. suite. Suite de la matiere medicale de M. Geoffroy. 3 tomes 12 mo. 1750 .

Ger. J. Gerards historie of plants. fol. 1597.

Ger. by Johns. Gerards herball enlarged and amended by T. Johnson. fol, 1633; 2nd ed. 1630.

Ger. $L$. Ludovici Gerardi flora gallo-provincialis. 8 vo. 1761 .

Gesn. hort. Gesneri horti Germaniae, at the end of Cord.

Geuns. Vans Geuns plantarum belgii coufoederati spicilegium. 8vo. 1788. 
Gis, ind. Giseke index in. Plukenetii opera et Dillenii historiam muscorum. 4to. 1779.

Gled. fung. Gileditsch methodus fungorum. 8vo. 1759. Gmel. J. G. sib. Gmelin J. G. flora sibirica. Tomi 4. 4to. 1747 .

Gmel. S. fuc. Gmelin historia fucorum. 4to. 1768. Gmel. S. reise. S. G. Gmelins reise. Ato. 1774.

Gort. Lelg. foed. Gorteriflora VII provinciarum belgii focderati. 8 vo. 1781.

Gou. hort. Gouan hort. monspeliensis. 8vo. 1762.

Gou. ill. Gouan illustrationes et observationes botanicac. fol. 1773.

Gou. monsp. Gouan flora monspeliaca. 8vo. 1765. Graing. Grainger on west india diseases. 8vo. 1802. Grant on fevers. 2 vols. 8vo. 1779.

Grew mus. Grews musacum regalis societatis, fol. 1681. Griff. hect. Griffith on hectic. 8vo. 1774. Gron. orient. Gronovii flora orientalis. 87o. 1755. Gron. virg. Gronovii flora virginica. 4to. 1762 ; ed. 1. partes 2. 8vo. 1739. 1743.

Guetl. Observations sur les plantes par M. Guettard. \& tomes. 12mo. 1747 .

Gunn. Gumneri flora norvegica. Partes 2. fol. 1766. Hall. enum. Ialleri enumeratio stirpium Helvetiac. Tomi 2. fol. 1742.

Hall. hist. Halleri historia stirpium Helvetiae. Tomi 3. fol. 1768.

Hall. opusc. Halleri opuscula botanica. $12 \mathrm{mo} .1749$. Hamilt. Alex. midw. Hamilton, Alex. on midwifery. 8 vo. 1784.

II anilt. mad dog. Hamilton, $\mathrm{R}$, on the bite of a mad dog. 8vo. 1785.

Haslam on insanity. 8vo. 1798.

Hass. Hasselquists voyages and travels in the Levant.

8vo. 1766. 
Hawkesw. Hawkesworths account of voyages to the southern hemisphere. 4 vols. 8vo. 1785.

Haw. mes. Haworth obsęrvations on the genus Mesembryanthemum. Svo. 1794.

Haw. misc. Haworth miscellanea naturalia. 8vo. 1803. at the end of Haw. lepidoptera britannica.

Hayg. fer. Haygarth on infectious fevers. 8vo. 1801. Heb. Heberden commentarii. 8vo. 1802.

Hedw. fund. Hedwigii fundamentum historiae muscorum frondosorum. Partes 2. 4to. 1782.

Hedw. stirp. Hedwigii stirpes cryptogamicac. Fasc. 4. 1785.

Hedw. theor. Hedwigii theoria generationis et fructificationis plantarum cryptogamicarum. 4to. 1784.

Helw. Helwingii florae campana seu Pulsatilla. 4to. 1720 ?

Herm. (in the medical references) Hermanni cynosura materiae medicae. 4to. 1726.

Herm. hort. Hermanni hortus lugduno-batavus. 8vo. 1687.

Herm. parad. Hermanni paradisus batavus. 4 to. 1698.

Herm. prodr. Hermanni paradisi batavi prodromus at the end of Schola botanica. 12 mo. 1689.

Herm. zeyl. Hermanni museum zeylanicum. 8vo. 1726.

Hern. Hernandes nova plantarum et animalium mexicanarum historia. fol. 1651.

Hill hort. Hill hortus kewensis. 8vo. 1709.

Hill. syst. Hills vegetable system. fol.

Hill, James Cases in surgery. 12mo. 1772.

Hill. (in the medical references) Hills history of the

materia medica. Ato. 1751.

Hillary on Barbadoes. 8vo. 1766. 
IIist. ox. Morisoni plantarmm historia universalis. Tomi 3. fol. 1715. The 1st vol. contains the plates; pars 2uda. fol. 1686 ; pars 3tia quam explevit Jacobus Bobartius. 1699.

IIoffm. Hoffnanni, Fred. opera. Tomi 6. fol. 1748. Home, F.clin. Homes clinical experiments. 8 vo. 1780 . Home, F. prin. Home principia medicinae. 8vo. 1762. Honck. Honckeny synopsis plantarum Germaniae. Tomi 2. 8vo. 1792.

Honck. rollst. Vollstandiges verzeichniss aller gewaclise teuschlandes. 8vo. 1782.

Hort. kew. and $H . K$. Hortus kewensis ed. i. 3 vols. 8 vo. 1789 ; ed. ii. Tomi I. II. 8vo. 1810. 1811.

Host. austr. Host synopsis plantarum in Austria provinciisque adjacentibus sponte crescentium. 8ro. 1797.

Houst. rel. Reliquiae Houstonianae. 4to. 1781. Houtt. Houttuyn nateunrlyke historie. 14vols. 8vo. 1773.

How. Phylologia britannica. 12mo. 1650.

IIuds. Hudsoni flora anglica. ed. 2. Tomi 2. 8vo. 1778. Hughes. Hughess natural history of Barbados. 1ol. 1750.

Hull phlegm. Hull on phlegmatia dolens. Evo. 1800. IIunt. J. jam. Observations on the diseases of the army in Jamaica by J. Hunter M. D. Svo. 1788. Hunt.J. ven. J. Hunter on the venereal disease. 4 to. Huxh. air. Huxham on the air and epidemic discases. 8vo. 1759.

Huxh. fev. Huxham on fevers. 8vo. imit. imitated.

impr. improved.

Jacks. Rob. fer. Jackson on fever. 8vo. 1798.

Jacks. Rob. jam. Jackson on the tevers of Jamaica. Svo. 1791. 
Jacq. amer. Jacquin stirpium americanarum historia. fol. 1763; 8vo. 1788. Figures omitted. American plants described in his other works introduced. Jacq. austr. Jacquin flora austriaca. Tomi 5. fol. 1773.

Jacq. coll. Jacquin collectanea. Tomi 4. 4to. 1786. Jacq. gew. Jacquin 300 americanische gerwachse. 8 vo. 1785.

Jacq. hort. Jacquin hortus vindobonensis. Tomi 3. fol. 1770 .

Jacq. ic. Jacquin icones plantarum rariorum. Tomi 3. fol. 1781 .

Jacq. misc. Jacquin miscellanea austriaca. Tomi 2. 4to. 1778.

Jacq. obs. Jacquin observationum botanicarum partes 4. fol. 1764.

Jacq. pict. Jacq. amer. an edition with coloured drawings in place of engraved figures. fol. 1781 .

$J a c q$. vind. Jacquin enumeratio stirpium quac crescunt in agro vindobonensi. $12 \mathrm{mo} .1762$.

Journ. de med. Journal de medicine. 12mo 1787. Juss. Jussieu, Ant. genera plantarum. 8vo. 1789. Kaempf. am. Kaempfer amoenitatum exoticarum fasciculi 5. 4to. 1712 .

Kaempf. ic. Kaempferi icones. fol. 1791. Outlines. Kalms travels into North America. 2 vols. 8vo. 1779. Ker recens. Recensio plantarum in repositorio botanicorum depictarum. 4to. 1801.

Kirkl. Kirklands medical surgery. 2 vols. 8 vo. Kirkl. apopl. Kirkland on apoplectic and paralytic affections. 8vo. 1792.

Kniph. Kniphof botanicon in originali. Centuriac 12. fol. 1757. Impressions of plants taken off with printers iuk and coloured. 
Knowles materia medica botanica. 4to. 1723.

Koelle de aconito. 8vo. 1787.

Kram. Kramer elenchus vegretabilium et animalium per Austriam inferiorem observatorum. 8vo. 1756.

Krock. Krocker flora silesiaca. 'Tomi 2. 8vo. 1787. 1790.

L. Linnacus.

L. anr. Linnaci amoenitates academicae. 8vo. Tom. I. Lugd. Bat. 1749. Tom. v, vi, x. ed. Schreb. The rest the original edit.

L. a Gmel. Linnaei systema naturae a Gmel. Tomi 3. in 10 vols. 8 vo. 1788 .

L. a Murr. Linnaei systema vegetabilium a Murray. 8vo. 1784 .

L. a Reich. Linne systema plantarum, curante Reichard. Tomi 4. 8vo. 1779.

L. $a$ Schreb. Linnaei genera plantarum a Schrebero. Tomi 2. 8vo. 1789.

$\boldsymbol{L}$ a Willd. Linnaei species plantarum a Willdenow. Tomi 4. 8vo, 1797.

L. cliff. Linnaei bortus cliffortianus. fol. 1737.

L. gen. Linnaci genera plantarum. ed. 6ta, 8vo. 1764 ; ed. 2nda, 1743 ; ed. 5 ta, 1754; a Reich. 1778.

L. lapp. Linnaci flora lapponica. 8vo. 1737 ; ed. a Smith 1792.

L. mant. Linnaei mantissá plantarum. The first part at the enil of L. nat. ii. The conclusion in a distinct vol. intitled Linnaei mantissa altera. Svo. 1771.

L. mat. med. Linnaci materia medica, de plantis. 8 vo. 1719.

L. nat. Linnei systema naturae. Tomi 3.8vo. 1766.

L. phil. Linnaci philosophia botanica. 8vo. 1751. 
L. $s p$. Linnaei species plantarum. ed. ii. Tomi 2. Svo. 1762; ed. i. Tomi 2. 8vo. 1753.

L. suec. Linnaei flora suecica. ed. ii. 8vo. 1755; ed. i. 1745 .

L. ups. Linnaei hortus upsaliensis. 8vo. 1748.

L. zeyl. Linnaei flora zeylanica. 8vo. 1748.

L. fil. dec. Linnaei filii decas plantarum rariorum. I et II. fol. 1762.

L. fil. fasc. Linnaei filii plantarum rariorum fasciculus I. fol. 1767.

L. fil. suppl. Linnaei (filii) supplementum plantarum Svo. 1781.

Lam. Lamarck dans l'encyclopedie methodique. 4 Tomes. 4to. 1783.

Lamb. cinch. Lamberts description of the genus cinchona. 4to. 1797.

Lecrs. Leers flora herbornensis, ed. i. 8vo. 1775; ed. ii. 1789.

Lempr. Lempriere on the diseases of the army in Jamaica. 2 vols. 8vo. 1799.

Le Pluche. Nature delineated. 4 vols. $12 \mathrm{mo} .1740$.

Lett. Letters and essays on diseases of the West Indies. 8vo. 1778.

Letts. mem. Lettsoms memoirs of the dispensary. $8 \mathrm{vo}$. 1774.

Lells. thea. Lettsom de Thea. 8vo. 1769.

Lew. Lewiss experimental history of the materia medica, edited by J. Aikin. 2 vols. 8vo. 1791.

Lew. disp. The new dispensatory. 8vo. 1770.

Lew. disp. by Dunc. The Edinburgh new dispensatory, edited by Andr. Duncan. 8vo.

Lezo. disp. by Dunc. jun. The Edinburgh new dispensatory, edited by Andr. Duncan junior. 8ro. 1810. 
Lew. disp. by Rolher. The Edinburgh new dispensitory, edited by J. Rotheram. 8vo. 1794.

Lher. stirp. L'Heritier stirpes novae. Fasc. 6. fol. 1784. 1785.

Lightf. Lightfoots flora scotica. 2 vols. 8vo. 1777.

Lind hot clim. Lind on diseases of hot climates. 8 vo. 1788.

Lind seam. Lind on the health of senmen. 8vo. 1779. Linn. (in the medical references) Linnaci mat. med. cd. 5 ta a Schrebero. 8vo. 1787 ; ed. 2da 1772 ; ed. 4 ta 1782.

Lin. tr. Transactions of the linnean society. 10 vols. 4to. 1791.

Lob. adv. Penae et Lobel stirpium adversaria. Partes 2. fol. 1605.

Lob. ic. Plantarum seu stirpium icones. Long 8 ro. 1581. ed. ii. 1591.

Lob. ill. Lobelii illustrationes. Ato. 1655.

Lob. obs. Plantarum seu stirpium historia Matthiae de Lobel. fol. 1576. The title at the head of the lst page, and the running title are stirpium observationes.

Loefl. Loefling iter hispanicum. (in Swedish with descriptions of plants in Latin) Svo. 1758. The descriptions reprinted by J. Forster at the end of his translation of Bossus travels.

Loes. Loeselii flora prussica. Ato. 1703.

Lon. Loniceri botanicon. fol. 1582.

Lond. rev. The London medical review. 8vo. 1808.

Long. History of Jamaica. 3 vols. 4to. 1774.

Lour. Lonreiro flora cochinchinensis, a Willd. Tomi 2. 8 vo. 1793.

Macl. Maclean on diseases of Domingo. 8vo. 1797. Magn, hort. Magnol hortus monspeliensis, 8vo. 1697. 
Magn. monsp. Magnol botanicum monspeliense. 12mo. 10670.

Marcọr. Marcgravii historia brasiliae. fol. 1618, at the end of Pis. bras.

Mart.J. Martyn, J. historia plantarum rariorum. fol. 1728.

Mart. T. pl. cant. Martyns plantae cantabrigienses. 8ro. 1763.

Mart. T. hort. Martyn catalogus horti cantabrigiensis. 8vo. $17 i 1$.

Mart. T. rust. Martyns flora rustica. 8vo. 1792.

Mursh. Marshalls arbustrum americanum. 8vo. 1785. Mavs. Masson stapeliae novae. fol. 1796. Matth. Mattbioli commentarii. fol. 1565. Matth. a C. B. Mathioli opera a Casparo Bauhino. fol. 1598.

May on pulmonary consumption. 8vo. 1792.

Mend mon. Mead monita et praecepta medica, a Wintringham. Tomi 2.8vo. 1773.

Med. comment. Medical commentaries, 20 vols. 8 vo. 1774. The last 10 vols. sometimes quoted as Decade the 2 nd.

Med. commun. Medical communications. 2 vols. 8 vo. 1784.

Med. ess. Medical essays and observations by a society in Edinburgh. 6 vols. 12mo. 1747.

Med. facts. Medical facts and observations. 8 vols. Svo. 1791.

Med. jurn. The London medical journal. 11 vols. 8 vo. 1731 .

Med. mus. Medical museum. 3 vols. 8vo. 1763. Med. olss. Medical observations. 6 vols. 8 vo. 1768. Med. pap. Medical papers of the Massachusetts medical socicty. 8vo. 1790. 
Med. rec. Medical records. 8vo. 1798.

Med. rev. The London medical revicw and magazine. 8 vols. 8 vo. 1799.

Med. trans. Medical transactions. 3 rols. 8 vo. 1779. Mem. ac. surg. Memoirs of the academy of surgery at Paris. 2 vols. 8 vo. 1750.

Mem. med. soc. Memoirs of the medical society of London. 6 vols. 8vo. 1787.

Mem. wern. Memoirs of the Wernerian natural history society. Vol. 1st. 8vo. 1811.

Mer. sur. Merian de generatione insectorum surinamensium. fol. 1726.

Merr. Merrett pinax rerum naturalium britannicarum. $12 \mathrm{mo} .1667$.

Mert. Mertens observationes medicac. 12mo. 1778. Mill. J. ill. Millers, J. illustration of the sexual system. fol. 1777.

Mill. Jos. Millers, Jos. botanicum officinale. 8vo. 1722.

Mill. Ph. dict. Philip Millers gardeners dictionary. ed. Sth. fol. 1768.

Mill. $P$. ic. Figures of plants described in the gardeners dictionary, by Ph. Miller. 2 vols. ful. 1771.

Mich. gen. Miclsclii nova plantarum genera. fol. 1729.

Michaux amer. Michaux flora boreali-americana. Tomi 2. 8vo. 1803.

Mihless ess. Medical essays and observations relating to physic and surgery abridged from the Philosoplical transictions by S. Mihles. 2 vols. 8vo. 1745. mispr. misprinted.

Mis. artif. Mizaldi nova et mira artificia comparandorum fructuum \&c. 12mo, 1565. 
Miz. hort. Mizaldi alexikerus, seu auxiliaris hortus. $12 \mathrm{mo} .1565$.

Monard. Monardes de simplicibus medicamentis interprete Clusio. 12mo. 1574; repr. in Clus. exot. Monro. (in the medical references,) A treatise on medical and pharmaceutical chemistry and the materia medica by Donald Monro. 4 vols. Svo. 1788. Monro, Don. sold. Mouro, Donald on the health of soldiers. 2 vols. 8 vo. 1780.

Monro, J. madn. Monros remarks on madness. 8vo. 1758.

Mont. Monti catalogi stirpium agri bononiensis prodromus. 4to. 1719 .

Mor. hort. Morison hortus blesensis auctus. 8vo. 1669. Mor. prael. Morisoni praeludia botanica. 8vo. 1699. Mor. umb. Morison plantarum umbelliferarum distributio nova, in the 1st vol. of Hist. ox.

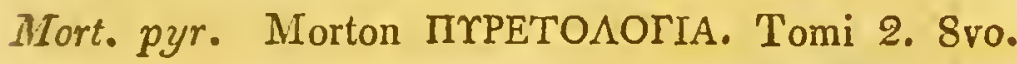
1692.

Mos. Moseley on tropical diseases. 8vo. 1789.

Mull. Mulleri flora friderichsdalina. 12mo. 1767.

Munt. phyt. Muntingii phytographia curiosa. fol. 1711.

Murr. Murray apparatus medicaminum. Tomi 6 . 8vo. 1776.

Murr. J. Elements of materia medica and pharmacy by J. Murray. 2 vols. 8 vo. 1804.

Murr. life Bruce. Murrays account of the life of Bruce. Ato. 1808.

Neal. Neals catalogue of plants in the Orford.garden. 8ro. 17.79.

New med. journ. The new London medical jourunl. 2 vols. 8vo. 1792.

Nero phys. journ. New medical and pliysical journal, 
conducted by Drs. Bradley and Shearman, 2 vols. 8 vo. 1810.

Northumb. guide. The butanists guide through the counties of Northumberland and Durlam, by Winch Thornhill and Waugh 2 vols. 8vo. 1805.

Olss. My manuscript observations mentioned in the preface.

Osb. Osbecks voyage to China. 2 vols. 8 vo. 1771.

Ogilhy china. Nieuhoffs embassy by Ogilby. fol. 1669.

Pall. reis. Pallis reise. 3 vols. Ato. 1771 .

Pall. ross. Pallas flora rossica. Tomi 2. fol. 1781.

Park. par. Paradisi (Park-) in (in-) sole (son) paradisus terrestris. fol. 1689.

Park. thealr. Parkinsons theatrum botanicum. fol. 1640.

Pears. $R$. A practical synopsis of the materia alimentariu and the materia medica. 2 vols. 8 vo. 1797 ; cd. 2nd. 8vo.

Perc. Rob. Percival, Rob. account of Ceylon. 4 to.

Perc. T. Percivals essays. 2 vols. 8 vo. 1788.

Pers. fung. Persoon synopsis fungorum. 12mo. 1801.

Pet. gaz. Petiveri gazophylacium. 1702. 1709, and repr. in the 1st vol. of his opera in 2 vols. fol. 1764.

Pet.herb. A catalogue of Mr. Rays english herbal, repr. in Petiveri herbarii britannici catalogus, in the 2nd vol. of his opera. fol. 1764.

Pet. mus. Musenm petiverianum. 8vo. 1695, sold as a 3 rd vol. of his opera.

$P h$. tr. abr. Philosophical transactions abridged by Lowthorp to 1700, 3 vols. 4to; by Jones to 1720 . 2 vols; by Reid and Gray to 1732, 1 vol. by Eames and J. Martyil to 1733.

Ph. tr. abr. by IIutt. Philosophical transactions 


\section{ABbreviations explatned. XXXV}

bo 1800. abrilged by Drs. Hutton, Shaw, and R. Pearson. 18 vols. Ato. 1809.

Pharm. austriaco-prov. Pharmacopoea austriacoprorincialis. ed. Ata. 8vo. 1780.

Pharm. edin. Pharmacopoeia collegii regii medicorum edinburgensis. 800 .

Pharm. lond. Pharmacopoeia of the royal college of physicians of London translated by Healde, and edited by Dr. Latham. 8vo. 1791.

Pharm. lond. noviss. 'Pharmacopocia of the London college, translated by Dr. Powel. 8vo. 1809.

Pharm. suec. Pharmacopoeia suecica. 8vo. 1789.

Phys. ess. Essays and ohservations physical and literary. 3 vols. 8 vo. 1771 .

Phys.jourz. The medical and physical journal, conducted by Drs. Bradley, Willich, Batty, Adams, Fothergill and Mr. Royston. 8vo. 1799.

$P$ is. bras. Piso de medicina brasiliensi. fol. 1648.

$P$ is. ind. Piso de indiac utriusque re naturali et medica. fol. 1658.

Plenc. Plenciz opera medico-physica. Tomi 2. 8vo. 1762.

Plin. Plinii historia mundi, a Dalechampio. fol. 1599.

Pluk. alm. Plukenetii almagestum botanicum. 4to. 1696.' An alphabetical enumeration of the species then known.

Pluk. amalth. Plukenetii amaltheum botanicum. 4to. 1705. A farther continuation of the almargest. Pluk. mant. Plukenetii almagesti botanici mantissá. 4to. 1700. A continuation of the almagest. Pluk. phyt. Pukenetii phytographia. 4to. 1691. Figures illustrative of his general catalogue, some few of which are copies. 'The references to the 
alm. amalth. and mant. are generally transcripts from other authors.

Plum. foug. Plumier fougreres de l'Amerique. fol. 1705.

Plum. gen. Plumier nova plantarum genera. 4to. 1703.

Plum.ic. Plumier plantarum americanarum fasciculi 10, a J. Burmauno editi. fol. 1755.

Plum. pl. d'amer. Plumier deseriptions des plantes de l'Amerique. fol. 1713.

Plum. sp. Plumier species plantarum, at the end of Plum. gen.

Poc. Pocockes description of the East. 2 vols. fol. 1743.

Poll. Pollich historia plantarum in palatinatu electorali nascentium. 'Tomi 3. 8vo. 1776.

Potl. Putts chirurgical works. 3 vols. 8 ro. 1790.

Port. mem. Portal menoires sur plusienrs maladies. 2 tomes. 8vo. 1800.

Pringle. Diseases of the army. 8vo. 6th edit.

Quar. anim. Quarin animadversiones practicae in diversos morbos. 8vo. 1786.

Quar. febr. Quarin de curandis febribus. 8vo. I7SI. Quin on dropsy of the brain. 8vo, 1790.

Raii cant. Raii catalogus plantarum circa Cantabrigiam. $12 \mathrm{mo} .1660$.

Raii cat. Raii catalogus plantarum Angliae. ed. ii. 12 mo. 1677 ; ed. i. 12 เno. 1670.

Raii eur. Raii stirpinm curopacarum extra britannias nascentium sylloge. 8vo. 1694.

Raii ext. Raii catalogus stirpium in exteris regionibus a nobis observatarum. Svo. 1679, at the end of Rays journ.

Raii hist. Raii historia plantarum. Tomi 3. fol. 1686. 
Raii meth. Raii methodus plantarum. 8vo. 1703.

Raii syn. Raii synopsis stirpium britannicarum. ed. 3tia (by Dill.) 8vo. 1724; ed. 2nda.8vo. 1696; ed. Ima 12mo. 1690.

Rays journ. Rays journey through the low countries Germany Italy aud France. Svo. 1673.

Ray's lelt. Rays letters. 8vo. 1718.

Rays rem. Rays select remains. 8vo. 1760.

Rays trav. A collection of travels and voyages published by J. Ray. 8vo. 1693.

Rantw. Rauwolffs travels translated by Staphorst in Rays coll. of trav. 8vo. 1693. No figures. These I believe are cop. in Dalech. app.

Rea. Reas flora. fol. 1665.

Recens. pl. See Ker.

Regn. La botanique par les Regnault. fol. 1774.

Reich. franc. Reichard flora moeno-francofurtana. 8vo. Partes 2. 1772.

Reid, T. phth. Reid on phthisis. 8vo. 1785.

Relh. Relhan flora cantabrigiensis. 8vo. 1785, with 3 supplements; ed. ii. 8vo. 1802. No plates. The plates of the 1st edition not reprinted, and the extracts froin Lyonss manuscripts omitted.

Ren. Renealmi specimen historiae plantarum. Ato. 1611.

repr. reprinted.

Retz. ols. Retzii observationes botanicac. Fasc. 6 . fol. 1779.

Retz. scand. Retzii flora scandinaviae. ed. ii. 8vo. 1795.

Rheede. Rheede hortus malabaricus. Tomi 12. fol. 1678.

Richt. Richteri observationes chirurgicae. 12mo. $17 \% 0$. 
River. prax. Riverii praxis medica. 12mo. 1658. Riv. monop. Rivini ordo plantarum quac sunt flore irregulari monopetalo. Fol. 1690.

Riv. tetrap. Rivini ordo plantarum quae sunt flore irregulari tetrapetalo. Fol. 1691.

Rob. ic. 319 plates of plants engraved by Robert Bosse and Chastillon, in folio, given by Lewis $\mathrm{XIV}, \mathrm{XV}$, and $\mathrm{XVI}$ to distinguished botanists.

Roberts. Robertsons observations on jail fever. Sro. 1789.

Robs. Robsons british flora. 8vo. 1777.

Rollo on diabetes. 8 vo. 1793 ; - ed. 1 st 2 vols. 8 vo. 1797. Rosenst. Rosenstein on the diseases of children. 8vo. 1776.

Roth catalect. Roth catalecta botanica. Tomi 2. Svo. 1797.

Roth germ. Roth flora germanica. Tom. I. II. IIItii pars I. 8vo. 1788. to 1800 .

Rottb gram. Rottboll desçriptiones et iconeș rariorum plantarum. fol. 1773.

Rox. Roxburghs plants of the coast of Coromandel. 2 Vols. fol. 1795.

Roy. Royen florae leydensis prodromus. 8vo. 1740. Rudb. rel. Reliquiae Rudbeckianac. fol. 1789.

Rumph. Rumphii herbarium amboinense. Tomi 7 . fol. 1750 .

Rupp. ab Hall. Ruppii flora jenensis ab Hallero. $12 \mathrm{mo} .1745$.

Rush medical inquiries. 5 vols. 8 vo. 1789.

Russ. oecon. Russells oeconomy of nature. \$ro. 1755. Russ. seu wat. Russel on sea water. 12mo. 1760. Rutty. Rutty materia medica. 4to. 1775.

Sal. $R$. hort. Salisbury prodromus stirpium in horto ad Chapel Allerton vigentium. 8vo. 1796. 


\section{ABBREVIATIONS EXPLAINED. XXXiX}

Sal. $R$. ic. Salisbury icones stirpium rariorum. fol. 1791.

Sal. R. par. Paradisus Londinensis. Ato. 1806.

$S_{a l}$. W. Salisburys, W. hortus paddingtonensis. Svo. 1797.

Sauv. chefs d'oeuvres de M. de Sauvages. 2 tomes. 1770.

Saur. nos. Sauvages nosologia. Tomi 2. 4to. 1768.

Schaeff. Schaeffer fungorum qui in Bavaria et Palatinatu circa Ratisbonam nascuntur icones. 'Tomi 4. 4to. 1769.

Scheuch.J. agrost. Scheuchzeri agrostographia. 4to. 1719.

Scheuch. J. Jac. itin. Scheuchzeri, J. Jac. OrPEII$\Phi 0 / T H \Sigma$ helycticus, sive itinera alpina. Itin. 3. 4to. 1708.

Schmid. Schmidel icones plantarum. Tomi 2. fol. 1762. 1776.

Schoepf. Schoepf materia medica americana. 8 vo. 1787.

Schreb. gras. Schreber beschreibung der graser. fol. 1774.

Schrel. ic. Schreber icones plantarum. fol. 1766.

Schreb. lips. Schreberi spicilegium florae lipsicac.

8 vo. 1771 ; consp. means a catalogue of plants following p. 148.

Schrod. Schroderi pharmacopoeia medico-chymica. 8vo. 1672.

Scop. (in the medical references) Scopoli funda* menta botanica. 8vo. 1786.

Scop. carn. Scopoli flora carniolica, cd. 2. Tomi 2. 8vo. 1772 ,

Scop. insubr. Scopoli florae et faurae insubricac partes 3. fol. 1786. 
Seb. Sebac thesaurus. Tomi 4. fol. 1734.

Seg. Seguier plantae veronenses. Tomi. 3. 8vo. $17 \pm 5$. Shaw. Shaws travels. fol. 1738.

Silb. Sibbald scotia illustrata. fol. 1681.

Sibth. ox. Sibthorp, J. llora oxoniensis. 8vo. 1794.

Silth. prodr. Sibthorp, J. florac graecac prodromus. 'Tom. Ius. 8vo. 1806.

Sims, James epid. Sims on epidemic disorders. 8vo. 1776.

Sloane cat. Sloane catalogus plantarum quae in Jamaica proveniunt. 12mo. 1696.

Sloane hist. Sloanes voyage to the islands Madera Barbados Nieves St. Christophers and Jamaica. 2 Vols. fol. 1707.

Smell. thes. Thesaurus medicus, sive disputationum in academia edinensi delectus. Tomi 4. 8vo. 1778. Smilh brit. Smith flora britannica. Tomi 3. 8vo. 1800.

Smith engl. English botany. 8vo. 1790.

Smith exot. Smiths exotic botany. 2 vols. 8vo. 1804. Smith ic. Smith plantarum icones. Fasc. 3. fol. 1789. Smith new holl. Smiths specimen of the botany of New Holland. 4to. 1793.

Sinith pict. Smith icones pictae plantarum rariorum. Fasc. 3. fol. 1790.

Smith spicil. Smith spicilegium botanicum. Fasc. 2. fol. 1791.

Smilh tracts. Smiths tracts. 8vo. 1798.

Sole. Sole menthae britannicae. fol. 1798.

Sonner. nouv. guin. Sonnerat voyage a la Nouvelle Guinec. Ato. 1776.

Sonnini travels translated by Hunter. 3 vols. Svo. Southw. ess. Medical essays abridged from the me- 
moirs of the royal academy by T. Southwell. 4 vols. Svo. 1764.

Spal. Spalowsky de cicuta \&c. 8vo. 1777.

Spielm. Spielmann institutiones materiae medicae.

Sro. 1774.

Stackh. Stackhouses nereis britannica. fol. 1795.

Slap. Theophrasti historia plantarum a Bodaco a

Stapel. fol. 1644.

Stark works. 4to. 1788.

Sterl. Sterbeck theatrum fungorum. 4to. 1675.

Still. Stillingfleets miscellaneous tracts. 8vo. 1762.

Stoll aph. Stoll aphorismi. 8vo. 1786.

Stoll med. Stoll ratio medendi. Partes 3. Sro. 1777.

Storck cicut. Storck de cicuta libellus secundus. 8 ro. 1761.

Storck colch. Storck de colchico. 8vo. 1763.

Storck flamm. Storck de flammula jovis. 8vo. 1769.

Storck medicam. Storck de novis suis medicamentis. 8ro. 1765.

Storck stram. Storck de stramonio hyosciamo aconito. 8ro. 1762.

Storck pulsat. Storck de pulsatilla. 8vo. 1771 .

Swart ic. Swartz icones plantarum. fol. 1794.

Swartz obs. Swartz observationes botanicae. Svo. 1791.

Swartz occid. Swartz flora indiae occidentalis. Tomi 3.8 80. 1797.

Swartz prodr. Swartz nova genera et speciẹs plantarum. 8vo. 1788.

Süert. Swertii florilegium. Tomi 2. fol. 1612.

Sxiiet. Swicten commentaria. Tomi 5. 4to. 1745.

Syd. Sydenham opera. 8vo. 1726.

Symes. Symess account of Ava. 3 Vols. 8 vo. with a vol. of plates in 4tu. 1800. 
Tab. ic. Tabcrnaemontani eicones plantarum. Long 8 vo. 1590 .

Thal. Thalii sylva hercynia. 4to. 1588, (at the end of Cain. hort.)

Theophr. Theophrasti historia plantarum. Gr. et Lat. a Bodaco a Stapcl. fol. 1644.

Thomps. Botany displayed by J. Thompson. 4 numbers. 4to. 1798. 'The author sent me down the 1st number with my name in the tirle page without my having had the least concern with it.

Thornt. Thorntons new family herbal. 8vo. $18: 0$.

Thunb. cap. Thunberg prodromus plantarum capensium. Pars 1. 8vo. 1794.

Thunb. eric. Thunberg de Erica, curante Ricardo Salisbury. 4to. 1800.

Thunb.jap. 'Thunberg fora japonica. 8vo. 1784. Tilli. Tilli hortus pisanus. fol. 1723.

Tourn. (in the medical references) Traité de la matiere medicale, par M. Tournefort. 2 tomes. $12 \mathrm{mo} .1717$.

Tourn. cor. Tournefort corollarium. 4to. 1703. at the end of the inst.

Tourn. hort. Tournefort catalogus horti parisiensis in Schola botanica edente S. W. A. (Shcrardo Wilheluo Angrlo ?) 12mo. 1689.

Tourn. inst. 'lournefort institutiones rei herbariae. Tomi 3. 4to. 1700.

Toum. paris. Tournefort histoire des plantes qui naissent aux environs de Paris. 12mo. 1698; cd. ii. 2 tomes. 1725.

Tourn. voy. Voyage into the Levant by M. Tournefort. 2 Vols. 4to. 1718.

Tr. coll. phil. Transactions of the college of Philadelphia. Svo. 1793. 
Tr. med. soc. Transactions of the medical society of London: Svo. 1810.

$T r$ soc. impr. Transaclions of a society for the improventent of inedical arid clirurgical knowledge: 2 vols. 8vo. 1793.

Tracts relative to botany translated (by M. Konig.) 8vo. 1785, a work meriting continuance and the encouragement of every lover of botany in Britain and the United States.

Trag. Tragi commentarii, interprete Kybero. 4to. 1552.

Trew.. sel. Trew plantae selectae, quarum imagiries pinxit G. D. Ehret. fol. 1750.

Triumf. obs. Triumfetti observationes. Ato. 1685.

Trolt. Trotters medlicina nautica. Vol. 20d. 8vo.' 1799. Turn. W. Turners new herball. fol. lst ed. 1551;

2nd ed. 1568.

Turn. S. Turner, S. embassy to Tibet. Ato.

Und. Underwoorl on diseases of children. 3 vols. $12 \mathrm{mo}$.

Vahl. ecl. Vahlii eclogae americánae. fol. 1796.

Vahl. enum: Vahlii enumeratio plantarum. Tóni 2. 8 vo. 1805.

Vahl. symb. Vahlii symbolae botanicae. Partes 3. fol. 1790.

Vaill. par. Vaillant botanicon parisiense. fol, 1727.

Vent. tabl. Ventenat tableau du regne vegetal. 4 tomes. 8vo. L'an 7. (1799.)

Vesl. Veslingii de plantis acgyptiis observationes. Ato. 1638.

Vill. Villars histoire des plantes de Dauphine. 8 tomes. 8vo. 1786.

Vog. Vogel historia materiae medicae. 12mo. 1764. $\mathrm{d} 4$ 
Vog. prael. Vogel praelectiones de cognoscondis et curandis corporis humani affectibus. 8vo. 1772.

Volck. Volckameri flora noribergensis. 4to. 1700.

Wach. Wachendorff horti Ultrajectini index. 8vo. 1747.

Wade. Wade catalogus plantarum in comitatu dublinensi inventarum. 12mo. 1794.

Walc. Walcotts fora britannica. 8vo. 1778.

Wall, J. Walls tracts. 8vo.

Wall, Mart. on opium in fevers. 8vo. 1786.

Walt. Walter flora caroliniana. 8vo. 1788.

Walth. Designatio plantarum quas hortus Waltheri complectitur. 8vo. 1735.

Warn. Plantae woodfordienses. 12no. 1771.

Febst. Medicinae praxeos systema ex academiae edinburgenac disputationibus inauguralibus digestum a C. Webster. Tomi 3. 8vo. 1781.

Westmac. Historia vegetabilium sacra, or scripture herbal, by W. Westmacot. 12mo. 1695.

Whately on ulcers of the legs. 8vo. 1799.

White. Whites voyage to New South WVales. 4to. 1790.

Whylt dropsy of the brain. Svo. 1768.

Wieg.obs. Weigel observationes botanicac. 4to. 1772. Willes on Jropsy. 8vo. 1777.

Willan cutan. Willan on cutaneous discases. Ato. 1798.

Willan lond. Willans diseases of London. $12 \mathrm{mo} .1801$. Hilld. ber. Willdenow florae berolinensis prodromus. 8vo. 1787.

Willd. phyt. Willdenow phytographia. ful. 1794.

Willich ill. Willich illustrationes quaedam botanicae. $12 \mathrm{mo} .1766$.

Willich obs. Willich de plantis quibusdam observationes. 12 mo. 1762. 


\section{AbBreviations explained. xlv}

Wils. brit. Wilson, J. synopsis of british plants. 8 ro. 1744.

Wils. febr. Wilson, Alex. on febrile diseases. 4 vols. 8vo. 1799.

With. forgl. Withering on the foxglove. 8vo. 1785 . With. scar. Withering on scarlet fever. 8vo. 1779. Woodv. Woodvilles medical botany.4 vols. 4 to. 1793. Zanich. Zanichelli istoria delle piante. fol. 1735.

Zanon. Zanoni istoria botanica. fol. 1675.

Zanon. a Mont. Zanonii rariorum stirpium historia. fol. 1742 .

Zarda pharmaca vegetabilia juxta pharmacopeam austriaco provincialem. 8 vo. 1782.

? subjoined to any of the botanical references expresses my doubts whether such plants furnish the article of medicine or food treated of.

?? expresses doubt amounting almost to disbelief. 


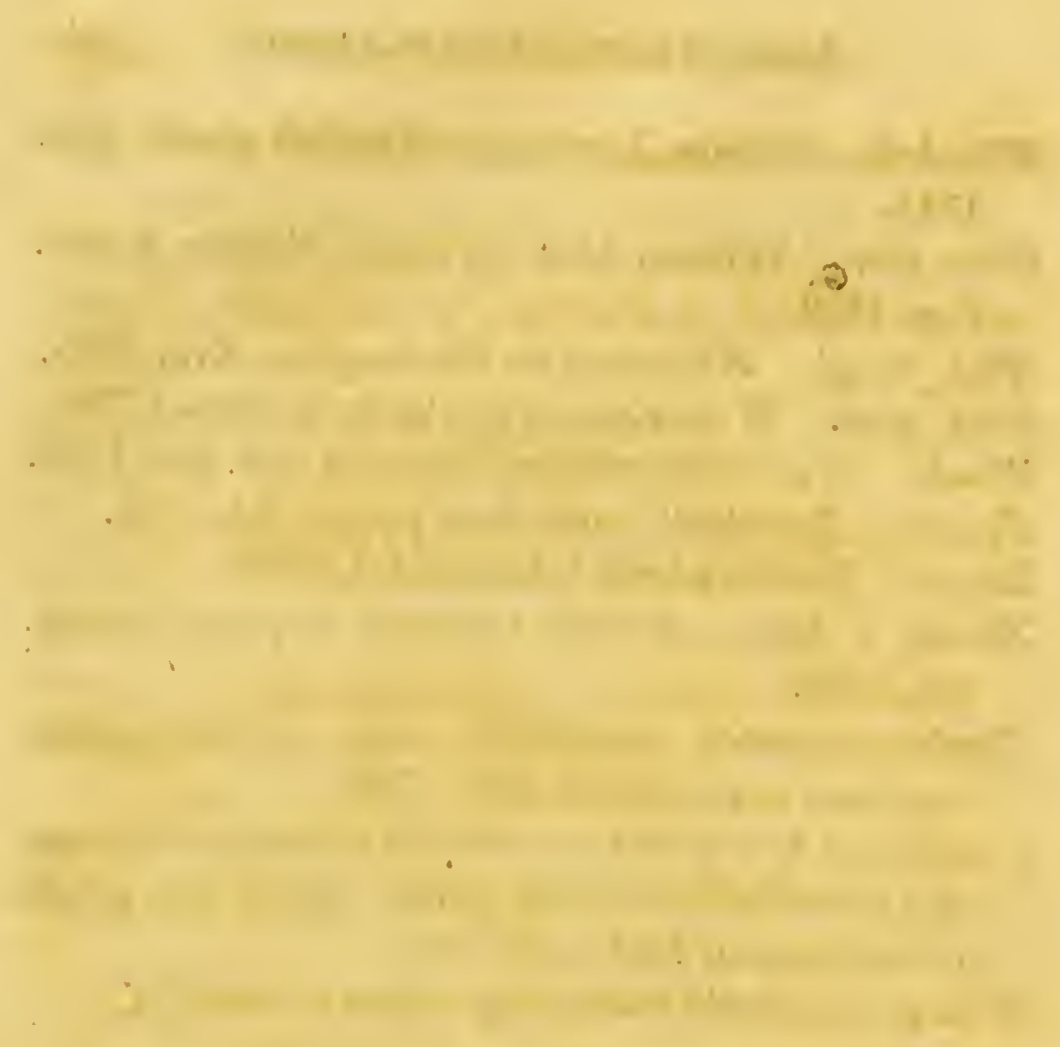




\title{
CHARACTERS
}

\author{
OF THE
}

\section{CLASSES AND ORDERS.}

I. Flowers if existing either not found, or so minute as not to be distinguishable without highly magnifying microscopes.

Class 23. CRYPTOGAMIA. Vol. iv. 581.

Order 1. MONOECIA. Stamina and pistils mostly found on the same plant. Vol. iv. 581.

Order 2. DIOECIA. Stamina and pistils found on different plants. Vol. iv. 582.

Order 3. GYNOECIA. Plants producing fruit, but no flowers hitherto discovered. Vol. iv. 582.

II. Flowers with stamina on one plant, and flowers with pistils on another.

Class 22. DIOECIA. Vol. iv. 485.

1. Male flowers. Stamina united.

Order 14. SYNGENESIA. Antherae united. Vol. iv. 495.

Order 13. MONADELPHIA. Filaments united. Vol. iv, 495. 
xlviii SYNOPSIS OF

2. Male flowers. Stamina distinct.

Order 1. MONANDRIA. Stamen 1. Vol. iv. 485. Order 2. DIANDRIA. Stamina 2. Vol.iv. 486. Order 3. TRIANDRIA. Stamina 3. Vol. iv. 487. Order 4. TETRANDRIA. Stamina 4. Vol. iv. 488.

Order 5. PENTANDRIA. Stamina 5. Vol. iv. 489.

Order 6. HEXANDRIA. Stamina 6. Vol. iv. 491.

Order 7. OCTANDRIA. Stamina 8. Vol. iv. 492.

Order 8. ENNEANDRIA. Stamina 9. Vol. iv. 492.

Order 9. DECANDRIA. Stamina 10. Vol. iv. 492.

Order 10. DODECANDRIA. Stamina .12 to 19. Vol. iv. 493.

Order 11. ICOSANDRIA. Stamina 20 and more, inserted into the inside of the calyx. Vol. iv. 494.

Order 12. POLYANDRIA. Stamina 20 and more, inserted into the receptacle. Vol. iv. 494.

3. Female flowers.

Order 1. MONOGYNIA. Style or stigma 1.

(1.) Flowers naked.

914. TropuIs.

Style 1. Berry monospermons. 
918. Cras,

$$
\text { Style 1. Drupe. }
$$

(2.) Flowers bracteate.

901. BRosIMUN.

915. Batis.

903. Cissampetos:
Style 1. Berry monospermous.

Stigma 1. Berry tetraspermous.

Style 1. Drupe monospermous.

(3.) Flowers nectariferous.

905. SAlII.

Style 1. Capsule unilocular. Seeds pappose.

(4.) Germen superior. Flowers incomplete.

949. TAXUS。

904. Ceeropia.

980. Baccaurea.

938. Populus.

946. SitgMAROTA.
Stigma 1. Drupe surrounded below by a pulp. Calyx polyphyllous. Nectarium very short, surrounding the base of the germen. Obs. 8956.

Stigma 1. Berry monospermous. Calyx bifid. Style none. Germen didymous.

Stigma 1, lenticular. Berry trilocular and quinquelocular. Calyx pentaphyllous.

Stigma quadrifid. Capsule bilocular. Seeds pappose.

Sligma rotate, sexfid. Berry unilocular, polyspermous. 
939. Mercurialis. Stigma bipartite. Capsule dicoccous. Calyx tripartite.

940. Tetranthera. Style 1. Berry. Calyz partite. Stigma sublobate.

952. Ruscus.

Style 1. Berry trilocular. Caly $x$ hexaphyllous. Nectarium ovate.

951. Myristica. Siyle 1. Berry monospermous. Seed arillate. Calyx trifid.

919. HipPophaE.

Style 1. Berry monospermous. Calyx bifid. Germen roundish. Stigma twice as long as the calyx.

(5.) Germen superior. Flowers complete.

913. Phoenix.

Style 1. Drupe monospermous. Calyx monophyllous.

922. Canarium.

Style 1. Drupe monospermous. Calyx diphyllous.

(6.) Germen inferior. Flowers incomplcte.

947. Treuis.

909. Osyris.

916. Viscum.

931. TAMUS.
Capsule tetracoccous.

Berry monospermous. Calyx trifid.

Berry monospermous. Calyx tetraphyllous.

Berry trilocular. 
Order 2. DIGYNIA. Styles or stigmata 2.

(1.) Germen superior. Flowers incomplete.

Styles and sligmala 2.

927. Humurus.

926. CANNabis.

920. MYRICA.

923. Picramaia.

910. Stilago.
Seed 1. Calyy entire.

Nut bivalve. Calyx gaping on one side.

Berry monospermous. Calyx diphyllous.

Berry bilocular and trilocular. Calyx tripartite and quinquepartite.

Drupe. Calyx urceolate.

(2.) Germen superior. Flowers incomplete. Pistils 2. 950. Ephedba. Seeds 2.

Order 3. TRIGYNIA. Styles or stigmata 3.

(1.) Flowers incomplete. Germen inferior.

914. Datrsca. Capsule unilocular.

933. Dioscorea. Capsule trilocular.

(2.) Flowers incomplete. Germen superior.

912. Caturus.

Capsule tricoccous. Calyx tripartite.

911. Excoecaria. Capsule tricoccous. Calyx diphyllous and triphyllous. Stigmata simple. 
902. Соммза.

Capsule tricoccous. Calyx triphyllous. Stigmata thickish.

945. FrACOURTIA.

Berry unilocular.

Calyx pentaphyllous.

932. Sminax.

Berry trilocular. Calyx hexaphyllous.

934. Fibraurea.

Berries 3, monospermous. Petals 6.

921. Pistacia.

Drupe. Calyx trifid.

(3.) Flowers complete.

929. Clytia.

Capsule trilocular. Calyx pentaphyllous. Petals 5 .

935. Braunea.

Berry tricoccous. Calyx triphyllous. Pelals 3.

942. Scilinus.

Berry trilocular. Caly $x$ quin. quepartite. Petals 5.

937. LIMACIA.

Drupe. Calyx hexaphyllous. Pelals 6.

907. Juniperus.

Drupe trispermous. Calyx poly phyllous.

Order 4. TETRAGYNIA. Styles or stigmata 4. 925. Spinacia. Pistil 1. Seed 1.

918. Gonus.

Pistil1. Drupes4.

917. BRUCEA.

Pistils 4. Neclarium quadrilobate. 
484. Sedum.

Pistils petails and nectaria 4. Obs. 2745 from $\mathbf{S}$. dioicum.

295. Hrdnocarpes. Stigmata 4. Berry unilocular. Order 4. PENTAGYNIA.' Styles or stigmata 5.

(1) Germen superior. Flowers incomplete. 924. Antidesua. Stigimati 5. Berry monospermous.

(2) Flowers complete. Germen superior.

941. Carica.

4S8. Lychis.

Stigmata 5. Berry unilocular. Styles 5. Capsule unilocular.: Petals 5, unguiculate. $\mathrm{Ca}$ lyx semiquinquefid. Obs. 4715, from L. dioica.

913. Coriakia. Pistils and Capsules 5.'

(3) Germen inferior. Flowers complete. 928. Feurllea. Siyles 5. Berry trilocular. Order 5. HEXAGYNIA. Styles or stigmata 6. 515. Stratiotes.

Styles 6, bipartite. Berry sexlocular and octolocular. Petals 3. Calyx trifid. Nectaria many.

Order 6. ENNEAGYNIA. Styles or stigmata 9. 908. Empetrum. Berry. Petals 3. Calyx tripartite.

Order 7. POLYGYNIA. Styles or stigmata many. 900. PandanUs. Fruit compound.

III. Stamina and pistils on the same plant but not in the sume flower.

Class 21. MONOECLA. Vol, iv. 306.

1. Male flowers. Stamina united. 
Order 12. SYNGENESIA. Vol. iv. 318. Order 11. MONADELPHIA. Vol. iv. 315. 492: Henitera. Antherae 5 to 10. Calyx quinquefid. Corolla none.

703. INGA. Stamina many. Calyx quinquefid. Corolla quinquefid.

2. Male flowers. Stamina distinct.

Order 1. MONANDRIA. Stamen 1. Vol. iv. 306. Order 2. DIANDRIA. Stamina 2. Vol. iv. 308. 17.1. Ophroхуцим. Calyx quinquefid. Coralla quinquefid. Nectarium cylindric. Antherae inserted into the nectarium.

Order 3. TRIANDRIA. Stamina 3. Vol. iv. 308. 52*. SPINIFEX.

Bracteae 2, uniflorous and biflorous. Calyx diphyllous. See Vol. i. 185.

81.." Androrogon. Bracteae none. Calyx diphyllous. Petal 1, linear.

Order 4. TETRANDRIA. Stamina iv. Vol. iv. 310.

874. THUIA.

Flowers bracteate. Antherae unilocular.

920. MynICA.

Flowers bracteate. Anthereae bilocular. From M. Gale. Obs. 8954.

78. GALIUM.

Calyx none. Corolla quadrifid. Obs. 8970 , from $G$. Cruciata.

Order 5. PLNTANDRIA. Stamina 5. Vol. ip. 311. 


\section{Classes and Orders.}

238. CELTIS.

Calyx quinquepartite and sexfid. Corolla none.

182. Govanta.

Caly $x$ quinquefid. Petals 5; inserted into the calyx.

Order 6. HEXANDRIA. Stamina 6. Vol. iv. 312.

311. KERNERA.

Flowers naked. Antherae sessile.

850. Betula.

Bräcteae multifid; segments incumbent, the outermost peliate. Obs. 8949, from B. alba.

364. VERATRUM.

Calyx none. Petals 6. $R u$. diment of a pistil.

Order 7. OCTANDRIA. Stamina 8. Vol. iv. 313.

400. ACEr.

Caly $x$ quinquefid and sexfid. Petals 5 and 6. Nectarium orbicular. Stigma. Obs. 89̈59, from A. campestre.

Order 8. DECANDRIA. Stamina 10. Vol. iv. 313.

468. Terminalia. Caly $x$ quinquepartite. Corolla none. Nectaria 5 .

435. Feronia.

Calyx quinquepartite. $\overline{\boldsymbol{P}}$ tals 5. Rudiment of a pistil.

400. ACER,

Calyx quinquefid and sexfid. Petals 5 and 6. Neciarium orbicular. Rudiment of a pistil. Obs. 8948, from A. Pseudoplatanus.

c 2 
Order 9. DODECANDRIA. Stamina 12 to 19. Vcl. iv. 314.

Order 10. POLYANDRIA. Vol. iv. 314.

545. ACAGIA.

Calyx quinquedentate. Corolla quinquefid.

555. Crusia.

Calyx imbricate. Petals 4 to 6 .

3. Female flowers.

Order 1. MONOGYNIA. Style or stigma 1.

(1) Flowers naked.

826. Zostera.

Style 1. Capsule monos: permous.

832. Artocarpus. Style 1. Berry monospermous.

893. NIPA,

Drupe. Stigma a lateral furrow.

827. ARUM:

Stigma orbicular. Berry polyspermous. Obs. 89:7, from A. maculatum, but $M$. Jussieu says monospermous and polyspermous. $\mathrm{Mr}$. Brown proposes to divide the genus into 2.

829. Caladium.

Stigma umbilicate. Berry polyspermous. From $L$. $a$ Will. but Mr. Brown says " monospermous?"

829. Calla. Style 1. Berry polyspermous.

(2) Flowers naked, intermixed with bracteae. 830. Prafanus. Style 1, permanent. Seed I. 
(3) Flowers bracteate.

891. GNetum.

Stigma trifid and quadrifid.

Drupe.

(4) Germen superior. Flowers incomplete.

890. T'rpha.

Style 1. Seed 1. Calyx capillary:

841. CAREX.

859. AMBROSIA.

898. Dorstbnia.

102. Parietaria.

858. VANIERIA.

815. Ficus.

839. ZEA.

223. AtripLEX.

853. URTICA.

812. Scleria.

844. TRAGIA.
Style 1. Seed 1. Calyx ampullaccous.

Style 1. Seed 1. Calyx bidentate at the end, with 4 teeth on the outside.

Style 1, bifid. Seed 1. Calyx quadridentate, prismatic.

Style 1. Seed 1, ovate. Cas $l_{y x} x$ quadrifid. Stigma round, hirsute. Obs. 7484.

Style 1. Seed 1, lenticular. Calyx quadripartite.

Style 1. Seed 1. Calyx quinquepartite.

Style 1. Stigma 1. Seed 1. Calyx diphyllous.

Style 1, bipartite. Seed 1, orbicular, compressed. $C a$. lyx diphyllous.

Stigma 1. Seed 1. Calyx tetraphyllous.

Style 1. Nut. Calyx diphyllous triphyllous and tco traphyllous.

Style 1. Capsule tricoccous. Calyx quinquepartite. e 3 
882. ОмтнаLEA.

876. Plukenetia.

892. HurA.

864. SAGUS.

884. Pipalia.

849. Tricarium.

834. Salisburia?

887. Hippomane.

835. Sparganium.
Style 1. Capsule tricoccous. Calyx pentaphyllous.

Style 1. Capsule tetracoccous. Pctals 4.

Style 1. Capsule duodecimloculiar.

Style 1. Berry monospermous. Calyx triphyllous:

Siyle 1. Berry monosperm. ous:

Stigma 1. Berry trilocular. Calyx quadripartite. Stig. ma 1, laciniate.

Style and Stigma unknown. Drupe. Calyx quadrifid.

Style 1. Drupe. Calyx triphyllous.

Style 1. Wrupe juiceless. Caly $x$ triphyllous and tetraphyllous.

(5) Germen superior. Flowers complete.

862. BACTRIS.

Style 1.

Drupe.

865. Caryota.

545. ACACrA.

810. Cors.

863. Elate:
Style 1. Corolla tripartite. Berry unilocular, dispermous.

Style 1. Legumen. Corolla quinquefid. Caly $x$ quinquedentate.

Style 1. Petals 2. Seed 1. Calyx diphyllous.

Style 1. Petals 3. Drupe.

Caly $x$ tridentate. 


\section{Classes and Orders.}

555. Ceusia.

Stigma peltate. Capsule quinquelocular. Caly $x$ imbricate. Petals 4 to 6. Nectarium.

S46. Hernandia. Style 1. Petals 8. Drupé.
Calyx entire.

(6) Germen inferior. Flowers incomplete. 836. Cynomorium. Style 1. Seed 1. Cilyx tetraphyllous.

869. Quzbcus.

Style trifid. Nut. Calyx sexifid. Obs. 8967.

870. Fagus.

Style trifid. Capsule formed from the involucrum, containing 2 and 3 nuts. Calyx hexaphyllous.

883. Srrtingta. Style 1. Capsule trícoccous. Corolla infundibuliform.

884. Crtinus. Style 1. Berry octolocular. Corolla campanulate.

(7) Germen inferior. Flowers complete. 788. TaNACETUM. to

819. Sphamranthus. Calyx pappose, quinquedentate and none. Corolla monopetalous, tubular and ligulate. Seed 1. See Vol. iv. 175 to 180.

895. MOMORdiCA.

Style 1. Corolla monopetalous. Capsule trilocular, opening elastically.

8е8. Sесніим. Style 1. Corolla monopetalous. Berry inonospermous.

898. Bryonis. Style 1. Corolla monopetalous. Berry polyspermous, unilocular. c 4 . 
894. Trichosanthes, Style 1. Corolla monopctalous, ciliatc. Berry polyspermous, trilocular.

897. Cucums. Slyle 1. Corolla monopetalous, quinquefid. Berry polyspermous, trilocular.

896. Cucurbita.

Style 1. Corolla monopetal. ous, quinquepartite. Berry polyspermous, trilocular.

899. Muricia.

Style 1. Corolla pentapetalous. Berry unilocular.

Order 2. DIGYNIA. Pistils styles or stigmata 2.

(1) Flowers bracteate.

851. AcNus.

Pistils 2. Seeds 2, angular.

850. Betula.

Pistils 2 and 3. Séeds 2 and 3, winged. Bracteae trilo. bate. Obs. 8949.

875. Cupressus.

Pistils 2. Nuts 2, angular. Bracteae entire. Obs. 8961.

874. ThuтA. Pistils 2. Nuts 2, winged. Bracteae entire.

873. Pinus.

Pistils 2. Nuts 2, winged. Bracteae double.

831. Moretha.

Styles 2. Drupe. Nut bilocular.

(2) Germen superior. Flowers incomplete. 320. MYrica.

Styles 2. Berry monospermous. Calyx diphyllous. From M. Gale.

843. Comptonta, Styles 2. Nut. Calyx bexaphyllous. 
854. Morus.

Styles 2. Berry monospermous. Caly $x$ tetraphyllous.

857. Xanthium: Styles 2. Capsule bilocular, birostrate, formed of the indurated calyx.

853. Liquidambar. Pistils 2. Capsules 2, unilo. cular. Seeds winged.

S56. Nephelium.

Pistils 2. Drupes 2. Calyx quadridentate.

(3) Germen superior. Flowers complete. S89. Aleurites. Stigmata 2. Berry dicoc. cous. Calyx trifid. Petals and nectaria 5 .

861. Zizania.

Styles 2. Seed 1. Caly.x diphyllous. Petals 2.

867. Poteriom.

Pistils 2. Capsules 2.' Calyx quadridentate. Petals 4.

(4) Germen inferior. Flowers incomplete.

871. CORYLUS.

Styles 2. Nut. Calyx diphyllous.

(5) Germen inferior. Flowers complete. 868. Juglans.

Style bipartite. Drupe. Corolla quadripartite.

Order 3. TRIGYNIA. Pistils styles or stigmata 3.

(1) Germen superior. Flowers incomplete.

855. HeveA.

880. Ricinus.

860. Araragthus. Styles 3. Capsule circumscinded, monosperinous. 
847. Payllantuus, Styles 3, bifid. Capsule tricoccous. Calyx sexpartite. Nectarium.with 12 teeth.

886. SARIUM. Styles 3. Capsule tricoccous. Calyx semitrifid.

881. AgYneia. Styles 3. Capsule tricoccous and multilocular. Calyx hexaphyllous.

877. Croton. Styles 3, bifid trifid and qua. drifid. Capsule trilocular. Calyx decaphyllous pentaphyllous and quinquepartite.

852. Bữus.

Styles 3. Capsule trilocular, trirostrate. Calyx polyphyllous.

(2) Germen superior. Flowers complete.

879. Iatropha. Styles 3, bifid. Capsule trilocular. Calyx pentaphyllous and quinquepartite.

(3) Germen inferior. Flowers complete. 866. Begonia.

Styles 3, bifid. Capsule trilocular and bilocular, polyspermous. Caly $x$ diphyllous and none. Petals 5, $6 \& 4$.

Order 4. POLYGYNIA. Pistils styles or stigmata many.

878. Tridesmis. Styles 15 to 20 , in 3 fascicula. Capsule trilocular.

IV. Slamina and pistils in the same flower. Stamina inserted into the pistil.

Class 20. GYNANDRIA. Vol. iv. 285. 
V. Stamina and pistils in the same flower. Antherae anited by their margins, forming a kind of

cylinder.

Class 19. SYNGENESIA. Vol. iv. 102.

Order 1. MONOGAMIA. All the flowers with stamina and a pistil. Vol. iv. 102. 175.

Order 2. POLYGAMIA SUPERFLUA. Flowers of the disc of the anthodia with stamina and a pistil, those of the circumference of the anthodia with a pistil. Vol. iv. 175.

Order 3. POLYGAMIA FRUSTRANEA. Flowers of the disc of the anthodia with stamina and a pistil, those of the circumference neutral with the rudiments of stigmata. Vol. iv. 178.

Order 4. POLYGAMIA NECESSARIA. Flowers of the disc of the anthodia with stamina and a pistil, with a clavate stigma, those of the circumference of the anthodia with a pistil. with frliform stigmata. Vol. iv. 179.

VI. Stamina and pistils in the same flower. Filaments united.

Class 16. MONADELPHIA. - Filaments united into one body. Vol. iii. 488.

Order 1. TRIANDRIA. Stamina 3. Vol. iii. 188. Order 2. TETRANDRIA. Stamina 4'. Vol. iii. 488. Order 3. PENTANDRIA. Stamina 5. Vol. iii. 488. Order 4. HEXANDRIA. Stamina 6. Vol. iii..489. Order 5. HEPTANDRIA. Stamina 7. Vol: iii. 489. Order 6. OCTANDRIA. Stamina 8. Vol. iii. 490. Order 7. DECANDRIA. Stamina 10. Vol. iii. 490. Order 8. DODECANDRIA. Stamina 12 to 20. Vol. iii. 492. 
lxiv

Order 9. POLYANDRIA. Stamina more than 20. Vol. iii. 492.

Class 17. DIADELPHIA. Filaments united in to 2 bodies. Vol. iv. 1.

Order 1. HEXANDRIA. Stamina 6. Vol. iv. 1. Order 2. DECANDRIA. Stamina 10. Vol. iv. 1. 735. ROBINIA.

Calyx with 5 divisions and entire. Legumen polysperm. ous. Obs. 8976 , from $R$. violacea.

Class 18. POLYADELPHIA. Filaments united into more than 2 budies. Vol. iv. 81.

Order 1. DECANDRIA. Stamina 10. Vol. iv. 81.

Order 2. DODECANDRIA. Stamina 12 to 19. Vol. iv. 81.

Order 3. ICOSANDRIA. Stamina 20 and more, inserted into the inner side of the calyx. Vol. iv. 82.

Order 4. POLYANDRIA. Stamina 20 and more. Vol. iv. 82.

VII. Stamina and pistils in the sume flower. Stamina distinct.

Class 1. MONANDRIA. Stamina 1. Vol.i.1.

Class 2. DIANDRIA. Stamina 2. Vol. i. 9.

Order 1. MONOGYNIA. Style or stigma 1. Vol. iv. 55.

837. LenNa.

Style 1. Calyx monophyls lous diphyllous and none. Corolla none. Capsule unie locular.

Order 2. TRIGYNIA. Styles or stigmata 3. 
Class S. TRIANDRIA. Stamina 3. Vol.i. 85. Orier 1. MONOGYNIA. Style or Stigma 1. Order 2. DIGYNIA. . Styles or stigmata 2. 814*. Andropogon. Styles 2. Bracteae none. Caly $x$ diphyllous. Petal 1, linear. Arisla between the inner phyllum and the germen. Seed 1 .

Class 4. TETRANDRIA. Stamina 4, of the same length. Vol. i. $18 \%$

Order 1. MONOGYNIA. Style or stigma 1. Order 2.. DIGYNIA. Styles or stigmata 2. Order 3. TERRAGYNIA. Styles-or stigmata 4.

Class 14. DIDYNAMIA. 'Stamina 4, 2 of which longer than the other 2. Vol. iii. 279. Ordor 1. GYMNOSPERmia: Seeds naked. Vol. iii. 279.

Order 2. ANGIOSPERMIA. Seeds in a seedvessel. Vol. iii. 283.

Class 5. PENTANDRIA. Stamina 5. Vol. i. 244.

Order 1, MONOGYNIA. Style or stigma 1. Vol. i. 244.

Order 2. DIGYNIA.

$$
\text { Vol, i. } 257 .
$$

Styles or stigmata 2.

Order 3. 'TRIGYNIA.

Vol. i. 264.

Styles or stigmata 3.

Order 4. TETRAGYNIA. Styles or stigmata 4. Vol. i. 265.

Order 5. PENTAGYNIA. Styles or stigmata 5. Vol. i. 260. 
300*. Comiaria.

Petals 5. Capsules 5, monospermous.

Order 6. POLYGYNIA. Styles or stigmata more than 5. Vol. i. 266.

Class 6. HEX 1 NDRIA. Stamina 6, of the same length. Vol. i. 195.

Order 1. MONOGYNIA. Style or stigma 1. Vol. ii. 195.

96. Gleditsia.

Calyx quadrifid. Pelals 4. Legumen.

Order 2. DIGYNIA.

Vol. ii, 200.

Styles or știgmata 2.

Order 3. TRIGYNIA.

Vol. ii. 200.

Order 4. POLYGYNIA. Styles or stigmata more than 6. Vol. ii. 202.

Class 15: TETRADYNAMIA. Stamina 6, 2 of which shorter than the other 4. Vol. iii. 419.

Order 1. SILICULOSAE. Fruit roundish. L. gen. 329. Vol. iii. 419.

Order 2. SILIQUOSAE. Fruit long. $\boldsymbol{L}$. gen. 329. Vol. iii. 420.

Class \%. HEPTANDRIA. Stamina 7. Vol. ii. 336.

Order 1. MONOGYNIA. Style or stigma 1. Vol. ii: 336.

Order 2. TETRAGINIA. Styles or stigmata 4. Vol. ii. 336. 


\section{Classes and Orders. Ixvii}

Class S. OCTANDRIA. Stamina 8. Vol. ii. 34 i.

Order 1. MONOGYNIA. Style or stigma 1. Vol. ii. 341.

Order 2. TRIGYNIA. Styles or stigmata 3. Vol. ii. 345.

Order 3. TETRAGYNIA. Styles or stigmata 3. Vol. ii. 345.

Class 9. ENNEANDRIA. Stamina 9. Vol. ii. 410.

Order 1. MONOGYNIA. Style or stigma 1. Vol. ii. 410 .

Order 2. TRIGYNIA. Styles or stigmata 3.

Vol. ii. 410 ,

Order 3. HEXAGYNIA. Styles or stigmata 6.

Vol. ii. 410.

Class 10. DECANDRIA. Stamina 10. Vol. ii. 435.

Order 1. MONOGYNIA. Style or stigma 1. Vol. ii. 435 .

436**. Bospelita.

Germen superior. Capsule trilocular; cells monospermous. Pelals 5. Nectarium shorter than the germen. Vol. 'iv. 700, where erase Filaments inserted into the nectarium.

Order 2. DIGYNIA. Styles or stigmata 2. Vol. ii. 441.

Order 3. TRIGYNIA. Styles or stigmata 3.

Vol. ii. 442.

Order 4. PENTAGYNIA, Styles or stigmata 5. Vol. ii. 443. 
Ixviii Synopsis of Classes and Orders.

Order 5. DECAGYNIA. Styles or stigmata 10. Vol. ii. 445.

Class 11. DODECANDRIA. Stamina 12 to 19. Order 1. MONOGYNIA. Style or stigma 1. Vol. iii. 1.

Class 12. ICOSANDRIA. Stamina more than 19 , inserted into the inner side of the calyx. Vol. iii. 55.

Order 1. MONOGYNIA. Style or stigma 1. Vol. iii. 55.

Order 2. TRIGYNIA. Styles or stigmata 3. Vol. iii. 57.

Order 3. PENTAGYNIA. Styles or stigmata 5. Vol. iii. 57 .

Order 4. POLYGYNIA. Styles or stigmata more than 10: Vol. iii. 58. :

Class 13. POLYANDRIA. Stamina more than 19, inserted into the receptacle. Vol. iii. 161.

Order 1. MONOGYNIA. Style, or stigma 1. Vol. iii. 161 .

Order 2. DIGYNIA. . . Styles or stigmata 2. Vol. iii.164.

Order 3. TRIGYNIA. Styles or stigmata 3. Vol. iii. 164.

Order 4. TETRAGYNIA. Styles or stigmata 4. Vol. iii. 164.

Order 5. PENTAGYNIA. Styles or stigmata 5. Vol. iii. 165.

Order 6. POLYGYNIA. Styles or stigmata more than 10. Vol. iii. 165. 


\title{
Class 1.
}

\section{O N A N D R I A.}

\author{
Order 1.

\section{MONOG Y N I A.}

3. Salicornia. Corolla none. Calyx entire, ventricose.

2. Flowers superior.

2. Maranta. Calyx triphyllous. Corolla multipartite." Style terete, recurvate at the end. Obs. 6847.

1. CANAA. Calyx triphyllous. Corolla multipartite. Style linear. Obs. 8209.

\section{MONOG Y I A.}

\section{CA N N A.}

Calyx superior; triphyllous. "Corolla multipartite; segments incumbent; outer limb of 3 segments. Anthera sessile, inserted into the corolla. Style linear. Capsule with 3 cells. Obs. 6847. L.-Roscoe in linn. trans, viii. 338. t. 20. f. 1 . 
1. CANNA ellipticifolia. Leaves elliptic, with patent veins. Obs. 6847.

C. indica. L. sp. 1. Hort. kero. i. I.

Cannacorus. Rumph.v. 177.t.71.f.2. Segments of the corolla entire.

C. indici rubra. Beysl. aut. ord. ii. $t$. 1. Segments of the corolla entire.

Arundo indica florida latifolia, sive Canna indica. Hist. o.x. s. 8. t. 14. f. 1.

(Meern. Marcgr. bras. 4, has paniculate flowers.) TOZCUITLAPIL XOCHITL. Hernand. 282. a mbra. The whole of the flower reddish. Leaves elliptico-ovate. IIort. kew. i. 1.

C. indica, flore rubro. Park. parad. 376. $t .381 . f$. 1.

Katu Bala. Rheede xi. 85. $t .43$. Two of the segments of the corolla bifid at the end.

Arundo florida. Ger. by Johns. 39.

Arundo indica latifolia. Bauh. J. ii. 489. No fig.

\& lutea. Inner petals erect, yellow. The revolute segment of the nectarium with reddish lines. Leaves ovato-elliptic. Hort. kew. i. 1.

C. indica, flore flavo punctato. Park. parad. 376.

Arundo indica latifolia, flore luteo punctato. Bauh. J. ii. 490. No fig.

Arundo florida, having yellow flowers with red spots. Johns. in Ger. by Johns. 39. No fig.

$\gamma$ coccinea. Inner petals erect, scarlet. The revolute segment of the nectarium yellow, with reddish lines. Leaves ovato-elliptic. Hort. kew. i. 1.

Caly $x$ erect, longer than the germen; phylla ovate, incumbent, the outer rather obtuse, the 2 inner acute, the intermediatc one the longest, the innermost somewhat longer than the outer and somewhat shorter than the intermediate one. Corolla supo 
rior, octopartite and septempartite, with 2 limbs; segments obliquely and obsoletely emarginate at the end ; outer limb of three segments; segments lanceolate, straight, erect, canaliculate, nearly equal, inserted at different heights into the inner limb, whitish purplish or yellowish and greenish above, the innermost spotted above with red; inner $\operatorname{limb} 1 \frac{1}{2}$ as long as the outer, of 5 and 4 segments, somewhat bilabiate, the upper lip formed by the 3 or 2 outer segments, and the lower by the 4th segment; the outer segment when present somewhat smaller than the 2 next, scarlet, the 2 next scarlet, nearly equal, patulous, lanceolate, unequal at the base, one margin being lower, the 4th larger, elliptic below, linear above, orange coloured with scarlet spots and a scarlet margin, the 5th similar to the 4 th, but smaller, bearing the anthera. Anthera in an unexpanded flower appearing as if growing from the margin of the 5th segment, but in the expanded flower appearing like a true stamen, whose filament was wholly consolidated with the petal. Obs. 2721 . ipatens. Hort. kew. i. 1. Three, outer segments of the inner limb of the corolla curvate, scarlet, the 4th revolute, yeliow with red spots. Obs. 6847. In Mr. Sitwell's garden.

C. indica. Curt. mag. t. 454 .

Stem $2 \frac{1}{2}$ feet long, erect. Germen ovali-turbinate, minutely tuberculate. Calyx permanent; phylla ovate, erect, incumbent, membranaceous at the mar-gin, the outermost balf as long again as the germen. Corolla supcrior, deciduous, octopartite; outer limb of 3 segments; segments lanceolate, acute, erect, inserted a little way above the germen, yellow below, greenish above, reddish at the margin; inner limb of 5 segments, the 3 outer reddish 
scarlet, forming a kind of upper lip, erect and linear below, spatulato-lanceolate and recurvate albove; the 4 th forming a kind of lower lip, revolute, yellow below, above yellow with short longitudinal red lines; the 5th lincar, erect, ycllow with short longitudinal red lines, standing midway between the 2 lips. Stamen 1. Filament growing to the outer margin of the 5th petal. Anthera sessile, inserted into the outer margin of the 5th petal, bilocular. Style linear, adhering below to the corolla, rather obtuse at the end, yellow below, reddish and shining above. Pollen white, adhering to one of the sides of the upper end of the style. Obs. 6847.

\section{MARANTA.}

Caly $x$ superior, triphyllous. Corolla, outer limb trifid; inner limb tripartite. Anthera sessile, inserted into the margin of the upper segment of the inner limb of the corolla. Style simple, recurvate at the end. Capsule. Obs. 8479, the account of the corolla and anthera from Swartz. obs. 7. L.-Roscoe in linn. trans. viii. 339. t. 20. f. 2.

1. MARANTA malaccensis. Stem herbaceous, simple. From authors. L. a Willd. i. 14. Burm. GALANGA malaccensis. Rumph. v. 176.t.71.f. 1.

2. MARANT'A arundinacea. Stem herbaceous, branched. Leaves ovato-lanceolate, slightly pilose underneath. L. a Willd. i. 13. L. sp. 2. Hort. kicw. i. 3. Swartz. obs. 8. Cultivated in the IVest Indies.Salisb. R. allert. 5. Roscoe in linn. trans. viii. 339.

Maranta. Browne 112. Cultivated in gardens.-Royen 11. 
Canna indica, radice alba alexipharmaca. Sloane cat. 129, cultivated in gardens in the West Indies, and said to be a native of Dominica; hist. i.253. $t .149$. f. 2. A leaf. Introduced into Jamaica from Barbadoes, and into Barbadoes from Dominica.

Leaves nervose, slightly pilose underneath towards the base; with transverse vcins between the ribs, not readily discernible without a microscope. $C^{\prime} a$ ly. $x$ green; pliylla ensiformi-oblong, erect, longer than the germen. Corolla thin, twice as long as the germen. Stigma angular. Capsule oval, not yet ripe, trivalve, monospermous. Seed oblong, nearly as long as the capsulc. Obs. 8209. Specinen gathered by Dr. Wright in Jamaica.-Leaves, the costa underneath at the base pilose. Obs. 8210. Specimen gathered in Fothergill's garden.

MARANTA arundinacea. Wright in med. journ. viii. 269. Swartz.obs. 8. Clark, James in med. facts vii. 301. Lempriere ii. 223, 233. Murr. J. i. 388. Sagittaria alexipharmaca. Dale 250. Arrowroot. Underw. i. 136; iii. 143. Indian Arrowroot. Chisholm 195. Arrowroot Starch. Graing. 38.

3. MARANTA fruticosa. Stem fruticose. From authors.

M. Tonchat. L. a Willd. i. 13.

ARUNDASTRUM. Rumph. iv. 22. t.7, who describes the corolla as hexapetalous, and the fruit as a drupa.

\section{S A L I C OR N I A.}

Calyx inferior, ventricose, entire. Corolla none. Sligma bifid, Seed 1. Obs. 1771. L. 
1. SALICORNIA herbucea. Leaves perfoliate. Stem herbaccous, branched. Obs. 1771. Specimen gathered at '́eignmouth by Mr. Boraston.-L. sp. 5; a Murr. 52. IIuds. 1. Bot. arrang. i. 3; iii. cxv. Roth. germ. ii. 1. a Smilh brit. 2 a Fl. dan. $t$. 303, cop. in Blacliw. auct. t. 598.

S. annua. Smith. engl. bot. t. 415.

Salicornia. Boerh. ii. 94, where marked as an annual. -Dill. ap. Raii syn. 136.

Kali geniculatum majus simplicius. Raii hist. 211, where described as an annual; cat. $e d .1 .183$; ed. ii. '176.

Kali geniculatum alterum vel minus. Raii syn. $\epsilon d$. i. 39 ; ed. ii. 67, where it is not marked as annual. Kali geniculatum annuum. Magn. monsp. 147.

S. sive Kali. Dalech. 1378, the right hand half.

S. sive Kali geniculatum vermiculatum. Lob. adv. -170 , repr. in ic. i. 395,

Salicornia. Dod. 82, \& S. sive Kali geniculatum. Ger. by Johns. 535, and cop. in Brit. herb. 83, \& Kali geniculatum. Dalech. 1378. \&

Cali geniculatum, sive Salicornia. Bauh. J. iii. 705. (The description belongs to S. fruticosa.) $f .2$. 2. and 3. cop. in

S. sive Kali geniculatum. Park. theatr. 280. n. 2, \&3. Number 1 is original.

S. erecta, foliis brevibus, cupressiformis. Stonestreet ap. R. syn. 137 ?

S. myosuroides procumbens, surculis longissimis. Stonestrect ap. R. syn. 137? Probably when in fruit.

Stem from 3 to 6 inches long, erect. Spikes terete, lineari-lanceolate. Obs. 1771.-Obs. 6842 from Freistone-shore, near Boston, Lincolnshire.-Stem $3 \frac{\mathrm{I}}{2}$ inches long, much branched. Branches very 


\section{Monogynia. 3. Salicomia.}

patent. Spikes terete, lanceolate. Obs. 6843. Specimen gathered by Dr. Cutler in New England, among specinens of $S$. simplex.

SALICORNIA. Bryant 109. Berg. 8. Vog. 117. Soda. Linn. 38. Murr. iv. 284.

9. SALICORNIA simplex. Leaves perfoliate. Stem lierbaceous, simple or with few branches. Obs. 6844. Specimens gathered by Dr. Cutler in New England.

S. virginica. L. a Murr. 52.

Stem 3 and $3 \frac{\pi}{2}$ inches long, erect; or slightly ascending, fuscous, one tenth of an inch thick. Leaves to $2 \frac{\pi}{2}$ tenths of an inch broad. Spikes terete, lanceolato-cylindric. Obs. 6844.

SALICORNIA. Schocpf 1 .

3. SALICORNIA fruticosa. Leaves perfoliate. Stem suffruticose. Obs. 5364. Specimen gathiered on the southern coast of England.-L.-Bot arrang. 3. Smith brit. 3.

Kali geniculatum perenne fruticosius prociumbens. R. syn. ed. i. 39; ed. ii. 67; ed. iii. 156. Found by Sloane in the isle of Shepey and by Dillenius in the isle of Grain.

Kali sempervirens grandius perpetuum. Raii exter. 157. In salt marshes on the coasts of the Mediterranean sea.

Kali geniculatum majus, multis ramis fruticans. Raii hist. 211.

Cali geniculatum, sive Salicornia. Bauh. J. iii. 704. The description. (Fig. 1 is a copy of a portion of S. sive Kali Matthioli. Dalech. 1378.-Fig. 2. n. 1, 2, 3, seem to be S. herbacea.)

Kali geniculatum majus sempervirens. Magn. monsp. 147. 
S. ramosior procumbens, foliis brevibus purpurascentibus. Stonestreet ap. Raii syn. 137?

Stem branclied, brownish green, 9 inches long, diffuse; internodia to $\frac{r}{2}$ incli long, attenuate downwards. Leaves patulous, membranaceous at the margin. Obs. 5364.

SODA. Linn. 39, nole.

4. SALICORNIA glauca. Leaves perfoliate. Stem suffruticose. Branches erect. Obs. 3278. In the nursery of Mr. Iunter, where it had never flowered.

S. arabica. L. sp. 5? but the internodia are not thicker at the base.-Hort. kew. iii. 5, where it is not mentioned as having ever flowered.-L. fil. suppl. 81 ? but the leaves are not alternately dehiscent.

Cali arabum aliud. Bauh. J. iii. 704.

Kali arabum secundum genus. Dalech. app. 20.

Stem erect, glaucous, both when recent and dried; branches erect, tough, cylindric; internodia $2 \frac{\pi}{2}$ tenths of an inch long. Leaves decussate, when recent not broader than the branches, when dried as wide again as the branches. Flowers none. Obs. 3278.--Stem glaucous; internodia cylindric. Branches, internodia obattenuate. Obs. 6841. Specimen gathered in Fothergill's garden.

SODA. Murr. iv. 285.

Al Kali. Power, account from in chiv. vev. ix. 152. 


\section{Class 2. \\ D I A N D R I A.}

Order 1.

\section{MONOGYNIA.}

1. Flowers inferior, monopetalous, regulur.

7. OLEA.

Corolla quadrifid; segments subovate. Drupe. Nut osseous, unilocular and bilocular, with 1 and 2 seeds. Vuhl.

S. Chronanthus. Corolla quadrifid; segments linear. Drupe. Nut monospermous. Obs. 8449.

6. Phillyrea. Corolla quadrifid. Drupe. Nut bilocular, of a paper-like texture. Seeds solitary. From Vahl.

5. Ligustrum. Corolla quadrifid. Berry bilocular. Seeds solitary. Obs. 3408.

9. Syringa. Corolla quadrifid, infundibuliform. Capsule bilocular. Seeds solitary. Obs. 1792.

11. Boerhavia. Corolla quinquedentate, or entire, in. serted into the calyx. Seed 1.

4. Jasminum. Corolla with from 5 to 8 divisions. Berry dicoccous and bilocular, or globose with 1 ccll. Seeds solitary. Obs. 4277. 
2. Flowers inferior, monopetalous, irreguldr. Capsule.

18. Verrena. Corolla quinquefid. Capsule unilo. cular, very thin.

13. Veronica. Corolla quadrifid; lower segment narrower. Capsule bilocular, quadrivalve.

15. Grationa. Corolla quadrifid and quinquefid; segments slightly unequal. Calyx pentaphyllous. Stamina 4, 2 mostly without antherae. Capsule bivalve. Obs. 5305.

16. Caranga. Corolla shorter than the calyx; lower lip broader. Calyx diphyllous. Capsule bivalve, polyspermous. From Vahl; and Jussieu.

14. Justicia. Corolla bilabiate. Capsule bivalve, opening elastically; dissepiment contrary. Obs. 6872.

17. Pinguicura. Corolla ringent, with a spur. Calyx quinquefid. Capsule unilocular. Obs. 4866.

3. Flowers inferior, monopetalous, irregular. Seeds naked, 4.

19. Lycopus. Corolla quadrifid; upper segment broader, emarginate.

24. Collinsonia. Corolla unequal; lower lip multifid. Seeds.4, 3 abortive. Obs. 717.

20. Cunira. Corolla ringent; upper lip erect, flat, emarginate. Stamina 4, 2 without antherae. From Vahl.

21. Monarda. Corolla ringent; upper lip linear, entire. Obs. 3084. 
29. Rosmarnos, Corolla ringent; upper lip bifid. Filaments with a tooth.

23. SiEviA.

Corolla ringent. Filaments fixed transversely to a pedicle. Obs. 5265.

4. Flowers inferior, tetrapetalous.

10. Fraxinus. Corolla tetrapetalous or none. Calyx quadripartite or none.

5. Flowers superior, monopetalous.

25. Kaempreria. Caly:x obsolete. Corolla, outer limb tripartite; 2 of the segments of the inner limb ovate, the third bipartite. From $\boldsymbol{L}$.

26. Curcuma. Calyx monophyllous. Corolla, upper segment of the inner limb with 4 horns. From Jacq.

27. Zivgiber. Calyx monophyllous. Corolla, outer limb tripartite; inner limb bilabiate; upper lip undivided, extended beyond the insertion of the antherae; lower lip tripartite. Capsule. Obs. 3257.

28. Costus: Calyx monophyllous. Corolla, outer limb tripartite; inner limb bilabiate; upper lip extended beyond the insertion of the antherae; lower lip trilobate. Capsule. From Swartz and Roscoe.

29. HEDYCHiUм. Caly $x$ monophyllous. Corolla, outer and inner limb tripartite. Antherae terminal. From Lamark and Roscoe. 
30. Revfalmia. Calyx monophyllous. Cor.lla, outer limb tripartite; inner limb bilabiate. Antherce adhering to the upper end of the middle segment of the upper lip. Berry trilocular in the mirldle. Obs. 7168.

31. Globia. Calyx monophyllous. Corolla trifid. Capsule. From $L$.

6. Flowers superior, dipetalous.

12. Circaea. Caly $x$ diphyllous.

7. Flowers natied.

Fraxinus excelsior. 10.

\section{Order 2. \\ T R I G Y N I A.}

32. Piper.

Calyx and Corolla none. Berry monospermous. $\boldsymbol{L}$.

\section{MONOGYN IA.}

\section{J A S M I N UM.}

Corolla hypocrateriform. Berry dicoccous, with 2 cells, or globose with 1 cell. Seeds solitary. Obs. 4277. $L$. 
1. Teeth of the calyx subulate, longer than the tube.

1. JASMINUM Sambac. Leaves opposite, simple, elliptic, ovate, and subcordate, dull. Smaller branches and petioles pubescent. Obs. 4354 . In a garden.-Hort. kew. i. S.

Nyctanthes Sambac. L. sp. 2.

Nyctanthes. L. ups. 4.

SAMBAC arabicum, sive Gelseminum arabicum. Raii hist. 1600.

a simplex. Corolla single. Hort. kew. a.

J. sive.Sambach arabum Alpino. Bauh. $J$. ii. 102.

$\beta$ oiale. Corolla with 10 segments; segments oval, about as long as the tube. Obs. 4354 .

Syringa arabica. Ger. by Johns. 1400.

Flos Manorae. Rumph. v. 52. t. 30.

\% duplicatum. Corolla with several rows of segments; segments oval. Obs. 8305. In Mr. Sitwell's garden.-Hort. kew. $\beta$

Flos Manorae flore pleno majore. Rumph. v. 55. $t$. 30. f. $A$.

ò plenum. Corolla double; segments roundish, longer than the tube. Hort. kew. ' $\gamma$.

2. JASMINUM officinale. Leaves opposite, pinnate; folioles acuminate. Buds nearly erect. Hort. kew. i. 10. L: sp. 9. Curt. mag. t. 31.

J. sive Gelseminum, flore albo. Bauh. J. ii. a. 101.

J. album. Dalech. 1430. Ger. by Johns. 892. repr. in

Jasminum. Dod. 405, and cop.'in

Gelseminum vulgatius. Lob. obs.542, which repr. in Gelseninum vulgatius Jasminum. Lob. ic. ii. 105, and inder the erroneous title of

J. lutcum. Ger. by Johns. 893. 
IASMINUM. Berg. 10. Dale 317. Lero. disp. by Rolher. 177; by Dunc. 343. Linn. 39. Mill. Jos. 242. Murr. ii. 31. Ruly 247. Vog. 152.

\section{IIGUSTRUM.}

Culyx quadridentate. Corolle quadrifid. Berry with 2 cells. Seeds solitary. Obs. 3408. $L$.

1. LIGUSTRUM vulgare. Leaves lanceolate and oblong. Obs. 3408. In hedges on the limestone and gravel of the eastern side of Derbyshire. $-L$. suec. n. $5 ;$ sp. 10.

^ deciduum. Leaves falling off in autumn.' Obs. 3108. -Murr. ap. L. a Murr. 56 a

L. vulgare, Curt. lond: v. 1.t. 300. Bot.arrang. 7. Swith brit. 12.

Phillyrea. Dod. 763, repr. in

Ligustrum. Lob. ic. ii. 131, and. Ger. a Johns. 1394. Fuchs. 468. c. 183, cop. in. Trag. 1005. Bauh. J. i. a. 528. R. hist. 1603; syn. 465. Boerh. ii. 215. Tourn. paris. 109. Vaill. paris. 116. Park parad. 445. t.445. f. 5 ; theatr. 1446. (The figure is that of Euphorbia dendroides.)

Leares lanceolate, acute; oblong and oval with a short cuspis at the end. Racemi terminal, compound; primary. branclies opposite; pedicles opposite and alternate. Berries with 1 and 2 seeds. Ots. 3408.

Native of Germany, Switzerland, France, the sea coast of Bahus in Sweden, England and Scotland, but not common in the latter kingdom; in marle, limestone, gravel and sometimes on gritstone. Schocpf speaks of it as a native of New York and Long Island, and Dr. Cutler observed it at Lynn.in New 


\section{Morogynia. 6. Phillyrea.}

England, but adds, that it is not very common in a wild state. Was it not imported from Europe?

LIGUSTRUM. Dale 317. Geoffr. iii. 719. Mill. Jos. 268. Rutty 285. Schoepf. 2. Spielm. 383. Vog. 107.

LYCIUM. Schrod. quoted in Dale 323.

$\beta$-sempervirens. Lenves falling off in the spring. Obs. 7899. In a garden.

L. vulgare. $\beta$ Murr. ap. L. a Murr, 56.

L. italicum. Mill. Ph. dict. n. 2.

Ligustrum. Dalech. 252.

L. myrtifolium italicum. R. hist. 1603.

Leares lanceolate, $2 \frac{1}{4}$ inches long. Berries oval, shining, purplish black, containing 2 seedls. Obs. 7899.

y stramineo-variegatum. Leaves green and straw coloured. Obs. 5832. In a garden.

L. foliis ex luteo variegatis. Boerh.'ii. 215. Vaill. paris. 116.

\section{PHILLYREA.}

Calyx quadridentate. Corolla quadrifid. Berry with 2 cells. Seeds solitary. Gaertn. $\boldsymbol{L}$.

1. PHILLYREA media. Leaves partially serrate, lanceolate or oblong. Obs. 7902. Speoimen from a garden.-L. sp. 10. Hort. kew. i. 11.

P. foliis lanceolatis, sub integerrimis. L. ups. 5 .

a ligustrifolia. Leaves oblongo-lanceolate. Hort. kez». i. 11.

P. folio ligustri. Boerh. ii. 215.

Cyprus latiore folio. Dod. 765, repr. in

P. tertia. Clus. hisp. 63; hist. i. 52,

P. uarbonensis, Lob. ic. ii. 121, \& 
P. latiore folio. Ger. a Jolins. 1395, and cop. in

P. latiusculo folio. Bauh. J. i. $a .539$, and

P. Penaie major. Dalech. 258. In flower.

Philyca. Dalech. 258, in fruit.

PHILLYREA. Dale 313. Geoffr. suite. i. 400.

B virgata. Leaves lanccolate. Branches erect, rodlike. II. $K$.

r pendula. Leaves lanceolate. Branches divaricato-pendulous. $\boldsymbol{H} . K$.

¿ olcaefolia. Leaves oblongo-lanceolate. Branclics nearly erect. $I . K$.

$\varepsilon$ buxifolia. Leaves oval-oblong, rather obtuse. $H . K$.

\section{O L E A.}

Corolla quadrifid; segments nearly ovate. Drupe with 1 seed. $L$.

1. OLEA europaea. Leaves entire at the margin, lanccolate. Racemi axillary, compact. Obs. 7992. Specimen from M. Broussonett, probably gathered near Montpelier.-Hort. kew. i. 12. L. sp. 11. Woodv. iii. 369. t. 136.

a communis. Leaves lanceolate, flat, hoary underneath. IIort. kew. i. 12.

O. gallica. Mill. Ph. dict. n. 1.

Olea. Dod. 809. Trag. 1061: Clus. hisp. 46, repr. in

O. cum fructu ac flore. Dod. 809,

O. sativa. Lob. obs. 566 ; ic. ii. 135, and Ger. by Jolns. 1392, and cop. in Park. theatr. 1439, and Bauh. J. i. b. 1. Dalech. 343. Raii hist. 1541; europ. 189. Bocrh. ii. 218. Magn. monsp. 189, where the different varieties produced in the neighbourbood of Montpelier are cnumerated. 
OLIVA. The Olive-trec. The fruit and its oil. Phum. Lond.-B Berg. 11. Vog. 258.

Olea. Dale 308. Geoffi. suite i. 225. IIcrrera in Ulloa i. 51, Lew. ii. 158. Mill. Jos. 319. Rutty $35 \overline{7}$.

O. europaed. The fixed oil of the fruit. Pharm. ediu.-Bryant 230. Lew. disp: by Dunc. 267. Murr. J. i. 377. 390. Synn. i. 95. 174; ii. 258.

Olivac. Carthens. i. 335. Linn. 39. Schoepf 2. Spielm. 107.

Olivarum fructus. MIurr. ii. 33.

Oleum olivarum. Quicr. in lett: \& ess. 177. Wall, J. tracts 97. Fordyce G. pract. 205. Denm. ii. 35. Pringle 267. Monro iii. 295.

Oleum olivae. II Iull phlegmat. 294. Heberd. 193.

Oleum. Stoll. med." ii. 287. IHeberd. 150. 152. 183. 360. Quar in febr. 375.

Oil of Olives. Cull. ii. 127. Darw. ii. 40. Hufeland, account from in phys. journ. vi. 72. Underw. i. 58.

Olive oil. Baldwin, account from in phys. journ. vi. 247, \& ann. med. lustr. II. ii. 127. Berchtold, account from in anl. med. ii. 376; in Trolter ii. 75 ; \& med. rev. iii. 209. Brefeld, account from in phys. journ. v. 490. Bucholz, account from in unn. med. iv. 267. Campet, account from in ann. med. lustr. II. ii. 132. Chalm. ii. 120. Chamberlaine, W. in med. soc. iii. 571. Gaitskell in med. soc. v. 4. Jaclison, $I$. of Georgia, account from in chir. res. xiv. 62. Kentsch, account from in phys. journ. xi. 480; xii. 382; \& chir. rev. xi. part. ii. 16. Miller, $J$. account from in chir. re: vi. 400. Neum. ii. 65. Oliver in phil. trans. xlix. 
for 1755, art. 13. Rush v. 123. Underw. ii. 153. Sweet Oil. Clegh. 252. Pringle 164. Rush iii. 292, 293. Underw. ii. 151.

Common Oil. Darw. ii. 46. 312. Underzi. i. 23. Williams in pliys. joum. xiii. 17. Med. rev. iv: S0.

Oil. Cull. pract. n. 1446. Darw. ii. 29, 39, 43, 61, 130, 136, 137, 145, 147, 750, 753, 754. Sims in med. soc. ii. 2. Shadzell in med. soc. iii. 461. Ploneq. libl. i. 191, 194, 351, 613. Aitken midw. 118, 128. Jackison $J$. account from in chir. rev. xii. part ii. 149. Moseley 23. Fordyce G. fer. iii. 231. Underw. i. 56. Pringle 151. Aitlen midw. 143, 153, 17\%. Assalini, account from in chir. rer. viii. 461. Faust \& Itunold, account from in phys. journ. xiv. 480. Wilson, account from in chir. rev. ix. part i. 5. Wittman, account from in chir. rei. x. part ii. 51 .

B syliestris. (Variation.) Leaves smaller. Drupe smaller, slenderer; the point iecurvate. From $\mathrm{Ray} \& \mathrm{Clu}$ sius.-L. sp. $11 \beta$

O. sylvestris, folio duro subtus incano. Boerh. ii. 218.

Oleaster. Clus. hisp. 48, rcpr. in

Oleae sylvestris ramulus. Dod. 809,

O. sylvestris. Ger. by Johns. 1392, and a branch cop. in

Oleaster, sive Olea sylvestris. Bauh.J.i. b. 21. The rest of the figure cop. from

O. silvestris septentrionalium. Lob. ic. ii. 136, which also cop. in

Oleaster cappadocius. Park. theatr. 1411.

O. sylvestris. Park. theatr. 1439. Raii hist. 1514. Magn. monsp. 189. 
O. sylvestris, sive Oleaster. Lob. adv. 422. repr. in ic. ii. 135.

OLEASTER. Dale 308.

r longifolia. Leaves lineari-lanceolate, flat, silvery underneath. Hort. kew. $\beta$

I latifolia. Leaves oblong, flat, hoary underneath. Hort. kiew. $\gamma$

- ferruginea. Leaves lanceolate, ferrugineous underneath. Hort. kew. i. 13. $\delta$

$\zeta$ obliqua. Leaves oblong, bent obliquely, pale underneath. Hort. kew. i. 13. $\varepsilon$

n buxifolia. Leaves oblong-oval. Branches patent, divaricate. Hort. kew. $\zeta$

2. OLEA microcarpa. Leaves elliptic, acuminate, serrate. Racemi terminal. Vahl. enum. i. 43.

PHILLYREA indica. Lour. i. 43.

\section{CHIONANTHUS.}

Calyx quadripartite. Corolla infundibuliform; tube - very short; limb quadripartite; segments linear. Stamina as long as the tube. Drupe. Nut striate. Obs. 8449. Juss. 105. L.

1. CHIONANTHUS triflora. Lateral peduncles triflorous, Obs.8449. Specimen gathered in Lee's nursery.

C. virginica. L. sp. 11. Hort. kew. i. 14.

Chionanthus. Gron. virg. 1. Royen 399.

CHIONANTHUS virginica. Marsh. 33.

a ocalifolia. Leaves ovali-elliptic. Obs. 8449,-Hort。 liewo. \&

$$
\text { c } 2
$$


Calyx tripartite; 2 of the segments irregularly bifid and trifid at the end. Corolla many times longer than the calyx. Antherac oblong, erect, longer than the filianents. Pistil shorter than the tube of the corolla. Obs. 8149.

B lancifolia. Leaves lanceoliate. ITort. kew. \&

Leares lanceolate and oblong. Obs. 8150. Specimen gathered in Lady Cliford's garden.

\section{SYRING $\Lambda$.}

Corolla infundibuliform; limb quadripartite. Calyx quadridentate. Capsule of 2 cells. Seeds solitary. Obs. 1792. L:

1. SYRINGA vulgaris. Leaves cordate. Obs. 1792. In a garden.-L. sp. 9. Hort. kew. i. 15. SYRINGA. Geoffr. suite iii. 136. Schoepf 3.

a caerulca. Corolla purplish blue. Obs. 2936. In a garden.-H.K. i. 15. Curt. mag. t. 183.

S. caerulea. Ger. by Johns. 1399.

S. flore cacruleo sive Lilac. Bauh. J. i. b. 201. \& violacca. Corolla violet coloured. $I I . K$. i. 15. $\gamma$ alba. Corolla whitc. $H$. K. i. 15.

\section{FRAXINUS.}

Caly $x$ quadripartite, or none. Corolla tetrapctalous, or none. Stamina inserted into the receptacle. Seed oblong. Obs. 235. $\boldsymbol{L}$.

Flowers in some species hermaphrodite; in $F$. excelsior hermaphrodite in one plant, male in another and female in a third. Obs. 235. 
Petals in F. ormus most clearly distinct, inserted into the receptacle opposite to the sinuses of the calyx. Seed in $F$. excelsior not a capsule, but as truly a seed as a bazle nut or carraway seed, consisting of a lanceolate kernel inclosed in a flatted coriaccous coat, extended outwards into a lauçeolate wiuglike border. 'The kernel is connected to the coat by an umbilical cord. $F$. ormus and excelsior appear to me to belong clearly to one genus, but why Linnæus and Bernard Jussieu have arranged it with Jasminum, Syringa, Ligustrum, \&c. in his natural order of Sepiariae I do not comprehend, unless from the number of stamina and the external resemblance between the corolla of Fraxinus Ornus, \& Chionanthus. M. Jussieu has followed their example, but suggests its connection with Acer $_{2}$, with which it scems to be really allied ${ }_{2}$

1. FRAXINUS excelsior. Falioles serrate. Petals none. L. sp. 1509 ; suec. n. 926 . Hort. kew. iii. 444. Bot. arrang. 1149. Smith brit. 13. Tourn. paris. 333. Vaill. paris. 56. Mill. Ph. dict. n. 1, Kalm quoted in Schoepf 154 under n. 337 ?

a communis. $H . K$. - Leaves pinnate; folioles lanceoIate. Branches erect or ascending. Obs. 235. In hedge-rows.

F. excelsior, flore petaloide, mas. Boerh. ii. 171.

F. excelsior, frugifera, foemina. Boerh. ii. 171.

Fraxinus. Cam. epit. 64. Dalech.83. Dod.821, repr. in Lob. ic. ii. 107, \& Ger. by Johns. 1472. Raii syn. 469.

F. cum fructu and pilulis. Dalech. 84, a branch with fruit, discased excrescences and no leaves; cop. in F. vulgatior. Bauh. J. i. b. 174. Ruii hist. 1702.

c 3 
F. vulgaris. Park. theatr. 1419.

The common Ash-tree. Evel. lyy IIunt. cd. i. t. at p.

150 ; ed. ii. t. at p. 145.

Native of Europe, and probably of $\Lambda$ merica.

FRAXINUS. Alst. ii. 8. Berg. 831. Dale 332.

Geoffr. iii. 495. HIerm. 210. Lew. i. 441; disp.

by Rother. 161. Linn. 267. Nill. Jos. 203.

Murr. iii. 535. Schoepf 154. Spielm. 215. Vog.

169. 280. Fordyce, G. pract. 156. Ploucq. bibl.

i. 484. Swiet. iv. 258.

F. excelsior. Coste \& Willemet in mcd. comment. v. 298. div. 2 \& 3. Lind. hot clim. 314. Schreger account from in med. comment. dec. II. viii. 151.

s pendula. Leaves pinnate. Branches pendent. Hort. licï. iii. $445 \beta$ Near Gamlingay, Cambridgeshire. Marlyn ap. Smith brit. 13 \& Relh. cd. ii. 5 \& $\gamma$ diversifoliu. Leaves simple and teruate. Obs. 6460.

In Mr. Sneyd's garden.-Hort. kew. y

d simplicifolia. Leaves simple. Obs. 8186. In a plantation.

F. excelsior. \& Bot. arrang. 1151.

$\varepsilon$ rolundifolia. Leaves pinnate; folioles obovato-ellip. tic, and elliptic. Obs. 538s. Specimen without flowers or fruit, gathered in the Paris garden; compared with a specimen in the herbarium of Sir Joseph Banks, marked in Prof. Jacquin's land writing, "F. Mamna. Sub loc titulo missa ex Hort. Argent." and with another the only one in flower, marked "Hort." introduced into the herbarium since the death of Solander.

F. rotundifolia. Mill. Ph. dict. n. 2. Solander ap. Hort. kew. iii. 445, who characterises it as having petals, but in the only specimen in flower in Sir Joseph Banks's herbarium the flowers are without petals. Is this variety liable to vary in this par. 
ticular, or are $F$. excelsior and $F$. Ormus both liable to a similar variation in the shape of the folioles?

F. alcpensis. Pluk. alm. 158. t. 182. f. 4, a good figure. He refers to the synonyms of Herm, and the Bauhines liere quoted, and adds. that it was conmonly known by the name of the Manna tree, "Mannae arbor vulgo."-Herm. hort. lugdb. 261, who says he received the plant from England, from Watts, and that it is smaller and lower than F. excelsior, and that the folioles are rounder.

F. rotundiore folio. Bauh. Casp. pin.416. Bauh, J. i. b. 177. Boerh. ii. 172. Raii hist. 1703. MANNIFERA ARBOR. Dale 332.

2. FRAXINUS Ornus. Folioles serrate, oblongo-elliptic, acuminate, petiolate. Flowers with petals. Obs. 5389. Specimen gathered in Fothergill's garden.-Hort. kew. iii. 445. L. sp. 1510. Host. 548. In Litorale and Istria. Woodv. i. 104. $t$. 36. Gouan. hort. 521. Mill. Ph. dict. n. 3. Ferber's trav. in Italy 212. On the road from Rome to Civita Vecchia and about Tolfa, and at the latter place Manna collected, as it is on Monte Gennaro, in the Apennines near Tivoli and at Arienza near Naples. In this excursion Ferber was accompanied by Guettard.

F. florifera. Scop. cain. n. 1250.

F. paniculata. Mill. Ph. dict. n. 4 , is probably as Reichard thought a male plant of $F$. Ornus.

F. floribus completis. L. ups. 304. Royen 396.

F. humilior, sive altera Theophrasti, minore and ten. uiore folio. Buerh. ii. 172.

Oraus. Dalech. 83, cop. in

$$
\text { C } 4 \text {. }
$$


F. tenuiori et minori folio. Bauh.J. i. a. 177, may liave been iutended for it. (J. Banhine's descrip)tion belongs probably to some varicty of $F$. excelsior with narrow folioles, found on mountains in the neighbourhood of L,yons )

MANNA. Pharm. Lond.-Alst. ii. 471. Bisset ess. 138. 182. Blane 419. 476. 492. Cuntheus. ii. 209. Chalm. i. 80, 100, 124, 127, 147, 165, 17т, 183,215 ; ii. $5,34,73,113,149,165,177$. Clark J. long roy. i. 181. 326; fev. 22. Clegh. 202, 252. Cull. ii. 508. Darw. ii. 272. Denm. i. 261, 269; ii. 515. Fordyce G. pract. 150, 107; 207, 217, 305 ; fer. ii. 54 ; iii. 222, 231 . Fordyce W. 167. Herm. 697. Hill 745. Hillary 162, 172, 218. 00. IIoffm. vi. 24. IIncli in Pringle 206. Hime, J. in lett. \& ess. 213, 217. IIunter jum. 224. Lei.. ii. 86. Lind serim. 253. Mread monit. i. 27, 34, 48; ii. 57. Monro ii. 452; sold. 365, .772; G. in lett. \& ess. 268. Mascley 16, 178, 442, 511. Murr. iii. 542; J. i. 260. Neum. ii. 67. Ploucq. bibl. i. 350. Pringle 203. Quarin febr. 219, 36t, 371, 407; animad. 35, 216, 219, 353. Mush i. 135. Rutty 306. Spielm. 622. Stoll med. ii. $27,76,91,100,148,234,253,367$; iii. 27,40 , 136, 210, 287; aph. n. S08. Underw. i. 25, 54, 55, 198*, 358; ii. 33, 6s, 121. Vog. 331. Ware opth. 149. Wintringh. in Mead monit. i. 205, 220; ii. 155.

Manna calabrina. Berg. 833. Linu. 26. Mill. Jos. 204.

Mauna calabra. Geoffr. ii. 581.

F. Ornus. The concrete juice. Pharm. edin.-Lew. disp. by Dunc. 226. Syn. i. 196.

3. FRAXINUS caroliniana. Petals none. Folioles ser- 
ratce, petiolate, linceolate, glibrous. Smaller branches glabrous, From Vahl. cnum. i. 51. L. a IFilld. iv. 1103. Mill. Ph. dict. n. 6. From seeds sent by Cateshy.

F. petiolis communibus teretibus, foliolis petiolatis. Gron. virg. 161.

F. carolincusis, foliis angustioribus utrinque acuminatis pendulis. Catesb. i. S0. t. 80. The nargin of the folioles represented as entire.

F. caroliniana latiore fructu. Rund 79. Lond. gard. 33. Fronı seeds sent by Catesby.

FRAXINUS americana. Schoepf 154.

\section{BOERHAVIA.}

Corolla campanulate, plaited, inserted into the calyx. Caly $x$ inferior; mouth entire. Seed 1, naked, envelloped by the indurated calyx. From Swartz obs. 12. L. -Venten. tabl. t. T. f. 6 .

1. BOERHAVIA crecta. Leaves ovate, acute, repandose. Flow่ers corymboso-paniculate. Fruit clavato-turbinate, pentagonal. Obs. 8509. Specimen gathered by Broughton in Jamaica.-Willd. phyt. 1. Swartz. obs. 10. L. a Murr. 52; sp. 4. 1675. Hort. Kew. i. 4. Goum. hort. 2. Jacq. hort. i. 2. 1. 5. 6. Burm. L. ind. 3. t. 1. f. 2.

BOERHAVIA erecta. Forst. G. esc. 71, but he describes the stems as procumbent.

* glabra. Glabrous. Obs. 8509.

Capsule with short white lines apparently strigate, but not to be elevated by a needle, monospermous, not opening. Obs. 8509.

P pubescens. Stem and petioles pubescent. Obs. 8510 . 
Specimen gathered by Dr. Wright, in Jamaica. B. erecta. L. manl. 315.

Leaves with numerous purplish eminencies, so min. ule as scarcely to render the surface rough to the hand. Obs. 8510 .

\section{CIRCAEA.}

Peials 2 , inserted into the calyx. Caly $x$ hypocrate. riform; limb bipartite. Capsule inferior, bilocular. Seeds solitary. Obs. 1001. L.

1. CIRCAEA ovatifolia. Upper leaves ovate. Obs. 1001. In shady places.

C. lutetiana. L. suec. n. 6 ; sp. 12. Bot. arrang. 23. Smith brit. 13. R. syn. 289. Tourn. paris. 419. Vaill. paris. 38. Boerh. i. 78. Lob. ic. i. 266, repr. in Ger. by Johns. 351, \& cop. in

C. Iutetiana major. Park theatr. 351.

C. caule adscendente, racemo unico. Cull. in amer. acud. i. 403.

0. cimastrum verrucarium. Bauh. J. ii. 977. The 2 separate flowers well done.

Nalive of Europe and New England. Obs. 7843. Specimen gathered by Dr. Cutler, in New England.

CIRCAEA lutetiana. Schoepf 3.

2. CIRCAEA cordifolia. Upper Ieaves cordate. Obs. 7858. In the grove below Matlock old bath, in sand, on the banks of the Darwent.

C. alpina. L. succ. $n .7$; sp. 12; a Murr. 58. IIuds. 11. at the foot of mountains in Westmorland and Yorkshire, and about Dallam Tower, in Westmorland, and observed by Hope in Hamilton 
wood, Scotland.-Lightf. 80. At the foot of monntains about Loch-Broom, Ross-shire, and obscrved by Burgess at the head of Yarrow-water, in the county of Peebles.-Bot. arrang. 24, where at line 7 th from the bottom after smootl insert ST.Smith brit. 14. Krock. n. 9. t. 1.

C. calice colorato. L. lapp. $n .3$.

C. minima. Col. ecphr. ii. 79, t. 80. Boerh. i. 78.

Stem 4 inches long, with microscopic scattered hairs below; hairs recurvate; above pubescent, with horizontal obtuse hairs. Petioles pubescent on the upper side. Leaves opposite, cordate, pubescent at the margin. Peduncle pubescent; hairs horizontal, obtuse. Obs. 7842. In Mr. Kuowlton's garden.-Sten 5 inches long, glabrous. Leaves dentate at the margin. Obs. 5237. Specinen from Lheritier.-Stem with 13 racemi. Obs. 5238. Specimen gathered in the garden of Pitcairn.-Root creeping. Stem from 7 to 17 inches long, with from 1 to 6 racemi, slightly pubescent. Leaves apparently glabrous, but mostly with a few microscopic hairs, pubescent at the margin, the upper surface dull, slightly nitid underneath, the largest of the smallest plant $I$ inch 4 tenths long, the largest of the largest plants 3 inches long. Petioles slightly canaliculate, and pubescent along the upper side. Peduncles patent, pubescent, with straight simple hairs. Calyx with a few hairs. Obs. 7858.

Native of the mountains of Switzerland, Germany, Scandinavia, Scotland, Cumberland, Westmorland, Furness in Lancashire; Yorkshire, Derbyshire and Merionethshire.

CIRCAEA alpina, Schoepf 3. 


\section{VERONICA.}

Corolla, limb quadripartite, lowermost segment the narrowest. Calyx quadripartite, quinquepartite, sexpartite, septempartite, and octopartite. Capsule with 2 and 3 cells. Obs. 4069. L.- The Jtalian vernacular name of $V$. officinalis, according to Camerarius in his epitome.

\section{Racemi terminat.}

1. VERONICA quinquefolia. Leaves verticillate, glabrous above. Tube of the corolla twice and a half as long as the limb. Obs. 4069 . In a garden. 12 Sept.

V. virginica. L. $I I . K$. i. 17.

VERONICA virginica. Schoepf 3.

* alba. Corolla white. Obs. 4069.-H. K. a

Stem 4 fect long, erect, slightly hirsute below, and above at the joints. Leares in sixes, fives and fours, 8 tenths of an inch broad, pubescent underneail. $P_{e-}$ dicles as short again as the calyx. Calyx partite, segnicnts unequal, 5 to 8 . Corolla white, before it is expanded flesh coloured at the end. Germen glabrous. Capsule with 3 and 2 cells; dissepiments extensions of the edgres of the valves. Obs. 4069.

B incarnata. Corolla flesh coloured. From $H$. K.

2. Racemi terminal and axillary.

2. VERONICA spicata. Leaves opposite, ablongo-lanceolate, serrate upwards. Stem ascending. Obs. 4066. In a garden.-L.-Bot. arrang. 8. Smith engl. bot. t. 2.

V. spicata recta minor. Bauh. J. iii. 282.

V. recta minima. Ger. by Jolns. 627. 
Germen pilose. Obs. 4066.

VERONICA spicata. Gcoffr. suile iii. 300.

3. VERONICA Beccalunga. Racemi oppositc. Capsules orbicular, emarginate. Leaves serrate, oval and oblong. Stem creeping. Obs. 3530. Specimen gathered in a brook.-L. sp. 16. Curt. lond. ii. 3. t. Walc. t. Bot. arrang. 12. Fl. dan. to 511. Woodv. i. 20. t.7. Lightf. 73. Huds. 5. Smith brit. 20.

V. aquatica major, folio subrotundo. Tourn. paris. 311. Vaill. paris. 201.

$V$. aquatica rotundifolia, Becabunga dicta minor. $R$. syn. 280.

Anagallis aquatica. Dod. 582, repr. in Lob. ic. i. $466, \&$.

Anagallis, scu Becabunga, Ger. by Johns. 620, \& repr. in

Anagallis aquatica vulgaris, sive Becabunga. Park. theatr. 1236.

Sium seu Lauer. Fuchs. 725. cop. in 12mo. ed. 687. c. 277 , and in

Sion non odoratum. Trag. 188, and

Anagallis aquatica, flore caeruleo, folio oblongo, major. Bauh. J. iii. 791. (The description belongs to $\mathrm{V}$. Anagallis.)

Brooklime. Sheldr. t.

Beccabunga. Riv. monop. irreg. t. 100.

BECCABUNG A. The herb. Pharm. lond.-Berg.

19. Hill 385. Lew. disp. by Dunc. 322. Murr.

ii. 208. Rutty 59. Schoepf 4. Spiclm. 555. Vog. 53.

Becabunga. Lew. i. 203. Mead mon. ii. 121. Limen. A0. Monro iii. 30.

V. Beccabunga. Bryant. 116. 
Beccabunga major. Geoffr. iii. 160.

Beccabunga minor. Geoffr. iii. 161.

Anagallis aquatica. Alst. ii. 80. Dale 186. Mill. Jos. 37.

Brooklime. Lind scam. 20.

4. VERONICA officinalis. Leaves elliptic, and oval, serrate. Sten procumbent. Obs. 6382. On banks, on commons, and on the sides of roads.-L. suec. n. 12; sp. 14. Bot. urrang. 9. Smith brit. 16. Curt. lond. iii. 1; $t$. the larger of the 2 right hand branches.-Fl. dan. t. 248. Lightf. 72. II uds. 4. Woodv. iv. 19. t. 219.

V. mas supina \& vulgatissima. Raii syn. 281. Boerh. i. 224. Tourn. paris. 165.

V. vulgatior, folio rotundiore. Bauh.J. iii. 6. 282, (misprinted 274.)

V. mas. Fuchs. 171. c. 59 ; cop. in Dalcch. 1319. abr. in

Teucriun. Trag. 207, and still more so in

V. spicata recta major. Bauh. J. iii. 282.

V. mas. Dalech. 1319, cop. in

V. assurgens. Dod.40, which repr. in

V. recta mas Matthioli. Lob. ic. i. 471, \&

V. recla mas. Ger. by Johns. 627; and cop. in

V. mas erecta. Park, theatr. 550. Leaves represented as entire at the margin.

V. mas serpens. Dod. 40, repr. in

V. major septentrionalium. Lob. obs. 250,

V. vera et major. Lob. ic. i. 471, \& Ger. by Johns.. 626; and cop. in

V. mas vulgaris supina. Park. theatr. 550. The peduncles represented as leafy.

Veronica. Cam. epit. 461. Tab.382.

Racemi opposite and altcrnate. Obs. 3531. 
VERONICA. Alst. ii. 244. Bcrg. 17. Carthcus. iv. 156. Herm. 512. Linn. 40. Mur\% ii. 205. Neum. ii. 153. Quarin febr. 368. Spielm. 395. Vog. SS.

V. oflicinalis. Schoepf 4 .

V. mas. Dale 186. Geoff', suite iii. 295. Lew. ii. 44S. Mill. Jos. 450.

a caerulea. Corolla pale blue. Obs. 6381.

V. mas supina \& vulgatissima. Vaill. paris. 200. \& incarnata. Corolla flesh-coloured. Obs. 6382. On gritstone.

V. mas, supina and vulgatissima, floribus rubellis. Vaill. paris. 200.

5. VERONICA bibarbata. Leaves ovate, rugose, obtusely serrate, sessile. Hairs of the stem in 2 opposite lines. Obs. 3533. In fields.

V. Chamaedrys. L. suec.n. 18; sp. 17 ; mant. 317. Bot. arrang. 13. Curt. lond. i. 2. t. Smith brit. 12. Walcot.

$\checkmark$. foliis cordatis sessilibus oppositis, ramis laxe flo* riferis. L. lapp. n. 8.

V. Chamaedrys sylvestris dicta. Raii syn. 281.

V. minor, foliis imis rotundioribus. Tourn. paris. 169. Vaill. paris. 201. Bocrh. i. 225.

Chamaedrys vulgaris foemina. Fuchs. 826. c. 334, cop. in Dalech. 1163,

Chamaedrys. Trag. 203,

Chamaedrys spuria latifolia. Bauh. J. iii. $6.286, \&$ Hierobotane mas. Dalech. 1337.

'Teucrium pratense, et T. spurium chamacdryoides. Lob. ic. i. 490, repr. in

Chamaedrys sylvestris. Ger. by Johns. 657 . CHAMLAEDR YS spuria latifolia. Dale 186. V. rotundifolia, Geoffr, suite iii. 298. 
B albescens. Petals purplish blue when they begin to expand, but when fully expanded white with bluish purple lines. Obs. 6617. Gathered by Dr. J.R. Stokes in a field near the Rother, at Chesterfield.

V. minor, foliis oblongis, flore albo. Vuill. paris. 201.

6. VERONICA Teucrium. The leaves at the base of the peduncles cordato-ovate, bluntish. Calyx quinquepartite, and quadripartite, the intermediate segments one third shorter than the lower. Stems ascending. Obs. 3857. In a garden.-L L. sp. 16; manl. 316; a Murr. 59. Dr. Snith says there is now no original specimen of it in the Linnacans herbarium.-Hort. licw. i. 22.

V. major frutescens altera. Boerh. i. 224. '

Teucrium I. C'lus. pann.613, repr. in

'Teucrium IV. Clus. hist. ii. 319,

Teucrium majus pannonicum. Ger. by Johns. 659, \&. cop. in

Chamaedrys spuria major frutescens. Park. theatr. 106.

Chamaedrys vulgaris mas. Fuchs. 820. c. 334, cop. in Dalech. 1162,

Chamaedris spuria angustifolia. Bauh. J. iii. ' $b$. $285, \&$.

Hierabotane focmina. Dalech. 1337.

'Teucrium primum Matthioli. Dalech. 1165.

Chamacdrys silvestris. Dod.45, repr. in

V. supina facie 'Teucrii pratensis. Lob. ic. i. 47 ,

'Teucrii IV tertia species. Clus. hist. i. 349, \&.

V. supina. Ger. by Johns. 628; and cop. in

V. teucrii facie. Park. theatr. 551. Leaves narrower than usual, and as the upper appear in the more advanced stages of its growth. 
Caly $x$ quinquepartite; the uppermost segment lanceolate, twice as small as the adjoining seginents. Obs. 7471. In the garden at the Oaks.

VERONICA Teucrium. Murr. ii. 207.

V. supina facie teucrii pratensis. Chom. 678 .

Tencrium. Lew. ii. 448. Vog. 121.

Teuerium verum. Cartheus. iv. 185.

Chamaedrys spuria angustifolia. Dale 186.

\section{JUSTICIA.}

Calyy $x$ inferior, with 5 divisions. Corolla bilabiate. Capsule with 2 cells, opening clastically; dissepiment contrary, inserted into the valves. Obs.6872, 68т3. Hort. kew. i. 26. L.

Nearly allied to Ruellia.

11. JUSTICIA Ecbolium. Spikes terminal, tetragonous; imbricate. Bracteae oval, oblongo-ovate, acumirate. Leaves oblongo-ovate, acuminate. Upper lip of the corolla linear. Vahl. enum. i. 117. Hort. keî. i. 26. L. sp. 20.

JUSTICIA Ecbolium. Lour. i. 29.

2. JUSTICIA picta. Racemi axillary and terminal. Flowers verticillate. Leaves elliptic, painted. Vahl. enum. i. 128. L. sp. 21. Lour. i. 29.

FOLIUN BRACTEATUM. Rumph. iv. 73. $t$. 30.

3. JUSTICIA Gendarussa. Spikes terminal, leafy. Flowers verticillate. Leaves lanceolate. From Vahl enum. i. 134. 
J. Gandiarussa. I. fil. suppl. 85.

GENDARUSSA vulgaris. Rumph. iv. 71. 1. 28.

GENDARUSSA femina. Rumph. iv. 72. t. 29.

4. JUSTICIA bivaliis. Peduncles axillary, trifid. Bracleac ovato-subrotund, nervose, aristate. Leaves ovato-oblong, subcrenate. Vahl. enum. i. 149. L. sp. 23.

FOLIUM TINCTORUM. Rumph. vi. 51. $t$. 22. $f$. 1. Leaves elliptico-ovate.

5. JUSTICIA pectoralis. Corolla bilabiate; the upper lip undivided. Leaves lanceolate, petiolate. Spikes paniculate. Bracteac minute. Antherae 2 to each filament. Stem herbaccous. From Hort. kew. i. 27. Swartz. ind. occid. 31. Vahl. cnum. i. 14 4. Jacq. amer. ed. 8io. 4 .

GARDEN BALSAM. Graing. 24.

\section{GRATIOLA.}

Corolla tubular; limb quadripartite and quinquepartite; scgments slightly unequal. Calyx pentaphyllous. Stamina 4, 2 mostly without anthcrae. Capsule of 2 cells, and 2 valves; dissepiment contrary to the valyes. Obs. 5305. 8132. L.

1. GRATIOLA officinalis. Leaves lanceolate, serrate, longer than the internodia. Flowers pedunculate. Obs. 8132. In Mr. Knowlton's garden.-L. $s p$. 24. Hort. kew. i. 29. Pollich n. 23. Scop. carm. n. 27. Gouan. hort. 13. At Mantpelier.Woodv. i. 132.1 .47 .

G. officinarum. Spalowsliy 22. $t$.

G. centauroides. Vaill. paris. 95. 
Digitalis minima, Gratiola dicta. Tourn. paris. 266. Boerh. i. 229.

Limnesium sive Centauris. Cord. fol. S6. p. 2.

Gratiola. Tab. 367. Cam. epit. 464. Dalech. 1085. Bauh. J. iii. b. 434. Raii hist. 1885; europ. 139. Dod. 358, repr.in Ger. by Johns. 581,

G. sive Gratia dei. Lob. obs. 238; ic. i. 435; and cop. in

G. vulgaris. Park. theatr. 220 .

Stem 14 inches long, erect, slightly compressed, the compressed sides convex, the intermediate sides canaliculate. Leaves ovato-lanceolate, opposite, semiamplexicaul, longer than the internodia, serrate above, trinerrose, below septemnervose, obscurely dotted. Peduncles filiform, axillary, solitary, only 1 at a joint, with a shoot in the opposite axilla. Bracteae 2 , of the same shape as the leaves, shorter than the peduncle, inserted at the base of the calyx below the 2 lateral of the 3 uppermost phylla, obsoletely serrate. Calyx one third shorter than the bracteae; phylla ensiform, unequal, the uppermost the longest, the 2.lowermost just sensibly shorter, the 2 lateral ones just sensibly shorter than the 2 lowermost. Corolla nearly thrice as long as the calyx, just sensibly ascending at the end; tube tawny with purplish brown lines, angular; limb quadripartite, purplish flesh-coloured; segments oblong, the uppermost roundish oblong, slightly emarginate, villose within at the base with capitate villi. Stamina 2 perfect, 2 barren; the 2 perfect ones inserted at the base of the uppermost segment about the middle of the tube, short; the 2 barren ones at the base of the tube below the lowermost segment, half as long as the corolla. Nectarium a glandular yellow ring surrounding the base of the germen. Gier- 
men superior, ovate, attenuate, bilocular. Stigma ovate, slightly concatve, oblique. Obs. 8132. July, August.

Nalive of Italy and Switzerland, and of. France and Germany as fur north as Paris and Bremen.

GRATIOLA. Alst.ii. 144. Beck, account from in phys. joum. xi. 435. Berg. 24. Bolduc in acad. sciences abr. by Southw. iii. 224. Chom. i. 29. Dale 195. Duverney in acad. sciences abr. by Southw. i. 63. Geofir. iii. 530. Herm. 540. Hill 388. Hufeland, account from in med. rer. ii. 447. Kramer, account from in med. ess. vi. 3Ti. Kostracesliz, account from in med. comment. vi. 141. Lentin, account from in ann. med. i. 41. Lero. i. 473. Linn. 40. Mill. Jos. 219. Monro iii. 123. Murr. ii. 197. Ploucq. bibl. i. 419. Quarin animad. 184. Schumacher, account from in med. rev. vii. 280, and phys. journ. vii. 81. Spalowsliy 22. Spielm. 613. Stoll med. iii. 431. Vog. 103.

G. officinalis. 'The herb. Pharm. edin.-Coste and Willemet in med. comznent. v. 295. Lew. disp. by Dunc. 229. Syn. i. 199. Mure. J. i. 304.

2. GRATICLA tetrandia. Lieaves obovato-oblong; margin entire. Peduncles with 1 flower. Stamina 4. Obs. 5305. Specimen gathered in Jamaica by Broughtoll.

G. Monnicria. Swart obs. 15. L.-II. K. i. 29. Monicra. Browne 269. $t$. 28. f. 3.

Capsule, dissepiment contrary to the valves. Obs. 5305.

GRATIOLA Monnicria. Roxb. corom.t. 178. 


\section{CARANGA.}

Caly $x$ diphyllous, one of the phylla larger. Corolla shorter than the calyx, the lower lobe broader. Capsule covered by the calyx, bivalve, bilocular, with many sceds.' Jussicu in Vaht.

1. CARANGA amara. Vahl. enum. i. 100. SERRATULA amara. Rumph. v. 459. 1. 170. $\int$. 1.

\section{PINGUICULA.}

Corolla with a spur; limb unequal. Caly $x$ quinqutefid. C'apsule with 1 cell. Obs. 4866. L.

1. PINGUICULA orala. Segments of the corolla minequal, rotundate; spur acute. Calyx tripartite; the upper segment trifid. Capsule ovate. Obs. 4866. Between Glapwell and Sutton, Nottingham. shire.

P. vulgaris. L. suec. n. 25; sp. 25. Bot. arrang. 16. Smith engl. bot. t. 70.

P. Gesneri. Bauh. J. iii. 6. 546. Tourn, paris. 517. Vaill. paris. 160. Raii hist. 751; syn. *281, where Dillenius notices its being found on Shooter's-hill and the little bog at Charlton, wherc it was sown, he says, by James Sherard. If these bogs are in existence it would be curious to ascertain if the plant las perpetuated itself in its new abode, during the course of upwards of 70 years. -Clus. pann. 361, repr. in hist. i. 310, \&.

P. sive Sanicula eboracensis. Ger. by Johns. 7SS. Park. theatr. 532. 
Cucullata. Dalech. 1206.

Stem $8 \frac{1}{2}$ inches long. Obs. 8005. Specinen gathered on Cannock Heath, Staffordshire.

Native of Italy, France, Switzerland, Germany, Scandinavia and Britain.

PINGUICULA. Dale 192. Geoffr. suilc i. 420.

Lew. ii. 222.

\section{VERBENA.}

Corolla infundibuliform, quinquefid; segments unequal. Caly. $x$ with 5 teeth, or bifid. Capsule, mostly so thin as to be scarcely perceptible. Secds 2 or 4 . Obs. 3069, 4.145, 3009. L.

\section{Stamina 2. L.}

1. VERBENA indica. Spikes very long, fleshy, naked, Leaves lanceolato-ovate, obliquely dentate. Stem smooth. L. sp. 27; mant. 317; a Murr. 66; a Reich. i. 52, where as also in L. a Willd. i. 115, the description of the sp. pl. is omitted.-Hort. kero. i. 31.

2. VERBENA ellipticifolia. Spikes several times longer than the leaves, leafless. Leaves elliptic or oval, serrate. Stem hirsutulous. Obs. 7140. From Mr. Hunter's nursery.

a acula. Leaves elliptic, acnte. Obs. 7140.

$V$. indica $L$ ? but the stem is described as smooth without hairs, and the leaves as not serrate but dentate, with oblique obtuse tceth.

Stem square, scabrous; hairs inflex, the upper poriion adpressed or parallel to the stem. Leaves gla- 
brous to the touch, the margin obsoletely scabrons; serratures unequal. Pctioles scabrous as the stem. Spikes terminal, solitary, to $10 \frac{I}{2}$ inches long, flexuose, with about 2 flowers in blossom at once, the lower part sometimes with patulous stipulae withont flowers. Peduncle with longitudinal depressions filled up by the flowers. Stipulae ovato-subulate, adpressed. Caly.x tubular, depressed, plaited; mouth with 4 teeth; teeth triangular, erect, 2 on the anterior side, the 2 lateral ones half as long again as the anterior ones. Corolla deep purplish blue; limb deeply quadrifid; segments roundish, incumbent, unequal. Stamina 2, in the lower part of the tube. Filaments glabrous, short, white. Antherae linear, bilocular; one cell at each end. Pollen tricocco-triangular. Pistil longer than the tube of the corolla. Stigma turbinate. Obs. 7140.

\& obtusa. Leaves oval. Obs. 7141. Specimen gathered by Broughton in Jamaica.

V. jamaicensis. L.-Hort. kew. i. 31 .

V. procumbens ramosa, foliis majoribus, spicis longissimis lateralibus. Browne 116.

Leares with a few hairs along the costa on each side; teeth ovate. In other respects similar to a. Calyx tubular, plaited, depressed; mouth with 4 teeth, and similar in all respects to that of $\alpha$. Obs. 7141 .

VERBENA jamaicensis. Wright in med. journ. viii. 289.

Vervain. Graing. 65, 67. Wright in Graing. 85. Moseley 50 .

2. Stamina 4. L.

3. VERBENA lappulacea. Fruit muricate, composed of 2 seeds. Sceds bilocular. Obs. 8007. Speci-

D \& 
men gathered by Broughliton in Jumaica.-L. sp. 28.

Scorodonir floribus spicatis purpurascentibus pentapetaloideis, semine unico majori echinato. Sloane cat. 66.

Culyx pubescent; hairs incurvate. Fruit turbinate, compressed, quadrilateral; sides rugose; angles muricate; when cut transversely apparently quadrilocular. Nuclei oval. Obs. 8007.

$V E R B E N A$ foliis cordato-ovatis, floribus spicatis, calicibus inflatis, seminibus echinatis. Browne 116, who says it has 4 stamina.

4. VERBENA urticifolit. Spikes filiform, paniculate. Leaves undivided, ovate, serrate, acute, petiolate. L. sp. 29. Hort. kicw. i. 33.

V. tetrandra, spicis filiformibus paniculatis, foliis in. divisis serratis petiolatis. L. ups. 9. Gron. zirg. $c d$. ii. 4 .

V. canadensis, folio urticac. Bocrh. i. 187.

VERBENA. Schocpf 4 .

5. VERBENA officinalis. Spikes filiform, paniculate. Leaves inciso-pinnatifid. Stem solitary. Obs. 4145. On the sides of roads near villağes and houses, and in courts in country places.-L. succ. $n$. 30. Found by Leclie about Helsingburg, but believed by Linnacus to have been wafted by the seat to Sweden;-sp. 29. Pollich. n. 26. Lour. i. 33. In Cochinchina and China.-Mill. Ph. dict, $n .1$. Never found above a quarter of a mile from a house.-Curl. Tond. i. 5. t. Lightf. 7S. Scop. carn. $n .749$, plicing it after Mentha at the end of the order Gymnospermia of the class Didynamia, con. sidering it as a genus connecting the Personatac to 
the Verticillatae.-IInds. 249, placing it between Nepeta and Mentha, apparcutly regarding it with Ray as really belonging to the Verticillatae, in which disposition he lias been followed by Walc. 6. Relh. 221. Sibth. 181, \& Smith brit. 608.Bot. arrang. 595, where it is ackinowledged to be erroneously placed in the order Gymnospermia of the class Didynamia.-Woodv. iv, 17. $t .218$.

V. communis, caeruleo flore. Tourn. paris. 309. Vaill. paris. 200. Boerh. i. 187.

V. recta. T:ag. 210.

Verbenaca rècta. Dod. 150, cop. in Dalech. 1336, s. repr. in

V. communis \& sacra recta. Lob. ic. i. 535, \&

V. communis. Ger. by Johns. 718, \& cop. in

V. vulgaris. Park theatr. 675. Raii hist. 535, describing the corolla as palc blue;-syn. 236. Bauh. $J$. iii. 443, justly describing the corolla as pale purplish ; improied from

Verbenaca supina, sive foemina. Fuchs. 566. c. 226.

Corolla whitish purplish. Obs. 4145.

Root perennial according to Ray and Curtis, Sibth. Salisb. W. and Smith; biennial according to Huds. Hort. kew. and Donn; anmual according to Boerh. Linn. and Lightf. Are we hence to conclude that it is sometimes perennial, sometimes biennial and sometimes annual, or to learn how little dependence in inrestigating plants is to be placed on the marks even of cultivating botanists, when we observe Curtis, $\mathrm{Ai}$. ton and Bocrhaave holding opposite opinions?

VERBENA. Alst. ii. 542. Dale 148. Geoffr. suite iii. 287. Herm. 558. Lew. ii. 447. Lim. 41. Mill. Jos. 449. Murr. ii. 209. Ploucq. bibl. i. 497. Rutty 594. Spielm. 232. Vog. 140. 


\section{LYCOPUS.}

Corolla quadrifid, one of the segments emarginate. Stamina distant. Seeds 4, naked, retuse. Obs. 5304. L.

1. LYCOPUS curopaeus. Iseaves inciso-serrate towards the base. Obs. 5304. On the sides of pools. -L. suec. n. 31 ; sp. 30. Curt. lond. iii. 2. $t$. 201. Bot. arrang. 20. Pollich n. 27. Smith brit. 29.

L. palustris glaber. Boerh. i. 186. Dill. ap. Raii syn. 236. Tourn. paris. 287. Vaill. paris. 123.

Marrubium aquaticum. Trag. 9. Raii syn. cd. ii. 125; hist. 535. Ger. by Johns. 700, repr. from

Marrubium aquatile. Dod.585, which repr. in

Marrubium aquaticum vulgi. Lob. ic. i. 524, and cop. in

Marrubium aquaticum vulgare. Park. theatr. 1230. Marrubium aquaticum quorundam. Bauh. $J$. iii. $b$. 318.

L. palustris villosus. Tourn. paris. 288. Vaill. paris. 193.

Sideritis prima Matthioli. Dalech. 1117.

Stem \& leaves slightly hirsute or pubescent. Obs. 5304.

LYCOPUS. Dale 147.

\& pinnatifidus. Leaves pinnatifid below. Obs. 8508 . Specimen gathered by M. Broussonett, probably near Montpelier.

\section{CUNILA.}

Corolla ringent; upper lip erect, flat. Stamina 2, with the rudiments of 2 others. Seeds 4 , naked. $L$. 
The description in $L$. gen. $n$. S5, accords with $M e$ lissa excepting in having only 2 perfect stamina.

1. CUNILA mariana. Leaves ovate, serrate. Corymbi terminal, dichotomous. L. sp. 30. Hort. kew. i. 35. Michaux i. 13. Vahl. enum. i. 213.

Satureia. Gron. virg. 88.

Thymus. Gron. virg. ed. i.64.

Calamintha mariana mucronatis rigidioribus \& crenatis foliis, flosculorum calyculis villis argenteis summo margine fimbriatis. Pluk. mant. 34. t. 344. fol. 35. pl. 1 .

Calamintha erecta virginiana, mucronato folio glabro. Hist. ox. iii. 413. s. 11.t. 19, f. 7. CUNILA mariana. Schoepf 6.

\section{MONARDA.}

Corolla ringent; the upper lip linear, entire, involving the filaments. Seeds 4, naked. Obs. 3084. L.

1. MONARDA fistulosa. Leaves lanceolato-ovate, villose underneath. Ols. 6089. In Miss Wood's garden.-Hort. kew. i. 36. L. $s p .32$.

M. floribus capitatis \& verticillatis, caule acute angulato, foliis lanceolatis serratis glabris. Trew-ehret. 31. t. 44, adopting a specific character from Buttner.

Clinopodium canadense fistulosum, foliis saturatius virentibus \& hirsutis. Boerh. i. 158.

Origanum fistulosurn. Corn. 13. t. 14, cop. in

Clinoporlium canadense majus hirsutum, floribus fistulosis. Ifist ux. iii. 374. s. 11. t. 8. f. 2. Stem, angles rounded. Leaves petiolate, blackish 
green. II ads roundish. Bracteae, the outer purplish brown. Flowers closely crowded. Corolla crimson; upper lip with the margins rolled in so as to form a kind of tube; lower lip trilobate, lateral lobes romuled, middle lobe elongate linear bifid at the end. Filaments crimson. Obs. 6089.

MONARDA fistulosa. Schoers 6.

Monarda. Linn. 41. Zigman, account from in med. rev. i. 93.

e Kicrmesina. Corollac crimson. Obs, 6089.-Curt. mas. $t .145$.

Leares dotted on both sides, obscurely so on the upper; the inner flocal leaves slightly tinged of a reddish huc. Meads.hemispheric, the central florets flowering first. Stamina 2, inserted into the base of the lower lip. Ols. 6089.

\& rubescens. Corolla whitish with a tinge of rose-colour. Obs. $308 t$.

2. MONARD1 didynama. Stamina 2, with the rudiments of 2 filaments on the upper lip. Obs. 459 . In a garden.

M. didyma. L. sp. 32. Hort. liew. i. 36. Curt. mag. t. 516. Mill. Ph. dict. n. 2. Each lip has 2 stamina terminated by antherae, and many flowers lave 2 shorter stamina without antherac.

Leeres cordate and ovate. Flowers in heads. PCduncles several times shorter than the calyx. Corollae scarlet. Filoments of the 2 barren stamina inserted at the base of the upper lip, very short, and sometimes scarcely any. Obs. 459 .

MONARDA didyma. Schocpf 7. Zigman, accounl from in med. rei. i. 93. 
Monogria. 22. Rosmarinus.

\section{ROSMARINUS.}

Corolla ringent; the upper lip bifid. Filaments crooked, with a tooth. Seeds 4, naked. Obs. 859. $L$.

1. ROSMARINUS officinalis. L. sp. 33. Hort. kerv. i. 37. Scop. carn. n. 30. In Istria.-Host. 15. In Littorale, near Porto Re.-Woodv. ii. 239. $t$. S7.

Nutize of the sea coast of the Mediterranean, and also of Switzerland.

w angustifolins. Leaves linear, white underneath. Obs.

S59. In a garden.

R. hortensis, angustiore folio. L. sp. 33 \& Goun monsp. 17 \& Boerh. i. 179. Niagn. hort. 1Tt, where $y$ is not noticed.

R. angustifolia. Mill. Ph. dict.n. 1.

Rosmarinus. L. ups. 11. Fiuchs. 467.c. 182, cop. in Trag. 55, which repr. in

R. minor. Cord. fol. 14S. p. 2, \& cop. in

R. coronarius fruticosus. Banh. J. ii. 25. Raiii hist. 515. Magn. monsp. 223.

R. coronaria. Dod. 2i2, cop. in

Libanotis coronaria, sive Rosmarinum vulgare. Park. theatr. $7 t$, \& repr. in

Rosmarinum coronarium. Lob. ic. i. 429, \& Ger. by Johns. 1292. Dalech. 967.

R. coronarius. Raii europ. 220.' On rocky hills near the sea coasts of Italy and the south of France. ROSMARINUS. The top and flower. Pharm. lond.-Alst. ii. 209. Berg. 20. Curlheus. iii. 102. Cull. ii. 151. Dete 141. Fordyce, W. fragm. 39. Groffr. suile ii. 260. Herm. 461. Ilill 426 . Isew. i. 280. Mill. Jos. 37T. Nonro iii. 23i. Murr. 
ii. 171; J. i. 289. Quarin febr. 80; animad. 10. Rutty 435. Spielm. 290. Vog. 78, 150. Wintringham in Mead mon. i. 230.

R. officinalis. The flowering tops. Pharm. edin.Bryant 141. Lcw. disp. by Dunc. 297. Syn. i. 112, 295; ii. 197.

R. hispanicus sive hortensis. Linn. 41 .

Anthos. Pharm. austriaco-prov.-Berg. 20. Linn.

41. Murr. ii. 171. Quarin animad. 17.

Rosemary. Neum. ii. 183. Chalm. ii. 116. Kirl:land apopl. 98, 143.

B auratus. Leaves with yellow blotches. Obs. 7997. In Mr. Shore's garden.

R. striatus, sive aureus. Boerh. i. 180.

Rosmarinum aureum. Park. parad.t.423. f. 6 .

Rosmarinum striatum, sive aureum. Park. parad. 425 ; theatr. 74. No fig.

(Gold striped Rosemary. Mill. Ph. dict. is said by

Miller to be a variety of $\gamma$ )

$\gamma$ latifolius. Leaves green underneath. From Miller.L. sp. 33 a Gouan monsp. 17 a

R. latifolia. Mill. Ph. dict.n.2.

R. spontaneus, sive latifolius. Boerh. i. 180.

Rosmarinus. Royen 310.

R. spontaneus latiore folio. Raii hist. 514 .

ROSMIRINUS spontancus, latiore folio. Boecl. пр. Herm. 462.

\section{SALVIA.}

Corolla ringent. Filaments fixed transversely to a pedicle. Sceds 4, naked. Obs. 5265. L.

1. Upper lip of the calyx entire.

1. SALVIA glutinosa. Leaves cordato-sagittate, ser- 
rate, acute. L. sp. 37. Hort. kew. i. 44. Scop. cam. n. 33. Host. 17. Krock. n. 44.

Sclarea glutinosa, floris lutei variegati barba ampla cara. Boerh. i. 164.

Colus jovis. Clus. pann. 577. No fig. Lob. ic. i. 557 , repr. in Ger. by Johns. 769,

Horminum sylvestre secundum. Clus. ii. 29,

Orvala tertia. Dod. 291, and abr. in

Galiopsis species lutea viscida odorata nemorensis. Bauh. J. iii. 6. 314; the upper half cop. in

Colus jovis. Dalech. 966, \&

Coli jovis flores. Park. theatr. 58; and the lower half cop. in

Phlomos Lychnitis altera syriaca. Dalech. 1304, \& Horminum luteum sive Colus jovis. Park. theatr. 58.

Galeopsis lutea. Dalech. 1248. The posterior angles of the leaves rounded.

Horminum luteum glutinosum. 'Raii europ. 147.

Calyx, upper lip entire. Obs. 3267. Specimen from Prof. Jos. F. Jacquin.

Native of Italy, the south of France, Switzerland, and Germany as far north as Nuremberg and Frankfort upon the Oder.

HORMINUM $\beta$ Vog. 104.

2. Upper lip of the calyx emarginate.

2. SALVIA Horminum. Leaves oblong, and ovate, serrato-crenate. Flowers verticillate. Uppermost floral leaves coloured, without flowers. Obs. 6055. In a garden,-L. sp. 34. Hort. kev. i. 39.

Horminum. Dalech. 964. Dod. 292, repr. in Lol. ic. i. 555, \&

Horminum sylvestre foliis purpurcis. Ger. by Johns. 771, \& cop. in 
Horminum genuinum sativum Dioscoridis. Purk. theatr. 56.

Leaves cauline, lower oblong, upper ovate. Calyx, upper lip straight, keeled, truncate, emarginate, lobes repandose, their outer angles mucronate. Corolla whitish, the upper lip brownish purple, a little longer than the lower; lower lip, middle segment obreniform flat, horizontal, the lateral ones oval, erect, as short again as the middle onc. Obs. 6055.

HORMINUM. Alst. ii. 148. Berg. 24. Linn. 42. Horminum sativum. Cartheus. iii. 111. Dale 149. Lew. disp. by Rother. 171.

a violacea. Uppermost bracteae violet-coloured. Obs. 6055. Hort. liew. $\alpha$

Horminum coma purpureo-violacea. Bauh. J. iii. 309.

Horminum sativum. Raii hist. 542. Bocrh. i. 166. B rubens. Uppermost bracteae pink. Obs.5271. Specimen gathered in the garden of Fothergill.-Hort. licw. $\beta$

Iorminum coma rubra. Bauh. J. iii. 309. Boerh. i. 166 .

3. Upper lip of the calyx with 3 teeth; teeth connivent.

3. SALVIA pralensis. Leaves cordato-oblong, cordato-lanccolate, and lanccolato-oblong, doubly crenate. Bracteac as long as the calyces. Helmet of the corolla glutinous. Obs. 4400. Specimen gathered in Surry, on clialk.-L. suec. $n .32 ; s p$. 35. Bol. arrang. 21. Smilh engl. bot. t. 153; brit. 30.

Sclarea pratensis, foliis serratis, flore caeruleo. Tourn. paris. 142. Vuill. paris. 180. Boerh. i. 
164. Dill. ap. Raii syn. 237. Found by Watts in Cobham park, Kent.

Orminum sylvestre. Fuchs. 547. c. 217. cop. in

Chamaedrys alpina flore fragariae albo. Bauh. $J$. iii. $b .290$, (the name and description is that of Dryas octopetala,)

S. sylvestris. Trag. 53, \&

Orvala sylvestris, species quarta. Dod.291, which repr. in

Horminum sylvestre Fuchsii. Ger. by Johns. 769, \& cop. in Dalech. 965, best express the plant, but Vaillant refers them to his Sclarea foliis profunde incisis $180, n .2$, the $S$. pratensis $\beta$ Willd. berol. n. 62 , a variety which $I$ have not seen.

Gallitrichi varietas. Bauh. J. iii. 311, seems to be the before mentioned variety of Vaillant.

Horminum pratense foliis serratis. Raii hist. 544; europ. 147. Common in Germany.

Hormini silvestris secundi prima species. Clus. pann. 579 , repr. in

Hormini silvestris quarti prima species. Clus. hist. ii. 30 ,

Horminum silvestre. Lob. ic. i. 556,

Horminum sylvestre, flore rubro. Ger. by Johns. 772, \& cop. in

Horminum sylvestrc italicum. Park. theatr. 56, \& Gallitrichum silvestre vulgo, sive silvestris Sclarea, flore purpurco caeruleove magno. Bauh. $J$. iii. b. 311 .

Leaves, the uppcrmost at the base of the flowering branches sessile, the pair next below sometimes on petioles. Obs. 4401. Specimen gathered between Charleville and Paris._Caly $x$ hirsutc, hairs globular at the ends; upper lip with 3 tecth at the end, the middle tooth shorter. Obs. 4400. 
Native of France, Germany, Sweden, Kent, Sussex, Surry, Gloncestershire, Oxfordshire and Bedfordshire, probábly all in calcarcous soil.

SALVIA pratensis. Cartheus. iii. 111. Krock.n. 42.

Sclarea pratensis. Dale 150.

Sclurea. Geaffi. suile ii. 420.

Horminum \& Vog. 104, 162.

4. SAI,VIA Verbenaca. Leaves cordato-oblong, sinuato-crenate and doubly crenate, rugose. Corolla a litile longer than the calyx. Obs. 539. Near Worcester on marlc.-L. sp. 35. Bot. arrang. 22. Smilh engl. bot. t. 154; brit. 31. Gouan hort. 19. Near Montpclicr.

Horminum silvestre quartuin, lavendulac flore. Clus. pann. 5S0. No fig, - Native of Spain and England. IIormini secundi suecies tertia. Clus. pann. 582, repr. in

Horminum sylyestre. Ger. byj Johns. 771, and cop. in

Horninum sylvestre lavendulac flore. Part. theatr. 57. Raii hist. 545; syn. 237. Vaill. paris. 105. Bocrh. i. 165.

(Sideritis quermo folio. Dalech. 1121, $\mathcal{\delta}^{\circ}$

Gallitrichis aftine Maru, si non genus aliquod, Sclarca hispanica Tabernac montani. Bauh. J. iii. $b$. 313, without any figure, cannot be the plant, as he describes it as having no distinguishable scent.)

Calyx, upper Jip with 3 teeth at the end; hairs globular at the end. Obs. 539.

Natice of Spain, France, Franconia, and Britain. IIORMIINUM sylvestre. Mill. Jos. 234. Oculus Christi. Dale 149. 
4. Upper lip of the cally $x$ with 3 teeth; teeth struight.

5. StLVIA Sclarea. Leaves cordate, obluse, crenate, rugose, villose. Bracteae coloured, longer than the calyx, concave, acuminate. Obs. 976. In a garden._L. sp. 38. Hort. kciv. i. 45. Gouan hort. 20. Near Montpelier.-Host. 18. In Lito:ali.Roth. germ. ii. 33. At Frankfort on the Oder.

Sclarea. Boerh. i. 163. Native of Holland.-V cill. paris. 179.

Horminum Sclarea dictum. Magn. monsp. 133. Orminum sativum. Fuchs. 547. c. 217, cop. in Gallitricum. Trag. 49, \&

Gallitrichum sativum. Bauh. J. iii. b. 309.

Orvala. Dod. 290, repr. in

Scarlea. Lob.ic. i. 556,

Gallitricum, sive Horminum. Ger. by. Johns. 768, and cop. in

Horminum sativum vulgare, sive Sclarea. Park. theatr. 55.

Gallitricum, sive Sclarea. Dalech. 966. Horminum sativum. Park. parad.478. t. 481. $f$. 1. Calyx, teeth subulate, somewhat spinose; upper lip with 3 teeth. Obs. 976.

Nutice of Italy, France, Holland, and Germany, as far as Frankfort. on the Oder, possibly in some of the more northern situations only the refuse of gar. dens.

SCLAREA. Dale 150. Linn. 43. Nurr. ii. 170.

S. Sclarea. Bryant 128.

Horminum Sclarea dictum. H Hcrm. 460.

Horminum hortense. Mill. Jos. 234.

Horminum. Gicoff. iii. 588. Lew, i. 498. Rutty 298. 
6. SAJVIA lanata. Leaves oblongr, simuato-dentate, woolly. Calyces woolly, spinose. Bracteac recurvate, spinose. Obs. 5270. Specimen from Prof. Jos. F. Jacquin.

S. Acthiopis. L. sp. 39. Hort. kew. i. 46. Sibth. prodr. $n .66$.

Sclarea vulgaris lanuginosa, amplissimo folio. Boerh. i. 163.

Ethiopis multis. Bauh. J. iii. b. 315 .

Aethiopis. Dalech. 1306. Raii hist. 543. Dod. 148, repr. in Ger. by Johns. 779, Lob.obs. 304, \& Aethiopis Phlomitis. Lob. ic. i. 566, and cop. in

S. aethiopica, sive Dethiopis, laciniatis \& non laciniatis foliis. Park. theatr. 57.

Calyx with ochre-coloured granules; upper lip with 3 teeth, the middlemost tooth the smallost. $\mathrm{Co}$ rolla with ochre-coloured granules. Obs. 5270 . AETHIOPIS. Dale 150. Diosc. l. 4. c. 105. Plin: l. 27. c. 4 .

7. SALVIA verlicillata. Leaves sagittato-cordate, and lyrato-pinnate, crenate. Bracteae shorter than the whorls. Style incumbent on the lower lip of the corolla. Obs. 5281. Specimen gathered in the Vienna garden, and in that of Fothergill.-L. sp. 37. Hort. lero. i. 44. Scop. carn. n. 3t. Host 17. Roth. germ. i. 12.

Lamium maximum foctens purpureum galea hormini. Boerh. i. 158.

Horminum sylvestre latifolium. Raii hist. 516; europ. 146. Ger. by Johns. 771, repr. from

Horminum silvestre latifolium alterum. Clus. pann. 770, rcpr. in

Horminum silvestre tertium. Clus. hist. ii. 29, and cop. in

Hormium grermanicum humile. Parli, theat. 56. 


\section{Movoarsia. 23. Salvit.}

Gallitricho affinis planta. Bauh.J. iii. b. 314.

Coly.r, upper lip with $\$$ teeth, the middlemost the shortest. Obs. 5284.

Natize of Carniola, Stiria, Austria, Thuringia, Misnia and Saxony.

HORMINUMI sylvestre. Dale 149.

\section{Upper lip of the caly.x semitrifid.}

3. SALVIA officinalis. Leares lanceolato-ovate, and oblongo-elliptic, crenulate, reticulate. Racemi verticillate. Calyx bilabiate; segments acute. Obs. 7945. In a garden.-L. sp. 34. Hort. kew. i. 35. Scop. carn. n. 31. On mountains near the sea coast.-Woodv. i. 110. t. 38. Blackiw. t. 10. Knorr del. ii. t. S. 14.

S. foliis lancenlato-ovatis integris crenulatis, floribus spicatis, calycibus acutis. L. ups. 10.

S. major, an Sphacelus Theophrasti. Boerh. i. 166. Salvia. Cam. 475, with a calyx which expresses its specific character.

S. latifolia. Trag. 52, and Bauh. hist. iii. b. 304, cop. from

S. major. Fuchs. 250, c. 93. Park. parad. t. 475. f. 6. Dalech. 879. Dod. 288, repr. in Ger. by Johns. 764, \&

S. major, scabrior Dioscoridis. Lob. ic. i. 554, and cop. in

S. major vulgaris. Park. theatr. 49.

SALVIA major. Cartheus. iii. 107. Geoffr. suite ii. 329. Monro iii. 245.

S. officinalis. The leaves. Pharm. edin.-Bryant 142. Lew. disp. by Dunc. 301. Syn, i. 92; ii. 198. Nurr. J. i. 324. Krock.n. 46.

E 3 
S. hortensis major. Dale 140. Mill. Jos. 386. Rutly $45 t$.

Salvia. Sage. The leaves. Phurm. lond.-Alst. ii. 215. Berg. 22. Cull. ii. 152. /1eberd. 3. Herm. 464, 573. Hill 371. Lew. ii. 323. Linn. 42. Murr. ii. 164. Ploucq. bibl. i. 486. Quarin febr. 47, 95, 240; animad. 91. Schoepf 7. Spielm. 293. Stoll med. ii. 38, 167, 171, 404. Vogr. 79.

Sage. Blare 396. Chalm. i. 167; ii. 116, 165. Cull. clin. 229. Darw. ii. 59, 194, 219, 251. Fordyce G. fev. iii. 215. Hume, J. in lell. \& ess. 218. Pringle 139. Rush i. 112. Underw. ii. 65.

Natize of the south of Europe.

a viridis. Leaves green. Obs. 7945.

Green Sagge. Mill. Ph. dict.n. 1. var. 1.

Leares sprinkled with minute white globules, oblongo-lanceolate, ovato-oblong, sometimes ovate, generally unequal at the base, crenulate, bluntish, whitish green. Stem whitish green, villose. Caly.x slightly woolly, with numerous minute globular glands; upper lip semitrifid, the middle segment shorter and broader than the other 4 ; lower lip more deeply divided than the upper; pentagonal, costatc; ribs, 3 between the two lowermost angles, 1 between the uppermost angle and each of the lateral angles, and 2 betwecn the lateral angles and the lower angle of each sirle. Corolla, lower lip entire. Germina 4, oval-roundisl, on a receptacle. Receptacle turbinato-subrotund, fleshy, it little prominent on the lower side, with 4 obsolete teeth. Obs. 7915.

B rubra. Leaves reddish. Obs. 7946. In a garden. Red Sage. Nill. Ph. dict. n. 1. iar. A.

Stems reddish dirty purple, pubescent. Leares orate, midrib and veins on the upper surface reddish dirty purple, crenulate, purplish green. Caly.x bi- 
mbiate; upper lip semitrifid, the middle segnent as short again as the other two, and not so tapering. Corolla purplish blue; lower lip obcordate, dotted towards the base with minute dots of a decper purple; throat with a whitish purple line running along the middle. Obs. 7946.

y absinthites. (Variation.) Leaves tasting somewhat like Wormwood. Obs. 7947. Specimen from an old herbarium formed in England.

S. absinthites. Johns. in Ger. by Johns. 764, n. 7. No fig. - Rraii hist. 511.

S. minor altera flore rubente. Park. theatr. 50. No fig.

Wormwood Sage. Mill. Ph. dict. M. 1. var. 2.

S. absinthium redolens. Bauh. J. iii. b. 307. Boerh. i. 167.

\section{Calyx quinquefid.}

9. SALVIA larandulifolia. Leaves lanceolate and lanceolato-oblong, crenulate, reticulate. Racemi verticillate. Segments of the calyx nearly equal. Obs. 5264. In a garden:

S. lavandulaefolia. Vahl. enumı i. 222.

* acutifolia. Lueaves lanceolate. Plant tomentose, smaller than $\beta$ in all its parts. Specimens in Sir Jos. Banks's herbarium under the following titles, "Herb. Miller. (1.) from the province of Granada, in Spain \& (2.) from the Chelsea garden, in 1752, Houston."

S. hispanica. Nill. Ph. dict.n.4.

S. hispanica, lavandulac folio. Tourn. inst. 181.

Leares sometimes of the colour of those of Lavender, but hroader, as obscrved by Casp. Bauhine, less tomentose atbove, in the specimen from Chelsea. Spem cimens alsove mentioned. 
SALVIA hispanica. Geoffr. suite ii. 333.

s obtusifolia. Leaves mostly rounded at the end. Obs. 5264. Specimen from the Chelsea garden.

S. officinalis $\beta$ Linn. sp. 34 .

S. auriculata. Mill. dict. n. 3.

S. minor aurita, \& non aurita. Bauh. Casp. pin. 237. Blackw. t.71. Tourn. inst. 181.

S. minor. Dod. 290, repr. in Lob. ic. i. 555, and Ger. by Johns. 764. Tab. 371, repr. in Ger. 623. Cum. epit. 476. $f: 2$, the best representation of it, with a figure of the calyx expressing its specific character.-Fuchs. 250. c. 93. cop. in

S. nilior auriculata. Bauh. J. iii. b. 305, \&

S. angustifolia. Trag. 52. Clus. i. 342. No fig. In Spain.

S. minor, sive primata. Park. theatr. 50 ; parad. 478. $t .475 . f .7$.

S. minor, sive Sphacelus. Matth. 710, the fig. with auriculate leaves.

Sphacelus verus Theophrasti. Dalech. 880 .

La petite Sauge. $R \operatorname{eg} n$.

Sphacelus. Theophr. l. 6.c. 2.

S. minor, aurita \& non aurita. Boerh. i. 166.

Stems woody at the base, ascending. Leares oblongo-lanceolate, rugose, with white sessile globules. Flowers verticillate, generally 6 in a whorl. Peduncles upright, not half so long as the calyx. Calyx very slightly compressed, semiquinquefid, scarcely bilabiate, ribbed; ribs numerous, elevated, slightly villose, the spaces between sprinkled with greenish globules; upper lip semitrifid. Corolla bluish purple, twice as long as the calyx, pubescent without; tube thrice as short as the calyx, slightly compressed, whitish; throat wrinkled, sliglitly keeled above, depressed underneath, twice as long as the tube, closed 
within at the base by a circle of whitish hairs; upper lip oblong, straight; lower lip nearly twice as long as the upper, marked with 2 oblong club-shaped white blotches irregularly dotted with purple; lateral segments reflected, oblong, with a minute obsolete tooth at the end; middle segment obcordate, with 2 blotches of a deeper hue at the base. Stamina 4, in 2 pairs, each pair supported by a common filament. Common filaments 2, from the lower side of the throat near to where it joins the base of the upper lip, whitish, supporting a cross arm like the top of a crutch; partial filiments 2 to each common filament, one bowed upwards, the other downwards, each supporting an anthera. Antherce 4, oblong, of one cell, all containing pollen, in pairs, 2 above 2 , the upper larger; the lower smaller and connected laterally to each other. Pollen white. Rudiments of 2 other stamina at the upper side of the throat, just below the junction of the throat and upper lip. Filaments very short, whitish, with an obsolete tooth analogous to the cross arm of the perfect stamina. Antherce generally purple, sometimes white, sometimes containing white pollen, in one instance adhering to one of the lower pair of perfect antherae. Germina 4, roundish, green, on a receptacle. Receptacle turbinato-subrotund, fleshy, purplish, gibbous on the lower side, with 4 obsolete teeth. Style somewhat shorter than the upper lip. Stigma cloven, the upper segment as small again as the lower. Obs. 5264.

SALVIA minor. Alst. ii. 216. Gcoffr. suite ii. 331. Mill. Jos. 386.

S. hortensis minor. Dale 140. Lew. ii. 324. Rutty 4.54 .

S. minor aurita and non aurita. Boccl. ap. Herm. 465. Cartheus. iii. 107. 
Tea Sage. Bryant 142.

Salvial. Sage. 'The leaves. Pharm. lond.-Berg. 22. Murr. ii. 164. Schoepf 7.

S. oflicinalis. Pharm. edin.-Lew. disp. by Dune. 301.

\section{Calyx tripartite.}

10. SALVIA digyna. Leaves lineari-lanceolate. Styles 2. Obs. 5282. Specimen gathered in the garden of Fothergill.

S. cretica. L. sp. 33. IIort. lezw. i. 38.

S. hispanica. Mill. Ph. dicl.n.4.

S. cretica angustifolia. Clus. hist. i. 313, from Cretan seeds; repr. in

S. indica. Ger. by Johns. $765, \&$ cop. in

S. cretica angustifolia non aurita. Park. theatr. 51.

(S. tenuifolia. Bauk. J. iii. b. 306, has flowers in panicles.)

Calyx, upper lip trifid. Obs: 5282.

SALVIA hispanica. Geoffr. suite ii. 332.

S. folio tenuiore. Dale 140.

\section{COLLINSONIA.}

Corolla unequal, the lower lip multifid, with capillary segments. Seeds naked, 3 abortive, 1 perfect. Obs. 717. L.

1. COLLINSONIA canadensis. Leaves ovate. Stems rlabrous. Obs. 717. In a garden.-L. sp. 39. Ilort. lic.. i. 47.

Collinsonia. L. cliff. 14. l.5. Gron. virg. cd. ii. 6. COLLINSONIA. Lim. 43. Schoepf 7. 
2. COLLINSONIA scabrinscultr. Leaves ovate, subcordate, slightly pilose. Stem slightly pilose, rough. Hort. Kew. i. 47.

COLLINSONIA. Bartr. W. trav. 409.

\section{KAEMPFERIA.}

Calyx superior, obsolete. Corolla, outer limb tripartite; inner limb of 4 segments, 2 of the larger obovate, the Srd bipartite, the 4th bifid at the end. Antherae 2. Capsule trilocular, trivalve. From L. cliff. gen. \& Lour.-L.

1. KAEMPFERIA Galang $a$. Laminae of the leaves ovate. Petioles adpressed. From L. \& Lour. i. 15. L. sp. 3. Hort. kew. i. 3.

Kaempferia. L. cliff. 2. t. 3. Royen 12.

Katsjula Kelengu. Rhecde xi. 81. $t .41$.

Calceolus philippensis. Pet. gaz.t. 19. f. 2, from a drawing sent him by Camel.

Contrayerva seu Doso. Camellus ap. Raii hist. 61\%.

Wanbom. Kaempf.901. t. 902.

(Alpinia sessilis. Koen. ap. Retz. obs. iii, 62, is described as having a tubular calyx.)

SONCHORUS. Rumph. v. 173. t.69. f. 2, who figures and describes it as having a scapus with 1 flower.

(Galanga minor is referred by some to this plant, but the roots are described by Rumphius as white.)

2. KAEMPFERIA rotunda. Laminae of the leaves clliptic. Petioles loose. From L. sp. 3, \&

Malan-kua. Raii hist. iii. 648, whose account from the description of Rheede xi. 17. t. 9. whose fisrure cop. in 
Zedoaria. Blackw. t. 399, \& Woodv. ii. 362. t. 133, but the lowermost petals in Woodville's copy rounded as in the specimen mentioned below.

Zerumbet. Garc. ap. Clus. cxol. 213, repr. in

Zerumbeth Serapionis. Lob. obs. 39; ic. i. 74, the 3 inner figures, \&

Zerumbeth, sive Zedoaria rotunda. Ger. by Johns. 34 , is probably intended to represent the drug $\mathrm{Ze}$. doary.

(Zerumbet Scrapionis \& Zeduaria ejusdem radicis parles. Lob. obs. 39, repr. in

Zeduarium officinarum. Lob. ic. i. 74, the 3 outer figures, \&

Zedoariae exactior icon. Ger. by Johns. 1623, \& cop. in

Zcdoariae longae \& rotundae genuina effigics. Park. theatr. 1612, do not resemble any specimens of $\mathrm{Ze}$ doary which I have seen.)

Corolla, inner limb, lacinulae of the bipartite segment rounded. Specimen from Sir Jos. Banks's sarden in his herbarium.

ZERUMBET claviculatum. Rumph. v. 172. $t$. 69. $f .1$.

ZEDOARIA. Zedoary. The root. Pharm. lond. -Alst. i. 538. Berg. 4. Cull. ii. 207. Geoffr. ii. 50. Herm. 12. Hill 565: Lew. ii. 482; disp. by Dunc. 241. Lind hot cline. 311. Mead mon. i. 119. Monro iii. 289. Murr. v. 82. Ploucq. bibl. i. 700, Spielm. 303. Vog. 215.

Zedoary. Neum. ii. 201.

Zedoaria rotunda. Cartheus. iii. 28. Linn. 39, note. - Rully 558.

Zedoaria longa. Cartheus. iii. 28. Dale 251. Linn. 38. Mill. Jos. 462. Murr. v. 82. Rutty 558. 5. yotunda. Murr.J. i. 197. Syn, ii. 181. 
Amomum Zedoaria. Loug Zedoary. The root. Pharm. dubl.-Lew. disp. by Dunc. 139. CAMPHORA e radice Zedoariae. Herm. 617.

This and the preceding article Zedoaria are inserted here, not from a conviction that they are the produce of this species, but because I cannot prove them not to be such. Rumphius, who was acquainted with K. rotunda \& Zingiber truncatum, to which last others have referred them, was of opinion that they were the produce of neither.

\section{CURCUMA.}

Calyx supcrior, monophyllous. Corolla, upper segment of the inner limb with 4 horns. Stigma bilamellate. From Jacquin's description and figure of C. longa. $-L$. from authors.

1. CURCUMA rotunda. Leaves lanceolato-ovate, lateral ribs very few. L. $s p$. . S.

Amomum Zerumbeth. Koenig ap. Rets. obs. iii. 55.

C. foliis ovatis utrique acuminatis, nervis lateralibus paucissimis. Royen 12, cop. in L. zeyl. 6.

C. radice rotunda. Herm. prodr. 33.

Manja Kua. Rheede xi. 19. t. 10. (The flower cop. from Herman's figure of C. longa.)

CURCURA rotunda. Lour. i. 12; ed. Ato 11.

2. CURCUMA longa. Leaves lanceolate; lateral ribs very numerous. L. sp. 3. Regn.-Hort. liew. i. 3. Lour. i. 11; ed. Ato 8. Koenig ap. Retzo obs. iii. 72. Woodv. ii. 359. t. 132.

Amomum Curcuma. Jacq. hort. iii. 5. t. 4.

c. foliis lanceolatis utrique acuminntis, nervis later- 
alibus nunuerosissimis. Royen. 12, cop. in L. zeyl. 3.

C. officinarum. Camell. ar. Raii hist. iii. 23. n. 11. Cannacorus radice crocea, sive C. officinarum. Boerh. ii. 127.

Manjella-koua. Rhecde xi. 21.t. 11, root \& Icaves. C. radicc longa. Burm. zeyl. 83. Zunon. 86. t. 59, lcaves and spike; $\iota$. 14. f. 2, a fanciful representation of the stamen.- $11 \mathrm{crm}$. prodr. 330 ; hort. 208. $t$. 209, cop. in

Curcuma. Blackw. t. 396, \&

Terra merita. Pomet i. 65. Lob. adv. 33. No fig. -ic. i. 72, repr. in

Cyperus indicus, sive Curcuma. Ger. by Johns. 1631, \& cop. in Park. theatr. 1584, the dried roots.

C. domestica major. Rumph. v. 162. t. 67, who does not uotice the drag $C$. rotunda.

C. sive Terra merita officinarum radice crocca. Bauk. J. ii. 746 , dried roots.

(Curcuma. Bont. 117. t. must be, as Rumphius obscrves, a species of Camna.)

CURCUMA. Turmeric. The root. Pharm. lond. -Alst. i. 424. Berg. 6. Dale 250. Hill 593. Lew. i. 356 ; disp. by Dunc. 215. Limn. 37. Mill. Jos. 166. Nomro iii. 84. Neum. ii. 161. Rutty 155. Spielm. 263. Vog. 192.

C. Ionga. Cartheus. iii. 37. Geoffr. ii. 45. Herm. 50. Murr. v. 73.

Turmeric. Neum. ii. 161.

CURCUMA rotunda. Cartheus. iii. 37. Gcoffr. ii. 45. Herm. 50. Murr. v. 73.

3. CURCUMA pallida. Scapus bracteatc. Spikc oblong. From Lour. 
Monogyna. 27. Zingiber.

Zerumberl. Rumph. พ. 168. t. 68?

CURCUMA pallida. Lour, i. 12.

\section{ZINGIBER.}

Caly.x superior, monophyllous. Corolla, outcr limb tripartite; inner limb bilabiate; lower lip tripartite. Antherae 2, sessile, adhering to the upper lip of the corolla below the erid. Capsule of 3 cells and 3 valves. Obs. 3257.-Gaerln. i. 39.

1. ZINGIBER cchinatum. Flowers fasciculate, sessile at the root. Capsules sulcate, echinate. From Amomum an Globba crispa. Koenig ap. Retz. obs. ii. 50 .

Amomum echinatum. L. a Willd. i. 8, from authors. Amomum verum Encaladac. Pet. gaz. t. 20. f. 2, from a drawing sent by Encalada to Camel.

GLOBBA crispa viridis. Rumph. vi. 157.t. 61. f. 1 .

2. ZINGIBER villosum.-Scapus reclinate, short. Bracteae linear. Fruit villose. Lour.

Globba crispa rubra. Rumph. vi. 137.t.61. f. 2 s t. 60. $B, C, D$. Spike sessile. AMOMUM villosum. Lour. i. 4.

3. ZINGIBER officinale. Scapus simple. Stigma ciliate with setaceous teeth. Bracteae of the spike glabrous. Obs. 325\%. A scapus from a lot house. -Giaertn. i. 33. t. 12.

Amomum Zingiber. L. sp. 1. L. a Willd. i. 6, but the leaves are described as ciliate at the end.Swartz obs. 2, who describes the leaves quite glabrous.-Mill. Ph. dict. ic. i. t. 26. Jacq. hort. i. 
t. 75,-cop. in Woodv. i. 31.t.11. Horl. kew. i. 2. Lour. i. 2.

Inschi, vel Inschi Kua. Rheede xi. 23. (misprinted 21.) $t .12$.

Z. majus. Rumph.v. 156.t.66.f. 1 .

Gingembre. Pomet i. 61. $t$.

Ginger. Ogilly's china 246, the root and sicm.

Zingiberis verior icon. Ger. by Johns. 61, root and stem cop. in

Z. forte brasiliense, nigra radice. Park. theatr. 1613. Zingiberis siliqua cum granis suis. Lob. ic. i. 71, the capsule and seeds, repr. in Ger. by Johns. 61, at the bottom of the inner figure; \& cop. in

Zingiberis siliqua \& semen. Park. theatr. 1613, \&

Z. et cjus siliqua. Bauh. J. iii. b. 743; and this and the preceding fig. cop. in

Zingiber. Theophr. a Stap. 1012. Diosc. l.2.c. 190. Plin. 303. l. 12. c. 7. Bauh. Casp. pin. 35. Sloane cat. 60 ; hist. i. 163. Browne 119. Bauh. J. iii. b. 743, cop. in

Z. Penac. Dalech. 1890, \& cop. from

Zingiberis ficta icon. Lob. ic. i. 70, repr. in Ger. by Johns. 61, is a fig. of the dried root with leaves added by the artist.

Leaves lanccolate; slightly pilose underneath towards the base; margin glabrous; ribs and veins longitudinal, without any transverse oues. Obs. 8210. Specimen gathered in Fothergill's garden, under the name of Cultivated Ginger.-Lcares lineari-lanccolate, attenuate, acute, slightly pilose underneath towards the base; ribs and veins longitudinal, without any transverse veins; margin glabrous. Obs. 8211. Specimen gatlıcred in Fotlıergill's garden under the name of Wild Ginger.-Scapus 6 inches long, solid, jointed, bractcate. Bracteae of the scapus oblong, 
rounded at the end with a very short acumen, nitid on the inner surfuce, scariose at the margin, vaginant for about one fourth of their length. Spike oblong, nromatic. Bractene in pairs; outer subrotundo-oval, scariuse at the margin, concave, generally containing a clear insipid scentless water; inner ovato-oblong, semi-transparent, as long as the unexpanded flowers and just rising above the end of the outer bractea, opposite to the outer bractea. Flowers before they are expanded lanceolate, subulate at the end, slightly compressed, generally 2 together in the lower part of the spike, one of which often abortive, and in the upper part of the spike solitary; one of the 2 flowers somewhat smaller, the smaller enveloped in another transparent bractea; when expanded rising to half the length of the bractea above the end of the bracteae, scentless, opening in the evening and begining to wither by morning, one in a spike flowering at a time. Caly.x transparent, wider than the tube of the corolla, cloven one third of the way on the inner side, the margin with a very shallow sinus on the outer side, and an obsolete angle on the lateral sides. Corolla, tube cylindrical, as long as the bracteae, whitish, and towards the end yellowish; outer limb palish tawny yellow, bilabiate; segments 3 , nearly equal, marked with scmi-transparent lines, the uppermost erect, lanceolate, concave, slightly incurvate, the 2 lower lorizontal, lineari-subulate, the ends from about one third of their length from the point hanging down; inner limb bilabiate, whitish tawny yellow and brownish crimson; upper lip as long as the outer limb, straight, incumbent on the middle segxnent of the lower lip, whitish below, the upper end above the antherae dark brownish red, margins em: bracing the style; lower lip tripartite; middle seg- 
ment oblong-square, retusc, convex, bclow whitish tawny yellow marked with red, the end and sides decp brownish crimson with ycllowish spots; lateral segments ovate, crect, brownish crimson with yellowish spots inserted between the segments of the outer limb, four times as small as the middle segment. Antherae inserted into the upper lip of the corolla, bilocular, white, separated by the narrow chink in which the style lies; cells bursting longitudinally. Pollen white. Style white, the end slightly inflected and perforated. Obs. 3257.

ZINGIBER. Ginger. The root. Pharm. lond.

-Alst. i. 541. Berg. 1. Cartheus. iii. 33. Chom.

i. 137. Cull. ii. 206. Dale 251. Geoffr. ii. 156. Heberd. 9. 335. Hill 569. Lew. ii. 486. Lim. 35. Long jam. iii. 700. Mead monit. ii. 90. Monro iii. 291. Murr. v. 52. Quarin febr. 376. Rosenst. 188. Sinall in med. obs. vi. 199. Spielm. 304. Vog. 215. Wright in med. journ. viii. 220. Zinziber. Herm. 17. Mill.Jos. 463. Rutty 559. Anomum Zingiber. The root dried. The candied. root imported from India. Pharm. edin.-Bryant 20. Lew. disp. by Dunc. 138. Murr. J. i. 196. Syn. i. 95, 114; ii. 167.

Ginger. Blane 461. Bree 292, 298. Chalm. i. 197, $149,181,191$; ii. 17, 41, 177, 182. Graing. 57. Lind seam. 96, 182. Murr. J. i. 340. Neum. ii. 203. Papin in phil. trans. abr. by Jones r. part ii. 185; and by IIutton vi. 53. Plouq. bibl. i. 487. Pringle 215. Underw. i. 110, 123; ii. 59; iii. $14 \%$.

4. ZINGIBER Zerumbet. Scapus simple. Stigma ciliate with sctaceous teeth. Bracteac of the spike pubescent at the end. Obs, 3258: Specimen ga= 
thered in the Schoenbrun garden. -Jacq. hort. iii. t. 54 .

Aniomum Zerumbet. L. sp. 1. Hort. kew. i. 2. Lour. i. 3.

Amomum scapo nudo, spica oblonga obtusá. Ehret pict. t. 14. Segments of the outer limb straight.Mill. Ph.ic. 17. t. 26.

Katou Inschi Kua. Rheede xi. 27. t. 13.

Lampnjum. Rumph. v. 148. t.64.f. 1.

(Z. latifolium sylvestre. Boerh. ii. 128. Herm.

lugdb. 636. t. 637, cop. in

Gingembre sauvage. Pomet i. 61. $t$ : is $\mathrm{Z}$. truncatum.)

Leares lanceolate, slightly pilose underneath towards the base; ribs and veins longitudinal without any transverse veins; margin glabrous. Spike ovate, obtuse. Obs. 3258.

ZERUMBET. Dale 251. Mill. Jos. 462. Rutty 558 .

Zerumbeth. Geoffr. ii. 154 .

5. ZINGIBER sylvestre. 'Scapus simple. Stigma pubescent. Bracteae striate, glabrous. Obs. 8213. Specimen gathered by Dr. Wright in Jamaica. - Swartz prodr. 11 ; ind. occid. i. 1. Amomum scapo florifero partiali aphyllo, spica longiori. Browne 113.

$Z$. sylvestre majus, fructu in pediculo singulari. Sloane cat. 61 ; hist. i. 165. t. 105 f. 2.

Brarteae 1 inch 4 tenths long, rufous. Caly.x tubular, striate, 7 tenths of an inch long, glabrous, rufous. Corolla tubular, somewhat shorter than the calyx; outer limb tripartite; segments oblongo-ovite, erect; inner limb of 2 segments, one inserted at the F 2 
base of the outer limb, just shorter than the outer limb, the other very short. Antherae 2, inserted into the shorter segment of the inuer limb of the corolla, parallel and close to each other. Stigma orbicular. Ols. 8213.

AMOMUM Zerumbet. Wright in med. journ. viii. 221.

6. ZINGIBER truncatum. Scapus with a loose truncate spike. From

Amomun scapo nudo, spica laxa truncala. Berg. mat. med 4, from a specimen gathered by Loureiro in Cochinchina, but I cannot find any plant in Loureiro which corresponds with that of Bergius.

Amomum Zedoaria. L. a Willd. i. 7, from authors. Kua. Rhecde xi. 13. t. 7.

Zedouria officinarmm. Pet. gaz. t. 23. f. 1.

Z. latifolium sy vestre. Boerh. ii. 128. Herm. hort. 635. 1.637, cop. in

Gingembre sauvage. Pomet i. 61. $\iota$.

Z. loaria. Camel. "p. Raii hist. iii app. 23.

ZEMOARIA Sce Kaenipferia rotunda, to which most iuthois have referred it. May not the $\boldsymbol{Z} \epsilon$ doaria longa be the parts of the root immediately connected with the sem, and the Zedoaria rotunda those which adhere by means of threads, as represented in Rumphins's figure of Curcuma longa?

7. ZINGIBER Mioga. Scapus very short. Capsule ovate. Leaves ensiform, acute. Thunb. jap. 14; trav. iii. 82 ; ir. 89.

DJOOKA. Kaempf. umoen. 826.

8. ZINGIBER compactmm. Scapus simple, very short. Leaves lanccolate. Capsules roundish. From 
Rumph \& Lour.-Thunb. trav. ii. 282; iv. 147, $16 \mathrm{~s}$.

Amomum Cardamomum. Lour. i. 4 ; ed. 4to, 4.

Cardamomum minus. Rumph. v. 152. t. 65. $f$ 1.

Cultivated in the gardens of Amboina, into which island it was introduced from Java in 1670 .

Capsules trilocular, roundish and obovate, trigonotricoccous, costate, the angles rounded, from 4 to $5 \&$ a half tenths of an inch long, and 4 and 5 broad, villose at the base and end; dissepiments very thin. Seeds angular, sides smooth, of a resinous bitterish warm taste, but not to be called aromatic. Obs. 8387 . In an apothecary's shop.

CARDAMOMUM rotundum. Cartheus. iii. 518. Spielm. 244.

Cardamomum capsula rotunda ampliore. Vog. 248. Middling Cardamoms. Neum. ii. 187.

Cardamomum medium rotundum. Rumph. v. 152, par. the last; 153. par. 3.

9. ZINGIBER Cardamomum. Scapi branched. Leaves lanceolate. Specimen of the leaves and scapi in flower in Sir Jos. Banks's herbarium, yathered by M. Sonnerat in Malabar.

Amomum repens seu Cardamomum. Woodv. 35̃6. $t$. 131.

Z. minus, Gaertn. i. 35. t. 12.

Amomum Cardamomum. Linn. sp. 2, $\approx=$ evident from the specific character of the fl. zeyl. and his adding the epithet of optima to the figure cited from Rheede, though the specinen found in his herbarium is $\mathbf{Z}$. compactuin.-Koenig ap. Retz. obs. iii. 59.

Amornum repens. Sonnerat ind. ii. 240. t. 136. I. 3 
On the mountains behind Malse in Malabar, which furnisle the greater part of the Cardamums sold in India.

Amonum scapo bracteis alternis laxis caule breviore. L. zeyl. 2.

Elettari species prima. Rheede xi 11.t. 4, the plant reduced, and a leaf; ( $t .6$ is probably Elettari tertia species. Rheede xi. 11, which is described as having acuminate capsules, ) t. 5 , the root, lower part of the stem, scapi in flower and fruit, and parts of fructification, cop. in.

Cardamomum minus. Blackw. $t$. 385, with an addition of $f .3,5,6$, representing the capsules and seeds.-Boerh. ii. 128.

Cardamomum minus vulgare. Lob. ic. ii. 201, repr. in Ger. by Johns 15 12 , \& cop. in

Cardamomum minus \& vulgare. Park. theatr. 1576. Cardamomi cum siliquis sive thecis brevibus. Bauh. $J$. ii. 205, the 6 outer capsules cop from

Cardamomum medium. Lob. ic. ii. 204, which cop. in Park. theat. 1576, the 6 inner capsules, and repr. in

Cardamomum vulgare minus. Ger. by Johns. 1542, the 6 inner capsules.

Cardamomum. Diosc. l. 1. c. 6.

(Cardamomum minus. Bont. ap. Pis. 126, is a different speries.-Rumph. v. 152.t. 65. f. 1 , is Z. compactum.)

Capsules triquetrous, oval and elliptic, striate, 5 \& 6 tenths of an inch long. Sceds angular, tuberculate, of a pleasant aromatic flavour, and warm. Obs. 8386. In an apothecary's shop.

CARDAMOMUM. Alst. ii. 337. Rutty 95.

Cardamonum minus. Smaller Cardamoms. The secds. Pharm. lond.-Berg. 3. Cull. ii. 206. 
Dale 252. Geoffir. ii. 368. II crm. 260. II ill 468. Lew. i. 2i9. Lim. 35. Mead mon. ii. 13. Mill. Jos. 112. MLonro iii. 45. Murr. v. 61. Spielm. 245. Vog. 248.

C. longum minus. Cartheus. iii. 525.

Lesser Cardamon. Neum. ii. 187.

Amomnm repens. Seed. Pharm. edin._Lew. disp. by Dunc. 139. Murr. J. i. 203. Syn. 166.

Cardamomum minimum trigonum. Rumph. v. 153. par. 3.

Cardamom. Fordyce G. fev. iii. 253. Underw. i. 123; iii. 146.

10. ZINGIBER Meleguetta. Capsule surrounded by fasciculate bracteae. From Gaertn. i. 34. t. 12. A capsule from an apothecary.

Amomum Granum paradisi. L. sp. 2, but the specific character appears to have been formed from the figure of Rheede cited below, which plant is a native of India.-Hort. kezo. i. 2. Had not flowered.-Donn. 1. Flowered in Aug. \& Sept. From Sierra Leone.

Milleguetta. Lob. ic. ii. 204, repr. in

Cardamomi. Ger. by Johns. 1542, the 3 upper and outer capsules, \& cop. in

Cardamomi genus maximum, Grana paradisi, sive Melegeta. Bauh. J. ii. 204, the 3 upper capsules, Meliguette, sive Cardamomum maximum \& Grana paradisi. Park. theatr. 1576, \&

Meliguetta. Theophr. a Stap. 1014. The capsules. Melegetta. Lob. adv. 445. No figure. From the western coast of Africa.

Cardamomum arabum majus. Tab.915. Capsules. Cardamomum majus. Matth. 27, cop. in Cam. epit. 11. f. L. Besl. mus. 14. 1.4. Capsules. 
(Elettari. Rheede xi. $t .6$, differs from t. 4 and 5 , as Mr. Knowlton suggested to me, in the surculi and scapi being cylindric and not bulbose at the base, but may possibly prove only the same plant in fruit. Its deciduous bracteae prove it however to be a different plaint from that of Gacrtner.)

MELEGUETTA. Geoffr. ii. 367.

Cardamomum maximum. Alst. ii. 337. Mill. Jos. 112.

Cardamomum piperatum Cordi. Cartheus. iii. 526. Cardamomum majus. Geoffr. ii. 365? Spielm. 244. Grana paradisi. Berg. 3. Cull. ii. 206. Dale 253. Herm. 267. Lez. i. 471; disp. by Dunc. 328. Linn. 36. Murr. v. 67. Rutty 96. Spielm. 269. Vog. 179.

Grains of paradise. Neum. ii. 212.

Malaguetta Pepper. Winterboltom, account from in chir. rev. x. 463, 464.

11. ZINGIBER medium. Spike on the stem, branched. Capsules not dividirig into valves, oblong, striate. From

AMOMUM medium. Lour. i. 5.

12. ZINGIBER globosum. Spike on the stem, branched. Capsules not dividing into valves, globular, smooth. From

AMOMUM globosum. Lour. i, 6 .

13. ZINGIBER Galanga. Spike on the stem, erect. Bracteae mostly triflorous. Capsules ovate, trigonous, glabrous. From

Amomum Galanga. Lour. i.

Maranta Galanga. L. sp. 5; a Murr. 51. 
a major. Root whitish within, an inch thick. From authors.

Galanga. Rumph. v. 143. t. 63.

Galanga major. Boerh. ii. 128. Banh. J. ii. 738.

f. 1. The root.-Ger. by Johns. 33, cop. in Park. theatr. 1585. The root.

GALANGA major. Alst. i. 447. Dale 252. Carthens. iii. 46. Geoffr. ii. 59. Herm. 14. Lew. i. 452. Linn. 37. Mill. Jos. 206. Murr. v. 69. Rulty 211. Spielm. 268. Vog. 196:

Larger Galangal. Neum. ii. 203.

B minor. Root rufous within, half an inch thick. Fron specimens of the root in the shops.

Galanga major. Bauh. J. ii. 739. No fig. The'fig. is at p. 735 , between Galanga Clusii and Galanga Acostae.-Lob. ic. i. 58, repr. in Ger. by Johns. 33, \& cop. in Park. theatr. 1585.

GALANGA minor. Alst. i. 447. Cartheus. iii. 46. Dale 252. Geoffr. ii. 48. Herm. 14. Lew. i. 452; disp. by Dunc. 162. Linn. 37. Mill. Jos. 206. Monro iii. 115. Murr. v. 69. Rutty 211. Spielm. 268. Vog. 196.

Galanga. Berg. 7. Lew. by Dunc. 344. Ploucq. bibl. i. 699.

Smaller Galangal. Neum. ii. 203.

14. ZINGIBER uncinatum. Racemus cauline. Stigma glabrous. Lateral segments of the lower lip of the corolla subulate, very short; middle segment semitrifid. Obs. 5254. Specimen gathered by Broughton in Jamaica.

Alpinia racemosa. Swartz. prodr. 11 ; obs. 6. Donn 1. (L. a Murr. 51 ; sp. 2 , is a different species.) Alpinia jamaicensis. Gaertn. i. 36. t. 12. 
Amomum minus, scapo vestito, floribus spicatis. Browne 113.

Z. sylvestre minus, fructu e caulium summitate exeunte. Sloane cal. 61; hist. i. 165. t. 105. f. 1. (A)pina racemosi alba, cannacori foliis. Plum. ic. 11. $\ell .20$, is a different species.)

Leaves lanccolate, glabrous, entire at the margin; veins large and small longitıdinal, with transverse veins. Flowers with semi-transparent dots. Caly $x$ tubiformi-tubular, twice as long as the germen, semitrifid, with about 10 ribs; segments patulous, semiorbicular. Corolla nearly thrice as long as the calyx; outer limb tripartite; segments ovali-oblong, incumbent; inner limb bilabiate; lower lip semi-tripartite, middle segment unguiculate, lamina reniform, obsoletely trilobate, more than twice as broad as the segments of the onter limb and somewhat shorter, veined; lateral segments very small, three times shorter than the middle segment, some times recurvate, appearing like 2 hooks; upper lip triangular, shorter than the lateral segments of the lower lip. Antherae 2, lanceolate, bilocular, parallel, syngenesious, united laterally but not by the margins of the valves, as long as and opposite to the lower lip. Obs. 5254.

LLPINIA racemosa. Wright in med. joum. viii. 221.

\section{COSTUS.}

Caly $x$ superior, monophyllous. Corolla, outer limb tripartite; inner limb bilabiate; lower lip trilobate. Antherae 2, sessile, adhering to the upper lip of the inner limb of the corolla. Capsule with 3 cells and 3 valves. From Süartz obs. 3, and Roscoe in linn. trans. viii. 349. t. 20. f. 9. L. 
Seems to differ from Zingiber merely in the lower lip being slightly trilobate and twice as long as the outer limb.

1. Costus conicus. Leaves glabrous. Petioles te. rete. Spike closely imbricate. From

Alpinia spicata. Jacq. amer. 1. t. 1; 8ro 1,

COSTUS spicatus. Sw̃art. prodr. 11 ; \& ind. occid. 6. Chisholm 25.

2. COSTUS crispiflorus. Leaves sericeo-villose underneath. Spike loosely imbricate. From Jacq. Swartw, \&

C. speciosus. Smith in linn. trans, i. 249. In Sion garden.-Salisb. R. allert. 5, who says that Sir Jos. Banks found it in the island of Pulo Pontangh.

C. arabicus. Swarts prodr. 11. Jacq. icon. i. 1. t. 1 ; coll. i. 143. Thunb. trav. ii. 282; iv. 146. In Javà.-Mill. Ph. dict. n. 1.

Banksea speciosa. Koen. ap. Rets. obs. iii. 75. In Malacca, where also cultivated in gardenc.

Costus. Royen 11. L. zeyl. n. 5 .

Zedoaria zeylanica, camphoram redolens. Boerh. ii. 128.

Tsiana kua. Rheede xi. 15. t. 8.

Herba spiralis. Rumph. vi. 143. t. 64. f. 1, judging from the description.

(Jacuacanga. Piso bras. 98, repr. in

Paco Caatinga. Marcgr. bras. 48, \& cop. in

Arundo indica conifera latifolia brasiliensis. Hist. ox. s. 8. t. 14. f. 8, and the description of which by Marcgr. is cop. in,

Canna brasiliensis conifera. Raii hist. 1202, has me- 
dical virtues, but is represented with a closely imbricate spike with rounded bracteae.)

COSTUS. Alst. i. 417. Dale 250, 421. Geoffr. ii. 43. II crm. 38. Lew. i. 370. Mill. Jos. 155. Spiclm. 211.

C. arabicus. Berg. 8. Linn. 36. Murr. v. 80.

C. dulcis. Linn. 36. Murr. v. 80. Vog. 235.

C. amarus. Murr. v. 80.

\section{HEDYCHIUM.}

Calyx superior, monophyllous. Corolla, outer and inner limb tripartite. Antherae terminal. From Lamark quoted by Juss. 448, and Roscoe in linn. trans. viii. 342. t. 20. f. 6. Koen.

1. HEDYCHIUM coronarium. Koen. ap. Retz. obs. iii. 73. Donn 1. Roscoe in linn. trans. viii. 312. GANI) ASULIUM. Rumph. v. 175. t. 69. f. 3.

\section{S0. RENEALMIA.}

Calyx superior, monophyllous. Corolla, outer limb tripartite; inner limb bilabiate; upjer lip cordate, longer than the outer limb: lower lip tripartite; segments linear. Antherae adhering to the middle segment of the lower lip of the corolla. Berry fleshy, trilocular in the middle. Obs. 7168, from R. nutans. The account of the fruit from $L$. fil. suppl. 7 .

1. RENEALMIA exaltata. I Leaves and germen glabrous. From L. fil. suppl. 79, \&.7. 


\section{GLOBBA.}

Corolla trifill; segments equal. Calyx superior, trifid. Capsule trilocular. Seeds many. $\boldsymbol{L}$. Probably differs not from Rencalmia.

1. GLOBBA uriformis. Spike lateral. L. mant. 171. Rumph. vi. 138. t. 59. f. 2 .

\section{T R I G Y N I A.}

\section{PIPER.}

Calyx none. Corolla none. Berry with 1 seed. $\boldsymbol{L}$. -Lour. i. 40.

Stamina uncertain in number, intermixed with pistils. Gaertn. 92.-What Jussieu describes as a squamula exterior will probably prove a scale-like calyx. If Gaertner's observation be followed this genus must be referred with Arum to the class Monoecia.

1. PIPER nigrum. Leaves with 7 ribs, ovate, coriaceous, glabrous. Joints of the branches knotty. From Vahl. enum. i. 329, L. zeyl. Rheede \& L. sp. 40. Woodv. 513.t. 187. Mill. J. illustr. i. t. 5. Donn 9. Regn.-Lour. i. 37, who describes the calyx as tetraphyllous.-Clus. exot. 183, repr. in Ger. by Johns. 1538, cop. in

P. nigrum vel album. Park. theatr. 1603, \&

P. riigrum Clusii. Baulı.J. ii. 182.

P. foliis oratis subseptemnerviis glabris, petiolis simplicissimis. L. . $e y l . n .26$. 
Malago-codi. Rheede vii. 23. t. 12.

P. rotundım ex Malabara, foliis latis quinquenerviis albicantibus. Herm. zcyl. 32.

Piperis albi uva ad vivum expressa. Clus. exot. 183, cop. in

P. nigrun \& album. Dalech. 1808, repr. in Lob. obs. 575 ; ic. ii. $147, \&$

P. album. Ger. by Johns. 1538; \& cop. in

Piperis albi racemus. P'ark. theatr. 1603,

P. nigrum. Bauh. J. ii. 181, \& Besl. mus. 7. $t$. 3. $f .2$.

P. rotundum nigrum. Bauh. Casp. pin. 411. Pluk. alm. 297. $t$. 437. f. 1. Petioles dentate at the base.-Hist. ox. iii. 602. s. 15. t. 1. f. 1 . Blackiw. t. 348, in fruit.

P. album. Besl. mus. 8. t. 3. f. 4 .

Long Pepper. Blackw. t. 356.f. 1, 2, 3, appears to liave been taken from a specimen of this species.

Lada, aliis Molanga, sive P. mas. Pis. mant. 180. Poivre noir. Pomet i. 191.

Round Pepper. Ogilby's china 258.

PIPER nigrum. Black Pepper. The berries. Pharm. lond.-The fruit. Pharm. edin.-Alst. ii. 310. Berg. 27. Cull. ii. 207. Dale 330. Fordyce, $W$. fragm. 45. Geoffr. ii. 377. Herm. 261. Hill 462. Lew. ii. 224; disp. by Dunc. 281. Lind hot clim. 313. Linn. 43. Mill. Jos. 348. Murr. v. 22; J. i. 201. Rutty 392. Spielm. 286. Syn. i. 92 ; ii. 196. Vog. 260.

Piper. Heberd. 107. Ploucq. bibl. i. 316, 4S6, 521. Quarin febr. 377; animad. 47, 50.

P. rotundum nigrum. Carthens. iii. 503.

Black Pepper. Darw. ii. 31, 128, 156, 264. Fothergill, $J$. in med. obs, vi. 108. Monro iii. 222. Neum. ii. 211. 
Pepper. Blisard, account from in med. rev. i. 328. Bree 296. Chalm. ii. 41. Fordyce, G. fev. iii. 253; iv. 131. Papin in phil.trans. abr. by Jones r. part ii. 1St; \& by Hutton vi. 52. Underw. i. S04; ii. 59.

PIPER album. Alst. ii. 311. Berg.'27. Cartheus. iii. 504. Dale 331. Geoffr. ii. 379. IIerm, 261. Lew. ii. 294. Linn. 43. Murr. v. 22. Ploucq, bibl. i. 203. Rutty 392. Spielm. 287. Vog. 260.

White Pepper. Monro iii, 222! Neum. ii. 211.

2. PIPER bidentatum. Berries unitcd. Lcaves sep. temneryose, ovate \& cordate. Petioles mostly bidentate. From

P. Betle. Lour. i. 39, L. sp. 40, \& Vahl. enum. i. 328.

P. qui Saururus foliis septemnerviis oblongo-acuminatis. Burm. J. zeyl. n. 193. t. 83. f. 2.

Betele Tambul, seu Betre. Burm. J. zeyl. 46.

Sirii folium. Rumph. v. 336. t. 116. f. 2.

Beetla-codi. Rheede vii. 29. t. 15.

Betre, seu Betle. Garc. ap. Clus. exot. 176, repr. in Betle, sive Betre. Ger. by Johns. 1541, \& cop. in. Park. theutr. 1615,

Betre, sive Bctelle. Bauh. J. i. b. 437, \&

Betre. Dalech.app. 14. .

BETLE. Dale 286.

Betel. Thunb, trav. ii. 268. Percival, Rob. ceyl. $175,323$.

3. PIPER Cubeba. Leaves obliquely ovate or oblong, veined, acute. Spike solitary, on a peduncle opposite to the leaves. Fruit on pedicles. $\boldsymbol{L}$. fil. suppl. 90. Gaertn. ii. 67. ᄂ. 92. f. 1, a spike of berries. 
P. candatum.' Berg. mat. med. 28. Besl. mus. '7. t. 3. f. 1, a racemus.

Piperis calldati uva. Clus. exot. 184, racemi, cop. in P. caudatum. Bauh. J. ii. 185, the lower half of the figures, and the larger racemus cop. in

P. caudatum orientale. Park. theatr. 1604.

Cubibae. Ger. by Joluns. 1548, cop. in.

Cubebae. Park.thentr. 1583. Clus. exot. 184. No fig. - Raii hist. 1813.

Cubebae officinarum. Camell. in phil.trans. xxiv. 1773.

CUBEBAE. Alst. ii, 281. Berg. 28. Cartheus. iii. 512. Cull. ii. 209. Dale 316. Geoffr. ii. 375. Herm. 258. Lew. i. 378; disp. by Dunc. 281. Linn. 4t. Mill. Jos. 161. Monro iii. 83. Murr. v. 37. Neum. ii. 211. Rutty 149. Spielm. 262. Vog. 252. Woodv. iv. 165.

Cubeba. Cubeb. Pharni. iond.

P. Cubeba. Murr.J. i. 202. Syn. ii. 195.

4. PIPER Malamivi Leavés quinquenervose, elliptico-ovate, scabrous, underneath; ribs elevated underneath. From L. zcyl. \& Rheede. Is. sp. 41. Vaihl. enum. i. 327.

Amolago. Rheede vii. 31.t. 16; spikes of an equal thickness throughout, longer than the leaves; descr. cop. in Raii hist. iii. 641.

WALLANRADHU. Herm. zeyl. 20.

5. PIPER Siriboa. Leaves with from 7 to 9 ribs, ovato-cordate, rugose underneath, veined, nearly equal at the base. From L.sp. 41, Vahl. enum. i. 332, \& Rumph.

(Betele. Bont. 91, has lanceolate leaves.) SIRIBOA. Rumph: v. 310.t. 117. 
6. PIPER Amalugo. Leaves quinquenervose, elliptico-ovate, slightly unequal at the base, glabrous. Berries contiguous. Obs. 8654. Specimen gathered by Broughton in Jamaica.- $L$. sp. 41 . Vahl. enum. i. 32s. Hort. kew. i. 49. Swart. obs. 19.

P. frutescens diffusum, ramis flexilibus geniculatis, foliis ovatis quinquenerviis ad petiolum leniter revolutis. Browne 121.

P. longum arboreum altius, folio nervoso minore, spica graciliori \& breviori. Sloane cat. 44; hist. i. 134.t. 87. f. 1 .

P. frutex, spica longa gracili. Pluk. alm. 297. $t$. 215. $f$. 2 .

Saururus foliis lanceolato-ovatis, quinquenerviis rugosis. L. cliff. 140.

(P. longum. Rumph. v. 333. t. 116. f. 1, is P. longum.)

Leares glabrous; quinquenervose, 2 of the 3 middlemost ribs uniting at the distance of a quarter of an inch above the base; dotted with microscopic dots; margin neither glandular nor undulate. Spikes witl distinct berries. Obs. 8655. Specimen gathered by Dr. Wright in Jamaica. Possibly a distinct species. PIPER Amalago. Wright in med. journ. viii. 276.

7. PIPER diffusum. Lower leaves șeptemnervose, cordato-ovate, the upper quinquenervose, oblong, unequal at the base, rugose underneath. From Vahl. enum. i. 333.

SIRIUM frigidum. Rumph. v. 345. t. 119, f. 2.

8. PIPER longum. Leaves septemnervose, cordate, petiolate; the upper quinquenervose, cordato-ob- 
long, sessile. From Lour. i. 40, Vahl. enum, i. 33t, \& L. sp. 41; ieyl. n. 30. Woodv. 516. $t$. 188. Rumph. v. 333. $\ell$. 116. f. I, has elliptic leaves, and Loureiro remarks that they do not at all agree with the plint. (Regn. t. seems from the sliape of the leaves and dentate petioles to be P. bidentatum.-Blackiw. t. 356.f. 1, 2, 3, is P. nigrum, \& f. 4, 5, 6, P. Amalago.) Garc. ap. Clus. exot. 183, repr. in Chus. exol. 20, \& Ger. by Johns. 1539; \& cop. in Park. theatr. 1601, Besl. mus. 8. t. 3. f. 3, \&

P. Iongum Clusii. Bauh. J. ii. 186. Specimen from Java. Leaves elliptico-ovate.

Cattu-tirpali. Rheede vii. 27.t. 14.

Poivre long des indes. Pomet i. 191.

Pimpilim. Pis. mant. 183.

P. longum orientale. Bauh. Casp. pin. 412.

P. longum Monardi. Lob. ic. ii. 205, a single spike, cop. in Bauh. hist. ii. 186, with the addition of a other spikes, \& in

Fructus Piper longum. Park. theatr. 1604.

(Piperi longo similis, pistolochia foliis absque pediculis, maderaspatanum. Pluk.aln. 297.t. 104. f. 4, seems more to resemble Jaborandi posterior. Pis. bras. 97.)

PIPER longum. Long Pepper. The fruit. Phatm. lond. edin.-Alst. ii. 311. Berg. 28. Brown, S. in phil. trans. xxiii. 1063. Cartheus. iii. 507. Cull. ii. 209. Dale 286. Geoffir. ii. 380. Heberd. 230. 335. Herm. 206. Hill 463. Lew. ii. 225; disp. by Dunc. 281. Limn. 4t. MTead mon. ii. 90. Mur. v. 35; J. i. 202. Rutly 392. Spielm. 286. Syn. i. 93; ii. 195. Vog. 261.

Long Pepper. MLonro iii. 222. Papin in phil. trans. abr. by Jones y. part ii. 1Si: \& by Mutton vi. 53. 
9. PIPER reticulatum. Leares with from 5 to 9 ribs, cordate, acuminate, glabrous. Petioles equal. From Vahl. enum. i. 330. L. sp. 41.

Saururus racemosus, seu Botrytes major \& Plum. amer. 238.

(Jaborandi prior. Pis. bras. 97, repr. in Jaborandi III. $P$ is. ind. 216, has petioles as long as the laminae.)

SAURURUS botryitis major, arborescens, foliis plantagineis. Plum. pl. d'amer. 57. t. 75. Pomet i. 196.

10. PIPER cardatun. Leaves novemnervose, cordate with a deep sinus at the base, attenuate, glabrous, reined. From Vuhl. cnum. i. 335.

P. caudatum, seu Nhamdu. Marcgr. 75, repr. from

NILANDU. Pison. bras. 96.

11. PIPER methyslicum. Leaves nultinervose, cordate, acuminate. Spikes axillary, solitary, very short, pedunculate, very patent. Forst. G. escul. T6; auslral. n. 21.

Sirium decumanum. Rrumph. v. 45. t. 27. KAVA PLANT. Cook roy. 3rdi. 190. 227. AVA. Cook roy. 3rd ii. 96.

12. PIPER umbellalum. Leaves multinervose, orbi culatn-corclate, acute. Spikes umbellate. Stem pubescent. Obs. 8009. Specinen gathered by Broughton in Jamaica,-L. a Willd. i. 167. $L$. sp. 43. Süarlz obs. 21.

P. longum racemosum malvaccum. Sloune cat. 45. Saururns arborescens, foliis amplis cordatis non un* bilicatis. I'lunn. amer. 55. ८. 73. 
Aguaxima. Pis. bras. 104.

SAURURUS foliis amplis orbiculato-cordatis sinu aperto, petiolis vaginantibus. Browne 203.

13. PIPER subpeltatum. Leaves multinervose, reniformi-cordate, acuminate. Spikes umbellate. Stem glabrous. From L. a Willd. i. 166, \& Vahl. enum. i. 337.

LOMBA. Rumph. vi. 133. เ.59. t. 1.

14. PIPER acuminatum. Leaves lanceolato-ovate, nervose, fleshy. Spikes conjugate and in threes. Stem rather crect. From L. sp. 42, \& Vahl. enum. i. 342 .

Saururus humilis, folio carnoso acuminato. Plum. pl. d'amer.54.t.71. Spikes conjugate and solitary.

P. longum humilius, fructu e summitatc caulis prodeunte, with smaller and more pointed leaves. Sloane hist. i. 137. In Barbadoes.

Mecaxuchitl. Worm. mus. 208, two spikes, one of which cop. in Pomet i. 191.

MECAXOCHITL. Dale 286. Raii hist. 1671.

15. PIPER pinnatum. Leaves ovate, pinnate. Sten erect, aculcatc. Vahl. enum. i. 356, from

PIPER pinnatum. Lour. i. 39, from a plant in fruit. 
Class 3.

\section{T R I A N D R I A.}

Order 1.

\section{MONOGYNIA.}

1. Flowers inferior. $\boldsymbol{L}$.

39. Comocladia. Corolla tripartite. Calyx tripartite. Style none. Drupe. $\boldsymbol{L}$.

37. Creorum. Petals 3. Caly.x tridentate, Ber$r y$ tricoccous. $\boldsymbol{L}$.

36. Rumphia. Petals 3. Caly $x$ trifid, Drupe. Nut trilocular. $L$.

33. Tamarindus. Petals 3. Calyx quadripartite. Legumen. Obs. 8198.

47. Xүris. Petals 3. Calyx diphyllous. Capsule unilocular. Obs. 4317. 48. Commelina. Petals 3 and 2. Caly $x$ triphyllous and tetraphyllous. Sta-. mina 3 and 2 perfect, 3 and 4 sterile with cruciform glands. Capsule trilocular and bilocular. From authors.

2. Flowers inferior, apetalous.

52. NARDUS.

Calyx diphyllous. Braciene none. Obs. 4424.

G 3 
49. Kyurngra. Calyx diphyllous. Bracteae 2, with 1 flower.

53. Penicrurarra. Caly $x$ diphyllous. Bracteae 2, trancatc. Style slightly bifid. Obs. 6569.

\section{Flowers superior. $\boldsymbol{L}$.}

34. Valerrana. Corolla quinquefid, infundibuliform, gibbous at the base. Arillus pappose. Obs. 7161.

35. FEDIA.

Corolla quinquefid, infundibul:iform. Arillus dentate at the end. Obs. 3776.

39. Melothria. Corolla quinquefid, rotate. Bcrry trilocular. $L$.

41. Crocus.

Corolla sexfid, infundibuliform, regular. Stigmata cunciform. Obs. 3324.

42. $\operatorname{Ixı}$.

Corolla sexfid, infundibuliform, regular. Stignata 3, simplc. Obs. 6245.

45. Gradrolus. Corolla sexfid, infundibuliform, irregular. Obs. 3847 .

43. Bermudiana. Corolla sexpartite. Stigmata3, dilate. Obs. 5302.

44. Ferraria. Corolla sexpartite; 3 outer segments broader. From IFilld.

46. InIs, Corolla sexpartite; every other segment reflex. Stigmata 3 , bilabiate at the end. Obs. 8117 .

40. AxI1. Corolla decemfid. Sced 1. Fron Lour. 
DIGYNIA.

4. Fowers bracteate.

50. Crperus. Bracteac distichous. Seel naked.

51. Scinpus. Bracteae imbricate. Sced pappose. Pappus scabrous. Obs. 2272.

Order 3.

\section{I G Y N I A.}

1. Bracteae none.

56. Penotis.

Calyx diphyllous.

2. Bracteae solitary.

69. Secale.

Bracteae uniflorous. Obs. 1064. 67. Loliug.

Bractene multiflorous. Obs. 4085.

3. Bracteae 2, lateral, parallel.

70. Hordeum. Colyx diphyllous. Obs. 536.

4. Bracteae 2, opposite, containing 1 flower, on a divided receptacle.

54. Alopectres. Calyx monophyllous, Arista inserted into the back of the calyx. Obs. 4802.

59. Phiczu. Caly $x$ diphyllous, membranaccous. Bracteac equal, carinate. Obs. 4406. 
57. Phatianis.

Calyx double, diphyllous, cartilaginous. Bracteae equal, car rinatc. Obs. 373.

55. Saccharmera. Calyx diphyllous. Bracteae. with long hairs at the base. Obs. 5343.

60. Holcus.

Calyx diphyllous, membranaceous; the outer phyllum with a twisted arista from the back. Bracteac cartilaginous. Obs. 1498.

61. Digrmaris. Calyx diphyllous; phylla carinate. Obs. 3239.

5. Bracteae 2, opposite, containing 2 flowers.

58. Panicum.

Calyx diphyllous, that of the fertile flower mostly cartilaginous. Obs. 6557.

6. Bracteae 2, opposite, containing several flowers. Spikes pedunculate.

63. Eleusine.

Calyx diphyllous. Arillus containing 1 seed. Obs. 6446.

62. PoA.

Calyx diphyllous; phylla ovate, without mucro or aristac.

64. Festucs. Calyx diphyllous; outer phyllum mucronate or terminating in an arista. Obs. 4168.

65. Avena.

Caly $x$ diphyllous. Arista geniculate, inserted into the back of the outer phyllum. Obs. 4992. 
Monogynia. S3. Tamarindus.

66. Anusdo.

Caly $x$ diphyllous; phylla pilose at the base. Obs. 1723.

6S. AEGILOPS.

Caly $x$ diphyllous; outer phyllum cloven at the end. Bracteae cloven at the end, aristate. Obs. 1557.

7. Bracteae 2, opposite, contuining seweral flowers. Spikes sessile.

71. Triticum.

Caly.x diphyllous; outer phyllum with an arista inserted below the end. Obs. 969.

\section{O N O G Y N I A.}

\section{TAMARINDUS.}

Caly $x$ turbinate at the base ; limb quadripartite, deciduous. Petals 3, inserted into the tube of the calyx. Stamina inserted into the tube of the calyx. Legumen pulpy. Obs. 8198. Swartz obs. 24. Jacq. amer. $-\boldsymbol{L}$.

1. TAMARINDUS indica. L. sp. 48. Hort. Kew. i. 54. Jacq. amer. 10. t. 10.179. f. 98; cop. in pict. 11. t. 13; ed. 8vo 12. Blacliw. t. 201, 221. Swartz obs. 25. Woodv. iii, 454. t. 166. 
lamarindi. Boerh. ii. 59. Bauh. J. i. 4. 429. Iob. ic. ii. 184, cop. in Dalerh. 1690, repr. in Tamarindus. Ger. by Johns. 1607, \& cop. in Park. theatr. 238. J. ups. 15. Browne 125. Sloane cat. 147. Riumph. ii. 90. t. 23.

'T. Acostae. Dalech. app. 9, seems to have becn drawn from nemory.

Balam-pulli. Rhecde i. 39. t. 23.

Siliqua arabica, qua Tamarindus. Bauh. Casp. pin. 40 .).

Racemi tcrminating short lateral branches. Pedicles patent. Bractece oblong, opposite, as long as the pedicles. Caly.x as long as the bracteae; segments ensiformi-oblong. Petals on one side of the calyx. Stamina 3 together on the side of the calyx opposite to that into which the petals are inserted. Obs. 8198. Specimen gathered by Dr. Wright in Jamaica.

- Vatizc of India, Arabia and Ethiopia, and naturalized in Eigypt and the West Indies.

TAMARINDT. Alst. ii. 318. Cartheus. i. 430. Fordyce, G. pract. 305. Geoffr. ii. 355. Ileberd. 3. II crm. 353. II ill 451. IIome, F. clin. 134. Lassone, jun. account from in med. comment. $\mathbf{x}$. 361. Monchy in Pringle 213. Murr. ii. 425. Ploucq. bibl. i. 494. Quarin febr. 14, 15, 59, 63, $111,141,144,160,217,219,233,344,381,382$, 407,423 ; animad. 57, 216, 219, 240, 211, 260, 261, 269. Rully 506. Spielm. 624. Stoll med. i. 126; iii. 27, 188, 264, 287; aph. и. S08. Vog. 204. Underw. i. 322. Wintringh. in Mead mon. i. 250 .

Tamarindus. The fruit. Pharm. lond.-Berg. 31. Cull. ii. 506. Dale 339. Lew. ii. 408. Linn. 46. Mill. Jos. 430. NIonro iii. 27S. Schoepf 107. 
T. indica. The preserved fruit. Pharm. edlin.Bryant S16. Leiv. disp. Uy Dunc. 316. Murr. J. i. 262, 358. Pearson, R. i. 211. Wright in med. joum. viii. 287.

Tamarinds. Blane 476, 499. Clark $J$. long roy. i. 181, 324; fer. 22. Dancer, account from in med. rev. vii. 4ST. Fordyce, G. pract. 150, 152, 206; fev. ii. 54; TF. fev. 167. Hillary 90, 162, 172. Maclean, Hector 165. Monro, Don. sold. ii. 186. Pringle 203. Rush i. 113; iii. 285. Sherwen in amn. med. lustr. II. ii. 278. Stoll med. i. 21 ; ii. 148 .

Tamarins. Chom. 40.

\section{S4. VALERIANA.}

Calyx superior, multipartite; segments involute. Corolla superior, infundibuliform and hypocrateriform; limb quinquepartitc. Arillus of 2 valves, crowned by a pappus. Obs. 7161, 3778. $L$.

\section{Stamina 3. L.}

1. VALERIANA celtica. Leaves ovatomoblong, obtuse; margin entire. L. sp. 46. Scop. carn. n。 45. Host 21.

Nardus celtica Salinnca. Lob. ado. 132, repr. in Nardus celtica. Lob. ic. i. 313. Cam. epit. 13, cop. in

Nardus celtica Matthioli, Dalech, 924.

Nardus alpina. Clus, pann. 515, repr. in hist. ii. 57, cop. in

Nardus celtica altera. Park. theatr. 117, \& repr. in Nardus celtica. Ger. by Johns. 1079; the root and 
leaves cop. in Bauh. J. iii. b. 205, the outer figure; the flowering stem of which cop. from

Spica celtica. Cam. epit. 14, the innermost figure.

Nardus ninima nardifolia. Bauh. J. iii. 6.206 , the outer figure, according to Scopoli.

Hirculus veterum. Garcias ap. Clus. exot. 202, roots and radical leaves, cop. in Dalcch. 925, and repr. in

Hirculus. Ger. by Jolins. 1079, and one of the figures cop. in

Nardus celtica. Bauh. J. iii. b. 205.

Arilli oblong, pappose at the eud. Obs. 3785. Specimen from Prof. Jos. F. Jacquin.

VARDUS celtica. Cartheus. iii. 91. Dale 110. Gcoffr. ii. 109. Lew. ii. 125. Mill. Jos. 308. Monro iii. 183. Rutly 342.

Nardus celtica Dioscoridis. Chom. 340.

Spica celtica. Alst. i. 523. Berg. 32. Linn. 46. Murr. i. 187. Spielm. 299. Vog. 151, 243.

Spica Nardi celtica. Herm. 42.

2. VALERIANA pyrenaica. Leaves cordate, crenate, petiolate, the uppermost ternate. Obs. 3782. Specimen gathered in the garden of Fothergill. $-L$. sp. 46. Hort. liew. i. 53.

V. maxima pyrenaica, cacaliac folio. Boerh. i. 74. NARD US moutana. Geoffr. ii. 111.

3. VALERIANA Spica. Radical leaves cordate, cnfire at the margin; cauline leaves entire. From Jones in asiat. research. ii. 416. $t$. at p. 405, cop. by Roxb. in asiat. research. iv. 451 . (where at $l$. 8, for generic real specific,) t. at p. 451. $f .3$, with the addition of a root and the lower part of the stem of another plant; $f .1,2$, roots and the 
lower part of 2 stcms; $f .4$, the drug sold in the shops of Hindostan. - Vahl. cnum. ii. 13.

(Nardus Dioscoridis. Lob. adv. 42, from the shop of

Martinelli at Venice, repr. in

Spica Nardi. Lob. ic. i. 83, \& imit. in

Spica nardi iudica. Dalech. 921, \&

Nardus iudica vulgaris. Bauk. $J$. iii. 6.203 , the upper figure, \& which cop. in

Spica nardi. Theophr. a Stap. 1018, the upper figure, \&

Nardus indica. Park. theatr. 1595, has no resenblance to the root of a Valeriana.-Plin. l. 12. c. 12. $p$. 305. is described as a shrub.-Garcias ap. Clus. exot. 202, from druggists shops, repr. in Ger. by Johns. 1080, cop. in Dalech. app. 16; \& abr. in Park. theatr. 1595,

Nardus indica vulgaris. Bauh. J. iii. b. 203, \&

Spica nardi. Theophr. a Stap. 1018, the lower figure, more resembles the root of an Iris than that of a Valeriana.)

JATAMANSI. Jones ib. 119. Roxb.ib.453.

4. VALERIANA tuberosa. Radical leaves entire at the margin, oval and lanceolatc; cauline leaves pinnatifid. Stem leafless upwards. Obs. 3784. Specimen from M. Broussonett.-L. sp. 46. Hort. kew. i. 52. Siblh. prodr. n. 75. On the mountains of Cilicia, Crete and Cyprus, and on Mount Parnassus.

V. bulbosa. Buuh. J. iii. b. 207.

Nardum montanum. Matth. 351. cop. in

Nardus montana. Dalech. 926, abr. in Cum. epil. $15, \&$ Lob. adi. 320, which repr. in ic. i. 717, \& Ger. by Johns. 1079. Cam. hort. 104. Chus. hist. ii. 56, repro in 
Nardus montana germinans. Ger. by Joluns. 1079.

Nirdus montanit. Cam. epit. 15, cop. in

Nardus montana longiori radice. Park. theatr. 118. NARDUS montana. Dale 110. Geoffr. ii. 111.

5. VALERIANA Saliuncu. Leaves lincari-cuneiform, sometimes tridentate, entire at the margin. Flowers umbellato-cípitate. From Vuhl. enum. ii. 15. Allioni.

Nardus sive Saliunca neapolitana. Bauћ. J. iii. 206, cop. from

SALIUNCA neapolitana. Dulech. 982.

6. VALERIANA dioica. Radical leaves entire; cauline leaves pinmatifid. Dioccious, some plants having stamina and in imperfect pistil, others a pistil and imperfect stamina. Obs. 602. In marshy grouud. Probably polygamous.-L. suec. $n .35$; sp. 44. Bot. arrang. i. 35; iii. cxvi. Curt. lond. iv. $47 . t . f .1$, the female plant; $f .2$ the male plant.-Smith brit. 37. Retz: obs. i. 12. T, with whom a plant regarded as a male produced perfect sceds.-Scop. carj. n. 40, who says all the plants lic rxamined produced some perfect seeds.-Pollich u. 30 . Fl. dan. t. 687.

V. Small marsh Valerian. Walc..

V. foliis caulinis pimnatis, polygama. Royen 235, who adds mas \& hermaphrodita.

Phu minimum. Dalech. 1043.

V. minima. Dod. 347, repr. in

V. minor sylvestris. Lob. ic. i. 715, \&.

V. minor. Ger. by Johns. 1075, \& cop. in

V. sylvestris. Parl. theatr. 123.

V. minor pratensis, vel aquatica. Bauh. J. iii. b. 211, \& 
r. sylvestris minor. Dalech. 1012. Riain syn. 200. The male pliust.

V. exigua. T'rag. 62.

V. palustris minor. Toum paris. 237. Vaill. paris. 199. Boerh. i. 74 .

V. aquatica minor, flore minore. Raii list. 389. Tourn. paris. 237. Vaill. paris. 199. The female plant.

V. sylvestris seu palustris minor altera. Raii synn. 200. The female plant.

V. sylvestris vel palustris alțera, flore minore deusius stipata. Boorh. i. 74. The female plant.

VALERIANA minor. Mill. Jos. 447.

V. palustris. Geoffr. suite iii. 270.

V. palustris mirror. Herm. 34.

V. sylvestris minor. Cartheus. iii. 71.

Phu minus. Dale 110.

:5. VALERIANA lavicaulis. Radical leaves entire; lower cauline leaves pinnatifid; the upper pinnate; the outer foliole or segment the largest. Stem smooth. Obs. 3786. In a garden.

V. Phu. L. sp. 45. Hort. Kew. i. 52. Krock. n. 50.

Phu magnum. Matth. 927. Fuchs. 812. c. 329, cop. in

Y. vera, seu Nardus agrestis. Trag. 60, which repr. in

Phu majus. Cord. 102, \& cop. in

V. major, odorata radice. Bauh.J. iii. U. 209. Raii hist. 388.

V. hortonsis. Dod. 316, repr. in Ger. by Johns. 1075.

Pha majus, sive V. major. Parli. theatr. 120. 
Calyx multipartite; segments subulate, closely involute, so as to make the calyx appear a striate rounded margin. Arillus lanccolato-ovate, compressed, with 4 costae on one side and 1 on the other. Obs. 7161. In a garden.

PHU. Linn. 45.

V. hortensis. Alst. i. 533. Carlheus. iii. 71. Gcoffr. suile iii. 260. Neum. ii. 135. Rutty 531.

V. major. Berg. 31. Mill. Jos. 446. Murr. i. 186. Vog. 213.

Plıu majus. Dale 109.

V. lortensis Phu, folio olusatri Dioscoridis. Boecl. ap. Herm. 35. Chom. 168. II crm. 34.

8. VALERIANA officinalis. All the leaves pinnate. I. suec. n. 34; sp. 45. Bol. arrang. 36. Smilh bril. 38. Scop. carn. n. 39. Fl. dan. t. 570. Woodr. ii. 262. t. 96.

V. sylvestris. Dod. 346, repr. in Lob. ic. i. 715, \& V. major sylvestris. Ger. by Jolins. 1075.

Phu germanicum. Fuchs. 857. cop. in S12. 12 mo ed. c. 329, \&

V. vulgaris. Trag. 61 .

V. sylvestris, the second species. Mill. Jos. 44 S.

V. sylvestris major. Raii hist. 388; syn. 200. Tourn. paris. 236. Vaill. paris. 199. Boerh. i. 74. Park. lleatr. 122. No fig.

Folioles to an inch wide. Obs. 5890.-Arilli subulato-ovate, with 3 costac on one side and 1 on the other. Ols. 3778.

VALLRIANA. Plouc. bibl. i. 516. Quarin febr. 69 ; animad. 250. Rcil, account from in med. comment. dec. II. ix. 26. Spictm. 301.

V. officinalis. The root. Pham. edin.-Irock. 
27. 49. Leẍ. disp. by Dunc. 321. Mrur. J. i. 14S. Pearson, R. ii. $200,216$.

V. sylestris. Wild Valerian.' 'Whe ront. Pharm. lond.-Alst. i. 533. Berge. 30. Bisset ess. 169. Conrudi, account from in phys. journ. i. 50. Cull. ii. 3i1. Dale 110. Duncan in Lew. disp. by Rother. 260. Geoffr. suite iii. 263. Hcberd. 64, 90, 145, 150, 203, 302. Hill 581. Fordyce, $W$. fragm. 73. Lew. ii. 443. Linn. 45. Mill. Jos. 447. Monro iv. 24. Mead mon. i. 33. Quarin animad. 25. 28. 114.48. Stoll aph. n. 715 ; med. iii. 420, 422. Whylt nerv. 513. Wintringh. in Mead. mon. i. 159.

V. sylvestris major: Boecl. ap. Herm. 35. Cartheus. iii. 71. Chom. 165; suppl. 56. Herm. 55. Neum. ii. 135. Rutty 531.

V. minor. Murr. i. 180. Vog. 215.

Valerian. Blane in trans. improv. ii. 209. Bree 251. Cull. clin. 155, 167. Darw. ii. 66, 137, 223, 392, 748. Home, F. clin. 147, 175. Kirkland apopl. 98, 143. Michnelis, account from in phys. journ. viii. 442. Ploucq. bibl. i. 222, 225, 251, 321, 333, 435, 645. Riehter quoted in Rollo diab. 370. Underw. i. 11., 148, 170, 173, 193. Withering in bot. arrang. 36 .

Wild Valerian. Baylies in med. pap. 44 Cull. pract. n. 1540. Marchant in acad. seiences abr. by Southw. iii. 248.

\& ungustifolia. Leaves rarrower. From Dill.-Bot. arrang. 36. var. 2.

V. sylvestris major montana. Dill. ap. Raii syn. 200.

V. major sylyestris montana. Boerh. i. 74. Native of Holland. 
V. sylvestris, the first species. Mill. Jos. 448.

Stem hirsute, sometimes nearly glabrous. Leaces lirsute; lateral folioles from 2 to 4 tenths of an inch broad. Obs. 8010. Specimen gathered in Dovedale, near Ashbourne, Derbyshire. Aug.

$V A L E R I A N A$ sylvestris major montana. Rutly 531.

\section{FEDIA.}

Caly $x$ with from 1 to many tecth. Corolla superior, infundibuliform; limb quinquepartite. Arillus of 2 valves, without a pappus. Obs. 3776, 3981, 3784, 3800. Gacrtn.

Valerianella. Bocrh. 75 .

1. FEDIA ecalyculata. One of the valves of the arillus bilocular. Calyx obsolete. Obs. 7120. On banks at Alport, and all over the limestone district of the Peak of Derbyshire.

F. olitoria. Vahl. enum. i. 19.

Valerianella olitoria. Pollichen. 32.

Valeriana olitoria. Willd. berol. 19. Roth germ. ii. 39. L. a Willd. i. 189.

Valeriana Locusta olitoria. L. $s p .47$.

Valeriana Locusta. L. suec. n. 36. Lyons ap. Relh. 14. Smith brit. 39. Curt. lond. v. 4. t. 819. LOCUSTA. Berg. 33.

Valerianclla. Geoffr. suite iii. 27\%.

Valeriana Locusta. Bryant 116. Krock. n.51.

Lactuca agnina. Dale 110. Spielm. 57.

Mache. Chom. 812.

\& integrifolia. (Variation.) Leaves entire. Obs.7120. Valeriana Locusta. Bot, arrang. 37 n 
Valerianella arvensis praecox humilis, semine compresso. Tourn. paris. 160. Vaill. paris. 199. Dill. ap. R. syn. 201.

Valeriana campestris inodora major. Raii hist. 392.

Valerianella arvensis praecox liumilior, semine dcpresso. Moris. umb. 53. Bocrh. i. 75. Native of Holland.

Valerianella arvensis praecox humilior, semine compresso. Moris. umb. 69. $t .1$. f. 58. 59, the seeds.

Valerianelia arvensis praecox humilis, flore dilute caeruleo, semine compresso. Hist. ox. s. T. $t$. 16 , the outer figure.

Album olus. Dod. 636, repr. in

Lactuca agnina. Ger. by Johns. 310. Raii syn. ed. ii. 98.

Locusta herba prior. Bauh.J. iii. 323, has elliptic leaves, and much broader than $I$ have ever observed.

Polypremum. Dalech. 554.

Root annual. Stem 5 to 7 inches long, dichotomous from the base. Germen inferior, oblong, slightly hirsutulous, oblique at the end, with an obtuse tooth on the upper side. Corolla whitish blue, infundibuliform, on the lower side of the end of the germen; segments oval. Stamina 3. Stigmata 2 and 3, slightly recurvate. Arilli stil green, slightly pubescent, irregularly ovate, ohtuse; one valve straight or slightly conver, divided internally into 2 cells; the other gibbous sometimes ending in an obsolete tooth. The valve with 2 internal cells on the top of which the corolla is placed, probably forms the communication between the style and the embryo seed. Obs. 7120. In flower to June 27, when all out of flower

H 2 
cxccpl plants whose main stems had becn caten off.Arillus subrotundo-ovate, slighlitly compressed; valves 2 , carinate, one ligneous, marked along the keel with a single stria, the other marked along the kecl with 3 costae, and divided internally into 2 empty cells, by a dissepiment inserted into the carina of the valve. Seed lanceolate, contrary to the sides and parallel to the carinae of the arillus. Obs. 37\%6. In a garden. $\beta$ serratifolia. (Variation.) Upper leaves scrratodentate towards the basc. Obs. 7059. Specimen gathered by Mr. Hollefear, probably in a garden.

F. olitoria dentatia. Vahl. enum. ii. 19.

Valeriana olitoria. L. a Willd. i. 183 \&

Valeriana floribus triandris, caule dichotomo, foliis linearibus. L. ups. $14 \beta$

Valerianella arvensis praccox lumilis, foliis scrratis. Vaill. paris. 199, placed, probably by mistake, under n. 2 instead of $n .1$.

Lactuca agnina, seu Valerianclla foliis serratis. Dill. ap. Raii syn. 201.

Phu minimum alterum. Lob. obs. 419, repr. in ic. i. 717, cop. in Dalech. 1127, repr. in

Lactuca agnina latifolia. Ger. by Johns. 310 ; cop. in

Locusta altora, foliis serratis. Bauh. J. iii. 324; $a b r$. in

Valerianclla arvensis praecox humilis, flore dilute caeruleo, semine compresso. Hist. ox. s. 7. t. 16, inner figure; \& cop. in

Lactuca agnina. Park. theatr. 812; parad. $499 \mathrm{t}$ 497. f. 9 .

2. FEDIA coronata. Calyx sexfid; segments equal, triangular. Obs. 3787. Specimen gatlered in the Paris garden.-Vahl. cnum. ii. 20. 
Valeriana coronata. Salisb. R. allert. 56. Host 22.

Valeriama Locusta coronata. L. sp. 48. HIort. Kew. i. 53.

Valcrianella nostras inajor, scabiosae semine. MIor. bles. 215.

Pseudo-Valeriana annua, semine hirsuto minore ro. tuiido. Hist. ox. 'iii.' 104. In Picardy.

Valerianella scabiosae semine minor bloesensis. Hist. $o . x$. s. 7.t. 16, $a b$. from, \&

Valeriana annua, sive aestiva Clusii. Park, theatr. 121, ill cop. from

VALERIANELLA semine scabiosae, stellato, hirsuto, \& etiam umbilicato. Col. ecphr. i. t. 209.

3. FEDIA radiata. Fruit subtetragonous, pubescent, naked at the end. From Michanx i. 18. Vehl. emum. i. 21.

Valeriana Locusta radiata. L. $s p .48$.

Valeriana. Gron. virg. 7.

VALERIANA Locusta. Schoepf 9.

\section{RUMPHIA.}

Calyx trifid. Petals 3. Drupe trilocular. L.

1. RUMPHIA amboinensis. L. sp. 49. Tsjem Tani. Rheedle iv. 25. $t$. 11. MYXA pyriformis, ossiculo trispermo. Raii hist. 1556.

\section{CNEORUM.}

Calyx tridentate. Pelals 3, equal. Berry tricoc. cous. $L$.

H 3 
1. CNTORUM tricoccum. L. sp. 49. Hort. kew. i. 54 .

C. tricoccon. Gouan. hort. 23. Near Montpelier.

Chamaclaea. Boerh. i. 255.

Chamelaca. Clus. hisp. 170, in the provinces of Villentia, Catalonia and Arragon, and in the neighbourhood of Montpelier; repr. in Dod. 359, \&

Chamclaea arabum tricoccos. Ger. by Johns. 1402; cop. in

Chamelaca Dodonaci. Dalech. 1665; repr. in

Chamelaea tricoccos. Clus. hist. i. 87; \& cop. in Park. thcatr. 202, \& Bauh. J. i. a. 584. Raii hist. 1710 ; curop. 93. Magnn. monsp. 59.

Mezereon arabum, Chamelaca tricoccos. Lob. adv. 157, repr. in ic. i. 369.

Stem and branches microscop!ically pubescent, angularly flexuosc. Leures somewhat shining, sometimes emarginate. P.eduncles axillary, short, with 1 flower and the rudiments of 1 or 2 more. .Caly $x$ iriphyllous, pubescent, green; phylla ovatc. Petals ycllow, oblong. Stamina yellow, somewhat shorter than the corolla. Pistil yellow, as short again as the stamina. Germen roundish, villose, slightly tricoccous, placed on the top of a roundisil fleshy ycllow receptacle, smaller than the receptacle.' Style as long as the germen. Stimgata 3, very short. Obs. 8619. In Mr. Sitwcll's garden.

Native of the north-castern quarter of Spain, Langriedoc and Provence.

OLIVELLA. Gcoffr. suite i. 237.

\section{COMOCLADIA.}

Caly.x tripartite. Corolla tripartite. Drupe oblong; kernel with 2 lobes. $L$. 
1. COMOCLADIA integrifolit. Folioles entire at the margin. L. sp. 49. Hort. kerw. i. 54 .

Prunus racemósa, caudice non ramoso, alato fraxini folio non crentito, fructu rubro subdulci. Sloane cat. 1St; hist. ii. 131. t. 222. f. 1.

COMOCLADIA. Browne 124.

\section{MELOTHRIA.}

Calyzi quinquefid. Corolla campanulate, monopetalous. Berry with 3 cells, and many secds. $L$.

1. MelothriA pendula. L. sp. 49. Hort. kew. i. 54.

Melothria. Royen 528. Gron. virg. 7. Browne 124.

Cucumis minima, fructu ovali nigro laevi. Sloane cat. 103; hist. i. 227. t. 142. f. 1.

Bryonia olivae fructu, minor. Plum.sp. $3 ;$ ic. $t$. 66. $f .2$.

Cucumis parva repens virginiana, fructu minimo. Pluk. t. 85. f. 5.

Leaves cordate, obsoletely quinquelobate, quinquangular, triangular; margin obsoletely crenate, and obsoletcly dentate. Obs. 8598. Specimen gathered by Dr. Wright in Jamaica.

MELOTHRIA pendula. Bryant 272.

\section{9*. ROTALA.}

Calyx tridentate. Corolla none. Capsule trilocular, polyspermous. $\boldsymbol{L}$.

1. ROTALA rerticillaris. $\boldsymbol{L}$. mant. 175. ENE-PAEL. Rheede ix. 159.t.81. 
Calyx trifid. Corolla monopetalous, decemfid. Seed 1. Vahl. enum. ii. 38, from .

1. AXIA cochinchinensis. Lour. i. 44.

\section{CROCUS.}

Corolla superior, infundibuliform; limb sexpartite, shorter than the tube. Calyx spathaccois. Stigmata 3, cunciform. Obs. 332t. L.

1. CROCUS setifolius. Calyx diphyllons. Iteaves setaccous, ciliate. Obs. 3405. In Mr. Ordoyno's nursery. 19 Nov.

C. officinalis sativus. Huds. 13 .

C. sativus officinalis. L. sp. 50, whose specific character, given in ed. i. to distinguish it from Ixic Bulbocodium; which he then referred to Crocus, has been reprinted in all his succeeding works, and those of his clitors and copyists.-Bot. arrang. 37, but not a native, and $I$ apprehend not even nnturalised.-Hort. Kcw. i. $56 \propto$

C. sativus. Woodv. iii. 479. $t$. 176. Bocrh. ii. 120. Gouan. hort. 24. Mill. Ph. dict. n. 1, who remarks that it never produces seeds in Englaud.Relh. n. 30. Formerly cultivated urear Gogmagog hills.-Sibth. prodr. n. 82. In Greece in ploughed land, and on mountains about Athens. - Smith. brit. 39. Cultivated about Saffron Walden, and thence dispersed through the neighbouring fields.

C. autumnalis. Smith engl.bol. 6.313 , from a p'ant sent from Saffion. Walden. 
Crocum floreris. Nutth. 69.

Crocim non florens. Matth. 70 .

Crocus. Iucks. 439. c. 168, cop. with the aldition of a figure, in Bank. J. ii. 637, who says he never observed it to produce seeds. - Trag. 763. Dod. 213, repr. in Lob. obs. 6S; ic. i. 137, and Ger. by Johns. 151. Raii syn. 374, who inserts it merely as a plant cultivated in fields; hist. 1176, who observes that it is cultivated in Europe from Sicily to England, but that he conld neither learn that. it ever produced seeds, nor ascertain its native place of growth.

Saffron. Sheldr. herb. t. Townsends truv: ii. 105, 107, who abserved it in flower.in. October from Salamanca to the borders of New Castile.

Saffron plant. Douglas in phil. trains. abr. by Reid and Gray vi. 226. part ii. 226. t. 4. f. 71.

C. verus sativus autumnalis. Park. parad. 16 $t, t$. 169. $f .2$.

CROCUS. Saffron. The stigmata. Ph. lond.Alst. ii. 116. Berg. 35. Boerh. 589. Cartheus. ii. 519. Cull. ii. 312. Dale 245. Geuffr. ii. 282. Herm. 577. II ill 435. Lew. i. 374. Mead monit. i. 33. Mill. Jos. 159. Monro iii. 79. Murr. v. 220. Neum. ii. 185. Ploucq. bibl. i. 28, 368. Quarin animad. 114. Rutty 147. Spielm. 260. Vog. 145.

C. sativus. Pharm. edin.-Lew. disp. by -Dunc. 209. Murr. J. i. 149.

C. orientalis. C. britannicus, Linn. 46.

C. vulgatior. Lob. adv. 53. l. 35.

Saffron: Bisset ess. 75.

Saffran. Chom. 174; suppl. 60.

Natize of Spain, Greece, and according to Willdenow of the east, but it is not enumerated either in the floras of Forskul or in Russel's Alcppo. 


\section{IXIA.}

Corolla superior, infundibuliform; $\operatorname{limb}$ scxpartite, longer thin the tube. Calyx diphyllous, and triphyllous. Śligmata 3. Obs. 6245. L.

1. Scapus shorter than the leaves. L. a Murr.

1. IXIA Bulbocodium. Leaves filiform, sulcate, flexuose. Scapus branclied; branches uniflorous. Spathac longer than the tube of the corolla. Vahl. enum. ii. 50. Thunb. cap. 9, \& ap. L. a Murr. 83. L. sp. 51; mant. 320; a Willd. i. 196. Hort. kew. i. 56. Sibth. prodr. n. 86. On the mountains of the Grecian islands.

Crocus angustifolius. Clus. hisp. 258. Called Nozellas pequenas by the Portuguese.

Native of Portugal, Spain, the south of Italy, the

Grecian islands, and possibly of the neighbourhood of Montpelicr.

* parvifora. Vahl. enum. 50.

Bulbocodium crocifolium, flore parvo violaceo. Tousm. cor. 50. Boerh. ii. 138.

Crocus italicus angustifolius, parvo flore, radice rostrata. Tourn. inst. 351.

Sisyrinchium minus angustifolium. Bauh. Casp. pin. 41. Hist. ox. ii. 346.

Sysirynchium Theophrasti. Raii hisl. 1167. Col. ecphr. i. 328. t. 327. f. 1, on the sides of roads near Cirignola in Apulia; cop. in Hist. ox. s. 4. t. 5, \&

Sysirinchium Fabii Columnac. Theophr. a Stap. 880, the 6 upper figures.

Crocus vernus minor 3. Clus. hisp. 261, repr. in Crocum vernum angustifolium 1I. Clus. hist 207, 
Crocus sylvestris hispanicus, vulgo Nozilicha major. Lob. obs. 69 ; ic. i. 142, \&.

Crocus vernus minor. Ger. by Johns. 152; \& cop. in

Crocus vornus. angustifolius tertius Clusio, flore multo minore caeruleo. Bauh. J. ii. 645.

SYS YRRHINCIIIUM. Dale 245.

Bulbi apuli. Plin.498. l. 19.c.5?

\& media. Vahl. enum. 50.

Crocum vernum angustifolium II. Clus. hist. i. 207. (The figure belong's to $\alpha$ )

Crocus vernus minor alter, flore minore ex albo purpureo. Bauh. J. ii. 645. Magn. monsp. 81; hort. 64.

CROCUS vernus minor alter. Clusi hisp. 260. No fig.

$\%$ grrandiflora. Vahl. enum. 50.

I. Bulbocodium. Jacq. coll. iii. 265 ; ic. ii. t. 271. segments of the corolla incumbent below.-Curt. mag. viii. $t .265$. Segments of the corolla distinct. Root with 2 attenuate processes.

Crocus flore fructui imposito, tubo brevissimo. Royen 41.

Sysirinchium asprensium angusto folio alterum. Col. ecphr. ii. 5. t. T. Raii liist. 1167.

Romulea. Maratti $t$.

Crocus vernus minor I. Clus. hisp. 259, repr. in Crocus vernus angustifolius I. Clus. hist. i. 207. Crocus sylvestris minor hispanicus, flore patulo, vulgo Nozilicha minor. Lob. obs. 68; ic. i. 141. f. $1, \&$

Crocus vernus. Gier. by Johns. 152.

Crocum vernum angustifolium, violaceo fl ore. Clus. hist. i. 208, from a bulb scnt from Tuscany, repr. in 
Crocus sylvestris minor hispanicus, flore patulo. Lol. ic. i. 141. f. 2, \&

Crocus vernus angustifolius, flore violaceo. Ger. by Jolns. 155; \& imil. in

Crocus vernus purpurcus, capillari folio. Park. parad. 165.t. 165.f. 9.

2. Scapus longer then the leaves. Glabrous. Leares flat. Valıl.

2. IXIA bulbifera. Leaves contrary, glabrous, with bulbs at the base. Stem flexuose. Tube of the corolla filiform below, obconic upwards. Bracteae lacerate, longer than the tube of the corolla; segments setaccous. Segments of the corolla elliptic. Obs. 717\%. Specimen gathered in the garden of M. Deutz.-L. sp. 51. Thunb. cap. 10. Gawl. in bot. mag. t. 545. Mill. Ph. dict. n. 6. Hort. kiew. i. 57.

Bracteac whitish, with blackish brown setaccous streaks. Obs. 7477.

IXIA bulbifera. Bryant 35.

3. 1XIA crocata. Leaves ensiform. Flowers secundose. 'Tube of the corolla as long as the bracteac. Segments of the corolla rhombic, transparent at the base. Obs. 6245. In Mr. S. Shore's garden.Hort. kew. i. 60. Thunb. cap. 10. L.

IXIA crocata. Bryant 35.

a crocea. Corolla of a saffron colour. Obs. 6245. Hort. kew. a

I. crocata. L. sp. 52; mant. 320. L. fil. fasc. 13. t. 7. Curt. mag. t. 184. 
I. hyalina. Sulisb. R. aliert. 38.

Leares vertical. Scapus with a joint; joint a little above the part which is clothed with leaves, with 2 lanceolate bracteae and the rudiment of a spike. Caly.x membranaceous, as long again as the germen. Corolla, tube extending a little beyond the calyx. Style filiform, longer than the stamina. Stigmata 3, filiform, pubescent. Obs. 6245. $\beta$ rubra. Corolla of a fine red. IIort. keze. $\beta$

\section{BERMUDIANA.}

Corolla superior, sexpartite. Sligmata 3, dilate. Obs. 5302. Tourn.

Differs from Ixia in the corolla having no tubs.

1. BERMUDIANA guttata. Obs. 7541. In the garden of Saville, who informed me that the root is similar to that of an Iris.

Moraea chinensis. Murr. ap. L. a Murr. 93. L. a Willd. i. 245. Thunb. jap. 34.

Ixia chinensis. L. sp. 52. Hort. liew. i. 62. Curt. mag. t. 171. Lour. i. 46.

Ixia foliis ensiformibus, floribus remotis. Trew select. 23. t. 52.'

Belan Canda Schularmani. Rhcede xi. 73. t. 37.

Stem compressed, geniculate. Leares ensiform, contrary, several times broader than the stem, perennial. Panicle trichotomous. Peduncles longer than the bracteac. Corolla, segments lanccolate. Strmina distinct. Obs. 7541.

$I X I A$ chinensis. Bryanl 34. 


\section{FERRARIA.}

Calyx nonc. Corolla sexpartite; 3 outer segments broader. Style 1. Capsule trilocular, inferior. From $\boldsymbol{L}$. « Willd. $\boldsymbol{L}$.

1. FERRARIA pavonic. Stem simple. Petals flat, the 3 inner as short again as the 3 outer. From $L$. a Willd. iii. 581, L. fil. suppl. 407, \&

F. 'Tigridia. Bot. mag. t. 532.

Tigridis flos, Dracunculi species putata. Bauh.J. ii. 684, cop. from

Tigridis flos. Lob. obs. 59, which repr. in ic. i. 111, Dod. 421, \&. Ger. by Johns. 122; \& cop. in Dalech. 1624. Raii hist. 1165.

OCOLOXOCIIITL, seu Flos Tigris. IIern. 276. t.

\section{GLADIOLUS.}

Corolla superior; tube curved; limb sexpartite, irregular; segments unequal. Caly $x$ none. Stigmata 3. Obs. 3847. Hort, liew. L.

1. GTADIOLUS communis. Corolla slightly ringent. Leaves ensiform. Bracteac louger than the tube. Flowers distinct. Obs. 3874. In a garden.-L. sp. 52. Hort. kew. i. 62. Curt. mag. t. S6.

Nutize of Italy, the south of France, Switzerland, Saxony, and the neighbourhood of Erford. GLADIOLUS. Dale 246.

Victorialis rotunda. Krock. n. 55. Spielm. 582.

a parviflorus. Flowers secundose. Corolla $1 \frac{\pi}{2}$ inch long. Obs. 8012. Specimen gathered in Lce's nursery. 
G. minimus. Lob. ald. 511. No fig. In the gardens of Coys and Franqueville in London.

B rubenti-grandiflorus. Flowers secuudose. Corolla 2 inches long, purplish red. Obs. 3874.-Goun monsp. 67. \& In meadows at la Lattes near Montpelier.-Hort. liew. i. 62. a

G. communis. Scop. cam. n. 48. Gouan hort. 25. a In cornfields near Montpelicr.-Goucn monsp. 67 a Mill. Ph. dict. n. 1. Host 25. Roth germ. i. 18. In Saxony and near Erford.

G. floribus uno versu dispositis, major, floris colore purpureo-rubente. Boerh. ii. 127.

Victorialis foemina. Cord. 97.

Gladiolus. Lob. adv. 47. No figure.-Dod. 209, repr. in

G. italicus. Ger. by Johns. 104, \&

G. narbonensis, Lob. ic. i. 98. Park. parad. t. 191. f. 1 .

G. sive Xiphion. Bauh. J. ii. 701. Between Ferrara and Bologna, and between Burdigni and Thuiri.-Raii hist. 1168. In Italy.

G. byzantinus. Park. parad. $t$. 191. f. 3. Mill. Ph. dict. n. 3.

\% incarnato-grandiflorus. Flowers secundose. Corolla 2 inches long, flesh coloured. Obs. 4912. In a garden.-Ilort. kew. i. $62 \beta$

G. carnei coloris, Boerh. ii. 127.

G. sive Xiphion pallidiore flore. Bunh. J. ii. 702. Specimen found by Agerius in a meadow.

i albo-grandiflorus. Flowers secundose. Corolla white. From IIort. kew. i. 62 \%

G. flore albo. Lob. adv. 511. No fig.

- distichus. Flowers distichous. Obs. 8013. Specimen gathered by M. Broussonett, probably near Montpelier.-Gouan monsp. 67. $\%$ in meadows with $a$, but more rare. 
C. utrinque floridus. Magn. monsp. 110. Bocrh. ii. 126 .

G. italicus. Park. parad. ᄂ. 191. f. 2. Mill. Ph. dict. ${ }^{2} .2$.

G. utrimque floriferus. Dod. 209, repr. in

G. italicus binis florum ordinibus cinctus. Lob. ic. i. 99,8

G. narbonensis. Ger. by Johns. 104.

Gladiolus. Dalech. 1620.

\section{IRIS.}

Corolla superior; limb sexpartite; every other segment reflected. Caly $x$ none. Stigmala 3 , bilabiate at the end, with a longitudinal fissure on the upper surface. Obs. 3716. L.

1. The reflected segments of the corolla bearded along the middle.

1. IRIS florentina. Germen trigonous. Stem longer than the lenves, with mostly 2 flowers. Branches uniflorous. Flowers sessile. Obs. 8117. In a garden.-L. sp. 55. Hoit. kew. i. 68. Woodv. i. 112. $t$. 39, who remarks that the roots in this comintry have not the odour of those produced in Italy.-Sims in bot. mag. t.671. Lob. adv. 31. No figure.-Ger. by Johns. 52, s"epr. from

Iridis altera icon. Dod. 213, which repr. in

I. nostras vulgaris candidis floribus. Lob. ic. i. 59, and cop. in

I. Hlore albo. Bauh. J. ii. 719, who was informed by Dourez that he had seen in Illyria or Sclaronia what he belicred to be this species.-Raii hist, 
1180; europ. 155. On the walls of Florence in great 'plenty.

I. alba illyrica vulgo vel potius florentina. Cam, hort. 79. On a hill near Piperno.

I. alba florentina. Park. parad. 180. .t. 183. f. 2: Boerh. ii. 124.

Stem $1 \frac{1}{2}$ foot long, erect, with 3 flowers. Branches distichous, alternate. Corolla bluish white; tube longer than the germen. Obs. 8117.

Nalize of Italy and probably of Illyria. IRIS florentina. The root. Pharm. cdin.-Berg. 39. Cull. ii. 459. Dale 247. Geoffr. ii.98. Herm. 48. Hill 616. Lew. disp. by Dunc. 239. Linn. 47. Mill. Jos. 244. Monro iii. 147. Murr. v. 265; J. i. 342. Spielm. 270. Syn. i. 110. Vog. 201.

I. alba florentina. Chom. 15. Neum. ii. 141. Rutly 252.

Iris. Florentine Orris. The root. Pharm. lond.Alst. i. 471. Cartheus, iii. 50. Lew. ii. 15.

2. IRIS germanica. Germen trigonous. Stem multiflorous, longer than the Ieaves. Inner segments of the corolla connivent, acute. Branches uniflorous. Obs. 3716. In a garden.-Thunb. quoted in $L$. a Willd. i. 229. L. sp. 55. Hort. lew. i. 68. Sims in bot. mag. t. 670. Gouan. hort. 25. On the sides of hedges about Montpelier.-Raii europ. 155. Throughout Germany. Pollich n. S4. Roth germ. ii. 41. Fuchs. 312, c. 120, imit. in Trag. 703, which repr. in

I. nostras. Cord. 139. \& cop. in

I. vulgaris violacea sive purpurea, hortensis \& tris. Rauk. J. ii. 709. 
I. hortensis latifolia. Vaill. paris. 109. Boerh. ii. 124.

I. vulgaris. Ger. by Jolins. 150, the description. ('The fig. is I. Pseudacorus.)-Lob. obs. 32, repr. in

I. nostras vulgaris. Lob. ic. i. 59, \&

I. palustris lutea. Ger. by Johns. 50, (the name and description belong to I. Pseudacorus.)

Iris. Dod. 243.

I. purpurea, sive vulgaris. Park. parad. 181. No fig.

I. dlomestica. Dalech. 1610.

I. silvestris. Dalech. 1611.

Leares contrary, lanceolato-ensiform, slightly curved, the end mostly incurvate, sometimes recurvate, attenuate downwards. Stcm with from 3 to 5 flowers, erect, from 2 to $2 \frac{1}{2}$ feet long. Branches erect, altcrnate, distichons, with 1 flower. Flowers solitary, sometimes sessile. Peduncles very short. Bracteae 2, membranaceous at the base of each peduncle. Germen trigonons, from $1 \frac{1}{2}$ to 4 times as long as the peduncle. Corolla with a scent analogous to the taste of candied orange peel; tube trigonous, somewhat longer than the germen, with 6 teeth at the month, projecting inwards from the commissures of the segments of the limb; segments, the 3 outer cuneiformi-obovate, recurvate, the upper half purple, the lower half white with brown veins; the 3 inner somewhat shorter than the outer, incurvate, unguiculate; ungues canaliculate, shorter than the tube, whitish with brown veins, slightly barbate within; laminae oval, repandose, acute at the end, bluish purple, rather broader than the outer. Stigmate elliptic, whitish blue; segments attonuate crose on the outer unargin. Olss. S716. 
Nutive of Italy and France, and of Germany as far north as Erford, Saxony, and Silesia.

IRIS germanica. Alst. i. 472. Coste \&: Willemet in med. conment. v. 298. Krock. n. 56.

I. nostras. Berg. 38. Lim. 47. Murr. v. 269.

I. nostras hortensis. Mill. Jos. 245.

I. vulgaris nostras hortensis. Dale 247.

I. vulgaris germanica, sive sylvestris. Chom. 14; suppl.5. Geoffr. ii. 98. 101. Lew. i. 14. Rutty 250. Vog. 201.

I. vulgaris violacea sive purpurea sylvestris. Neum. ii. $I 40$.

\section{Corolla glabrous.}

3. IRIS Pseudacorus. Inner segments of the corolla smaller than the stigmata. L. sp. 56. Curt. lond. iii. 4. t. 197. Bot. arrang. 39. Smith brit. 41. Woodv. i. 114. t. 40. Vahl. enum. ii. 138. Sibth. prodi. 27. Fl. dan. t. 494.

I. foliis ensiformibus, corollis imberbibus, petalis interioribus stigmate minoribus. L. suec. $n .37$.

Pseudoiris. Dod. 248, repr. in

Acorus nostra palustris. Lob. ic. i. 58, \&

I. vulgaris. Ger: by Jolins. 50, (the name and description belonging to I. germanica,) cop. in

Acorus palustris, seu Pseudoiris lutea palustris. Park. theatr. 1219; and repr. in

I. palustris lutea. Gcr. by Johns. ed. ii. 50. Raii hist. 1186; syn.374. Vaill. paris. 109.

Acorum, Gladiolus luteus. Fuchs. 13. c. 4. cop. with the addition of a flower in

Acorum adulterinum. Trag. 699, which repr. in

I. Pseudoacorus. Cord. $134 ; \&$ cop. in

I. palustris lutea, sive Acorus adulterinus. Bauh, 
$J$.ii. 732. The germen not well represented.Tourn. paris. 278. L. lapp. n. 16.

Stem slightly compressed, with from 4 to 9 flowers. Corolla ycllow; outer segments obovate, from less than 1 to 2 inclies broad, narrowest in young shoots, the base of the laminac and ungues with purplish brown lines; ungucs greenish on the outer side; inner segments oblong, cordate at the base. Stigmata yellow, bilabiate; upper lip bipartite, eroso-serrate. Antherae linear, brownish purple. Obs. 1836.

Native of Europe from Italy to Lapland.

IRIS Pseudacorus. The root. Pharm. edin.Krock. 2. 59. Lew. disp. by Dunc. 239. Spielm. 271.

I. palustris. Lew. ii. 16. Lim. lapp.n. 16 \& MIonro iii. 148. Rutty 253.

I. nostras. Cull. ii. 439. Quarin animad. 185. Vog. $201 \beta$

Acorus palustris. Berg. 39. Limn. 47. Murr. จ. 275.

Acorus vulgaris. $V o g .230$.

Acorus adulterinus. Alst. i. 472. Dale 247. Geoffr. ii. 5. Mill. Jos. 13.

e straminea. Corolla palc yellow. From Smith brit. 42.

1. palustris pallida. Dale ap. Raii syn. 375. Between Hertford and Welling. What Ray says in the preceding paragraph of a white flower observed by Wale probably belongs to this.

4. IRIS foetida.-Inner petals very patent. Stem with 1 angle. Leaves ensiform. L.-L. a Gmel. ii. 115.

I. foetidissima. L. sp. 57. Bot. thrang. 40. Smith brit. 12. Gort. belg. n. 33. 
I. foctidissima, seu Xyris. Vaill. paris. 109.

I. sylvestris, quam $\mathbf{X}$ yrin rocant. Raii syn. 375 .

Sphatula foctida. Fuchs. 754. c. 306, in fruit, cop. in

Sphatula foetida, seu Gladiolus italicus. Trag. 904, \&ं

Spatula foctida, plerisque Xyris. Bauh. J. ii. 751, with a figure in flower.

Xyris \& I. agria Theophrasti. Lob. ic. i. 70, \&

I. sylvestris byzantina peramoena. Lob. ic. i. 69, (the name belongs to I. sibirica,) repr. in

Spatula foetida. Dod. 247, \&

Tyris. Ger. by Johns. 60, \& cop. in

Xyris Lobellii. Dalech. 1621.

Xyris Matthioli. Dalech. 1622, in fruit.

Native of Italy, France, Holland, the west of England, Kent, Essex, Bedfordshire, Cambridgeshire, Norfolk, and thic south of Worcestcrshire, where rare. IRIS foetida. Dale 248.

Xyris. Geoffr. suite iii. 426. Linn. 48. Spatula foetida. Mill. Jos. 420. Rutty 490.

\& íariegata. Leaves with straw coloured stripes. Obs. 5332. In a garden.-Bot. arrang. 40. var. 2.

5. IRIS virginica. Stem two-edged. L. $a G m$. ii. 115. L. sp. 58. Hort. kew. i. 72.

I. corollis imberbibus, germine trigono, caule ancipiti. Gron. virg. 7; ed. i. 11.

IRIS virginica. Schoepf 9.

6. IRIS versicolor. Germen triquetrous. Leaves ensiform. Stem slightly compressed. Obs. 7808. In Mr. Knorwlton's garden.-L. sp. 57. Hort. 
liew. i. 71. Curl. mag. $t .21$, inner segments of the corolla represented as acute.

Root acrid. Leares contrary, even with the stem, lanceolato-ensiform, the inner and sometimes the outer margin straight. Stem from 18 to 30 inches long, erect, branclied from near the base, with 3 branclies. Branches distichous, with from 2 to 4 flowers, leafless, erect, slightly compresscl. Flozers fusciculate, erect. Bracleae at length scariose, brown: Peduncles obsoletely trigonous, as long as and longer than the bracteae. Germen once, twice, and thrice as short as the peduncle. Corolla, tube twice as short as the germen; 3 outer segments spatulate, twisting up as a cord after florescence; ungues greenish yellow with purplish brown veins; 3 inner segments oblongo-lanceolate, crenate at the end. Style as long as the tube of the corolla. Stigmata as long as the inner segments of the corolli, keeled on the upper side, blue above, flesh coloured below ; keel purplish pink; upper lip bipartite; segments eroso-serrate; lower lip bifid; segments triangular, rather obtuse. Obs. 7808. June and July.

IRIS versicolor. Bart. 33. Bartr. W. trav. 454. Schoepf 9.

7. IRIS verna. Stem shorter than the leaves, with 1 flower. Root fibrous. L. sp. 58. Hort. kew i. - 73.

IRIS verna. Bart. 33. Schoepf 10.

8. IRIS edulis. Leaf linear, pendulous, glabrous. Stem glabrous, multiflorous. Thunb. cap. 12. Recens. pl.n. 26.

Moraea edulis. .Sims in bot. mag. $t .613$.

I. longifolia. Andr. repos. $t .45$. 
Moraea fugar. Jacq. ap. L. a Murr. 93; hort. iii. 1. 20 .

IRIS edulis. L. fil. suppl.98.

9. IRIS Sisyrinchium. Lcaves canaliculate. Scapus with from 3 to 5 flowers. Bullbs when the plant in fiower 2 , one of which above the other. From $L$. Vahl. Clus. \& Park.-Vahl. enum. ii, 144. L. sp. 59. Hort. liew. i. 74. Sibth. prodr. n. 95. In Laconia, and the isles of Cyprus Cimoli and Zante.

* majus. Leaves shorter than the scapus. Froin

Sisyrinchium majus. Park. partd.t. 169. f. 6, \&

Sisynrichium majus. Clus. hist. i. 216, which repr. in Dod. 210, Ger. by Johns. 103,

Hyacinthus poeticus hispanicus, gemino gladioli reticulato bulbo. Lob. obs. $50 ; \&$

Sisynrichium Cordi \& Clusii. Lob. ic. i. 97 ; \& cop. in

Iridi bulbosae affine, Sisyrinchium majus. Bauh. $J$. ii. 708.

Sisyrhynchium majns, flore lutea macula notato. Raii hist. 1166.

Sysirhynchium majus. Raii europ. 243. In Sicily. SIS YRICHION majus. Clus. hisp. 279. No fig. \& minus. Leaves longer than the scapus. From Clus. Sisyrynchium minus. Raii hist. 1166.

Sisynrichium minus. Clus. hist. i. 210, which repr. in Dod. 210, Gier. by Johns. 103,

E:oups:xsov Theophrasti. Lob. obs. 51, \& Parva Noselha. Lob. ic. i. 97 ; cop in

Iridi bulbosac affine, Sisyrinchium minus. Bauk. $J$.

ii. 708 , \& repr, from

SISSYRICHIUM minus II. Clus. hisp. 281. 


\section{KYLINGIA.}

Bracteae 2, with 1 flower. Caly $x$ diphyllous. Seed 1, triquetrous. Obs. 8103. L. fil. suppl. 11. Rottb.

Is a true Gramen.

1. KYLINGIA monocephala. Stem filiform, triquetrous. Spike roundish, sessile. Involucrum with 4 unequal bracteac. Obs. 8403. Specimen gathered by Bronghton in Jarnaica.-L. fil. suppl. 104. Salisb. R. allert. 31. Swartz. obs. 32. Rottb. gram. 13. t. 4. f.4. Vahl. cnum. ii. 379.

Scirpus cephalotes. Jacq. hort. i. 42.t.97.

Schoenus coloratus. L. sp. 64.

Pee Motenga. Rhcede xii. 99. $t$. 53, the bracteae of the involucrum equal.

(Gramen cyperoides spica compacta alba, foliis ad spicam partim albis partim viridibus. Sloane hist. i. 119. t. 78. $f .1$, is a different species.)

Involucrum, all the bracteae unequal. Spike, bracteae membranaceous, one lanceolate, the other ovate. Caly.x membranaceous; phylla ovate, somewhat mucronate, compressed, nervose, many times longer than the bracteac; carina aculeate, green. Petal lanceolato-oblong, membranaceous, so thin as to be difficultly discernible, somewhat longer than the grermen. Pistil as long as the calyx. Style filiform, bifid. Stigmata filiform. Obs. St03.

GRAMEN capitatum. Rumph. vi. 8. t.3. f. 2.

2. KYLINGIA triceps. Heads mostly in threes, sessile, glomerate. Spikes very much crowded, somewhat imbricatc. Vahl. enum. ii. 381. L. fil. suppl. 104. Rottb. gram. 14.t.4. f. 6. 
Monograit. 50. Cyperus.

Kyllinga tricephala. Salisb. R. allert. 32.

MOTENGA. Rheede xii.97.t. 52.

\section{CYPERUS.}

Bractease in disticlious spikes. Calyx and Corolla none. Seed 1, naked. Obs. 4957: $\boldsymbol{L}$.

1. Stem and scapus terete. L.

1. CYPERUS articulatus Scapus articulated. Obs. S664. Specimen gathered by Broughton in Jamaica.-L. sp. 66.

C. culno nudo articuloso. Royen 51 .

Juncus cyperoides creberrime geniculatus, medulla farctus, aquaticus, radice rubra tuberosa odorata. Sloane cat. 36 ; hist. i. 121. t. 81. f. 1 :

C. rotundus americanus, caulibus articulatis. Hist. ox.s.8.t. 11. row $1 . f .4$, but the spikes improperly altered to imbricate, cop. from APO YOMATLI, seu Phatzisiranda. Hern. 33.

\section{Stem triquetrous. Spikes alternate. Vahl.}

2. CYPERUS esculentus. Stem naked. Spikes lineari-lanceolate, distant. Umbels leafy, simple and compound. Leaves erect. Tubera ovate. From Royen, \& Vahl. enum. ii. 345. L. sp. 67. Gouan. monsp. 389. Near pools and in salt water ditches in the neighbourhood of Montpelier.-Donn 8. Raii hist. 1301.

C. culmo triquetro nudo, panicula foliosa, radicum tuberibus ovatis zonis imbricatis. Royen 51. Ger. Lud. prov. 118.

C. paniculis squamosis, an Trasi. Raii curop. 112. In Sicily. 
Malinathalla. Col. phytob. t. 5, cop. in

I'rasi. Bauh, J. ii. 505. Malth. 513. cop. in Das lech. 1581, \&

Dulcichinum cum flore. Iod. 340, which repr. in

I'rasi cum fore. Lob. obs. 41,

Trasi veronensium. Lob. ic. i. 78, misprinted 77, the inner figure, \&

C. esculcntus, sive 'Trasi italorum. Ger. by Johns. 32 ; cop. in

C. esculentus, sive Trasi cum flore. Park. theatr. 147, \&

C. dulcis Thcophrasti. Tab. ic. 657, which repr. in

C. rotundus esculentus angustifolius. Bauh. Casp. thcatr. 222. Scheuch.J. agrost. 382. Specimen found by Jussieu near Montpelier.-iMont. 12, who says it was not to be found near Verona, nor in the Bolognese.-Boerh. ii. 166.

Dulcichinum. Dod. 338, repr. in

Trași veronensium. Lob. obs. 41 ; ic. i. 78, misprinted 77 , the outer figure, \&

C. esculentus, sine caule \& flore. Ger. by Johns. $32 ;$ \&. cop. in

C. dulcis rotundıs esculentus Trasi dulce vocatus. Park. theair. 147. No flowers.

Native of Italy and the south of France.

CYPERUS esculentus. Bryant 29.

Trasi. Dale $25 \%$.

5. CYPERUS rotundus. Stem naked. Umbel leafy, supradecompound. Spikes lanceolate, acute. Tubera oblong. Sibth. prodi. n. 100. In Paros, Naxos, Santorini, and other Grecian islands. - $L$. p. 67 is C. hexastichos.) 
C. rotundus odoratus parvus. Mich. gen.45. On the banks of the drno.

Cyperus. Wutth. 26, cop. in Cam. cpit. 9, the inner half, which cop. in

C. rotundus. 'T'ab. ic. 656, which repr. in

C. rotundus vulgaris Bauh. Casp. theatr. 210, who says he found it at Montpelier, \& which cop. in

C. rotundus odoratns vulgaris. Hist. ox. s. 8.t. 11, row.1. f. 1. Kaii hist. 1299. n. 2. par. A.

C. panicula crassiore minus sparsa. Bauh. J. ii. 501, misprinted 493, $w^{i}$ th a portion of the panicle. At Monbeliard. He describes the root as swect to the taste, and when recent scentless.

C. rotundus vulgaris. Hist. ox. iii. 235. Garid. 143. Tourn. inst. 597.

C. Hodveg. Alp. aegypt. 44, cop. in

C. syriaca \& cretica, rotundave. Bauh. J. ii. 502. $f .2-f .1$, roots received by Dourez from Venice, cop. in

C. rotundus odoratus orientalis major. Hist. ox. s. 8. t. 11. row 1. f. 2.

C. orientalis major. Bauh. Casp. pin. 13; theatr. 209. No fig.-Hist. o.x. iii. 236.

CYPERUS rotundus. Alst. i. 431. Berg. 42. Carthers. iii. 42. Dale 257. Geoffr. ii. 49. Herm. 40. Lew. i. 393. Linn. 49. Mill. Jos. 171. Murr. v. 317. Neum. ii. 200. Spiclm. 264. Vog. 236.

C. odorata. Rutty 162.

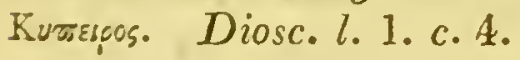

4. CYPERUS Papyrus. Stem naked; angles obtuse. Compound spikes umbellate. Spikes subulate. The 4 outer bracteac of the involucrum lanceolate, 
shorter than the umbel. From Vahl. enum. ii. 365, \& L. a Murr. 97; sp. 70. Doun 15.

C. culmo triquetro nudo, umbella simplici foliosa, pedunculis simplicissimis distiche spicatis. Royen 50.

C. enodis, nudus, culmis e vaginis brevibus prodeuntibus, spicis tenuioribus. Scheuch. agrost. 387. t. 8. f. 14 .

Papyrus. Bruce v. 1. $t$.

Papyrus nilotica. Raii hist. 1302. Lob. ado. 38, repr. in ic. i. 78, \& Ger. by Johns. 40; \& cop. in Bauh. J. ii. 506,

Papyrus aegyptia. Dalcch. 1883, \&.

Papyrus nilotica Alpino. Park. theatr. 1207.

PAPYRUS. Dale 257.

C. Papyrus. Bryant 85.

5. CYPERUS longus. Stem leafy. Panicle umbellato-corymbose. Spikes lineari-lanceolate, approximatc. Bracteae of the involucrum screral times longer than the umbel, aculcatc at the margin. Obs. 2254. Specimen gathered in Soles garden.L. sp. 67. Jacq. coll. iii. 191; ic. ii. t. 297. Sibth. prodr. n. 99. In Grecce frequent.-Bot. arrang. 45. Scop. carn. n. 55. Most. 29, who describes the secd as triquetrous. - Smith brit. 47. Found by Sir J. Cullum near St. Davids.-Raii hist. 1299. In Italy, Sicily, and about Montpclier; syn. 425. Folnd by Newton in the isle of Purbeck, Dorsetshire.-Dod. 336, repr. in Ger. by Johns. 30**, \&.

C. Iongus odoratior \& habitior. Lob. ic. i. 75, and rop. in

C. Iongus odoratior. Dalech.992, $\&$ -

C. rotundus odoratus syriacus minor. Park, theatr. 
Monogria. 50. Cyperus.

146. (The name and description belong to a clifferent species.)

C. culno triquetro folioso, panicula foliosa supradecomposita, pedunculis nudis, spicis alternis. Royen 50. Ger. Lud. prov. 118.

C. longus odoratus, sive officinarum. Magn. monsp. S4.

C. longus odoratus major, panicula sparsa speciosa. Hist. ox. s. 8. t. 11. row 2. f. 13.

C. odoratus, radice longa, sive C. officinarum. Mich. gen. 45. Near Florence.-Magn. hort. 67. Gurid. 143. Vaill. paris. 45. Boerh. ii, 165. Scheuch. J. agrost. 378. t. S. f. 12.

C. panicula sparsa speciosa. Bauh. J. ii. 501, cop. from

Cyperus. Fuchs. 453, which cop. in 12 mo ed. 444. c. 173, and which abr. in Trag. 915. Matth. 26, cop. in Dalech. 991, and Cam. epit. 9, the outer half, which outer half cop. in

C. longus. Tab. 656. which repr. in

C. longus odoratus. Bauh. Casp. theatr. 216. Park. theatr. 146. No figure.-Hist. ox. iii. 237.

CYPERUS longus. Alst. i. 430. Berg. 42. Cartheus. iii. 42. Dale 257. Geoffr. ii. 48. Herm. 40. Lez̈. i. 392. Linn. 49. Mill. Jos. 170. Murr: v. 316. Spielm. 264. Vog. 236.

Cyperus. Lew. disp. by Rother. 153.

6. CYPERUS hexastichos. Stem leafy at the base. Spikes lineari-lanceolate, mostly in sixes. Bracteae of the involucrum 2 and 3 , longer than the umbel, glabrous, linear. Leaves glabrous, linear. From Vahl and Scheachzer.-Rotlb.

C. rotundus. L. sp. 67. Vahl. enum. ii. 349. Thunb. trat. iv, 148. In Jaya. 
C. orientalis, radice olivari, spicis longis e spadiceo purpurascentibus. Scheuch. J. agrost.391.1.9. f. 3, a panicle, gathered by S. Brown in india.

Gramen cyperoides rarius \& tenuius spicatum e $\mathrm{Ma}$ deraspatan. Pluk. alm. 179. t. 192. f. 1, though the engraver has given it the appearance of being aristate.

Gramen cyperinum zeylanicum minus, Kalandura zeylonensibus. Burm. J. thes. 107, but he refers to figures more like Scirpi.

CYPERUS rotundus. Lour. i. 53.

7. CYPERUS canescens Spikes sessile, imbricate. Spikes and spiculae oblong, nearly terete, reflex. Vahl. enum. ii. 355.

WARA PULLU. Rheede xii. 77. t. 42.

S. CYPERUS Iria. Stem leafy below. Spikes linear. Flowers rather remote, obtusely mucronate. Bracteac of the involucrum microscopically aculeate at the nargin. Leaves glabrous. From L. sp. 67, Vahl. cnum. ii. $360, \&$

C. borneaceus, limonii panicula. Scheuch. $J$. $a$ grost. 392. t. 9. f. 4, from a specimen gatliered by S. Brown in India.

Gramen cyperoides indiae orientalis elatius, panicula sparsa pallescente. Pluk. alm. 179.t. 191.f.7, is probably

C. madraspatanus, paniculis semen santonici aemulans. Scheuch. J. agrost. 390. t. 9. f. 2, which has shorter spikes, and is thought by Vahl to be $\mathbf{2}$ younger plant.

ITA, seu Balari. Rheede xii. 105. t. 56 . 


\section{SCIRPUS.}

Bracteae imbricate. Calyx and Corolla none. Seed 1, pappose at the base; pappus scabrous. Obs. 2272. Bot. arrang. 55, note. $-H a l l .-L$.

1. Bracteae shorter than the rachis. Spikes many, lateral.

1. SCIRPUS articulatus. Scapus articulated. Spikes ovate, in globular heads. From Vahl. enum. ii. 25s. L. sp. 70.

TSIELI. Rheede xii. 135. t. 71.

2. Bracteae shorter than the rachis. Spiles many, terminal.

2. SCIRPUS maritimus. Bracteae trifid at the end. Spikes crowded. Stem triquetrous. Obs. 5328. Specimen gathered at Friestone Shore, Lincolnshire. -Vahl. enum. ii. 269. L. sp. 74 ; suec. n. 47. Bot. arrang. 50. Smith brit. 56. Pollich n. 49. In salt marshes in the Palatinate.-Reich. maeno. franc. n. 926. On the banks of the Maine.Schreb. lips. 60. Roth germ. i. 23. On the banks of rivers and ditches and on the sea shore.-Scop. carn. $n .57$.

SCIRPUS maritimus. L. amoen. v. 67 .

a littoreus. Spikes to 9 tenths of an inch long. Obs. 5328. Curt. lond. iv. 4. t. 284. L. $\beta$ Bot. arrang. 50 a Huds. $21 \beta$

Cyperus panicula compacta, e spicis teretibus crassioribus composita. Scheuch.400. t.9. f.9. 10. Gramen cyperoides palustre, panicula sparsa. Raii syn. 425. 
Gramen aquaticum cyperoides vulgatius. Ger. by Johns. 22, cop. in

Gramen cyperoides vulgatius aquaticum. Bauh.J. ii. 495.

Pappus microscopically aculcalc; aculei reflex; not adhering to the ripe seeds, but to the receptacle. Obs. 3167. Specimen gathered in England.

- palustris. Spikes 4 tenths of an inch long. Obs. 14S1. Salt marsh at Shirley Wich, Staffordshire. -L. $\delta \varepsilon$ Huds. 21. a Bot. arrang. $50 \delta \varepsilon$

Cyperus rotundus littoreus. Ger. by Johns. 31.

Cyperus rotundus littoreus inodorus. Raii syn. 426. Found by Doody and Dale about London and Maldon. (Lob. ols. 40, repr. in ic. i. 77, and cop. in Bauh. J. ii. 503, is represented as having axillary spikes.)

3. SCIRPUS squarrosus. Stem slightly trigonous. Spikes sessile, 1 to 4 . Involucrum of 2 bracteac. Bractene of the spikes ovate, aristate. From $\boldsymbol{L}$. ment. 181, \& Vahl. cnum. ii. 259.

Gramen cyperoides orientale perpusillum, capitulis subrotundis hispidis, plerumque gemellis. Pluti. mant. 98. t. 350. fol. 98. pl. 6 .

(Avcnka. Rheede xii. 72. $t$. 36, is a species of Adiantum.)

MOTTA-PULLU. Rhecde xii. 72. $t .38$.

4. SCIRPUS argenteus. Stem triquetrous. Spikes sessile, numerous, cylindric, crowded. Involucrum . very long, of 3 and 4 bracteae. From Rotll. quoted in L. a Willd. i. 311, א.

Fimbristylis argenteum. Vahl. emum. ii. 294. MULLEN-PULLU. Rheede xii. 101: t. 54. 


\section{1 * REMIREA.}

Bracteae 2, containing 1 flower. Caly $x$ dipliyllous, smaller than the bracteac. From

1. REMIREA maritima. Vahl. enum. ii. 391...Aubl. PARATURA. Pis. braș. 115; ind. 238. No. fig.

\section{NARDUS.}

Bracteae none. Calyx dipliyllous. Corolla none. Obs. 4424. $L$.

- Differs from Festuca in the want of bracteae, and in the single style.

1. NARDUS indica. Spike setaceous, incurvate, glabrous:" Vahl. enum. ii. 397. L. fil. suppl. 105: NARDUS indica. Lour. 57 .

\section{PENICILLARIA.}

Bracteae 2, truncate, containing 2 flowers. Caly. diphyllous, concave, larger than the bracteae. Style 1; slightly, bifid at the end. Seed obovate. Obs. 6569. The account of the style from $L$. and Royen.

1. PENICILLARIA solitaria. Obs. 6569. Specimen in fruit.from Prof. Jos: F. Jacquin.

Holcus spicatus. L. sp. 1483, who describes 2 flowers within each pair of bracteac, $I$ of which biemaphrodite, the other male.-Salisb. W. 46. Donn 220. 
Panicum spica simplici aequali, pedunculis bifloris. lioyen 54.

Panicum cacruleum. Raii hist. 1247, who says it is a native of Peru.-Nill. 13h. dict. n. 5. Gicr. by Johns. 81, where are represented 3 peduncles with 1 sced in eacli pair of bracteac; repr. from

Panicum indicum. Dod. 498, which repr. in ed. ii. 507 ; \& cop. in

Panicum cacruleum, sive indicum. Bauh. J. ii. 441, with a separate spike and 2 peduncles with 2 seeds witlin each pair of bracteae, which he also describes as mostly 2.

Panicum cacruleum indicum. Loひ. adr. 15, raised from seediffom India sown in the gardens of Montpelier; repr. in ic. i. 43; cop. in Tab. ic. 280, which repr. in

Panicum indicum, spica obtusa cacrulca. Bauh. Casp. theal. 522; abr. in IIist. ox. s. S. t. 3. row 3. f. 5; repr. in

Panicum americanum. Ches. hist. ii. 215; and cop. in

Panicum indicum caeruleum. Park, theatr. 1140. Cam. horl. 116.

Gramen álopecuroides indicum maximum. Raii his . 1908. In the garden of Compton from Indian seeds.-Hist. ox. iii. 189. $n$. 7 .

Panicum indicum, spica longiore villosa et interrupta. Mist. ox. s. S. t. 3. row 3. f. 7. Bracteae acute. Spike aristate.

Gramen alopecuroides, spica maxima indliae orientalis. Plut. phyt. t. S2. f. 4, bracteac acute. Spike withoint aristac.

Gramen paniceum, sive Panicum sylvestre maximum indiac orientalis. Pluk. alm. 174. 
Stem erect. Leares hirsute. Petioles hirsute. Peduncle striate, hirsute. Racemus oblong, with seeds set close. Pedicles hirsute, idpressed. Invalucrum poly phyllous, as long as the pedicles, whitish brown; phylla setaceous, plumose, containing I flower. Flower a little longer than the involucrum, nearly sessilc. Bracteae 2 , ciliate, the upper margin retuse; lower bractea very short, oblong square, the longitudinal diameter the shortest; the upper thrice as long, square, with 3 ribs. Caly $x$ diphyllous, more than twice as long as the upper bractea, greenish ; phylla ovate, concave, nearly equal, ciliate, the lower with 7 ribs, glabrous, and slightly shining on the outside; the upper liirsute on the outside, quadrato-ovate, with 2 ribs, the sides on the outer side of the ribs membranaceous. Filaments 3. 'Seed obovate, glabrous, bluish white, terminated by the remains of the style, as long as the calyx, the upper part composed of the farinaceous cotyledon. Obs. 6569.

PANICUM cacruleum. Mill. Ph. dict.n. 5.

\section{I G Y N I A.}

54. ALOPECURUS.

Inserted on an erroncous supposition that the $\boldsymbol{P}$ an icum alopccurodeum of Mill. was $A$. indicus.

\section{SACCHARIFERA.}

Bracteae 2, with long hairs at the base. Caly $x$ diK 2 
phyllous. Petuls 2. Obs. 5343. Specimen of S. spontanea from Sonth Carolina.

Saccharum. L. gen. 73 from dried specimens; mant. 22. from another dried specimen.-Juss. 30. Gaerln. 82.

1. SACCHARIFERA offinalis.-Flowers paniculate. Leaves flat. $L$.

Saccharum oflicinarum, L. $s p .79$. Hort. kew. i. 85. Lour. i. 66.

Saccharum. Browne 129.

Arundo saccharifera. Bauh. Casp. pin. 18. Sloane cat. 31 ; hist. i. 108. t. 66, a panicle.-Rumph. v. 186. t. 74. f. 1. Boerh. ii. 162. Dalech. 1002, and Theophr. a Stap. 483, cop. from

Harundo saccharina indica. Lob. ado. 19, repr. in ic. i. 49, which cop. in

Arundo saccharina. Bauh. J. ii. 531. Raii hist. 1278. Ger. by Johns. 38, cop. in

Harundo saccharifera. Park. theatr. 1210.

Arundo saccharifera Rottanga. Rumph. v. 19l. $t$. 74. $f .2$, probably described in the text under the title of

Arundo saccharifera tertia. 187 , seems to be a variety with narrower leaves.

Sacharum. Cord. 211.

Sugar Canes. Ogilby's china 252. t. Cazand in ph. trans. cop. in gent. mag. xlix. 580. $t$.

Bractcae 2, opposite, nearly equal. Calyx diphyllous, naked, withont aristae. Obs. 3389 . Specimen gathered by Dr. Wright in Jamaica.

Native of India.

ARUNDO saccharina. Dale 266.

Sugar Cane. Blane 59.

Cane plant. Clarli, James in med. facts vii. 307. 
CANE JUICE. Graing. 10.13.

Cane liquor. Graing. 28.

SACCHARUM. Alst. ii. 473. Fordyce Gr. pract. 205. Geoffir. ii. 732. H crm. 703. Hill 794. Leì. ii. 287. Limn. 50. Mill. Jos. 383. Monro ii. 443. Murr. v. 390. Pearson, R. i. 90. Ploucq. bibl. i. 289. Rutty 44t. Spielm. 571. Vog. 334.

Saccharum officinarum. Bryant 71. Lew. disp. by Dunc. 298. Pearson, R. i. 208. Wright in med. journ. viii. 281.

Saccharon. Diosc. l. 2. c. 104.

Saccaron. Plin. 304. lin. i. l. 12. c. 8.

Sugar. Blane 59. 303.-Cull. ii. 402. Darw. ii. 74. 466. Fothergill $J$. in med. obs. vi. 123.

Neum. ii. 71. Mosely, account from in chir. rev. vi. 432. Slare in phil. trans. abr. by Jones v. part i. 353 ; and by Hutton vi. 72. Trotter, account from in chir. rev. ii. 51.

Saccharum non purificatum. Brown Sugar. Pharm. lond.

Saccharum vulgare. Cartheus. ii. 190.

Saccharum rubrum. Fordyce G. pract. 151.

Saccharum canariense. Schoepf. 11.

Saccharum purificatum. Refined Sugar. Pharm. lond.

Saccharum album. Ware ophth. 60.

MELASSES. Blane 58. 309. 506. 122. Rush ii. 72.

SPIRITUS sacchari. Aaskow in act. haun. i. 308.

Rum. Blane 323. 305. Chalm. i. 144. Darw. ii. 704. Emerigon in Dawson rheumat. append.9. II unter jam. 289. Jaclison jam. 397. Lettsom in K 3 
med. obs. vi. 163. Moseley 79. Pearson, R. i. 106. Rush ii. 69. Pringle 283. Sandford, account from in med. rev. iii. 116.

Punch. Bisset ess. 253. Chalm. i. 167. 176. Iothergill $J$. in med. obs. vi. 131. Phys, journ. iii. 217. Rush i. 113.

a alba. Stem long, white; knots distant. From Lour. var. 1.

\& rubra. Stem short, red; knots approximate. From Lour. vor. 2.

y elephantina. Stem long; knots approximate. From Lour. var. 3.

\section{PEROTIS.}

Bracteae none. Calyx diphyllous; phylla equal, aristate. From Hort. licw.

1. PEROTIS latifolia. Stem simple; kinots glabrous. From Hort. licw. i. 85, \& L. « Willd. i. 324. Saccharum spicatum. L. sp. 79. Thunb. cap. 20. (Burm. Laur. ind. 23.t. 9. f. 3, lias flat leaves.) Alopecuros malabarica, foliis undulatis, spica practenui. Scheuch. J. agrost.91. t.2. f. 9. G. H. Specimen gathered by S. Brown in India.

Gramen geniculatum brevifolium crispum, spica purpuro-sericea, maderaspatanum. Pluk. alm. 177 ; phyt. t. 119. f. 1.

Tsjeria-kuren-pullu. Rhecde xii. 117. 1.62. Alopecuros madraspatana, folio brevi crispo, spica purpurosericea. Hist. ox. iii. 191.

SACCIIARUM spicatum. Lour. i. 67. 


\section{PHALARIS.}

Bracteae 2, carinate, equal. Caly $x$ cartilaginous, double. Obs. 373. $L$.

1. PHILARIS canariensis. Panicle nearly ovate, spikelike. Keel of the bracteac bordered, entire. Phylla of the outer calyx Ianceolate. Obs. 373. In a garlen.-L. sp. 79. Hort. kezo. i. 85. Bot. arrang. 65. Smilh brit. 62. Roth germ. i. 25. Huds. 23. On rubbish and the sides of roads.Gouan hort. 33. On the sea coast near Montpelier.

P. major, semine albo. Dill. ap. Raii syn. 394, where it is noticed as a plant cultivated in fields.Hist. ox. iii. 186. s. S. t. 3. f. 1. Boerh. ii. 15S. Vaill. paris. 159. Scheuch. J. agrost. 52. Nagn. monsp. 202; hort. 158.

P. Dioscoridis. Cord. 101, repr. from

Phalaris. Trag. 669. Dalech. 415. Bauh. J. ii. 442. Raii hist. 1248. Dod. 501, repr. in Lob. ic. i. 43, Ger. by Jolnzs. 86, \& cop. in

P. vulgaris. Parli, theatr. 1163.

PHALARIS. Dale 262.

P. canariensis. Bryant 342. Krock. n. 85 .

Semen canariense. Linn. 50.

\& nigra. Fruit blackish brown, smaller than that of ж. From

P. major, semine nigro. Raii hist. 1248; europ. 202. Ahout Mrssina, Baiac, Naples and Montpelir growing wild.-Bauk. J. ii. 443. No fig. -Magn. monsp. 202. On the sea coast near No tpelier.-Magn. hort. 158. Boerh. ii. 159. Hist. Ox. iii. 186

P. semine nigio. Park. theatr. 1163. No figure. 
Somewhat less than $\alpha$ in stalk, leaf, head, and chicfly in the fruit.

\section{PANICUM.}

Bracteac 2, mostly containing 2 flowers. Caly $x$ diphyllous, that of the fertile flower mostly curtilaginous; that of the neutral flower sometimes monophyllous. Obs. 6557. L.

When there are 2 flowers the uppermost is mostly neitral, sometimes male as in $P$. polygamum, aud $P$. hordenceum. Obs. 6559. Specimen gathered by Broughton in Jamaica.-The neutral and male flowers are of a texture similar to that of the bracteae. To be convinced of the justness of this view of its structure, which was conjectured by Jussicu as early at least as the year 1782, it will be necessary to cxamine $P$. polygamum, where what Linnacus calls the third valve and that which in Bot. arrang. 55, I have described as a fourth valve, compose the flower which contains the stamina, while the pistil is protected by a cartilaginous calyx. In other species I had before suspected the fourth valve to be the rudiment of a second flower, from observing that its margins were folded back on the side facing the third valve, and not facing the lower flower. In $P$. hirtellum, I have not been able to discover the inner phyllum of the upper flower.

1. PANICUM indicum. Panicle cylindric, straight, aristate. From Mill. Ph. dict. n. 3, and Browne. Panici americani sesquipedalis spica. Clus. hist. ij. 216, cop. in Bauh.J. ii. 411 , \& 
Panici indiani dune species. Park. theatr. 1140; the onter figure, repr. in

P. americanmm spica longissima, Ger. by Johns. St, and cop. in

P. indicum, spica longissima. Mist. ox. iii. 188. s. S. t. 3. row 3. f. 6. Pluk. alm. 278. Bauh. Casp. pin. 27; theatr. 523. No fig.-Sloane cat. 26 ; hist. i. 10t. Introduced from Guinea into Jamaica, where sometimes cultivated in the gardens of the negroes.

P. acthiopicum. Clus, exot. app. alt. 262. No fig. $P A N I C U M$ erectum maximum, panicula stricta cylindracea aristata. Browne 134. Negroe Guinea-corn. Cultivated in several parts of Jamaica.

2. PANICUM alopecurodeum.-Spike simple. Involucra setaceous, agwregate, at the base of the flowers. Gron.-W Mill. Ph.

P. spica simplici, aristis aggregatis flosculo subjectis. Gron virg. 12.

P. glaucum y L. sp.ed. i. 56.

P. indicum altissimum, spicis 'simplicibus mollibus in foliorum alis pediculis longissimis insidentibus. Toum. inst. 515.

PANICUM alopecurodeum. Mill. Ph. dict. $n$. 4, who speaks of it as a native of both Indies.

3. PANICUM rerticillatum. Spike compound. Involucra setaceous, microscopically aculeate; aculei deflex. Obs. 6561. Specimen gathered in the Paris garden.-Roth germ. i. 26; ii. 69. L. sp. 82. Curt. lond. iv. 6. t. 260. Bot. arrang. 55. Smith brit. 64. Gouan monsp. 115.

P. vulgare, spica simplici et aspera. Tourr. paris. 123. Vaill. paris. 156. 
Gramen geniculatum. Tal. ic. 200, cop. in Ger. by Joluns. 15,

Gramen geniculatum minus. Park. theatr. 1177, \& Gramen geniculatum 'l'aberu. Bauk.J. ii. 469; \& repr. in

Gramen paniceum spica aspera. Banh. Casp. thealr. 139. Magn. monsp. 116. Scheuch. J. agrost. 47. Raii cat. ed. ii. 148. Found by Willisel in a garden between Deptford and Greenwich.-Raii hist. 1263; syn. 394. Found by Newton in a ficld of turneps between Putney and Rough-liamptoll, and ncar Chelsea.

Leaies glabrous; margin microscopically aculeate; aculei patulous. Pctioles amplexicaul, one nargin lapping over the other; margin and end pilose. Peduncle scabrons to the hand, microscopically pubescenti-aculeate; aculei deflex. Rachis of the spitie microscopically hirsute; hairs horizontal; those of the spiculae microscopically aculeate. Incolucra attenuate, flexuose, patent, in threes in pairs and solitary, extending beyond the flowers and the end of the rachis. Pedicles very short, from the sides of the rachis and the base of the involucra, in pairs and solitary. Obs. 6562. Specimen from Curtis. PANICUM verticillatum. Honck. n. 312. Thunb. trav. iv. 88.

1. PANICUM sativum. Spike decompound. Invo. lucra setaceous. Fertile flowers glabrous. Rachides villose. Obs. 6567. Specimen gathered in the Vienna garden.-L. cliff. 26.

P. italicum. L. sp. 83; mant. 323. Hort. licw. i. 89. Gouan monsp. 31. Near Montpelier. Varies in the colour and size of the spike.-Lour. i, 58 . 
PANTCUM. Dale 262. Geoffr. suite i. 311. Mill. Jos. 398.

P. italicum. Bryanl 341. Krock. n.91. Pearson, R. i. 76 .

Milium. RIurr. v. 430.

a setosum. Involucra thrice and four times longer than the calyces. Obs. 8665. Specimen from Dr. Boehmer.

P. italicum. L. a Willd. i. 336. Honck. n. 315. Mill. Ph. dict. n.2.

P. quale Linnaei. Krock. n. 92.

Tenna. Rheede xii. 151.t. 79.

Panici secunda speries. Rumph. v. 202.

Panicum. Fuchs. 255. c. 95, the inner fig. cop. in Theophr. a Stap. 930; both figures cop. in

P. vulgare. Bauh. J. ii. 440 ; \& the fig. with the bending spike cop. in

Milium exiguum. Trag. 661.

P. indicum panicula villosa. Raii hist. 1247. Park. theatr. 1139, cop. from

Panicum. Matth. 406, which cop. in

Panici indici spica. Dod. 498, which repr. in ed. ii. 507,

P. alind indicum, et hispanicum, panicula villosa. Lob. obs. 25,

P. aliud indicum, panicula villosa. Lob. ic. i. 42,

P. vulgare. Clus. hist. ii. 215. \&

P. indicum., Ger. by Johns. 84; \& cop. in

P. puniceum (misprinted punicum.) Bauh. J. ii. 440; the inner fig. cop. in

Panicum. Cam. epit. 195, the inner of the 2 figures, P. sativum. Dalech.412, \&

P. indicum villosum hispanicum. Tab. ic. 2\%9, whtch repr. in 
P. italicum, sive panicula majore. Bauh. Casp. thealr. 519, and cop. in II isl.ox. s. 8. . 3. f. 2. Boerh. ii. 158.

P. spica divulsa. Buuh.J. ii. 440.

Involucra about as long as the rachis of the spiculac... Obs. 6567.

\& multifidum. Spike multifid at the end. From

Panici tertia species. Rumph.v. 202. t.75. f.A.

\% submuticum. Involucra twice as long as the calyces.

Obs. 3230. Specimen gathered in the Paris garden.

P. italicum. Krock. n. 91.

P. germanicum. Roth. germ. i. 27; ii. 71. Mill. Ph. dict. n. 1. L. a Willd. i. 336. Honck.n. 316.

P. spica composita, aristis flosculo brevioribus. $L$. ups. 19.

P. spica composita, aristis gluma brevioribus. Royen 54.

Panicum. Rumph. v. 202. t.75. f. 2.

P. Melyne. Tab. ic. 278, repr. in

P. germanicum, sive panicula minore. Baul. Casp. theatr. 518, and cop. in Hist. ox. s. 8. t. 3. row 3. f. 1. Raii hist. 1247. Boerh. ii. 158.

Panicum. Dod. 498, repr. in ed. ii. 507, Lob. obs. 24, \& ic. i. 41; abr. in Cam. epit. 195, outer fig. repr. in

P. vulgare. Ger. by Johns. 85 ; \& cop. in

P. album vulgare. Park. theatr. 1139.

Calyx of the lower flower cartilaginous, glabrous, with microscopic dots disposed in longitudinal lines, but no prominent points; that of the upper flower diphyllous, the upper phyllum linear, membranaceous. Obs. 3230. Specimen gathered in the Paris garden. 
5. PANICUM corripes.-Spikes alternate, secundose. Spiculae subdivided. Calyces mostly aristate, hispid. Rachis trigonous. $\boldsymbol{L}$.

P. Crus corvi. L. sp. St. IIort. kew. i. 89. PANICUM Crus corvi. Thumb. trav. iv. 88.

6. PANICUM sangitinale. Spikes'verticillate, with a knot at the base on the inner side. Flowers in pairs, without aristae. Petioles dotted.-L $L$. sp. 8t. Bot. arrang. 57. Curt. lond. iv. 7. t. 242; grass. 49. IIuds. 25. Near Battersea and Guildford in Surry.-Smith brit. 66. Krock. n. 95.

Digitaria sanguinalis. Scop. carn. $n .72$.

Gramen dactylon, folio latiore. Scheuch. J. agrost. 101. t. 2. f. 2. G, H, at the botton of the plate. In and about gardens in Zurich, growing spontaneously.

Gramen Ischaemon Plinii, sive Dactylon. Dalech. 426.

Gramen dactylon latiore folio. Raii syn. 399. Found by Willisel in the ploughted fields about Elden in Suffolk, and in pastures at Great Witclingham, Norfolk, but in the latter place Dr. Smith says it is not now to be found;-hist. 1272; eutrop. 135. In Italy, France, and Germany in corn fields.-Tourn. paris. 339. Vaill. paris. 85.

Gramen mannac prius Matthioli.-Dalech.414, abr. in

Graminis genus, Deus caninus III, sive Gramen I, vel Galli crus. Bauh. J. ii. 444 .

Ischaemon vulgare. 'Lob. ic. i. 24, repr. in Ger. by Johns. 2T, \& cop. in

Ischacmon sylvestre latiore folio. Park, theatr. 1178. 
Gramen mannae primum. Jorl. 519, repr. in

Gramen mamac esculentum. Lob. ic. i. 2t.

Nalive of Italy, France, Sivitzerland, Germany, Surry, Suffolk, and Norfolk.

GRAMEN Mannae. Dale 264.

7. PANICUM miliaceum. Panicle lax, flaccid. PCtioles hairy. Bracteac mucronate, nervose. L. sp. 86. Hort. kew. i. 90. Roth germ. i. 28. Naturalised about Frankfort, Berlin, and Jena.Krock. n. 99. Lour. i. 59.

Milium Panicum. Mill. Ph. dict. n, 1 .

Milium semine luteo. Boerh. ii. 162. Vaill. paris. 127.

Milium semine luteo vel albo. Baut. C'asp. pin. 26; theatr. 502, cop. from

Milium. Matth. 405, a panicle and leaf.-Racii hist. 1251. Fuchs. 411: ed. fol. cop. in 404. c. 158, \&. Turn. ii. fol. 57. p. 2; abr. in Bauh. J. ii. 446; and imit. in Trag. 658. Cam. epit. 193. Brunsf. iii. 216. Dod. 497, repr. in ed. ii. 506, Lob.obs. 24; ic. i. 39, \& Ger. by Johns. 80, and cop. in

Milinm vulgare album \& nigrum: Park. theatr. 1137.

Milium nostras. Dalech. 409.

Bracteae 2, with 2 flowers, ovate, acuminate, nervose, glabrous; the upper one third longer than the lower. Flowers, the lower hermaphrodite, thic upper neutral. Caly.x of the lower flower cartilaginous, glabrous, shining, straw-coloured, oval; that of the upper flower of the same texture as the bracteae, the lower phyllum ovate, acuminate, just shorter than the upper bractea, the upper phyllum ovate, 
obtuse, half as large as the lower. Seed invested by the permancnt calyx, farinaccous. Obs. 3231. Speeimen gathered in the Paris garden.

fo album. Seeds white. From Roth germ. ii. 73. var. s.

Milium semine albo. Vaill. paris. 127.

y nigrum. Sceds blaek. From Roth germ. ii. 73. . $a r .2$.

Milim nigrum. Cam. hort. 101. No fig.-Tab. ic. $2 i \mathrm{~S}$, repr. in

Milium semine nigro. Bauh. theatr. 505; pin. 26. Vaill. paris. 127. Boerh. ii. 162.

Milium semine nigro, et latiore juba. Lob. obs. 25.

No fig.

MIILIUM. Alst. ii. 363. Cartheus. ị. 287. Dale 262. Linn. 50. Mill. Jos. 297. Murr. v. 430. Rutty 330. Spielm. 22. Vog. 178.

Miliun vulgare. Geoffr. suite i. 59.

P. miliaceum. Bryant 341. Pearson, R. i. 76.

Millet. Fordyce G. fer. ii. 28. Underw. i. 342.

Miques. Linn. amoen. v. 67.

\section{PHLEUM.}

Bracteae 2, equal, kceled. Calyx, phylla 2, unequal, membranaccous. Obs. 4400. Bot. arrang. 61. $L$.

Linnaens's eharaeter of caly.x truncate is taken from the appearance of the side view of the bracteae when elosed, and is merely owing to the bracteae in some speeies being olluse with a mucro instead of graduully tapering into a mucro as in species the most nearly allied to them. 
1. PHLEUM africanum. Spike cylindric, compact. Peduncles triflorous, pilose. Lour. i. 61.

\section{HOLCUS.}

Bractcae 2, cartilaginous, containing I flower. Calyx diphyllous, membranaceous; the outer phyllum witl a twisted arista inserted into the back. Obs. 1498. L.

Male flowers interspersed. Obs. 1498.

1. HOLCUS Sorghum. Bracteac pubescent. Hermaphrodite flowers aristate. Panicle compact, ovate. Obs. 1498. Specimen from Mr. Ballard's garden.-L. mant. 500 ; sp. 1484. IIort. keẅ. iii. 424 .

II. Durra. Forsk. 174.

H. glumis villosis. L. ups. 301, where for Dalech. read Bauh.

H. glumis villosis, seminibus aristatis. Kram. 286. Panicum erectum maximum, panicula singulari crecta sparsa. Browne 135. Guinca corn.

Milium arundinaceum, subrotundo scmine, Sorgo 'nominatum. Boerh. ii. 162.

Milium indicum, arundinaceo caule, granis flares. centibus. Sloane cat. 25.

Sorgum fiuctu rubro. Besl. hort. aut. ord. i. fol. 13. $f .1$.

Sorgum fructu albo. Besl. hort. ant. ord. ii. fol. I3. $f .2$.

Sorghum. Raii hist. 1252. Cultivated in Friuli. Sorgi. Fuchs. 771, cop. in ed. 12 mo 732. c. 296, Sorghi. Bauh.J.ii. $447_{2}$ \&: 
Milium indicum, sive Melica Dodonaci. Dalech. 410 ; and abr. in

Panicum. Trag. 660, which repr. in

Milium indicum. Cord. 143. Matth. 408; abr. in Cam. epit. 194; cop. in Matth. a Casp. Bauh. 330 ,

Milium indicum, sive Melica Matthioli. Dalech. $410, \&$

Sorgum. Tab. ic. 280; which repr. in

Milium arundinaceum, sive indicum, semine subrotundo. Bauh. Casp. theatr. 511. Hist. ox. s. 8. t. 5. row 2. f. 7 .

Melica sive Sorghum. Dod. 499, cop. in Park. theatr. 1137, \& repr. in

Sorgho. Lob. obs. 24,

Surgo, Melica italorum. Lob. ic. 1. 41, \&

Sorghum. Ger. by Johns. 83, has a panicle rather loose.

Panici americani species \& Sorghi cujusdam. Park. theatr. 1140.

Bracteae of the hermaphrodite flowers glabrous in the middle and sometimes to the very base. Seed elliptico-oval, slightly compressed, yellowish brown. Ols. 6568. Specinen gathered in the Vienua garden.

SORGHUM. Dale 263.

H. Sorghum. Bryant 335. Linn. amoen. v. 66. Pearson, R. i. 85 .

Milium indicun.'Geoffr. suite i. 63.

Guinea Corn. Edwards west ind. i. 197. Graing. 11.

Durra. Ncibuhr's trav. ii. 342.

Dourra. Sonnini's liav. ii. 31 . 
2. HOLCUS saccharatus. Bracteac villose. Hermaphrodite flowers aristate. Panicle loose. Obs. 5317. Specimen gathered in the Paris garden.L. mant. 500; sp. 1484. Hort. kew. iii. 425.

H. Dochna. Forsk. 174.

H glumis villosis. L. cliff. 469.

Panicum erectum maximum, paniculis plurimis de. clinatis. Browne 135. Guinea Wheat.

Sorgum. Rumph.v. 194. Ł.75. f. 1. Sceds black, brown, and white.

Miliuı arundinaceum, seminc plano et albo. Raii hist. 1253.

Sorghi album, Milium indicum, Dora. Bauh.J. ii. 448 , the description. (The fig. is probably $I I . b i$ color.)

Bractcae of the hermaphrodite flowers sericeo-villose, sometimes glabrous in the middle, but I suspect from the hairs having been rubbed ofl. Seed elliptico-oval, very slightly compressed, yellowish brown. I suspect that this and $H$. Sorghum, and perhaps $\boldsymbol{H}$. bicolor, will prove to be only varities of oue species. Obs. 5347.-Rachis scabrous. Obs. 5351. Specimen gathered in the Paris garden.-Obs. 8387. specimen gathered by Dr. Wright in Jamaica, where called Guinea Wheat.

HOLCUS saccharatus. Bryant 330.

Indian Millet. Rauwolff by Staph. 171.

. HOLCUS bicolor. Bracteac glabrous, black. Seeds aristate, globular, white. L. mant. 301. In the Upsal garden.-Domn 220.

II. glumis glabris, $L$. cliff. 468 .

Milium indicum, arundinaceo caule, semine fusco, glumis splendentibus atris. Pluk. alm. 250, is probably a variety with brown secds. 


\section{Digynia, 61. Digitaria.}

Sorghi album, Milium indicum, Dora. Bauh. $J_{0}$ ii. $44 S$, the figure, which seems to have been formed by adding a stem and leaves to a panicle and seeds received from Florence under the name of the White Sorghum of Candia. (The description which belongs to $H$. saccharatus, was probably formed from the Antwerp specimen.)

Milium majus sabaeum. Hist.ox. s. 8. t. 5, row 2. f. 6 ?

Milium sabaeum. Bauh. pin. 26?

MELICA candida. Dod. 499.

Millo. Vander-Hagen ap. Clus. cur. post.65. In the kingdom of Sabo in Guinea.

\section{DIGITARIA.}

Bracteue 2, nearly equal, carinate. Caly $x$ diphyllous; both the phylla carinate. Obs. 3239. Hall. Juss.

Is not this a Panicum, in which if I may so express myself, a single membranaceous calyx performs the same office as the membranaceous and the cartilaginous calyx do in $\boldsymbol{P}$. polygamum; in other words a Panicum without any superfluity in the calyx ?

1. DIGITARIA Dactylon. Spikes verticillate, terminal. Obs. 3239. In a garden from a root found by J. Sibthorp between Penzance and Marazion, Cornwall.-Scop. carn. n. 73.

Panicum Dactylon. L. sp. 85. Bot. arrang. 58 ; ed. iv. 116. t. 21, by Mr. Stackhouse.-Krock. n. 96. Gramen legitimum. Tourn. paris. 460. Clus. hist. ii. 217, repr. from

I. 2 
Gramen. Clus. hisp. 498, \& in

Gramen canarium alterum. Lob.ic. i. 23,

Gramen dactiloides radice repente. Ger. by Johns. 28, and ccp.in

Gramen canarium ischaemi paniculis. Park. theatr. 1179.

Gramen Dactylon, radice repente, sive officinarum. Scheuch. J. agrost. 104. t. 2. f. 11. I. Vaill. paris. 85.

Gramen vulgare: IDalech.421.

Gramen repens cum panicula graminis mannac. Bauh.J. ii. 459. (The fig. is Coronilla varia.)Raii hist. 1271. In Italy; europ. 135; syn. 399. Native of Spain, Italy, France, Switzcrland, Germany as far north as Jena, and of the sea coast of the western extremity of Cornwall.

GRAMEN Dactylon. Dale 261. Geoffr. iii. 527. Seguier quoted in Linn. 52. note. Tourn. ii. 104. Gramen dactylon, folio arundinaceo majus, aculcatum forte Plinio. Chom. 224.

\section{POA.}

Bracteae 2, with many flowers. Calyx, phylla 2, ovate, without aristac. Obs. $5375 .-L$.

1. POA ccrealis. Panicle capillary, loose, erect. Spikes with from 5 to 9 flowers, lineari-lanceolate. Smaller bractea somewhat shorter than the calyx. Leaves glabrous. Obs. 8602. Specimen gathered in the Viema garden.-Salisb. $R$. allert. 20.

P. abyssinica. Jacq. var. t. 43; misc. ii. 364. Hort. liew. i. 100. 
Stem glabrous. Panicle scabrous, without hairs. Seeds oval, rufous, with an angle on one side at the base, nearly the twentieth of an inch long. Obs. S60?.

TEFF. Bruce trav. v. 79. $t$, and an account from, in med comment. dec. II. v. 1SS, judging from the description of the seed, pistil and stamina; but the figure of the panicle and the description of what is called a capsula do not at all agree either with my specimens or Jacquin's figure.

2. POA amboinensis. Panicle compact, secundose.

Stem terete. L. mant. 557 ??

PHOENIX amboinica montana. Rumph.vi. 19.

t.7. f. 3 , is described as having aristate flowers, and is therefore probably not a Poa. Retzius observes that a specimen sent him by Koenig for $P$. amboinensis differed widely from the figure and description of Rumphius.

\section{ELEUSINE.}

Bracteae 2, with many flowers. Caly $x$ diphyllous. Arillus containing one seed. Obs. 6446. Gaertn.

1. ELEUSINE sphaerosperma. Seed subgiobose. Obs. 6447. Specimen gathered in the Paris garden.

E. coracana. Gaertn.

E. cerealis. Salisb. R. allert. 19.

Cynosurns coracanus. L.-H. K. i. 106.

Panicum gramineum. Rumph. v. 203. t. 76. f. 2.

Tsjetti-pullu. Rheede xii. 149. $t .78$.

L 3 
Gramen dactylon orientale majus frumentaceum, semine napi. Pluk. alm. 174.t.91. f. 5.

CYNOSURUS coracanus. Bryant 333. Thunt. trav. iv. 88.

Coracan. Perciv. Rob. ceyl. 335.

2. ELEUSINE macrosperma. Seed oblong. Obs. 6446. In the garden of Mr. S. Shore, from seeds from the Calcutta garden.

E. gracilis. Salisb. R. allert. 19.

Cynosurus indicus. L. $-\boldsymbol{H} . \boldsymbol{K} . \mathrm{i} .106$.

Stems ascending, tough. Obs. 6446.

GRAMEN vaccinun mas. Rumph. vi. 10, t. 4 . f. 2.

3. ELEUSINE mucronata. Seed ovate. Bractcae and calyces mucronate. Obs. 6448. Specimen gathered by Broughton in Jamaica.

Cynosurus aegyptius. L. sp. 106. Hort. liew. i. 106

Kavara-pullu. Rheede xii. 131. $t .69$.

Gramen ischaemum malabaricum speciosius, longioribus mucronatis foliis. Pluk. alm. 175. t. 300 . f. 8.

Meiem el Msalib. Alp. aegypt. 48.

Gramen crucis, sive Neiemelmsalib. Bauh. J. ì. 460.

Graimen dactylum aegyptiacum. Hist. ox. s. 8. t. 3. row $1 . f \cdot 7$.

Stem glabrous, shining. Leaves shining, ciliate towards the base. Petioles glabrous. Spikes terminal, 4 together with soinetimes a fifth in the center, the 4 divaricate and horizontal, the fifth patent. Inolucra diphyllous, at the base of each spike, setaceous. Flowers distichous, on the under side of 
the rachis. Bracteat 2, with 4 flowers, mucronate. Calyces mucronate. Styles 2. Obs.6556. In Mr. Shore's garden, raised from seeds from the Calcutta garden, GRAMEN vaccinum femina. Kumph. vi. 10. $t$. 4. $f: 1$.

\section{FESTUCA.}

Bracteae 2, multiflorous. Calyx diphyllous, the outer mucronate, or aristate at the end. Petals 2. Obs. 4168. $\boldsymbol{L}$.

1. FESTUCA fluitans. Panicle secundose, or spike compound. Spiculae lanceolato-linear. Petioles two-edged. Upper bractea oblong. Calyces scabrous, without aristae. Obs. 6358 . In a meadow on the side of a drain with $F$. pratensis. $-L$. sp. 111. Schreb. gram. 37.t. S. Fl. dan. t. 237. Huds. 46. Lightf. 103. Bot. arrang. 100.

a paniculata. Flowers in a panicle. Obs, 6358. Curt. lond. i. 7. $t$.

Gramen fluviatile. Park. theatr. 1275. Ger. by Johns. 14, repr. from

Gramen aquis innatans. Lob. ic. i. 12, \& cop. in

Gramen aquaticum cum longissima panicula. Bauh. J. ii. 490. R. syn. 412.

Gramen aquaticum, fluitans, multiplici spica. Tourn. parts. 273.457.

Gramen paniculatum aquaticum fluitans. Vaill. paris. 02.

Flote Fescue Grass. Stilingfl. t. 10.

Stem ascending, to 4 feet long, compressed. Leares ensiform, striate, $2 \frac{\mathrm{I}}{2}$ tenths of an inch broad, in drying conduplicate; margin obsolctely micros- 
copically aculeate. Panicle straight, at first filiform and contracted, at length patent; branches in pairs; the longer branch when in flower divaricate, the other adpressed; when in fruit one patent, the other adpressed. Spilies lanceolato-lincar, greenish, to 1 inch 1 tenth long, compressed. Bracleae obtuse, green with whitish shining membranaceous margins, the lower ovato-oblong. Calyx, the lower phyllum oblong, green, the end whitish shining and membranaccons, with 7 ribs. Stamina fallen off. Obs. 6358.

FESTUCA Anitans. Bryant 333. Honck.n. 467. Krock.n. 159. Pearson, R. i. 85.

Mannæ semina. Schreb. ap. Linn. 268.

Mannæ grana. Berg. 47.

Manna Schwaden. Spielm. 21.

s spicata. Flowers in a compound spike. Obs. 458.

Near Worcester.

F. fluitans loliacea. Huds. 47. Bot. arrang. 101.

Gramen fluitans, locustis longis spicam aemulantibus. Dill. ap. R. syn. 412.

2. FESTUCA indica. Panicle contracted, erect. Spikes compressed, inostly aristate, with mostly 6 flowers. Retz. obs. iv. 21.

TSIAMIA PULLU. Rheede xi. 75.t. 45.

\section{6**. BROMUS.}

Bracteae 2. Calyx diphyllous; with an arista inserted below the end of the outer phyllum. Petals 2 , ovate, at the base of the germen. Obs. 4167 . L. 


\section{Bracleae containing several fowers.}

1. BROMUS seculimus. Flowers imbricate, the lower shorter than the rachis. Spilses elliptic, with 10 and 11 flowers. Aristae crect. Obs. 6368. Specimen gathered in corn fields between Winkburn and Newark, Nottinghamshire. 15 Aug.-Smith in linn. trans. iv. 281; brit. 125; engl. t. 1171. L. sp. 112. Bot. arrang. 103.

Festuca culmo paniculato, spicis compressis ovatis. L. lapp. n. 28.

BROMUS secalinus. Krock. n. 160.

a pubescens. Spikes pubescent. Obs. 6369. Specimen gathered by Mr. Ballard in Worcestershire.Bot. arrang. $\beta$

Festuca spicis habitioribus, glumis incanis. Dill. ap. R. syn. 414.n. 8. par. 2.

Festuca graminea, glumis hirsutis. Rudb. reliq. 14. $t$.

Gramen gros montbelgardensium. Bauh. $J$. ii. 438. Vaill. paris. 95.

Gramen spica hirsuta, ad Gramen du gros accedens.

Tourn. paris. 91.

Leares hirsute above, pubescent underneath, $\boldsymbol{P e}$ tioles glabrous. Peduncle glabrous. Pedicles pubescent. Bracteae, the lower with 3 and 5 ribs, the upper with 5 and 7 . Obs. 6369.

a glaber. Spikes glabrous. Obs. 6368.-Bot. arrang. $\alpha$

B. secalinus. Lightf. 1086.

Festuca avenacea, spicis habilioribus, glumis glabris. R. syn. ed. i. 192; cd. ii. 261 ; ed. iii. 414.

Gramen murorum Dalechampii. Tourn. paris. 90. Gramen avenaceum segetale majus, gluma turgidiore. IIist. ox, s. 8, t. 7. f. 16. 
Gramen avenaceum, locustis majoribus squamatis, segetale majus. Hist. ox. iii. 212. Aegilops, sive Festuca. Cam. epit. 927.

Stem 30 inches long, glabrous. Leaves hirsute above, pubescent underneath. Petioles glabrous. Stipula erose. Panicle 5 inches long. Peduncles mostly uniflorous, sometimes biflorous. Spikes elliptic, flat, an inch long, with 10 and 11 flowers; flowers patulous, distinct. Bracteae nervose, obsoletely scabrous, membranaccous at the margin; the lower ovate, 2 tenths of an inch long, with 3 and 5 ribs; the upper oval, rather acute, with 9 and 6 ribs, one fourth longer than the lower. Calyx when in fruit nearly terete, the lower phyllum oval, nervose with 7 ribs, obsoletely scabrous at the margin and on the outside, one fourth longer than the upper bractea, emarginate at the end, the teeth obtuse, connivent; arista straight, erect, about the length of the phyllum, inserted at an eighth of the length of the phyllum below the end; upper phyllum lanceolate, ciliate, just sensibly shorter than the lower. Seed oblong, nearly terete, as long as the calyx. Obs. 6368.

2. BROMUS catharticus. Panicle patent, erect, nearly simple. Spikes elliptico-lanceolate, striate, scabrous. Aristae short, straight, Vahl. symz. ii. 22.

GRAMEN bromoides catharticum, vulgo Guilno. Feuill. per. 705. t. 1, cited by Vahl.

\section{AVENA.}

Bracteae 2, containing from 2 to several flowers. Calyx diphyllous, with a geniculate arista from 
the back of the lower phyllum. Petals 2. Obs. 4992. $L$.

In most of the species the arista is twisted, but in A. uncinata, and odorata it is not. In several specics the arista is always or occasionally wanting.

\section{Bracteae containing 2 flowers.}

1. AVENA elatior. Paniculate. Bracteae with 2 flowers, the hermaphrodite one without aristae, the malc one with aristae. L. sp. 117. Bot. arrang. 112. Curt. lond. iii. 6. t. 191. Fl. dan. t. 165, the reduced fig. ill done.

Holcus avenaceus. Scop. carn. n. 1239. Sibth.ox. n. 126. Smith brit. 90. Wiggers.

a aequalis. - Stem equal at the base. Bot. arrang. 112. L. sp. $117 \propto$

A. elatior. L. suec. n. 102. Schreb. gram. 25. $t .1$.

Gramen avenaceum elatius, juba longa splendente. Raii meth. 179. Scheuch. J. agrost. 239. Vaill. paris. 89.

Gramen avenaceum panicula acerosa, semine pap. poso. Dill. ap. Raii syn. 406.

8 nodosa. Stem ovate at the base. From Bot. arrang. 112. L. $s p .117$ \&

A. calycibus bifloris, flosculo hermaphrodito, masculo aristato. L. suec. ed. i. n. 98.

Gramen nodosum, avenacea panicula. Raii syn. ed. ii. 260 ; ed. iii. 406. Scheuch. J. agrost. 237. $t$. 4. f. 27. 28. Vaill. paris. 89. Tourn. paris. 199. Gramen bulbosum nodosum. Lob. adv. 2, repr. in ic. i. 23, with the addition of a figure accurately representing the bulbous base of the stem; the former cop. in 
Gramen nodosum vulgare. Park. theatr. 1176, and the latter repr. in

Gramen caninum nodosum. Ger. by Johns. 23. Raii hist. 1284.

Gramen nodosum. Bauh.J. ii. 456. Dalech. 429.

Gramen avenaceum elatius, radice tuberculis praedita. IIist.ox. s. 8. t. 7. row 2. f. 38.

Gramen caninum bulbosum vulgare. Parli.theatr. 1176.

GRAMEN nodosum avenacea panicula. Rutty 221.

2. AVENA sativa. Paniculate. Bracteac with 2 and sometimes 1 flower. The lowermost flower sessile, sometimes with an arista, sometimes without. Obs. 6705. In a corn field, cultivated. $31 \mathrm{July} .-L$. sp. 118. Hort. kew. i. 113.

A. dispermis. Mill. Ph. dict.

Avena. Cam. epit. 191. Fuchs. 185. c. 67, cop. in Bauh. J. ii. 432, and improved in Trag. 653. Dod. 502, repr. in

A. vesca. Lob. ic. i. 31, \& Ger. by Johns. 75; and cop. in Park. theatr. 1134, (but the aristae omitted in the copy which therefore represents $\gamma$ )

Bracteae ovato-lanceolate, each with 11 ribs, $8 \frac{r}{2}$ and $8 \frac{3}{4}$ tenths of an incle long, $2 \frac{1}{2}$ broad. Calyces mostly glabrous, or with only a few hairs at the base, nearly smooth, the ribs being scarcely obvious except at the end. Arista one third longer than the calyx, about the tenth of an inch longer than the bracteac. obs. 6711 .

AVENA. Oats. The seeds. Pharm. lond.Bang in act. haun. i. 216. Berg" 58. Blane 308. 310. Cullen $₫$ i. 278. Fordyce, G. pract. 207. Lew. i. 445. Linn. 51. Mill. Jos. 68. Murr. v. 
383. Quarin febr. 204, 348, 355, 381, 382, 424. Rulty 47. Schoopf. 11. Spielm. 16. Vog. 158. Wintringham in Mead mon. i. 229. 261.

A. sativa. Pharm. edin.-Bryant 326. Lew. disp. by Dine. 166. Pearson, R. i. 71.

Oats. Fordyce G. pract. 149 ; fev, ii. 28. FARINA avenacea. MLead mon. i. 34, 98. Oatmeal. Blane 310. Fordyce W. fev. 143. GRUEL. Bree 292. Chalm. i. 153; ii. 90. Darw. ii. 221. Denm. ii. 510. Fothergill, J. in med. obs. vi. 135.

Water Gruel. Cull. clin. 229. Fordyce, G. fer. iii. 230. Pringle 132. 158. Wright in ann. med. ii. 369.

SOWINS. Blane 310.

CEREVISIA. Krock.n. 178.

a nigra. Lower flower sometimes aristate. Calyces when ripe blackish brown. Obs. 6741. In a field, cultivated.

A. nigra. Bauk. J. ii. 432. R. syn. 389. Vaill. paris. 19.

Panicle with only 1 flower with an arista. Obs. 6741.

AVENA nigra. Chom. 746. Dale 263. Geoffi. iii. 146.

B alba. Lower flower aristate. Calyces when ripe straw coloured. Obs. 6742. In a field, cultivated.

A. alba. Raii hist. 1253 ; syn. 389.

A. vulgaris, sive alba. Vaill. paris. 19. Boerh. ii. 161.

AVENA alba. Cartheus, i.284. Geoffr. iii. 145. Avena. Dale 263.

A. vulgaris seu alba. Chom. 746 .

White Oat. Bryant 326. 
$\gamma$ mutica. (Variation of $\beta$ ) Calyces without aristac. Obs. 950. In a field, cultivated.

A. vesca. Park. theatr. 1134.

Stem 3 feet 4 inclies long, erect. Petioles with scattered flexuose hairs along the margin. Peduncles turbinate at the end. Bracteae, the lower with 8 ribs, one tenth shorter than the upper; the upper with 11 ribs. Calyces glabrous at the base, the lower phyllum one fourth shorter than the lower bractea, microscopically scabrous, lanccolato-ovate, with 7 ribs, slightly scariose and membranaceous at the end. Germen pilose. Obs. 6705.

$\delta$ uniflora. Bracteae with 1 flower. From

A. alba scotica, semine simplici, pediculo laxo pendente. Richardson «p. R. syn. 389.

2. Bracteae containing 2 and 3 flowers.

3. AVENA nuda. Paniculate. Bracteac with three flowers. Calyces of the lower flowers aristate, glabrous. Receptacle about as long as the bracteae. Obs. 1516. Among oats near Worcester, 28 Sept. -L. a Murr. 122; sp. 118. Bot. arrang. 113. Curt. grass. 44. Hort. kew. i. 113. Hist. ox. iii. 209. n. 4. s. 8. t. 7. row 1. f. 4. Boerh. ii. 161. Lob. adv. 9. No figure; ic. i. 32, repr. in Ger. by Johns. 75, Dod. 502, and cop. with an omis. sion of the aristae, in Park. theatr. 1134. Raii hist. 1254, where he asserts that the calys adheres more firmly to the seed than in A. sativa; but in Camd. by Gibson 26, he says, the seeds are as it were naturally denuded of the husk.-Bauh. $J$. ii. 433.

Petiolcs pilose at the margin, that of the uppermost reaching nearly to the base of the panicle. 
Punicle contracted, attenuate. Flowcrs erect, thrice as narrow as those of A. sativa. Bracteae sometimes with the rudiment of a fourth flower. Calyces, the uppermost without an arista. Receptacle sometimes longer than the bracteae. Caly $x$, the outer phyllum striate at the base, dotted on each side of the striae, bifid at the end. Aristae extended beyond the flowers, somewhat shorter than the bracteae, geniculate, green, scarcely twisted below the geniculation. Obs. 1516.

AVENA nuda. Bryant 327.

\section{ARUNDO.}

Braclene 2, with from 2 to many flowers. Calyx diphyllous, pilose at the base. Obs. 1723. $\boldsymbol{L}$.

1. Bracteae with more than 1 flower.

1. ARUNDO Phragmites. Bracteae with 4 and 5 flowers. The lowermost flower without hairs at the base. Obs. 1723. Specimen gathered near Worcester.-L. suec. n. 105 ; sp. 120 . Bot. arrang. 116. Smith brit. 144; engl. t. 401. Pollich $n$. 127. Krock. n. 185.

A. vulgaris, sive Phragmites Dioscoridis et Theophrasti. Vaill. paris. 16.

A. vulgaris, sive Phragmites Dioscoridis. Boerh. ii. 161. Scheuch. J. agrost. 161. t. 3. f. 14.D.

A. vulgaris palustris. Hist. ox. s. 8. t. 8. row 1 . f. 1. Bauh. J. ii. 485, cop. from

Harundo Phragmites. Dod. 592, which repr. in

Calamos, A. vallatoria, sive Phragmites Dioscoridis. Lob. ic, i. 51; cop. in 
Ilarundo vallatoria, sive vulgaris. Park. theatr. 1209, \&

A. vallatoria. Dalech. 1000 ; and repr. in Ger. by Johns. 36. Ruii hist. 1275; syn. 401.

Harundo. Trag. 67 t.

Natice of Europe from Italy to Lapland

ARUNDO. Dale 265. Mill. Jos. 54. Vog. 231.

2. $\Lambda$ RUNDO Donax. Bracteac with 5 flowers. Panicle diffuse. Stem fruticose. L. a Murr. 123; sp. 120. Hort. kew. i. 115.

A. sativa, quac Donax Dioscoridis. Scheuch. $J$. agrost. 159.t. 3. f. 14. A, B, C. Bocrh. ii. 162. Raii hist. 1275.

Harundo Donax, sive cypria. Dod. 592, repr. in A. Donax sativa, sive cypria. Lob. ic. i. 51,

A. cypria, Ger. by Johns. 36, cop. in

Harundo donax. Park. thealr. 1209, \& abr. in

A. maxima et hortensis. Bauk. J. ii. 486.

A. palustris. Dalech. 1000 .

ARUNDO Donax. Dale 265.

\& versicolor. Leaves striped. Obs. 5367. Specimen gathered in the gardens of Fothergill and Paris.L. sp. 123 \& Hort. liew. i. 115 \&

A. indica variegata, seu laconica Theophrasti. Boerh. ii. 162.

A. laconica Thcophrasti. Com. t. 55, cop. in

A. Iaconica versicolor. Frist. ox, s. 8. t. 8. row 1 f. $9, \&$ abr. in

IIarundo indica laconica versicolor. Park. theatr. 1209. Not in flower.

\section{LOLIUM.}

Bracteae solitary. Obs. 3249. $L$. 
$L$. perenne in the structure of the flowers agrees with Poa; Lo temulentum with Bromus, and Tris ticum; and $L$. bromoides is referred by Curtis to Festuca. Perliaps all had better be referred to the above mentioned genera. Elymus Mystria though destitute of bractene is justly considered as an Elymus.

1. LOLIUM temulentum. Spike compound, with aristae; spiculae contiguous. Obs. 4085. In a corn field near Chesterfield.-L. suec. n. 109; sp. 122. Bot. arrang. 121. Pollich n. 130. Schreb. gram. t. 36. Leers n. 98. t. 12. f. 2. Smith brit. 150. Fl. dan. t. 160.

Natice of Europe from Italy to Sweden.

LOLIUM. Dale 264. Marsh in phys, journ. i. 423.

L. temulentum. Davis in phys. journ. ii. 105. Krock. n. 190. Landau, Mojon \&ilvano, account from in edinb. journ. i. 106.

a aristatum. Aristae twice as long as the calyx. Obs. 4085.

L. verum Gesneri, L. album. Boerh. ii. 157.

Gramen loliaceum, spica longiore, seu L. Dioscoridis. Scheuch. J. agrost. 31. t. 1. f. T. E, F.-Willich ill. 12. $n$. 10, who notices an inner bractea.

Gramen loliaceum; spica longiore. Rudb. reliq. t. 12. $f .4$.

L. gramineum spicatum, caput tentars. Bauh. J. ii. 437 .

L. verum Gesneri. Hist. ox. iii. 181.s. 8. t. 2. razi 2. the fig. with aristae.

Lolium. Cam. epit. 198. Tab. ic. 239.

Spiculae as long as the bractea. Arisiae straight, half an inch long. Obs. 4085. 
B submuticum. Aristac flaccid, capillary, twice as short as the calyx. Obs. 4086. Specimen from Withering, probably from Curtis's garden.-Bot. arrang. 121. rar. 2. Roth germ. ii. 155. var.

L. arvense. Smith brit. 150. Found by Mackay in fields to the north of Forfar, Scotland;-engl. $t$. 1125. With. in bot. arrang. ed. iv. 168, probably from a specimen gathered with that above described.

Lolium. Dalech. 417. Dod. 529, repr. in

L. ct Triticum temulentum. Lob. ic. i. 35, \&

L. album. Ger. by Johns. 78; and cop. in Park. theatr. 1145. Raii hist. 1263 ; syn. 395.

Gramen loliaceum, spica longiore, sine aristis. Vaill. paris. 80.

L. verum Gesneri. IIist. ox. iii. 181. s. 8. $t$. 2. row 2 , the 2 figures without aristac.

\section{AEGILOPS.}

Bracteae 2, equal, cloven at the end; segments terminating in aristae. Caly $x$ diphyllous, the outer pliyllum cloven at the end. Obs. 135\%. L.

1. AEGILOPS ovata. Aristae of the bracteae very patent, thrice as long as the bractea. Obs. 1357. In a garden from seeds found among Malaga raisins.-L. sp. 1489. Hort. Few. iii. 427. Gouan. hort. 515. In corn fielis and uncultivated places near Montpelicr.-- Hosi. 513. In Littorale and Istria.

A. spica ovata, aristis breviore. L.ups. 301. Biennial.-Allion. nic. 229. In corn fields.

Phleum Aegilops. Scop. carn. n. 7S. About Trieste. 
Aegilops. Lob. adv. 10. No fig.-Dod. 530, repr. in

Festuca, sive Aegylops narbonensis. Lob.ic. i. S4, cop. in Park. theatr. 1148, repr. in

Festuca italica, Ger. by Johns. 73, \& cop. int

A. Lobellii et Penae. Dalech. 406.

A. narbonensis. Raii hist. 1290, where erase the A prefixed;-europ. 52. In Sicily, Italy, and the south of France.

A. secunda. Dalech. 406.

Gramen spicatum durioribus et crassioribus locustis, spica brevi. Vaill. paris. 82. Scheuch. J. agrost. 11. $t$. 1. $f .2$.

Festuca graminea annua, sive A. capitulis duris. Hist. ox. s. 8. t: 7. row 1. f. 10.

A. peregrina. Tab. ic. 236, repr. in

Festuca, sive A. altera capitulis duris. Bauh. Casp. theat. 151.

A. altera. Cam. epit. 928.

Native of Sicily, Italy, the south of France, and observed by Vaillant near Paris.

FESTUCA. Dale 264.

\section{SECALE.}

Bracteue 2, containing 2 flowers. Caly $x$, phylla 2 , the outer acuminate, ending in an arista. Petals 2. Ols. 1064. $L$.

Differs from Festuca only in the spiculae being disposed in a compound spilie, and in the calyx containing only from 2 to 3 florets.

1. SECALE cercale. Ciliae of the calyces bowed up: 
wards. Obs. 1064. Cultivated in a field. $-\mathbf{L}$. sp. 124.

SECALE. Bang in act. haun. i. 251-256. Berg. 48. Dale 261. Geoffr. suite iii. 1. Lere. disp. by Dunc. 347. Mill. Jos. 405. Murr. v. 343. Ploucq. bibl. i. 431. Quarin febr. 218. Rutty 477. Spielin. 24. Vog. 83.

S. cereale. Bryanl 330. Pearson, R. i. 78.

Rye. Catander, account from in phys. journ. ii. 270. Fordyce G. fer. ii. 28. Underw. ii. 105.

PANIS sccalinus. Quarin febr. 29.

a hybernum: (Variation.) Sown in autumn. From althors.-L. sp. 124. Hort. liew. i. 118.

S. hybernum vel majus. Vaill. paris. 181. Becrh. ii. 156.

Sccale. Cum. epit. 190. Raï hist. 1241; syn. 388. Tab. ic. 258, repr. in

S. hybernum, sive majus. Bauh. Casp. theatr 425.

Siligo. Trag. 645, the inner figure. The outer stem cop. from

Sccale. Fuchs. 728. c. 294, which also cop. in Bauh. J. ii. 426. Dalech. 396. Lob. ic. i. 28, repr. in Ger. by Johns. 68, and cop. from

Rogga, sive Secale. Dod. 490, \& in

S. vulgatius. Park.theatr. 1128.

SECALE hybernum vel majus. Chom. 741.

B iernum. (Variation.) Sown in spring. From authors.-X.sp. 124. Hort. kew. i. 118.

S. vernum vel minus. Boerh. ii. 156. Dill. ap. Raii syn. 385. On the authority of Petiver, but. laty says it is never sown in the spring in Britain. Siligo acstiva. 'Trag. 046. No figure. 


\section{HORDEUM.}

Bracteae 2, on one side of the flower. Calyx diphyllous. Petals 2. Obs. 2587. L.

1. Bracteae containing one flower.

1. HORDEUM hexastichum. All the flowers hermaphrodite, aristate. Seeds disposed in 6 rows. Obs. 537. In a garden.

H. hexastichon. L. sp. 125. Hort. Kew. i. 119.

H. flosculis omnibus hermaphroditis, seminibus sexfariam aequaliter positis. L. ups. 23. Kram. 25. Cultivated in fields about Trautmamsdorff, and Leytaepont [Bruck?] in Lower Austria.

H. spica polysticha, floribus omnibus hermaphrodi. tis longe aristatis. Hall. hist. n. 1534.

H. polystichum vernım. Boerh. ii. 159,

H. hexasticlum pulchrum. Bauh.J. ii. 429. No fig.-Vaill. paris. 105.

Hordeum. Brunsf. iii. 208. Tourn. inst. t. 29j. $O$.

H. polystichum hybernum majus. Tab. ic. 274, repr. in

H. polystichum hybernum. Bauh. Casp. theatr. 438.

Root similar to that of $\boldsymbol{H}$. distichum. Stems 3 feet long, similar to those of $\mathrm{H}$, distichum. Leares similar to those of $\mathrm{H}$. distichum. Spike terete, near. ly erect, $7 \frac{I}{2}$ inches long, exclusive of the aristae $2 \frac{2}{4}$ inches long. Aristae more than twice as long as the spike. Seeds patulo-patent. Obs. 537.

HORDEUM hexastichon. Bryant 329, Murr. v. 361. Spielm. 18. 
H. polystichum vernum. Boecl. ap. Herm. 364. Chom. 739. Geoffr. iii. 564.

2. HORDEUM tetrastichum. $\Lambda$ ll the flowers lie:maphroditc, aristate, in four ruws. Obs. 2587. In a corn field, near Kidderminster.

H. vulgare. L. sp. 125. Hort. kicw. i. 118. Mill. Ph. dict. n. 1 .

H. flosculis omnibus hermaphroditis, seminibus corticatis. L. ups. 22. Kram. 25. Generally cultivated in Austria.

H. spica subdisticha, calyce folioso setacco, Roribus omnibus hermaphroditis longe aristatis. Hall. - hist. n. 1533.

H. polystichum hybernum. Boerh. ii. 159. Magn. monsp. 132. Cultivated in fields; hort. 99. Hist. ox. iii. 206. s. 8. t. 6. row 3. f. 3.

Hordeum. 'Matth. 395.' Cam. epil. 188. Dod.492, repr. in Lob. obs. 15 ; ic. i. 28,

H, polystichum vernum. Ger. by Johns. 70, aind cop. in

H. polystichum. Park. theatr. 1130. Bauh. J. ii. 429. No fig.-Fuchs. 430. c. 167, cop. in Trag. 638, inner fig.-Raii hist. 1244; cant. 77, among wheat; syn. 388. Vaill:paris. 105. Da. lech. 399.

H. polystichum vernum, Lob. ic. i. 29. Bauh. Casp. thealr. 439, repr. from

H. polystichum aestivum. Tab. ic. $2 \% 5$.

Spikes 'slightly' compressed, from 6 to $7 \frac{1}{2}$ inches long inclusive of the aristae, $2 \frac{3}{4}$ long exclusive of the aristae; seeds from 20 to 45 , the lateral ones patulous, the intermediate ones almost adpressed, more numerous, but miny imperfect, and none so large or well tasted as those of $\mathrm{H}$. disticlium. Aristac nearly twicc as long as the spike. Obs. 2587. 
HORDEUHY vulgare. Bryant 327. Cartheus. i. 2S4. Pearson, R. i. T3. Spielm. 18.

Hordeum. Berg. 55. Murr. v. 360.

Barley. Neum. ii. 255.

H. polystichum hybernum. Boecl. ap. Herm. S6t. Chom. 738. Geoffr, iii. 563.

\& nudum. Calyx not adhering to the seed. From

H. vulgare caeleste. L. sp: 125 .

H. flosculis omnibus hermaphroditis, seminibus decorticatis. L. ups. 23.

Zeopyron. Dod.486, repr. in

Zeopyrum, sive Triticum. Spelthum, H. nudum yocatum. Lot. ic. i. 30, \&

H. nudum. Ger. by Johns. 72, \& cop. in

Zeopyrum, sive.Tritica-speltum. Park. theatr. 1123,

Zeopyron gynmocrithon: Dalech. 394, \&

H. nudum, sive Gymnocrithon, Bazuh. J. ii. 430. Raii. hist.1908. Bobert ap. Raii-syn. ed. i. 236. Cultivated in fields about Islip Oxfordshire, and in other places.

Triticum spica hordei londinensibus; Raii syn. $2 S 7$. Boerh. ii. 155.

ZEOPYRUM. Dale 260.

3. HORDEUM distichum,-Lateral flowers male without aristae. Seeds angular, imbricate. L.-Vaill. paris. 105. Raii hist. 1245 ; cant. 77 ; syn. 388. Tab. ic. 2T4, repr. in Bauh. Casp. thealr. 440. Fuchs. 439, cop. in ed. 12mo, 430. c. 167, Bauh. J. ii. 429, Dalech. 398, \&

H. minus. Trag. 638, inner figure.

H. distichon. L. sp. 125. Hort. keì. i. 119. Dod. 492, repr. in ed. ii. 501, Lob. ic. i. 29, and Ger. 
by Johns. 70; and cop. in Park. thealr. 1130. Magn. horl. 99. Boerh. ii. 159.

H. Zeocriton. Mill. Ph. dict. n. 2, where for Zeo. criton read distichon.

H. flosculis latcralibus masculis muticis, scminibus angularibus imbricatis. L. ups. 23. Kram. 25. In fields particularly about Leytaepont [Bruck?] in Lower Austria.

H. floribus lateralibus masculis muticis. $\boldsymbol{L}$. cliff. 24.

Hordeum. Tourn. inst. t. 295. L.

H. vulgare distichum. Hist. ox. iii. 206. s. 8. t. 6. row 3. $f .1$.

Spike $7 \frac{3}{4}$ inches long inclusive of the aristae, 4 inches long exclusive of the aristae. Flowers in threes, sessile; lateral flowers abortive; intermediate flowers fertile. Bracteae subulate, hirsutulous underneath; those of the lateral flowers contiguous, those of the intermediate flower remote, aristate; aristae shorter than the bracteae. Calyx of the lateral flowers without aristae; outer phyllum of the intermediate flower aristate; arista terminal, more than twice as long as the spike. Obs. 536. In corn ficlds, cultivated.

HORDEUM. Barley. The seeds. Pharm. lond. -Alst. ii. 354. Blane 303. 309. 504. Cook in phil. trans. for 1776. art. 22. Cull. i. 274. Dale 261. Heberd. 27. Lew. i. 445. Linn. 51. Mill. Jos. 233. Monchy in Pringle 213. Monro iii. 134. Murr. v. 360. Mead. mon. i. 29. 32. 98. 110. Quarin febr. 15. 16. 19. 27. 89. 91. 103. 120. 127. 133. 142. 149. 162. 204. 219. 276. 282. 306. 319. 346. 355. 357. 381. 382. 407. 424. 429. 431 ; animad. 65. 215. 233. 252. Rutty 236. 
Stoll aph. n. 579. S08; med. i. 111. Vog. 162. Wintringham in Mead mon. 'i. 229. 261.

H. distichon. The seed deprived of its rind. Pharm. edin.-Boecl. ap. Herm. 364. Bryant S29. Lezv. disp. by Dunc. 233. Murr. J. ii. 46. Schoepf. 11. Spieln. 18.

H. mundatum et perlatum: Dale 261.

H. perlatum. Pearl Barley. The seed deprived of its rind. Pharm. lond.-Lewisi i. 447.

Barley. Blane 309. Bree 292. Chalm. i. 218; ii. 90. 120. Clegh. 189. Denm. i. 270. 510. Darw. ii. 37. 97. 194. Fordyce, W. fev. 143. 167; G. fev. ii. 28. 34. 36 ; iii. 197.216 ; iv. 119 ; pract. 149. Pringle 132. 138. 158. 276. 285. 310. Reid T. 177. Rush ii. 241 ; v. 120 . Underw. i. 342. 355. Willan lond. 113. Wright in ann. med. ii. 368.

BYNE. Ploucq. bibl. i. 322 .

Maltum. Quarin animad. 202. 316.

Malthus. Rogert in act. haun. i. 189.

Malt. Blane 57. 122. 504. 506. Darw. ii. 74. Monro, Don. sold. ii. 191. Rulty 238.

MUSTUM hordei. Collin obs. iv. 133.

Wort. Aikin in Lew. i. 448. Blane 59. Clark, J. long. roy. 421. Richter quoted in Rollo diab. 369. Rush ii. 286. Rutty 238.

CEREVIS1A. Pearson, R. i. 102; ii. 202. Ploucq. bibl. i. 190.316, 518. Quarin febr. 372; animad. 101.

Malt-liquor. Blane 320. 495. Bree 292. 298. Fothergill, $J$. in med. obs. vi. 109. May 50. Trotter, account from in edinb. journ. i. 75.

Beer. Brozen J. ii. 249. Darco. ii. 99. 226. 245. 218, Fothergill, J. in med. obs. vi. 130. Rush ii. 71 . 
Cerevisia fortis. Mead mon. i. 34 .

Cerevisia meraca.. Callisen in act. haun. i. 362.

Ale. Brown ii. 249. Clark J. long voy. 263.

- Darw. ii.217.274. Hull phlegmat. 287. Monro Alex. sen. in med. ess. vi. 17. 18. Underw. ii. 21.

Cerevisia tenuis. IIeberd. 2.

Small Beer. Darw. ii. 132. 139. 218. 223. Fordyce G. fev. iii. 216.

PORTER. May 50. Rush v. 120. 180.

.SPIRITS. Blane 495.' Fothergill, J. ix med. obs. - vi. 130. Lettsom in med. soc. i. 163.. Willan lond. 133.

Distilled Spirits. Chalm.i. 153.

GIN. Darw. ii. 704. 745. Lettsom in med. soc. i. 163.

Dutch Spirit of Juniper. Pringle 216.

YEAST. Bradley in phys. journ. v. 145. Brown, C. in phys. journ. iii. 533. Cartwright, account from in chir. rev. i. 297: Chir. rev. viii. 84. Custance in plyys. journ! iv. 19; v. 143. Edlin ib. v. 422. Grose ib. iii. 105; iv. 401. 539 ; v. 271. Heath, account from ib. xii. 192. Hosack, account from in med. rev. vi. 65. Lewin in phys. journ. ii. 374. Pearson, $R$. in Beddoes airs iii. 81; and account from in ann. med. i. 259. Phys. journ. iii. 561. Rolfe in phys. journ. v. 508; vi. 112. 196. Thornton in Beddoes airs ii. 100; and account from in ann. med. i. 260.

Barm. Rutty 527.

FOECES CEREVISIAE. Ploucq. bibl. i. 515.

s nudum. L. sp. 125.-Calyx not adhering to the seed. Obs. 474. In a garden.

Turkie Barley. Park. theatr.1129. No fig. 
Seeds elliptic, tawny, glabrous, 3 and two thirds tenths of an inch long. OUs. 474 .

4. HORDEUM Zeocriton. Lateral fowers male, without aristae. Seeds angular, patent. Obs. 7937. Cultivated in a field near Stafford.-L. $s p .125$. Hort. kew. i. 119.

H. distichon. Mill. Ph. dict. n. 3. where for distichon read Zeocriton, and for imbricatis read patentibus corticatis.

H. flosculis lateralibus masculis muticis, [seminibus] anguiaribus horizontalibus. 'L. ups. 23.

H. distichum, spica breviore et latiore, granis confertis. Raii hist. 1243 ; 'syn. 388. Vaill. paris. 105. Boerh. ii. 159.

II. distichon, spica lata compressa. Hist. ox. s. 8. 6. 6. row' 3. $f .2$.

1. disticlium minus. Raii cant. 77:

H. dictum germanis Oryza. Bauk. J. ii, 429 .

Sprit Barley, Park. theatr. 1129. No fig.

Spike compressed, ovato-lanceolate, the aristae inclusive $7 \frac{\mathrm{I}}{2}$ inches long, the aristae exclusive $2 \frac{\mathrm{I}}{4}$ inches long. Flowers in threes, sessile; ternations alternate; lateral flowers abortive; intermediate flower fertile. 'Bracteae adpressed, slightly hirsute on the outer side; those of the lateral flowers contiguous, one rather lower than the other, 'subulate, mostly aristate; those of the intermediate flower rem te, acute, mostly aristate; aristae twice and 'thrice as long as the bractea. Caly $x$ of the lateral flowers without aristae; outer phyllum of the intermediate flower aristate; arista terminal, sometimes more than thrice as long as the spike. Obs. 7937.

HORDEUM Zeocriton. Bryant 330. 


\section{TRITICUM.}

Bracteae 2, opposite, containing several flowers. Caly $x$ diphyllous, mostly aristate; arista inserted below the end of the outer phyllum. Spiculac sessile. Obs. 969. $\boldsymbol{L}$.

Differs from Bromus only in the spiculac being disposed in a compound spikc.

1. TRITICUM hyủernum. Spiculae with 4 flowers, ventricose, imbricate, mostly without aristac. $L$. sp. 126. Hort. kew. i. 120.

TRITICUM. Whicat. Flour. Starch. Pharm. lond.-Alst. ii. 378. Bell surg, i. 73. Berg. 49. Blane 309. Cartheus. i. 287. Clark, J. long roy. 516. Cull. i. 280. Dale 260. Geoffr. suite iii. 244. Lew. 1. 445; disp. by Dunc. 318. Mill Jos. 442. Murr. v. 319. Rutty 523. Spielm. 27. T. hybernum. Bryant 319. Murr. J. i. 388. Pearson, R. i. 81 .

Wheat. Fordyce G. fev. ii. 28.

FLOUR. Blane 307. Darw. ii. 16. Denm.i. 268; ii. 521. Le Roy, account from in phys. journ. i. 84. 154; and chir. rev. vi. 393. Lempriere ii. 223. Monro, Don. sold. i. 364. Triquet in Pringle 276. Underw. i. 136 ; iii. 142.

SEMOLINA. Underw..i. 223. 342; iii. 137. Willich encycl. iv. 51.

PANIS. Berg. 49. Heberd. 3. 280. 366. 405. Ploucq. bibl. i, 357. Quarin febr. 318. 35\%. Rutty 527.

Bread. Blane 494. Bree 292. Cull. pract. n. 1207. Fordyce G. fer. ii. 29. Fordyce $W$. fer. 143. 
Fothergill, J. in med. obs. vi. 126. Pringle 276. Underw. i. 154 ; iii. 142.

FERMENTUM. Rutty 527.

PANADA. Clegh. 193. Darw. ii. 226. 302. Fordyce W. fev. 168; G. fev. ii. 36. Fothergill $J$. in med. obs. vi. 135. Pringle 131. 132. 158. 276. 314. Underw. i. 264.

Panado. Chalm. i. 84, 147. 153. Clark J. long voy. i. 187.

Panade. Callisen in act. haun. i. 362. Panatella. Quarin febr. 19. 94. 127.431. BISCUIT. Blane 307.494. Bree 292. Underw. i. 135.

Panis biscoctus. Fordyce G, fev. ii. 30, Ploucq " bibl. i. 659. Quarin febr. 183.

Sea Biscuit. Darw. ii. 128.

Bisket. Chalm. i. 218 ; ii. 18.

RUSKS. Fordyce G. fev, iii. 193. Underw. i, 135. 154.

FURFUR. Rutty 527.

Bran. Rush ii. 241.

AMYLUM. Pharm. lond. edin-Bell surg. i. 73. Berg. 49. Cull. ii. 415. Dale 260. Home, F. clin. 114. Heberd. 128. Lew. disp. by Dunc. 141. Linn. 52. Mead mon. i. 132. Murr. J. ii. 37. Quarin animad. 233. Rutty 525.

Starch. Blane 484. Cull. clin. S08. Darwin ii. 59. 60. 180. Hunter, J, jam. 2s7. Monro, Don. sold. 364. Pringle 272. 273. 279.

PULVIS CYPRIUS. Berg. 49. Linn. 52. Schoepf 12.

SPIRITUS frumenti. Bang in act. haun. i. 5. 8. Quarin anim. 316. Ranoë in act. haun. i, 36. 386.

OLEUM tritici. Wise in ann. med. v. 479; and account from in med. rer. vii. 171. 
a submuticum. Flowers mostly without aristae. Oǔr.

153. Cultivated in corn ficlds neal Worcesier.

Tritici primum genus. Füchs. 618. c. $25 \mathrm{l}$, cop. in

T. primum. Trag. 634. f. 2, \&

T. vulgare, glumas triturando deponens. Bauh. J. ii. 407.

T. hybernum aristis carens. Mist. ox. 's. 8. $t .1$. row 1.f. 1. Vaill. paris. 196. Boerh. ii. 155. Bauh. Casp. theatr. 352. repr. from

Triticum. Tab. ic. 258. Dod.480, repi. in

Siligo spica mutica. Lob. ic. i. 25, \&

T. spica mutica. Ger. by Johns. 65; and cop. in Park. theatr. 1120, and Dalech. 378. Raii syn. 386.

TRITICUN hybernum aristis carens. Chom. 742.

$\gamma$ aristalum. Spike aristate. Obs. 7941. Specimen gathered in a corn field at Stone near Kidderminster, cultivated.

T. aristis circumvallatum, granis et spica rubentibus, glumis laevibus et splendentibus. Raii syn. 387. Vaill. paris. 196. Boerh. ii. 155.

T: aristis munitum, rubentibus granis et spica, glumis laevibus et splendentibus. Raii hist. 1238.

Triticuin." Cam. epit. 185. Matth. 391. The outer fig. cop. in Dalech. 377, which repr. in

Le Froment. Dalech. par Moul. 316.

T. typhinum. Tab. ic. 260, repr. in

T. longioribus aristis, spica alba. Bauh. Casp. theatr. 374.

Seeds oblongo-oval, 3 tentlis of an inch long, tawny. Ots. 7941.

2. TRITICUM aestioum. Spiculae with \& flowers, ventricose, glabrous, imbricate, aristate. $L$. $s p$. 126. Hort. kew. i. 121.-Vaibl. paris. 196. Dill. 
ap. Raii syn. 387. Hist. ox. iii. 175. Sown in spring.

T. trimestre. Hist. ox. s. S. t. 1. row 2. f. 10.

TRITICUM aestivum. Bryant 319. Lew. disp. by Dunc. 319. Pearson, R, i. 81. Rutty 523. Spielm. 26.

Triticum. Nherr. v. 319.

6 decompositum. Spike decompound. From

T. compositum. L. fll. suppl. 115. L. a Murr. 126.

T. multiplici spica. Raii hist. 1238. Ger. by Johns. 66, cop. in Park, theatr. 1120.n. 4, the lower figure.

3. TRITICUM turgidum. Spiculae with 3 and 4 flowers, villose, imbricate, obtuse. Obs. 5937. Specimen gathered in corn fields near Worcester, cultivated.-L. sp. 126. Hort. kew. i. 120.

TRITICUM turgidum. Bryant 320. Murr. v. 321.

a brachystachyon. Spikes shorter than those of $\beta$ From authors.

T. turgidum. Mill. Ph. dict.n. 3.

T. radice annua, glumis ventricosis villosis imbricatis obtusis. L. ups. 21.

T. radice annua, glumis villosis. L. cliff. 24.

T. spica quadrata villosa breviori. Boerh. ii. 155.

T. spica villosa quadrata breviore et turgidiore. Hist. ox. iii. 176. n. 14. Square gray Wheat. Gray pollard Wheat. Duckbill Wheat.-Vaill. paris. 196.

T. spica villosa breviore: Irist. o.x. s. 8. t. 1. row 2. f. 14 .

T. aristatum, spica maxima cinericca, glumis hirsutis. Raii syn. 387. 
Tragns, frumenti genus spica cacrulea. Dalech. 377.

Robus, sive $\mathrm{T}$. insulanis gallo-belgis Loca vocatum. Lob. ic. i. 27.

B. macrostachyon. Calyces with aristae as long as the spike. Obs. 5937.

T. quadratum. Mill. Ph. dict. n.4.

T. turgidum aristiferum. Bryant $\mathbf{3 2 1 .}$

T. spica quadrata villosa longiori. Boerh. ii. 155.

T. spica villosa longiore. Hist. ox. s. 8.t. 1. rowo 2. $f .13$.

T. spica villosa quadrata longiore, aristis munitum. Hist. ox. iii. 176. Cone Wheat.-Raii syn. 387. Vaill. paris. 196.

T. nigrum peregrinum. Tab. ic. 259, repr. in.

T. longioribus aristis, spica cacrulea. Buuh. Casp. theatr. 372.

Tritici tertium genus. Fuchs. 618. c. 251, cop. in

T. tertium. Trag. 635. t.634. f. 1, \&

T. cinericeum maximis aristis donatum, triturando glumas deponens. Bauh.J. ii. 408, \&

Tipha Fuchsii. Dalech. 392.

T. Loca vocatum alterum, et T. lucidum gallo-belgarum. Lob. ic. i. 27, cop. in

T. lucidum. Park. theatr. 1120.

T. typhinum. Dod.481, repr. in cd. ii. 490,

T. aristis circumvallatum. Lob. ic. i.26, and Ger. by Johns. 66, \& cop. in

'T. tiphinum. Dalech. 393,

T. aristis munitum. Park. theatr. 1120, \&

T. tiphinum hispanicum. Park. theatr. 1125, raised from seeds found among seeds of Phalaris canariensis imported from the Canary islands, is described as having a stem shorter and slenderer and sceds smaller than those of $\mathrm{T}$. hybernum. 


\section{Digria. \%1. Triticum.}

y submuticum. Calyces with aristac scarcely longer, and shorter than the calys. Obs، 5938. In a corn ficld near Kidderminster, whether among $\alpha$ or 'T. hybernum I have omitted to notice.

T. aristis carens, glumis pubescentibus. Vaill. paris. 196 .

T. turgidum conicum album. Bryant 321.

T. turgidum conicum rubrum. Bryant 321.

\& polystachyon. Spike decompound. Calyx aristate. Obs. 5939. Specimen from a corn field near Rotherham.-L. cliff. $\beta$

T. turgidum spica multiplici. Bryant 321.

T. cum multiplici spica glumas facile deponens. Bauk. J. ii. 407.

T. typhinum multiplici spica. Tab. ic. 260, repr. in

T. multiplici spica. Bauh. Casp. theatr. 371. Lob. ic. i. 26. (Ger. by Johns. 66, is probably T. aesti= vum decompositum.)

T. spica multiplici. Vaill. paris. 196. n. ร. Raii syn. 357. Boerh. ii. 155. Bauh. Casp. pin. 21. Hist. ox. iii. 175. s. 8. t. 1. row 1 .

4. TRITICUMI Spella. Spike compressed. Spiculac with 4 flowers. The 2 lowermost flowers aristate, the upper rudiments of flowers. Internodia of the rachis slightly hirsute at the end. Obs. 7939. Specimen from Dr. Heise.-L. sp. 127; a Murr. 126. Hort. kiew. i. 121. Gouan. hort. 5\%. At Alais and Castres, near Montpelier;-monsp. 128.

T. calycibus truncatis quadritloris; floscralis aristatis hermaphroditis, intermedio neutro. L. ups. 21. Zen, sive Spelta. Magn. hort. 209.

TRITICUM Spelta. Bryant 329. Murr. v. 321. Pearson, R. i.81. Spiclm. 2\%. 
Zea. Dale 261.

Olyra. Dale 261.

a cristatum.' Spike aristate. Obs. 7939.

Zea major, sive dicoccos. Dalech. 385. the outer figure.

Candidum Far. Trag. 645. f. 2, imit. in

Frumentum amyleum. Tab. ic. 262, which repr. in

Zea amylea, sive Olyra. Bauh. Casp. theatr.419; and imit. in

T. amyleum. Ger. by Johns. 69, which cop. in

Olyra. Park. theatr. 1126. Dalech. 390.

Zea verna. Bauh. J. ii. 413. Raii hist. 1243.

Leares 5 tenths of an inch broad. Spite 6 inches long, $3 \frac{3}{4}$ long exclusive of the aristae. Aristae patulous. Flowers glabrous, whitish glaucous. Bracteae ovate, acute, with an obsolete tooth on the outer side of the extremity, the outer half larger than the inner half. Calyx, outer phyllum ovate, carinate, the keel bordered towards the end, acute, tridentate and entire, the costa terminated by an arista. Rudiments of flowers 2, monophyllous. Obs. 7939.Leaves 3 tenths of an inch broad. Bracteae obtuse, obtusely tridentate. Obs. 7940. Specimen from Dr. Bochmer.

\& muticum. Spike without aristae. From

Zeae primum genus. Fuchs. 283. cop. in ed. 12mo, c. 109,

Spelta. Trag. 642. the inner fig. $\mathcal{\&}$ :

Zea, sive Spelta. Bauh. J. ii. 412. Ger. by Johns. 69, cop. from

Zea adorea. Tab. ic. 261, which repr. in

Zea dicoccos, sive major.' Bauh. Casp. theatr. 413, \&. cop). in

Zea spica mutica dicoccos, vel major. Hist. ox, s. 3. t. 6. row 3. f. 1 . 
Zea. Cam. epit. 189, cop. in

Zea dicoccos spica mutica. Park. theatr. 1124.

5. TRITICUM monococcum. Spike compressed. Spiculae with mostly 3 flowers. Lowermost flowers aristate, the middlemost barren. Rachis glabrous. Obs. 7938. Specimen from Prof. Jos. F. Jacquin. -L. sp. 127; a Murr. I26. Hort. kerw. i. 121. Roth germ. i. 50. Among corn near Erlang; ii. 147. Gouan. hort. 57. At Montpelier;-monsp. 128.

Zea Briza, dicta-Monococcos. MIagn. monsp. 282 Amongst rye.

Monococcon. Dod. 484, repr. in ed. ii. 493,

Briza monococcos. Lob. ic. i. 31, Ger. by Johns. 73, \& cop. in

Briza. Dalech. 395, \&

Zea monococcos aristis munita. Park, theatr. 1194, the 3 inner figures.

Zeae alterum genus. Fuchs. 283. c. 119, cop. in

Spelta. Trag. 642. f. 1, \&

Zea monococcos, Briza quibusdam. Bauh. J. ii. 413. Aristae short.

Zea monococcos. Tab. ic. 201, repr. in

Zea, Briza dicta, sive Monococcos germanica. Bauh. Casp. theatr. 415, and perhaps cop. in

Z. spica barbata, Briza dicta, Monococcos german. ica. Hist. ox. s. 8. t. 6. row 3. f. 2.

Zea minor altera et monococcos. Dalech. 385. $f$. 1.

Leares $1 \frac{\pi}{2}$ and $1 \frac{3}{4}$ tenth of an inch broad. Peduncle glabrous. Spike $4 \frac{1}{4}$ inches long the aristae included, 2 inches long the aristae excluded, compound, distichous. Spiculae sessile, alteruate, just contigu․ 2 
ous, triflorous, with 2 sceds. Bracteae ovate, pubescent, glaucous. C'aly.x, the lower phyllum ovate, glabrous and tawny below, pubescent and glaucous above, the costa terminating in an arista, with a min- ute acute tooth on each side. Arista scabrous, attenuate, with 3 longitudinal lines. Seeds like those of 'T. acstivum. Obs. 7938.

TRITICUM monococcon. Bryant 322. Murr. v. 321.

Briza. Dale 261.

Spelta. Mill. Jos. 421.

6. TRITICUM polonicum. Spiculae of 5 flowers. The inner phyllum of the calyx of the lowermost flower as short again as the outer pliyllim. Aristae of the 2 lowermost flowers longer than the phylla. Obs. 5936. Specimen from a corn field near Rotherham.-L.sp. 127. Hort. kew. i. 121. Pluk. phyt.t. 231. f. 6 .

T. majus, longiore grano glumis foliaccis incluso. Boerh. ii. 155.

'T. majus, longiore grano glumis foliaceis incluso, seu 'T. poloniae dictum. Dill. ap. Raii syn. 387.

T. majus, gluma foliacea, seu T. polonicum D. Boberti. Raii syn. ed. ii. 245.

T. majus, gluma foliacea. Bobert ap. Raii syn. ed. i. 236, who received it out of Worcestershire, where it was cultivated.

Far clusinum. Dalech. ST6, who says it was brought from Italy; the description cop. in

T. dictun Far clusinum Dalechampio. Bauh. J. ii. 408. No fig.

T. speciosum, grano oblongo. Bauk. J. ii. 110. In a gardeı. No fig. 
T. majus, longiore grano glumis foliaceis incluso, poloniae dictun. Hist. ox. iii. 175. n. 8 . T. polonine. Irist. ox. s. 8. t. 1. row 2. f. 8 . TRITICUM polonicum. Bryant 322.

7. TRITICUM repens. Bractcae striate, acute and aristate, with more than 5 ribs. Calyces cuspidate and aristate; aristae shorter than the calyces. Root creeping. Obs. 969. Near Worcester.L. suec. n. 114; sp. 128. Bot. arrang. 128, Smith brit. 158. Schreb. gram. t. 26. Krock. n. 194.

GRAMEN. Aaskow in act. haun. i. 309. Alst. i. 374. Berg. 54. Dale 265. Herm. 73. Lew. i. 471; disp. by Dunc. 348. Linn. 52. Murr. v. 338. Ploucy. bibl. i. 482. Quarin felr. 18. 106. 125. 133. 143. 151. 158. 162. 163. 204. 239. 276. 282. 305. 307. 315 328. 344. 350. 366. 407. 424. 426. 427; animad. 123. 240. 241. 254. 261. Schoepf 12. Spielm. 561. Stoll med. ii. 44. 204. 347. 357. 403; iii. 7. 18. 22. 27. 109. 115. 129. 130. 135. 168. 192. 188. 185. 287. 376. 377; aph. n. 467.

Gramen caninum. Mill. Jos. 217.

Gramen caninum vulgare. Geoffr. iii. 527.

Gramen caninum arvense, seu Gramen Dioscoridis. Chom. 223. Rulty 221.

Gramen loliaceum radice repente, sive Gramen offcinarum. Tourn. ii. 404.

Dog Grass. Brera, account from in med. rev. i. 580.

z mucronatum. Aristae a tenth of an inch long. Obs 141. Near Worcester._Bot. arrang. 129. $\beta$ T. repens. Smith engl. $t, 909$. 
T. radice repente, foliis viridibus. L. lapp. $n .33$. In the fields of the colonists.

Gramen caninum arvense, sive Gramen Dioscoridis. Scheuch. J. agrost. 5.

Gramen spica triticea repens vulgare, caninum dic. tum. Raii syn. 390.

Granen caninum arvense, sive primum, sive Gramen Dioscoridis et officinarum. Tourn. paris. 271. Bauh. Casp. theatr. 7.

Gramen caninum, spica triticeae aliquatenus simili. Raii meth. 171. Boerh. ii. 155.

Gramen triticea spica compacta, latifolium. Bauh. Casp. theatr. 131, repr. in

Gramen latifoliım, spica triticea compacta. Bauh. Casp. prodr. 17.

Gramen loliaceun radice repente, sive Gramen offlcinarum. Vaill. paris. 81.

Gramen canarium. Lob. ic. i. 20, cop. in

Gramen caninum vulgatius. Park. theatr. 1173, with a separate spike. $H$ ist. ox. iii. 118. s. 8. $t$. 1. f. $\mathrm{s}$.

(Gramen. Dod. 548, repr. in

Gramen caninum. Ger. by Johns. 23, \& cop. in

Gramen vulgare Dodonaei, Dalech. 421, has creeping roos, but the stem is paniculate.)

Native of Europe from Italy to Lapland, and of New England, into which latter country probably introduced from Europe along with Wheat. Obs. 8021. Specimen gathered by Dr. Cutler in corn fields in New England.

3 aristatum. Aristae from 2 to tenths of an incl long. Obs. 969. Bot. arrang. 129. var. 3. T. repenș. $F l$. dan. $t .748$.

'1. caninum. Gouan, hort. 58. On the sea shore near Montpelicr;--monsp. 128. 
Gramen loliaceum, radice repente, sive Gramen officinarum aristis longioribus donatum. Vaill. paris. SI.t. 17. f. 2. Spiculae too patulous.

Omitted in the Order

\section{O N O G Y N I A.}

\section{XYRIS.}

Calyx diphyllous. Petals 3. Nectaria 3, with articulated villi. Capsule superior, with 1 cell 3 valves and many seeds. Obs. 4317, from X. caroliniana. $-L$.

11. XYRIS Jupicai. Scapus two-edged above. Ca* pitulum ovato-oblong. Phylla emarginate with a mucro. From Vahl.-Act. soc. h. nat. par. X. americana. Vahl, enum, ii. 205. Aubl.

Gramen florens capitulo squamoso, Jupicai brasilien. sibus. Raii hist. 1318.

JUPICAI. Pis. bras. 119; ind. 238.

62. XYRIS indica. Scapus sulcate, multangular. Capitulum ovate. Vahl. enum. ii. 204. L.sp. 63. Gladiolo lacustri accedens malabarica, e capitulo botryoide florifera. Pluk. alm. 170. t. 416. f. 4. KOTSJILETTI-PULLU. Rheede ix. 139. t. 71. 


\subsection{COMMELINA.}

Caly.x triphyllous and tetraphyllous. Petals 3 and 2. Stamina 3 and 2 perfect, 3 and 4 sterile with cruciform glands. Cupsule trilocular and bilocular. From L. Juss. and Lour.

\section{Petals 2. L.}

1. COMMELINA communis. Leaves ovato-lanceo. late, subsessile, acute, glabrous. Stem creeping, glabrous. Involucra cordate, conduplicate. Vahl. enum. ii. 170, L. sp. 60, Horl. kero. i. 76. Thunb. jap. 35 .

C. procumbens annua, saponariae folio. Dill. elth. 93. $t$. 78. f. 89.

Ephemerum dipetalum japonicum. Kaempf. amoen. t. 889.

Planta imominata. Marcgr. bras. 8. $f .1$.

Ephemerum africanum annuum flore bipetalo. Herm. hort. 231. Hist. ox. iii. 606. s. 15. t. 2. f. 3.

(Coapotiragra. Marcg. Uras. 8. is a different plant.) COMMELINA communis. Lour. i. 48.

\section{Pelals 3. L.}

2. COMMELINA edulis. Scapus naked. Leaves lanceolate. Flowers alternately spicate. From COMMELINA tuberosa. Lour. i. 50.

3. COMMELINA medica. Scapus nearly naked. Leaves subulate. From Lour. i. 50. 
A. COMMELINA tuberosa. Leaves ovato-lanceolate, sessile, ciliate. Involucra cordate, conduplicate. Stem erect. Vahl. enum. ii. 171. L. sp. 61. Hort. kew. i. 76.

C. corollis acqualibus, foliis ovato-lanccolatis subciliatis. L. ups. 18.

C. foliis ovato-lanceolatis, petalis tribus majoribus acqualibus. L. cliff. 21. Royen 38.

C. radice anacampserotis. Dill. hort.94.t.79. f. 90. From Mexican secds.

(Ephemerum phalangoides virginianum majus erectum. Pluk. alm. 135. t. 174. f. 4 , is a different species.)

MATLALYTZTIC TETZOCANA. Hern. 253.

\section{2*. SPINIFEX.}

Bracteae 2, containing 1 and 2 flowers. Caly $x$ diphyllous. Style 1. From L. fil. ap. L. amoen. x. pars ii. 30.39, t. 1 .

Male flowers, with imperfect hermaphrodite flowers interspersed, on a distinct plant. From $L$. fll . $i b$.

1. SPINIFEX squarrosus. $\boldsymbol{L}$. mant. 300; a Murr. 902. L. fil. suppl. 432.

Gramen dactylon pumilum malabaricum, spicis loliaceis in acutam spinam terminatis. Scheuch. $J$. agrost. 112.t.2. f. 11. $O$. Specimen gathered by S. Brown in Malabar.

Cyperus littoreus. Rumph. vi, 6, t. 2. f. 2. 
180 Triandria. 52*. Spinifex.

(Arundo arborescens tabaxifera. Hist. ox. iii. 219 s. 8. t. 8. f. 11, is Bambos quinqueflora.)

ILY-MULLU. Rheede xii. 143. t. 75. 


\title{
Class 4. \\ T E T R A N D R I A.
}

\author{
Order 1. \\ MONOGYNIA.
}

1 Corolla monopetalous, inferior. Seed 1. L.

72. Globulania. Corolla bilabiate, and ligulate. Seed naked. From L. and Juss.

74. Scabiosa. Corolla equal and unequal. Seeds with a pappus. Obs. 4973.

2. Corolla monopetalous, superior. Seed 1. 73. Dipsicos. Seeds columnar.

3. Corolla monopetalous, superior. Fruit dicoccous. $\mathrm{L}$.

80. Roвіs. Corolla campanulate. Berries 2.

78. Galium: Corolla rotate or campanulate. Capsule. Obs. 507.

77. Aspenula. Corolla' infundibuliform. Cap. sule, Obs. 1187. 
76. Spermacoce. Corolla tubular. Fruit coro. nate. Seeds bidentate.

79. Crucraxelua. Corolla infundibuliform; segments caudate. Fruit naked. Seeds linear. Obs. 8616.

4. Corolla monopetalous, inferior. Fruit single. L.

84. Callicarpa. Corolla tubular. Calyx quadrifid. Berry tetraspermous. L.

86. Scoparia. Corolla rotate. Calyx quadripartite. Capsule unilocular, cut round.

85. Plantago. Corolla, limb bent back. Calyx quadripartite. Capsule bilocular, cut round. $L$.

100. Saltadora. Corolla campanulate. Calyx quadridentate. Berry mono. spermous. $\boldsymbol{L}$.

5. Corolla monopetalous, superior. Fruit single, and didymous.

82. Pavetra. Corolla infundibuliform. Berry bilocular; cells monospermous. Stigma simple. Obs. 8459.

81. IXORA.

Corolla hypocrateriform and in. fundibuliform. Berry bilocular; cells monospermous. Stigma bifid. Obs, 6822. 
S9. Mitchelia. Corolla tubular, 2 to one germen. Calyces quadridentate, 2 to one germen. Berry bifid, tetraspermous. Obs. 3273.

75. Hedrotis. Corolla tubular. Calyx quadripartite. Capsule didymous, polyspermous, opening at the end. $L$.

91. Oldentandia. Corolla tubular. Calyx quadripartite. Capsule didymous, polyspermous, opening between the teeth. $\boldsymbol{L}$.

6.-Petals 4. Flowers inferior. $L$.

91. FAgara.

Caly $x$ quadrifid. Capsule simple or didymous. Seeds solitary.

93. Prezra. Calyx quadripartite. Stigma. ta 2. Samara bilocular, monospermous. Obs. 8380.

92. Monetia. Calyx quadrifid. Petals linear, Berry bilocular. From L. a Willd.

96. Gleditsia. Calyx quadrifid, triphyllous, and pentaphyllous. Legumen. From $\boldsymbol{L}$.

87. Sargursonba. Calyx urceolate. Petals inserted into the calyx.' Stigmata pencil-shaped. Obs. 4960.

7. Pelals 4. Flowers semiinferior.

88. Cissus.

Berry monospermous. 
8. Petals 4. Flowers superior. L.

97. Trapa. uli

90. Cornus.

95. Santalum.
Caly. $x$ quadripartite. Nut unilocular, monospermous. Obs. 5336.

Calyx quadridentate. Drupe. Nut bilocular. Obs. 3898. $P$ etals inserted into the calyx. Berry monospermous. $\boldsymbol{L}$.

9. Petals 4, superior. Calyx inferior.

89. Allasias.

Berry unilocular, polyspermous. From Lour.

10. Flowers corolline, inferior.

98. Potros.

P.ctals 4. Calyx none. Berry bilocular. From $L$.

99. Krameria. Petals 4. Calyx none. Ber$r y$ monospermous, dry, echinate. From $L$.

11. Flowers calycine, inferior.

102. Parietaria. Calyx quadrifid. Seed 1. Obs. 7487.

109. Alchemilia. Calyx octofid.

101. Самphonosma. Calyx tetraphyllous. Obs. 4286. 


\section{Order 2. \\ D I G Y N I A.}

105. Cuscuta. Petal 1. Capsule bilocular. Obs. 4389.

106. Hypecour. Petals 4. Calyx diphyllous. Siliqua.

104. Hamamelis, Petals 4. Nectaria 4. Calyx tetraphyllous. Nut bilocu. lar.

Order S.

\section{T E T R A G Y N I A.}

107. ILEX.

Corolla monopetalous. Cålyx quadridentate. Berry tetraspermous. $\boldsymbol{L}$.

108. Mrginda. Corolla tetrapetalous. Calyx quadripartite. Drupe monospermous. $\boldsymbol{L}$.

\section{O N O G Y N I A.}

72. GLOBULARIA.

Caly $x$ inferior, quinquefid. Corolla inferior, infundibuliform, quinquefid. Seed 1, naked. Obs. \$667, 
from a specimen of $G$. vulgaris, gathered in Fo. thergill's garden. The account of the seed from $\boldsymbol{L}$. and Juss. 97, who describes the corolla of $G$. Alypum as ligulate and tridentate.

1. GLOBULARIA Alypum. Stem shrubby. Leaves lanceolate, tridentate, and margin entire. Heads terminal. Hort. kew. i. 131. L. sp. 139. Sibth. , prodr. n. 269. In Greece and the islands of the Archipelago.

G. fruticosa, myrti folio tridentato. Garid. 210.t. 42.

Thymelaea foliis acutis, capitulo succisae, sive Alypum monspeliensium. Magn. monsp. 253.

Alypum montis ceti, sive Herba terribilis narbonensium. Raii hist. 1443 ; europ. 60.

Alypum montis ceti narbonensium. Lob. adv. 158, repr. in ic. i. 370 , \& cop. in

Alypum monspeliensium, sive Herba terribilis. Park. theatr. 199.

Hippoglosum valentinianum. Clus. hisp. 180, repr. in hist. 1. 90, and cop. in Park. theatr. 199, and repr. in

Alypum montis ceti. Ger. by Johns. 506.

Alypum monspelianum, sive Frutex terribilis. Bauk. J. i. a. 598.

Empetrum phacoides. Dalech. 1671, repr. in

Alypum Penae. Dalech. 1680.

(Alypun. Matth. 1280, cop. in Dalech. 1680, and abr. in Cam. epit. 985, which cop. in

Alypum Matthioli, tithymalis affine. Bauh.J. iii, 676 , is a different plant.)

ALYPUM. Dale 287. 


\section{DIPSACUS.}

Cullyx superior; obsolete. Corolla tubuliur, quadrifid. Seed columnar, crowned by the calyx. from $L$. and Juss.

1. DIPSACLS fultonim. Leaves connäte; oblong; obtuse. Paleae recurvate. Obs. S023: Specimen of a leaf from an old hęrbal._-Obs. 5333: Spceimen of a head from Dr. Bochmer.-Roth germ: ii: 161. L. a Filld. i. 543. Bot. arrang. 137, where it ought not to have. been inserted as no one has ever observed it growing wild in Britain.Smith brit. 168. L: sp. 140 \& Mill. Ph. dict. n. 2. Krock: i. n. 200. a who says it is cultivated and also found growing spontaneously in Silesia.-

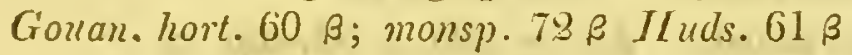

D. albus. Fuchs. 223. c. 82 ; cop. in

D. sativus. Bauh. J. nii. a. 73. Boerh. i: 133. MLugn. hort. 70. Raii hist. 382; synn.192; cat. 94 ; in which two latter worls it is enumerated as being cultivated in fuclds:-DDorl. 723 , repr. in Ger. Gy Johns: 1167, cop. in Parli. theatr. 981, with a scparate ripe head; and repr. in

Carduus fullonum, sive Dipsacus sativus. Lob. ic. ii. 1 .

D. scu Labrum veneris: Dalech. $14+7$.

D. sativus alter. Dalech. 1417 .

Labrum venteris. Cam. epit. 431.

Carduus fullonum.. Trag. S47, repr. in

D. sylucstris. Cord. fol. 105.p.2. The paleac not sufficicntly recurvate.

Nulize of Saxony and Silesin according to Leyser 
and Krocker, but probably only naturalised, and possibly only the refuse of fields or gardens.

DIPSACUS sativus. Chom. 423; suppl. 132. Dale 102. Mill. Jos. 179. Rutty 168.

Dipsacus. Geuffr. iii, 405.

2. DIPSACUS sylvestris. Leaves connate, acute. The uppermost paleac straight. Obs. 5334. Specimen gathered near Worcester.-Mill. Ph. dict. n. 1. Bot. arrang. 137. Smith brit. 168; eng.t. 1032. Host 68. Pollich 2. 137. Krock. i. n. 200. Scop. carn.n. 141. Jacq. ap. L. a Murr. 143; austr. v. t. 402. Curt. lond. iii. 9. t. 202. Sibth. prodr. n. 271. Roth germ. ii. 160. Dod. 723, repr. in Ger. by Johns. 1167, cop. in Park. theatr. 984, and repr. in

Labrum veneris. Lob. ic. ii, 18.

D. purpureus. Fuchs. 223, c. 82, cop. in

D. silvestris major. Dalech. 1448, and

D. sylvestris, sive Labrum veneris. Bauh. J. iii. 74. Raii syn. 192. Magn。 monsp. 86.

D. fullonum. Lightf. 113. Near Dumfermling in Fifeshire.

D. sylvestris, aut Virga pastoris major. Tourn. paris. 266. Vaill. paris. 47. Boerh. i. 193.

Labrum veneris alterum. Cam. epit. 432.

Native of Europe from Sinyrna to Denmark, and of Britain as far north as Fifeshire. I have never observed it except on limestone or marle or in vallies in the vicinity of limestone.

DIPSACUS sylvestris. Dale 102. Nill. Jos. 179. Rutty 168.

3. DIPSACUS pilosus. Leaves on petioles. Obs. 535. Near Powick, Worcestershire.-L. sp. 141. 


\section{Monogynia, 74. Scabiosa.}

Curt. lond. i 10. t. Bot. arrang. 138. Smith brit. 169; engl.t. 877. Jacq. austr. iii. t. 248.

D. sylvestris capitulo minori, vel Virga pastoris minor. Boerh.i. 133. Vaill. paris. 47.

D. minor, sive Virga pastoris. Raii hist. 382; syn. 192. Ger. by Johns. 1168, repr. from

D. tertius. Dod. 723, which repr. in

Virga pastoris. Lob. ic. ii. 18. Park. theatr. 984. Cam. epit. 433.

D. silvestris minor, seu Virga pastoris. Dalech. 1448.

Virga pastoris vulgaris. Bauh. $J$. iii. a. 75 .

Native of Germany, the north of France, and Briv tain.

VIRGA PASTORIS. Dale 102.

\section{SCABIOSA.}

Calyx inferior. Corolla tubular. Seed pappose. Obs. 4973. $L$.

1. Corolla quadrifid. L.

1. SCABIOSA Succisa. Corollae equal. Inner calyx quinquepartite. Leaves lanceolate. Stem simple. Obs. 5002. In moist meadows: $-\dot{L}$ : suec. $n .119$; sp. 142. Bot. arrang. 139. Curt. lond. iii. 10.t. 189. Smith brit. 170 ; engl. $t: 878$, corolla co: loured of a sky blue. $-F l$. dan.t. 279 .

S. radice succisa, flore globoso. Raii syn. 191.

Morsus diaboli. Dalech. 1067. Trag. 246, kqp. from

Succisa. Fuchs. 678, which cop. in

Succisa, sive Morsus diaboli. Bauh. J. iii. a. 11.

Raii hist. 380. Dod. 124, repr. in

$$
02
$$


Morsus diaboli. Lob. ic. i. 546, \& rop.in

Morsus diaboli vulgaris. Park. theatr. 492.

S. folio integro hirsuto. Toum. paris. 141. Vaill. paris. 177.

Leaves more or less hirsute. Ohs. 5002.

a caerulea. Corolla blue. Ols. 5002.

S. integrifolia glabra, radice praemorsa. Bocrh.i. 129.

SUCCISA. Alst. ii. 220. Rutty 501. Vog. 228.

S. Succisa. Kroct. n. 203. Withering in bot. ara rang. 140.

Succisa hirsuta. Choin. 277.

Morsus diaboli. Bcrg. 59. Inale 102. Geoffr. suite ii. 402. Lim. 53. Mill. Jos. 298. Murr. i. 179. Spichm. 394.

f camea. Corolla fleshcoloured. Obs. 5003. Specimen gathered near Worcester.

S. folio integro, glabro, flore incarnato. Vaill. paris. 178. Boerh. i. 129.

y albe. iGorolla white. Obs, 5004. Specimen ga. thered by Mr. Hollefear in Worcestershirc.

S. folio integro, glabro, flore albo. Vaill. paris. 178.

S. folio integro, flore albo. Boerh. i. 129.

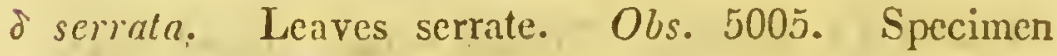
gathered by Mr. Hollefear in Worcestershire.

S. foliis imis integris, caulescentibus incisis. Vaill. paris. 178.

2. SCABIOSA arensis. Corollae radiate. Leaves pinnatifid and cut. Stem hispid. Receptacle setaceous. Obs. 4973. On the borders of fields. L. suec. n. 117 ; sp. 143. Curt. lomt. iv. 1S. $t$. 288. Smith brit. 170; engl.t. 659. Bot. arrang. 140. Krock. n. 205. 1\%. dan. t. 44t, radiate flowers too small. 
S. mnjor communior folio laciniato. Raii syn. 191.

S. pratensis hirsuta, quae officinarum. Toum. paris. 139. Yraill. paris. 176.

S. vulgaris major. Dod. 192 , repr. in

S. major satorum, vulgatior. Lob. ic. i. 536, \&

S. major vulgaris. Ger. by Johns. 719.

Scabiosa. Fiuchs. 680. c. 273, cop. in Trag. 242, s. in

S. major communior hirsuta folio laciniato. Bauk. J. iii. a. 2.

S. alter campestris, sive segetum et satorum. Lob. ic. i. 537, repr. in

S. campestris, sive segetum. Ger. by Johns. 720, is possibly the variety mentioned by Vaillant with all the florcts regular.

C'aly $x$ of the fruit rigid, hard, tetragonous, compressed, obsoletely quadridentate at the end. Pap. pus multipartite; segments subulate, 9 to 11 , intermixed with hairs. Obs. 4973.

SCABIOSA. Alst. ii. 220. Berg. 60. Dale 101. Geoffr. suile ii. 398. Lew. disp. by Dunc. 347. Linn. 53. Mill. Jos. 399. Monro iii. 251. Murr. i. 177. Ploucq. bibl. i. 576. Rutty 468: Spielm. 39.1. Vog. 81.

S. pratensis liirsuta, quac officinarum. Chom. 270; suppl. 89.

\& purpurascens. Corolla pale reddish purple. Near Chesterfield in gritstone.

\% alba. Corolla white. Obs. 4975. Between'Baslow and Curbar, Derbyshire.

- integrifulia. Leaves entire. Obs.7669. Specimen gathered by Mr. Hollefar in Worcestershire. 5. major communior, folio non laciuiato. Vaill. paris. 1 i7. 
$\varepsilon$ inaequalis. Inner florets of the same shape and length as the outer. From

S. vulgaris flore pleno. R. cat. ed. i. 277. About Teversham, Balsham, and elsewhere in Cambridgeshire.

2. Corolla quinquefid. L.

3. SCABIOSA cochinchinensis. Leaves undivided, Ianceolate, undulate. Stem nearly naked. Pappus pilose. Lour. i. 85 .

\section{HEDYOTIS.}

Calyx superior, tetraphyllous, permanent. Corolla infundibuliform; limb quadrifid. Capsule bilocular, polyspermous, opening transversely. Obs. 8453. 8454. L.

1. HEDYOTIS Auricularia. Leaves lanceolato-ovate. Flowers verticillate. L. sp. 147.

Valerianella palustris, foliis nervosis oblongis, flosculis ad caulium nodos inter foliorum sinus collectis. Burm. J. zeyl. 227. t. 108. f. 1.

Muriguti. Rheede x. 63. $t .32$. AURICULARIA. Linn. 53.

2. HEDYOTIS herbacea. Leaves lineari-lanceolate. Stem herbaceous, dichotomous. Peduncles in pairs. L. sp. 147 .

PARPADAGAM. Rhecde x. 69. t. 35.

3. HEDYOTIS tinctoria. Leaves lanceolato-linear, opposite, in threes and fours. Flowers subumbellate. Umbels terminal, leafy. From Roxb. fig. 
Oldenlandia umbellata. L. sp. 174.

Lysimachiae affinis, saturejae folio, maderaspatensis, capsulis in summitate fere umbellatis. Pluk. alm. 236; phyt.t. 119. f. 4 .

OLDENLANDIA umbellata. Roxb. corom. i. 1. $t$. $S$, from a cultivated plant.

\section{SPERMACOCE.}

Corolla monopetalous, infundibaliform. Secds 2, bidentatc. $\boldsymbol{L}$.

1. SPERMAGOCE scabra. Leaves roundish, hispidoscabrous. Stem hispido-scabrous. Flowers verticillate. Stamina projecting. L. a Willd. i. 572 ?

TARDAVEL. Rheede ix. 149. t. 76. Leaves oblongo-elliptic and elliptic.

\section{ASPERULA.}

Corolla infundibuliform. Fruit dicoccous, Obs. 1187. $L$.

Not essentially distinct from Galizm. See the obm servation from Wiggers in Bot. arrang. 158.

1. ASPERULA cynanchica. Leaves in fours, in the upper whorls two of the leaves minute. Stem ascending. Obs. 4428. In Surry, on chalk. $-L$. sp. 151. Bot. arrang. 159. Smith engl. bot. $t$. 33 , corresponding with all my specimens of Eng. lish growth whether indigenous or cultivated;brit. 172.

$$
04
$$


Aspcrula. Allioni nic. 7 .

Rubcola vulgaris quadrifolia lacevis; foribus purpura. scentibus. Toum. paris. 137. Vaill. paris. 171. Dill. "l). Raii syn. 225.

Galium moutanum lątióliusn cruciatum. Col.cephr. i. 296.

Galium tetraplytlon montanum cruciatum. Col. ecphr. i. . 297, corresponding with specimens fiom the Paris and Vicnna gardens.

Rubia cynanchica. Bauh. J. iii. b. 725. Raii syn. cl. ii. 118. Magn. monsp. 225.

Synanchica. Dalech. 1185. Goodyer. in Ger. by Johns. 1120. No fig.

Corolla in dried specinıens scabrous as Dr. Smith remarks, when moistened nearly glabrous. Obs. $44 \approx 8$.

RUBIA synanchica. Dale 134.

Rubcola. Geoflr. suite ii. 2730.

2. ASPERULA odorata. ILeaves in eights, lanceolate. Panicles pednnculate: Qbs. 1187. In woods.J. suec. n. 121 ; sp. 150. Curt. lond. iv. 15. $t_{q}$ 219. Bot. arrang. 15S. Smith brit. 172; engl.t. 755. Krock. n. 211. Fl, dam. t. 562.

Asperula. Raii hist. 483; syn. 224. Ger. by Jahns, 1124, repr: from.

A. aut Aspergula odora nostras. Lob. ic, i. 801, which cop. in

A. aut Aspergula odorata, Park. theatr. 563, and repro. in

A. odorata, flore albo., Dod. 352. Boerh. i. 149. Aparine latifolia humilior montana. Tourn. paris; 389. Vaill. paris. 14.

Matrisylva. 'Trag. 496. 
Rubiis accedens, Asperula quibusdam, sive Hepatica stellaris. Bauh.J. iii., 718.

A. Dodonaci. Dalech. 870.

ASPERULA. Dale 13t. Mill. Jos.60. Spielm. 389.

Matrisylva. Berg. 61. Limn, 54. Murr. i. 374. Vog. 139.

Hepatica stellata. Chom. 501,

\section{\%8. GALIUM.}

Corolla rotate, or campanulate. Frnit, dicoccous, Obs, 5027. L.

\section{Fruit glabrous. L.}

1. GALIUM Cruciatcl. Leaves in fours, ovato-lanceo. late, yillose. Stems simple, hirsute. Racemi lateral, with 2 or 3 leaves. Obs. 4358. Under hedges.-Bot. arrang. 149. Scop. carn. n. 145.

G. cruciatum. Smith engl. t. 1433; brit. 173.

Valantia Cruciata. L. sp. 1491. Walc. to Bot. arrang. 1139. Gort. belg; foed. n. 830.

Cruciata hirsuta. Tounn. paris. 73. 191.426. Vaill. paris. 43.

Cruciata. Raii syn. 223; hist. 479. Dod. 353, repr. in Ger. by Johns. 1123, \&

Cruciata minor. Lob. ic. i. 804, \& cop. in

Cruciata vulgaris. Park. theatr. 566.

Gallium latifolium, Cruciata quibusdam flore luteo. Bauh. J. iii. 717.

Rubia quadrifolia glabra angustifolia. Bauk. $J$. iii. 717 , the inner figure. (The outer figure, name, and description belong to a different species.) 
Caly $x$ a circle of green globules round the base of the corolla. Corolla flat, quadripartite, yellow; tube none. Styles 2, erect, as short again as the germen. Germen very frequently none. Obs. 4358.

Native of France, Switzerland, Germany, Holland, and Britain.

CRUCIATA. Dale 132. Geoffr. iii. 371. Mill. Jos. 160.

Cruciata hirsuta. Chom. 595.

2. GALIUM tinctorium. Leaves linear; cauline leaves in sixes; those of the branches in fours. Stem flaccid. Peduncles with mostly 2 flowers. L. $s p$. 153.

G.ALIUM tinctorium. Schoepf 12.27.

3. GALIUM revum. Leaves in eights, linear, mucronate, revolute at the margin. Flowering branches short. Obs. 507. Near Worcester, on marle.L. sp. 155. Bót. arrang. 155. Curt. lond. vi. $t$. 13. Smith brit. 178; engl.t. 660.

Gallium. Fuchs. 196. c. 72, abr. in Trag. 492, and cop. in

Gallion verum. Bauh. J. iii. 720 .

Gallium. Dod. 351, repr. in

Gallium luteum. Lob. ic. i. 804, \& Ger. by Johns. 1126, and cop. in Park. theatr. 564. R. syn. 224. Tourn. paris. 197. Vaill. paris. 78. Boerh. i. 148. 'In Holland.

GALIUM lutcum. Bcrg. 62. Geoffr. iii. 51 . Linn. 54. Murr. i. 3i1. Vog. 101.

Gallium luteum. Chom. 365; suppl. 113. Mill. Jos. 208.

Gallium. Dale 133. Lew. i. 455. Rutty 215.

G. veruin. Krock. n: 221. Foodv. iv. 149. 


\section{Monogynta. 78. Galium.}

14. GALIUM Mollugo. Leaves in eights, lanceolatoobovate, mucronate, microscopically aculeate at the margin, deflex. Stem square, glabrous. Branches patent. Obs. 5027. Nẹr Chesterficld. -L.sp. 155. Bot. arrang. 155. Smith brit. 178. Fl. dan. t. 455 .

Gallium album, vulgare. Tourn. paris. 335. Vaill. paris. 77 .

Mollugo vulgatior. Raii syn. 223.

Mollugo. Dod. 351, repr. in

Mollugo belgarum, Mollugo montana Dodonaei. Lob. ic. i. 802, \&

Gallium, sive Mollugo montana. Ger. by Jolins. 1127 , as evident from the crowded flowers and the number of the floral leaves.

Mollugo vulgatior herbariorum, Galion album quorundam. Lob. ic. i. 802, repr. in

Gallium album. Ger. by Johns. 1126, having leaves in sixes may have been intended for some other species.

Rubia silvestris. Dalech. 1329. Lob. ic. i. 798, repr. in Ger." by Johns. 1118, having leaves in sixes and fives may have been intended for some other species.

Rubia sylvestris. Fuchs. c. 108. 281, cop. in Rubia angulosa aspera. Bauh. J. iii. 715.

Stem erect, weak, 3 feet and upwards long, glabrous above, slightly hirsute below; sides depressed; angles rounded; joints swoln; branched; branches patent, horizontal, and deflex. Leaves glabrous above, underneath sometimes slightly hirsute; those of the stem in eights, patent; those of the flowering branches in sixes; those of the last ramifications of the panicle in twos. Flowers numerous, crowded. Peduncles 2 and often 3 together. Corolla straw. 
colomed white. Antherac yellow, when out of flower brown. Fruit şlabrous. Obs. 505. Near Worcester, on marle.-Corolla rotate; segments cuspidate. Germen glabrous. Obs. 5027.-Fruit when immature becoming rugose-in drying without any projecting points. Obs. 7859.

MOLLUGO. Dale 133.

Gallium album. Gcoffr. iii. 516.

Gallium album vulgare. Chom. 365.

\section{Fruit scabrous.}

5. GALIUM tuberosum. Leaves in fives, lanceolate. Peduncles axillary, crowded. Lour. i. 99.

\section{Fruit hispid. L.}

6. GALIUM Aparine. Leaves in eights, Ianceolate; the carina scabrous with prickles pointing backwards. IKnots of the stem villose. L. a Murr. 151; sp. 157 ; succ. n. 128. Curt. lond. ii. 9. t. Walc. t. Bot. arrang. 157. Woodo. iv. 148. $t$. 269. Smith brit. 180; $\in$ ngl. $t$. 816. Fl. dan. $t$. 495.

Aparine vulgaris. Toum. paris. 2i6. Vaill. paris. 14. t. 4. f. 1. b.' Boerh. i. 150. Park. theatr. 567 , cop. from

Aparine. Dod. 350, which repr. in Lob. ic. i. 800, and Ger. by Johns. 1122. Dalech. 1331. Raii hist. 481; syn. 225. Fuchs. 50. c. 14, сор. in Bauk. J. iii. 713, and abr. in

A parina. Trag. 494.

APARINE. Boerh. 213. Cull. ii. 36. I)ale 133. Geoffr. iii. 102. Lew. i. 112. Mill. Tos, 43. Rully 32. Vog. 93. 
Aparine vulgaris. Chom. 244; suppl. 82.

Clivers. Denm. i. 170.

\section{CRUCIANELLA.}

Corolla superior, monopetalous, infundibuliform; segments caudate at the end. Calyx none or an obsolete margin. Seeds 2, linear. Ols. 8646. L.

CRUCIANELLA angustifolia. Stem erect. Leares in sixes, linear: Flowers spicate. L. $s p .157$ ?

CRUCIANELLA angustifolia. Lour. i. 100, who describes the stem as simple and terete, 'whereas in - Linneus's plant it is branched and tetragonous.

\section{RUBIA.}

Corolla monopetalous, campanulate. Berries 2, mo. nospermous. $\boldsymbol{L}$.

RUBIA tinctoria. Stem prickly. Leaves annual, lanceolate; prickles of the anterior part of the leares incurvate. Obs.8024. Specimen gathered in a grarden.

R. tinctorum. L. a Murr. 152 ; sp. 158; mant. 330. Hort. keww. i. 146. Raii hist. 480; syn. 223. Cultivated in ficlds.-Mill. $P$ h. dict. $n$. 1. t. Gouan. hort. 69 \& Woodv. ii. 190. t. 68. Scop. carn. n. 160. About Tricste and the isle of Veglia.-Hosl. 76 . In Littorali, near the sea. - Siblh. prodr. n. 310. In the Grecian islinds and Asia Minor.-Rolh germ. ii. 177. Honck. $n$. 538. Ger. by Johns. 1118, repr. from 
R. major. Lob. obs. 463, which repr. in ic. i. 798, Clus. hist. ii. 77 ; cop. in Theophr. a Stap. 1114 , Garance. Pomet i. $85, \&$.

R. major sativa. Park. thealr. 274; \& repr. in

Rubia. Dod. 349. Trag. 498, cop. from

R. sativa. Fuchs. 281. c. 108. Bauh. J. iii. b. 715. No figure.-Dalech. 1329.

R. foliis senis. Guett. ii. 54. a. Near Estampes.Royen 254. L. ups. 28.

R. tinctorum sativa. Vaill. paris. 174. Magn. monsp. 224. In the hedges of gardens and fields near Montpelier;-hort. 174. Boerh. i. 147.

Native of Asia Minor, the Grecian islands, Italy, France, and the neighbourhood of Spire in Germany. RUBIA. Root. Pharm. lond.-Alst. i. 376. Boerh. 209. Chom. i. 222. Copland in med. journ. xi. 230. Cull. ii. 38. 553. Dale 132. Geoffr. suite ii. 275. I Ierm. 93. Hill 597. Lew. ii. 282. Monro iii. 238, Rutty 436. Spielm. 569. Tourn. i. 378.

R. tinctorum. Root. Pharm. edin.-Aitken nidw.. 131. Berg. 64. Cartheus. iv. 89. Home, F. clin. 388. Limn. 55. Mill. Jos. 378. Murr. i. 363; J. i.289. Pearson, R. i. 295. Reece, account from in phys. journ. viii. 568. Vog. 222.

R. tinctorum sativa. Chom. 222; suppl. 71. Madder. Denm. i. 167. Lew. in Neum. ii. 164. Epuipodavov. Diosc. l. 3. c. 160.

RUBIA sylvestris. Dale 133.

\section{S1. IXORA.}

Corolla superior, hypocrateriform, or infundibuliform. Calyx superior, quadridentate. Stamina inserted at the commissures of the carolla. Stigma 
bifid. Berry bilocular; cells monospermous. Obs. 6822. The account of the fruit from Gaertn. i. 117. t. 25. $L$.

1. IXORA coccinea. Leaves elliptic. Corymbi terminal. Segments of the corolla lanccolate, distinct. From L. sp. 159. (Curt. mag. t. 169, and Hort. kew. i. 148, are I. obtusiflora.)

I. foliis ovalibus semiamplexicaulibus. L. zeyl. 22. Jasminum flore tetrapetalo. Burm. J. zeyl. 125. $t$. 57.

Schetti. Rheede ii. 17. t. 13.

Bandhuca. Jones in asiat. research. iv. 253.

Jasminum indicum, lauri folio, inodorum, umbellatum, floribus coccineis. Pluk. alm. 196. t. 59. f. 2.

Arbor indica, lauri amplioribus foliis obtusis, regione binis, floribus jasmini summo ramulo umbellatum positis. Pluk. mant. 20 ; phyt. t. 364. $f$. 2, the fig. marked fol. 20. pl. 2, (misengraved 1.) Laciniae of the corolla distinct.

FLAMMA SYLVARUM. Rumph. iv. 105. $t$. 46.

IXORA alba. Leaves lanceolato-ovate. Flowers fasciculate. L. sp. 160. Mill. Ph. dict. n. 2. Flowers scentless.

Jasminum indicum, lauri folio, inodorum, umbellatum, floribus albicantibus. Pluk. alm. 196; phyt. t. 109. f. 2. Flowers fasciculate.

BEMSCHETTI. Rheede ii. 19. $t$. 14, (misengraved 13) Panicles with few branches, and the bracches with fery flowers. 


\section{PAVETTA.}

Corolla superior, monopetalous, infundibuliform: Calyx superior, quinquedentate. Stigma simple: Berry bilocular; cells monospermous. Obs. 8159. The account of the fruit from Gaertn. i. 116. $t$. 25. $L$.

1. PAVETTA indica. Leaves oblong, acuminate at each end. Umbels terminal, fasciculate. Calyx short, acute, L. fil. suppl. 121. L. a Willd.i. 610. L. sp. 160, where the stigma is described as bifid.-Burm. Laur. ind. 35. t. 19. f. 3.

P. alba. Vahl. symb. iii. 11, (where at p. 12. l. 1, for alba read indica.)

Pavetta. L. amoen. i. 114, where the stigma is described as simple;-zeyl. n. 56.

Pavate. Acosta ap. Clus. exot. 266. No fig.-Raii hist. 1581. Dalech. 1863, cop. in Park. theatr. $1603, \&$

Pavate arbor foliis mali aureac. Bauh. J. ii. 103.

(Arbor maderaspatensium Pavette. Pluk. phyt. $t$. $147, f .1$, has alternate leaves.)

PAVETTA, seu Malleamothe. Rheede จ. 19. $t$. 10. Stigma represented as simple.

\section{MITCHELLA.}

Calyces 2 to 1 germen, quadridentate. Corollae 2 to 1 germen, superior, monopetalous. Stigmata 4. Berry tetraspermous, bifid. Obs. 3273. L.

Belongs to the order Rubiacce of Juss. 196. I would arrange it between division the second and 
third. Fruit dicoccons, with 4 seeds. It forms the connecting link between the Stellatce division 1 and 2 , and the rest of the order, and bears the same relation to Psychotria and Coffea as Xylosleum to Lonicera.

1. MITCHELLA repcns, L. sp. 161. Hort. kiew. i. 148. Citl. in amer. acad. i. 410. Obs. 3273. Specimen gathered by Dr. Cutler in New England.

Mitchella. Gron. virg. 18.

Syringa baccifera, myrti subrotundis foliis, floribus albis gemellis. Pluk. amalth. 198. $t$. 444. $f .2$. Calesb. i. 20.t. 20.

Baccifera mariana, clematis daphnoides minori folio. Pet. gaz. 1. t. 1:f: 13.

MITCHELLA repens. Bart. 49.

Partridge berries. Mather in phil. trans. abr. by Jones v. part ii. 160; and by Hulton vi. 86.

\section{CALLICARPA.}

Calyx and Corolla quadrifid. Berry with 4 seeds. L.

11. CALLICARPA vibumifolia. Leaves crẹnato-ser^ rate, ovali-elliptic, villoso-tomentose underneath. Panicles axillary, compact. Obs. 8028. Specimen gathered in the garden of Fothergill, without fructifications.-Salisb. R. allert. 53.

C. americana. L.sp. 161; a Mfurr. 153, the name. (The specific cbaracter and reference to mant. 198, misprinted 128, belongs to $\mathrm{C}$. canla.)-L. a Reich. i. 313 , the name and synonyms. (The specific sharacter, place of growth, and description, belong 
to C. cana.)-L. a Willd. i. 619. The name, synonyms, place of growth, and the mark that he had scen the plant alive. (The specific character and description belong to C. cana.)-Hort. liez:. i. 148. (The specific character belongs to $\mathrm{C}$. cana.)-Marsh. 22. Walt. carol. 84. Michaux i. 95.

Johnsonia americana. Dale of Carolina in Mill. $P h$. dict.

Callicarpa. Gron. virg. 19.

Anonymos baccifera verticillata, folio molli et incano ex america. Pluk. alm. 33. t. 136. f. 3.

Frutex baccifer verticillatus, foliis scabris latis dentatis et conjugatis. Catesb. ii. 47. t. 47.

CALLICARPA. Schoepf 13.

2. CALLICARPA cana. Leaves ovate, denticulate, semidecurrent down the petioles, villose and hoary underneath. Panicles axillary, dichotomous. From Vahl. symb. iii. 12, t. mant. 198, \& Reti. obs. v. 1.

C. americana. L. a Murr. 153, the specific claracter and reference.-Lour.i. 88.

C. americanae simillima ex india orientali. L. nat. ii. 120.

MASHANDARI. Jones in asiat. research. iv. 255. n. 15.

\section{\$5. PLANTAGO.}

Caly $x$ quadrifid. Corolla quadrifid; limb bent back. Stamina very long. Capsule bilocular, cut round. L. 


\section{With a scapus.}

1. PLANTAGO major. Leaves ovato-oval, nearly glabrous. Scapus terete. Several seeds in each cell. Obs. 8030. Specimen gathered on the sides of paths. $-L$. suec. n. 129 ; sp. 163. Bot. arrdng. 142. Curt. lond. ii. 11. t. Scop. carn. n. 161. Smith brit. 182. Woodv. i. 39.t. 14. Lour. i. 90. Fl. dan. t. 461. Fuchs. 38, cop. in

P. unajor, folio glabro non laciniato ut plurimumi Bauk. J. iii. b. 502.

P. latifolia. Curt. mat. med. t. 4. Ger, by Johns. 419, repr. in

P. vulgaris latifolia. Lob. obs. 162, cop. in Das lech. 1254, repr. in

Arnoglossa. Lob. ic. i. 303, \&

P. major. Dod. 107, which cop. in

P. maxima. Park, theatr. 493, \&

P. latifolia vulgaris. Park. theatr. 493. Raii hist. 87S; syn. 314.

P. scapo spicato, foliis ovatis. L. lapp. n. 62. (The variety of the height of a man is probably P. maxima.)

P. foliis ovatis. Gron. virg. 19.

Plantago. Browne 145. In most parts of Jamaica, especially in the mountains.

P. latifolia sinuata. Tourn. paris. 222. Vaill. paris. 160.

P. rubea. Brunsf. i. 25, cop. in Trag. 225.

Nalice of Lurope from Italy to Lapland, and of Virginia and Jamaica.

PLANTAGO latifolia. Berg. 69. Herm. 416. Linn. 55. Mill. Jos. 351. Murr. i. 190. Rutty 398. Schoepf 13. 
P. major. Gcoffi. suite ii. 11. Krock. n. 231. Spielm. 389.

P. vulgaris. Dale 214.

Plantago. Alsl. ii. 199. Lew. ii. 231; disp. lyy Dunc. 219. Vog.75. 179. 242.

P. latifolia sinuata. Chom. 583; suppl. 165.

Plantinil. Blizard, account from in med. rev. 1. 331. Lind hot clim. 313. Ware ophth. 178.

Plantane. Graing. 81. Percioal ii. $37 \%$, and in IIcase 164.

2. PLANTAGO incana. Leaves pubescent, elliptic, and ovali elliptic. Spike cylindric. Scapus tcrete. One and 2 seeds in each cell. Obs. 504. Near IVorcester, on marle.

P. media. L. suec. n. 150; sp. 163. Bot. arrang. 143. Curt. lond. iv. 14. t. 252. Walc. t. Smitt brit. 183. Pollich n. 160. Scop. carn. n. 162. Fl. dair. $t .581$.

P. latifolia incana. Toum. paris. 223. Vaill. paris. 160. Bocrh. ii. 100.

Caly.x quadripartite. Corolla infundibuliform; segments patent and horizontal. Obs. 504.

Nutice of Europe on calcarcous soils as Hudson observes, rarely on gritstone. Linnaus says on clay and Ray on gravel.

PLANTAGO media. Geoffr. suite ii. 14. Spiclm. 389.

P. incana. Dule 214.

Plantago. Pharm. austriaco-proi. 57. Lew. disp. by Dunc. 345.

P. latifolia incana. Chom. 583.

a oralifolia. Leaves ovali-elliptic. Obs. 504.

P. incama. Raii hist: S77. Ger. by Johns. 419 , repr. from 
P. media. Dod. 10i, which cop. in

P. major hirsuta, media a nomullis cognominata.

Bauk. J. iii. 6. 504, the lower fig.-repr. in

P. major incana. Lob. ic. i. 304, and one of the spikes cop. in Park. theatr. 493. Raii syn. 314.

P. major. Dalech. 125t. Brunsf. i. 22, cop. in

P. latifolia. Trag. 226.

6 ellipticifolic. (Variation.) Leaves elliptic. Obs.

8029. Specimen from Withering.

P. minor. Fuchs. 38. c. 11, cop. in

Cynoglossum quorundam. Dalech. 1261, \&.

P. major hirsuta, media a nonnullis cognominata. Bauh.J. iii. 50t, the upper fig.

3. PLANTAGO lanceolata. Leaves lanceolate. Spike at first elliptico-ovate, at length cylindric. Keel of the phylla ciliate at the end. Scapus angular. Obs. 99. In a field. - L. suec. n. 131; sp. 164. Curt.lond. ii. 10. t. Walc.t. Bot. arrang. 143. Fl. dan. t. 437. Smith brit. 184; engl. t. 507. Fuchs. 39. c. 11, cop. in Bauh. J. iii. 505, \&

P. minor Dodonaei. Dalech. 1255.

P. minor longa. Dalech. 1255.

P. lanceolata. Trag. 225. cop. from

P. minor. Brunsf. i. 23. Dod.107, repr. in

P. quinquenervia, sive Lanceala. Lob. ic. i. 305, cop. in

P. angustifolia sive quinquenervia major. Park. theatr. 496, and repr. in

P. quinquenervia. Ger. by Johns. 422. Raii hist. 877 ; syn. 314.

P. angustifolia major. Tourn. paris. 223. Vaill. paris. 160. Boerh. ii. 100.

Scapus sometimes 2 feet long. Obs. 2470. In a field. $-2 \frac{2}{2}$ feet long. Obs. 8032. In a garden, P 3 
PLANTAGO lanceolata. Dale 214. II crm. 416. Krock. n. 234. Mill. Jos. 351.

P. minor. Geoffr, suitc ii. 15. Lew. ii. 232. Spielm. 389.

P. major angustifolia. Rutly 398.

P. angustifolia. Noef, account from in phys. journ. vi. 276.

P. angustifolia major, Chom. 583.

Native of Europe from Italy to Sweden.

4. PLANTAGO coronopus. Leaves dentato-pinna. tifid. Scapus terete. Obs. 8037. Below Great Malvern Worcestershire, and half way up Mal. vern Hill.-Huds. 64, cop. in Smith brit. 185; engl. t. 892. Bot. arrang. 145. Fl. dan. t. 272.

P. foliis laciniatis, Coronopus dicta. Raii syn. 315.

Coronopus Matthioli.'Dalech, 669.

Coronopus hortensis. Tourn. paris. 329. Vaill. paris. 42. Boerh, ii. 101.

Coronopus. Fuchs. 439. c, 171, abr. in Trag. 99, which repr, in Cord. fol. 137. p. 2, \& cop. in

Coronopus, sive Cormu cervinum vulgo, spica plan. taginis. Bauh. J. iii. 509.

Herba stella, sive Cornu cervinum. Dod. 109, repr. in

Cornu cervinum. Lob. ic. i. 437, and Ger. by Jolins. 427, and cop. in

Coronopus vulgaris, sive Cornu cervinum, Park. theatr. 502. Raii hist. 879.

Natioe of Europe from Italy to Sweden.

CORONOPUS. Dale 214. Mill. Jos. 152.

Buckshorn Plantain. Clegh, 24. 


\section{With a stem.}

5. PLANTAGO Psyllium. Stem branched, herbaceous. Leaves lanceolato-linear. Bracteae and phylla cuneiform. Obs. 80ss. Specimen gathered between Ostend and Paris, probably in Champagne.-L. sp. 167. Hort. kew. i. 154. Host. 78. Scop. carn. n. 165. Roth germ. i. 62. Krock. n. 240.

P. caule ramoso, foliis dentatis, spicis nudis. $\boldsymbol{L}$. ups. 28. (The synonym and place of growth belong to $\mathrm{P}$. indica.) In the description as also in that of the species n. 2, for flores destituti read flores distincti.

Psyllium majus erectum latifolium annuum. Boerh. ii. 101.

Psylhum majus erectum. Bauh. J. iii.513. No fig.-Tourn. paris. 353. Vaill. paris, 165.

Psyllium alterum. Dalech. 1173, imit. from

Psyllium. Fuchs. 843. c. 341. Trag. 167. Dalech. 1172. Dod. 115, repr. in

Pulicaris herba. Lob.ic. i. 436, \&

Psyllium, sive Pulicaris herba. Ger. by Johns. 587, \& $a b r$. in

Psyllium vulgare. Park. theatr. 278. Raii hist. 881; europ. 209. About Montpelier. Natice of Europe, from Italy to Paris and Berlin. PSYLLIUM. Alst. ii. 369. Cartheus. i. 278. Chom. 73. Dale 215. Herm. 330. Lew. ii. 248; disp. by Dunc. 345; by Rother. 221. Linn. 56. Mill. Jos. 360. Murr. i.. 193. Spielm. 636. Vog. 171. Wintringham in Mead man. i. 228.

Psyllium annuum. Geaffr. suite ii. 101.

Psyllium majus erectum. Chom. 813. Rutty 414, 
6. PLAN'I'AGO squarrosa. Stems herbaccous branched difiuse decumbent. Leaves linear, entire at the marerin. Heads squarrose. Murr. in L. a Murr. 156. Hort. kew. i. 154.

P. acgyptiaca. Jacq.rar. i. t. 28; coll. i. 45.

Kalli IIL. Alp. acgypt. 51.

Kali aegyptiacum, foliis valdc longis hirsutis. Raii hist. 1915.

SODA. Murr. iv. 286.

7. PLANTAGO Cynops. "Stem branclied, suffruticose. Leaves subulate. Bracteac and pliylla oval. Obs. 1663. In the Edinburgh garden.-L. sp. 167. Hort. kew. i. 154.

Psylliun niajus supinum angustifolium et perenne. Boerh. ii. 101.

Psyllium majus supinum: Bauh. J. iii.513. Raii hist. 882; europ. 209 . In Italy and about Mont. pelier.

Psyllium plinianum forte. Lob. obs. 239, repr. in Psyllium plinianum forte, radice perenni supinum. Lob. ic. i. 437, \&

Psyllium sempervirens Lobelii. Ger. by Johns. 587, S. cop. in

Psyllium vulgare. Park. theatr. 279, (the name and description belonging to $P$. Psyllium, ) \&

Psyllium sempervirens. Hist. ox. iii. 262. s. 8.t. 17. f. 1 .

Psyllium majus sempervirens. Park. theatr. $27 \%$. No fig.

Native of Italy and the south of France.

PSYLLIUM perenne. Geoffi: suile ii. 99.

Psyllium. Berg. 71. 


\section{S6. SCOPARIA.}

Cally, $x$ quadripartite. Corolla quadripartite, rotate. Capsule of 1 cell, 2 valves, and many seeds.i $L$.

1. SCOPARIA dulcis. Leaves in thirees. Flowers on peduncles, L. sp. 168. Hort. kew. i. 155.

Veronica fruticosa erecta dulcis, hexangulari caule, flore dilute caeruleo. Sloane cat. 81 ; hist. i. 195. t. 10s. $f .2$.

Veronica americana crecta frutescens et ramosa. Herm. parad. 241.t.

Phyteuodes americanum, flore albo tetrapetalo, staminibus referto, foliis et ramulis per intervalla ternis, sapore dulci. Pluk, alm, 296; phyt. t. 215. f. 1.

Basourinha, sive Tupeicava. Pis. bras. 110 , cop. in ind. 246.

SCOPARIA dulcis. Jacq. amer. 17, repr. in 8ro 21.

\section{8\%. SANGUISORBA.}

Caly $x$ inferior, tetragonous, urceolate, the mouth surrounded by a fleshy ring. Petals 4, ovate, inserted into the calyx. Stamina 4, inserted into the fleshy ring of the calyx. Germen inclosed within the calyx. Style 1. Stigma pencilsliaped. C'apsule inclosed by the permanent calyx. Obs. 4960. $L$.

1. SANGUISORBA officinalis, Stamina as long as the corolla. Spikes oval, oblong, and round. Obs. 4960. In a meadow.-L. succ. $n .137 ; s p$. 
109. Bot. arrang. 147. Smith brit. 186; cngl.t. 1312. Krock.n. 243. Fl. dan. t. 97.

Pimpipella spica brevi rubra. Boerh. ii. 99.

Pimpinella, S. major. Vaill. paris. 159.

Pimpinella sylvestris. Raii hist. 402. Ger. by Johns. 1045, cop. from

Pimpinella sylvestris, S. major. Dod. 105, whick repr. in

S. altera major, sive Pimpinella. Lob. ic. i. 719, and cop. in

Pimpinella major vulgaris. Park. theatr. 582. Raii syn. ed. ii. 100.

S. major, flore spadiceo. Dill. ap. Raii syn. 203. Bauh. J. iii.b. 120, cop. from

太. major. Fuchs. 749. ed. fol. and 12 mo c. 301, which imit. in Cord. fol. 143. p. 2, which repr, from

Pimpinella italica. Trag. 470, \& cop. int

Pimpinella, sive S. major. Dalech. 1088.

Pimpinella, sive S. major Matthioli. Dalech. 1087.

Spikes oval and oblong, brownish purple, begining to flower at the top. Stipulae sometimes at the base of the partial petioles of the lower leaves. Bracteae 2 at the base of each flower. Stamina caducous. Obs. 4960. Meadows near Chesterficld on gritstone. SANGUISORBA. Vog. 224.

Pimpinclla italica. Linn. 56. Miurf: i. 190.

Pimpinella, S. major. Boecl. ap. Herm. 171.

\section{CISSUS.}

Berry monospermous, encompassed by the calyz and quadripartite corolla. $L$. 
1. CISSUS latifolia. Leaves cordato-ovate, villose, acuminate, serrate; teeth setaceous. Branches tetragonous. Vahl, symb, iii. 18.

Schunambu-valli. Rheede vii. 21.t. 11.

FUNIS CREPITANS major. Rumph. v. 446. t. 16t.f. 1 .

12. CISSUS quadrangularis. Leaves cordate, fleshy, serrato-dentate. Stem tetragonous. Internodia swoln. L. a Murr. 158; mant. 39.

C. quadrangula. Salisb. $R$, allert. 66 .

Saelanthus quadragonus. Forsk. 33. t.2.

(Planta baccifera scandens epidendros maderaspatana, geniculato et quadripinnato caule, flosculis exiguis, ad genicula capreolis donata. Pluk. alm. 298; phyt. t. 310. f. 6, has no leaves, and has a solitary flower and solitary berry.)

FUNIS QUADRANGULARIS. Rumph. v. 83. t. 44. f. 2 .

3. CISSUS crenata. Leaves ternate; folioles roundish, crenate. Vahl. symb. iii. 19.

Vitis trifolia. L. $s p .293$.

FOLIUM CAUSONIS. Rumph. v. 451. t. 166. f. 2. Leaves ovali-elliptic.

4. CISSUS acida. Leaves ternate, rhombeo-obovate, inciso-crenate, glabrous, fleshy. Obs. 8668. Specimen gathered by Dr. Wright in Jamaica. $-L$, a Murr. 158; sp. 170. Swartz, obs. 49. Hort.kezw. i. 156 .

Vitis foliis subrotundis serratis. Plum. a Burm. 259. t. 259. f. 5 .

Vitis trifolia minor, uva corymbosa, acinis majoribus turbinalis. Plum. sp. 18. 
Bryonioides trifoliatum indicum, foliis succulentis crassis et crenatis. Pluk. alm. 71 ; plyyt. $t .152$. f. 2. No fructifications.

Chamacdryfolia scandens claviculata et corymbosa jamaicensis. Pluk. alm. 96 ; phyt. t. 81.f. 5, in flower, is thought by Sloane to have been drawn from a specimen in which the lateral folioles had fallen off.

BRYONIA albạ triphylla geniculata, foliis crassis acidis, Sloane cat. 106; hist. i. 233. t. 142. f. 5 and 6. In fruit.

5. CISSUS carnosa. Leaves ternate, ovate, obtuse, scrrate, glabrous. Branches and petioles terete. Vahl. symb. iii. 19.

Funis crepitans trifolius, Rumph. v. 447.t. 165. TSJORI-VALLI. Rheede vii. 17. t.9.

6. CISSUS pedata. Leaves pedate; folioles lanceolate, serrate, tomentose underneath. L. a Willd: i. 659 .

BELUTTA-TSJORI-VALLI. Rheede vii. 17. เ. 10 .

\section{ALLASIA.}

Berry with seeds dispersed throughout the pulp. Calyx inferior, quinquefid. Corolla superior, tce trapetalous. . Lour.

1. ALluaSIA Payos. Lour. i. 107. 


\section{CORNUS.}

Caly.x superior, quadridentate. Petals 4. Drupe. Nut with 2 cells. Seeds solitary. Obs. 3898 . $L_{s}$,

\section{With an involucrum. H.K.}

CORNUS biramis. Stem with 2 branches. Obs. 374t. Specimen gathered by Mr. Robson in the Howl of Horkham near Kirkby-moor-side, in the north riding of Yorkshire.

C. suecica. L. suec. n. 139; sp. 171 ; a Willd. i. 660. Bot. arrang. 161. Smith engl. bot. t. 310; brit. 188. Lightf. 119, on the Highland mountains. - Fl. dan. t. 5, abr. in

C. herbacea. Pem. scot. \& hebrid.t. 39, at p. 314 . Huds. 71. On Pickering Moor and near Tadcaster Yorkshire.-Teesdale in linn. trans. ii. 105. In the Hole of Huckham near Pickcring.

C. pumila herbacea, Chamaepericlymenum dicta, Dill. hoit. 108. t. 91.

Chamaepericlymenum. Raii hist. 655, on the Cheviot hills Northumberland; syn. 261, found by Wood on the Pentland hills near Edinburgh. Clus. hist. 'i. 60, repr. in Ger. by Johns. 1296, and cop. in Park. theatr. 1461, repr. from

Periclymenum II. Clus. pann. 88, to whom the figure communicated by Penney; \& cop. in

Periclymenum parvum prutenicum Clusii. Bauh. J. ii. 108.

CORNUS herbacea. Linn. lapp.n.65. t. 5. f. 3.

2. CORNUS, florida. Stem woody. Involucrum many times longer than the unibel; the ends of the 
bracteac inflex. From L. sp. 171, and Curt.mags t. 526. Ilort. liew. i. 157.

C. involucro maximo, foliolis obverse cordatis, $L$. cliff. 38. Gron. virg. 20; ed. i. 17.

C. mas virginiana, flosculis in corymbo digestis, a perianthio tetrapetalo albo radiatim cinctis. Cattesb. i. 27. t. 27. Plut. alm. 121; phyt, t. 20. f. 3. Bracteac of the involucrum rhombeo-oval.

CORNUS florida. Coxe 370. Marsh. 35. Schoepf 14. Wallier, account from in chir. rev. xviii. 15.

3. CORNUS praecox.-Stem woody. Involucrum as long as the umbels. $L$.

C. mascula. L. a Murr. 159. Hort. kew. i. 158.

C. mas. L. sp. 171. Host 79. Krock. n. 244. Dalech. 329. Raii hist. 1536 ; europ. 106. In a wood near Rome, in the Milanese, and in Piedmont. -Ger. by Johns. 1466, repr. from

Cornus. Dod. 791. Trag. 1024, repr. in Cord. fol. 1S8. p. 2. Lob. ic. ii. 169, cop. in

C. mas, fructu rubro. Park. theatr. 152I, and alr. in

C. mas. Park. parad.t. 569. f.7.

G. sativa, seu domestica. Bauk. J. i. a. 210.

C. hortensis mas. Tourn, paris. 424. Vaill. paris. 42. Boerh. ii. 256.

Native of Italy, France, Switzerland, and Germany.

CORNUS. Dale 307. Geoffr. iii. 360. Mill. Jos. 152. Rutty 142.

Corni. Spielm. 104.

C. mascula. Bryant 229.

Cornouillier. Chom. 621 .

4. CORNUS sericea. Last years branclies smooth. Cymes depressed. Leaves elliptic, silky under- 
Death, the younger ferruginous underneath. Obs. 3899. Specimen without fructifications gathered in the garden of Fothergill.-L. mant. 199. Hort. kew.. i. 158. (L. a Murr. 159 must be C. alba or some other species, the branches being described as having wartlike ash coloured dots, whereas in L. mant. 199. the branches are described as smooth. Reichard in syst. pl. has united these contradictions into one mass without pointing out the contradictions or citing the opposing authorities, and Willdenow has omitted them.)

C. americana sylvestris, domesticae similis, bacca caerulei coloris. Pluk. phyt. t. 169. f. 3. CORNUS sericea. Coxe 370. Walker, account from in chir. rev. xviii. 15.

C. Amomum. Schoepf 14.

\section{FAGARA.}

Calyx quadrifid. Petals 4, Capsule simple, or didymous. Seeds one in a cell. From Gaertn. L.

1. FAGARA Pterota. Leaves pinnate; folioles emarginate. Spikes axillary. Obs. 8044. Specimen gathered by Broughton in Jamaica.-L. sp. 172; amoen. v. 393; mant. 331. Hort. kew. i. 161.

Pterota subspinosa, foliis minoribus per pinnas mar. ginato-alatas dispositis, spicis geminatis alaribus. Browne 146. t. 5. f. 1.

Lauro affinis, jasmini folio alato, costa media mem* branulis utrinque extantibus alata, ligni duritie ferro vix cedens. Sloane cat. 137; hist. ii. 25. $t$. 162, has acute folioles, agreeing with the charas: texs of $F$. acuminata of Swartz. 
Leares withont aculei; folioles obovate, emarginate at the end; margin revolute, entire. Obs. 8044 .

FAGARA. Lim. 56:

2. FAGARA Pipcrila. Folioles crenate, ovate. From Kaempfer.-Hort. licw. i. 161. Lour. i. 101: L. $s p .172$, from

Piper japonicum. Kaempf. amoen. t. 893. Folioles acute; 5 pairs with an odd one.

FAGARA Piperita. Thunb. jap. 64; trai. iii. 62, 150 ; iv. 89.

3. FAGARA oclandra. Folioles tomentose. L. mant. 40, from

Elaphrium tomentosum. Jacq. amer. 105. $t$. $\%$ I. $f$. $1,2,3 ; 8$ io edit. 193. He says a glutinous balsam cxudes from every part of the tree, but he does not even compare it to the Tacamahaca of the shops.

Tacamalhacca americana, rosacis foliis alata. Seb.49. t. 48. f. 3. Peduncles axillary, distant. Leitves. lanuginose; folioles 5 .

Therebinthus americana, sorbi aucupariae foliis rachi medio appendicibus alata, arbor americana re sinosa, foliis ad rosarmu folia accedentibus. Pluk. phyt. t. 228. f. 7 . Folioles 5.

TACAMAMACA in testa. Berg. 72, apparently on the atuthority of Des Marchais.

4. FAGARA ETaphrim. Leaves pinnate, glabrous; folioles oblongo-lanccolate, obtusely dentate. Petioles articulated, winged. Stamina 8. L. a IFilld. i. 668 . 
Elaphrium glabrum. Jacq. amer. 106.t.71. f. 4, a leaf; Sro ed. 133.

Copalli Quahvitl, seu arbor guminifera copallifera I. HIern. 45.

Copalifera. Berg. mat. med. n. 565.

- COPAL. Alst. ii. 409. Berg. 896. Dale 315. Geoffr. ii. 515. Lew. i. 364; disp. by.Rother. 148; in Neum. ii. 27. Linn. 285. Mill. Jos. 292. Monro ii. 359. Rutty 225. Schocpf 39. Spielm. 313. Vog. 317.

Gomme Copal. Chom.671.

5. FAGARA Avicennae. Leaves pitinate; folioles lanceolate, entire at the margin, glabrous. $L$. $a$ Willd. i. 668, from Lamarck.-Clus. exot. 185, repr. in Lob. obs. 565, \& ic. ii. 133, cop. in Dalech. 1831, repr. in

Fagara. Ger. by Johns. 1548, cop. in Tab. ic. 923, \& abr. in

F. major. Bauh. J. i. a. 350, the 6 upper figures. -Raii hist. 1814.

Fagara seu Cayutana Luzonis. Camell. 74, in Raii hist. iii.

FAGARA. Dale 316.

\section{MONETIA.}

Calyx quadrifid. Petals 4. Berry bilocular; cells monospermous. L. a Willd.-Lherit.

1. MONETIA diacantha. Spines opposite. Leaves pubescent. L. a Willd. i. 670, from Arnaranthoides indicum verticillatum, parietariac 
hirsutis foliis, spinosum. Pluk. alm. 7. t, 133. f. 3, \&

TSJEROU KARA. Rheede v. 73. t. 37.

\section{PTELEA.}

Petals 4. Calyx inferior, quadripartite. Stigmata 2. Samara roundish, bilocular, monospermous. Obs. 8380. L. a Willd. i. 670. L.

Flowers sometimes dioecious and sometimes poly. gamous. L. a Willd. \& L. a Schreb.

1. PTELEA trifoliata. Leaves ternate. L. sp. 173. Hort. kew. i. 162.

P. foliis ternatis. Gron. virg: 20.

Frutex virginianus trifolius, ulmi samaris. Dill. hort. 147.t. 122. $f .148$.

Samara bilocular; one of the cells containing a seed. Obs. 8380. Specimen gathered in Fother. gill's garden.

PTELEA trifoliata. Schoepf 15.

\section{OLDENLANDIA.}

Corolla monopetalous, quadrifid. Calyx superior, quadripartite. Capsule bilocular, polyspermous. From L. gen. \& Gaertn. 30.

In L. a Murr. 161, L: a Willd. i. 674, \& Hort. kew. i. 163, read corolla monopetala, for corolla tetrapetala, an error which Linnaeus omitted to correct, on detecting the error'adiopted from Plum. gon. t. 36 . 
If this be, as Schreber in L. a Schreb. 820 suggests, the same genus with Hedyotis, those species described by Koenigg as having 5 petals may retain the name.

1. OLDENLANDIA depressa. Stem diffuse. Leaves elliptic, petiolate, glabrous. Peduncles in pairs, axillary, L. a Willd. i. 675, from

NELATSJERA. Rheede x. 61, t. 31, who describes it as having 4 petals.

\section{SANTALUM.}

Calyx superior, quadrifid. Petals 4, very small, inserted into the calyx. Stigma with 4 lobes. Berry with 1. cell and 1 seed. From Roxb. $L$ L.

1. SANTALUM myrtifolium. S. album. $L$. $s p$. 497; a Murr. 164; a Reich. i. 344; a Willd. i. 691, where, as also in $\boldsymbol{L}$. a Reich. the observations in L. mant. \& a Murr. are omitted.-Bauh. Casp. pin. 392. Burm. ind. 87. Woodv. iv. 136. t. 264, from a specimen in the herbarium of Sir Jos. Banks._Lour. i. 109. Tab. ic. 933, specimen of the wood.

Sirium myrtifolium. L. mant. 200; a Murr. 160. Roxb. i. 2. t. 2.

S. verum ligno citrino et albo, foliis laurinis. Breyn. prodr. 94.

S. album et citrinum officinarum. Breyn. ic. 19. t. 5. $f .1$, a branch without fructifications, from a dried specimen sent to his father from India. Sandalum album timorense. Rumph. ii. 42. t. 11 a branch without fruetifications.

\& 2 
S. flavum: Tab. ic. 933, specimen of the wood. Naticc of the East Indies. Spccimens in Sir Jos. Banks's herbatium gathered at Tranquebar by tlie Moravian missionaries, by Koenig, ג. P. Howe, and Pat. Russell.

SANTALUM citrinum. Alst. ii. 48. Berg. 299. Cartheus. iii. 196. Cull. ii. 211. Dale 325. Herm. 228. Hill 683. Lew. ii. 329; disp. by Rother. 234. Linn. 58. Mill. Jos. 391. Murr. ii. 87. Neum. ii. 213. Spiclm. 392. Wintring. ham in Mead mon. i. 231.

S. flavum: Geoffr: ii. 240: Ruity 461.

S. pallidum. Chom. 344.

SANTALUM album. Alst: ii. 48. Berg. 299. Cartheus: iii. 196. Chom. 344. Dale 325. Geoffr. ii. 240. Herm. 229. Lew. ii. 330. Linn. 58. Mill. Jos. 391. Murr. ii. 87; J. i. 197. Spielm. 392. $\operatorname{Vog}_{\mathrm{b}} 288$.

\section{GLEDITSIA.}

Calyx of the hermaphrodite flowers quadrifid; of the male flowers triphyllous; of the female flowers pentaphyllous. Corolla of the hermaphrodite flowers tetrapetalous, of the inale flowers tripetalous, of the fimale dowers pentapetalous. Legus men. From $L$.

1. GLEDITSIA polysperma. Spines trifid. Legímina polyspermous. Obs. 8669. Specimen gathered in Fothergill's garden, wilhout fructifica. tions.

r. mcliloba. Wrat. carol. 251. 
G. triacanthos. L. sp. 1509 a ; "Willd. iv. 1097. Gouan. hort. 520. Michanux ii. 257.

G. Triacanthus. Mill, Ph. dict. n. 1 .

G. triacanthos polysperma. Hort. kew. iii. 444.

G. spinosa, Marsh. 54.

Gleditsia, Gron. virg. 161. L. ups. 298.

Caesalpinioides. L. cliff. 489, who says that he had never seen the flowers, but that the fruit is a polyspermous legumen, probably on the authority of Clayton.

Acacia americana, abruae foliis, triacanthos, sive ad axillas foliorum spina triplici donata. Cat. lond. 3. $t$. 21, without flowers, with a long polysper-. mous legumen inserted into a branch, probably from North America, the flowers being said to drop off in the neighbourhood of London, without producing legumina.

Acacia triacanthos, siliquis latis fuscis, pulpa virescenti subdulci. Gron. virg. ed. i. 59.

Acacia americana, abruae folio, triacanthos. Pluk. mant. 1. t. 352. f. 1. No fructifications. GLEDITSIA triacanthos. Schoepf 154.

\section{TRAPA.}

Petals 4. Calyx quadripartite. Nut of 1 cell, and 1 seed, surrounded with spines formed from the calyx. Obs. 5336. $L$.

1. TRAPA quadricornis. Nuts with 4 patent spines. Obs. 5336. Specimen from M. Hertel. T. natans, $L$. fil. suppl. 128. L. suec. n. 140;

Q 3 
sp. 175; mant. 332. Hort. Kew. i. 164. Silth. prodr. n. 368.

Tribuloides vulgare, aquis innascens. Vaill.paris. 194.

Tribulus aquaticus major. Park. theatr. 824, cop. from

Tribulus aquatilis. Dod. 571 , which repr. in

Tribulus aquaticus. Lob. obs. 324 ; ic. i. 596, and Ger. by Johns. 824, and cop. in Dalech. 1083. Bauh. J. iii. 775. cop. from Trag. 811, the 4 uppermost figures.-Cam. epit. 715.

Panover-Tsjeraua. Rheede xi. 63.t. 33.

Native of Hindostan, the northern borders of Greece; Italy, France, Germany, and Sweden. TRAPA natans. Bryant 365. Krock. n. 246. Tribulus aquaticus. Chiom. 623. Dale 267. Geoffr. suite iii. 229. Murr. iv. 86. Spielm. 122.

Nux aquatica. Berg. 72 Linn. 57. Mill. Jos. 314. Vog: 273.

Water Nuts: Thunb. trav. iv. 38.

Sringataca. Jones in asiat. research: ii. 350.

\section{POTHOS.}

Calyx none. Petals 4. Berry bilocular. Seeds solitary. From L.

1. POTHOS scandens. Petioles about as broad as the laminae of the leaves. Stem radicant. From $\boldsymbol{l}$. a Murr. 829; sp. 1374,

Adpendix duplo folio. Rumph, v. 490, t. 184, \& ANA-PARUA. Rheede vii. 75. $t$. A0 Laminae broader than the petiole. 
Monogynia. 101. Cumphorosma. 231

2. POTHOS pinnatifida.-Leaves pinnatifid. $l$.

'P. pinnata. L. sp. 1374.

ADPENDIX LACINIATA. Rumph. v: 489.

t. 183. f. 2.

\section{KRAMERIA。}

Calyx none. Petals.4. Nectaria 2; the upper tripartite, the lower diphyllous. Berry dry, echinate, monospermous. $L$. $\quad \cdots \quad \cdots$

1. KRAMERIA triandra? Stamina 3. From Ruis quoted by Gillespie in phys. journ. xiv. 127...

\section{0.' SALVADORA.}

Calyx inferior, quadridentate: Corolla quadrifid, campanulate. Style none or very short. Berry monospermous., From Koenig in Roxb. and Roxb. - L .

Wallenia of Swartz differs in having a tubular corolla and a style half as long as the corolla.

1. SALVADORA persica... L.:sp. Its; a Mrurr. 166. Vahl. symb. i. 12. $t$. 4. Roxb. i. 26. $t$. 26.

Rivina paniculata. L. a Hurr 165.

SALVADORA. Vog. 117.

\section{CAMPHOREOSMA.}

Calyx tetraphyllous. ' Corolla none. Style bifid. Capsule of 1 call, with 1 seed. Obs.4286. L.

Q 4 
1. CAMPHOROSMA hirsuta. Leaves subulate, hirsute. Obs. 4286. Specimen gathered in the $\mathrm{P}_{2}$. ris grarden.

C. monspeliaca. L. sp. 178. Hort. Kezo. i. 166. (Mill. $P h$. dict. n. 1 is described as an annual.)

Camphorata hirsuta. Buxb. i. 18. t. 28. f. 1 . R'aii hist. 210; europ. 83. In the south of France.

Camphorata monspeliensium. Magn. monsp. 47. Bauh. J. iii. b. 379.

Camphorata monspeliaca. Lob. adr. 174, repr. in ic. i. 403, \& cop. in

Camphorata major monspeliensiuin. Park. theatr. 568.

Selago, sive Camphorata. Dalech. 1201. Caly $x$ apparently quadrifid, Obs. 4286.

CAMPHORATA. Berg. 74. Burlet in acad. sciences abr. by Southw. iii. 240. Dale 77. Geoffr. iii. 245. Linn. 58. Mill. Jos. 106. Murr. iv. 333.

Camphorata hirsuta.' Chom. 230. Vog. 95.

2. CAMPHOROSMA glabra. Leaves subtriquetrous, glabrous, not rigid. L. sp." 178. Mill. Ph. dict. n. 2.

Chamaepeuce Plinii, Camphorata minor. Dalech. 1179.

Camphorata minor. Raii hist. 211.

CAMPHORATA glabra. Vog. 95.

\section{PARIETARIA.}

Calyx inferior, quadrifid. Carolla none. Staminas 
4. Style filiform. Stigma round, hirsute. Seed 1, ovate. Obs. 7484. Juss. 404. L.

Female flowers interspersed, and in $\boldsymbol{P}$. judaica the flowers appear to be male and female,

1. PARIETARIA indica. Leaves trinervose, lanceolate. Bracteae subulate. From L. mant. 128, \&. Smith bril. 189, in treating of $\mathrm{P}$. officinalis. CRATEOGONUM amboinicum majus. Rumph. vi. 25. t. 10 .

2. PARIETARIA officinalis. Leaves triplinervose, - lanceolato-elliptic, and rhombeo-elliptic. Involucra tripartite. Obs. 7484. On the walls of Tutbury Castle, Staffordshire, and on old stone walls at Worcester and Lichfield, all built of red cos, but Mr. Knowlton informs me that he has seen it on the walls of York, built of magnesian limestone, and of Lismore Castle, in the county of Waterford, Ireland, built of schistus, and among the schistose rocks of Ouneshade Glen near Lismore.-Smith brit. 189. L. a Willd. iv. 953; sp. 1492; a Murr. 908. Pollich n. 940. Walc. t. Curt. lond. iv. 63. t. Lightf. 634. Bot. arrang. 1141. Gouan. hort. 516. Fl. dan. t. 521. Woodv. iii. 384. $t$. 142.

P. judaica. Mill. Ph. dict. n. 2. On old walls in most parts of England.

P. foliis elliptico-lanceolatis. Hall. hist. $n$. 1612.

P. foliis lanceolato-ovatis. L. cliff. 469. Royen 211.

P. foliis helxines. Boccon. sic. 47. t. 24. A.

P. officinarum, et Dioscoridis. Tourn. paris. 292. Vaill. paris. 157. Boerh. ii. 92. In Holland.Magn. monsp. 199; hort. 153. Hist. ox. s. 5.t. 30. row 3. f. 1, abr. from 
Helxine. Cam. epit. 849. Lonic. 166. Füchs. fol. ed. 277, cop): in

Helxine, seu Parietaria. Fuchs. 12 mo ed. 278. c. 107,

Parictaria. Turn. ii. 14, and Bauh. J. ii. 976. Tab. ic. 550. 'Brunsf. i.'262, cop. in Trag. 193. Raii syn: 158. Dod. 102; repr. in Ger. by Johns. 331 ,

Helxine sive Parictaria.' Lob.obs. 131, cop. in P. vulgaris. Park. theatr. 437, repr. in Helxine. Lob. ic. i. 258, and cop. from Matth. 1113:

Stems pubescent, brittle, mostly erect, to 2 foet long. 'Branches short. Levives triplinervose at the base; upper surface slightly shining and slightly scabrous; young ones pubescent, at length nearly glabrous. "Heads" orbicular, axillary, sessile, in pairs, on the stem and branches, with frequently a young branch between them. ' Involucra generally with 7 flowers," tripartite; the lowermost segment lanceolate; the lateral ones deeply trilobate; segments subrotundo-ovate, the '2 lateral ones with 2 subrotundo-ovate appendages rising from the base. Flowers from 3 to 7 in each involucrum; the female one solitary, in the center, at the base of the middlemost segment; and the hermaphrodite. ones fertile, generally 3 in each of the lateral lobes, the middlemost flower of eacl set placed at the base of the iniddlemost lobe, and each of the remaining 2 at the base of the lateral lobes and supported on the sides by the appendagés. Calyx greenish, tinged with purplish pink, villose, within lanuginose; that of the female flower ovate, acute, probably quadrifid, being easily separable into 4 triangulari-subulate segments cohering by villi and lanugo; slightly tetra- 
gonous, as long as the segment of the involucrum at its base ; that of the hermaphrodite flower campanulate, quadrifid, extending a little bcyond the involucrum; segments triangulari-ovate, acute, concave. Stamina somewhat longer than the calyx. ' Filaments subulate, fleshy, with transverse rugae, bowed in before flowering. Germen shining. Style as long as the germen, crimson, caducous. Stigma crimson; bairs at the base longer and more patent than the rest. Obs. T4S4.

PARIETARIA. Herb. Pharm. lond.-Alst. ii. 195. Berg. 824. Geoffr. suite i. 328. Hill 378. Lew: ii. 188; disp. by Dunc. 274. Linn. 265. Mill. Jos. 333. Monro iii: 198. Murr. iv.570. Rutty 379. Spielm.566. Vog. 74. Helxine. Dale 76.

Pellitory of the wall. Bisset ess. 162.

Parietaire. Chom. 711 ; suppl. 194.

\section{ALCHEMILLA.}

Calyx octofid. Corolla none. Stamina 4 , or 1. Seed one. Obs. 4746. $\boldsymbol{L}$.

1. ALCHEMILLA lobata.-Leaves lobate. $L$.

A. vulgaris. L. suec. $n .141 ; s p .178$. Mill. Ph. dict. n. 1 ; ic. 12. t. 18. Fl. dan. t. 693. Krock. n. 247. Bot. arrang. 162. Smith brit. 189; engl. t. 597.

ALCHIMILLA. Alst. ii. 78. Cartheus. iv. 208. Dale 76. Geoffr. iii. 51. Herm. 562. Lew. i. 43. Linn. 58. Mill. Jos. 21. Rutty 12. Spielm. 374. Vog. 49.

Alchimilla vulgaris. Chom. 567. 
Alchemilla. Berg. 75. Lew. disp. by Dunc. 86. Murr. iii. 149. Ploucq. bibl. i. 406.

- glabriuscula. Leaves pubescent at the margin and underneath. Obs. 4746. In Wingerworth park near Cliesterfield.

Pes leonis. Fuchs. 584. c. 231, cop. in

Pes leonis, sive Alchimilla. Bauh.J. ii. 598. i. \& Alchimilla. Dod. 140, which repr. in Ger. by Johns. 949. Trag. 512. Raii hist. 208; syn. 158. Lob. ic. i. 663, cop. in

Alchymilla major vulgaris. Park. theatr. 538.

Stellaria. Dalech. 1281.

Stem 13 inches long. Leares glabrous on the upper surface. Calyx, the 4 outer segments as narrow again as the 4 inner, nearly as long. Obs. 4746.

6 pubescens. Iscaves pubescent all over. Obs. 387.

On the side of a rivulet in a plashy ground just under Malvern wells Worcestershire, and in the plain below Malvern hills.

A. vulgaris $\beta$ L. sp. 179 where $\beta$ ought to be placed opposite to the line A. minor.-Huds. \& Bot. arrang. $162 \beta \delta$

Alchimilla pubescens minor. Schol. bot. 230. Pluk. aln. 18; phyt. t. 240. t. 2.

A. hybrida. Mill. Ph. dict. n. 2; ic. 12. t. 18, inner fig.-Leaves obsoletely lobed.

Alchymilla minor, hirsuta cineritia italíca. Barr.t. 728.

2. ALCHEMILLA monandra. Leaves multifid. Stamen one. Obs. 413. In corn fields.-Swartz prodr. 38 ?

A. A phānes. Bot. arrang. 163. Roth germ. ii. 195. Retz. scand. n. 206. 
A. arvensis. Scop. carn. n. 175. Smith brit. 190; engl. t. 1011.

Aphaues arvensis. L. suec. $n .143$; sp. $179 . F \%$ dan. t. 973.

A. montana minima. Col. ecphr. i. 145. t. 146. Tourn. paris. 48. Vaill. paris. 4.

Percepier anglorum. Ruii hist. 209; syn. 159. Lob. adv. 32t, repr. in ic. i. 727; Ger. by Johns. 1594, and enlarged in Dalech. 713, which cop. in

Polygonum selinoides, sive Percepierre anglorum. Park. theatr. 449.

Perchepier anglorum quibusdam. Bauh. $J$. iii. $b$. 74. Boerh. ii., 93.

Natice of Europe from Italy to Sweden, and pro.bably of America from the Antilles to Virginia. PERCEPIER. Dale 76. Mill.Jos. 338.

\section{I G Y N I A.}

\section{HAMAMELIS.}

Calyx tetraphyllous. Petals 4. Nectaria 4, alternating with the stamina. Nut with 2 horns, and 2 cells. Obs. 2645. $\boldsymbol{L}$.

1. HAMAMELIS virginica. L. $s p .180$; mant. 393. Hort. Kezo. i. 167.

Hamamelis. Gron. virg. 22. Calesb. append. 2. t. 2. Cutl. in amer. acad. i. 412.

H. androgyna. Walt. carol. 255. 
Calyx, phylla ovate, obtuse, recurvate, slightly villose at the margin. Petals of the same colour as the calyx, glabrous, inserted at the base of the germen. Neclaria compressed, obtuse, fleshy, reflexopatent, as long as the filaments, inserted between the petals and the germen. Antherae bilocular. Germen with a few scattered hairs. The number 4 prevails in a remarkable manner, and the styles are half the number. Obs. 2645. In a garden, in Feb. when none of the leaves had appeared.

HAMAMELIS virginiana. Schoepf 15.

\section{CUSCUTA.}

Calyx quadrifid, and quinquefid. Corolla monopetalous. Capsule with 2 cells. Obs. 4389. 4391. 4386. Specimens dried.-L.

1. CUSCU'TA urceolata. Nectaria none. Obs. 4552. Specimen gathered by Broughton in Britain.

C. europaca L. suec. n. 144 a; sp. 180 a; a Murr. 167. Bot. arrang. 165. Smith engl. bot. t. 378; brit. 232. Fl. dan. t. 199.

Cassutha. Dalech. 1683. Dod. 545, repr. in Epithymbra, Epithymum, et Cassitha Plinii. Lob. obs. 233,

Cassitha Plinii, C, officinarum. Lob. ic. i. 427, \& C. sive Cassutha. Ger, by Johns. 577, \& cop. in Cuscuta. Park. theatr. 10. Raii hist. 1903. Cassutha, sive Cuscutha. Fuchs. 343, c. 132, cop. in

Cassuta, sive Cuscuta. Bauh. J. iii. b. 266, and imit. in

Androsaces, vulgo Cuscuta. Trag. 810. 
C. major. Vaill. paris. 43.

Corolla urccolnte. Neclaria so small, if present, as not to be distinguished in dried specimens. If not present in this species the absence of nectaria will afford the best characteristic. Obs. 4391. Mar. 5 . 1797, before I had seen Sroith eng, t, 378 though published $1 \mathrm{Jan}$.

CUSCUTA. Berg. 76. Dale 186. Herm. 524. Krock. n. 250. Linn. 50. Mill. Jos. 166. Murr. i. 194. Spieln. 633.

C. major. Alst, ii. 124. Chom, 504. Geoffr. iii. 386.

2. CUSCUTA campanulata, Nectaria at the base of the stamina. Stigmata simple. Obs. 8042. Spemen gathered by Dr. Winstanley in the west of England.

C. Epithymum. L. a Murr. 167. Bot. arrang. 166. Smith engl. bot. 378; brit. 283. Fl. dan. $t$. 427.

C. europaea. L. suec. n. 144 \& Huds, 104. Smith engl. bot. $t .55$.

C. europaea epithymum, L. sp. 180.

C. minor. Tourn. paris. 426. Vaill. paris. 43.

Epithymum Matthioli. Dalech. 1682.

Epithymum graecorum et arabum. Lob. ic. i. 427, cop. in Dalech. 1682.

Epithymum, Park.theatr. 10.

Epithymum, sive C. minor. Raii hist. 1904.

EPITH YMUNI. Alst. ii. 124. Berg. 77. Chom.

74. Dale 186. Geoffr. iii. 386. Herm. 524.

Krock. n. 250. Lewo. i. 414. Linn. 59. Mill.

Jos. 186. Murr. i. 195. Rutty 180.

Epithymum, sive C. minor. Chom. 505. 


\section{HYPECOUM.}

Caly $x$ diphyllous. Petals 4 , the 2 outer broader. Siliqua. Willd. $L$.

1. HYPECOUM procumbens. Siliquac bowed, compressed, jointed. The 2 larger petals obtusely trilobate. L. a Willd. i. 704. L. sp. 181. Hort. kew. i. 168. Gouan. hort. 74. In several places about Montpelier;-monsp. 173. Sibth. prodr. n. 377.

H. siliquis articulatis incurvis erectis. Magn. hort, 101.

H. latiore folio. Bocrh. i. 30T.

Hypecoum. Magn. monsp. 134.

Hypecoon. Clus. hisp. 407, in the south of Frarice: about Salamanca, and throughout Castile, Granada and Murcia ; repr. in Dod. 446,

H. legitimum. Clus. hist. ii. 93, \&

Cuminum corniculatum, sive H. Clusii. Ger, by Johns. 1067.

Cuminum sylvestre, II Matthioli.. Dalech.697, the drawing probably made from a specimen gathered by J. Bauhine at Baleruch near Montpelier.

II. siliquosum. Bauh. J. ii. 899. (The fig. is Papaver amplexicaule.)

H. legitimum Clusii. Park. theatr. S71. Raii hist. 1328. Near Messina in Sicily.

Natice of Greece, Italy, Spain, and the south of France.

HYPECOUM. Boerh. 387.

Hypecoon. Dale 268.

Үør:xoov, Diosc, l, 4: c. 68. 


\section{T E T R A G Y N I A.}

\section{0\%. ILEX.}

Caly $x$ quadridentate. Corolla rotate. Style none. Berry tetraspermous:s: $\boldsymbol{L}$ :

1. ILEX Cassine. Leaves lanceolate, and lanceolatooblong, serrato-dentate, and margin nearly entire, evergreen, distant, alternate; teeth acuminate. Obs. 8045. In Mr. Knowlton's garden.-Hort. kew. i. 170 .

a dentata. Leaves lanceolato-oblong, serrato-dentate, glabrous. Obs. 8045. Hort. kero. i. $170 \propto$

I. Cassine. L. sp. 181.

Agrifolium carolinense, foliis dentatis, baccis rubris: Calesb. i. 31. t. 31. In fruit.

CASSINE. Schoepf 17.

Cassina. Linn. 59.

B integerima. Leaves mostly entire at the margin; costa villose underneath. Ols. 8337. Specimen 'gathered in Fothergill's garden.

I. Cassine angustifolia. Hort. kerw. i. 170.

I. Dahoon. Walt. carol.241. Michaux ii. 228.

2. ILEX romitoria. Leavies oblong, bluntish; crenato-serrate, distant, alternate; serratures without spines. $H . K$. i. 170 :

1. Cassena. Michaux ii. 229.

Cassine vera flóridanorum, arbuscula baccifera, alaterni ferme facie, foliis alternatim sitis, tetrapyrene. Pluk. mánt. 40.t. 3í6. f. 2. No fructi- 
fications. Leaves acute-Catesb. ii. 57. t. 57.

In fruit. Leaves acute.

Arbor non spinosa. Gron. virg. 22.

Native of Florida, South and North Carolina, and Virginia.

CASSINE. Vog. 97.

Cassina. J)alc 319.

Arbor non spinosa. Schoepf 17.

I. vomitoria. Bart. 38.

Cassena. Coxe 369.

3. ILEX Aquifolium: Leaves elliptic, spinose and entire at the margin, shining, undulate. Flowers axillary, and internodial, mostly umbellate. Obs. 5337. Specimen gathered at Corby castle near, Carlislc.-L. sp. 181. Bot. arrang. 168. Walc. t. Smith brit. 192; engl. t.'496. F. dan.t. 508. Sibth. prodr.n. 379.

Agrifolium. Raii hist.1622 ; syn. 466: Dod.746.

Ger. by Jolins. 133s, repr: from

Aquifolium, sive Agrifolium. Lob. ic. ii. 153.

Aquifolium sive Agrifolium vulgo. Bauh.J. i. $b$.

114. No fig.-Tourn. paris. 392. Vaill. paris. 15.

Aquifolia. Trag. 1067.

Aquifolium. Dalech. 147; (misprinted 247.)

Agrifolium sirc Aquifolium. Part. theatr. 1487.

Aquifolium folio levi et aculeato toto. Park. theatr.

1487.

The Holly Tree. Evel. by Hunt. ed. ii.t. at i. p. 262.

a rubra. Berries red. Obs. 5338. Neàr W Worcester. I. Aquifoliun vulgaris. Mớt. kęs. 169. I. Aquifoliun lieterophylla." Hort.liew. i. 169. Aquifolinn baccis rubris. Bocrh. ii. 219. 
Texkagyria. 108. Myginda.

Native of Europe from Greece and Italy to Scotland and Denmark.

AQUIFOLIUM. Geoffr. iii, 107. Murr. iv. 10. Schoepf 16.

Agrifolium. Dále 322. Lew. disp. by Dunc. 342.

I. Aquifoliüm. Bandelow, account from in physs. journ. ii. 466. Ploucq. bibl. i. 131. 193. 484.

Houx. Chom. 733; suppl. 199.

VISCUM aucuparium. Berg. 77.

B nigra. Berries black. From

ILEX Aquifolium: Lour. i. 114.

\section{MYGINDA.}

Calyx quadripartite. Petals 4. Drupe globular. L.

1. MYGINDA uragoga. Leaves subcordate, acuminate, subserrate, pubescent. Swartz. prodi. 39; ind. occid: 941. L. 'sp.'1661.

MIYGIND'A urágoga." Jacq. amer. 24.'t, 16; the descr. repr. in sro"ed. 31. 


\section{Class 5. \\ P E N T A N D R I A.}

Order 1.

\section{O N O G Y N I A.}

1. Flowers monopelalous, inferior, monospermous. L.

134. Mrrabilis:

Nut invested by the base of the corolla. Stigma globular. Stamina united at the base. Obs, 5200.

135. Plumbago. Capsule monospermous. Stigma quinquefid.

2. Flowers monopelalous, inferior, tetraspermous. L.

119. EсHIU⿴.

Corolla, throat open; limb irregular. Obs. 4055.

109. Heliotropium, Corolla with an open throat, hypocrateriform, with plaits between the segments. Obs. 5378.

114. Pulmonaria. Corolla with an open throat; infundibuliform. Obs. 1319. 
116. ONosma.

Corolle with an open throat, campanulate and tubiform. Obs. 8058.

111. Lithospernum. Corolla with 5 oblong prominences in the throat, infundibuliform. Obs. 5741.

115. Symphytum. Corolla with 5 subulate prominences in the throat, infundibuliform. Obs. 202.

117. BORAGO,

Corolla with 5 emarginate appendages in the throat, rotate and hypocrateriform. Obs. 4496. 1315.

118. LYCOPSIS.

Corolla, throat closed by 5 appendages; tube curvate. Obs. 3955.

113. Crxoglossury. Corolla, throat closed by 5 appendages. Sceds depressed. Obs. 4797.

112. ANCHUSA.

Corolla, throat closed by 5 appendages. Seeds hollowed out at the base. Obs. 6387 .

110. Mrosotis.

Corolla, throat with 5 appendages; segments of the limb emarginate, Obs. 3818 .

3. Flowers monopetalous, inferior, Seeds in a pericarpium. L.

207. Achyranthes. Capsule monospermous, not opening. Corolla quinquepartite, Caly $x$ pentaphyllous. Obs. 6966.

ำ 9 
208. Celosia.

Capsule unilocular, cut round, polyspermous. Corolla semi. quinquefid. Calyx pentaphyllous. Obs. 6507.

157. Corss:- Capsule unilocular, quinquevallve. Corolla irregular. Stigma capitate. $\boldsymbol{L}$.

127. Hydrophylum. Capsule unilocular, bivalve. Corolla with 5 lamellar nectaria. Stigma bifid., Obs. 7784.

122. Cortusa.

Capsule unilocular, quinquevalve. Corolla infundibuliform. Stigma subcapitate. Obs. 7296.

129. Anagaluis. Capsule unilocular, cutround. Corolla rotate.

128. Lixsmachia.

Capsule unilocular, quinquevalve and decemvalve. $\mathrm{CO}^{-}$ rolla rotate. Obs. 3089.

124. Cýcuanes. Capsule unilocular, pulpy within. Corolla reflex. Stigma acute. $L$.

123. Soldanelua. Capsule unilocular. Calyx lácerate. Stigma simple. $\boldsymbol{L}$.

121. Primula. Capsule unilocular. Corolla hypocrateriform, and infun: dibuliform; throat open. Stigma globular. Obs. 4733.

125. Menianthes e! Capsule unilocular. Corolla infundibuliform, hirsute on the inner side. Stigma bifid. Obs. 4475. 
126. Limvanrunes. Capsule unilocúlar. Corolla rotate; segments denticulate. Obs. 4474.

218. Allamanda. Capsule unilocular, bivalve, orbicular; valves boatshaped. Secds imbricate.

172. Chrronia. Capsule unilocular, apparently bilocular. Corolla infundibuliform. 'Pistil declinate. Stigma obtuse. Obs. 6498.

132. Listavthus: Capsule bilocular; margíns of the valves involute. $\mathrm{Co}$ rolla infundibuliform, ventricose. Style permanent. Siigma bilamellate." Seeds numerous.

130. Spigelia.

Capsule hilocular, didymous. Corolla infundibuliform. Stigma simple. $\boldsymbol{L}$.

131. Ophrorhiza. Capsule bilocular; bípartite. Corollainfundibuliform.Stig. ma bifid. $\boldsymbol{L}$.

159. DatURA:

Capsule bilocular, quadrivalve. Corolla infundibuliform. Calyx, the upper half deciduous.

160. Hyoscyamus. Ciipsule bilocular, operculate. Corollainfundibuliform. Stig. ma capitate. $\boldsymbol{L}$.

161. Nicotians,

Capsule bilocular. Corolla infundibuliform. : Stigma emarginatc. $\boldsymbol{L}$.

R 4 
158. VERBASCUM.

Capsule bilocular. Corolla rotate. Stigma obtuse. Stamina declinate. $L$.

135. Convorvulus. Capsule bilocular, trilocular and quadrilocular. Corolla campanulate, plicate. Stigmala 2, and trilobate. Seeds solitary. Obs. 3089.

136. Iromoza. Capsule trilocular. Corolla infundibuliform. Stigma capitate. $L$.

137. Polemonium. Capsule trilocular. Corolla, mouth of the tube closed by the base of the stamina. Stigmata 3. Obs. 7103.

220. NERIUM.

Follicles 2. Corolla with a double limb. Seeds plumose. Obs. 5913.

221. ECHITES,

Follicles 2. Corolla infundibuliform. Seeds pappose.

222. Plumeria; Follicles 2. Seeds with a membranaceous border.

223. Tabernaemontaina. Follicles 2, pulpy. Co. rolla hypocrateriform. Seeds .... naked. $\boldsymbol{L}$.

219. VINCA.

Follicles 2. Corolla hypocrateriform, Seeds naked, Obs. 2705.

214. Cerbera.

Drupe monospermous. Nut bilocular, quadrivalve. From L.

179. BUMELIA.

Drupe monospermous. Corolla quinquefid; segments 
with a smaller segment on each side. Nectaria 5, inserted into the tube of the corolla. From Swartz.,

175. Cordia.

Drupe monospermous. Nut quadrilocular. Stigmata 4. Caly $x$ growing to the drupe. Corolla infundibuliform. Obs. 8477.

176. VARRONIA.

Drupe monospermous. Nut quadrilocular, and unilocu. lar. Stigmata 4. Corolla tubular., Obs. 5582.

211. Raurolfia. Drupe dispermous. Nuts bilocular.

174. BOURERIA. Drupe tetraspermous, separating into 4 parts. Nuts bilo. cular.

168. Ignatma,

Drupe polyspermous. Corolla infundibuliform; tube very long. Willd.

172. ERETIA:

Drupe bilocular. Nuts bilocular, 2 in each cell.

212. Paederia.

Berry dispermous, inflated, brittle. $\boldsymbol{L}$.

167. StRYChNos.

Berry unilocular, with from 1 to 5 seeds, with a hard rind. Stigma capitate.

196. LEA.

Berry unilocular, pentaspermous. Corolla quinquefid. Nectarium quinquefid. Sta. mina inserted into the nectarium, 
178. 'Sneroxyuur:" Berry unilocular, pentaspermous. Corolla decenfid, the inner segments connivent.

195: Dartús.

Berry unilocular, polysper. mous, diaphanous. Corolla campanulatc. Stigma quinquelobate. From Lour.

171: Ormoxxum.

Berry bilocular, didymous; cells monospermous. Corolla tubiform, quinquefid at the end. Calyx pentaphyllous. Obs. 7866.

120. Tounnefortri. Berry bilocular; pierced at the end; cells dispermous. Willd.

166. Capsicun. Berry bilocular, juiceless. Corolla rotate. Antherae connivent. Obs. 6485.

165. Solavion. Berry bilocular: Corolla rotate. Antherae mostly coherent, and opening at the end by 2 pores. Obs. 6483.

164. Prysalis: Bèry bilocular. Corolla rotate and cańpanulate. Antherae connivent. Calyz of the fruit inflated. Obs. 6048.

162. Atrop A. Berry bilocular. Corolla campanulate. Stamina distant, incurvate. .L.

170. Lycrił。 Berry bilocular, polyspermous. Corolla tubular, closed by hairs.

213. Carissa.

Berry bilocular ; cells disper. 
mous and tetraspermous. Co.r. rolla infundibuliform. Seeds icompressed. From authors. 169. Cеsтrum. 1... Berry bilocular, mous. Corolla infundibuliform. Seeds roundish. Obs, 5459.

163. Nicandia. Berry trilocular, quadrilocu. darand quinquelocular. ' $\mathrm{Ca}$ rólla campanulate. Calyx quinquepartite, with 5 angles projecting backwards. Obs. 6047.

197. ABGYEEIA. Berry quadrilocular; mónospermous and dispermous. Corolla quinquepartite, plicate. Calyx pentaphyllous. From Lour.

177. Chrysophylunum. Berry decemlocular: Seeds solitary. Corolla quinquefid. Stigma quinquecrenate. Obs. 5580.

4. Flowers monopetalous, superior. L.

141. Saẓolus. Capsule unilocular, quinquevalve at the end. Corolla hypocrateriform. Stigma capitate. $\boldsymbol{L}$.

156. MUSSAENDA. Capsule bilocular, polyspermous. Calyx quinquefid. Seeds in 4 rows.

145. Crinchona. Capsule bilocular, bivalve, polyspermous. Calyx quin- 
quedentate. Dissepiment in. serted into the edges of the valves. Obs. 2556.

143. Pobrlandia.

Capsule bilocular, bivalve, pentagonal; dissepiment in. serted into the sides of the valves. Calyx pentaphyllous. Obs. 2312.

139. Phyteuma.

Capsule bilocular and trilocu. lar, perforate. Corolla quinquepartite; segments linear. Stigma bifid and trifid. Obs. 4627.

138. Campañua. Capsule trilocular, quinquelocular, and sexlocular, perforate. Corolla campanulate and rotate, Stigma trifid and quinquefid. Obs. 6501.

110. Lовízis.

Capsule bilocular, trilocular, quadrilocular and quinquelocular. Corolla cloven lon. gitudinally along the upper side. Antherae united into a cylinder. . Obs. 2963.

144. ScaEvola.

Drupe monospermous. Co. rolla irregular, flabelliform, with a longitudinal fissure. $\boldsymbol{L}$.

151. Morinda.

Berry monospermous, . Stigma bifid. Corolla infundi. buliform.

149. Psychotrin.

Berry dispermous. Corolla hypocrateriform. Stigma bi: partite. Obs. 8185 . 
150. Antherura.

14S. Vanguebia.

147. Chrococca.

146. Coffea.

215. Canthium.

216. Genipa.

217. GardenIA.

1ว้2. Loricera.

153. Triostaux.
Berry dispermous. Corolla rotate. Antherae caudate. Stigma simple. From Lour. Berry tetraspermous and pentaspermous. Corolla hypocrateriform; tube globular; throat hairy. L. a Willd.

Berry bilocular. Seeds solitary. Corolla infundibuliform. Stigma simple. Obs. 5479.

Berry bilocular. Seeds solitary, arillate. Corolla hypocrateriform. Stigma bipartite. Obs. 7979.

Berry bilocular; cells monospermous. Corolla infundibuliform. Stamina not pro。 jecting.

Berry bilocular; cells polyspermous. Corolla infundibuliform. Calyx entire. From Plum.

Berry unilocular, bilocular, and quadrilocular, polyspermous. Corolla infundibuliform and hypocrateriform. Calyx with 5 divisions. From $\boldsymbol{L}$.

Berry bilocular and trilocular, polyspermous. Corolla unequal. Stigma capitate. Berry trilocular; cells mon. 
(4...) . Corolla nearly. -cqual. Sligma oblong.

155. Enirilalis." "Berry decemlocular. Corolla 'rotate. Calyjx' cquinquedentate.

\section{Flowers pentápelalous, inferior. L.}

201. Argiceras. Capsule unilocular, univalve, monidspermous, bowed. Calyx quinquefid. Willd.

189. Vióna. is Capsiele unilocular, trivalve. Córolla irregular, calcarate. Calyjx pentaphyllous. Antherae coherent. Willd.

190. Inpatiens. Capsule uniloculàr, quinquevalve. Corolla irregular, calcarate; petals 5 and $3 . \mathrm{Ca}$ ly $x$ diphyllous. Ols. 5896.

142. Naudzea. Capsule bilocular, polyspermous: Corolla infundibuliform.'

188. Hovenia:

Capsule trilocular; cells mo. nóspermous. 'Stigmata' 5 . From L. a Willd.

1S6. Neunotiat.

Cipsule trilocular, polyspermous. Caly $x$ campanulate; tube permanent; teeth deciduous. From Lour.

185. Celastrus. Capsulè trilocular; cells with 1,2 , and several seeds. Obs. 5614.

184. Scoroura. Capsule berrylike, quinquelo- 


\section{Monogynia.}

cular; cells monospermous. Stigma capitate. $L$. a Willd.

187. Evoryuss. Capsule pentacoccous and tetracoccous; cells with 1 and 2 seeds. Obs. 3735.

183. Ceanothus.

Berry dry, tricoccous; "cells monospermous. Petals inserted into the calyx. Obs. 5616.:

180. Rhamés. Capsule or berry with from 2 to 5 seeds. Caly $x$ campanulate. Petals 5 ; 4 , or none, inserted into the calyx. Obs. 358.

200. BOtrY A.

Berry unilocular, monospermous." Calyx campanulate. Style none. Stigma concave.: From Lour.

199. VITIS.

Berry unilocular, with from 1 to 5 seeds. Style none. Germen quinquelocular and bilocular. Obs. 6058.

193. Mangifera. Drupe monospermous. Calyx pentaphyllous. Stamina 3 and 4 barren.

181. ZızYPHUS. Drupe monospermous and dis: permous. Nut bilocular. Calyx monophyllous.

192. Elazodendrum. Drupe monospermous." Nut bilocular. C'alyx pentaphyllous.

191. Valkeria. Drupes '5, monospermous. Calyx quinquepartite. . L. a : : W. 
6. Fowers pentapetalous, supcrior. L.

202. LagOeCIA.

Seed 1. Petals with 2 horns. Calyx with multifid seg. ments.

182. Gousinis.

Capsule trilocular, cells monospermous. Pelals inserted into the calyx.

194. Ríes.

Berry polyspermous. Petals inserted into the calyx. Style bifid. $L$.

198. HEDERA.

Pomum with from 3 to 5 cells. Calyx semisuperior. Stigma simple. Obs. 4176.

7. Flowers incomplete, inferior. ' $\mathbf{L}$.

209. Gomphrena.

Capsule monospermous, cut round. Obs. 5135.

206. Herniaria'.

Capsule monospermous, scarce. ly opening. Caly $x$ quinquepartite. Seed orbicular, vertical. Obs. 6518.

204. Ilze cebrum. Capsule monospermous, quinquevalve. Calyx pentaphyllous. Obs. 6513 .

205. Polium.

Capsule inilocular; polyspermous. Calyx decaphyllous. From Lour.

210. Ceratoria. Legumen. Calyx quinquefid. Stamina 5 to 7. Obs. 3275.

8. Flowers incomplete, superior. L.

154. Conocarpus,

Capsule monospermous, not opening. Calyx quinquefid. 
203. MuZs.

Berry trilocular. Caly $x$ di phyllous. Obs. 5362.8569。

Order 2.

\section{I G Y N I A.}

1. Flowers monopetalous, inferior. $\mathbf{L}$.

241. Gevitiana.

240. Sivertid.

236. CRESSA:

231. Stapelia.

229. СуNATCHUM:

226. Periploca:

Capsule unilocular, bivalve. Corolla rotate, campanulate, infundibuliform and bypo: crateriform. Calyx quinquepartite. Obs. 4461.

Capsule unilocular, bivalve. Corolla rotate, with nectariferous pores at the base of the segments. Calyx quinquepartite.

Capsule unilocular, bivalvè. Corolla hy pocrateriform; limb reflex. Calyx pentaphyllous. Follicles 2. Corolla rotate. Nectaria stellate. $\boldsymbol{L}$.

Follicles 2. Corolla rotate. Nectarium cylindric. $\boldsymbol{L}$.

Follicles 2. Corolla rotate. Nectarium quinquefid; seg. ments filiform at the end. Obs. 5561 . 
228. Asclepias.

294. UnCEOLA.

230. Ceropegia.

225. APOCYNU.

227. Pergularia.
Follicles 2. Corolla rotate. Nectarium infundibuliform. Antherae bilocular. Pollen none. Glands 5, bilobate, filling the antherac. Obs. 3997.

Follicles 2. Seeds immersed in a pulp. Corolla urccolate.

Follicles 2. Corolla infundibuliform. Nectarium, stamina, and pistil as in Ascle. pias. From Roxb.

Follicles 2. Corolla campanulate, with 5 triangular appendages at the base on the inner side. Nectaria 5, 0vate, glandular. Obs. 1373. Follicles 2. Corolla hypo. crateriform. Nectaria 5, semisagittate. $L$.

2. Flowers pentapelalous, inferior. L.

239. Hetcher $\Lambda$.

Capsule bilocular, birostrate. Petuls inserted into the calyr. Filld.

3. Flowers pentapetalous, superior, dispermous, sessile or subumbellate.

Calyx in this and section 4,5 and 6 frequently obsolete. 212. ERYigits.

Secds covered witl scariose squamae. Caly.x pentaphyllous. Obs. 4522 . 
243. Hrorocotyle. Fruit orbicular. Seeds semiorbicular, united by tlieir margins. Obs. 7849.

216. Ecrinophora. Seeds covered by the indurated involucellum. Mrarginal flowers barren; central flower sessile. From Juss.

4. Flowers pentapetalous, superior, dispermous, umbellate, with incolucra and involucella.

Q44. Astrantia.

Flozers abortive. Involucra coloured; Fruit costate; cos* tae serrate. Obs. 1675.

260. HERACLEUM.

Flowers radiate, abortive. Fruit compressed, oval, emarginate. Seeds bordered, tricostate in the middle. Obs. 5149 .

267. Oenanthe.

Flowers radiate, those of the radius abortive. Caly $x$ quinquepartite. Seeds crowned, striate. Obs. 4049.

248. Caucalis.

Flowers radiate, abortive. Seeds hispid. Calyx quin. quedentate. Obs. 675.

219. Artedia.

Flowers radiate, abortive. Inrolucrum pinnate. Fruit with a deeply crenate border.

247. Tordxuium. Flowers radiate, fertile. Inrolucrum simple. Fruit orbicular; border elevated, crenate. Ols. 4969.

s 2 
259. LASERPITIUM.

255. Peucedanum。

252. Coniuxi.

251. BunIUM。

254. Athamanta.

945. BupleuruM。

263. Sivir。

253. Selinum.
Fložers flosculose, abortive. Petals emarginate. Sceds with winged angles. Obs。 5038.

Flowers flosculose, abortive. Seeds bordered, sulcate in the middle. Petals entire. Obs. 7725 .

250. Anм1. Flowers flosculose, fertile. Involucrum pinnate. Fruit striate. Petals emarginate.

Flowers flosculose, fertile. Petals cordate. Seeds gibbose, costato-sulcate; costae crenate. Inrolucella dimi. diate.

Flowers flosculose, fertile. Pelals cordate. Incolucella setaceous. Fruit ovate.

Flowers flosculose, fertile. Petals cmarginate. Seeds ovato-oblong. Obs. 4660.

Flowers flosculose, fertile. Petals entire. Fruit slightly compressed, striate. Obs. 4657.

Flowers fosculose, fertile. Petals emarginate. Secds costate. Obs. 4658.

Flowers flosculose, fertile. Petals emarginate. Secds Hat, bordered, with 3 ridges in the middle. Obs. 5033. 
266. Comsur.

258. Ferula.

256. Crithius.

265. Bubon.

257. CACHRYs,

261. Ligueticum。

262. Avgelica,

264, Sịson,

Flowers flosculose, fertile. Petals cmarginate. Seeds tricostate, with 4 alternate hispid ridges. Obs. 7729.

Flowers flosculose, fertile. Petals entire. Seeds tricostate, flat. Obs. 7694.

Flowers flosculose, fertile. Petals entire. Fruit oval, compressed, striate. From L.

Flowers flosculose, fertile. Petals lanceolate. Calyy quinquedentate. Fruit ovate, striate, From $\boldsymbol{L}$.

Flowers flosculose, fertile. Petals entire. Fruit with a corklike rind. From $\boldsymbol{L}$.

Flowers floșculose, fertile. Petals entire. Seeds sulcate. Obs. 7688.

Flowers flosculose, fertile. Petals entire. Seeds bordered, convex, with 3 membranaceous angles.

Flowers flosculose, fertile. Petals entire. Seeds costate. Obs. 6317.

5. Flowers pentapetalous, superior, dispermous, umbellate, with involucella.

270. Aethusa.

Flowers subradiate, fertile, Seeds sulcate, Obs. 5140, s 3 
271. Corrandrum. Flowers radiate, abortive. Fruil splıcrical or didymous. Pelals bipurtitc.

272. Scandix. Flowers radiate, abortive. Pelals emarginate. Seeds rostrate. Obs. 121.

273. MrRRIIS.

Flowers radiate. Pelals emarginate. Seeds oblong, sulcate and striatc. Obs. 7704 .

274. Chaerophylum. Flowers flosculose, abortive. Seeds oblong, attenuate, smooth. Obs. 5894.

268. Phellandrum. Flowers flosculose, fertile. Petals obcordatc. Calyx quinquedentate. Fruit smoath. Obs. 5048.

275. SESELI. Flowers flosculose, fertile. Petals emarginate. Seeds sulcatc. Obs. 7712.

269. Crcuta.

Flowers flosculose, fertile. Petals ovate. Calyx quinquepartite. Fruit sulcate. Obs. 7482.

6. Flowers pentapetalous, superior, dispermous, umbellate; wilhout involucra and involucella.

278. Smyrnium。

Flowers flosculose, abortive. Petals lanceolate. Seèds, the outer side with 3 angles, the inner edge acute. Obs. 5159. 
280. Caruk. Flowers flosculose, abortive. Petals emarginate. Seeds quinquecostate. Obs. 5741.

276. Tirarsia. Flawers flosculose, fertile. Seeds emarginate, with a membranaceous border. $\boldsymbol{L}$.

277. Pastinaca.

Flowers flosculose, fertile. Seeds bordered, compressed, even, tricostate in the middle. P.etals entire. Obs. 3060.

279. Axethun. Flowers flosculose, fertile. . Petals entire. Seeds bordered, flat, on the outerside convex, sulcato-tricostate in the middle. Obs. 7705 .

282. ApIUM.

Flowers flosculose fertile. Petals entire. Seeds costate. Obs. 5028.

281. Pinpinelia. Flowers flosculose, fertile. Petals emarginate. Seeds quinquecostate. Obs. 5152.

7. Flowers pentapetalous, superior. Seeds in a pericarpium.

283. PANAX.

Berry bilocular; cells monospermous.

8. Fowers incomplete. L.

232. Cinexopodium. Seed 1, lenticular, horizontal. Caly $x$ pentaphyllous.

54 
233. Arbiplex:

235. Salsola,

238. Celtis,

234. BETA.

237. Ulmus.
Seed 1, lenticular, that of the hermaphrodite flowers hori. zontal; that of the female flowers vertical. Calyx of the bermaphrodite flowers pentaphyllous, that of the female flowers diphyllous.

Capsule monospermous. $C a$ ly $x$ quinquepartite. Seed reniform. Obs. 4472.

Capsule monospermous. Calyx pentaphyllous. Seed cochleate.

Capsule monospermous, compressed, with a membranaceous border. Calyx quinquefid and sexfid. Obs. 2678.

Drupe. Calyx quinqueparo tite and sexfid.

Order S.

\section{T R I G Y N I A.}

1. Flowers inferior, $\mathbf{L}$.

290. TamaniX.

Petals 5. Capsule unilocular. Seeds pappose. Style none. Obs. 3733.

293. SAROTHAA。

Petals 5. Capsule unilocular. Styles 3. 
289. Staphýlea. Petals 5. Capsules 3 and 2, connate. Olis. 260.

2S5. RHus. Petals 5. Berry monospermous. $L$.

2St. Avacardium. Pelals 5. Drupe cordate, cellular, monospermous. $\boldsymbol{L}$. fil.

2ST. Paliurus.

Pctals 5. Drupe dry, with a circular wing round the middle. Nut with 3 and 4 cells. Obs. 5610.

201. Pharnaceun. Petals 5, or none. Calyx pentaphyllous. Capsule trilocular, From $\boldsymbol{L}$.

292. Basella. . Corolla none. Calyx septemfid, becoming a berry. Seed 1 .

2. Flowers superior. L.

286. Viburnum. Corolla quinquefid. Berry monospermous. $\boldsymbol{L}$.

288. Sambocus. Corolla quinquefid. Berry trispermous. $\boldsymbol{L}$.

Order 4.

\section{T E T R A G Y N I A.}

295. Erozvulus.

291, PARKA881A
Corolla monopetalous. Fram L.

Petals 5. Nectaria 5, ciliate; hairs globiferous. 


\section{Order 5. \\ P E N T A G Y N I A.}

1. Flowers inferior. L.

297. Sratice.

301. Crassula.

299. Drosera.

298. LrNum.

300. Gisekia.
Corolla quinquepartite. Seed 1.

Corolla quinquepartite. Capsules 5 , polyspermous. $L$.

Petals 5. Capsule unilocular, opening at the end. $\boldsymbol{L}$.

Petals 5. Capsule decemlocular; cells monospermous. Obs. 4146.

Corolla none. Calyx pentaphyllous. Capsules 5; cells monospermous.

2. Flowers superior. I.

296. Arilia.

Petals 5. Berry quinquelocular. Obs. 4177.

Order 6.

\section{P O L Y G Y N I A.}

302. Myosunus.

Petals 5. Calyx pentaphyllous. Obs. 5453.

303. Xanthoxylum. Petals 5, or none. Capsule pentacoccous. Obs. 2314. 
Monogynia, 109. Heliotropium. 267

304. Xanthormiza. Pelals 5. Capsules several. Obs. 5383.

\section{O N O G Y N I A.}

\section{HELIOTROPIUM.}

Corolla hypocrateriform, quinquefid, with plaits interposed; throat open. Nuts 4. Obs. 5378. L.

1. HELIOTROPIUM indicum. Leaves cordato-ovate, acurte, roughish. Spikes solitary. Fruit bifid. $L$. sp. 1S7. Hort. kew. i. 174. Swarti. obs. 54. Michanx i. 128. Mill. Ph. dict.n.2.

H. foliis ovatis acutis, spicis solitariis. Royen 405 . H. americanum caeruleum, foliis hormini. Boerh. i. 190. Pluk. alm. 182; phyt. t. 245. f. 4 . Sloane cat. 94; hist. i. 213. Herm. prodr. 340; hort. 307.

Aguaraciunha-acu. $\boldsymbol{P}_{\text {is. }}$ bras. 109, repr. in Jacua acanga. Pis. ind. 229, and Marcgr. 7.

Leares hirsute, the younger rugose underneath. Fruit ovate, bifid at the end, the seeds separating into 2 pairs. Obs. 8648. Specimen gathered by Dr. Wright in Jamaica.

HELIOTROPIUM indicum. Lour.i.'126.

2. HELIOTROPIUM europaeum. Leaves oval, entire at the margin, slightly birsute. Spikes conjil- 
gate. Obs. 8050. Specimen gathered betwecr Paris and Versailles.-L. sp. 187. Hort. licw. i. 175. J acq. austr. iii. t. 207. Krock.n. 268.

H. nıajus Dioscoridi. Tourn. paris, 96. Vaill, paris. 96. Boerh. i. 190.

Heliotropium. Dod. 70, repr. in

H. majus et Herba cancri. Lob. ic. i. 160, cop. in

H. majus, flore albo. Bauh, J. iii. 604, and repr. in

I. majus. Ger. by Johns. 334. Dalech. 1350. Raii hist. 501; europ. 141. In Sicily, Italy, the south of France, and about Mentz.-Park. theatr. 438.

Native of the south of Europe, Austria, the Palatinate, and as far north as Paris and Mentz.

IIELIOTROPIUM majus. Chom. 650 ; suppl. 182. Dale 138.

Heliotropium, Geoff?. iii. 550.

8. HELIOTROPIUM supinum. Leaves ovate, ob. tuse, entire at the margin. Spikes solitary. Frone L. sp. 187, and Gouan. monsp. 17. t. at p. 1. Near Montpelier.-Hort. kew. i. 175. Clus. hisp. 394, in melon grounds near Salamanca; repr. in hist. ii. 47, and Dod. 70, cop. in

H. humi sparsum. Dalech. 1352, \& repr. In

II. supinum Clusii et Lobelii. Ger. by Johns. 335. Raii hist. 501.

II. minus supinum. Boerh. i. 191.

H. minus quorundam, sive supinum. Bauh.J. iii. 605. No fig.

Verrucaria alia minor. Dalech. 1351.

HELIOTROPIUM minus. Dale 138. 


\section{MYOSOTIS.}

Corolla hypocrateriform; the throat surrounded with 5 sacklike prominences. Nuts 4 , imperforate. $-L$.

1. MYOSOTIS hamosa. Seeds smooth. Racemi without bracteae. Hairs of the calyx patent, the lower hooked. Obs. 3818.

M. arvensis. Roth germ. ii. 222. Sibth. ox, 68. L. a Willd. i. 74T.

M. scorpioides arvensis. L. suec. n. 157; sp. 188. Bot. arrang. 188.

M. scorpioides. Fl. dan. t. 583, outer fig. Smith brit. 212 a; engl. $t .480$, inner fig.

M. hirsuta arvensis major. L. lapp. n. 74 .

Heliotropium minus angustifolium arvense, seu hirsutum. Boerh. i. 190.

Lithospermum arvense minus. Tourn. paris. 112. Vaill. paris. 119. La plus commune.

M. scorpioides hirsuta. Raii syn. 229.

Echium scorpioides solisequum. - Bauh. $J$. iii. 589. Scorpioides tertia. Dod. 72, repr. in Alsine Myosotis, sive Auricula muris. Lob. ic. i. $461, \&$

M. scorpioides arvensis hirsuta. Ger. by Johns. 338 , . cop. in

M. scorpioides hirsuta. Park. theatr. 691.

MIYOSOTIS scorpioides arvensis. Coste \& Willemet in med. comment. v. 298.

Echium minimum. Vog. 100.

2.MYOSOTIS adpressa. Racemi without bractear. Seeds smooth. Calyces with straight hairs pressed to. Obs. 3819. Neur water. 
M. scorpioides. L. a Willd. i. 746. Fl. dan. t. 583,

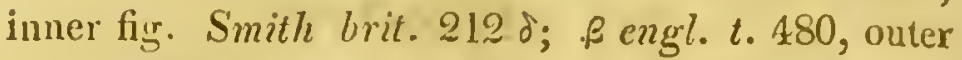
uncoloured fig.

M. palustris. Ro'h grerm. ii. 221. Sibth. ox. 68.

M. scorpioides palustris. L. suec. n. 157; sp. 188. Bol. arrang. 189. Curt. lond. iii. 13. t. 165. Walc. t. Raii syn. 229. Ger. by Johns. 338, repr. from.

M. scorpioides partim repens partim erecta. Lob. ic. i. 462, which cop. in

M. scorpioides repens. Park. theatr. 691.

M. glabra pratensis. L: lapp. $n .75$.

Meliotropium minus angustifolium palustre, sen glabrum. Boerh. i. 191, where it is marked as annual.

Iithospermum palustre minus. Tourn. paris. 210.

Lithospermum palustre minus, flore caerulco. Vaill. paris. 119.

Echium scorpioides solisequum flore majore. Buиh. $J$. iii. 589. No fig.

Secds ovate, obtuse, shining. 'Obs. 3819.

MYOSOTIS scorpioides palustris. Coste \& Willemet in med. comment. $\mathrm{v} .298$.

\section{LITHOSPERMUM.}

Corolla infundibuliform; throat surrounded with 5 oblong prominences. Calyx quinquepartite. Nuts 4, imperforate. $L$.

1. LITHOSPERMUM ochroleucum. Sceds smooth. Corolla scarcely longer than the calyx. Obs. 916. On the sides of roads, in calcareous soils.

L. officinale. L. suec. n. 159 ; sp. 189. Bot. ar. rang. 189. IIuds. 79, on calcareous soil.-Snith 
engl. bot.t. 134; brit. 213, on gravelly and calcareous soil. -Woodv. iv. 7. t. 213. Krock. n. 271.

L. inajus erectum. Tourn. paris. 283. Vaill. paris. 119. Boerh. i. 190.

L. minus. Dalech. 1176. Dod. 83, repr. in Lob. ic. i. 45T, Ger. by Johns. 609, and cop. in

L. vulgare minus. Park, theatr. 432.

L. sativum. Fuchs. 475. c. 187, cop. in

L. sive Milium solis. Bauh. J. iii. 590,

L. Fuchsii. Dalech. 1177, \&

Milium solis. Trag. 536, which repr. in

Lithospermon. Cord. fol. 94. p. 1.

LITHOSPERMUM. Alst. ii. 361. Dale 138. Lew. ii. 73. Linn. 60. Mill. Jos. 273. Murr. ii. 98. Rutty 293. Vog. 178.

L. erectum. Geoffr. iii. 742 .

L. majus erectuin. Chom. 245.

Milium solis. Herm. 322. Spielm. 654.

2. LITHOSPERMUM repens. Seeds smooth. Corolla twice as long as the calyx. Obs. 3836. Specimen from Dr. Heise.-Clus. pann. 684, repr. in

L. repens majus. Clus. hist. ii. 143, Lob. ic. i. 458 , Ger. by Johns. 609, cop. in

L. vulgare majus. Park. theatr. 431, \& repr. in

L. majus. Dod.83. Dalech. 1177.

L. purpureo-caeruleum. L. sp. 190. Bot. arrang. 190. Smith engl. bot. t. 117; brit. 214. Found by Dr. Lathiam near Greenhithe, Kent.-Jacq. austr. $t .14$.

L. minus repens latifolium. Boerh. i. 190.

L. majus Dodonaei, flore purpureo, senine ancliusae. Bauh.J. iii. 592. (The figure is a Saxifraga.) Raii hist. 503; syn. 229. Near Denbigh, and Taunton Somersetshire. 
Sedum alpinum minimum foliis cinereis, flore candi= do. Bauh. J. iii. 692, the figure. (The name and description belong to a Sedum.)

Pulmonaria minor. Dalech. 1328.

L. anchusae facie. Lob. ic. i. 458, repr. in Ger. by Johns. 610, and cop. in Park. thealr. 432, arid Dalech. 1179.

LITHOSPERMUM repens. Geoffr. ii. 745.

L. majus repens latifolium. Chom. 245.

\section{ANCHUSA.}

Corolla infundibuliform or hypocrateriform; the throat surrounded by 5 sacklike prominences. Sceds hollowed out at the base. Obs. 6387. 3691 . L.

Buglossum. Gaertn. i. 322. $t .67$.

1. ANCHUSA paniculata. Calyx quinquepartite. Leaves lanceolate. Racemi conjugate. Sacklike prominences penicillate, extending beyond the base of the sinuses and two thirds as long as the limb. Ols. 6387. Specimen gathered in Saville's gar. den.-Hort. kew. i. 177. In Madeira.-Sibth. prodr. n. 404. In Greece.

A. italica. Retz. obs. i. 12. n. 15. Murr. ap. L. a Murr. 186. Salisb. Wr. 7. Donn 33.

Burglossum vulgare angustifolium majus. Raii europ. 78.

Buglessum angustifolium majus, flore cacruleo. Boer $/$. i. 188.

Buglossum angustifolium majus. Tourn, 251. Vaill, paris. 23. Mign. monsp. 40. 
Buglossum vulgare. Dalech. 579. Raii hist. 4939. About Messina:

Cirsium italicum: Fucks. 418, ed. fol. cop. in cd. $12 m o, 336 . c .130$,

Buglossum vulgare majus. Bauh. $J$. iii. 578 ; \& Buglossa italica. Trag. 232, which repr. in Buglossa longifolia. Cord. fol. 135, \& cop. in Buiglossa vulgaris. Dod. 617. Ger. by Johns. 798, repr. from

Buglossum angustifoilium. Lob. obs. 310, wihich repr. in ic. i. 576, \&

A. Alcibiadion. Dod. 618, \& cop. in Buglossum minus sativum. Park. theatr. 767.

Buglossum. Park. purad. 249. No fig.

Corolla half an inch long; prominences oblong, hirsute above; the hairs crowded; cylindric, more than half as long as the prominence: Obs. 6387.

BUGLOSSUM. Berg. 79. Dale 136. Geoffr. iii. 226. Krock. n. 274: Lew. i. 242; disp. by Ro: ther. 119. Linn. 60. Murr. ii. 99. Ploucq. bibl. i. 407. Spielm: 555. Vog: 125:' 153 .

Buglossa. H Herm. 602.

Buglossum hortense. Mill. Jos: 95:

Buglose. Chom. 98. 74; suppl. 28:

(A. officinalis. Lour. i. 127, is described as lavining a red root, and whitish red corollae.)

2. ANCHUSA angustifolia. Calyx quinquefid. Saclslike prominences extending half way to the base of the sinuses; and one fourth as long as the limb. Racemi conjugate and simple. Upper leaves ovato-ensiform. Obs. 6391: Spccimen gathered in Fothergill's garden.-Hort. kew. i. 178. L. sp. 191. Salisb. W. 7. Mill. Ph. dict, 2l, 2. Sibth. prodr. $n .405$. 
Boragine silvestre perenne, di candia, di fiore rosso cremesino, Zan. ist.49.t. 20, repr. in

Buglossum sylvestre inajus nigrum. Zan. list. 57. t. 39 .

Buglossum minimum, cchii facie, flore rubente. Lob. obs. 310 , repr. in ic. i. 576, \&.

A. Alcibiadion. Ger. ly Johns. 800, \& cop. in

Buglossum ninimum, ecliii fucie, floribus rubentibus.

Park. thealr. 765.

ANCIIUSA angustifolia. Krock. n. 275.

3. ANCHUSA tinctoria. Calyx quinquepartite. Sacklike prominences obsolete. Leaves linear, acute. Obs. 6388. Specimen gathered by M. Broussonett in the south of France or north of Spain.-L. $s p$. 192. Ilort. kew. i. 179. Gouan. monsp. 19. (Woodv. 251. t. 92, seems rather to be A. angustifolia.)

Lithospermum tinctorum. Gouan hort. 80. Near Montpelier.

Lithospermum villosum, caulibus procumbentibus simplicissimis. Allion. nic. 12.

A. monspeliana. Bauh. J. iii. 584. A good figure excepting that the stamina are represented as longer thain thic corolla.-Magn. monsp. 18. Raii hist. 496 ; europ. 62.

A. puniceis floribus. Magn. hort. 14 .

A. mirior purpurea. Park. theatr. 516, but the stamina represented as longer than the corolla.

A. minor, seu Alcibiadon, val Onochiles. Lob. adv. 218, repr. in

A. parva Lob. ic. i. 578.

(Buglossum uninimum echii facie, flore rubente. Lob. .ic. i. 576 , repr. in

A. Alcibiadion. Ger. by Jolms. 800 , sop. in 
Monogy nia. 118. Cynoglossum. 275

Buglossum minimum, echii facie, floribus rubentibus.

$P$ ark, tireatr. 765; has lanceolate leaves and the whole has not the habit of my specimen.)

Root fusiform, 4 inches long, brownish purple, staining the paper which contains the specimen. Stems simple, ascending; 5 inches long, hispid. Leares $1 \frac{1}{2}$ tenth of an inch broad; hispid; hairs White at the base. Racemi terminal, conjugate. $C o$ rolle; sacklike prominences in one flower very short, transversely semilanceolate, in another flower only ore and subulate. Seed 1 in a calyx, scabrous. Obs. 6383.

ANCHUSA tinctoria. Root. Pharm. edin:-Alst.

i. 361. Dale 156. Hill 598. Lew. i. 81; disp. by

Dunc. 143. Mill: Jos. 37. AYurr. ii. 101. Rutty

26. Vog. 230. Murr. J. i. 216.

A. officinalis. Cartheus. iv. 93.

Alkanna. Murr. ii. 100. Spiclm. 375.

Alcanna. Berg. 80. Herm. 163.

Alcanna spuria. Krock. n. 276. Linn. 61. Vog. 230.

Alkanct. Lew. in Neum. ii. 88.

\section{CYNOGLOSSUM.}

Corolla funnelshaped; throat with 5 sacklike appen. dages. Nuts A, depressed, fixed to the style by the inner side only. Obs. 4797. $L$.

1. Secds echinate.

1. CYNOGLOSSUM officinale. Corolla longer than stamina, about as long as the calyx. Leaves villose, at length scabrous on the upper surface,

т 2 
Obs. 7117. On the sides of the road between Pleasly and Mansficld, on brown cos. 21 June.L. sp. 192. Curt. lond. iv. 16. t. 249. Bot. arrang. 192. Smith brit. 216; engl. 1.921. Woodz. iv. 12. t. 216. Scop. cam.n. 191.

C. vulgare. Bauh. J. iii, 598. Ruii hist. 489.

C. vulgare Matthioli. Dalech. 1263, without fruetifications.

Cynoglossum. Raii syn. 226. Dod. 53, repr. in

C. vulgare. Lob. ic. i. 580, \&

C. majus. Ger. by Johns. 804, the plant without fructifications cop. in

C. maximum nontanum. Parli. theatr. 512, and the plant with fructifications cop. in

C. majus yulgare. Park, theatr. 511. Tourn. paris. it. Niative of cold and temperate climatcs.-Vaill. puris: 44.

Stem striatc, villose. Root leaves elliptico-lanceolate; stem leares sessile, lanceolate, the upper some. what ovate at the base, soft, villose, without any white spots either when recent or dried, about an inch from onc another. Racemi terminating the stem and branches; each with 1 floral leaf; those of the branches simple; thosc of the stern 3 togcther with a single flower in the strichotomy. Floral leares ovato-lanccolitc, anılexicaul, a little below the lowcrnost flower. Caly.x, phylla oblongo-ovate, villose on the outside. Corolla just longer than the calyx; limb brownish red, quinquefid, half as long again as the tube; segmerits roundisl ; tube grey, tinged here and there with purplish blue; appendages oblong, purple, purplish blue at the cnd. Stamina inserted near the end of the tube of the corolla just below the base of the appendages opposite to the intervals between the appendagres. Obs.7117. 
CXNOGLOSSUM. Alst. i. 428. Berg. S2. Geoffr. iii. 394. Krock. 11. 27T. Lew. i. 390 ; disp, 159. Mill. Jos. 170. Spielm. 45̄5. Vog. 198, 236. Cynogiossa. Dale 135. Herm. 178. Lim. 61. Murr. ii. 102.

C. majus vulgare. Chom. 815. Rutty 160 .

2. CYNOGLOSSUM lucidum. Corolla longer than the stamina, as long as the calyx. Leaves glabrous on the upper surface, scabrous underneath. Bracteae of the peduncles amplexicaul. Obs. 7115. Specimen gathered in the garden of Fothergill.

C. virginicum. L. a Murr. 186 ; sp 193.

C. foliis amplexicaulibus ovatis. Gron. virg. 21.

C. foliis amplexicaulibus. Gron. virg, ed. i. 19.

(C. virginianurn virenti folio, floribus et seminibus minoribus. Hist. ox. iii. 449. s. 11. t. 30. row 2. $f .9$, is figured and described as having leayes attenuate at the base:)

Leares oblongo-lanccolate, acute, sessile, the uppermost semiamplexicaul and amplexicaul; scabrous underneath with white spots composed of minute tubercles, with sometimes a hair procceding froun the center; hairs scattered along the costa. Calyj $x$, segments oblong. Corolla about as long as the calyx; limb as long again as the tube, quinquefid; segments oblong; appendages one thircl as long as the limb. Stamina inserted into the tube of the coralla one third of the way below the appendages, opposite to the spaces between the appendages. Sẹeds echinate. Obs. 71 I. 5 .

CYNOGLOSSUM. Sckoepf 18.

T $2 \div 1 \div \mid \times 1=\therefore$ 


\section{PULMONARIA.}

Corolla funnelshaped; throat open. Calyx with 5 divisions. Obs. 1319. L.

1. Calyx as long as the tabe of the corolla. L.

1. PULMONARIA maculata: Calyces semiquinquer fid, hirsute. Leaves of the barren stems elliptic and cordato-ovate. Obs. 5774. In a garden, when it had been in flower some time.-Obs. 8063 . In a garden.

\& lancifolia. Leaves lanceolate. Obs. 4655. Specimen gathered in Fothergill's garden.

P. angustifolia. Hort. Kewo. i. 181 a Host. 89.

P. II angustifolia, caéruleo flore. Clus. pann. 673. t. 674, repr.in

P. III austriaca. Clius. hist. ii. 169,8 .

P. angustifalia II Clusii. Ger. by Johns. 808, \& cop. in

P. angustifolia, caeruleo flore. Bauh. J. iii. 596. Tourn. paris. 521 .

P. angustifolia non maculosa, flore caeruléo. Vúill. paris. 165. 'In the forest of St. Germain near Paris.

Buglossa sylvestris. Trag, 234, reproin

Anchusa. Cord fol. 93. p. 2.

Steme is inches high. Leaves semiamplexicaul, not spotted, 6 tenths of an inch broad. Calyccs se: miquinquefid Stamina inserted just below, the villi at the mouth of the tube of the corolla. Obs. 4655 .

$\beta$ ellipticifolia. Leaves of the barren shoots elliptic.

Corolla blue. Obs. 5774 .

P. angrustifolia. L. suec. n. 163; sp. 194. Hort. kcxo. i. 181 \& Roth germ. ii. 212. Pollich. $n$. 
189. Bot. arrang. 194. Park parad. 218. t. 251. Fl. den. 483. Leaves without spots.

P. oflicinalis. Smith engl. bot. t. 118, from a plant found by Mr. Robson near Darlington, Durham. Spats of the leaves whitish, distinct. No leaves of the shoots for next year's stems;-brit. 21\%. Woodv. iv. 5. t. 212 from a plant of Jritish growth, probably the same from which the preceding figure was drawn, with 2 elliptic leaves from the young shoots taken from garden specimens. - Abbot 42. Between Thurleigh and Milton-Ernys Bedfordshire.

P. saccharata. Mill, Ph. dict. n. 3 .

P. foliis radicalibus lancecolatis. Guett. ii. S8.

P. foliis echii. Raii hist. 489; syn. 226. Vaill. paris. 165. Boerh. i. 193. Lob. ic. i. 586, repró in Ger. by Johns. ed. ii. 808,

P. maculosa. Ger. by Johns, ed. i. 808, \&.

P. V. pannonica, Clus. hist. ii. 170, \& cop. in

P. rubro flore, foliis echii. Bauh. J. iii. 597. In an advanced stage of flowering, in which the flowers appear pedunculate.-Toutrn. paris. 521, ? P. Plinii. Cord. fol. 131. p. 1. The separate leaf, Stem when fully grown to 15 inches long. Leares the upper semiamplexicaul, elliptico-lanceolate, 7 tenths of an inch broad, the lower lanceolate, tapering downwards with linear petioles; leaves of the young shoots for next year's stems elliptic, 2 inches broad, with greenish white spots; spots confluent. Corolla purplish red before it is expanded, blue afo terwards; limb semiquinquefid, with 10 slight depressions at the base; mouth of the tube with 5 tufts of hairs, Stamina inserted just above the middle of the tube. Filaments very short. .Obs. 5774. 
PULMONARIA angustifolia. Geoffr. suile ii, 109.

P. foliis echii. Chom. 86. Dale 135 .

r cordifolia. Leaves of the barren stems ovato-cordate, with pale green spots. Corolla blue. Obs. 8063. In a garden.

P. oflicinalis. L. sp. 194 a Bot. arrang. 193. Walc. $t$. The spots represented as darker than the rest of the leaf instead of paler.-Gouan. monsp. 20. Roth germ. ii. 212 $\propto$ Fl. dan. $t$. 482. Spots distinct. Common in woods. (Berg. mat. mect. $n$. 57 is P. rubro flore foliis echii. Vaill. paris. 165.)

P. foliis radicalibus ovato-cordatis. Guett. i. 88.

P. alpina, foliis mollibus subrotundis, flore caerulco. Boerh. i. 193.

P. major. Dalech. $132 \%$.

P. maculosa. Raii hist. 488; europ. 210. In mountainous woods on the banks of the Rhine and near Geneva.-Lob. ic. i. 586, repr. in Ger. by Jolins. ed. ii. $808, \&$.

Symphytum naculosum. Dod. 1.35, \& abr. in

P. latifolia naculosa. Park. parad. t. 251. $f$. 1, who mentions its having been found in England by Goodyer;-\& repr. in

P. foliis echii: Ger. by Johns. ed. i. 808, who mentions its having been found by Goodyer in a wood by Holbury house in the New Forest Hampshire.-Raii cat. ed. i. 255, following the second ed. of Ger. by Johns. where Goodyer's observation was not made to accord with the change made in the figures; and not attending to the anterior testimony of Parkinson. It is marked as a plant he had not himself seen growing wild in Great Britain, and the name of Goodyer is stibjained to its place 
of growth.-Raii syn. 226; ed. i. 75. . Thie same place of growth but the name of Goodyer omilted. P. italorum ad buglossum aćcédens. Bauh. $J$. iii, 595. In Italy.

Stems a foot long. Leaves of the young shoots for next year's stems cordate; 2 to $3 \frac{1}{2}$ inches broad, upper surface dark green with distinct roundish pale green spots; those of the stem ovali-elliptic, the lower petiolate, the upper sessile, the uppermost amplexicaul, spotted with whitish green spots, to $l$ inch 2 tenths broad. Corolla red, becoming blue. Obs. 8063.

Notice of Europe from Italy to Sweden, and of Hampshire, Bedfordshire, and Durlıam.

PULMONARIA latifolia. Geoffr. suite ii. 106. Pulmonaria. Berg. 83. Lew. ii. 251. Spielm. 391. Vog. 77.

P. maculata. Murr. ii. 97.

P. maculosa. Chom. 86. Dale 135: Krock. n. 280. Linn. 135. Mill. Jos. 363.

immaculato-cordifolia. Leaves as in $\gamma$, without spots. From Park. \&

P. officinalis. L. suec. n. 163; sp. 194 y Roth germ. ii. $212 \beta$

P. folio non maculoso. Vaill. puris. 165. Bocrh. i. 193.

P. Plinii. Cord. fol. 191. p. 1. The entire plant. P. altera non maculosa. Park. parcud, 248. No fig.

2. PULMONARIA procumbens. Calyces quinquepartite; segments ovate. Obs. 5406. Specimen gathered in the garden of Fothergill.

P. maritima. L. sp. 195. Bot. arrang. 194, where in the 2nd line of the references to figures read 
"Park. 766. 5-(Sibbald \&c.)"-Lightf. 134. $\iota$. 7. Smith brit. 218; engl. bot. t. 308. Fl. dan. $t$. 25. Honck. ii. 134. In Holstein.-Retz. scand. 21. 291. (Krock. n. 281, is probably a different plant.)

Echium marinum. How 36. Near the salt pans between Berwick and Holy island.-Sibbald ii. 55. $t$. 12. f: 4. On the south side of the Firth of Forth.-Raii cat. cd. ii. 93; syn: ed. i. 76; ed. ii. 120; ed. iii. 228. Found by Lawson on the coast of Lancashire, and by Llwyd on that of Anglesea and Caernarvonshire.

Cerintle maritima procumbens. Dill. hort. 75. $t$. 65. f. 75 .

Cyroglossum procumbens glaucophyllon maritimum 4. nostras, floribus purpuro-caeruleis, semine laevi. Pluk. alm. 126; phyt.t. 172. f. 3, cop. in

Cynoglossum britannicum glaucifolium procumbens perenne. Hist. ox. s. 11.t. 28. row 2. f. 12, \&

Sca Bugloss. Pet. herb. $t .29 . f .3$.

Buglossum dulce, ex insulis. lancastriac. Park. theatr. 766.

Stem procumbent. Leaies elliptic, scabrous on the upper side. Peduncles axillary and internodial. Obs. 5406.

Native of the sea coasts of Norway, Holstein, Scotland, Cumberland, Lancashire, Anglesea, and Cacrmarvonshire.

P'ULMONARIA maritima. Curt. lond. vi. $t$. 378.

3. PULMONARIA glaUra. Calyx quinquefid, glabrous. Leaves glabrous. Obs. 5407. Specimen gathered in Fothergill's garden. 
P. virginica. L. sp. 194. Curt. mag. t. 160. Hort. kew. i. 182.

Pulmonaria. Trew elcret. 11, t. 42.

Synphytum, sive P. non maculata, foliis glabris acuminatis, flore patulo caeruleo. Pluk. alm. 359; phyt. t. 227. $f .6$.

PULMONARIA virginica. Schoepf 18.

\section{SYMPHYTUM.}

Corolla infundibuliform; throat with 5 subulate prominences. Obs. 202. $L$.

1. SYMPHYTUM officinale: "Leaves ovato-elliptic and elliptic, decurrent. Calyx as long as the tube of the corolla'; segments crect. Obs. 202. Sides of ditches near Worcester.-Sibth. ox. 70. L. $s p$. 195. Lightf. 134, Bot. arrang. 195. Curt. lond. iv. 18. t. 230. Fl. dan. t. 664. Woodv. iv. 10.t. 215. Smith brit. 218; engl.t. 817.

a albidum. Corolla yellowish white. Obs. 202. 1. Roth germ. ii. 215. var. 1.

S. Consolida major; flore pallide luteo, quae foemina. Tourn. paris. 306. Vaill. paris. 190.

S. Consolida major foemina, flore albo vel pallide luteo. Boerh. i. 195.

Consolida major. Raii hist. 505. Trag. 240, repr. in

S. majus. Cord. fol.167. p. 1, cop. from

S. magnum. Fuchs. 658. c. 266, which cop. in Bauk. J. iii. 593. Dalech. 1074. Raii syn. 230. Dod. 134, repr. in

S. Alum seu Alus. Lob, ic. i. 583, 
Consolida inajor, flore purpurco. Ger. by Johns. 806, \& cop. in

S. majus vulgare. Park. theatr. 523.

S. majus. Cam. epit. 700.

Corolla, prominences erect, dentate at the margin; teeth crowded. Obs. 202.

SYMPIITUM. Alst. i. 525. Cartheus. i. 270. Cutl.415. Dale 138. Mill. Jos. 465. Murr. ii. 92. Quarin febr. 366 ; animad. 101.

Symphitum. Herm. 158. Lew. disp. by Dunc. 348.

Conssolida. Lew. i. 362. Neum. ii. 85. Rutty 135. Wintringham in Mead. mon. i. 266.

Consolida major. Pharm . austriaco-prov. 31.-Berg. 55. Geoffr. iii, 354. Krock, n. 282. Linn. 62. Quarin animad.56. Schoepf 19, Vog. 191.

Grande Consoude. Chom, 578; suppl. 164.

\& rubens. Corolla dullish purple. Obs. 202. With a -Bot. arrang. 195 \& Roth germ. ii. $215 \alpha$

S. magnum flore purpureo. Raii syn. 230.

S. Consolida major, flore purpuro-caeruleo. Tourn. paris. 306. Vaill. pariș. 190.

y kermesimum. Corolla crimson. Obs. 6385. In Mr. S. Shore's garden.-Bot. arrang. 195 \& pink coloured.

S. Consolida major, flore purpureo, quae mas. Tourn. paris. 306. Vaill. paris. 190.

S. patens. Sibth. ox. 70. Banks of the Thames by Caversham Oxfordshire.

Leaves elliptic, and ovato-elliptic, decurrent to the base of the 2nd internodium; floral lenips lanceolate, opposite and alternate. Calyx as long as the tube of the fully expanded corolla, longer than the tube of the carolla not yet grown to its greatest length; segments crect. Corolla when first expanded blackish purple and $4 \frac{1}{2}$ tenths of an 
inch long; when fully grown crimson and 6 tenths of an inch long. Stamina not reaching to the end of the corulla. Obs. 6385.

\section{ONOSMA.}

Corolla campanulate and tubiform; throat oper. Seeds 4. Obs. 8058, L.

1. ONOS.MA echioides. Corollae cylindric. Fruit erect. Leaves linear, hispid. Obs. 8679. Specimen from Prof. Jos. F. Jacquin, gathered near Buda in Hungary. -Sibth. prodr. n. 423. L. sp. 196 ß. Hort. kew. i. 183. Host 91. Jacq. austr. iii. t. 295. Gouan. monsp. 22.

Cerinthe echioides. Scop. carn. n. 197. Gouax. hort. 84. At Montpelier.-Jacq. vind. 29. Symphytum echii folio angustiore, radice rubra, flore luteo. Bocrk. i. 195.

Cerinthe foliis lanceolato-lincaribus hispidis. Guett. ii. 436. Found by Villars at Rochelle.

Anchusa flore exalbido. Clus. pann. 6is, repr. in Anchusa exalbido flore. Clus. hist. ii. 165, \& Anchusa quarta, sive Pseudoanchusa. Dod. 619, cop. in

Anchusa lutea major. Park. theatr. 516, Anchusa flore albo aut pallido Clusii. Bauh. $J$. iii. $583, \&$

Anchusa major lutea. Hist. ox. s. 11. t. 27. row 1. $f .1, a b r$. in

Anchusa. Park. parad. 250. t, 251. f.6, \& repr. in

Anchusa lutea. Ger. by Johns. S00. Dalech. 1102. Between Lyons and Valence.-Raii hist. 497; 
curop). 61. Not far from Lyons on the road to Genevir.-Bauh. J. iii. 585. At Lyons, between Lyons and Vicnne, and in the Euganean mountains in Lombardy.

(Anclusa tertia. Cam. epit. 736, is described as having red flowers.)

Native of Italy, Hungary, Austria, the south of France and as far north as Lyons and Rochelle.

ANCHUSA lutea. Pharm. austriaco-prov. 17.Dalc 137.

\section{1\%. BORAGO.}

Corolla rotate and hypocrateriform; appendages cmarginate. Obs. 4496. 13I5. L.

1. BOR $\perp G O$ officinalis. ILeaves petiolate, all alternate. Obs. 4496. On dunghills and rubbish.L. sp. 197. Bot. arrang. 197. Smith engl. bot. t. 36; brit. 219. Woodv. iv. 14. t. 217.

Borrago floribus cacruleis \& albis. Raii hist. 493. Bruh. J. iii. 574, cop. from

Buglossum, sive Borrago. Fuchs. 149. c. 51, which cop. in

B. flore albo. Ger. by Johns. 797, which repr. from Borago. Dod.616. Trag. 237, repr. in

Buglossa urbana. Cord. fol. 109. p. 2.

Buglossum latifolium, sive Borrago. Lob. obs. 309, repr. in ic. i. 575.

B. hortensis. Ger. by Jolns. 797. Raii syn. 228. On road sides and walls.

Borrago. Park. parad. 249. t. 251. f. 3. Dalech. $5 \pi 8$. 
(Borrago sylvestris tenuifolia. Bauh. J. iii. 577, has elliptic leaves.)

Natice of Aleppo, and naturalised in Europe. $\boldsymbol{L}$. BORAGO. Berg. 87. Cartheus. iv. 249. Dale 136. Krock. n. 287. Lew. i. 229. Linn. 63. Murro ii. 95.

Borrago. Alst. ii. 91. Chom. 98; suppl. 28. Cleghorn 24. Geoffr. iii. 201. Herm. 602. Lew. disp. by Rother. 117. Mill. Jos. 90. Monro iii. 33. Rutty 69. Spielm. 354. Vog. 55.

B. officinalis. Bryant 95 .

\section{LYCOPSIS.}

Corolla with an incurvated tube. $\boldsymbol{L}$.

1. LYCOPSIS ariensis. Leaves obsoletely dentate, hispid. Calyces quinquepartite, when in fruit erect. Obs. 3955. In corn fields. $-\boldsymbol{L}$. suec. $n$. 167; sp. 199. Curt. lond. v. 17. t. 336. Bot. arrang. 198. Smith brit. 221; engl. t. 938. Fl. dan.t. 435.

Lycopsis. L. lapp. n. 77.

Buglossum sylvestre minus. Tourn, paris. 62. Vaill. paris. 23. Boerh. i. 188.

Echium. Fuchs. 270. c. 103, cop. in

Echium Fuchsii, sive Borrago silvestris. Bauh. $J$. iii. 581,

Buglossum minus silvestre. Dalech. 580, \& Buglossa sylvestris. Dod. 617, which repr. in Buglossa sylrestris minor. Ger. by Johns. 799. Riaii syn. 227 ; hist. 494.

BUGLOSSUMI sylvestre. Dale 136. Mill. Jos. 96. 


\section{ECHIUM.}

Caly.x quinquepartite. Corolla infundibuliform, and tubular; limb oblique; quinquefid; segnients unequal; throat open. Obs. 4055. L.

\section{Slem Rierbaceous.}

1. ECHIUM vulgare. Stamina mostly longer than the corolla. Stem hispid. Leaves lanceolate. Obs. 4055. In corn fields.-L. suec. n. 168; sp. 200. Bot. arrang. 200. Smith engl. bot. t. 181; brit. 229. Scop. carn. n. 200, Host 99. Roth germ. ii. 210. Raii hist. 498; syn. 227. Tourn. paris. 75. Vaill. paris. 48. Boerh. i. 194. Mill. Ph. dict.n. 2. Fl. dun. t. 445.

Buglossa sylvestris. Brunsf. i. 111.

Onosma. Dalech. 1107, root and radical leaves.

Native of Europe from Italy to Sweden.

ECHIUM. Dale 137. Mill. Jos. 183.

Viperina. Geoffr. suite iii. 330.

E. vulgare. Chom. 100.

a simplex. (Variation.) Lateral spikes sessile, or nearly sessile. Obs. 4055.

E. Matthioli. Dalech. 1105:

Echium. Dod. 620, which repr. in

E. sive Buglossum silvestre. Lob. ic. i. 5i9,

E. vulgare. Clus. hist. ii. 163, \& Ger. by Johns: 802, which cop. in Park. theatr. 414.

Style pilose to the end or to three fourths of its length. Obs. 4055.

e ramosum. (Variation.) Stem diffuse. Obs. 8055. Specimen gathered by Mrs. Stokes at Barmouth, North Wales. 
Lycopsis altera anglica. Lob. obs. 312; repr. in ic. i. 579 ,

Echii altera species. Dod. 620, \&.

Lycopsis anglica. Ger. by Johns. 802, and cop. in : Dalech. 1263, and Park. theatr. 519.

Cynoglosson. Trag. 230.

Cynoglossum. Fuchs. 401.c. 156.

E. vulgare. Bauh.J. iii. 586 .

Corolla twice as long as the calyx, 7 tenth of an inch long. Stamina even with the end of the corolla. Style, pilose to near the end. This variation often orving to the end of the stem having. been taken off in an early stage of growth. Obs. 8143. In a wood.

\section{TOURNEFORTIA.}

Berry superior, bilocular; perforated at the end with 2 pores; cells dispermous. From $L$. and Start:.

1. TOURNEFORTIA argentea. Leaves linguiform, tomentoso-sericeous. Spikes terminal, compound. From L. fil. suppl. 133.

BUGLOSSUM lanuginosum. Rumph. iv. 119. t. 55 .

2. TOURNEFORTIA montana. Leaves ovato-lanceolate, rugose. Spikes mostly simple, recurvate, terniral. Isour. i. 150.

\section{PRIMULA.}

Corolla. hypocrateriform or infundibuliform; segrnents obcordate; mouth of the tube open. Cap- 
sule of 1 cell, and many seeds, opening with 10 teeth. Ols. 1733. L.

1. PRIMULA unifora. Leaves rugose, dentate. Diameter of the corolla exceeding the length of the calyx. Calyx quinquefid, villose. Peduncles from the root, with 1 flowcr. Obs. 4729. Woods, hedges and ditch banks.

P. veris acaulis. L. sp. 205, who doce not notice it as a native of Sweden.

P. acaulis. Bot. arrang. 204. Fl.dan.t. 194. Curt. lond. vi. 16. t. 376. Jacq.

P. sylvestris. Scop. carn. n. 20:4.

P. vulgaris. Smith engl. bot. t. \&; brit. 222, Walc. $t$.

P. veris floribus ex singularibus pallidis majoribus simplicibus. Bauh. J. iii. 497. No fig. About Coire in the Grisons flowers during the winter, if not prevented by snow.-Magn. hort. 164 .

P. veris pallido flore humilis. Tourn. paris. 520. Vaill-paris. 164. Boerk. i. 198.

P. veris minor. Dod. 147, repr. in Ger. by Johns. 781, and cop. in.

P. veris vulgaris. Park. theatr. 535. Raii syn. 284 ; hist. 1080.

P. sylvarum. Lob. adv. 244. No fig. In England, Dauphine, and Savoy.

Alisma prima. Col. phytob. 22.

Alisma sylvarum. Col. phytot. t. 21. inner fig. PRIMULA veris. Date 187. Lew. ii. 185. Mill. Jos. 35\%. Rutty 410.

2. PRIMULA elatior. Leaves rugose, dentatc. Diamcter of the corolla exceeding the length of the ca. lyx. Calyx semiquinquefut. Scapus villose, witb 
several flowers. Obs. 4731. Growing under a hedge near some plants of $P$. uniflora, in a pasture full of $\mathrm{P}$. odorata. $-L$. amoen. vi. 51. on the lower parts of the sand hills of Holland.-P. odorata and $P$. uniflora not being enumerated in the floras of Holland are probably not natives, an additional proof that these 3 plants are distinct species.-Bot. arrang. 203. Smith brit. 223; engl. t. 513.

P. veris clatior. L. sp. 204; suec. 171. In one place in Scania.

P. veris. Gort. belg. n. 179.

P. reris officinalis. Fl.dan. $t .434$.

P. inodora. Honck. n. 569.

P. veris pallido flore elatior. Vaill. paris. 164. Boerh. i. 199.

P. veris altera. Cam. epit. 884 .

P. veris major. Dod. 147, repr. in

P. pratensis inodora lutea. Ger. by Johns. 780. Raii syn. 284; hist. 1081.

Paralysis altera odorata flore pallido polyanthos. Park. parad. 244.

Verbasculum non odoratum. Fuchs. 805. c. 327, cop. in

P. veris caulifera, pallido flore inodoro aut vix odoro. Bauh. J. iii. 496. Magn. monsp. 213, who does not notice either P. uniflora or P. odorata.

Alisma secunda. Col. phytob. 22.

Alisma pratorum. Col. phytob. t. 21, outer fig. HERBA PETRI. Dale 188.

9. PRIMULA odorata. Leaves rugose, dentatc. Diameter of the corolla not equal to the length of the calyz. Calyx semiquinquefid, pubescent. Scapus

บ 9 
pubescent, with several flowers. Obs. 4733. In a pasture.

P. ofticinalis. Bot. arrang. 203. Curt. lond. vi. 15. t. 375. Scop. carn. n. 205. who does not notice P. clatior.

P. veris officinalis. L. $s p, 204$.

P. veris. L. suec, $n .171$ a. IIuds, 85. Walk. $t$. but more like P. clatior.-Smith engl. bot. $t .5$; brit. 223. Cam. epil. 883.

P. veris elatior. Fl. dan. $t .433$.

P. veris odorata, flore luteo simplici. Bauh. J. iii. 495. No fig.-Tourn. paris. 520. Vaill. paris. 164.

Paralytica rotundifolia montana. Col. ecphr. i. $t$. 256.

P. veris major. Ger. by Johns. 780. Raii syn. 284 ; hist. 1081.

P. veris umbellatil odorata pratensis. Boerh. i. 199.

P. vulgaris pratensis, flore flavo simplici odorato. Parli. parad. 244. No fig.

Verbascum odoratum. Fuchs. 805. c. 327.

Herba paralysis vulgaris. Trag. 201.

PRIMULA veris. Alst. ii. 204. Berg. 88. Bryant 107. Cartheus. iv. 235. Geoffr. suite ii. 72. Herm. 595. Krock. n. 295. Limn. 62. Murr. ii. 22. Spiclm. 346.

Verbasculum. Lcw.. ii. 185.

Primevere. Chom. 362 ; suppl. 112.

Paralysis. Dale 187. Mill. Jos. 332. Murr. ii. 22. Ploucq. bibl. i. 426. Rutty 378. Vog. 154.

4. PRIMULA Auricula. ILeaves cuneato-obovate, serrato-crenate, pubescent. Obs. 3409. In a garden.-L. sq. 205. Hort. kicw. i. 193. 
a facsa. Coralla pale yellow. Obs. 3109. $L_{0} \alpha$ Hort. kitw. a

P. A uricula. Jacq. austr. t. 415 .

Alisma. Col. phytol. 1S. $t .17$.

Auricula ursi I. Clus. pann. 344, cop. in hist. i. 302,

Auricula ursi. Dod. 148, \&

Paralytica alpina Sanicula, sive Auricula ursi lutea. Lob. ic. i. 569, cop. in

Auricula ursi lutea. Park. theatr. 536, \& repr. in Auricula ursi flore luteo. Ger. by Johns.'784. Bauk. J. iii. 499.

Leaves crenate, oblongo-cuneiform. Corolla, mouth of the tabe without any glands. Obs. 3409. - Leaves in places obsoletely serrate, the rest of the margin repandose or entire. Corolla infundibuliform, Obs. 6944. In Mr. S. Shore's garden. AURICULA URSI. Dale 188,

\section{CORTUSA.}

Corolla infundibuliform; segments entire. Capsule of $I$ cell, and 5 valves. Obs.7296. L.-Boerh. i. 206.

1. CORTUSA Matthioli. Calyx shorter than the corolla. L. sp. 206. Hort. Kew. i. 194. Park. parad.t. 237. f. 8. Flowers too large.-Krock. n. 297. Clus. hist. i. 307, cop. in Dalech. 1269, repr. in

Cariophyllata yeronensium, flore saniculae ursinae. Lol, ic. i. 699, \&

Sanicula alpina Clusii, sive C. Matthioli. Ger, by Johns, 788, cop. in 
Sanicula alpina, sive C. Matthioli. Park. theatr. 533, \& abr. in

Cortusa. Bauh. J. iii. 499.

Sanicula montana altcra. Clus. pann. 443.

Leaves cordate, doubly crenate. Pctioles longer than the laminac, villose; hairs jointed. Antherac ovato-lanccolate. Capsule, valves ovate, acute, whitish within. Obs. 7296. Specimen gathered in Fothergill's garden.

CORTUSA. Dale 188.

\section{SOLDANELLA.}

Corolla campanulate, lacerato.multifid. Capsule of 1 cell, opening at the end with several teeth. $L$.

1. SOLDANELLA alpina. I. sp. 206; a Murr. 194. Hort. lew. i. 195. Jacq. austr. i. t. 13. Curt. mag. t. 49. Clus. pann. 354, cop. in Park. parad. t. 233. $f .6$, repr. in

S. alpina major. Ger. by Johns. 838, and cop. in Park. theatr. 168.

S. montana. Lob. adv. 262 ; ic. i. 602 , repr, in .

S. alpina minor. Ger. by Johns. 839.

Lunaria alia minor caerulea. Dalcch. 1314.

S. alpina rotundifolia. Boerh. ii. 202.

S. montana quibusdam. Bauh. J. ii. 817.

Capsule oblong;; mouth patulous, multifid; segments 10 and 11. Obs. S069. In Mr. Knowwlton's garden.

SOLDANELLA alpina. Dale 184. 


\section{CYCLAMEN.}

Calyz: quinquefid. Corolla hypocrateriform; tube globular; limb quinquepartite, retroflex. Capsule pulpy within. Obs. 405t. L.

1. CYCLAMEN cordifolium. Leaves cordate, crenate. Obs. 3137. In a garden.

C. europaeum. L. sp. 207. Hort. kew. i. 196. Jacq. uustr. v. 1. t. 401. Sibth. prodr. n: 442. Mill. Ph. dict. n. 1. Gouan hort. 89. Near Montpelier.-Krock. n. 298.

Cyclaminus curopaeus. Scop. carn. n. 211.

C. flore cernuo, segmentis revolutis. Irall: hist. $n$. 635.

C. byzantinum. Magn. monsp. 83; hort. 66 .

C. orbiculato folio inferne purpurascente. Boerh. ii. 150.

Cyclaminus prior: Dalech. 1605.

Cyclaminus orbicularis rotundifolius. Dod. 335, in the forest of Ardennes and the adjoining districts of Flanders; repr. in ed. ii.' 337,

Cyclaminus odorato purpureo flore. Clus. kist. i. 264 ,

C. vulgare officinarum orbiculato folio. Lob. ic. i. $604 ; \&$

C. orbiculato folio. Ger. by Johns. 843, cop. in

Cyclaminus vulgaris. Dalech. 1604, \&

Ciclamen folio rotundo. Theophr. a Stap. 1060, \& $a b r$. in

C. vulgare folio rotundo. Park. parad. t. 197. f. 9.

Cyclaminus. Cam. epit. 357. Fuchs. fol.' ed. 450. c. 170, cop. in 441. c. 172, 12 mo cd. and Trag.

บ 4 
006, which repr. in. Cord. fol. 132. p. 1; \& cop. also in

Cyclaminus folio rotundiore, vulgatior. Bauh. J. Zii. 551. Plentifully on Mount Saleve near Geneva, and on the mountains of the Grisons in June and July.-Raii hist. 1206. In the mointains of Stiria and the neighbourhood of Geneva in. June and July;-curop. 110, where for elatior read vilgatior. C. acstivum. Park parad 195. t. 197. f. 2.

Oyclaminus foilis subrotundis. Gesn. ap. Cord. fol. 256. p. 1. At the foot of mountains near the lake of Wallestadt and other,places in Switzerland, and in the Grisons.

Cyclaminus parva radice, Bauh, J. iii. 553.

C. vernum majus flore albo odorato. Munt, phyt. t. 151 .

C. aestivum, flore carneo. Munt. phyt. t. 146. Leaves slightly dentate at the margin.

C. rotundifolium hyemale. . Munt. phyt. $t .147$. Leaves entire at the margin.

C. alcppicum, flore purpureo odorato., Mant. pliyt. t. 145 . Leaves dentate.

Cyclamen. : $T a b$. ic. 758 .

Leaves, laminae $3 \frac{1}{2}$ inches long, 3 inches broad, with.whitish-green spots. Scapi 10 inches long, attenuate each way. Flowers of the scent of Rosa spinosissina. Corolla white; segments obsoletely serrate, 8 tenths of an inch long. Obs. 3137.

Nalive of the mauntains of Switzerland, the Grisons, Stiria, and Carniola, and possibly of Silesia, Montpelier; and Flanders.

CYCLAWEN. Pharm. austriaco-proo. 34.-Berg. 90. Genffi. iii. 391. Herm. 111, Murr. ii. 25. Putby 156. Spielm, 633. 
C. orbiculato folio inferne purpurascente. Chom. 81 ; suppl. 16.

Cyclaminus. Alst. i. 420.

Artbanita. Dale 253. Lew. i. 172; disp. by Rother. 103.

Artanita. Mill: Jos. 51.

2. CYCLAMCN hederifolium.-Leaves cordate, angular; margin dentate.' Hort. kew.

C. hederaefolium. Hort. kew. i. 196.

C. vernale. Mill. Ph. dict. n. 4 ?

Cyclaminus foliis angulosis.! Gesn. ap. Cord. fol. 256. $p$. 1. No fig.

CYCLAMEN. Dale 253. Linn. 63. Vog. 235.

Kuxлzusvos. Diosc. l. 2. c. 194.

- sublobatum. Leaves sublobate. Obs. 8670. Specimen gathered in Saville's garden.

C. hederae folio. Boerh. ii. 151, Magn. hort. 66. Raii hist. 1206.

C. folio hederae. Clus. pann. 255. Found by Mouton in a wood near Tournay. No fig.-Lob. adv. 264 , in the country of the Grisons. No figure; ic. i. 605 , repr. in Ger. by Johns. 843,

Cyclaminus inodoro purpurascente flore. Clus. hist. i. 265, \&

Cyclaminus orbicularis. Dod. $395, \&$ cop. in Cyclaminus altera orbicularis. Dalech. 1606.

C. autumnale folio hederae. Park. theatr. 1364,

Cyclaminus, flore rubro graciliori, et flore albo, vernus. Bauh.J. iii. 554, \&

Ciclamen folio hederaceo, Theophr. a Stap. 1059.

C. folio hederae autumnale. Park. parad. 196. $t$. 197. $f .5$.

Pangulosum. Lcaves angular. Obs. 8615. In the Norton garden. 
C. curopacum. 'Smilh brit. 224; cngl. t. 518. Found by Mr. Davy on a bank near Bramfield, Suffolk, apparently wild.

C. folio anguloso. Boerh. ii. 151 .

C. vernum. Raii europ. 110. Betwcen Massa and Lucca in Italy, in April.-Lob. ic. i. 605, repr. in Ger. by Johns. 843, \& cop. in

Cyclaminus folio anguloso. Bauh. J. iii. 553, but. the corollae seem longer in proportion to the leaves than in the specimens examined above-Raii eu. rop. 110.' Near Rome in Sept.-Boerh. ii. 151.

C. vernum tlore purpureo, Park. parad. t. 197. f. 1 .

Flowers scentless. Corolla purple in the middle; the segments whitish purple towards the margin. Germen inferior. Obs. 4054. Aug. Sept.-Leaves, laminae from 1 .inch one tenth to 1 inch 4 tenths long. Obs. 6815. Oct, 10.-Leeves, laminae $2 \frac{\mathrm{I}}{2}$ inches long. Obs. 8001. Specimen from Mr. Hollifear.

Native of Italy, scarcely of the north of France or of England.

y subinteger. Leaves nearly entire at the margin. Obs. 2738. In Mr. Hunters's nursery. Apr. May. C. romanum autumnale. Park. parad.t.197. f. \&.

\section{MENIANTHES,}

Calyx quinquepartite. Corolla infundibuliform, hir. sute on the inside; segments oblongo-ovate. Cap. sule of 1 cell. Seeds oval, compresșed, glabrous. Obs. 4475.

Menyanthes. $\boldsymbol{L}$. 
1. MENIANTHES petioliflorai Leaves reniform.

Flowers inserted into the petioles. From

Menyanthes indica. L. sp. 207. Swartz. obs. 58.

Menyanthes. Browne 151.

Nynpheae minoris affinis indica, flore albo piloso. Sloane cat. 121 ; hist. i. 252.

Nedel-ambel. Rheede xi. 55. $t .28$.

NYMPHAEA indica minor. Rumph. vi. 172. $t$. 72. $f .3$.

2. MENIANTHES trifoliata. Leaves ternate. $\boldsymbol{L}$. suec. n. 173; sp. 208. Bot. arrang. 206. Curt. lond. iv. 17. t. 240. Smith brit. 225; engl. t. 495. Woodv. 5. t. 2. Bart. 45. Native of Pensylvania. -Fl. dan.t. 541 .

Menyanthes. L. lapp. $n .80$.

M. palustre. Tourn. paris. 494 .

Menyanthes palustre latifolium et triphyllum. Vaill. paris. 126. Boerh. i. 205.

M. palustre triphyllum latifolium et angustifolium. Dill. ap. Raii syn. 285.

Trifolium palustre. Bauh. J. ii. 389. No lfig.Cord. fol.96. p. 2. Raii hist. 1099; syn. ed. ij. 226. Dod. 570 , repr. in

Trifolium paludosum. Lob. obs. 496; ic. ii. 33, \&

Ger. by Johns. 1194, \& cop. in Park. theatr. $1212, \&$

M. palustre Theophrasti. Dalech. 1020. In fruit. M. palustre Dalechampii. Dalech. 1020. In flower. Portulaca hortensis latifolia. Bauh. J. iii. 678. (The name and description is Portulaca.)

Flowers racemose, the lower verticillate. Stigma bifid and trifid. Capsule roundish, bivalve and trivalve. Seeds adhering to the sutures, shining. Obs. 4475. In a bog. 
- MENIANTHES. Geoffr. suile i. 22.

Menyanthes. Cull. ii. 75.

Menyanthes trifuliata. The leaves. Pharm. edin. Lew. disp. by Dunc. 254 Murr. J. i. 190. Thunberg, acconnt from in pliys. journ. ii. 498.

Trifolium paludosum. Buckbean. The herb. Pharm. lond.-Helierd. 51. 347. Hill 395. Lev. ii. 140. Mill. Jos. 441.

'I'rifolium palustre. Alst. ii. 239. Cartheus. ii. 337. Chom. 510. Dale 189. Monro iii. 284. Rully $52 \%$.

Trifolium aquaticum: Berg. 90. Krock. n. 299. Limn. 63.

'Trifolium fibrinum. Pharm. austriaco-prov. 72.Ansheim in act. med. haun. i. 461, and account from in med. cominent. dcc. II. iv. 73. Bang in act. haun. i. 294. Cartheus. ii. 392. Murr. ii. 27. Quarin animad. 41. 169. 172. 177., 250. Spielm. 2.31. Stoll med. iii. 82.83. 88. Vog. 87. Trefoil. TKonro, Don. sold. ii. 186.

\section{LIMNANTHES.}

Culyx quinquepartitc. Corolla rotatc; segments ob. ovate, incumbent, denticulate. Nectaria 5, at the base of the germen. Capsule of 1 cell, and 2 valves. Seeds obovate; compressed, ciliate, fixed to thic 2 sutures. Obs. 4474.

Limnanthemum. Gmel. J. $G$.

Nymphoides. Tourn. t. 67. Boerh. Venten. tabl. iv. t. 10 f. 5.

1. IIMNANTHES nymphoides. Obs. 4474. Specimen gatbered in Lady Clifford's garden. 
Menyanthes nymploides. L. sp. 207. Bot. arrang. 206. Huds. 85. About Kíngston and Hampton.- Relh. n. 159. In the Cam below Cambridge, Streatham ferry, and the fens near Ely.-Gouan monsp. 29. Roth germ. i. 91. Fl. dan. t. 339.

Menyanthes nymphaeoides. Smith engl. t. 217, who has subjoined "e MS. Linn." to a synonym already found in the works of Linnaeus.

Nymphoides aquis innatans. Tourn. paris. 215. V will. paris. 145. Boerh. i. 282. In Holland.Magn. hort. 145.

Nymphaea minor lutea, (misprinted in the title over the fig. alba) Dulech. 1010, cop. in

Curld yellow Water Lily. Pet. herb.t.71. f. \&, \&.

Nymphaea minor lutea, flore fimbriato. Bruch.J. iii. 772. Leaves represented as cordate, and made still more acute in the copy._Raii syn. 36s; hist. 1320. In the isle of Ely plentifully.

Nymphaea lutea minor septentrionalium. Lob. adr. 257, in the Thames; ic. i. 505, \& repr. in

Nymphaea lutea'minima. Ger. by Johns. 820, and cop. in

Nymphaea lutea minor.- Park. theatr. 1252, \&.

Nymphaea minor lutea. Bauh. J. iii. 779. Referred by Boerhaave to his Micronymphiea, which he marks as a native of Holland, but which is not noticed in Gort. belg. foed. nor Geuns.

Natice of Japan, France, Germany, Holland, Middlesex, Buckinghamshire, Oxfordshire, and Cambridgeshire.

MENYANTHES nymphoides. Thunb. jap. 82: srat. iii. 227. 


\section{HYDROPHYLLUM.}

Corolla campanulate. Neclaria 5, each formed by 2 parallel lamellae projecting from the inner side of the corolla. Stigma bifid. Capsule unilocular, bivalve. Obs. 7784 . $L$.

1. HYDROPHYLLUM lobatum. Leaves lobate. Obs. 1417. In Mr. Hunter's nursery.

H. canadense. L. sp. 208. Hort. kew. i. 197.

IIYDROPHYLLUM. Schoepf 19.

\section{LYSIMACHIA.}

Corolla rotate. Capsule globular, unilocular; valpes 5 or 10 . Obs. 3089. L.

1. Peduncles with many flowers. L.

1. LYSIMACHIA rulgaris. Stem paniculate: Florrers terminal, corymbose. Leaves ovato.elliptic. Obs. 3090. In Mr. Hunter's nursery.-L. suec. $n$. 175; sp. 209. Bot. arrang. 208. Curt. lond. v. 49. $t$. 288. Tolerably frequent about London.Smith engl. bot. t. 761 ; brit. 227. Sibth. ox. n. 230. Relh. n. 162. Lightf. 138. On the sides of lakes in the isle of Mull.-Krock. n. 301. Fl. den. $t .689$.

L. foliis lanceolatis, caule corymbo terminato. $\boldsymbol{L}$. lapp.n. 81.

L. Iutea major, quac Dioscoridis. Tourn. paris. 212. Vaill. paris. 123. Boerh. i. 202.

L. Matthioli. Dalech. 1059.

Lysimachium legitimum. Dod. 84, repr. in 
L. lutea sive Salicaria. Lob. ic. i. 342, cop. in

L. lutea major vulgaris, Park, theatr. 544, \& repr. in

L. Iutea. Ger. by Johns. 474. Bauh. J. ii. 903. (misprinted 901. The figure is a Cardamine.) Raii cant. 92 ; hist. 1021 ; syn. 282, in watery places and near rivulets: Found by Richardson about Carlisle.-Blackst. haref. 56. In meadows near Uxbridge moor.-Warner woodf. 92. On the banks of the Rhodon near Luxborough House Essex.-Fuchs. 477. c. 188, abr. in

Lysimachia. Trag. 183.

L. lutea, foliis brevioribus et obtusis, floribus in summitate congestis. Dill. ap. Raï syn. 282. Found by James Sherard? Probably in the Sherardian herbarium.

Flowers sometimes verticillate. Obs. 8060 . Specimen from Prof. Jos. F. Jacquin.

Native of Europe from Italy to Lapland.

LYSIMACHIA. Dale 188. Mill. Jos. 278.

L. Iutea. Rutty 297.

Pellibossa. Geoffr. suite i. 343.

2. Peduncles with 1 flower. L.

L. vulgaris.

2. LYSIMACHIA quadrifolia. Leaves in fours, nearly sessile. Peduncles in fours, with 1 flower. $\boldsymbol{L}$. sp. 210.

I. foliis quaternis subsessilibus, pedunculis quaternis unifioris. Gron. virg. 26. Cutl. in amer. acad. i. 415.

L. foliis orato-acutis quaternis. Gron. zirg. $c d$. i. 20.

Anagallis mariana lutea, foliis latis stellatis. $P_{\ell \ell}$. gaz. 5. t. 2. f. 5 . 
Anagrallis lutea, foliis et floribus ex codem exorta quatuor ex acqualibus surculorum intervallis criqciatim positis. Pluk. mant. 13; phyt. t. 333. f. 1.

LYSIMACHIA. Schoepf 20.

3. LYSIMACHIA repens. Flowers solitary and in pairs. Stem creeping. Obs. 5881. On the side of a wet ditch.

L. Nummularia. L. suec. n. 177; sp. 21]. Bot. arrang. 209. Curt. lond. iii. 14.t.149. Walc.t. Fl. dan. t. 493. Smith engl. t. 528.

L. humifusa, folio rotundiore, flore Iuteo. Tourn. paris. 287.

Nummularia. Cam. epit.755. Dalech. 1062. Raii hist. 1099 ; syn. 283. Trag. 808. Dod. 590, repr. in Lob. obs. 251, \& Ger. by Johns. 630, cop. in

Nummularia vulgaris. Park. theatr. 555, and repr. in

Nummularia, sive Centinorbia. Lob. ic. i. 474. Bauh. $J$. iii. 370, cop. from

Centummorbia, sive Nummularia. Fuchs. 395. c. 153.

Nummularia niajor lutea. Vaill. paris. 144. Boerh. i. 203.

Nummularia minor. Park. theatr. 555.

Stems perennial. Leares evergreen. Obsered during the winter of 1799-1800.

NUMMULARIA. Berg. 92. Chom. 539; suppl. 158. Dale 188. Gcoffr. suite i. 199. Krock. n. 305. Lew. ii. 146. Linn. 64. Murr. ii.9. Vog。 73.

Anagallis flore luteo. Stoll med. ii. 299. 


\section{ANAGALLIS.}

Corolla rotate. Capsule cut round. $L$.

1. ANAGALLIS punctifolia Leaves ovate. Stems procumbent. Obs. 552. In corn fields.

A. arvensis. L. sp. 21.1. Bot. arrang. 210. Smilh brit. 230.

Anagallis. Trag. 389.

ANAGALLIS. Pharm. austriaco-prov. 18.-Car theus. iv. 219. Lew. i. 80; disp. by Dunc. 328. Linn. 64. Murr. ii. 1. Rutty 25. Schoepf 20. Spielm. 198.

a rubra. Corolla red. Obs. 552.

A. arvensis. Curt. lond. i. 12. $t$; mat. med. $t, 20$. Walc. t. L. suec. n. 178. Fl. dan. t. 88. Smith engl. t. 529.

A. flore phoenicco. Raii syn. 282. Tourn. paris. 245. Vaill. paris. 12. Boerh. i. 204.

A. phoenicea mas. Bauh. J. iii. 369, cop. from

A. mas. Fuchs. 20. c. 6. Dalech. 1236. Raii hist. 1023. Dod. 32, repr. in Ger. by Johns. 617, \&

A. mas phoenicea. Lob. ic. i. A65, \& cop. in

A. floribus phoeniceis. Park. theatr. 558.

A. phocnicea. Tab. 716 .

Leares dotted underneath with purplish brown spots. Capsulcs with 5 lines apparently marking out a separation into 5 valves. Obs. 552. ANAGALLIS phoeniceo flore. Chom. 363; suppl. 113.

A. mas. Geoffr. iii. 89. Ploucq. bibl. i. 407 (misprinted amara.):

A. terrestris mas. Dale 187. Mill. Jos. 36.

A. terrestris. Alst. ii. S2. 
Anagallis. Krocl. n. 306. Ploucq. bibl. i. 638.

\& trifolia. Upper leaves in threes. Obs. 6130. On the side of a road where manure had Iain. -

A. mas. Cam. cpit. 394.

\% quadrifolia. Leaves in fours. From

A. phoenicea foliis amplioribus ex adverso quaternis. Raii syn. 282.

¿ caerulea. Corolla blue. Obs. 5208. Specimen from Withering.-Silith. ox. n. 233. Charlbury and Stoney Middleton Oxfordshire.

A. caerulea. Abbot $n$. 159. Oakley west field, and Barton hill Bedfordshire.-Willd. berol. n. 257. Schreb. lips: 5. Roth germ. i. 88; ii. 226. Tab. 717.

A. caeruleo flore. Tourn. paris. 245. Vaill. paris. 12. Boerh. i. 204.

A. caerulea foeninia. Bauh. J. iii. 369, cop. from

A. foemina. Fuchs. 20. c. 6. Cam. epit. t. 395. Dalech. 1237. Raii cant. 11. Near Histon Cambridgeshire; syn. 282; hist. 1024; rather rare in England, but in France and Italy not less common than a-Dod. 33, repr. in Ger. by Johns. 617, found by Gerarde in a chalky corn field between Southfleet and Longfield downs, and by Johnson at Wrightsbridge in lissex; \&

A. foemina cacrulea. Lob. ic. i. 465, \& cop. in Alsine minor. Park. theatr. 760. (The name and description belong to a different plant.)

Calyx, phylla ovato-lanceolate, exactly corresponding with those of a. Obs. 5208.

Native of Europe from Italy to Germany, and of Devonshire, Somersetshire, Surry, Essex, Worcestershire, Oxfordshire, Bedfordshire and Cambridgeshire. 
ANAGALLIS femina. Geoffr. iii. 89. Mill. Jos。 36.

A. caeruleo flore. Chom. 363.

A. terrestris foemina. Dale $18 \%$.

\section{SPIGELIA.}

Corolla infundibuliform. Capsule didymous, witli 2 cells, and many seeds. $\boldsymbol{L}$.

1. SPIGELIA quadrifolia. The uppermost leaves four together. Obs. 8218. Specimen gathered in Jamaica by Dr. Wright.

S. Anthelmia. L. sp. 213; a Murr. 197; amocn. v. a Schreb. 133. t. 6. Hort. kew. i. 202. Anthelmenthia. Browne 156. t. 37. f. 3, cop. in L. amoen. v. 133. t. 2. Arapabaca. Marcgr. 34. Anthelmia. Browne in gent. mag. xxi. 544. t. at $p$. 545. $f . a-l$ :

Capsule didymous, bilocular; dissepiment very thin, whitish. Obs. 8218.

SPIGELIA Anthelmia. Clark, James, in med. facis vii. 297. Lew. disp. by Dunc. 347.

Spigelia. Linn.64. Murr. i. 378. Vog. 120.

Anthelmenthia. Wright in med. journ. viii. 285.

Wormgrass. Graing. 9. 28.

2. SPIGELIA oppositifolia. Leaves oppositc. Obs. 8219. In Mr. Hunter's nurscry.

S. marilandica. L. a Murr. 197; mant. 338. Hort. kew. i. 202. Curt. mag. t. 80. Walt. 92. Woodi, ii. 288. $t .105$. 
Joniccra marilandica. I. sp. 249.

Lonicera spicis terminalibus, foliis ovato-oblongis acuminatis distinctis sessilibus. Gron. virg. 30.

Periclymeni virginiani flore coccineo planta marilandica, spica crecta, foliis conjugatis. Catesb. ii. $t$. r8.

Lcares microscopically scabrous at the margin. Bracteae subulato-setaceous, 2 to each flower excepting the lowermost, one at the base of the flower, the other on one side of the base of the peduncle. Style attenuate, pubescent towards the end. Obs, 8219.

SPIGELIA marilandica. The root. Pharm. edin. -Burt. 59, repr. in phys. journ. viii. 428. Lew. disp. by Dunc. 307. MTurr. J. i. 378.

S. marylandica. Home, $F$. clin. 420. Rush i. $185 \%$ Schoepf 21.

S. americana. Monro iii. 270.

Sprigelia. Indian Pink. The root. Pharm. lond.Berg. 94. Lew. ii. $37 \%$.

Anthelmia. Vog.216.

Lonicera. Chalm. i. 67.

Indian Pink. Garden in phys. ess. iii. 145. Graing. 93. Lining in phys. ess. i. 436.

\section{Ís1: OPHIORHIZA.}

Corolla infundibuliform. Germen bifid. Stigmata 9. Fruit bilobate. $\boldsymbol{L}$.

I. OPHIORHIZA Mungos. Leaves lanceolato-ovatc. L. sp. 213.

O. serpentum radix. L. mat. med. ed. ii. t. at $p$. 59. 
Monogrnia. 193. Plumbago.

MUNGOS. Murr. i. 375.

Mungo, Cartheus. ii. 32t.

Serpentum radix. Linn.65. Vog. 227.

\section{LISIANTHUS.}

Corolla, tube ventricose; segments recurvate. Caly, $x$ carinate. Stigma bilobate. Capsule bilocular, oblong. $L$.

1. LISIANTHUS chelonoides. Glabrous. Leaves opposite, slightly connate, oblong. Panicle terminal, dichotomous, racemose. L. fil. suppl. 134.

\section{PLUMBAGO.}

Corolla infundibuliform. Stamina inserted into the scales which close the base of the corolla. Stigma quinquefid. Seed 1, oblong, tunicate. $L$.

1. PLUMBAGO europaea. Leaves amplexicaul, scabrous. Obs. 8220. Specimen gathered in the Paris garden.-L, a Willd. i. 837 ; sp. 215. Gouan hort. 92. Near Montpelier.-Hort. kew. i. 204.

Tripolium Dioscoridis. Col. ecphr. i. 160. t. 161.

P. quorundam. Boerh. i. 77. Clus. hisp. 434, cop. in

Lepidium monspeliacum, Dentillaria dictum. Park. theatr. 855, \& repr. in

P. Plinii. Ger. by Johns. 1254. Raii hist. 394; europ. 206. About Syracuse, Rome, and Montpelier. 
Dentillaria Rondeletii. Bauh. J. ii. 911. About Montpelier, Arles, and $\Lambda$ vignon.

Denturia. Lob. adv. 136, repr. in ic. i. 321.

Native of Sicily, Italy, and the south of France.

DENTELLARIA. Dale 111.

Dentaria. Linn. 65. Mill. Jos. 176. Murr. i. 519.

$\operatorname{Vog} .114 .236$.

P. curopaea. Ploucq. Zibl. i. 427.

2. PLUMBAGO seylanica. Leaves petiolate, ovate, glabrous. Sten filiform. L. sp. 215. Hort. kew.

i. 204. Forst. G. austral. n. 73.

Lychnis indica spicata, ocymastri foliis, fructibus lappaceis oblongis, radice urente. Commel. hor. ii. 169 t. 35.

TUMBA CODIVELI. Rheede x. 15. t. 8.

3. PLUMBAGO scandens. Leaves petiolate, ovate, glabroụs. Stem flexuose, climbing. I. $s p .215$. Hort. kcw. i. 205. Swartz. obs. 61.

Dentellaria lychnoides sylvatica scandens, flore albo. Sloane cat. 91; hist. i. 211. t. 133. f. 1.

Caapomonga. Marcgr. 28, cop, in Pis. ind. 200. CHILMECHATL. Hern: 140. No fructifications.

4. PLUMBAGO rosea. Leaves petiolate, ovate, gha brous, subdenticulate. Joints of the stem gibbose. L. sp. 215; mant. 335. H. K. i. 204. Curt. mag. t. 230.

Schetti codiveli. Rheedex. 17. t. 9.

Racemi to 10 incles long, flexible, straight. Flowers nearly sessile. Bractece 2, the lower ovate; the upper bipartite and bifid; segments ovate, acute. Corolla pink; segments oval, acute, cuspidate. 
Obs. 8340. Specimen gathered in Mr. Hunter's nursery.

RADIX VESICATORIA. Rumph. v. 453. t. 168 .

\section{MIRABILIS.}

Calyx inferior. Corolla infundibuliform, globular at the base. Filaments united at the base, with a tooth between each. Seed 1, covered by the permanent base of the corolla. Obs. 5200. $L$.

Seems to differ from Abronia Juss. 448, in having a calyx.

1. MIRABILIS pedunculata. Flowers shorter than the leaves, pedunculate. Obs. 5200. In a garden. M. Jalapa. L. sp. 252. Hort. kew. i. 234. Curt. mag. $t .371$.

M. odorata. Osb. trav, i. 326.

Mirabilis. L. ups. 43. Rumph. v. 253. t. 89. Browne 166.

Jalapa flore purpureo. Boerh. i. 78.

Jasminum rubrum. Dalech. 1433.

Marabillas del Peru. Clus. pann. 400, repr, in

Mirabilia peruviana, flore luteo, Ger. by Johns. $343, \&$

Admirabilis peruana flore rubro. Clus. kist. ii. 89. Sloane cat. 91 . In Jamaica.

Atzoyatl. IHern. 170, outer fig.

Jasminum mexicanum, sive Flos mexicanus multis. Bauh.J. ii. 814:

Mirabilia peruviana. Park. parad. 364. t.361,f. 9. 
MIRABILIS Jalapa. Berg. 101. Cosle \&. Wille. met in med. comment. v. 298. Lour. i. 121. Schocpf 23. Wright in med. journ. viii. 271.

B alba. Corolla white. From $H . K$. \% \& Admirabilis peruma, albo flore. Clus. hist. ii. 90, repr. in

Mirabilia peruviana flore albo. Ger. by Johns. 343.

2. MIRABILIS dichotoma. Flowers shorter than the leaves, sessile. Obs. 5201. Specimen gathered in the Vicnna garden.-L. sp. 259. Hort. kew. i. 235.

MIRABILIS dichotoma. Berg, 99.

3. MIRABILIS longiflora. Flowers longer than the leaves, sessile. Obs. 1139. In a garden.-L. sp. 252. Hort. kew. i. 235.

Leaves sessile. Calyx campanulate, permanent; mouth quinquefid; segments subulate, patent. Corolla infundibuliform; tube at the base globular, fleshy, greenish, glabrous, permanent, and investing the germen after the separation of the upper part, above greenish white and purplish, glutinous, separating transversely from the globular base and falling off together with the limb; limb campanulate, plaited, quinqueficl, white. Stigma globular, purple, composed of numerous short crowded threads turbinate at the ends. Obs. 1139.

MIR_ABILIS longiflora, Berg. 101.

\section{CONVOLVULUS.}

Calyx inferior, pentaphyllous. Corolla infundibuliformi-campanulate, plicate. Stigmata 2 , and trio 
lobate. Capsule with 2, 3, and 4 cells. Obs. 3089. 3092. $7185 . L$.

\section{Stem twining. L.}

1. CONVOLVUlus peltatus. Leaves peltate. Peduncles multiflorous. L. sp. 221. Forst. G. austral. $n .78$.

CONVOLVULUS laevis indicus major albus. Rumph.v. 42S. t. 157. f. 1 .

2. CONVOLVULUS Jalapa. Leaves cordato-ovate, obtuse, obsoletely repandose, villose underneath. Peduncles with from 1 to 3 flowers. Obs. 6897 . Specimen in Sir Jos. Banks's herbarium gathered in Kew garden in 1780.-Hort. kew. i. 211. L. mant. 43, apparently from Miller. No specimien of it in the Linnaean herbarium.-Mill. Ph. dict. 2. 31, who raised plants of it from seeds, but they produced no flowers.-Woodv. i. 59. t. 21, from a dried specimen in Aiton's herbarium as informed by the althor. Peduncles with 2 flowers. Accords with the specimen in Sir Jos. Banks's herbarium. The corolla is described as yellowish, but very properly coloured purple as the corollae in the specimen from the Kew garden exbibit marks of purple.

C. americanus, Jalapium dictus. Raii hist. 742 .

Bryonia Mechoacana nigricans. Bauh. J. ii. 151, cop. by Johns. in Ger. by Johns. 872. n. 3. No fig.

Peduncles with the marks of 2 and in one instance of 3 flowers. Corolla exhibiting marks of purple. Obs. 6897. 
JALAPA. Pharm. ausiriaco-prov. 42.-Alst. i. 463. Berg. 100: Geoffr. ii. 81. Ncum. ii. 111.

Jalappa. Pharm. succ.-Beck, account from in physs. journ. xi. 434. Cartheus. ii.404. Cull. ii. 539. Fordyce, G. pract. 207; W. fragm. 66. Hill 519. Linn. 66. Murr. i. 502. Ploucq. bibl. i. 474. Quarin animad. 10. 157; febr. 377. Schrod. 768. Spielm. 641. Vog. 199.

Jalapium. Root. Pharm. lond.-Dale 183. Lew. ii. 2. Mead mon. i. 96; ii. 14. 108. Mill. Jos. 241. Monro iii. 138. Oberne in phys. journ. x. 38. Rulty 246. Wintringham in Mead mon. i. 205.

C. Jalapa. Pharm. edin.-Lew. disp. by Dunc. 206. Murr. J. i. 268. Pearson, R. i. 192; ii. 255. Schoepf 21.

Jalap. Alibert \& Dumeril, account from in chir. rev. vi. 484. Bree 240. Campet, account from in amm. med. lustr. II. ii. 130. Chalm. i. 17. Chom. 58. Clark, James, account from in ann. med. ii. 165; and chir. rev. iv. 226. 288. Cull. clin. 309 ; pract. n. 1448. Darw. ii. 51. 130. Davidson in Rush iv. 109; v. 112. 171. Fordyce G. feo. ii. 55. 57; iii. 224. Hammick in contrib. 380. Hull phlegmat. 270. 295. Hunter jam. 212. 253. Jackson, Rob. feo. 284. 326. 331. Hufeland, ac= count from in med. rev. ii. 416. Lempriere ii. 119. 165. 170. 214. Monro, Don. sold. ii. 81. Rush i. 127. 186. 218. 222; iii. 200. 244. 254; iv. 89. Selden and Whitehead in phys. journ. x. 271. Underwood i. 25. 56. 148. 149.279. Ware ophth. 46.

Iallap. Pott ii. 71.

Gialappa. Herm, 123. Swiet. iv. 738. 
S. CONVOLVULUS Mechoucama. Leaves corlate. Fruit very large, tomentose. Berg. mat. med. n. 6S, probably from authors as he gives no farther description.

Męchoacan. Ger, by Johns. 873, cop. in

Mechoacan. Bauh.J. ii. 149, with the addition of a flower.-Dod. 393. repr. in

Mechoncan peruviana, Ger. oy Johns. 873, \& cop. in

Bryonia alba peruana, sive Mechoacan. Park. theatr. 179. No flowers nor fruit.

MECHOACANNA. Pharm. anstriaco-prov. 48. -Berg. 99. Geoffr. ii. 101. Herm. 128. Lew. disp. by Dunc. 341; by Rother. 194. Linn. 67; amoen. iii. 6S. Murp. i. 507. Rutty 313. Schrod. 769. Spielm. 644. Vog. 240.

Mechoacana. Alst. i. 481, Lew. ii. 96.

Mechoacanna alba. Cartheus. ii, 408. Chom. 60. Mill. Jos. 288.

Mechoacana alba, Dale 183.

4. CONVOLVULUS purpureus. Leaves cordate, undivided. Fruit cernuous. Pedicles thickening. L.-Hort. kew. i. 209. Mill. Ph. dict. n. 4.

C. calycibus tuberculatis pilosis, L. ups. 38. Gron. rirg. 29.

" major. Corolla purple. Mill. Ph.-Hort. kew. a Curt. mag. t. 113.

C. caerulens, folio rotundo.- Johns. in Ger. by Johns. 864, the leaf cop. in

C. caeruleus major, folio rotundo, sive Nil Avicennac. Park, theatr. 169.

C. major, caeruleus. Park. parad. t. 361. f. J.

C. indicus, flore ampló roseo. Ehret. $t .7 . f .2$. 
C. major, folio subrotundo, flore purpureo. Sloane hist. i. 154. $t .98$.

C. major, folio subrotundo, flore amplo purpureo. Sloane cat. 55.

Campanula indica. Bauh. J. ii. 165.

Slem twining from right to left. Peduncles with 2, 3, and 1 flower. Bracleae subulate, 2 at the base of the umbel, or single pedicle, and when there are more than one pedicle 2 also a little above the base of each pedicle, articulated just above the base, the upper part falling off and leaving an obtuse mucro. Caly $x$ pentaphyllous, hirsute below on the outside; phylla acute, the 3 outer broader, subulato-linear, the 2 imner subulate. Corolla infundibuliformi-campanulate, four times longer than the calyx, tubular and purple from 11 at night to 2 in the morning, expanded before 5 in the morning some being purple others purple with specks of blue, becoming purplish blue in the course of the day, and shrivelling up before evening, deciduous; tube white; limb purplish blue with 5 reddish purple streaks. Filaments hirsute below. Style glabrous. Stigne roundish, depressed, trilobate, lobes granulose. Capsule trilocular, subrotundo-ovate, acuminate at the cnd. Secds 2 and 1 in each cell. Obs. 7185. In a garden.

MECAPATLI mecatlensis. Hernand. 304.

5. CONVOLVULUS bifidus. Leaves cordate, oblong, acuminate, very soft underneath. Peduncles bifid, multiflorous. L. a Willd. i. 857, from Vahl.

a lanuginosa. Stem lanuginose. From CONVOLVULUS laevis minor mas. Rumph.v. 431.

\& slaber. Stem glabrous. From 
Monogyia. 155. Convolvulus. 317

CONVOLVULUS minor femina. Rumph. $\mathrm{r}$. 431. t. 150.

6. CONVOLVULUS Turpethum. Leaves cordate, augular. Stem quadrangular; angles membranaceous. Peduncles multiflorous. L. sp. 221. Hort. kiєw. i. 211. Forst. G. esculent. 77; austral. 2. 75.

C. indicus alatus maximus. Raii hist. 1882.

Turbith alexandrinum officinarum. Lob. ic. i. 37I, repr. in Ger. by Johus. 415, ill cop. in

Turbith officinarum. Park, theatr. 1610. The root. TURPETHUM. Pharm. austriaco-prov. 72.Alst. i. 529. Berg. 97. Geoffr. ii. 145. Lew. ii. 441; disp. by Rother. 259. Linn. 66. Murr. i. 510. Rutty 529. Schrod. 776. Spieln. 647. Vog. 243.

Turbith. Chom. 63. Dale 183. Herm. 129. Mill. Jos. 443. Neum. ii. 113.

Turpethum vegetabile. Cartheus. ii. 419. Quarin animad. 186.

7. CONVOLVULUS tomentosus. Leaves trilobate, tomentose. Stem lanuginose. L. sp. 222?

C. polyanthos sub hirsutus, foliis cordato.ovatis quandoque lobatis, floribus fasciculatis alaribus calicibus longioribus hirsutis. Browne 152 ?

C. minor lanuginosus, folio subrotundo, flore caeruleo. Sloane cat. 58.

CONVOLVULUS tomentosus. Lour. i. 133.

8. CONVOLVULUS panduratus. Leaves cordate, trilobate, and panduriform. Calyces smooth. From L.sp. 219 and Dill.-Hort. kew. i. 208. 
C. foliis cordatis integris panduriformibusque, caly: cilus laevibus. Gron. virg. 28.

C. scandens, foliis trilobis quandoque cordatis septinerviis, pedunculis minus ramosis alaribus. Browne 152.

C. megalorhizus, flore amplo lacteo fundo purpureo. Dill. ellh. 101.t. 85. f. 99.

CONVOLVULUS panduratus. Bart. 30 ? Schoepf 21 ?

9. CONVOLVULUS Nil. Leaves cordate, with 3 lobes. Corolla semiquinquefid. Peduucles shorter than the petioles. L.-Hort. kew. i. 209. Curt. mag. t. 18S. Thunb. in linn. trans. ii. 330.

Nil arabun quibusdin, sive C. cacruleus. Bauh. $J$ : ii. 164 .

Cimpana cacrulea. Dod. 392, repr. in

C. caerulcus Ger: by Johns. 86t, \& cop. in

C. major, purpureus, sive trifolius. Park.theatr. 169.

C. trifolius, sen hederaceus. Park. parad. $\ell .361$. f. 2.

IPOMOEA triloba. Thunb. trav. ii. 62.

10. CONVOLVULUS Batatas. Leaves cordate, hase tate, with 5 ribs. Stem creeping, hispid, producing tubcrous roots. 'L. sp. 220. Hort. kew. i. 210. Lour. i. 131. Mill. Ph. dict. n. 7. Spanísh. Potatoes.

C. radice tuberosa csculenta, spinachiae folio, flore albo fundo purpureo, semine post singulos flores singulo. Sloane cat. 53.

C. radice tuberosa esculenta. Calesb. ii. t. 60. Leaves entire at the margin, with 11 ribs, as long as the flowers. 
Kappa-kelengu. Rheede vii. 95. t. 50.

Jetica. Marcgr. 16. Lower leaves angular, upper entire.

BATATAS. Dale 184.

C. Batitas. Bryant 5. Pearson, R. i. 55. Schocpf 21. Wright in med. journ. viii. 248 .

Sweet Potatoes. Edwuards west ind. i. 199.

a luteus. Roots yellow. From authors.

C. floribus pancioribus, pedunculis longis alaribus, radice crasso carnoso luteo. Browne 154.

CONVOLVULUS chrysorrhizus. Forst. G. escul. 55?

Sweet Potatoes. Cook voy. 3rd. iii. 269. 279. 508.

Potatoes. Cook roy. 3rd. ii. 144; iii. 129.

Potatoe slip. Long 774. n. 109.

B albus. Roots white. From authors.

Batatta alba. Rumph. v. 367.t. 130. f. 1 .

C. foliis cordatis angulato-nervosis, caule repente tuberifero. Gron. virg. 28.

C. floribus paucioribus, pedunculis longis alaribus, radice crasso carnoso albo. Browne 154.

C. indicus, Batatas dictus. Raii hist. 728 .

Battades Ignames. Lob. adv. 317, the roots, cop. in Batatis affinis, Igname, sive Inhame. Bauh. J. ii. 793, f. 2, and repr. in

Batata hispanorum. Lob. ic. i. 647, outer figure, with the addition of a figure of a root and stems, which repr. from obs. 369 , and repr. in

Batatas. Clus. hist. ii. 78, \&

Sisarum peruvianum, sive Batata hispanorum. Ger. by Jolns. 925, \& cop. in

Batatas. Bauk. J. ii. 792, and Dalech. 1910, and abr. in

Battatas occidentalis indiae. Park. theatr. 1383 ,

Sisarum peruvianum. T'ab. 482, imit. in 
Batlatas hispanorum. Park. parad. .517. f. 2. CONVOLVULUS Batatas. Clark, James in med. facts vii. 305.

Sweet Polatoc. Long 774. n. 108.

y ruber. Roots red. From Rumphius:

C. radice tubcrosa esculenta minore purpurea. Sloane cat. 54.

BATATTA rubri. Rumph.v. 370. t. 130. f. 2.

11. CONVOLVULUS mammosus. Leaves cordatc, acuminate, repaudose. Tubera aggregate. Lour. i. 132 .

19. CONVOLVULUS maximus. Leaves cordate, ovate, acuminate, entire at the margin, glabrous. Stem and petioles glabrous. L. fil. suppl. 137, who had not scen the flowers.

TIRU-TALI. Rheedexi. 109. t.53. Leaves cordate, the upper hastate.

13. CONVOLVULUS malabaricus. Leaves cordate, glabrous. Stem perential, villose. L. sp. 221.

C. foliis cordatis acuminatis, caule arboreo scandente. Royen 429.

KATTU-KELENGU. Rheede xi. 105. t. 51 .

14. CONVOLVULUS arrensis. Leaves sagittate, the posterior angles entire. Peduncles with 1 and 2 flowers. Bracteae subulate, remote from the flowers. Obs. 3089. On banks on the sides of roads. - Bot. arrang. 213. Sinilh engl. bot. t. 312, calyces represented as dentate;-brit. 232. L. suec. $n$. 181; sp. 218; a Murr. 200. Lightf. 140. Huds. 88. Sibth. ox. 76 ; prodr. n. 457. Pollich n. 201, where for album read alvun.-Curt. lond. ii 13. 
t. 119. Scop. carn. n. 219. Relh. n. 184. F\%. dan.t. 459. Krock. n. 307. Willd. berol, n. 262. Walc. t. Honch. n. 592: Roth germ. ii. 235. Lour. i. 130, but he describes the corolla as short. C. minor vulgaris. Raii syn. 275.

C. minor, arvensis, flore rosco. Tourn. paris. 72. Vaill. paris. 40. Boerh. i. 245.

C. minor purpureus. Lob. obs. 340, repr. in ic. i. 619 ,

C. minor. Clus. hist. ii, 50,

Smilax laevis minor. Dod. 389, \&

Snilax lenis minor. Ger. by Johus. 861.

Helxine Cissampelos, sive Convolvulus. Fuchs. ed. $12 m o$ 260. c. 98, cop. in

Helxine Cissampelos multis, sive C. minor. Bauh. $J$. ii. $15 \%$.

Volubilis minor. Trag. 806.

Helxine Cissampelos. Dalech. 1424.

Leares sagittate, triangular, and hastate, the upper part sometimes oblong, ovato-oblong, and rounded at the end, sometimes emarginate; posterior angles acute, sometimes one of the angles truncate, sometimes with a solitary tooth between the angles and the base. Obs. 3089.

CONVOLVULUSS minor. Geoffr. suite iil. 77. Helxine Ciss.mpelos. Dale 184.

C. minor, arvensis, flore roseo. Chom. 761 ; suppl. 201.

a albus. Corolla white. Obs. 161. Near Worcester.

C. minor, arvensis, flore candido. Tourin. paris. 73. Vaill. paris. 40.

C. minor arvensis, flore albo. Boerh. i. 245 .

15. CONVOLVULUS sepium. Leaves sagittate, the postcrior angles mostly truncate. Peduncles four- 
- cornered, with 1 flower. Bracteae, cordate, close to the flower. Obs. 3092. In hedges.-L. sp. 218; suec.n. 182. Bol. arrang. 213. Curt. lond. i. 13. t. Walc.t.-Smilh engl. bot. t. 313; brit. 233, who says the corolla is occasionally flesh coloured and sometimes deep rose coloured.- Krock. 2. 308. Fl. dan. $t .458$.

Smilax Ienis, sive laevis major. Ger. by Johns. 861, cop. in

C. major albus. Park. theatr. 163.

Sinilax levis. Fuchs. c. 275. ed. 12 mo 682, cop. in

C. major. Bauh.J. ii. 154.' Corolla snowy white. -Raii syn. 275, where Dillenius speaks of the corolla as sometimes flesh-coloured and rose-coloured, referring to Merret and Pluk.

C. major, albus. Tourn. paris. 72. Vaill. paris. 40. Corolla entirely white.

CONVOLVULUS major. Geofir. suite iii. 74. Murr. i. 510. Rulty 137.

Snilax lacvis. Dale 183.

C. major albus. Chom. 38; suppl. 18. Mill. Jos. 148.

16. CONVOLVULUS Scammonia. Leaves sagittate, the posterior margins with a tooth. Peduncles terete, with mostly 3 flowers. Obs. 6898. Specimen gathered in the garden of Fothergill.-L. sp. 218. Lour. i. 130. Russel, Alex. in med. obs. i. 25. t. 1, abr. in Woodv. 13. t. 5. Hort. kew. i. $20 \%$.

C. syriacus, et Scammonea syriaca. Bocrh. i. 245. Scanmonium. Lod. 357. repr. in Lob. obs. 340, Scammonium syriacum, antiochenum, Scammonec. Lob. ic. i. 620, \&. 
Scammonium syriacum. Ger. by Johns. 866, and cop. in

Scammonia syriaca, flore majore convolvuli. Baul, J. ii. 163.

Scamnonia syriaca legitima. Park. theatr. 163. Corollac represented as quinquefid.

Scammonia syriaca. Raii hist. 729 ; orient. 18. SCAMHO NIUMT. 1 gum resiu. : Pharm. lond. -Alst. ii. 467. Berg. 96. Cartheus. ii. 45s. Cull. ii. 541. Dale 183. Geoffr. ii. 665. II erm. 686. Hill 769. Lew. ii. 348. Linn. 65. Mead mon. ii. 100. Mill. Jos. 400. Monro ii. 431. Nurr. i. 494. Neum. ii. 33. Quarin anim. 300. Rutty 469. Schrod. 784. Underw. i. 72. 14S. 201. 208*. 303. 343.

Scammonium aleppense. Pharm. suec.

Scanmoneum. Ploncq. bibl. i, 486. Spielm. 644. Vog. 323.

C. Scammonia. Pharm. edin.-Lew. disp. by Dunc. 205. Murr. J. i. 276. Pearson, R. i. 194; ii. 255.

Scammony. Alibert and Dumeril, account from in phys. journ. iii. 167; and chir. rev. vi. 484. Bisset ess. 92. Darw. ii. 743. Fordyce G. fev. ii. 55; iii. 224. Hufcland, account from in chir. revi. vii. 62. Mronro, Don. sold. ii. 81.

Scammonee d'Alep. Chom. 56.

Diagrydium. Fordyce, W. frag. 27.

17. CONVOLVULUS Redium. Leaves lineari-has. tate, acuminate; auricles dentate. Pcduncles uniflorous. Phylla sagittate. L. sp. 218; mant. 336, where for Camp. read Conv.-Lour. i. 130. Hort. kezo. i. 208.

TALA-NELI: Rheede xi. 113.t. 55.

$$
\text { y } 2
$$


324 Pentandria. 135. Convolvulus.

18. CONVOLVULUS tridentatus. Leaves cunciform, tricuspidate, dilated and dentate at the base. Peduncles with 1 flower. L. sp.ed. i. 15T; a Willd. i. 848. IIort. liew. i. 208.

Evolvulus tridentatus. L. sp. 392 ; a Murr. 299. SENDERA-CLANDI. Rheede xi. 133. t. 65.

19. CONVOLVULUS paniculatus. Leaves palmate; lobes 7, ovate, acute, entire at the margin. Peduncles paniculate. Lo sp. 223. Donn 38.

PAL-MODECCA. Rheede xi. 101. t. 49.

в L. a Willd. i. 865.

MODECCA. Rheede viii. 39. t. 20.

3. Stem not twining.

20. CONVOLVULUS scoparius. Leaves linear, slightly pilose. Peduncles with mostly 3 flowers. Calyces silky; phylla ovate, acute. Stem shrubby. Branches rodlike. Hort. liew. i. 213. L. fil. suppl.' 135.

LIGNUM RHODIUM? L. fil. ib.

21. CONVOLvUluS Cantabrica. Leaves lanceolate and lanceolato-linear, hirsute. Stem branched, hirsute. Peduncles longer than the leaves. Calyces hirsute. Olis. 5211. Specimen from Prof. Jos. F. Jacquin.-L. sp. 225. Host 104. Scop. carn. n. 221. IIoncl. n. 594. Gouan hort. 94. Near Montpelier.-Hort. liew. i. 213 a. Mill. Ph. dict. n. 25. Jacq. austr. iii. 53. t. 296.

C. foliis lineari-lanceolatis acutis, caule ramoso recto, pedunculis bifforis. Allion. nic. 20. Kram. 45.

C. folio linariac lıumilior. Bocrh. i. 247.

C. linariate folio assurgens. Boerh. i. 247. 
C. spicaefolius. Raii hist. 726; errop. 105. In Sicily, Italy, and the south of France.-Park. theatr. 172, \&

Tolvulus terrestris. Bauh. J. ii. 160, cop. from

Cantabrica quorundan II. Clus. hisp. 385, which repr. in hist. ii. 49 ,

C. minimus spicaefolius. Lob. obs. 342; ic. i. 629. f. 1, and Ger. by Johns. 862, \& abr. in

C. linariae folio. Hist. ox. ii. 17. s. 1.t. 4. f. 3, judging from the proportionate lengths of the peduncles and leaves, but the lineate leaves would lead one to suspect that the drawing was made from an inspection of C. Cantabrica and C. lineatus.Lob. adv. 274, repr. in ic. i. 622. $f$. 2, has also lineate leaves.

Volvulus terrestris. Dalech. 1425.

Stem 17 inches long, pilose, with lateral branches below and peduncles above; hairs yellowish. Leaves lanceolate, alternate, hirsute, not silky, to three tenths of an inch broad; veins of the upper surface slightly depressed. Panicles terminal and lateral, capitate, dichotomous, consisting of from 2 to 7 flowers; branches very short. Peduncles, the lateral ones axillary, twice as long as the leaves, pilosonsericeous, not shining; hairs adpressed, some patent. Bracteae lineari-lanceolate, 2 at the base of each panicle, nearly as long as the panicle, and others at the base of the divisions of the panicle. Pedicles shorter than the calyx, Calyces hirsute; outer phylla ovato-lanceolate; inner ovate below, subulate above. Corolla sericeous on the outer side at the angles. Obs. 5211.-Root woody. Stems numcrous, erect, pilose, 7 inches long. Leaves linear, and lanceolato-linear, silky and pilose. Flowers in 
terminal lieads. Olss. 6893. Specimen gathered by M. Broussonett on Montserrat in Spain. CANTABIICA. Dale 184.

22. CONVOLVULUS replams. Leaves liastato-lan. ceolate; auricles rounded, Stem creeping. Pcduncles uniflorous. L. a Murr. 203; sp. 225. Osh. trav. i. 313. Lour. i. 133.

OLUS TACIUM. Rumph. v. 419. t. 155. f. 1.

23. CONVOLVULUS biglandulosus. Leaves emarginate, with a very shortacumen. Petioles with 2 glands, at the end. Peduncles, with mostly 3 flowers. From Plumier \&

C. brasiliensis. L. sp. 226. IIort. Kew. i. 215.

C. maritimus, foliis nitidis subrotundis emarginatis, petiolis biglandulis. Browne 153.

C. marinus catharticus, folio rotundo, flore purpureo. Plum. amer. 89. t. 104. Peduncles with 3, 4, and 1 flower.

C. marinus, sive Soldanella brasiliensis. Marcgr. 51 . C. marinus. Pis. ind. 258. repr. from

Salsa do Praya. Pis. bras. 103.

CONVOL VULUS brasiliensis. Schoepf 22. Wright in med. journ. viii. 247.

24. CONVOLVULUS Sóldanella. Leaves reniform, or cordate. Peduncles with 1 flower. Bracteae cordato-oblong, close to the flower. Obs. 4501. Specimen gathered at Ostend.-L. sp. 226. Bot. arrang. 214. Smith engl. bot. t. 314; brit. 233. Scop. cam. n. 222. Near Trieste and Molo.

C. foliis reniformibus, perlunculis unifloris. Gouan hort. 94. Ont the sea coast near Montpelier. 
Monogryia. 135. Convolvulus.

C. maritimus nostras rotundifolius. Boerh, i. 245. In Holland.

C. maritimus, Soldanella dictus. Raii syn. 276 ,

Brassica marina. Cord. fol. 205. p. 2.

Brassica marina, Soldanella officinarum. Dalech. 526.

Soldanella marina. Raii hist. 726. Ger. by Johns. S3S, repr. from

Soldanella. Dod. 391, which repr. in Lob. obs. 329, and

Soldanella, sive Brassica marina. Lob. ic. i. 602, \& cop. in

Soldanella, sive Volubilis marina. Park. theatr. 167, inner. figure, \&

Brassica marina, sive Soldanella. Bauh. J. ii. 166. On the sea shore' near Venice, Genoa, and Montpelier, and on the coast of Holland.

Leares mostly emarginate. Obs. 4501.-Leaves reniformi-cordate, cuspidate. Obs. 8341. Specimen gathered by M. Broussonett, probably near Montpelier.

SOLDANELLA. Alst. ii. 229. Berg. 98. Dale 183. Geoffr. suite iii. 95. Herm. 539. Linn. 67. Murr. i. 512. Schrod. 775. Vog.,120.

C. Soldanella. Bryant 63.

C. maritimus. Rutty 137 .

Brassica marina. Lew. i. 238; disp. 108. Mill. Jos. 92.

Soldanella maritima minor.' Chom. 18 ; suppl. 7.

25. CONVOLVULUS capripes. Leaves cordate, emarginate. Peduncles with 1 flower. Stem creeping. From Roycn, Rumphius's figure, \&

C. Pes caprae. L. sp. 226. Hort. kcto. i. 214. 
Schovanna-adamboc. Rheede xi. 11\%.t.57. Leaves emarginate.

C. maritimus, scu Soldanclla e maderaspatan, folio in summitate sinuato, Pluk. pluyt. t. 24. f. 4. No fructifications.

C. maritimus zeylanicus, folio crasso cordiformi. Herm. hort. 174. $t$. 175. Corolla repandose at the margin, - Raii hist. 1881.

C. maritinus majore folio chinensis, Pluk, $t .24 . \mathrm{f}$. 5. A leaf.

CONVOLVULUS marinus. Rumph. v. 433. $\%$ 159. $f .1$. Corolla pentagonal at the margin.

26. CONVOLVULUS edulis. Leaves cordate, entire trilobate and quinquelobate, glabrous. Stem creeping, angular. From L. a Willd. i. 875.

CONVOLVULUS edulis. Thunb. trav. iii. 82; iv. 84,89 ;

\section{IPOMOEA.}

Corolla infundibuliform. Stigma capitato-globose. Capsule trilocular. $L$.

1. Leares simple. Flowers distinct. L. a Gmel.

1. IPOMOEA campanulato: Leaves cordatc. Pedincles multiflorous. Outer calyx orbicular. Carolla campanulate, lobate. $L . s p .228$.

ADAMBOE. Rheede xi. 115. $t .56$.

2. IPOMOEA Quamoclit. Leaves pinnatifid, linear: Flowers mostly solitary. L. $-I I . K . \mathrm{i}, 215$. Curt. mag. $t .2 \pm 4$. 
Convolvulus pennatus exoticus, Quamoclit. Col. aquat. 73. t. 72. Bauh. J. ii. 177.

Qunmoclit, sive Jasminum americanum. Clus. cur. 9, repr. in

Quamoclit, sive Convolvulus pennatus. Ger. by Johns. 1598, cop. in

Convolvulus pennatus americanus. Park. theatr. 169.

Tsjuria-cranti. Rheede xi. 123.t. 60.

FLOS CARDINALIS, Rumpl. v. 421. t. 155. f. 2 .

3. IPOMOEA tuberosa. Leaves palmate; lobes 7, lanceolate, acuminate, entire at the margin. $\mathrm{Pc}$. duncles triflorous. L. sp. 227; a Murr. 204. Hort. Kew. i. 216. Jacq. amer. 8vo 37, who des, cribes the peduncles as multiflorous.

I. foliis palmatis, lobis septenis lanceolatis integerrimis. L. ups. 39 ,

I. heptadactyla major scandens, flore majori campan* ulato, calice membranacco, seminibus majoribus villosis. Browne 155.

Convolvulus major, heptaphyllos, flore sulphureo odorato speciosissimo. Sloane cat. 55; hist. i. 152. t. 96. f. 2. No fructifications.

Convolvulus americanus, wandiocae multifido folio, heptaphyllos, flore albo fundo purpureo, radice tuberosa, cortice albo. Pluk. alm. 116, t. 276. f. 6. No fructifications.

Leares pedato-septempartite; folioles lanceolate, cuspidate. Obs. 8351 . In Mr. Sitwell's garden.-Folioles acuminate, rounded at the end with a minute euspis. Obs. 8650. Specimen gathered by Broughton in Jamaica. 
IPOMTOEA tuberosa. Lour. i. 138, but the co. rolla is described as purple.

2. Leares simple. Flowers aggregate. L. a Gmel.

4. IPOMOEA tigripes.-Leaves palnate. Flowers aggregate. $L$.

I. Pes tigridis. L. sp. 230. Hort. Kew. i. 217.

Volubilis zeylanica, Pes tigrinus dicta. Dill. hort. 429. 1. 318. f. 411 .

Convolvulus zcylanicus villosus pentaphyllos et hep. taphyllos minor, Pes tigrinus. Herm. hort. 181. t. 187.

PULLI-SCHOVADI. Rhecde xi. 121.t. 59.

\section{POLEMONIUM.}

Caly. $x$ inferior, quinquefid. Corolla rotate and infundibuliform; mouth of the tube closed by the base of the filaments. "Filaments ovate at the hase. Stigmata 3. Capsule trilocular. Obs.77103. 874. L.

1. POLEMONIUM caeruleum. Leaves pinnate. Tube of the corolla shorter thair the calyx. Obs. 7103. In thickets and meadows between Alport and Rowsley, Derbyshire.-L. sp. 230; suec. n. 183. Bot. arrang. 215. Smith engl. bot. to 14; brit. 234. Fl. dan. t. 255.

- Polcmoniun. I. lapp. 86.

P': vulgare cacrulcum et album. Dill. ap. Raii syn. 228.

- Valcriana gracca. Raii cat. ed. i. 310. Found by Lister in Carleton-beck at the falling of it into the 
Air; - $-e d$. ii. 228, but more plentifully both with a blue flower and a white about Mallham near Setlle in Yorkshire.-Park. parad. 385. 1. 387. f. 6. Dod. 348, repr. in Ger. by Johns. 1076, and cop. in Park. theatr 123, \&

Valeriana graeca quorundam, colore caerulco et albo. Bauh. J. iii. 6. 212. ' In the country of the Grisons.

Stems crect, straight, brittle, villosulose, pubescent abore, angular; angles caualiculate. Leaves villosulose; folioles to. 14 pairs with an odd one at the end, ovato-lanceolate, unequal at the base, glabrous above, villosillose underneath.. Flowers, the upper expanding and producing fruit the first. Calyx cyathiform, quiuquefid, pubescent; segments semielliptic, erect, with a line along the middle. Corolla rotate, twice and a half as long as the calyx; tube whitish, three times shorter than the tube of the corolla; limb horizontal, quinquepartite, purplish bluc, whitish at the base with blackish lines; segments rhombeo-subrotund, incumbent, lineate. Nectarium green, glandular, scutelliform, surrounding the base of the germen, half as long as the germen. Stamina inserted into the mouth of the tube of the corolla. Filaments white, ovate and villose at the base, above filiform, blue. Antherae orange-yellow, oval. Germen ovato-subrotund. Stigmata subulato-linear, recurvate. Obs. 7103.

Nulize of Scandinavia, Silesia, Hesse, Switzerland, the country of the Grisons, and of Yorkshire and the north of Derbyshire, on limestone.

POLEMONIUM cacruleum. Krock.n. 309.

\& album. Corolla white. Obs. 4. In a garden.Mill. Ph. dict. n. 1. Hort. kiew. i. 218 \& 


\section{CAMPANULA.}

Caly.x superior, quinquepartite pentaplsyllous and hexaphyllous. Corolla campannlate and rotate, with 5 and 6 divisions. Filaments dilated at the base. Stigma trifid and quinquefid. Capsule with 3,5 , and 6 cells, opening with lateral apertures. Obs. 6501. L.

\section{Capsules obpyramidal. Leares glabrous.}

1. CAMPANULA Rapunculus. Leaves lanccolate, crenato-serrate, undulate. Paniclc coarctate. Obs. 449.9. Specimens gathered in a nursery near Enville, Shropshire, where it appeared to grow as a weed, and in a pasture near the garden at Hindlip near Worcester, in both which places possibly only a naturalised plant.-L. sp. 232. Biennial.-Bot. arrang. 217, the description from the plant gathered at Enville.-Smith engl. bot.t. 283; brit. 236. Roth germ. i. 98. Perennial,-Gouan liort. 96. Near Montpelier.

CAMPANULA Rapunculus, Bryant 27. Irock. n. 312.

C. esculenta. Dale 184 .

Rapunculus esculentus. Chom. 813. Geoffr. suile ii. 205.

* caerulca. Corolla blue. Obs. 4199.

C. radice esculenta, flore caeruleo. Tourn. paris. 63. Vaill. paris. 27. Boerh. 1. 248. Biennial.

Rapunculus esculentus vulgaris. IIow 104. Raii cat. ed. i. 263 ; ed. ii. 253. On ditch banks and the borders of fields, but rather rare.

Rapunculus esculentus. Raii hist. 739; syn. 277. On ditch barıs and in fallow fields. Armual. 
Rapum sylvestre sive Rapunculus. Fuchs. 214.c. 77 , cop. in

Rapunculus yulgaris campanulatus. Bauh. J. ii. $795, \mathcal{S}$.

Rapunculus minor. Dalech. 641, and improred in Rapunculum vulgare. Trag. 725.

Rapunculum. Dod. 165, repr. in

Rapuntium parvum, Pes locustae Avicennac. Lob. ic. i. 328, \&.

Rapuntium parvum. Ger. by Johns. 453, and cop. in

Rapunculus esculentus vulgaris. Park. theatr. 648. Rapunculus. Park. parad. $t .511$.

Lesser Garden Rampion. Park. parad. 514.

Stem erect, angular, glabrous, smooth. Branches erect. Calyx superior, quinquepartite; segments subulate, with one and two patulous teeth near the base. Germen turbinate, with 3 depressions on the outside. Capsule with 3 cells. Obs.6501. in Mr. S. Shore's garden.

Native of Italy, France, and Germany, but possibly only naturalised in England.

\section{Capsules obpyramidal. Leares seabrous.}

2. CAMPANULA rigida. Leaves serrate, the lowermost cordate, the upper ovate and elliptico-ovate. Flowers secundose, nutant. Germen pubescent. Obs. 6890. Specimen gathered in the nursery of Messrs. Brunton and Hunter.

C. rapunculoides. Smith brit. 237. Found by $\mathrm{Dr}$. Skrimshire at Blair;-engl. t. 1969.-L.-Roth germ. ii. 254.

C. hortensis, rapunculi radice. T'ourn. paris. 406. Vaill. paris. 26. 
C. repens, flore minore caeruleo. Bauh. J. ii.806, stem and branches represented as nutant; imil. in

C. hortensis, rapunculi radice. II Ist. ox. s. 5.t. 3. f. 32.

Stem rigid like that of Cichorium Intybus, erect, from 9 to 30 inches long, pubescent, rough to the touch, rarely branched; branches 3, half as long again as the leaves. Leaves, the lower petiolate, the upper sessile, pubescent, rough to the touch. Racemi terminal, 4 to 14 inches long, leafy below. Flozers remote helow, gradually more approximate upwards. Peduncles mostly shorter than the calyx, with 1 flower, the lower sometimes with 2 and 3 flowers. Calyx quinquepartite, pubescent; phylla ensiform, entire at the nargin. Corolla obpyramidali-campanulate, twice and a lialf as long as the calyx, with lanuginose hairs on the inside. Germen obpyramidal; hairs deflex, acute. Style scabrous. Stigmata 3. Fruit cernuous. Capsule with apertures at the base. Obs. 6890.-Stems erect, and bowed, 13 inches long. Obs. 6891. Specimen gathered be. tween Ostend and Paris.

CAMP P NULA rapunculoides. Krock. n. 315. Rapi sylvestris quartum genus. Dod. 165. No figure.

3. CAMPANULA latifolia. Leaves serrate, ovate and elliptico-ovate. Peduncles of the fruit cernuous. Germen glabrous. Obs. 5872. Between Uttoxeter and Ashbourne.-L.-Bot. arrang. 218. Huds. 96. Near Holywell Flintshire. Smith engl. bot. t. 302 ; brit. 236. Fl. dan. t. 782.

Trachelium majus belgarum, sive giganteum. Ger. by Johns. 448, repr. from 
Trachelium majus belgarum. Clus. hist. ii. 172, \& cop. in Park. theatr. 643.

C. maximu foliis latissimis. Raii syn. 276 .

C. pulchira a Tossano Carolo missa. Bauh. J. ii. 276 . The hairs on the inside of the corolla too conspicuous.

Caly $x$ superior; phylla 5 , minutely serrate. $\mathrm{Co}$ rolla blue. Obs, 5872 .

Natize of Sweden, the north of Germany, the northern parts of Britain, and southwards as far as Flintshire, Staffordshire, Bedfordshire, and, Suffolk, on limestone, marle, gravel, and gritstone.

CAMPANULA latifolia. Gough in bot. arreng. ed. IV. ii. 239.

R alba. Corolla white. From Mill. Ph. dict. n. 5. C. latifolia. Fl. dan.t. 85 .

Trachelium candidum anglicum majus, foliis fere digitalis vel campanulae. Bauh.J. ii. 807.

4. CAMPANULA Trachelium. Stem angular, hispid. Leaves serrate. Peduncles of the fruit cernuous. Obs. 4077. Specimen gathered near Wurcester.-L.-Bot. arrang. 218. Smilh brit. 238. engl.t. 12; hairs not expressed.

Cervicaria major. Dod. 164, abr. in

Trachelium giganteum. Park. parad. t. 355. f. 4, and repr. in

Trachelium majus. Ger. by Johns. 448 .

C. vulgatior, foliis urticae, vel major et asperior. Raii syn. 2T6. Toum paris. 40T. Vaill. paris. 26.

Campanula. Fuchs, 425. c. 166, cop. in

C.: major et asperior folio urticae. , Buuh..J. ii. \$0.5, and abr. in

Lvularia. Trag. 92T. 
TRACIIELIUM. Dale 185.

Uvularia. Geoffr. suite iii. 419.

5. CAMPANULA Cervicaria. Hispid. Flowers sessile. Capitulun terminal. leaves lanceolato. linear, undulate. L. suec. n. 191; sp. 235. Ilort. lew. i. 222. Host 108. Pollich u. 213. Schreb. spic. 6. Reich. moeno-frank. ii. 196. Specinen gathered by Senckenberg.-Honck. $n$. 650. Fl. dan. t. 787. Style longer than the corolla.

C. caule simplici aspero, foliis lingulatis aspcris, floribus capitatis. IIall. hist. n. 636.

C. hispida, floribus sessilibus, capitulo terminali, foliis lauceolato-linearibus undulatis. $\operatorname{Kr} \mathrm{r} \mathbf{m} .48$.

C. foliis echii. Bauh. Casp. prodr. 36.

'I'rachelium altissimum, foliis asperis angustis, floribus parvis. Bauh. J. ii. 801 .

Rapunculus umbellatus angustifolius. Bauh. Casp. pin. 92.

Rapunculus sylvestris cacrulcus umbellatus major. Thal. 91.

Rapunculus sylvestris umbellatus. Thal. $\ell .8$. f. 1, cop. in Parl. theatr. 649, outer fig. \&

Rapunculus sylvestris caeruleus umbellatus major italicus. Barr. t. 523. f. 2.

Native of Germany and Sweden.

CAMPANULA Cervicaria. Krock. n. 318.

3. Capsules obpyramidal. Altemate segments of the caly.x reflex.

6. CAMPANULA Medium. Capsules with 5 cells. Stem erect, simple, leafy. Flowers erect. L.Mill. Ph. dict. n. 3. Roth germ. ii. 258. Hort. liєi். i. 223. Krock.n. 320. 
Vola mariana. Dod. 163, repr. in Gr.r. by Johns. 445, and abr. in Park. parad. 354. t. 355. f. 3. Viola mariana Dodonaei, quibusdam Medium. Bauk J. ii. S04.

Floral leaves, the lowermost thrice as broad as the stem. Panicle pyramidal. Peduncles, the lowermost 6 times as long as the flowers, with from 4 to 6 oblong bracteae, the uppermost shorter than the flowers, with 2 bracteae. Corolla campanulate, ventricose at the base, with short hairs along the lines in the middle of the segments, and long hairs on the inside; more than twice as long as the calyx. Obs. 138.

VIOLA mariana. Dale 185.

7. CAMPANULA edulis. Stem branched, hispid. Leares ovate, acute, serrate, sessilè. $L$. a Gmel. ii. 350 .

CAMPANULA edulis. Forsk. 44.

4. Capsules columnar or prismatic.

8. CAMPANULA Speculum. Capsules prismatic. Leaves oblong, subcrenate. Stem much branched. Segments of the calyx linearislanceolate, and lanceolate, as long or nearly as long as the germen. Obs. 135. L.-Ilort. kew. i. 224. Curt. mag.t. 102.

Speculum veneris. Wrillich obs. 50, in n. 87. Ger. by Johns. 439, repr. from

C. arpensis minima. Dod. 168, \& cop. in

Avicularia Sylvii quibusdam. Bauh. J. ii. 800, with the addition of a branch in fruit. Flowering branches represented as leafy and with only $l$ 
flower. Hence it possibly might have been in. tended as Tournefort thinks for C. hybrida.

C. arvensis crecta. Tourn. paris. 252. Vaill. paris. 27, who renıarks that it is generally decumbent.

Branches axillary, with 3 and 4 flowers. Floral leaves oblong, lanceolate, and lanccolato-linear. Corolla in some plants as long as the calyx. Obs. 135. Specimen gathered in a rarden.-Corolla longer than the calyx. Obs. 5410. Specimen gathered in a garden by Mr. Hollcfear.

CAMPANULA arvensis crecta. Krock.n. 324.

9. CAMPANULA pentagona. Stem very much branched. Leaves linear, acaminate. From $L$. -Salisl. W. 19.

C. Pentagonia. L. sp. 239. Mill. Ph. dict.n. 11. Lower leaves oblong, obtuse, those towards the ends of the branches narrower and pointed. Has bcen long in the English gardens.

C. pentagonia, flore amplissimo, thracica. Boerh. i. 248.

Speculum veneris flore amplissimo, thracicum. Raii hist. 742. Cultivated by Dent from sceds gathered by Covill in Thrace.

CAMPANULA Pentagonia. Bryant 59.

\section{PHYTEUMA.}

Caly.x superior, pentaphyllous. Corolla rotate, quinquepartite; segments linear. Stigma bifid and trifid. Capsule bilocular and trilocular. Obs. 4627. L. 
1. PHYTEUMA orbiculare. Head roundish. Leaves crenate and serrate, ovato-oblong, and lanceolate. Bracteac ovato-lanceolate. Obs. 4625. Specimen gathered in Surry on chalk. $-L . s p .242$, who characterises the radical leaves as cordate. Judging from my specimens and Columnas figure, the cordatc leaves are to be found only on the stems which are to flower the succeeding year.-Jacq. austr. v. t. 437. Huds. 97. Bot. arrang. 220. Smith engl. bot. $t$. 142 ; brit. 240.

Rapunculus folio oblongo; spica orbiculari. Tourï. paris. 527. Vaill.paris. 171.

Rapuntium montanum rarius corniculatium. Col. ecphr. i. 223. t. 224, cop. in

Rapunculus folio oblongo, spica orbiculari. Hist. ox. s. 5.t. 5. f. 47,

Rapunculus corniculatus caeruleus minor. $\boldsymbol{B} a r r \cdot t_{\text {: }}$ $525, \&$

Rapunculus corniculatus montanus. Grer. by Johns. 455. Raii hist. 744; syn. 278 . In many places on the Downs of Sussex and Hampshirc. (The 7 th paragraph in that page does not belong either to n. 2. or n. 1, but to n. 4 of p. 277 , as evident from a comparison of the following synonyms: Raii cal. ed. i. 263; cd. ii. 252; syn. ed. i. 104; erl. ii. 159, where the paragraph in the index of ed. i. 301 is erroncously placerl under the second species of Rapunculus in p. 159, instead of Rapuncnlus esculentus of p. 158.

Aplyyllanthes II. Dalech.864.

Rapunculus corniculatus cacruleus montanus major italicus. Barr. $t .526$.

Rapunculus alopecuroides orbiculari pene spica. Clus. hisi. ii. 173. No fig. 
Rapunculus flore globoso purpuren. Bauh. J. ii. 810. (The fig. is Campanula rotundifolia.)

Stem 6 to 14 inches long. Bracleae ciliate. Stigmata 3 and sometimes 2, very slightitly pilose; hairs very short. Obs. 4625. - Stem 2 feet long. Obs. 4626. Specimen gathered in Saville's garden, from a root dug up near Tartham in Surry.

PII YTEUMA orbiculare. Spielm. 67, who may have inserted it as an article of food on the authority of the misplaced paragraph of Ray's synopsis above noticed. The roots however, I doubt not, are equally good with those of

2. PHYTEUMA spicatum. Spike oblong. Leaves serrate, the lower cordate. Bracteac subulate. Capsules with 2 cells. Obs. 4627. Specimen from Prof. Jos. F. Jacquin.-L. sp. 242. Hort. liew. i. 226. Fl. dan. $t .362$.

Rapunculus spicatus. Tiaii hist. 743; europ. 217. Near Spa and Geneva.

Rapunculus spicatus caeruleus. Bauk. Casp. prodr. 32, cop. in

Rapunculus corniculatus spicatus sive alopecuroides, flore albo ct caeruleo. Hist. ox. s. 5. t. 5. f. 46.

Rapunculus spicatus, flore flavescente. Tourn. paris, 526. Vaill. paris. 171.

Rapunculıs spicatus albus. Vaill. paris. 171.

Rapunculum sylvestre. Trag. T26.

liapunculus spicatus, sive comosus, albus et caeru. lcus. Buuh. J. ii. 809.

Rapunculuni alopecuron. . Iod. 165, repr, in Rapuntimm mijus, alopecuri comoso flore. Lob. ic. i. 329 , 
Rapunculns alopecuroides, longiore spica. Clus. hist, ii. 171, \&

Rapuntium majus. Ger. by Johns. 453, \& cop. in Rapunculus spicatus alopecuroides. Park. theatr. 648.

Rapunculus major. Dalech. 641.

Greater garden Rampions, Park, parad. 514. No fig.

Leares, the 2 lowermost stem leaves cordate, doubly serrate; secondary serratures crenato-serrate. Calyx, phylla subulate. Petals linear, veined; veins longitudinal. Stigmata 3 and 2 , slightly pilose. Obs. 4627 .

PII YTEUMA spicatım. Krock.n. 327. Spielm. 67.

Rapunculus spicatus. Geoffr. suite ii. 207.

Phyteuma. Darbalestrier in med. comment. dec, II. พ. 445 ?

3. PHY'iEUMA pinnatum. Leaves pinnate. From P. pinnata. L- $-H . K$. iii. 486.

Petromarula cretica, sive Rapunculus creticus. Park. theatr. 649, cop. from

RAPUNCULUS creticus Petromarula, Bazh, $J$, ii. 811 ,

\section{LOBELIA.}

Calyx superior, quinquepartite. Corolla superior, cloven longitudinally along the upper side; limb quinquefid. Antherae united by the edges into a cylinder. Capsule with from 2 to 5 cells. Obs: 2963. $-L$. 
Natives of the 4 quarters of the grlobe.

1. Leares not cnlire al the margin. Peduncles solilary.

1. LOBELIA longiflora. Peluncles axillary, with 2 bracteae. Leaves lanceolate, sinuato-dentate. 'Tube of the corolla many times longer than the pedun. cles. Obs. 3345. Specimen gathered in Mr. Wilkinson's garden.-L. sp. 1319; mant. 482. Hort. lew. iii. 283. Jacq. hort. i. t. 27.

L. foliis lanceolatis dentatis, pedunculis brevissimis lateralibus, tubo floris tenui longissimo. Browne 322.

Rapunculus aquaticus, foliis cichorii, flore albo tubulo longissimo. Sloane cat. 58; hist. i. 158. $t$. 101. f. 2 .

Trachelium sonchi folio, flore albo longissino. Plum. a Burm. t. 253. f. 1.

LOBELIA longiflora. Jacq. amer. 219, repr. in $8 v 0,281$.

\section{Flowers in racemi.}

2. LOBELIA reflexa. Sinuses of the calyx reflex. Obs. 4217. In a garden.

L. syphilitica. L. amoen. iv. 524; sp. 1320 ; mant. 482. Hort. kew. iii. 284. Woodv. i. 177. t. 63, separate leaf uncoloured.

Rapuntium americanum, flore dilute caeruleo. Boerh. i. 250.

Fapunculus galeatus virginianus, flore violaceo majore. Hist. ox. s, 5. t. 5. f. 55 . 
Lactescent, acrid when chewed somc little time, but not fiery as L. longiflora. Stem erect, angular, slightly hairy, leafy to the crid, frequently with a purplish red tinge. Leaves lanceolate, slightly pubescent; margin serrato-dentate; teeth whitish at the ẹnds, pointing different wayș, irrẹgularly placed, mostly alternate, sometimes several near together. Racemus terminating, leafy. Peduncles sliorter than the calyx. Bracteae 2, awlshaped, opposite, at the base of the calyx. Calyx more than half as long as the corolla, exceedingly similar to that of some of the Campanulas; segments sagittate, tapering at the end, reflected at the sides, sparingly dentate, slightly pubescent at the margin. Petals, the 2 smaller below separate from each other their whole length, and also from the larger below and above, but agglutinated by their edges to the edgres of the larger one, so as to give it the appearance of a tube as Linnaeus has described it. 'The same structure takes place in all the other species which I have hitherto examined. Capsule cells 2. Obs. 4217.

LOBELIA syphilitica. The root. Pharm. edin. -Chisholm 25. Lew. disp. by Dunc. 249. Pear. son, J. account from in ann. med. lustr. II. i. 271; and chir. rev. vii. 161.

Lobelia. Bart. 36. Lew. ii. 73. Linn. 231; amoen. iv. 524. Monro iii. 160; sold. ii. 243. Murr. i. 514. Kush i. 31. Schoepf 128. Vog. 108.

Tau-tuttipang. Mather in phil. trans. abr. by Jones v. part ii. 160; and by IIutton vi. 86.

3. LOBELIA coccinea. Racemus terminal, secundose. Leaves lanceolate, scrrate, or dentate. Obs. 4209. Specimen gathered in New England by Dr. Cutler. 2 \& 
L. Cardinalis. L. $-I$. K. iii. 284. Curt. mag. t. 320.

L. canle crecto, foliis lanceolatis obsolete serratis, raceino terminatrici. Gron. virg. 134.

L. caulc erecto, foliis lanceolatis serratis, spica terminali. i. ups. 270. Cutler in amer. acad. i. 484.

Flos Cardinalis Barberini. Col. ap Hern. 880.

Cardinalis Rivini. Rupp. ab Hall. 248.

Rapuntium galeatum virginianum, coccinco flore majore. Hist. ox. s. 5.t. 5. f. 54 .

Trachclium americanum, sive Cardinalis planta. Park. parad. t. 355. f: 6 .

LOBELIA Cardinalis. Bart. 41.

4. LOBELIA inflata. Racemi terminal. Leaves ovate, serrate, longer than the peduncles. Capsules inflated. Obs. 4212. L.-H.K. iii. 284.

LOBELIA inflata! Bart. 38. Schocpf 128.

\section{SAMOLUS.}

Corolla hypocrateriform. Stamina defended by the scales of the corqlla, Capsule with 1 cell, inferior. L.

1. SAMOLUS bracteatus. Racemus multiflorous. PC. dicles bracteate. From

S. Valcrandi. Smith brit. 259; cngl. t. 703. L. sp. 243. Bot. arrang. 22!. Thunb. cap. 38. Michaux i. 109. Fl. dan. t. 198. Curt. lond. iv. 20, t. 268. Dill. ap. Raii syn. 283. Bauh. J. jii. 791, cop. fram 
Anagallis aquatica altera. Lob. obs. 219, which cop. in Dalech. 1090, repr. in

Anagallis aquatica tertia. Lob.ic. i. 467, cop. in Veronica aquatica, folio subrotundo non crenato. 11 ist. ox. ii. 323. s. 3. t. 2t. row 2. f. 26, \& Anagallis aquatica tertia Lobelii, folio subrotundo non crenato. Park. theatr 1237, \& repr. in

Anagallis aquatica rotundifolia. Ger. by Johns. 620, (misprinted 626.) Raii hist. 1101; syn. ed. ii. 227.

5. africanus, folio rotundiore. Walth. hort. 162.t. 23.

Alsine aquatica, foliis rotundis beccabungae, Hist. ox. ii. 324. s. 3. t. 24 , row $3, f .28$,

Leares obovate. Obs. 8674. In the park at Calne, Wiltshire.-Leaves obovato-oblong, acute at the end. Obs. S675. Specinen from M. Broussos net.

Natice of the four quarters of the world. SAMOLUS. Geoffr. suite ii. 360.

5. Valerandi. Sckoepf 22,

\section{NAUCLEA.}

Corolla infundibuliform. Capsule inferior, bilocu. lar, polyspermous. From L. and Roxburgh's figures.

Differs from Cephalanthus in the cells of the capsule containing several seeds.

3. NAUCLEA purpurea. Calyz quinquefid, Leaves lanceolate. Stamina not projecting. From Roxb. i. 4l. t. 54, and L. a Willd. i. 928.

Sadamba. Jones in asiat. research. iv. 262. n. 21. 
Arbor indica, fructu aggregato globoso, Katu Trjaka dicta. Raii hist. 144l, from

Katou Tsjacn. Rhecde iii. 29. $t .33$.

BANCALUS. Rumph. iii.84. t. 55 .

2. NAUCLEA hamosa.-With interfolinceous spines. From

Nauclea. Juss. gen. 209.

FUNIS UNCATUS latifolius. Rumph. iị. 63. t. $34 . f .1$.

\section{PORTLANDIA.}

Corolla campanulato-tubiform. Calyx pentaphyl. lous. Capsule pentagonal, crowned by the calyx, with 2 cells and 2 valves; dissepinent inserted into the sides of the valves. Obs. 2312. $L$.

Differs from Catesbea in the fruit being a capsule, and the calyx being pentaphyllows instead of quinquedentate.

1. PORTLANDIA grandiflora. Leaves acute. Phylla elliptico-lanceolate. Obs. 2312. Specimen gathered by Broughton in Jamaica.-L. $s p .244$. Hort. kew. i. 228. Jacq. amer. 62. $t .44$.

PORTLANDIA grandiflora. Wright in med. journ. viii. 277.

a ovata. (Variation.) Leaves elliptico-ovate. Corolla 6 and 7 inches long. From

Portlandia. Browne 164. t. 11, where the phylla are represented as elliptico-lanceolate.

P. grandiflora. Swartz. obs. 69.

8 minor. (Variation.) Leaves elliptico-ovate, and ovato-clliptic. Corolla 4 inches long. Obs, 2312. 
-Obs. 5475. Specimen gathered by Dr. Wright in Jamaica.

Peduncles in the uppermost set solitary, in the set below them ternate. Calyx, phylla lanceolate. Obs. 2312.

\% lanceolata. (Variation.) Leaves Ianceolato-elliptic. From

P. grandifora. Smith pict. i. 6. t. 6, who observes that in some of the flowers the parts were 6.Curt. mag. t. 286.

\section{SCAEVOLA.}

Corolld monopetalous; tube longitudinally cloven; limb lateral, quinquefid. Drupe inferior, monospermous. Nut bilocular. $L$.

1. SCAEVOLA Lobelia. Leaves glabrous, entire at the margin. From L. a Willd. i, 956. Murr. ap. L. a Murr. 213. Jacq. amer. 8vo.81. Swarts. obs. 70.

Lobelia Plumierii. L. $s p .1317$. Osb. trav. ii. 57. Jacq. amer. 219. t. 179. f. 88.

L. frutescens, portulacae folio. Plum. a Burm. $t$. 165. f. 1. Catesb. i. t. 79.

BUGLOSSUM litoreum. Rumph. iv, 116.t.54.

\section{CINCHONA.}

Corolla infundibuliform and hypocrateriform. Calyx quinquedentate. Capsule inferior, with 2 cells 2 ralves and many seeds; dissepiment inserted into 
the margins of the valves, dehiscent. Obs. 2556, \& 6211. H. K. i. 228. Swartz. obs. 71. L. gen. n. 228, from authors.-Gacrtn. i. t. 33. Juss. 201.

1. Segments of the corolla lanceolate, tomentose. Stamina scarcely projecting.

1. CINCHONA officinalis. Leaves elliptic, acute. Capsules ovato-oblong. Specimen in Sir Jos. Banks's herbarium from the herbarium of Miller. -Specimen in Mr. Knowlton's herbarium, intitled "Quina Quina vera from Quito, given by Mor. timer in the year 1745" to Knowlton.-Vahl in liobenhavn. naturhist. selsk. i. 17. t. 1, from a specimen gathered at Loxa in Peru and given to him by M. Jussieu.-Lamb. cinch. 16. t. 1, said to be cop. from a plate annexed to De Castro Sarmento de uso e abuso das minhas agoas de Ingla. terra published at London in 1756, engraved at the expence of the royal society from a drawing made by Mr. Hawkins from specimens sent by Condamine then in Peru to Mortimer, an impression of which is in Mr. Knowlton's library, and on which is engraved " $\mathrm{J}$. Hawkeens delin. ad vivam 1739;" right hand figure cop. in Pulteney diss. inaug. ap. thes. med. a Smellie iii. 12. $t .1$. f. 1, which cop. in cncyclop, brit. ix. 125. t. 252. l. nat. ed. x. 929 ; sp. 244; gen. el. vi. 91. Gaert. i. 169. t. 33. f. 4. Linn. pflanzen syst. i. 258.t.6. f. 1. Woodv. 546. t. 200, cop. from

Quinquina. Condam. dans. l'hist. et mem. de l'acdd. sc. année 1738, mem..226. t. 5 \& 6. p。 244, capsules mostly ovate, which cop. in 
Cortex-tree. Condamine in acad. sc. abr. by Southw. iii. 272. t.9. at p. 392, and the account of its culture translated in med. mus. ii. 428.

C. condaminea. Humboldt and Bonpland, account from in edinb. journ. ii. 485.

Arbor febrifuga peruviana. Raii hist. 1796 .

Peruvian or Jesuits Bark. Arrot in phil.trans, abr.

by Hutton viii. 142; and account from in Mihles's ess. ii. 332, \& med. ess. vi. 375.

Leares glabrous, thin; tufts of short hair at the superior axillae of the lateral ribs at their insertion into the costa, but no obvious scrobiculi. Capsule rather acuminate at the end, smooth, blackish rufous. Obs. 8677. Portions of a specimen sent by Gronovius to Vienna, and given me by Prof. Jos. F. Jacquin.

CINCHONA. The bark, commonly called Peruvian Bark. Pharm. lond.-Bree 367. Davies, $I$. in phys. journ. v. 534; xvi. 496. Fordyce, G. fev. ii. 119; iii. 17 ; iv. $145,182,185,186$; ఛ. $59,88,93,101$; vi. $36,57,60$. Harrold in phys. journ. xiv. 325. Heberd. 90. Mossman in phys, journ. x. 12, 18, 19. Murr. J. i. 288. Parker, account from in chir. rev. iv. 59. Pearson, $J$. account from in ann. med. lustr. II. i. 270. Ploucq. bibl. i. 70, 209, 280, 327, 346, 412, 461, $463,467,474,481,493,505,506,514,519,521$, 522, 524, 548, 572, 640, 655, 698. Stichel, account from in med. rev. i. 573. Valentine, ac. count from in chir. rev. xi. 240.

C. officinalis. The bark. Pharm. edin-Lew. disp. by Dunc. 189. Murr. J. i. 175; ii. 30 , 43. Pearson, R. ii. 213.

Kinkina. Pharm. suec.-Sauv. ii. 340. 
Quinquina. Chom. 469. Cohuusen archeus, account of in med. ess. iv. 391. Vaume, account from in chir. rev. iii. 393, 397, 400. Alibert, account from ib. vi. 485.

Kina Kiua. Geoffr. ii. 179. Hill 671.

Quinaquina. Alst. ii. 10.

Chinchina. Murr. i. 546. Quarin febr. 79.

Cortex peruvianus. Aasheim in act. haun. i. 175, 178, 180, 181. Aaskow ib. 162, 200. Badenoch in med. obs. iv. 156. Bang in act. haun. i. 5, 8, $19,100,104,106,108,109,112,119,241,247$, 255, 257, 277, 297, 298. Bissct ess. 170. Bromfield i. 83. Bruce in Lind hot clim. 25. Buchhave in act. haun. i. 228, 231, 234. Callisen ib. 72, 74, 362-367, 416, 421, Cartheres. iष. 261. Cull. ii. 89, 431; pract. n. 1334; clin. 76. Dale 291. Fordyce, G. pract. 153, 154, 156, 161, 169, 207, 209, 210; W. fragm. 19, 25, 33, 38, 44, 57, 60, 94. Fothergill, $J$. in med. obs. i. 303. Galeatius, account from in med. comment. i. 172. Goolden in med. ess. iii. 33. Gulbrand in act. haun. i. 145. 305. Hamillon Rob. account from in med. rev. vii. 476. Heberd. 5, 9, 14, 26, 28, 59, 92, 95, $110,122,126,148,155,159,161,169,175,176$, $259,280,281,302,321,397,340,346,366,386$, 415. Hillary 22, 164, 315. Home, F. clin. 15, 112, 194, 324. Hull phlegmat. 277 ; caesar. 351. Lew. ii. 194. May 45. Mead mon. i. 30, 41, 55, 76, 120; ii. 29, 144. Med. mus. i. 121. Mertens 15. Neza in act. ned. haun. i. 40. Monro iii. 200. Morton pyretol. i. 424. Neum. ii. 59. Nev, account from in med. comment. v. 156. Pearson, G. in Rollo diab. 306. Rand. in mct. pap. 68. Ranöe in act. haum. i. 35, 456. Reid T. phthis. 163. Rogert in act. haun. i. 18S. Quarin fcbr. 
$30,42,44,46,47,59,60,68,74,75,77,78,80$, 81, SS, 90, 93, 94, 95, 105, 107, 111, 112, 123, 157, 144, 146, 149, 165, 188, 207, 209, 240, 287, 289, 307, 315, 320, 329, 369, 370, 377, 400, 412, 430,434 ; inimad. $13,37,38,60,65,83-88,92$, $113,158,169,170,175,202,203,207,208,224$. 298, 282, 306, 311, 315. Quier in lett. \& ess. 146. Rutty 142. Schonheyer in act. haun. i. 168. Shipton in phil. trans. abr. vii. by Eames and Martyn 617. Stoll med. i. 29, 78, 82, 105, 105; ii. $12,17,45,52,98,123,159,165,181,183$, $200,204,206,228,235,248,252,298,314,336$, 362 ; iii. $7,16,68,71,78,83,420,422.94,95$, 98, 181. 169 ; aph. n. 192, 372, 452-458, 467, $478,496,497,547,556,678,715,808,809,830$. Sydenh. 301, 304. Tozensend's trav. iii. 137, 341. Underw. i. $79,109,192,195,360$; ii. 62. Ware ophthalm. 55. Wintringham in Mead mon. i. 45, 104, 169-172, 221-223, 230, 232, 250; ii. 212, 228, 229, 232, 247.

Cortex peruanus. Heberd. 51, 88, 90, 98. Nill. Jos. 154.

China Chinae. Pharm. austriaco-prov. 29.-Herm. 203. Vog. 287.

Chinae cortex. IIoffm. vi. 32, Linn. 68. Spielm. 252.

Peruvian bark. Aitkien midzo. 118, 12T, 132, 134, 136, 182. Albers in ann. med. lustr. II. ii. 410. Ann. med lustr. Ir. i. 454. Baker in med. trans. iii. 141. Barbarin, account from in chir. rev. xviii. part ii. 47. Binns in phys. journ. xv. 492. Bisset ess. 75, 77, 101, 181, 183, 233, 271. Blair in med. rev. ii. 74, Blane 399, 402, 420, 422, 490, 504, 523. Bouffey, account from in phys. journ. 1. 104. Bree 278, 310. Brisbane 
guotcd in Rolio dinb. 370. Bromficld i. 73; ii. 40. Brown ii. 260, 277, 296, 305. Bruanl, account from in ann. mcd. lustr. IJ. ii. 103. Bryce, account from in ann. med. i. 125, 130. Cappcl, account from in med. rev. iv. 44. Chalm. i. 65, $73,80,82,83,95,104,124,130,133,137,149$, $153,15 t, 181,193,200,220$; ii. $6,9,17,21$, 22, 42, 88, 93, 94, 98, 102, 113, 123, 167, 177, 182, 208. Clark, Jamcs, account from in ann. med. ii. $175,179,180,181$; J. fev. 18; long voy. 184, 331, 431; account from in med. comment. ii. 13. Collingwood in mcd. comment. x. 265. Cornette account from in med. journ. $v$. 249. Cull. pract. n. 226, 227, 232, 272, 317, 403, 469, 577, 623, 629, 663, 69.1, 713, 729, 818, $920,1089,1169,1215,1334,1354,1425,1464$, 1695, 1732, 1755, 1808. Darw. ii. 47, 66, 73, 78, $113,117,185,204,217,222,252,256,311,441$, 710, 711, 716, 723, 733, 748. Davidson in med. comment. dec. II. v. 397. Denm. ii. 523. Duncan cases 92. Fenwich, account from in chir. rew. xvii. 255. Fischer, account from in ann. med. $i$. 67. Fordyce, G. fev. i. 179, 204; iv. 175; J. in med. obs. i. 184; $W$. fevers 114, 221. Fowlcr, T. arsenic 89, 106; rheum. 283. Gaultieri, account from in chir. rev. i. 385. Haygarth, account from ib. xii. 91, and in phys. journ. xir. 273. Hamilton, Rob. of Lynn, account from in chir. rev. ix. 554, 559; and med. rev. vii. 471 . IIolliday, account from in chir. rcv. iii. 52. Home, Ezerard, account from in ann. med. iii. 52. II feland, account from in chir. rev. vii. 62. Hunter jam. 108. Irving, account from in mcd. commcnt. dcc. II. ii. 257. Jackson, Rob. jam. 210, 232, 235, 238, 294, 297, 307, 317, 329, 
3S2, 336, 3St; fev. 276. Leigh, acrount from in phil. trans. abr. by Hutlon iii. 602. Lempricre i. 50, 179; ii. 162. Lettsom dispensar. 12, 13, 15-17, 46, 93, 114, 253. Monro, Alex. in med. ess. v. St; Don. sold. i. 310 ; ii. 13. Moodic in phys. journ. xii. 25s. Morris in med: obs. iii. 281. Moseley 161. Paisley in med. ess. iii. 39; iv. 4S. Pearson, $R$. account from in med. rev. ii. 507. Percival ii..195. Portal, account from in ann. med. iii. 175. Pott i. 447, 454; iii. 358. $P_{y j}$ in med. ols. ii. 245. Quier in lett. \& ess. 62, 158. Rail in med. comment. ix. 354. Reil, ac. count from in med. comment. dec. II. ix. 26. Robertson, fev. 1S5̃. Rush. ii. 128, 288: Rushworth, \&c. account from in med. ess. ii. 325. Schoenheider, account from in med. joum. 383. Sellie ib. ii. 114. Shipton in phil. trans. abr. by Hutton vii. 574. Skicete, account from in med. comment. dec. II. ii. 232. Smyth jail dist. 66, $78,116,119,197$; and account from in ann. med. i. 94, 98, 102. Tainsh in phys. journ. v. 539; \& chir. rev. viii. 86. Tavares, account from in phys. journ. xii. 142. Thomas, account from in med. rev. viii. 99, 105. Ticc in phys. journ. xi. 24r. Todd in ann. med. i. 341. Underw. i. 306. IVare epiphor. 23; ophth. 46. Wells in trans. improc. ii. 225. Western in med. comment. dec. II. vi. 363. Whatcly ulcers $45,76,105$. Willan lond. 38, 93, 155, 234. Wright in ann. med. ii. $348,35 \pi, 358,362,370$.

Bark. Ailin in med. soc. iii. 394. Alibert, account from in phlys. journ. vii. 377. Alibert und Dumeril, account from in phys. journ. ii. 468; iii. 168. Baylics in mad. pap. 46. Bisset css. 44, 70. Blane $890,451,461,536$. Blizard, account 
from in med rev. i. 330. Bond in med. ols. ii. 265. Bree, account from in chir. rev. v. 32, 33. Bromfield i. 108, 126, 129, 311 ; ii. 69. Cameron in gent. mag. xxi. 543, republ. in med. mus. $\mathrm{i}$. 281. Chalm. i. 149, 151, 153, 154, 179, 212, 217 ; ii. $64,78,152,158,180,192,204$. Chapman in med. commun. i. 260. Chiarenti, account from in phys. journ. ii. 467. Chisholm 157, 164, 170, 171. Clark, James, account from in chir. rev.iv. 288, 289; J. long voy. 189, 253, 300, 395, 441; fev. 23, 25, 251. Clegh. 203,. 206-225, 242, 256. Conyngham in mem. med. soc. ii. 114. Crawoford, J. in Trotter ii. 92. Call. clin. 87, 157, 232, 274, 292, 311, 312, 328. Currie, James, in Rollo diab. $147 ; W$. account from in med. rev. vi. 64. Dallas in ann. med. iii. 330. Darw. ii. 16, 17, 47, $48,68,69,70,72,73,74,79,87,97,102,108$, $114,132,139,137,157,162,209,217,218,235$, $245,251,269,276,292,298,302,810,329,392$, $359,360,381,395,401,403,460,463,495,497$. 500, 506, 515, 715, 717, 793, 735. Davidson in Rush iv. 109; v. 149, 182, 186. Denm. i. 102, 176; ii. 398, 511. Dickinson 165. Douglas in phil. trans. abr. vii. by Eames and Martyn 645; and by Hutton vii. 572. Downey in Trotter ii. 107. Dumas, account from in phys. journ. $x$. 541. Edlin ib. 445. Ferguson, account from in sned. rev. vii. 136. Ferriar i. 114, 115, 123, 177; ii. 151, 163. Fleniing in Trotter ii. 142. Fordyce, G. pract. 179, 185, 263, 274, 29т, 314, 332, 356, 357, 365, 567, 375. Folherg. J. in gent. vzag. xxiii. 63. Fowle, account from in mcd. rev. iv. 346. Freser, T. in lett. \&. ess. 111. Goodwin, $W$. in phys. journ. iii. 442. Graing. 39, 43, 51, 73. Grindall in med. mus. ii. 171. Il alls in med. com- 
menit. dec. II. x. 330. Hammick in contril. 383. Heberd. T. in med. trans, i. 34. Hillary 127. Home F. clin. 155. Hoven, account from in med. rev. ii. 363. Hufeland, account from ib. 451, 458. Hull phlegm.'221; caesar. 351. Hume, J. in lett. and ess. 226, 230, 210, 251, 256. Hunt. account from in chir. rev. x. 242, 243, 265, 271. Hunter J. in Pringle Ato ed. 275, 312, 318, 319; app. cviii; ven. 199; jam. 126, 130,131, 146, 151, 208, 226. Jackson, Rob. jam. 278; fev. 257, 307, 521, 330. Laficiente, account from in phys. journ. xiv. 531. Lempriere ii. 61, 91, $127,128,160,162,166,172,174,189,192,225$, 231, 263. Lind hot clim. 22, 33, 54, 65, 69, 94, 104, 190, 242, 249, 282, 292, 317; seam. 56, 62, 144, 202, 261, 276. Lowry in pliys. journ. xiii. 350. Macgregor in ann. med. iii. 342. Mackensie in med. obs. i. 81. Maclean, 122, 133, 128, 170; and account from in ann. med. ii. 202. May 28, 31, 54. Mease, mad dog 107, 117. Med. mus. iii. 460. Milne, account from in chir. rev. x. 399, 496. Monro, Don. sold. i. 211, 212, 245, 250, 265, 287, 289, 558, 365, 373; ii. $43,65,89$, $104,113,130,148,185,196,206,235,257,274$; G. in lett. \& ess. 268. Moseley 162, 222, 232, 4493, 447, 457, 484, 489. Munckley in med. mus. ii. 27. Paisley in ann. med. lustr. II. i. 420, 427, 434. Pearson, $R$. account from in chir. rev. vi. 463, and med. rev. viii. 272. Percival, T. i. 57, 92, 398. Phys. journ. iv. 568. Polidori, account of in phys. journ. i. 104. Portal, account from in med. rev. v. 340. Pott ii. 217, 222; iii. 158. Pringle 132, 144, 166, 182, 183, $189,200,202-205,209,214,216,274,275$. Pye in med. obs. i. 113. Quier in lett. \& ess.

$$
\text { A } 2 \text { 2 }
$$


1.7, 160. Reece, account from in phys.. journ. vii. 473; viii. 569, \& med. rev. viii. 410. Reilly in Trolter ii. 129. Robertson fev. prcf.xx. 18, 15t, 188, 368, 357, 419, 487. Rollo diab. 22. Tosenst. 197. Juush i. 114, 125, 136, 109, 196; ii. 109, 242, 285; iii. 194, 195, 229, 288, 298, 303; iv. 96 ; v. 7 ; in phlilad. coll. i. 186; and accounts fiom in med. comment. dec. II. ix. 158; x. 57, 75, 121. Sandiford in med. obs. iv. 316. Sannders in med. journ. xi. 67. Sherwen in amm. mcd. lustr. II. ii. 266, 268. Shipton account from in Mihles's ess. ii. 269. Shouft in med. soc. ii. 108. Sims, James 30, 217. Snall in med. obs. v. 211. Sydenh. 537. Trotter, nccount from in chir. rcv. iv. 10. Underw. i. 36, $73,88,89,101,110,173,190,208 * 209 *, 216$, $228,259,260,261,264,302,317,322,325,330$, $331,334,344,348$; ii. $64,75,93,106,128$. Vaughan in med. soc. ii. 12T. Wall, J. in gent. mag. xxi. 497 ; republ. in merl. mus. i. 111 , \& Wall, J. tracts 58, 35, 355. Watherston in Trotter ii. 145. Whately ulcers 52, 99, 11S, 129. Whytt in phys. ess. iii. 366. Willan lond. 18, $119,180,285$.

Cortex. Assalini, account from in chir rev. vii. 461. Pang in act. haun. i. 109, 262, 275, 284; ii. 51. Bonzart in acud. sc. abr. by Sonthw. iii. 161. Callisen in act. haun. i. 74. Gilchrist in med. ess. vi. 68. Monro, Dorr. sold. i. 285; ii. 36. Quarin felr. 79, 80, 125, 143, 289, 290, 292, 390, 346, 34S, 404; animarl. 2S, 112, 117, 47, 58, 94, 167, 132, $901,225,210,246,266,273$, 302, 305. Reneaume in acad. sc. abr. by Southw. iii. 269. Stoll med. i. 1S, 11S, 15it, 139; ii. 909, 401; iii. 390: Undcrw. i. 77 ; ii. 150. 
Pale Bark. Maclean 124.

Brown Cinchona. Fordycc, Cr. fcr. 120.

Orange coloured Peruvian Bark. Mutis, account from in chil. veo. vii. 99.

South American extract of Bark. Clark, J. long roy. 209. Saunders in mod. journ. xi. 67.

CINCHONA flava. Vaughan, Walt. account from in chit. rev. ii. 537. Westling, account from in med. rev. yi. 172.

Yellow Perụvian Bark. Marabclli, account from in ann. med. iii. 197. Mutis, accounnt from in chir. rev. vii. 29. Oryan, lettcr on, 19. Relph, account from in med. comment, dec. If. ix. 404.

Tellow Bark. Fowle, account from in med. rev. ị. 346. Ręlph, account from in chir. reci. i. 150. Thomas, account from in med. rev. viii. 100. Yellow Cinchona. Fordyce, G. fco. ii. 120. CINCHONA rubra.

Kina Kina foemina., Geoffi. ii. 202.

Red Peruvian Bark. Blane 457. Clack, James, ae count from in amm. need. ii. 168, 175. Halliduy in med. journ. iv. 416. Ilunter jam. 152. Med. journ. v. 422. Mutis, account from in chir. rcv. vii. 99. Saunder's, account from in med. comment, viii. 167. Simmons in med. journ. iv, 30t.

Red Bark. Clarke, James, account from in chir: rev. iv. 282; J. long roy. 308. II unter jam. 212. Lindsay, account from in chir. rev. ii. 279. Maclean 125. Mary 14. Ware epiphor. 33.

Red Cinchona. Fordyce, G. fev. ii. 120.

\& pubesccns. Specimcn in Sir Jos. Banks's herbarium with the title of C. officinalis altera e regn. St. Fid. cum flore.

C. officinalis. Lainb. çinch. 16. t. 1, the upper panicle in fruit? or the lower?

$$
\wedge \text { a } 3
$$


Leaves, 2, one elliptic the other ovate. Petioles pubescent. Cymé pubescent. Capsule lanceolatooblong, one third longer than that of $\alpha$. This and C. pubescens I consider as varieties of $C$. officinalis differing only in the size of the fruit, and the greater or less pubescence of the leaves. Specimen abore mentioned.

2. CINCHONA pubescens. Leaves elliptic, pubescent underneath. Capsules oblong. From Vahl. in kiobenharn. naturhist. selsk. i. 17. t. 2, cop. in Lamb. cinch.21.t.2, from a specimen gathered in Peru, and given to Vahl by M. Jussieu.

WHITE PERUVIAN BARK. Jussieu, Jos. account from in med. journ. iv. 306. Mutis, account from in chir. rev. vil. 99.

3. CINCHONA macrocarpa. Leaves elliptico.ob long, pubescent underneath. Calyx obsoletely dentate. From Vahl in kiobenhaon. naturhist. selsk. i. 17. t. 3, cop. in Lamb. cinch. 22. t. 3.

C. officinalis. L. nat. ii. 164; a Murr. 213, from specimens sent by Don Mutis, as evident from the description of the leaves and teeth of the calyx, and Vahl assures us that the specimen in the Linnaean herbarium is his C. macrocarpa.-L. fil. suppl. 144 .

C. cortex peruvianus ruber. Woodv. 555. t. 201, from a drawing in the Linnacan herbarium said to have been sent to Linnaeus from America, but the calyx is represented as quinquefid.

Native of Santa Fe. Specimen in Sir Jos. Banks's herbarium from Don Ortega.

CINCIIONA macrocarpa. Vahl translaied ịn Lamb. cinch. 13. 
2. Segments of the corollu linear, glabrous. Stamina projecting beyond the tube of the corolla.

4. CINCHONA myrtifolia. Peduncles axillary, uniflorous, solitary. Tube of the corolla somewhat longer than the linb. Obs. 6211. Specimen gathered by Broughton in Jamaica.

C. caribaea. L. sp. 245 ; mant. 338, (where mis. printed herbacea.)-Hort. kequ. i. 228. Jacq. amer. 61. t. 179. f. 95, the fruit; 8vo ed. 78; obs. ii. 27. f. 47, cop. in pict. 35. $t$. 68, with the fruit.-Vahl in kiobenhavn. naturhist. selsk. i. 20. Gaertn. i. 169. t. 33. f. 4. Lamb. cinch. 24. t. 4 , from a specimen in the herbarium of $M$. de Ponthieu. Fruit represented as costate.

C. jamaicensis seu caribbeana. Wright in phil. trans. Ixvii. 504. t. 10, segments of the corolla represented convex instead of concave.-Encyclop. brit. ix. 124. t. 252.

(Periclymeno recto accedens arbuscula virginiana siliquosa. Pluk. alm. 288, t. 103, $f, 3$, has fruit with a permanent style.)

Leares lanceolate, glabrous; tufts of hair underneath in the axillae of the lateral veins at their insertion into the costa. Capsule oblong separating into 2 parts, truncate at the end, terete, smooth. Obs. 2556. Specimen gathered by Broughton in Jamaica.

CINCHONA caribea. Pharm. edin.-Clark, James, account from in ann. med. ii, 176. Lew. ii. 209; disp. by Dunc, 195. Murr. i. 551 ; $J$. i. 182. Wright in med. journ. viii. 239.

Cortex caribaeus. Schumacher, account from in phys. journ. vi. 376 ; vii. 81 ,

A a 
Caribean Bark. Rush iv. 99.

5. CINCIION t triflor . Flowers axillary, 3 together. From Wright in med. journ. viii. 240. Found by Mr. Roberts in Jamaica.-Encyclop. brit. ix. 124.

6. CINCHONA floribunda. Panicle terminal. Segments of the calyx very short. Capsules oblongocylindric. Leaves elliptic. Specimens gathered in Dominica by M. de Ponthieu, and with smaller leaves gathered in Jamaica by Drs. Dancer and Swartz in Sir Jos. Banks's herbarium.-Swartz prodr. 41; ind. occident. i. 375. Lamb. cinch. 27. 1. 7, from' a specimen in Sir Jos. Banks's herbarium, gathered by Mr. Mason in Saint Lucie.Vahl in kiobenh. naturhist. selsk. i. 23. In Hispaniola and Martinico.

C. montana. Badier in journ: de phys xxxiv. 129. $t$. 1. In Guadaloupe and Martinico.

C. floribus paniculatis glabris, laciniis linearibus tubo longioribus, staminibus exsertis, foliis ellipticis glabris. Bants in phil. trans. Ixxiv. 453. Found by Mr. Davidsoṇ in Saint Lucia.

Capsule slightly costate, glabrous; ribs 10 to 12. Specimens above mentioned.

CINCHONA floribunda. Encyclop. brit. ix. 121. Westring, account from in med. rev. vi. 172.

C. montana. Mallet \& Badicr, account from in encyclop. brit. ix. 124,

C. Sanctae Luciae. Kentish, account from in mod. comment. xii. 281.

Cortex Sanctac Luciac. Harrison in new med. journ. i. 19. 
Cinchonae species quae insulae Sanctae Lucine imna scitur. Monro iv. 282.

Bark 'Tree of the isliunl of St. Lucia. Davidson in phil. trans. Ixxiv. 452; \& account from in med. journ. vi. $175 ;$ v. 202.

7. CINCHONA brachycarpa. Panicle terminal. Calyx twice as short as the germen. Leaves elliptic; Capsules oral, costate. Obs. 8678. Specimen from Dr. Wright, without corollae or fruit.-The account of the fruit from specimens in Sir Jos. Banks's herbarium gathered by Dr. Lindsay in Westmorland in Jamaica.-Swartz. prodr. 42; ind. occid. 378. Vahl in kiobenhavn. naturhist. setsk. i. 24. Lamb. cinck. 28. $t$. 8. from a specimen in Sir Jos. Banks's herbarium. L Lindsay in edin. trans. iii. $t$.

Branches glabrous. Leaves glabrous; axillae of the lateral ribs underneath with tufts of hair. Panicle glabrous. Calyx, segments subulate, erect. Obs. S678.

CINCHONA brachycarpa. Clark, James, account from in ann. med. ii. 176. Lindsay, account from in chir. rev. ii. 378; med. facts $\mathrm{v}, 131$; \& encycl. brit. ix. 125. Wright in med. journ: viii. 210 .

3. Species not hitherto characterised.

8. CINCHONA Cambar. Köenig ap. Retz̈. obș. iv. 6 . 


\section{COFFEA.}

Carolla hypocrateriform. Stamina inserted into the base of the limb of the corolla. Berry inferior. Seeds 2, arillate. Obs. 7979. In flower.-L.Juss. 204. Venten. tabl.t. 13. f. 1.

1. COFFEA arabica. Corolla quinquefid. Leaves elliptic, acuminate. Peduncles axillary, aggregate. Obs. 8221. Specimen gathered by Dr. Wright in Jamaica where it is cultivated. $-L$. a Willd. i. 973; sp. 245. Woodv. iv. 48. t. Lour. i. 179 .

C. fruticosa, foliis oppositis, floribus plurimis sessilibus ad alas. Browne 161.

Jasminum arabicum lauri folio, cujus semen apud nos Caffe dicitur. Juss. dans les mem. acad sc. Paris pour 1713. p. 388. t. 7, cop. in

Coffea. L. amoen. vi. 167.t.3. at p. 178.

Jasminum arabicum castaneac folio. Boerh. ii. 217.

Coffee-tree. Bradl. kalend. 78. $t .1$. f.2. at p. 17. Coffee Shrub. Sloan in phil. trans. abr. by Low. thorp ii. 659.t. 8. at p. 662. f. 165; \& by Hutton iii. 622 .

Bon. Alp. aegypt. fol. 26, p. 1. t. p. 2. cop. in Arbor Bon, cum fructu suo Buna. Park. theatr. 1623, with the addition of the fruit.

Bon, vel Ban arbor. Bauh.J. i. a. 422. Raii hist. 1691.

COFFEA. Lew. i. 354; disp. by Rother. 146. Murr. i. 386.

Coffaca. Heberd. 61, 371.

Caffea. Spielm. 115. 
Coffec. Bree 283, 292. Cull. pract.n. 1198, 1241. Dale 317. Darw. ii. 297. Fothergill J. in med. obs. vi. 129, 123, 181. Herm. 324. Houghton in phil. trans. abr. by Lowth. ii. 660; \& by Hutton iv. 420. FIunter jam. 112. Juch, account from in phys. journ. v. 372. Nill. Jos. 144. Neum. ii. 151. Percival i. 353. Ploucq. bibl. i. 218, 220, 603. Quarin animad. 36, 37. Rutty 129. $\operatorname{Vog} .250$.

Coffe. Alst. ii. 274. Linn. 69.

Caffe. Bang in act. haun. i. 101. Berg. 111. Chom. 446. Geoffr. ii. 431.

C. arabica. Bryant 311. Pearson, R. i. 101. Schoepf 22. Wright in mell. journ. viii. 246.

2. COFFEA racemosa. Leaves scabrous. Racemi terminal. Lour. i. 179.

3. COFFEA Zanguebariae. Corolla sexfid. Berries angulato-costate. Lour. i. 180.

\section{CHIOCOCCA.}

Corolla obconico-campanulate. Caly.x superior, quinquepartite. Berry with 2 cells, crowned by the calyx. Seeds solitary. Obs. 5479. Szuartw obs. 76. $L$.

1. CHIOCOCCA racemosa. Stipulae entire. Corol. la quinquefid. Panicles axillary. Obs. 5479. Specimen gathered by Broughton in Jamaica.L. fil. suppl. 145. L. sp. 246; a Willd. i. 975. Sizartz, obs. 76. Hort, kew. i. 229, 
Periclymenum racemosum, flore flavescente, fructu niveo. Plum. a Burm. 211. 1.217. f.2. Dill. hort. 306. เ. 228. f. 29j.

Jasminum forte, folio myrtino acuminato, aliorum adminiculo se sustentans, flore albicante racemoso. Sloune cal. 109; hist. ii. 97. t. 188. f. 3.

Lcares elliptico-lanceolate. Stipulae interfolia. ceous, cuspidate, the uppermost ovate, the lowermost transversely semilanceolate. Panicles racemiform, the lower foliaceous, with 1 and 2 leaves, longer than the leaves, branched below, racemose above; branches with 2 and 3 flowers. Bracteae subulate. Pedicles 3 and 4 times longer than the bracteac. Germen oval. Calyx partito-quinquefid, as long as the germen; segments triangulari-ovate. Corolla cy: athiform, 5 times as long as the calyx, from 2 to 3 tentlis of an inch long; segments ovate. Stamina reaching nearly to the commissures of the corolla. Filaments subulate, united at the base and slightly adhering to the base of the corolla, pubescent abore. Antherae linear, erect, inserted by the base, whitish, twice as long as the filaments. Style somewhat longer than the corolla, filiform below, thickening above, microscopically scabrous and triemarginate at the end. Obs. 5479.

CIIIOCOCCA sarmentosa, foliis myrtincis oppositis, spicis pluribus tenuissimis et terminalibus et ex alis supremis. Browne 164 .

\section{VANGUERIA.}

Calyx quinquedentate: Corolla, tube globular; 
Moxogyia, 149. Psychotria.

throat hairy. Stigma bilamellate. Berry inferior, with 4 and 5 secds. $L$. a IFilld.

1. TANGUERIA edulis. Vahl. symb. iii. 36.

\section{PSYCHOTRIA.}

Caly $x$ superior, and semisuperior, quinquefid. Corolla hypocrateriform, quinquefid. Stigmata 2. Berry dispermoús, bilocular and unilocular. Obs. 8485, and from Jacq. Swartz \& Brotero.-L.

Cephaëlis. Süartz. ind. occid. 435.

Callicocca. L. a Schrel. 126, 822.

\section{Flowers capitate.}

1. PSYCHOTRIA Ipecacuanha. Capitula pedunculate, terminal. Bracteae as long as the flowers. From

Callicocca Ipecacuanha. Brotero in linn. trans, vi. 187.t. 11. at p. 140.

Ipecacuanhia. Woodv. iii. 562. t. 203, root, stem, and leaves, from a specimen which $I$ saw in spirits in Sir Jos. Banks's museum, sent from Brasil by Gov. Phillips.

Ipecacuanlua altera. Pis. bras. 102, t. 101, repr. in ind. 231, \&

Ipecacoanha. Marcgr. Uras. $1 \%$. $t$. the longer stem with berries, the smaller with flowers.

Igpecava, or Pigaya. Purchas pilgrimes iv. 1811. IPECACUANHA. Root. Pharm. lond. edin. -Adair, James in med. commont. ix. 215; x. 234. Alst. 1. 468. Bang in act. haun. i. 103. 
Baylies in med. pap. 43. Berg. 102. Brce 28.2. Broughtou in med. comment. ix. 368. Callisen in act. haun. i. 416, 421. Cardin in med. soc. iii. 517. Chalm. i. 72, 74, 75, 131, 211; ii. 9, 74, 168, 177. Clark, James, account from in ann. mel. ii, 177; $J$. long roy. i. 181, 328. Clegh. 249, 255. Crawford, J. in Trotter ii. 92. Cull. ii. 474; clin. 306, 307, 309; pract. n. 1081. Dale 170, 420. Darw. ii. 216, 463, 742, 760. Denm. i. 268. ii. 333, 514. Fothergill, $J$. in med. abs. vi. 186. Fordyce, G. pract. 155, 159, S26; fev. i. 200 ; ii. 106, 112, 145 . iv. 65, 95, 100 ; v. 58, 88; vi. 28. Gibson, account from in med. rev. ii. 53. Helvetius.? translated in phil. trans. abr. by Lowth. iii. 114; and by Hutt. iv. 237. Hill 562. Home, Everard in trans. improv. i. 337. Huck in Pringle 260. Ir Iull phlegm. 217, 268, 274, 276, 278, 281, 294, 296. Jackson, Rob. jam. 231, 333. Lassone \& Cornette in med. journ. v. 363. Lempriere ii. 158, 169, 212, 217, 218, 232. Lew. ii. 8. Lind hot clim. 92; seam. 249. Maccormick in med. comnent. ix. 349. NIay 44. Me a a, jun. in act. med. haun. ii. 32. Milne, account from in chir. rev. \%. 504. Nonro iii. 140. Moseley 215, 219, 238, 240. LTossman in phys. journ. x. 15. Murr. i. 521 ; J. i. 288, 317, 329; i. 61. Phil. trans. abr. iii. 114. Pringle 202, 209, 213, 261, 264, 271, 280, 283, 284, 308. Pye in med. obs. i. 240. Quarin febr. 12, 55, 106, 328, 982; animad. 110, 215, 218, 232, 266. Reid, T. phthis. 178, 180, 190, 393. Kosenst. 196. Rush i. 124, 190, 135, 390. Simmons in med. journ. vi. 69. Small in med. olss. vi. 210. Spielm. 615. Stoll med. i. 58, 119, 125; 
ii. $31,44,96,116,200,210,261,335,346,347$, S81, 425; iii. 49, 79, 82, 167, 192. Underw. i. 25, 27, 110, 192, 218, 316,343. Vog. 200. Whytt in Pringle 275. Withering scarl. fev. 76, 79. Wright in ann. med. ii. 570 .

Ipecacoanha. Aasheim in act. haun. i. 176, 180. Akenside in med. trans. i. 93. Bang in act. haun. ii. 59. Buchhave ib. 320. Callisen ib. i. 74 . Fordyce, IF. fragm. 24. Heberd. 152. Hillary 950, 209, 213. Lind hot clim. 261; seam. 202, 249. Mead mon. i. 76, 95, 129, 146. Monro, Don. sold. i. 211, 308, 340, 359. Ploucq. bibl. i. 319, 327, 510, 596. Ranöe in act. haun. i. 33. Sims, James 108, 111, 149, 197. Wintringh. in Mead mon. i. $253,262$.

Ipecacuana. Balmain in med. soc. v. 210. Blane 424, 475, 507. Chalm. i. 185. Chom. 65. Mill。 Jos. 243.

Ipecacuan. Fordyce $W$. fev. 155. Richter quoted in Rollo diab. 570. Rollo diab. 42.

Ipecacoan. Daubenton, account from in phys. journ. xvi. 569.

Ipecacohan. Bree 242, 252, 268, 284, 287, 365; \& account from in chir. rev. . .30. Ipecacuanha fusca. Geoffr. ii. 90. I pecacuanha vulgaris. Linn. 68.

Ipecacoanha fusca. Cartheus. ii. 396.

Brown I pecacuanha. Douglass in phil. trans. abr. by Reid \& Gray vi. part ii. 219; by Hult. vii. 357; and in Mihles's ess. ii. 207.

Ipecacuanha brun. Pomet i. 46.

P. emetica. Pearson, R. i. 175, 257.

Cephaëlis Ipecacuanha. Lew. disp. by Dunc. 184. Callicocca Ipecacuanha. Pearson, R. ii. 212. 
PULVIS IPECACUANITAE ET OPII.

Pharm. edin.-Fiordyce, W. fragm. 45. Murr. J. ii. 231. Pringle 207, 203, 281, 283.

Pulvis Ipecacuanliac compositus. Pharm. lond,Jenm. ii. 521.

Pulvis Loveri. IIeberd. 347. Quarin animad. 229, 276.

Dovars powder. Bromfield i. 12.

Dovers powder. Brown ii. 162, 168. Cull. clin. 87, 158, 231, 237. Denm. ii. 700. Falconer in Rollo diab. 143. Fowler, T. rheum. 233. Jackson, Rob. fev. 321, 326.

Dovers sudórifick powder. Chalm. ii. 66, 178 . BLACK IPECACUANHA: Douglass in phil. trans. abr. by Reid \& Gray vi. part ii. 219; by Itull. vii. 357 ; and in'Mihles's ess. ii. 207 ?

2. PSYCHOTRIA cmetica. Capitula pedunculate, axillary. Bractene minute. From $L$. fil. suppl. 144, from the communications of Don Mutis, who - received a specinen from the governor of the pro: vince of Giron, gathered at Cannaverale near the banks of the Magdalena in Terra Firma, and which was believed by an empirical practitioner to be the true Ipecacuanha, which he had seen collected for exportation at Simiti in the government of Carthagena.

IPECACUANIIA cinerea. Dale 420. Gcoffr. ii. 90 ?

Ipecacuinha grisea. Cartheus. ii. 396. Spichn。 $616 ?$

Grey Ipecacoanh. Neum. ii. 118?

Grey Ipecactianha. Douglass in phil. trans. abr. by Reid and Graiy vi. part ii. 219; by Hutton vii. 35T; and in Mihles ess. ii. 207? 
Ipecacuanha gris. Pomet i. 46?

\section{Flowers pedunculate.}

3. PSYCHOTRIA herbacea. Stem hcrbaceous, creeping. Leaves cordate, petiolate. L. sp. 245. Jacq. amer, 66. t. 46 ; 8ro 85. Swartz. obs. 74. Forst. G. austral.n. 91 .

Psychotrophum herbaceum repens silvaticum, foliis subrotundo-cordatis oppositis, floribus paucioribus alaribus, liciniis corollae erecto-patentibus. Browne 161.

KARINTA-KALI. Rheede x. 41. t. 21.

\section{ANTHERURA.}

Corolla rotate. Antherae caudate. Berry dispermous. Lour.

1. ANTHERURA rubra. Lour. i. 178.

CARYOP H YLLASTER ruber. Rumph. l. 5. c. $55 . t .136$.

\section{MORINDA.}

Curolla infundibuliform, Stigma bifid. Berry monospermous. From L. \& Juss.

1. MORINDA citrifolia. Stem arboreous. Peduncles solitary. L. sp. 250. Forst. G. austral. n, 100 ; escul. 41.

Rancudus latifolia. Rumph. iii. 157. t.99.

$$
\text { s } b
$$


Arbor indica, fructu aggregato conoide, Cada-Pilava dicta. Raii hist. 1442, from

Cada-pilava. Rheede i 97.t.52, \& ARBOR conifera, Macandau. Bont. 97.

\section{LONICERA.}

Calyx quinquepartitc. Corolla monopetalous, tu. bular, irregular, with 5 divisions. Berry with 2 and 3 cells, and several seeds. $-L$.

\section{Stem twining.}

1. LONICERA Periclymenum. Corolla bilabiate. Heads terminal. Leaves deciduous, distinct. Obs. 29. In a garden. Ilori. kew. i. 231. Smith brit. 260. L. sp. 247; suec. n. 193. Bot. arrang. 222. Gouan hort. 101. About MontpelierLour. i. 185. Krock. n. 329. Fl. dan. t. 908. Curt. lond. i. 15. $t$; mat. med.t. 18. Jacq. rind. 38, rather rare.

Caprifolium germanicùm. Tourn. paris. 322. Vaill. paris. 27. Dill. ap. Raii syn. 458. Dod. 406, repr. in

Periclymenum. Ger. by Johns. 891, \& cop. in Periclymenum, sive Caprifolium vulgare. Park. theatr. 1460. Raii hist. 1490; syn. ed. ii. 300.

Periclymenum. Fuchs. 615. c. 250, cop. in

Pcriclymenum non perfoliatum. Bauh.J. ii. 10\%. CAPRIFOLIUM. Berg. 104. Dale 294. Geoff iii. 253. Linn. 69. Mill. Jos. 109. Murr. i. 38t. Rutty 93. Vog. 126. n.2.

Caprifolium germanicum. Chom. 663.

Caprifolium non perfoliatum. Schrod. 554. 
LYCIUM. Schrod.725.

2. LONICERA Caprifolium. Corolla bilabiate, terminal, verticillate. Leaves deciduous, the uppermost connato-perfoliate. Hort. kew. i. 230. L. sp. 246. Pollich 2. 217. Scop. carn. n. 242. Gouan hort. 101. About Moutpelier;-monsp. 76. Roth germ. i. 102. Near Erford Giesen and Jena.-Smith brit. 260. Found by Mr. Butt in a wood near Elsfield near Oxford, and by Mr. Relhan in Chalk-pit close Hinton, and in a coppice in the same parish.-- $\tilde{J}_{\text {ucq. }}$ austr. iv. $t$. 357 ; rind. 38. Host. 113. Asso \%. 183. Krock. n. 328. Naturalised in orchards in Silesia.

L. floribus verticillatis terminalibus sessilibus, foliis summis connato-perfoliatis. L. ups. 42. Kram. 50. Naturalised.

Periclymenum italicum. Mill. Ph. dict. n.5.

Caprifolium. Mill. Ph. ic.53.t. 79.

Caprifolium italicum. Lond. gard. 14. t. 5. Boerh。 ii. 226. Dod. 406, repr. in

Periclymenon jerfoliatum calidarum regionum. Lob. obs. 35\%, \&

Periclymenum perfoliatum calidarum regionum officinarum. Lob. ic. i. 6S2, cop. in

Periclymenum perfoliatum sive italicum. Park. theatr. 1460, \& repr. in

Periclymenun perfoliatum. Ger. by Johns. S91. Dalech. 1427. Magn. monsp. 201. Bauh. J. ii. 104. About Montpelier.-Raii hist. 1490; europ. 200. In Italy and the south of France. Periclymenum. Cam. epit. 713.

Native of Italy, Carnio'a, the south of France, the Palatinate and Franconia, and naturalised in

B b 2 
Austria and Silesia. The plants found in Oxfordshire and Cambridgeshire I suspect to have risen from sceds carricd by birds.

CAPRIFOLIUM perfoliatum. Schrod. 554.

2. Peduncles with 2 flowers. Berries distinct. From I.

3. LONICERA pubescens.-Leaves entire at the mare gin, pubescent. $\boldsymbol{L}$.

L. Xylosteum. L. suec. n. 194; sp. 248. Hort. kew. i. 232. Pollich n. 219. Roth germ. i. 102. Gouan hort. 101? About Montpelier, but he describes the leaves as serrulate;-monsp. 77. Scop. carn. n. 244. Bot. arrang. 222, note, where it is mentioned as having been said by $\mathrm{Wallis}$ in his natural history of Northumberland to have been found under the Roman wall on the western side of Shewing Sheels.-Lour. i. 186. Smith brit. 1393; engl. t.916. Found by Mr. Borrer in a coppice near Arundel in Sussex. Corolla tinged with red, and of a yellower hue than I have ever observed it, and the whole having more of the habit of L. Periclymenum than of L. pubescens. - Fl. dan. $t .808$.

L. pedunculis bifloris, baccis distinctis, foliis integerrimis. Dalib. 69. Guett. ii. 134.

Xylosteum. Dod.407, repr. in ed. ii. 412, \&.

Periclymenum rectum germanicum. Ger. by Johns. 1294.

Periclymenon allobrogum. Lob. obs. 358, repr. in ic. i. 633, \&. cop. in

Periclymenum rectum fructu rubro. Park. theair. 1462, and Bauh. I. ii. 106. Clus. pam. 87. 
No fig.-Raii hist. 1491; europ. 200. Throughout Germany.

Native of Sweden, Germany, Hungary, Switzerland; but whether of France or England rather doubtful.

PERICLYMENUM rectum. Vog. 126.

4. LONICERA Symphoricarpos. Heads lateral, pedunculate. Leaves petiolate. L. sp. 249. Hort. kew. i. 233.

L. capitulis lateralibus pedunculatis foliis petiolatis. Gron. virg. 30.

Symphoricarpos foliis alatis. Dill. hort. 371. $t$. 278. $f$. 360 .

Vitis idaea caroliniana, foliis subrotundis hirsutis. Lond. gard. 85. t. 20.

SYMPHORICARPOS. Linn, 70. Schoepf 22.

5. LONICERA Diervilla. Peduncles terminal and axillary. Leaves serrate. Obs. 2518. In a garden.-Obs. 8214. Specimen gathered by Dr. Cutler in New England.-L. sp. 249. Hort. kew. i. 233. Willich obs. n. 76 .

Lonicera. Cutl. in amer, acad. i. 418.

Diervilla. L. cliff. 63. $t .7$.

DIERVILLA. Lew. by Dunc. 343. Linn.70. Murr. i. 385. Schoepf 23.

3. Peduncles with 2 flozwers. Berries united. From L.

6. LONICERA alpigena. Berries didymous. Leaves ovali-lanceolate. L. a Murr. 216; sp. 248. Hort. kew. i. 233. Silth. prodr. n. 519. On B b 3 
Mount Athos.-Gouan hort. 101. Near Montpelier.-Host 114. Scop. carn. n. 215. Honcl. ii. 285. Jacq. austr. iii. $t$. 274.

I. baccis bifloris concretis, floribus bilabiatis. Royen 298.

Chanaccerasus alpina, fructu gemino rubro duobus punctis notato. Boerh. ii. 227.

Chamaccerasus inontana. Cord. fol. 213. p. 2, imit. in

Idaea Ficus nostra, vulgo Frangula. Dalech. 200.

Periclymeni IIII flores. Clus. hist. i, 59, the lower fig. repr. in Ger. by Johns. 1296, \& cop. in

Periclymeni flores. Bauk. J. ii. 107, the upper of the two lower figures.

Periclynenum rectum IIII cum fructu. Clus. hist. i. 59 , repr. in

Chamaecerasus alpigena. Lob. obs. 593, \&.

Xylosteum alterum. Dod. 407, cop. in

Chamaecerasus Gesneri, vel Chamaepericlymenon quoddam alpinum. Bauh. J. ii. 107, \&

Chamaecerasus alpina. Dalech. 201, \& repr. in

Periclymenum rectum, fructu rubro. Ger. by Johns.

1295. Raii hist. 1492, on Mount Jura and on Mount Saleve near Geneva ;-curop. 201.

Native of Greece, the Pyrenees, the south of France and Germany, Hungary, Silesia, Savoy, and Switzerland, mostly on high mountains. LONICERA alpigena. Krock. n. 332.

\section{TRIOSTEUM.}

Corolla monopetalous, as long as the calyx; segments nearly equal. Berry inferior, trilocular; cells monospermous. from L. \& Juss. 
Monogyia. 154. Conocarpus.

1. TRIOSTEUM perfoliatum. Leaves connate. Flowers sessile. From $L$ a Willd. i. 990 ; sp. 250 Hort. kew. i. 234. Mill. Ph. dict. n. 1.

T. floribus verticillatis sessilibus. Gron. virg. 31 . Triosteospermum latiore folio, flore rutilo. Dill. kort. 394. t. 293. f. 378.

TRIOSTEUM perfoliatum. Bart. 29. Coxe 377. Triosteum. Schoepf 23.

Triosteospermum. Vog. 229.

2. TRIOSTEUM angustifolium. Leaves connate. Peduncles uniflorous. From L. a Willd. i. 991; sp. 250. Mill. Ph. dict. n. 2

T. floribus oppositis pedunculatis. Gron. virg. 31 . Periclymenum herbaceum rectum virginianum. Pluk, phyt. t. 104. f. 2.

Periclymeno affinis planta virginiana, flore ochroleuco. Hist. ox. s. 13. t. 1. row 3. f. 8. TRIOSTEUM angustifolium. Schoepf 23.

\section{CONOCARPUS.}

Calyx quinquefid. Petals 5, ar none. Capsule not opening, monospermous. Obs. 8373. 8375, and the account of the fruit from Jacq. $-L$.

1. CONOCARPUS erecta. Flowers oapitate. Stem erect. Leaves lanceolate. Obs. 8373. Specimen in flower gathered by Broughton in Jamaica.-Obs. 83it. Specimen gatlered by Dr. Wright in Jamaica.-L. $s p .250$. Hort. kew. i. 234. Swartz. obs. 79. Jacq. amer. 8ro, 98.

C. foliis oblongis, petiolis brevibus, floribus in caput conicum collectis. Browne 159.

B b \& 
Alnus maritima myrtifolia ccriariorum. Pluk. phyt. t. 240 . f. 3.

Alni fructu, laurifolia arbor maritima. Sloane cat: 135; hist. ii. 18. t. 161. f. 2.

Innominata. Plum. a Burm. 135. t. 144. f. 2.

Frutex instar salicis pumilae, foliis salignis. Marcgr. 76, outer fig.

Capilula spicato-racemose, the lower pedunculate, the upper sessile. Racemi terminal and axillary. Bracteae ovato-lanceolate, acuminate, hirsute at the margin, at the base of the flowers. Flowers closely crowded, obconic. Germen inferior, obconic, villose, monospermous. Calyx cyathiformi-campanulate, the base narrower than the top of the germen, quinquefid; segments triangular. Petals none. Stamina 5, longer than the calyx. Filaments filiform, hirsute at the base. Style filiform, shorter than the calyx, hirsute at the base. Obs. 8373.

CONOCARPUS erecta. Schoepf 23.

\section{ERITHALIS.}

Corolla rotate, quinquepartite. Calyx quinqueden: tate, superior. Berry decemlocular. From Brozone \&. $L$. but

Jacquin in amer. 8vo, 92 describes the berry as unilocular, and Swartz obs. 80, the corolla as pentapetalous.

1. ERITHALIS polygama. Leaves obovate. Flowers axillary, the male cymose, the bermaphrodite solitary. Forst. G. austral. n. 101.

B angustifolia. 'Forst. $G$. 
TIMO NIUS. Rumph. iii. 216. t. 140. Berries smooth. Leaves lanceolate. Corolla infundibuliform; tube thrice as long as the calyx.-Can it belong to this genus?

\section{MUSSAENDA.}

Corolla infundibuliform. Stigmata 2, thickish Berry inferior, oblong. Seeds in 4 rows. $L$.

1. MUSSAENDA villosa.-Branches and leaves of the branches and panicle villose. Vahl.

M. frondosa. Vahl. symb. iii. 37. L. sp. 251; a Murr. 218. Lour. i. 188. Forst. G. austral. n. 102.

M. fruticosa. L. nat. ii. 168 .

M. formosa. L. mant. 338.

M. zeylanica, flore rubro, fructu oblongo polyspermo, folio ex florum thyrso prodeunte albo. Burm. zeyl. $165 . t .76$.

Belilla. Rheede ii. 27. $t$. 18.

Frutex indicus baccifer, fructu oblongo polyspermo. Raii hist. 1493.

FOLIUM PRINCIPISSAE. Rumph. iv. 111. t. 51 .

\section{CORIS.}

Corolle monopetalous, irregular. Calyx inferior, spinose. Capsule quinquevalve. From $\boldsymbol{L}$.

1. CORIS monspeliensis. L. sp. 252. Hort. kew. i. 23j. Sibth. prodr. 149, Host 114. Near Trieste. 
-Gouan hort. 102. About Montpelier, in one place annual; - monsp. 75. Asso n. 186.

C. quorundam. Clus. hisp. 484, about Salamanca and on the sra crast of Valentia and the south of France; repr. in hist. ii. 174, \&

C. monspelliensium. Lob. obs. 220, cop. in Park. theatr. 571 , repr. in

C. caerulca nonspiliaca. Ger. by Johns. 51t, \&

C. monspelliaca. Lob. ic. i. 402. f. 2. ado. 17t, repr. in Lob. ic. i. 402. f. 1.

C. monspessulana purpurea. Bauh, J. iii. 431.

C. cacrulea maritima. Raii hist. 88\%; europ. 106. Syunphytum petraeum. Cam. epit. 699.

Native of Spain, and of the shores of the Mrdi= terrancan.

CORIS. Berg. 115. Linn, 70. Vog. 100. Symphytum petracum. Lale 195.

\section{VERBASCUM.}

Corolla rotate, slightly uncqual. Capsule of 1 cell, and 2 valves. $L$.

1. VERBASCUM decurrens. Leaves tomentose, de. current. Obs. 1730. On hedgebanks.

F. 'Thapsus. L. suec. n. 195; sp. 252. Bot. arrang. 223. Snith brit. 249 ; engl. t. 519. Hoodv. ii. $312 . t .125$.

V. mas latifolium luteum. Raii syn. 287. Tourn. paris. 161. Vaill. paris. 199. F\%. dan.t: 631.

V. candidum mas. Fuchs. 803. c. 327, cop. in

V. album mas. Dalech: 1301,

V. angustifolium rimosum, flore aureo, folio crass- 
iore. Bauk. J. iii. 872 , (the description is that of $V$. pulverulentum,) \&

V. angustius. Dod. 149, which repr. in

Thapsus barbatus flore albo. Ger. by Johns. 773.

V. I Matthioli. Dalech. 1298, cop. in

V. latius. Dod. 143, zihich repr. in

V. mas. Lob. obs. 303,

V. aut Phlomos vulgaris mas Dioscoridis. Lob. ic. i. 561 , cop. in

V. album vulgare, sive Tapsus barbatus communis. Park. theatr. 60, \& repr. in

Tapsus barbatus. Ger. by Johns. 773. Raii cant. 161.

VERBASCUM. Pharm. austriaco-prov. 73. suec. -Alst. ii. 241. Berg. 116. Dale 189. Herm. 551. 607. Home, $F$. clin. 434. Krock: n. 333. Lewo. ii. 446; disp. by Dunc. 349; by Rother. 260. Mill. Jos. 448. Quarin febr. 89. 125. 282. 287. 292. 308; animad. 36. 57. 45. 84. 86. Schoepf 24. Vog. 139. 243.

Thapsus barbatus. Geoffr. suite iii. 277.

Verbasci folia, flores. Murr. i. 487.

Verbasci herba. Linn. 71.

V. mas latifolium luteum. Chom. 720; suppl. 195. Rutty 533.

Mullein. Neum. ii. 225.

2. VERBASCUM rhombifolium. Leaves tomentose underneath, nearly glabrous above, rhombeo-lanceolate, oblongo-lanceolate, lanceolate. Peduncles longer than the calyx. Segments of the calyx lanceolate. Obs. 4502. 4515.

a album. Corolla whitish. Obs. 4502. 4503. 1783. Specimens gathered on the ramparts of Brussels, 
near the Rock Houses Kinfare Staffordshire, and between the Stewponey and Whittington Worces. tershire.

V. Lychnitis. L. suec. n. 196; sp. 253 \& Bot. arrang. $225 \beta$ Smith engl. bot. $t$. 58. Leaf uncoloured;-brit. 250. Pollich n. 221. Fl. dan. $t$. 586.

V. candidum foemina. Fuchs. 803. c. 327, cop. in

V. album foemina flore albo. Dalech. $1300, \&$

V. flore albo parvo. Bauh. J. iii. 873. Raii hist. 1095 ; syn. 287. Tourn. paris. 165. Vaill. paris. 200: Bocrh. i..228.

V. foemina. Lob. obs. 303, cop. in Dalech. 1300, and repr. in

Phlomos mas alter. Lob. ic. i. 562, \&

V. Lychnite Mathioli. Ger. by Johns. 775.

V. mas, foliis longioribus. Park. theatr. 60. No fig.

Phlomis Lychnitis Matthioli. Jalech. 1303.

Corolla tomentose, without any globular glands. Obs. 4517.

VERBASCUM album. Dale 190.

3. VERBASCUM phlomoides. Leaves tomentose, ovate, the lower petiolate. L. sp. 253. Hort. kero. i. 236. Roth germ. i. 93. In Hesse, Sax= ony, and near Tubingen;-ii. 239. Gouan monsp. 74 .

V. foemina, flore luteo magno, Tourn. paris. 163. Vaill. paris. 199.

V: nigrum. Fuchs. 804.c. 327, cop. in

V. vulgare, flore luteo magno, folio maximo. Bauh. $J$. iii. $8 \% 1$. (the description belongs to V. decurrens,) \& abr. in 
Verbascum. Trag: 217.

Thapsus burbatus maximus odoratus meridionalium. Lob. adv. 249. No fig.

Thapsus barbatus maximus odoratus meridionalium, femina flore albo. Lob. ic. i. 560, repr. in

V. album. Ger. by Johns. 775, \& cop. in

V. maximum meridionalium odoratum album. Bauh, $J$. iii. S7l. $f .1$.

'V. maximum album femina, flore subpallido. Lob. ic. i. 561, repr. in

V. Lychnite minus. Ger. by Johns. 775, and cop. in

V. maximum meridionalium odoratum luteum. Bauh. J. iiii. Si1. f. 2. Raii hist. 1094.

Native of Italy and Germany.

VERBASCUM foemina, flore luteo magno. Boecl. ap. Herm. 552. Chom. 721. Rutty 539.

Thapsus barbatus alter, seu femina. Geoffr. suite iii. 279.

4. VERBASCUM cordifolium. Leaves tomentose underneath, oblongo-cordate, petiolate. Obs. 8215. Near Hagley Worcestershire on gravel, and plentifully between Alport and Rowsley Derbyshire, on limestone.

V. nigrum. L. suec. n. 197; sp. 253. Bot. arrang. 226. Smith engl. t. 59, leaves uncoloured; -brit. 251. Raii cant. 173. Fl. dan. t. 1088. Dod. 144, cop. from, and Trag. 218, abr. from

V. sylvestre. Fuchs. 804. c. 327, which cop. in

Y. nigrum flore parvo apicibus purpureis. Bauh. J. iii. 873. Raii syn. 288; hist. 1095.

V. nigrum, flore ex luteo purpurascente. Tourn. paris. 165. Vaill. paris. 199. Boerh. i. 228. 
V. nigrum Dioseoridis. Lob. ic. i. 562, repr. in

V. nigrum. Ger. by Johns. 775, \& cop. in

Blatiaria lutea odorata. Park. theatr. 61. (The description belongs to some other species.)

V. III. Matthioli. Dalech. 1299.

V. nigrum latifolium luteum. Lob. adv. 242. No fig.

VERBASCUM nigrum. Dale 189. Rutty 533.

Verbasci radix. Linn.71. Murr. i. 489.

5. VERBASCUM nitidum. Leaves shining, crenate; radical leaves pinnatifid at the base. Peduncles solitary, longer than the calyx. Obs. 4508. Specimen gathered on a bank on the outside of a garden at Clevelode Worcestershire, in marle, 27 Oct. I791, and where I had gathered it also the preceding year. The plant was not known by the inhabitants of the adjoining house ever to have grown in the garden.

V. Blattaria. L. sp. 254. Gouan hort. 103, about Montpelier;-monsp. 75. Muds. 91. About Plymouth and Ashburton Devonshire.-Bot. arrang. 229. Smith engl. bot. t. 393, from a specimen found on a bank near the Medway, 3 miles from Rochester.-Pollich n. 223.

V. foliis amplexicaulibus oblongis glabris, pedunculis solitariis. L. ups. 46.

Blattaria foliis oblongis sinuatis obhusis. Guett. ii. 309.

Blattaria lutea, folio longo laciniato. Tourn. paris. 179. Vaill. paris. 21. Boerh. i. 226.

V. leptophyllum. Cord. fol. 153. p. 1, repr. from Blattaria. Trag. 925, which abr. from Fuchs. 184. c. 60, which cop. in 
Blattaria lutea. Bauh. J. iii. 87.. Raii hist. 1096; europ. 77. Italy, the sonth of France, and Gicrmany.-Dill. ap. Raii syn. 285. In the lane betwixt Mitchan common and Casalton, and near Horns-place by Rochester.

Blattaria. Cam. epit. 884. Dod. 145, repr. in Lob. obs. 304,

Blattaria Plinii. Lob. ic. i. 564, and Gcr. by Johns. 776, and cop. in

V. nigrum vulgare. Park. theatr. 61. (The nane and description belong to $V$. cordifolium.)

Blattaria lutea humilior. Cam. hort. 26.

Blattaria flore luteo. Ger. by Johns. 778, cop. in Park. theatr. 61.

Blattaria lintea altera vulgatior. Park. parad. 884. No fig.

PERBASCUM Blattaria. Krock.n. 338.

\section{DATURA.}

Corolla infundibuliform, plaited. Calyx tubular, angular, deciduous. Capsule with 4 valves. $t$.

\section{Capsules spinose.}

1. DATURA ferox. Capsules spinose, erect, ovate; uppermost spines very large, converging. L. $\boldsymbol{L} p$. 255. Hort. lew. i. 238.

Stramonium ferox. Boerh. i. 261. Boccon. sic. 50. t. 26. Spines of the capsules much shorter than in Zanon. hist. 210.t. 162, repr. from

D. di coccino spinosissimo. Zunon. ist. T6. t. 29 , rehick cop. in 
Stramonium pomo crassioribus et robustioribus spinis armato. Hist. ox. s. 15. $t$. 2. row 3. $f$. 4 , in which the margin of the leaves made more dentate.

Stramonium longioribus aculcis. Barrel. t. 1172.

Solanum foctidum, pomo grandibus aculcis donato. Raii hist. 748.

DATURA. Dale 185.

D. ferox. Saunders in Turner trav. 398.

2. DATURA Strumonium. Capsules spinose, erect, ovate. Leaves ovate, glabrous. L. suec. n. 198; sp. 255. Bot. arrang. 230. Woodv. ii. 338. $t$. 124. Curt. lond. vi. t. 17. Pollich n. 224. Fl: dan.t. 436. Smith brit. 254; engl. t. 1288.

D. turcarum. Besl. hort. aut. ord. 2. fol. 12. $t$.

Datura. Brozone 167. Dalib. 70. Spalowsliy 1. $t$. cop. in

Stramonium. Med. mus. i. 448. $t .6$.

Stramonium foetidum. Scop. carn. n. 252.

Solanum pomo spinoso oblongo, flore calathoide, Stramonium vulgo dictum. Raii syn. 266; ed. ii. 150, (the 3 following paragraphs belong to the preccding plant, Atropa Belladouna.)

Stramonia altera major, sive Tatura (a misprint for D. or Tatula) quibusdam. Bauh. J. iii. b.624. Sloane cat. 59.

Tatula. Cam. epit. $1 \% 6$.

Solanum manicun Dioscoridis. Column. plyytob. 46. $t$. $4 \pi$.

Stramonium spinosum. Ger. by Johns. 348.

Stramonium majus album. Park. parad. 360. Raii hist. 748.

Stramonium majus, scu Pomum spinosum. Park. parad. t. 36l. f. 4. 
Natize of America, now found in Europe on rubbish and dunghills, and once in the middle of a wide sandy road not far from the Stewponey inn near Stourton castle Worcestershire, but whether it prow pagates itself in those places is doubtful.

STRAMONIUM. Pharm. suec.-Bart. 18, re. publ. in phys. joum. viii. 426. Berg. 120. Clralm。 ii. 67. 101. 179. Cull. ii. 281. I)ale 185. Fowler, T. in med. comment. v. 161. Geoffr. suite iii. 126. Lentin, account from in phys. journ. iii. 575. Lew. ii. 390. Mease, account from in phys. journ. viii. 88; and chir. rev. viii. 534. Mill. Jos. 426. Monro iii. 276. Murr. i. 456. Odhelius, account from in med. contment. i. 368. Papin in phil. trans. abr. by Jones v. part ii. 185; and by Hutton vi. 53. Quarin animad. 24. Razoux, account from in med. journ. ii. 292. Rush, account from in med. comment. i. 74. Rutty 500. Schoepf 24. Spielm. 524. Storck's experiments translated in med. mus. i. 446. Swaine in phys. ess. ii. 272. Wedenberg, account from in med. comment. iii. 18.

Datura. Krock. n. 339. Limn. 72. Vog. 176.

D. Stramonium. Herb. Pharm. edin.-Bart. 46. Bartram, Moses in philad. coll. i. 199; and account from in med. comment. dec. II. ix. 101. Cooper, account from in chir. rev. xvii. 4. De Witt, accoint from in phys. journ. i. S4. Johnson, James of Lancaster, in med. facts v. 78. King, account from in phys. journ. i. 278. Lew. disp. by Dunc. 217. Med. journ. x. 285. Murr. J. i. 134. Pearson, R. ii. 236. Ploucq. bibl. 1. 302. 414. 640.

Stramonium officinarum. Spalowsliy 30.

C C 
Thorn-apple. IIufeland, account from in phys. joum. iii. $48 S$.

3. DATURA Talulu. Capsules spinose, erect, ovate. Leaves glabrous, dentate. From L. sp. 256, and Roth. gctm. ii. 237. Hort. kew. i. 239. Mill. P'l. dicl. n. 2. Honck. n. 598.

Stramonium fructu spinoso oblongo, caule et flore violacco. Boerh. i. 261.

Stramonium majus purpurcum. Park. purad. 360. Ruii hist. 748 . In his garden at Cambridge.

STRAMONIUM fructu spinoso oblongo, flore violaceo. Toum. 301.

4. DATURA Mclel. Capsules spinose, nodding, glo* bose. Leaves cordate, nearly entire, pubescent.

- L. sp. 256. Hort. kew. i. 239. Lour. i. 135.

Stramonium fructu spinoso rotundo, flore albo sim. plici. Bocrh. i. 261.

Dutra alba. Rumph. v. 213. t. 87. f. 1. Spines not longer than those of $\mathrm{D}$. fastuosa.

Stramonia. Jod. 457, repr. in ed. ii.660, cop. ir Dolech. 629, repr. in

Stramonium peregrinum. Lob. obs. 156; ic. i. 261, and Ger. by Johns. 349, and cop. in

Stranonicum minus sive peregrinum simplex. Park. theatr. 355.

Stramonia, sive Solanum mortale. Fuchs. 654. c. 265, cop. in

Stramonia, sive Pomum spinosum. Trag. 896, \& Stramonia multis dicta, sive Pomum spinosum. Bauh. J. iii. 624. f. 2.-f. 1 .

Stramonium minus, seu Nux Metel flore albo. Part: parad. 360. 
D. seu Stramonium minus. Park. parad. t. 361. f. 5 .

D. Acostac. Dalech. 1918.

Nux Metel. Matth. 280.

Nux Metella. Cam. epit. 175.

Hummatu. Fheede ii. 47. t. 28.

DATURA. Berg. 123.

Pomme epineuse. Chom. 788.

5. DATURA fastuosa. Capsules tuberculate, nodding, globular. Leaves ovate, angular. L. $d$ Murr. 220; sp. 256. Hort. Kew. i. 239. Mill. Ph. dict. $n .6$.

DATURA rubra. Rumph, v. 243.

a simplex. Corolla single. From

NILA HUMMATU. Rheede ii. 49. $t .29$.

Fruit represented as glabrous, but described as sometimes beset with rigid points.

\& duplicata. One corolla within another. Obs. 6486. In Mr. S. Shore's garden raised from seeds from the Calcutta garden.

D. rubra. Rumph. v. 213. t. 87. f. 2.

Stramonium, fructu spinoso rotundo, flore violaceo duplici triplicive. Boerh. i. 261.

Stramonium minus, flore geminato purpurante. Park. parad. 362. t. 361. f.7.

Mudela-nila bummatu. Rheede xi. 51.t. 30. Capsules represented as glabrous. Leaves scarcely red pandose.

Leares ovate, unequal at the base, dentate. Obs. 5186. 


\section{HYOSCYAMUS.}

Corolla infundibuliform. Capsule operculate, with 2 cells. Obs. 6045. $L$.

1. HYOSCYAMUS niger. Leaves amplexicaul, sinuate. Flowers nearly sessilc. Ols. 6045. At Whiston near Rotherham Yorkshire.-L. suec. n. 199 ; sp. 257. Bot. arrang. 231. Woodv. i. 143. t. 52. Corollae too yellow.-Scop. carn. n. 253. Smith brit. 254 ; engl. t. 591 . Corollae too yellow.-Dod. 447, repr. in Lob. obs. 139, Ger. by Johns. 353, cop. in med. mus. i. 507.t. 7, and repr in

Hynscyamos. Lob. ic. i. 268, \& abr. in

H. niger, vel vulgaris. Park. iheatr. 363.

H. vulgaris, niger. Tourn. paris, 201. Vaill. paris. 106. Boerh. i. 229. L. lapp. n. 87. A single plant.

H. flavus. Fuchs. 791, c. 323, cop. in

H. vulgaris. Bauh. J. iii. 627. Raii hist. 711; syn. 274. Besl. hort. aestiv. ord. 8. fol. 8 t.

Hyoscyamus. Trag. 133. Spalowsky t. Dalech. 1716. Cant. epit. 807.

Leares semipinnatifid; segments acute. Corolla strawcoloured with purple veins. Obs. 6045 .

Native of Europe.

II YOSC YAMUS. Pharm. suec.-Berg. 23. Bree 285. Buchhave in act. haun. i. 226. Chir. rev. xii. part ii. 93. Collin obs. ii. 130. Cull. ii. 271; clin. 233. 276; pract. n. 1342. 1445. Dale 181. Fotherg. Ant in mid.soc. i. 310, republ, in med. comment. xiii. 30. Hecker, account from in phys. journ. vi. 94. Hill 545. Himly, account 
Monogynia. 160. Hyoscyamus.

from in phys. joum. vi. 275. Ilome F. clin. 197. Hufeland, account from in phys. journ. i. 284; iii. 576 ; med. rev. ii. 453. and chir. rev. vii. 62; viii. 143. Krock. n. 340. Lew. i. 449. Murr. i. 444. Ploucq. bibl. i. 264. 281. 334. 349. 579. 692. Razoux, account from in med. joum. ii. 293. Spielm. 512, Stoll med. iii. 13. 423. Vog. 104. 169. 238. Withering in med. comment. dec II. vi. 367.

H. niger. Herb. Seed. Pharn. edin-Alst. ii. 356. Geoffr. iii. 593. Hartz, account from in chir. rev. viii. 374. Horles, account from in med. rev. vii. 74. Kinglake in phys. journ. v. 438. Lew. disp. by Dunc. 236. Linn. 72. Mill. Jos. 236. Monro iii. 134. Murr.J. i. 126; ii. 22. 78. Pearson, R. ii. 215. 237. Rutty 242. Stoll med. ii. 183.

H. officinarum. Spalowskiy 53. $t$.

Henbane. Bree 251. 253. 257. Brown, Jos, in phys. journ. iii. 406. Dyce in phys. journ. ii. 271. Patouillat in acad. sc. abr. by Southw. iii. 149. Sloane in phil.trans. abr. by Hutton vii. 610, and in Mihles ess. ii. 278, which republ. in med. mus. iii. 231. Storck, accou $t$ from in med. mus. i. 497. Wilmer, account from in med. journ. i. 338 .

H. vulgaris, vel niger. Boecl. ap. Herm. 434. Chom. 778; suppl. 205.

2. HYOSCYAMUS albus. Leaves on petioles, sinuate, obtuse. Flowers séssile. L. sp. 257. Hort. kiew. i. 240. Raii hist. 712. On walls and rocks about Geneva.-Sibth. prodr. n. 532. In Greece. -Dalech. 1717. Dod. 448, repr. in Lob. obs. 139; ic. i. 269, and Ger. by Johns. 353. Gouan:

c c 3 
hort. 105. About Montpelicr.-Bauh. J. iii. 627. At Orange in Provence.-Besl. hort. aestiv. ord. 8. fol. 8. $t$.

H. candidus. Trag. 134.

H. albus major, vel tértius Dioscoridis, et quartus Plinii. Boer\%. i. 230.

H. albus vulgaris. Clus. hist. ii. 84, cop. in

H. albus minor. Bauh. J. iii. 628.

Native of Greece, the south of France, and Swit. zerland.

II YOSC YAMUS albus. Alst. ii. 356. Dale 181.

Geoffr. iii. 501. II amilton, Archib. in phys. ess.

ii. 268. Krock. n. 341. Lew. i. 499. Mill. Jos. 237. Murr. i. 255. Rutty 210. Sauv. ii. 691. Hyoscyamus. ITerm. 433.

\section{NICOTIANA.}

Corolla infundibuliform; limb plaited. Stamina inclinate. Capsule bivalve, bilocular. $L$.

1. NICOTIANA fruticosa. Leaves lanceolate, sub. petiolate, amplexicaul. Segments of the corolla acute. Stem frutescent. L. a Murr. 221; $s p$. 258. IIort. kew. i. 241. Mill. Ph. dict.n. 4 . NICOTIANA fruticosa. Lour. i. 136.

9. NICOTIANA Tabacum. Leaves lanceolato-ovate, and lanceolate, decurrent. Segments of the co. rolla acute. 'Obs. 1521. In a garden.-L. sp. 255. Hort. kew. i. 241.

N. major latifolia. Sloane cat. 51 .

Nicotiana. Hamilton, Rob. diss: inaug.t. 1. at p. 4. 
NICOTIANA. Tobacco. Leaves. Pharm. lond. -Alst. ii. 189. Bishopric in med. comment. dec. II. viii. 3S2. Blune 555. Bartlett in phys, jomm. xii. 401. Carthens. ii. 507. Chalm. i. 9S. Chom. 76. Cull. ii. 272. 438. Dale 181. Darw. ii.682. Dore in med, comment. dec. $I I$. viii. 379. Ferriar i. 75 ; ii. 159. Garnct in med. comment. dec. II. vi. 271. Heberd. 225. 244. 400. Hcrm. 541 . Lew. ii. 133. Mill. Jos. 312. Monro iii. 184. Nnrr. i. 464; J. i. 283. 329. 344. Noble, accomt from in chir. rev. $x .400$. Quarin febr. 398. 402; animad. 129. Ploucq. bibl. i. 570. 234. 612. Rulty 316. Simmons, $W$. in physs. joum. vii. 57. Spielm. 537. Stoll aph. n. 320; med. ii. 183. Vog. 71.

Tabacum. Berg. 117. Fordyce, W. fragm. 58. Haen. i. 55. 87. 93. Heberd. 56. 61. Limn. 73. Qnarin febr. 391; animud. 14. 31.111. Schocpf 25. Wintringham in Mead mon. i. 270.

Tobacco. Bartr. Mos. in philad. coll. i. 195; and account of in med. comment. dec. II. is. 161. Bishop in phys. journ. vi. 318. Blair in mad. soc. v. 328; and phys. journ. xvii. 20. Bree 251. 261. Chalm. i. 98. Conradi, account from in med. rev. iv. 191. Cooper, acconent from in chir. rev. xi. 330. Cull. pract. n. 11261198. 1447. Darw. ii. 56. 69. 105. 111. 312. 495. 701. 719. 745. Dewar, account from in phys. journ. ix. 177. Ferriar i. 95. Fowler, T. reports on, and account from in med. comment. x. 123; and med. journ. vi. 185. Garden in mcd. comment. iii. 330. Graing. 42. Grant in med. comment. dec. II. i. 327. Hamilton, Rob. of Ipswich, account from in chir. rev. i. 505. Itawkins life of Johns. 320. Heberd. in med.trans. i. 47. 'Hcy, account

$$
\text { c c \& }
$$


from in chir. rev. ix. 71. Hunter, J. occon. 124; J. jam. 291. Kilgour in med. comment. viii. 75. Killer in phys. journ. vi. 322. Lala, account from in chir. rev. i. 369. Mogniot in acad. surg. 370. Neum. ii. 115. Pemberton, account from in chir. rev. xiii. 25. Pott ii. 72. 85 ; iii. 303. 306-311. Power, account from in chir. reo. ix. 152. Rosenst. 196. Smylh jail dist. 177. Sted. man in med. ess. ii. 41. Turner in med. obs. ii. 309. Underwood i. 12; ii. 16. Ware ophth. 52. 178. Weston in phys. journ. xiv. 305.

N. Tabacum. Pharm. edin.-Bart. 41. Lew. disp. by Dunc. 264. Murr. J. i. 133. 242. 302; ii. 62. Pearson, R. i. 11. 151. 203. 227 ; ii. 239. 258.

a latifolia. Leaves oblongo-ovate. From

$N$. foliis amplis oblongo-ovatis, floribus comosis. Browne 167.

N. major latifolia. Boerh. i. 230.

N. major, sive Tabacum majus. Bauh. J. iii. 629.

Tabacco latifolium. Park. parad. 363. t. 361. f. 8. Raii hist. 713.

N. sive Tabacum. Dalech. 1895.

Sana sancta indorum, sive $\mathbf{N}$. gallorum. Lob. adr. 251 , repr. in ic. i. 584 .

Hyoscyamus peruvianus. Dod. 449, repr. in Ger. by Johns. 357.

BлEvvoxor. Renealm. 38. t. 37, misengraved 33.

NICOTIANA major lạtifolia. Chom. 126; suppl. 44.

N. major. Geoffr. suite i. 164.

\& angustifolia. Hori. kew. i. 242.

N. angustifolia. Mill. Ph. dict: n. S. 
N. Tabacum. Berg. mat. med. n. 76. Woodv, 102. t. 60 .

Tobacco angustifolium. Park. parad, 363? No fig. Raii hist. 714? In a garden.

N. major angustifolia. Boerh. i. 230?

Herba sancta, sive Tabacum minus. Lob. obs. 316, repr. in

Tabacum, sive Herba sancta minor. Lob. ic. i. 585 ,

Hyoscyami peruviani altera icon. Dod. 449, \&

Suna sancta indorum. Ger. by Johns. 357?

NICOTIANA major angustifolia. Chom. 127.

N. major, seu Tabacum angustifolium. Geoffr. suile i. 167.

3. NICOTIANA rustica. Leaves petiolate, ovate; margin entire, Segments of the corolla obtuse. L. sp. 258. Hort. keiv. i. 242. Krock.n. 342.

N. minor. Boerh. i. 230. Dod.ed. ii. 454; repr. from

Hyoscyamus luteus. Dod. ed. i. 447, which repr. in Ger. by Johns. 356,

Hyoscyamus dubius luteolus solanifolius. Lob. obs. 140 ; \& ic. i. 269.

Priapeia, quibusdam N. minor. Bauh. J, iii. 630. Raii hist. 715.

Hyoscyamus niger. Dalech. 1717.

Native of America, and sometimes found on dungbills in England.

Cultivated by Gerarde in 1596.

NICOTIANA minor. Boecl. ap. Herm. 543.

Dale 181. Lew. ii. 135. Mill. Jos. 313.

Nicotiana. Pharm. austriaco-prov. 52.

N. focmina. Geoffr, suite i. 167. 
Petum anglicum. Pharm. batean. 144.

English Tobacco. Culpepp. 32t.

\section{ATROPA.}

Calyx inferior, quinquefid. Corolla campanulate, semiquinquefid. Berry with 2 cells. Obs. 6673. L.

1. ATROPA Belladonna. Stem herbaccous. Iseaves entire. Obs. 6673. On rubbish below the Old Hall in Hardwick Park Derbyshire, and near a quarry of gritstone to the south of the Old Hall, which stands on limestone. $8 \mathrm{July}$ - L.-Curt. lond. v: n. 16. t. 347. Bot. arrang. 233. Retz. scand.n. 276. In woods. -Smith brit. 255; engl. 1. 592. Asso n. 194. Woodv. i. 1. t. 1. Bulliard t. Jacq. vind. 35, in mountainous woods; austr. iv. t. 309. Fl. dan. t. 758, in a wood.-Mill. Ph. dict.n. 1; ic. t. 62. Sibth. ox. n. 242, in Whichwood forest;-prodr. n. 535, on Mount Athos.

Belladona. Vaill. paris. 20.

Belladonna majoribus foliis et fructibus. Tourn.pa. ris. 397.

Belladonna. Raii syn. 265. Clus. punn. 503, repr. in

Solanum lethale. Clus. ii. 86, Dod. ed. i. 453, cd. ii. 456, and Ger. by Johns. 340, cop. in Park. theatr. 346, \& repr. in

Solanum somniferum lethale. Lob. obs. 134; \& ic. i. 263.

Solanum somnificum Fuchsii. Dalech. 1721. 
Solanum somniferum. Fucks. cd. fol.,659, cop. in 653. c. 265, abr. in

Solanum hortense. Trag. S01, \& cop. in

Solanum manicum multis, sive Belladomn. Bauh. J. iii. 611. f. 2. f. 3.

Pubescent. Stem dichotomous, tough. Leaves elliptico-ovate, acute, at the dichotonies of the branches mostly opposite, above in pairs at each joint on one side of the branch, the lowermost of each pair smaller than the upper, the young ones shining, af.terwards dull; veins sparingly pubescent. Flowers pendulous, solitary, between one of the leaves and the dichotomy, or between the 2 leaves and the branch. Peduncles about as long as the flower. Caly $x$ partito-quinquefid; segments triangular, acutc. Corolla campanulate, somewhat tubular at the base, purplish brown, semiquinquefid, pubescent on the outside; segments triangular, acute, somewhat recurvate. Stamina as long as the corolla, inserted into the tube. Filaments incurvate at the end, pubescent at the base, glabrous above the flexure. Antherae oval. Pistil at first shorter, at length as long as the corolla. Stigma semiorbicular, green. Obs. 6673.

Native of Europe from Greece and Spain to Norway, but not of Sweden. In Britain it has been found in different places from Rochester to Icolmkil, but I bave never met with it excepting near old buildings as castles, halls, and abbies.

BELLADONNA. Pharm. suec.-Arnemann, account from in phys. journ. i. 26; and chir. rev. vi. 193. Berg. 127. Bree 251. Boullduc in acad. sc. abr. by Southw. iii. 242. Brumwell in med. obs. vi. 222. Chom. 786. Cull. ii. 269. Evers; account from in med. journ. ii. 14. Fordyce, G. pract, 209. Geoffr. iii, 163. Geudron in 
plit. trans. abr. by Hutt. iv. 471. Goellling, ac. count from in phys. journ. vi. 475. Graham in med. comment. i. 419. Grassmeyer, accoun: from in phys. joum. iii. 368. Hahnemann, account from ib. vi. 368. II feland, account from in med. rev. ii. 45t. Kacufer, account from in phys. journ. ii. 72. Krock. n. 343. Limn. 73. Munch, account from in med. comment. xii. 137. Murr. i. 430. Paget in phys. journ. vi. 352; chir. reo. viii. 290; and med. rev. vii. 364. Phys. journ. ii. 466. Quarin animad. 17. 25. 249. Reimarus, account from in chir. rev. iv. 459, and phys. journ. iii. 367. Rutty 490. Saunders, J. in phys. journ. xvi. 55. Suuter, account from ib. vi. 93. Schwin, account from in med. journ. ii. 16. Spielm. 507. Stoll med. iii. 405-416. Theden, account from in phys. joum. ii. 182. Wain. wright, T. in phys. journ. iv. 5. Vog. 270.

A. Belladonna. Leaves. Pharm.edin.-Buchhare, account from in med. comment. dec. II. viii. 128. Lew. disp. by Dunc. 164. Murr. J. i. 127 ; ii. 21. Pearson, R. ii. 212. 230. Ploucq. bibl. i. 12. 34. 409. 452.601. 622. 638. Ranöe in act. med. haun. ii. 346.

Solanun Belladonna. Lew. ii. 372.

Solanum lethale. Dale 172. Mill. Jos. 416.

Solanum furiosum. Pharm. austriaco-pror. 68.

2. ATROPA acaulis. Scapi uniflorous. Obs. 7951. Specimen gathered in Mr. Thompson's nursery.

A. Mandragora. L. sp. 259. Hort. kew. i. 242. Woodv. iv. 35. t. 225.

Mandragora officinarum. Mill. Ph. dict. Mandragora fructu rotundo. Boerh. ii. 70. Mandragora. Fuchs. 515. c. 209, cop. in 
Mandragoras mas. Bazh. J. iii. 617. Dalcch. 1726. Park. parad. t. 381. f. 2.

Maudragora. T'rag. 696, repr. in

Mandragoras albus. Cord. fol. 204. p. 2.

Mandragoras. Dod. 454, and the fruit marked maris, repr. in

Mandragoras mas. Lob. ic. i. 267, and Ger. by Johns. 352, and cop. in

Mandragora. Theophr. a Stapel. 585, \&

Mandragoras mas et foemineus. Park. theatr. 344, and the inner fruit.

Mandragora mas. Magn. hort. 130.

MANDRAGORA. Pharm. suec.-Alst. i. 479. Dale 170. Herm. 180. Lew. disp. by Rother. 192. Linn. 73. Mill. Jos. 283. Murr. i. 441. Ruty S06. Spielm. 513. Vog. 239.

Mandragora mas seu candida. Geoffr. iii. 808.

Mandragora fructu rotundo. Chom. 782.

$\&$ angustifolia. Leaves smaller, narrower and more undulate. From Lamarck, quotcd in L. a Willd. i. 1017.

Mandragora Alore subcaeruleo purpurascente. Boerh. ii. 70 .

Mandragora femina. Clus. hisp. 400. No fig.hist. ii. 87. Bauh. J. iii. 618. No fig.-Magn. hort. 130.

Mandragoras focmina. Cord. fol. 204. p. 2, cop. in Dalech. 1726, with turbinate capsules without calyces, which copied with the addition of a calyx in the figures of Dod. Lob. Ger. by Johns. and Park. cited under $a$.

IIANDRAGORA foemina, scu nigra. Geoff?. iii. 808.

MI. flore subcaeruleo purpurascentc. Boecl. ap. JIcrm. 182. Chom. 782. 


\section{NICANDRA.}

Caly $x$ quinqucpartite, with 5 angles projecting backwards. Corolla campanulate, semiquinquefid. Berry with 3, 4, and 5 cells. Obs.6017. Juss。 125. Gaertn. t. 131. Adans.

1. NICANDRA physaloides. Gacrtn. ii. 237. t. 131. Atropa physalodes. $L$ sp. 260; mant. 339. Atropa physaloidcs. L. a Murr. 221. Hort. kew. i. 243. Jacq. ols. iv. 12.t. 98.

PII YSALIS peruviana. Nill. Ph. dict.n, 16.

\section{PHYSALIS.}

Corolla rotate, and campanulate. Antherae connivent. Berry superior, of 2 cells within an inflated. calyx. Obs.6048. $L$.

\section{Perennial. L.}

1. PIIYSAliS flexuosa. Stem fruticose. Branches flexuose. Flowers crowded. L. sp. 261.

Baccifera indica, floribus ad foliorum cxortus, fructu sulcato decapyreno. Raii hist. 1632, from PEVETTI. Rheede iv. 113. t. 55.

9. PIYSALIS Alkekengi. Leaves rhombeo-ovate, the upper in pairs. Stem herbaceous, mostly simple. Obs. 6048. In a garden,-L. sp. 262. Hort. kew. i. 245. Host 117. Woods, hedges, and near villiges.-Jacq. vind. 35. Woods near the Danube.-Woodv. iv. 33. t. 224. Gouan hort. 10S. Near Montpclier,-Lour. i. 164. 
P. Halicacabum. Scop. carn. n. 256.

Physalis. Dalib. 73.

Solanum vesicarium. Dod. 451, repr. ise

Solanum Halicacabuin. Ger. by Johns. 342, cop. in

Alkakengi, sive Halicacabum vulgare. Park. theatr. 463, and abr. in

Alkakengi, sive Solanum Halicacabum et vesicarium. Park. parad. t. 531 . f. 5 .

Halicacabum vulgare. Fuchs. 652, cop. in

Halicacabon. Trag. 302, \&

Solanum Halicacabum vulgare. Bauh. J. iii. 609.

Fiaii hist. 681, an an island in the Danube near $V$ ienna, and on rubbish near Rome.

Caly. $x$ campanulate, semiquinquefid, many times smaller than the corolla, gradually increasing in size after the impregnation of the germen, becoming much larger than the corolla had been, and being ovate decangular acute quinquedentate and umbilicate at the base. Corolla campanulate, pentagonal, with an emarginature between each angle, pubescent, whitish. Stamina thrice as short as the corolla. Filaments subulate, villose at the base. Antherae with 2 cells; cells opening laterally. Obs. 6048.

Native of Italy, France, and Germany. ALKEKE NGI. Alst. ii. 254. Berg. 130. Chom。 210. Dale 172. Geoffr. iii. 55 Herm. 318. Krock. n. 344. Lew. i. 44. Linn. 74. Mill. Jos. 22. Murr. i. 463. Rutty 13. Schrod,529. Spiclm. 650. Vog. 269.

3. PHYSALIS viscosa. Stem herbaccous, paniculate above. Leaves repandose, obtuse, subtomentose, those of the branches often in pairs. From $\boldsymbol{Z}_{\text {s. }}$ 
sp. 261, and Jacq. hort. t. 136. Hart. kew. i. 214.

Alkekengi bonariense repens, bacca turbinata viscosa.

Dill. hort. 11. t. 10. f. 10.

PHYSALIS viscosa. Schoepf 25.

\section{Annual. L.}

4. PHYSALIS angulata. Very much branched. Branches angular, glabrous. Leaves opate, den. tate. 'L. $-\boldsymbol{H}$. K. i. 245.

.P. annua ramosissima, ramis angulosis glabris, foliis dentato-serratis. L. ups. 50, where for Comm. read Cam.

Alkekengi indicum majus. Boerh. ii. 66.

Halicacabum sive Solanum indicum, Cam. hort. 70. t. 17 , cop. in

Solanum, sive Halicacabum indicum. Bauth. J. iii. 609.

B capsicifolia. $-L$.

Alkekengi indicum glabrum capsici folio. Dill. hort. 12.t. 11. f. 11.

Solanum vesicarium erectum, solani vulgaris folio.

Sloare cat. 110.

PIIYSALIS. Browne 176.

5. PHYSALIS minima. Stem very much branched. Peduncles of the fruit Ionger than the leaves. Leaves villose. L. sp. 263. Hort. kew. i. 246. Mill. Ph. dict.n. 11.

Alkekengi indicum minimum, fructu virescente. Boerh. ii. 66.

Solanum vesicariun indicum minimun. Herm. hort. 569. t. 571 . 
Inota-inodien, seu Moctoe. Rheede x. 199. t. 70.

(Pee-inota-inodien. Rheede x. 140. t. 71, is a different plant.)

HALICACABUS. Bont. 149.

\section{SOLANUM.}

Corolla rotate. Antherae mostly coherent. Berry superior, bilocular. Obs.6483. $L$.

Antherae nearly united in most of the species, but in S. bonariense and laciniatum distinct; mostly opening at the end by 2 pores, but in S. Lycopersicon opening laterally.

\section{Without prickles or spines.}

1. SOLANUM laciniatum. Leaves pinnatifid; seg* ments ensiform. Stem fruticose, glabrous. Corymbi axillary, 2 and 3 together. Obs. 8299. In Mr. Sitwell's garden. 10 June.-Hort. kew. i. 247; iii. 501. Curt. mag. t. 349.

SOLANUM aviculare. Forst. G. esculent. 42.

2. SOLANUM Dulcamara. Stern frutescent. Up. per leaves mostly trilobate. Cymes mostly opposite to the leaves. Obs. 1491. On the sides of moist ditches.-L. suec. n. 201; sp. 264. Bot. arrang. 235. Fl. dan. t. 607. Woodv. 97. t. 33. Pollich n. 228. Curt. lond. i. 1. t. Smith brit. 256 ; engl. t. 56 J.

S. scandens, seu Dulcamara. Tourn. paris. 43. Vaill. paris. 188. Boerh. ii. 67.

S. lignosum, sive Dulcamara Park. theatr. 349.

D d 
The description. (The figure has another name.) -Raii hist. 672; syn. 265.

Amara dulcis. Tab. ic. 893. Lob. ic. i. 266, repr. in Ger. by Johns. 350,

Dulcamara. Jod. 398, \&

Circaea monspeliensis. Lob. obs. 136, \& cop. in

Dulcamara, seu Solamm lignosum. Park. theatr. 350.

Dulciamara. Dalech. 1413.

Vitis sylvestris. Cam. epit. 986.

Dulcis amara. Trag. S16.

Glycypicros, sive Amara dulcis. Bauh. J. ii. 109. Native of Europe from Italy to Sweden.

DULCAMARA. Pharm. austriaco-prov. 36. suec. -Berg. 130. Chom. 77. Cull. ii. 554. Geoffr. iii. 412. Hacn i. 355. Hallenberg, account from in med. comment. iii. 15. Krock. n. 345. Lew. ii. 375; disp. by Dunc. 306. Linn. 74. Monro iii. 102. Murr. i. 423. Quarin febr. 335 ; animad. 110. 113. Richter, account from in chir. rcv. i. 98. Schoepf 26. Stoll med. iii. 158. 167. Vog. 193.

S. Dulcannara. Coste and Willemet, account from in med. cornment. v. 298. II ufeland, account from in med. rev. ii. 454. Murr. J. i. 302. Pearson, R. i. 233. 262. Ploucq. bibl. i. 431.

S. lignosum. Dale 171. Mill. Jos. 415. Rutty 170.

S. scanders, seu Dulcamara. Chom. 781; suppl. 209.

Amara dulcis. Percival T. ii. 275.

Douce amere. Carrere, account from in phys. joum. i. 307 .

3. SOLANUM nigrum. Stem herbaceous. Leares 
ovate, dentato-ingular. Racemi distichous, nodding. L. suec. ". 200; sp. 266. Bot. urrang. 236. Smith brit. 256; engl. t. 566. Wrodv. iv. 37. t. 296. Curt. lond. ii, 14. t. Fl. dan. t. 460.

S. hortense. Dod. 451, repr. in Ger. by Johns. 339, \& cop. in

S. vulgare. Park. theatr. 346. Raii hist. 672; syn. 265. 266. par. 1, 2, 4, 5 .

S. hortense. Fuchs. 651. c. 265. cop. in

-S. hortense, sive vulgare. Bauh. $J$. iii. 608, and abr. in

S. vulgare. Trag. 303.

S. officinarun, acinis nigricintibus. Boerh. ii. 67.

Peduncle extra-ixillary, but frequently alove the middle of the internodium. Obs. 8650 . In driving sand between Kirdderminster and Stourport plentifully, some only $2 \frac{\pi}{2}$ inches high. Common in Worcestershire, Warwickshire, and Staffordshire, but in the circuit of 17 miles round Chesterfield I have hitherto obscrved only 1 plant at Whiston near Rotherham.

SOLANUM. Pharm. austriaco-prov. 68. suec.

-Berg. 140. Boerh. 507, species 4. Fordyce, $G$. pract. 209, Gataker on-Geoffr. suite iii. 87. Frork. n. 346. Lew. ii. S79. Lim. T5. Mur. i. 427. Schorpf 26. Spielm. 523.

S. hortense. IFill. Jos. 414. Rutly 489.

S. officinarum. Chom. 784; suppl. 209. Dale 170. Boerh. aph.n. 976.

e irginicum. Branches angular, dentate. Leaves repandose, glabrous. L. sp. 266. E. Süariz obs. 83. Hort. kew. i. 949.

S. nigrum volgari simile, caulibus exasperatis. Dill. horl. 368. 1. 275. f. 256 . Lower leaves sinuate, incise. 
SOLANUM humilius diffusum, foliis ovatis, $\mathrm{ra}$. mulis marginatis, umbellulis florum sparsis. Browne 174.

y tomenlosum. Jeaves tomentose, subcrenate. Stem glabrous. Umbels axillary. From

SOLANUMI nigrum. Lour, i. 160.

\section{Leares pinnate.}

4. SOLANUM tuberosum. Stem herbaccous. Folioles very entire. Peduncles subdivided. L. $s p .265$.

Lycopersicon tuberosum. Mill. Ph. dict.n. 7 .

S. tuberosum esculentum. Bauh. Casp. prodr. 89. Dill. ap. Raii syn. 265. Cultivated about London, but much more so in Wales and Ireland.Vaill. paris. 188. Boerh. ii. 67.

Papas americanum. Bauh. J. iii. 621.

Battata virginiana, sive virginianorum, et Pappus. Ger. by Johns. 927.

Pappas, seu Battatas virginianorum. Park. parad. t. 517. f. 3.

SOLANUM tubcrosim. Berg. 132. Bryant 15. Geoffr. suite iii. 92. Lim. amoen. v. 67. Pearson, R. i. 57. Schoepf 26.

Battata virginiana. Dale 171.

Pyra terrae. Spielm. 34.

Potatoc. Blane 60. Blizard, account from in med. rev. i. 331. Cavander, account from in phys. joum. iii. 270. Fordyce $W$. fev. 206. Nisbet, account from in med. rev. vi. 414.

5. SOLANUM Lycopersicon. Stem herbaccous. Ieaves pinnate and bipinnate; folioles incise. Panicles dichotomous, leafless. Fruit glabrous. Obs. 6483. In Mr. S. Shore's garden.-Jacq. 
Monogryia. 165. Solanum.

ap. L. a Murr. 224. L. sp. 265. Hort. liew. i. 249.

Lycopersicon subhirsutum, foliis varie incisis interrupte et abrupte pennatis, calicibus septempartitis. Browne 175.

S. pomiferum fructu rotundo striato molli. Raii hist. 675.

Pomum amoris. Rumph. v. 416.t. 154. f. 1.

Poma amoris fructu luteo. Besl. aut. ord. 1. fol. 1. $t . f .1$.

Poma amoris fructu rubro. Besl. aut. ord. 1. fol. 2. $t$.

Poma amoris. Cam. epit. \$21.

Lycopersicon Galeni. Boerh. ii. 69.

Aurea mala. Dalech. 628. Dod. 455, repr. in

Ger. by Johns. 316; Lob. obs. 140; ic. 1. 270, \& cop. in

Pomum amoris majus. Park. theatr. $353 ;$ parad. $t_{\text {. }}$ 381. f. 3.

Mali aurea odore foetido, quibusdam Lycopersicon. Bauh. J. iii. 621.

Stem hispid. Leaves interruptedly pinnate and bipinnate with an odd foliole. Panicles internodial. Calyx sexpartite. Stamina 8 and 10. Antherue subulate, slightly cohercnt. Germen superior, ovate, with several furrows. Style sulcate. Ols. 6483.

SOLANUM Lycopersicun. Bryant 212. Swartz. obs. 83.

Poma amoris. Dale 171.

Amoris pomum. Mill. Jos. 32.

Pomme doree. Chom. 789.

6. SOLANUM peruvianum. Stem herbaccous. Leaves pinnate, tomcntose; folioles incise. Racemi bi-

D d 3 
partite, leafy. Burries subpilose. L. sp. 285. Jacq. coll. ii. $284 ;$ rat. ii. $\iota .327$.

SOLANUM peruvianum. Lour. i. 162.

3. Slem somctimes prickly, sometimes wilhout prickles.

7. SOLANUM orifcrum. Stem herbaceous, with and without prickles. Leaves ovate, repando-sinuate, tomentose. Peduncles internodial, pendant, thickening. Calyces with and without prickles. Ous. 6549. In Mr. Shore's garden.-Sulisb. R. allert. 134.

S. Melongena. L. a Murr. 224; sp. 266. Ilort. licz. i. 250. Lour. i. 161.

S. pomifernm fructu oblongo. Raii hist. 673 .

S. pomiferum quartum, sive fructu oblongo. Sloane cat. 108.

Mala insana syriaca. Park. theatr. 353, cop. from

Mala insana. IJod. ed. ii. 458; ed. i. 455, which repr. in Ger. by Johns. 345. Trag. 894. Fuchs. 518. c. 203, cop. in

S. pomiferum fructu rotundo. Bauk. J. iii. 618.

MELONGENA. Berg. 13S. Geoffr. suite i. 17. Mala insana. Dale 171.

S. Melongena. Bryant 213.

a album. Berries white. Obs. 6549. In a garden.

Melongena ovata with white fruit. Mill. Ph. dict. n. 1 .

Melongena fructu oblongo albo. Boerh. ii. 70.

Stem prickly; prickles few, slightly hooked, small. Lecres without prickles, the young ones hoary, the older slightly hoary with radiate tomentum. $P_{\varepsilon}$. duncles prickly, tomentose. Calyces prickly, with soflish straight prickles, Corolla purple. Stamina 
7, connivent. Antherae opening at the end. Berry white, with 3 cells, Obs. 6519 .

EGG PLANT. Hawkesw. voy. iv. 3H.

s violaceum. Berries purplish blue. From

Melongena fructu oblongo violaceo. Boerh. ii. 70, $\mathcal{E}$

FOKKE FOKKES. Thunb. trav. ii. 293.

Mayenue. Chom. 790.

8. SOLANUM inscmum. Stem herbaceous, with and without prickles. Leaves ovate, tomentose. Peduncles pendant, thickening. Calyces aculeate. From L. \& Swart obs. S3. Peduncles terminal.

Nila-barudena. Rheede x, 147. t.74. Calyx represented as long as the corolla. Stem and the costa of the leaves underneath, aculeate. Fruit oval.

Melantzana nigra. Dalech. app. 23, cop. in

Solanumi pomiferum fructu spinoso. Bauh. J. iii. 819

S. pomiferum, magno fructu ex albo et atropurpureo nitente, folio et calyce spinoso. Pluk. alm. 350; phyt. t. 226. f. 3, \&

S. pomiferum fructu nigro spinoso. Hist. ox. s. 13. t. 2. row 1. f. 2.

Solani species, Fockii Fockii dicta. Bont. 123. $t$. Calyx as long as the corolla.

Trongum hortense. Rumph. v. 238. t. 85. Peduncles lateral and terminal.

SOLANUM hirsutum et spinosum, fructu maximo, calice majori spinoso. Browne 173.

9. SOLANUM sanctum. Stcm aculeate, fruticose.

D d 4 
Aculei tomentose. Leares tomentose, obliquely ovite, repandose. L. $\quad$ sp. 269.

S. acthiopicum maxime tomentosum caule solumıno. do non foliis aculeatum. Pluk. alm. 351; phyt. t. 316. f. 2.

SOLANUM sanctum. Bryant 214.

10. SOLANUM bahamense. Stem aculeate, fruticose. Leaves lanceolate, repandose, obtuse, reflex at the margin. Racemi simple. L. sp. 270.

S. bahamense spinosum, petalis angustis reflexis. Dill. hort. 263. t. 271. f. 250.

S. fruticosum bacciferum spinosum, flore caeruleo. Sloane cat. 108.

SOLANUM erectum, caule tereti aculeatissimo, foliis oblongis ad basin inaequaliter porrectis. Browne 174.

Canker-berry. Graing. 52.

\section{CAPSICUM.}

Coralla inferior, rotate. Antherae connivent. Berry juiceless, with 2 cells. Obs, 6485. L.

1. CAPSICUM anpiuum. Stem herbaceous. Peduncles solitary. L. sp. 270. Hort. kew. i. 253. Lour. i. 157.

Piper indicum. Cam. epit. 347. Besl. hort. aut. ord. 1. fol. 6 to 13.

Siliquastri triplex varietas. Cam epit. 348.

Vallia-capo-molago. Rheede ix. 65. $t .35$.

Chilli, Piper siliquosum mexicanum. Hern. 135.

* longum. Capsules long, pendent. From Mill. P\%。 Hort. kew. i. 253 a Foodv. 391. t.144. 
C. annuum. Mill. Ph. dict. n. 1.

C. siliquis longis propendentibus. Boerh. ii. 68.

Piper indicum vulgatissimum. Raii hist. 676.

Siliquastrum majus et minus. Fuchs. 693. c. 28I,

a part cop. in the lower part of

Siliquastrum. Trag. 928, which repr. in

Piperitis. Cord. fol. 88. p. 1.

Siliquastrum oblongius. Fuchs.693. c. 281, cop. in

C. recurvis siliquis. Dod. 704,

C. oblongius. Dalech. $632, \&$

Piper calecuticum, sive C. oblongius. Bauh.J. ii. $943, \&$ the fruit cop. in the upper part of

Siliquastrum. Trag. 928, which repr. in

Piperitis. Cord. fol. 88. p. 1.

C. nıajus et minus. Dalech. 632.

C. oblongum minus recurvis siliquis. Park, theatr. 358. No fig.-Sloane cat. 113.

Capsici siliquae variae. Ger. by Johns. 365. f. 9. 10, cop. in

Capsici species. Park. theatr. 357. f. 5.6.

C. oblongioribus siliquis." Dod. 704, which repr. in ed. ii. 716 ,

C. Piper indicum. Lob. obs. 172.

C. Actuarii. Lob. ic. i. 316,

Capsicum. Monard. ap. Clus. exot. 340*,

Piper americanum vulgatius. Clus, cur. post. 54, $\&$

C. Tongioribus siliquis'. Ger. by Johns. 364, \& cop. in

C. longum. Park. theatr. 356.

C. majus vulgatius oblongis siliquis, Park. theatr. 356.

CAPSICUM annuum. The fruit. Pharm. edin. -Bryant 183. Lewo disp. by Dunc. 173. Murr. 
J. 1. 200. Pearson, R. i. 93; ii. 172. Schoepf

27. Wrighth in med. journ. viii. 234.

Capsicum. Dale 172. Mill. Jos. 109. Vog. 265. Piper indicurn. Guinea Pepper. 'The fruit. Pharm. lond.-Berg. 142. Geoffr. suite ii.-1. Lew. ii. 227. Linn. 75. Rutty 394.

Piper indicum, sive lispanicum. Murr. i. 475.

Piper indicum vulgatissimum. Chom. 143.

2. CAPSICUM grossum. Sten suffrutescent. Capsules thickening upwards, variously shaped. $L$. mant. 47. Hori. kew. i. 254.

C. tetragonum. Mill. Ph. dict. n. 3 .

Piper indicum, bifurcata siliqua. Besl. hort. aut. ord. 1. fol. 8. f. 2.

CAPSICUM grossum. Thunb. jap. 93.

3. CAPSICUM baccatum. Stem fruticose, smooth. Peduncles in pairs. L. mant. 47. Hort. kezo. i. 253. Lour. i. 157.

C. frutescens $\beta$ L. sp. 271.

C. minimum. Mill. Ph. dict. $n .10$.

C. fructu minimo conico rubro. Browne 176.

C. minus, fructı parvo pyramidali erecto. Slocme cat. 112 ; hist. i. 210. t. 146. f. 2.

C. rubrum minimum. Rumph. v. 252.t. 88. f.2, but peduncles solitary.

C. minimis siliquis. Dod. 705, repr. in Ger. by Johns. 364,

C. brevioribus siliquis. Lob.obs. 173,

C. Piper indicum, brevioribus siliquis. Lob. ic. i. 31T,

C. brasilianum. Monard. ap. Clus. exot. $310 *$, \& Piper brasilianum. Clus. cur. post. 55, \& cop. in 
Piper siliqua parva brasilianum. Banh. J. ii. 944. CAPSICUM baccatum. MnTr. i. 477. Pearson, R. i. 93. Wright in med. jonm, viii. 234.

Capsicum. Blane 461. Chisholm 81. Clark, James in med. facts vii. 293. Collins in med. commun. ii. 363. Cull. ii. 210. Fordyce G. fev. iv. 131. Lempricre ii. 162. Pearson, $R$. account from in med. rev. ii. 442. Thunb. trav. ii. 268. Winterbottom, $T$. account from in chir. reo. x. 450. Wright in amn. med. ii. 367.

Piper cayense. Adair in med. comment. ix. 208. Headly in phys. journ. v. 425.

Cayenne Pepper. Gerard in med. soc. iv. 359. Jackson Rob. fev. 290. Lempriere ii. 192. Lew. ii. 228. 494. Maclean 169 143, and account from in ann. med. ii. 202. Stephen in med. comment. dec. II. ii. 377. Stewart account fiom in med. conmmn. ii. 372; med. comment. dec. 11. ii. 377; and by Aikin in Lew. ii. 494. Thomas, account from in med. rev. viii. 103. Underw. ii. 50. Wright in med. facts vii. 11; and ann. med. ii. 372.

Cayan Pepper. Darw. ii. 744.

Chili. Turn.trav. 11.

Chilly. Percical, Rob. ceyl. 323.

Red Pepper. Winterbottom, account from in chir. rev. x. 464.

Small red Pepper. Stephen in med. comment. dec. II. ii. 377. Stewart, account from in med. commun. ii. 372; med. comment. dec. II. ii. 377; \& by Aikin in Lew. ii. 494.

Green Pepper. Graing. 36. 63.

4. CAPSICUM frutescens. Stem fruticose, roughish. 
Peduncles solitary, L. a Murr. 227 ; sp. 271 a. Hort. kew. i. 254. Lour. i. 158.

CAPSICUM frutescens. Bryant 185. Wright in med. journ. viii. 234.

Bell Pepper. Panton in Daroson rheum. append. 56.

Cayenne Pepper. Lew. disp. by Dunc. 174.

a majus. Capsule red. Obs. 8342. Specimen gathered by Dr. Wright in Jamaica.

C. maximo cordiformi biloculari rubro. Browne 176.

C. majus rubrum. Rumph. v. 247. t. 88. $f .4$.

$\beta$ minus. Capsules red, smaller than those of $\alpha_{\text {. From }}$ C. minus rubrum. Rumph. v. 248. t. 88. f. 1 .

$\gamma$ conoides. Capsules red, conic. From

C. conoide. Mill. Ph. dict. n. 8, seeds from Antigua.

IIEN PEPPER. Wright in med. journ. viii. 234.

¿ flavum. Capsules yellow. From

C. minus flavum. Rumph. v. 248. t.88. f. 3.

CAPSICUM fructu cordiformi minori luteo. Browne 176.

\section{STYRCHNOS.}

Calyx inferior, quinquefid. Corolla infundibuliform; limb quinquepartite. Berry unilocular, with a hard rind. Seeds 1 to 5. Ols. 8476, and the account of the fruit from Roxt. \& $L$.

1. STRYCHNOS ovalifolia. Stem arboreous. Leaves oval. Obs. 8476. Specimen from Dr. Wright, probably from India. 
S. Nux vomica. L. sp. 271. Hort. kew. i. 254. Roxb. corom. i. t. 4. Lour. i. 154. Woodv. iv. 29. $t$. 22S, from a spccimen in Sir Jos. Banks's herbariul1.

Strychnus foliis quinquenerviis. Wachend. 32, from Caniram. Rheede i.67.t.37. Raii hist. 1661. Solanum arboreum indicum maximum, foliis oenopliae sive napecae majoribus, fructu rotundo duro rubro semine orbiculari compresso maximis, nuces vomicas et lignum colubrinum ferens. Breyn. prodr. 97 .

Nux vomica major et officinarum. Herm. prodr. 357.

Nuces vomicae. Ger. by Johns. 1546, cop. in

Nux vomica. Park, theatr. 1601. The seeds. Raii hist. 1814.

Nux vomica vulgo officinarum compressa hirsuta. Bauh. J. i, 339. The seeds.

Leaves oval, and elliptico-oval, trinervose, with 2 smaller ribs near the margin mostly uniting with the costa below the insertion of the larger ribs. $\mathrm{Ca}$ lyx pubescent; segments triangular. Corolla many times longer than the calyx. Stamina 5, inserted into the corolla just below the commissures of the limb. Filaments shorter than the antherae. Antherae oblong. Pistil nearly as long as the corolla. Germen ovate. Style filiform. Stigma capitate, emarginate. Obs. 8476.

NUX VOMICA. Pharm. suec,-Alst. i. 28. Berg. 144. Dale 327. Geoffr. ii. 448. Herm. 336. Hufeland, account from in amn. med. i. 50; iv. 265. Lew. ii. 150; disp. by Rother. 205; by Dunc. 348. Linn. 76. Mill. Jos. 316. Murr. i. 477. Ploucq. bibl. i. 370. Lianöe in act. haun. i. 460. Vog. 273. 
S. Nux vomica. Murr. J. i. 137. Ploucq. Libl. i. 354.432 .614 .

Nux vomica, the larger sort. Neum. ii. 100.

Nuces vomicac. Spielm. 232.

2. S'PRYCHNOS colubrinc. Stem fruticose. Leaves ovate, acute. From Breyn. and Rheede.

Naga Musadie. Roxh. corom. i 10?

Solanum arborescens indicum foliis napecae minoribus, fructu rotundo duro et semine orbiculari compresso ininoribus. Breyn. Jac. prodi. ii. 98.

Lignum colubrinum. Brcyn. J. ic. 19. t. 5. f. 2. Rumph. ii. 121. $t$. 35. The prickles on the fruit not noticed in the description.

Strychnus foliis trinerviis ovato-lanceolatis pinnatis.

Wachend. 32, probably from

Sche:u-katu-valli-caniram. Rheede vii. 9, t. 5.

Nux vomica minor moluccana. Herm. prodr. $35 \%$. (not repeated in parad. or hort.)

Fructus orbicularis peregrinus, granis nucis vomicae similibus. Bauh. .. i. 311. Fruit.

LIGNUM COLUBRINUM. Alst. ii. 37. Berg. 147. Cartheus. ii. 346. Dale 327. Geoffr. ii. 456. Herm. 234. Lew. ii. 152. Mill. Jos. 146. Mur. i. 485. Spiclm.210. Vog. 282 .

Lignum colubrimm vulgare. Limn. 76.

NUCIS TOMICAE species tertia. Geoff. ii. $45 \pi$.

Nux vomica, the smaller sort. Neum. ii. 101.

3. STRYCINOOS cirrhosa. Stem herbaceous. From Rherede

S. colubrina. I. sp. 271; fit. suppl. 149. Berg. mal. mad. n. 90. 
S. foliis ovatis acutis, cirrhis simplicibus. L. mad. med. $n .78, \delta$

Strychnus foliis trinerviis ovatis binatis. Wachend. 32, from

MODIRA-CANIRAM. Rheede viii. 47.t.24.

4. STRYCHNOS monosperma. Berry with one seed. From

STR YCIINOS potatorum. L. fil. suppl. 148, \& Roxb. i. 10.t. 5.

\section{IGNATIA.}

Caly $x$ quinquedentate. Corolla infundibuliform, very long. Berry unilocular, polyspermous. Seeds angular. From L. a Willd. L. fil. and Lour.

1. IGNATIA amara. L. fil. suppl. 149.

Ignatiara philippinica. Lour, i. 155.

Strychnos Ignatii. Berg. mat. med. n. 89.

Nux Pepita. Sloan in' phil. trans. abr. by Lowth.

ii. 648. t. 8. f. 163, at p. 662.

Catolongay. Camelli in phil.trans. abr. by Lowth. ii. 649. t. 8. f. 164, at p. 662.

FABA Ignatii. Pharm. suec.-Linn. 77.

Faba Sancti Ignatii. Alst. ii. 38. Cull. ii. 76. Dale 328. Berg: 146. Joannes in phil. trans. abr. by Hult. iv. 356. Lind. hot clim. 308. Neum. ii. 102. Eog. 168.

Fabae Sancti Ignatii. Spielm. 214.

Faba febrifuga. Gieoffr. ii. 459.

Faba indica. Lezo ii. 153.

Nux Pepita. Phil. trans. abr. by Lowth. ii. 648. 
Igasur. Camelli in phil. trans. abr. by Lowth. ii. 649 ; \&. by IIult. iv. 356.

\section{CESTRUM.}

Corolla tubuloso-infundibuliform. Calyx inferior, with 5 teeth. Stamina shorter than the corolla. Germen and Berry with 2 cells. Obs. 5439, the flower; and the account of the fruit from Juss. 126 \& Lherit. stirp. 74. $L$.

\section{Filaments without a tooth at the base.}

1. CESTRUM vespertinum. Leaves lanceolato-ellip. tic. Corolla glabrous. Racemi axillary. Obs. 8381. Specimen gathered by Dr. Wright in Jamaica.-L. mant. 206. Swartz. obs. 85. Lherit. stirp. i. 72. Hort. kew. i. 255.

Jasminum laurinis foliis, flore pallide luteo, fructu atro-caeruleo polypyreno venenato. Sloane cat. 169; hist. ii. 96. t. 204. f. 2.

(Ixora alternifolia. Jacq. amer. 16. t. 177. f. 8, flowers and fruit; 8 ro, 19, has a corolla with ensiform distinct seginents, and the tube is described as being twice as long as the limb.

Jasminum aliud arborescens, foliis solani minus. Plum. cat. 17; a Burm. 150. t. 157. f. I, is Ixora alternifolia of Jacq.

Nandi-ervatam minor. Rheede ii. 107. t. 55 is probably a Nerium.)

Racemi corymbose, nearly sessile, twice and thrice as long as the petioles. Peduncles shorter than the petioles, tomentose. Pedicles mostly shorter than the calyx. Corolla yellowish, semitransparent; tube 
tubiform; limb reflex, 5 times shorter than the tube; segments ovate. Filaments without teeth, scarcely longer than the antherac. Obs 8581.-Lentes not ill scented. Obs. 6825. Specimen gathered in the Paris garden.

CESTRUM. Browne 173.

2. CESTRUM auriculatum. Leaves elliptic. Com rolla pubescent. Peduncles terminal and axillary. Obs. 6896. Specimen from Mr. Hunter's nursery.-Hort. kew. i. 255.

C. foetidum. Salisb. R. allert. 111.

Very similar to $C$. vespertinum. Stipulae none. Peduncles about as long as the petioles; the lateral ones with 2 flowers, the lowermost flower sessile; the terminal peduncle paniculate with 4 flowers, the uppermost flower but one sessile. Corolla pubescent on the outside; tube tubiform; limb erect. Fila ments without a tooth. Obs. 6826 .

CESTRUM auriculatum. Lherit. stirp. iv. 71.t.35.

\section{LYCIUM.}

Corolla tubular, and hypocrateriform; throat closed by threads. Berry of 2 cells, with many seeds. Obs. 8185. L.

1. LYCIUM barbarum. Leaves lanceolate and oblong. Branches angular. Tube of the corolla once and a half, as long as the calyx. Obs. 2879. In the garden at Areley-house, Lower Arcley, Worcestershire.-IIort. kew. i. 257.

a wulgare. Style as long as the stamina.' Hort. kew'. a. 
L. barbarum. L. sp. 277; mani. 341. Sibth. prodi. n. 541. Mill. Ph. dict. n. 4, but lie describes the flowers as small and white.

L. foliis oblongo-lanceolatis sine ordine, ramorum spinis rarioribus. Trew select. 33. $t$. 68, but the corolla decp bluc.

Jasminoides aculeatnm, polygoni folio, floribus parvis albidis. Sharo trav. ed. ii. 464. n. 145.t. at $p$. 465. $f$. 145 , but he describes the branches as tomentose.

Rhamnus secundus monspeliensium. Lob. adv. 438, cop. in Dalech. 140, repr. in.

Rhamnus secundus Dioscoridis monspeliensium. Lob. ic. ii. 181, \& cop. in Park. theatr. 1006.

(Rhamnus peregrinus, rosmarini folio, candidior. Pluk. alm. 317 ; mant. 160; phyt. t. 322. f.2, has distichous leaves.)

Calyx quadridentate and quinquedentate, sometimes cloven on both sides and on one side so as to appear bilabiate. Corolla hypocrateriform; tube nearly twice as long as the calyx; limb purple, about the throat whitish with blackish purple lines. Pistil just longer than the stamina. Obs. 2879.

$\beta$ chinense. Style longer than the stamina. Hort. kicw. $\beta$

L. clongatum. Salisb. R. allert. 136.

Kooki. Kaempf. amoen. 777.

LYCIUM barbarum. Lour. i. 165. Thunb. jap. 94.

2. LYCIUM obliquifolium. I.eaves oblique. Branches flexuose, terete. Tube of the corolla four times as long as the calyx. From $L$. and the account of the corolla from Michelis figure. 
L. europacum. L. sp.ed.i. 192 ; mant. 47. Silth. prodr. n. 542. Hort. liew. i. 25\%. Gouan hort. 111. About Montpelier; monsp. 34. Asso n. 198. L. salicifolium. Mill. Ph. dict. n. 3 .

L. foliis cuneiformibus. Royen 436 .

Jasminoides aculeatum, salicis folio, flore parvo ex albo-purpurascente. Mich. 224.t. 105. f. 1 .

Rhamnus spinis oblongis, cortice albo monspeliensium. Boerh. ii. 212.

Rhamnus I. Clus. hisp. 67, repr. in hist. i. 109, Dod. $742, \&$

Rhamnus I Clusii flore albo. Ger. by Johns. 1934, cop. in

Rhamnus I Clusii. Dalech. 141, and a branch cop. in

Rhamnus cortice albo monspeliensis. Bauh. $J$. i. $b$. 31 , with the addition of a branch without fructifications.-Magn. hort. 172. Raii europ. 218.

Rhamnus spinis oblongis, flore candicante. Raii hist. 1592. About Montpelier and Florence.

(Rhamnus secundus monspeliensium. Lol. adv. 438, cop. in Dalech. 140, repr. in

Rhamnus secundus Dioscoridis monspeliensium. Lob. ic. ii. 181, and cop. in Park. theatr. 1006, has -infundibuliform corollae whose breadth is equal to their length.)

RHAMNUS cortice albo monspeliensis. Magn. monsp. 221.

\section{OPHIOXYLUM.}

Corolla inferior, tubiform, quinquefid at the end. C'alyx pentaphyllous. Neclarium of the male Qnvers in the mouth of the tube of the corolla.

E 2 
Stamina of the male fiowers 2. Berry bilocular, didymous. Seeds solitary. Obs. 7866. L. from authors.

Flowers hermaphrodite and male.

1. OPHIOXYLUM serpentinum. L. sp. 1478 ; a Murr. 911. Hort. kew. ii. 433. T'kunb. trav. iv. 395 .

Ligustrum foliis ad singula internodia ternis. Burm. J. zeyl. 141.t. 64, in fruit.

Radix mustelae. Rumph. vii. 29. $\iota .16$. In flower. Tsjovanna-Amel-Podi. Rheede vi. 81. t. 47.

Leaves elliptic, glabrous, entire at the margin. Peduneles bifid at the end. Flowers aggregate. Calyx, phylla subulato-ovate, incumbent. Corolle reddish crimson with a mixture of white; segments oblong, with a white beard at the base on the inside. Stamina inserted into the corolla about the middle. Filaments very short. Germen oval, surrounded by the nectarium. Nectarium fleshy, green, loose from the germen. Style filiform. Stigma capitate, whitish. Obs. 7866. In Mr. Hunter's nursery. Aug.

LIGNUM SERPENTINUM. Lim. 267; amoen. ii. 111.

Lignum serpentum. Murr. i. 383.

\section{CHIRONIA.}

Corolla inferior, infundibuliform. Pistil declinate. Stigma obtuse. Seedressel unilocular, appurently hilocular. Obs. 6198. 3992. L. 
1. Antherae spiral after flowering. Stem herber ceous.

1. CHIRONIA angularis. Angles of the stem acute. Leaves ovate, amplexicaul. L. sp. 272. Michoux i. 146.

CHIRONIA. Co.re 369. Schoepf 27.

\section{ERETIA.}

Corolla campanulate, quinquefid. Stigmata 2. Drupae bilucular. Nuts 2 in each cell, bilocular. Seeds solitary. From Browne, Swartz, \& L.

1. ERETIA tinifolia. Leaves oblongo-oval, glabrous. Flowers paniculate. Obs. 8333. Specimen gathered by Dr. Wright in Jamaica.-L . sp. 274. Hort. kew. i. 259.

Ebretia. Trew select. 4. t.25. Erowne 168. t. 16. f. 1.

Ceraso affinis, arbor baccifera racemosa, flore albo pentapetalo, fructu flavo monopyreno eduli dulci. Sloane cat. 169; hist. ii. 94.t. 203. f. 1.

EHIRETIA. Browne 168 ,

\section{BEURERIA.}

Corolla infundibuliform, limb quinquepartite. Stigmata 2. Drupa with 4 nuts, separating spontaneously into 4 parts, Nuts with 2 cells. Seed solitary. Obs. 2333.-'The account of the frui from

Bourreria. Brozine 168.

$$
\text { E } е 3
$$


1. BEURERIA succulenta. Drupe succulent. From Beurreria succulenta. Jacq. obs. ii. 2. Ł. 20.

Bourreria. Browne 168. t. 15. f. 2.

Eliretia Beurreria. L. a Murr. 230. Jacq. amer. 8ro, 59.

Ehretia Bourreria. L. sp. 275. Hort. kew. i. 259. Ehretia Boureria. L. mant. 341.

Cordia Bourreria. L. amoen. v. 395.

Jasminum periclymeni folio, flore albo, fructu flavo rotundo tetrapyreno. Sloane cat. 169; hist. ii. 96. Ł. 204. f. 1 .

'Mespilus americana laurifolia glabra, fructu rubro mucilagrinoso. Commel. hort. i. 153. t. 79.

Pittoniae similis, latreolae foliis, floribus albis, baccis rubris. Catesb. ii. . 79.

Branches pubescent. Leares oblongo-elliptic, revolute at the margin, those at the base of a branch scabrous, those above pubescent. Corymbi com. pound, terminal. Peduncles \& calyces pubescent. Obs. 2333. Specimen gathered by Broughton in Jannaica.

BEURRERIA succulenta. Jacq. amer. 44.

\section{CORDIA.}

Corolla infundibuliform. Stigmata 4 \& 2 . Drupa. Nut quadrilocular. Obs. 8477 , \& from $L$.

1. CORDIA. Myxa. Calyces with 10 striae. Leaves ovate, glabrous above. Corymbi lateral. From L. a.Murr. 230; \& sp. 273; mant. 341. Hort. liew. i. 258.

C. monoica. Roxb. i. 43. t. 58 so much resembles a specimen of C. Myxa gathered in the garden 
of Fothergill, and J. Bauline's figure of Myxa silvestris, that I suspect it will prove to be the wild plant.

Vidi-maram. Rheede iv. 77. t. 37. Raii hist. 1563. Myxos arbor, sive Sebestena nostra. IJalech. 359. Leaves narrower than in my specinen.

Sebestenae, Myxa, sive Myxara. Ger. by Johns. 1499.

Prunus Sebestena. Pluk. alm. 306; phyt. t. 217. t. 2.

Prunus Sebestena, longiori folio, maderaspatensis. Pluk. alm. 306; phyt. t. 217. f. 3. Segments of the corolla reflex

Sebestena officinalis. Dill. hort. t. 255.

Sebesten domestica. Commel. hort. 139. t.72. Alpin. acgypt. fol. 12. p. 2. Leaves entire at the margin.

Sebesten sylvestris. Alpin. aegypt. fol. 13. p. 1.

Mixa domestica. Bauh. J. i. a. 199.

Myxa silvestris. Baut. J. i. a. 199.

Sebesten. Park. theatr. 252.

Myxa, sive Sebesten. Raii hist. 1555.

SEBESTENA. Alst. ii. 316. Lew. disp. by Rother. 240.

Sebesten. Dale 297. Geoffr. ii. 311. Herm. 397. Linn. 77. Mill. Jos. 405. Murr. ii. 105. Rutty 476. "pielm. 465. Vog. 273.

C. Myxa. Bryant 246.

Pruna Sebestena. Cartheus. ii. 187.

Sebestes. Chom. 78. 113.

2. CORDIA Sebestena. Leaves oblongo-ovate, repandose, scabrous. L. sp. 274. Hort. kew. i. 259. Jacq. amer. 42; ed. 8ro, 54.

E e 4 
Cordia. Browne 202.

Novella nigra. Rumph. ii. 226. $t$. 75.

Wansey. Bruce v. 54. $t$. Limb of the corolla figured and described as entire.

Caryophyllus spurius inoisorus, folio subrotundo scabro, flore racemoso hexap taloide coccineo speciosissino. Slorme cat. 136 ; hist. ii. 20. t. 64. Cales?. ii. t. 91.

C. nucis jiglandis folio, flore purpureo. Plum. a Burm. 95. ८. 105.

Scbestena scabra, flore miniato crispo. Dill. hort. 341. . 255. f. 331 .

Leaves sericeo-hisute, dull, ovali-ovate. C'alyces resembing cloves. Corolla cloven. Style bifid at the end. Obs. 8343. Specimen gathered by Dr. Wriglit in Jamaica.

CORDIA Sebestena. Bryant 247.

Sebesten. Berg. 148.

\section{1\%6. VARRONIA.}

Caly $x$ inferior, quinquefid. Corolla tubular. Stigmala 4. Drupe. Nut quadrilocular and unilocular. Obs. 5582. $L$.

1. VARRONIA alba. Flowers cymose. Leaves cordate. From L. sp. 276.

Mespilus americana, alni vel coryli foliis, fructu mucilaginoso albo. Commel. hart. i. 155. t. S0. No fructific tions.

VARRONIA alba. Jacq. amer. 14; ed. S־о, 53.

2. VARRONIL integerrima. Leaves entire at the margin. From 
Mosogrvia, 177. Chrysopbyllum. 425

VARRONIA sinensis. Lour.i. 171.

\section{CHRYSOPHYLLUM.}

Calyx pentaphyllous. Corolla campanulate, quinquefid. Style none. Sligma with 10 crenae. Berry decemlocular; with many and 1 seed; cells monospermous. Obs. 5580. L.

1. CHRYSOPHYLLUM Cainilo. Leaves ovali-elliptic, silky underneath. Obs. 5580. Specimen gathered by Broughton in Jamaica.-L. sp. 278. Hort. kew. i. 260.

a sphaeroideum. Berry spheroidal. From

CHR YSO PHYLLUM Cainito. Jacq. amer. 51.

t. 37. f. 1; 8\%o, 65 .

B suboiatum. Berry subovate. From

C. Cainito jamaicense. Jacq. amer. 52; $8 v 0,66$.

C. fructu inajori globoso, foliis subtus ferrugineis. Browne 171. t. 14. f. 2. Berry with four and five seeds.

Anona foliis subtus ferrugineis, fructu rotundo majore laevi purpureo, semine nigro partim rugoso partim glabro. Sloane cat. 206, cultivated in Jamaica in fields and gardens;-hist. ii. 170. t. 229.

Leares elliptic, acute, ferruginous underneath, 2 inches long, cracked at the margin so as to appear crenate. Calyx pentaphyllous. Germen multilocular. Obs. 8502. Specimen gathered by Dr. Wright in Jamaica.-Leaves elliptico-oval, rufous underneath, 3 to 4 inches long. Caly $x$ calathiform. Corolla campanulato-infundibuliform, twice as long as the calyx. Germen multilocular. Obs. 5580. 
426 Pentandria. 177. Chrysophyllum.

CIIRISOPIIYLLUM Cainito. Bryant $18 \mathrm{~s}$.

Edwards west ind. i. 200.

y caeruleum. Berry globular. From

CIIRYSOPIIYLLUM Cainito caerulenm. Jacq. amer. 52. . 37* Leaves represented as elliptic, acuminate, veined.

5 monopyrenum. Berry ovate, monospermous. From C. monopy renum. Sicartz. ind. occid. 480 , who has omitted to mention the number of the cells of the germen, and whether there are any abortive sceds.

C. microphyllum. Jacq. amer. 52. t. 37. f. 2. $\Lambda$ branch with leaves.

Leaves elliptic, acute, tomentoso-sericcous and rufous underneath, $1 \frac{x}{2}$ to 3 inches long. Calyy $x$ pentaphyllous; segments roundish, incumbent. Corolla campanulato-infundibuliform; tube as long as the calyx; limb quinquepartite; segments oblongoovate. Germen ovate. Obs. 8500. Specimen gathered by Dr. Wright in Jamaica.

CHR YSO P I YLLUN fructu minori glabro, foliis subtus ferrugineis. Browne 171 .

2. CIRYSOPHYLLUM argenteum. Leaves falcato-ovate, tomentose and shining underneath. Jacq. amer. 53.t. 38, $f$. 1, leaves represented as elliptic, falcate at the end, veinless, and drupe as oval, though described as roundish.- $I$. $K$. i. 261 .

C. Cainito $\beta$ L. sp. 278.

Cainito folio subtus aurco, fructu olivaeformi. Plum. gen. 10; a Burm. 57. t. 69.

CIIR YSO P II YLLUM argenteum. Jacq. amer. Sะo, 67 .

3. CIRYSOPIYLLUM microcarpum. Leaves ovate, pubescent underneath. Berries oblong, oblique, with one secd. From Swartz. ind. occid. 482. 
4. CHRYSOPHYLLUM glubrum. Leaves glabrous.

From L. sp. 278. Jacq. amer. 53. t. 38. f. 2, leaves represented as veinless, elliptic, concave;Sio, 68.

CHR YSOP II YLLUM glabrum. Bryant 189.

\section{SIDEROXYLUM.}

Caly $x$ quinquefid. Corolla rotate, quinquepartite. Nectaria 5, inserted into the corolla. Stigma simple. Berry with from 1 to 5 seeds. From $\boldsymbol{L}$.

1. SIDEROXYLUM lycioides. Spinose. Leaves deciduous, lanceolate. L. sp. 279. Hort. kezo. i. 262.

SIDEROXYLON lycioides. Schocpf 27.

\section{BUMELIA.}

Calyx quinquepartite. Corolla quinquefid; segments with a smaller segment on each side at the base. Nectaria 5, at the base of the stamina on the inside of the tube of the corolla. Drupe with 1 seed. From Swartz. ind. occid. 486. t.8.

1. BUMELIA nigra. Leaves terminal, oblongo-lanceolate, glabrous, undulate at the margin. Branches limber; smaller branches rodlike, bearing flowers. Srartz. ind. occid. 487.

ACHRAS fructibus minoribus glabris per ramos sparsis, seminibus subrotundis, cicatricula minima ovata. Browne 201. 
2. BUMELIA retusa. Leaves cuncato-ovate, retuse, rigid. Peduncles crowded, axillary. Swarti. ind. occid. 490.

ACIIRAS fructu minori glabro, foliis ovatis, floribus confertis alaribus. Browne 201.

3. BUMELIA salicifolia. Peduncles fasciculate, axillary. Leaves lanceolate. Segments of the corolla obtuse. Obs. 8334. Specimen gathered by Dr. Wright in Jamaica. The account of the corolla from Browne's fig.-Swartz. ind. occid. 491. Trunk and fresh branches lactescent. Flowers whitish.

Achras salicifolia. L. sp. 470. Hort. kew. i. 478. Arbor salicis folio lato splendente, floribus parvis pallide luteis pentapetalis e ramulorum lateribus confertim excuntibus. Sloane cat. 170; hist. ii. 98. $t$. 206. $f \cdot 2$.

Leaves, costa above sometimes from about the middle to the base with ferrugineous sericeous liairs. $\boldsymbol{P}$ eduncles sericcous, ferrugineous. Calyces not yet expanded, sericeous, ferrugineous. Obs. 8334.

ACHRAS foliis oblongis nitidis utrinque productis, floribus confertis, fasciculis infra frondes sparsis. Browne 201. t. 17. f. 4. No leaves. No part of the plant lactescent. Berries black.

4. BUMELIA Mastichodendrum. Peduncles fasciculate. Leaves lanceolate. Segments of the corolla acute. Fron

Sideroxylon Mastichodendrum. Jacq. coll. ii. 253, who describes the flowers as wholly yellow, $\delta$.

CORNUS foliis laurinis, fructu majore luteo. $C a$ tesb. ii. 75. t. 75. Peduncles, flowers, and drupes yellow. 


\section{RHAMNUS.}

Caly $x$ campanulate. Petals 5,4 , or none, inserted into the calyx. Berry or Capsule with from 2 to 5 seeds. Obs. 3349. $L$.

In the generality of the species the style is surrounded by an orbicular fleshy nectarium, into the margin of which the stamina are inserted. The calyx of the fruit is entire, the upper half having fallen off.

1. Spinose. Calyx quadrifid, or trifid. Petals and stamina 4.

1. RHAMNUS lycioides. Leaves linear, entire at the margin. Obs. 5611. Specimen gathered by M. Broussonett on Montserrat in Spain.-L. sp. 279. R. III. Clus. hisp. 70, repr. in

R. forte niger Theophrasti. Clus. hist. i. 111,

R. primae speciei tertius. Lob. ic. ii. 129,

R. tertius. Dod. 743, \& Ger. by Johns. 1334, and cop. in Dalech. 141. Bauh. J. i. b. 35, \&

R. niger Theophrasti. Park. theatr. 1007. Raii hist. 1593.

Lycium. Dalech. 151, cop. in

Lycium gallicum avenionense. Park. theatr. 1010, and a branch cop. in

Lycium gallicum. Bauh.J. i. b. 58. f. 1.

Lycium hispanicum. Lob. ic. i. 129, repr. in Gcr. by Johns. 1332, cop. in Dalech. 149, \&

Lycium hispanicum folio oblongo. Park. theatr. 1010, no fructifications.

Leaves spatulato-linear, acute. Calyx of the fruit 
orbicular. Berries dry, bilocular. Arilli, 1 in each cell. Obs. 5611 .

Nalive of Spain.

RIIMNUS niger. Dale 315.

2. RHAMNUS catharticus. teaves ovali-clliptic, serrate. Stem erect. Flowers sometimes dioicous. Obs. 4881. On the limestone of Nottinghamshire and Derbyshire, but less frequently on the intermediate gritstone. In marle near Worcester, but not in the sand of the northern part of the county.-L. suec. n. 202; sp. 279. Woodv. 312. t. 114. Bot. arrang. 239. Fl. dan. t. 850 . Simith brit. 261. Bauh. J. i. b. 55. Raii hist. 1625; syn. 466. Tourn. paris. 355. Vaill. paris. 172. Boerh. ii. 212. Dalech. 146. Garid. 400.

Rhamni alia species. Trag. 979, repr. in

Cervispina. Cord. fol. 175. p. 1.

Spina infectoria. Matth. 158. Cam. epit. 82. Lob. obs. 597, repr. in ic. ii. 181, \&

Spina infectoria prima. Clus. hist. i. 111, (the name and description belong to $R$. infectorius, ) cop. in

R. solutivus, seu Spina infectoria vulgaris, Park. theatr. 243, \& repr. in

R. solutivus. Ger. by Johns. 1337. Dod. 744, repr. in

R. solutivus minor. Ger. by Johns. 133T.

Rhamni solutivi vulgaris exactior icon cum floribus. Parl. Theatr. 243.

Spines not always to be found when the plant is in flower. Caly.x of the flower quadrifid; that of the fruit orbicular, obsoletely quadridentate. Berry slightly spheroidal; rind purplish black; pulp 
green. Seeds 4, ovate, convex on the outer side, with an acute angle on the inner side. Obs. 4881 . RHAMNUS catharticus. Juice of the berries. Pharm. edin.-Chom. 10; suppl. 2. Coste and Willemet, account from in med. comment. v. 298. Cull. ii. 541. Dale 322. Geoffr. suite ii. 211. Lew. disp. by Dunc. 291. Mill. Jos. 373. Murr. iv. 1; J. i. 272; ii. 55. Pearson, R. i. 204. Spina cervina. The berries. Pharm. lond.-Berg. 148. Haslam insan. 139. Krock. n. 356. Lew. ii. 378. Lim. 77. Monro iii. 275. Quarin animad. 172. Rutty 492. Spielm. 610. Vog. 203. Wintringham in Mead mon. i. 204.

Buckthorn. Lew. in Neum. ii. 234.

3. RHAMNUS infectorines. Flowers dioicous. Stems procumbent. From L. mant. 49. Asso n. 198. Hort. kew. i. 263.

R. Lycium. Scop. carn. n. 260.

R. spinis terminalibus, floribus quadrifidis dioicis, corollarum laciniis longitudine tubi. Ger. Lud. prov. 462.

Lycium gallicum. Bauh. J. i. b. 58. f. 2., About Avignon and Carpentras in Provence.-Magn. monsp. 172.

R. catharticus minor. Raii hist. 1626; evrop. 219. Magn. hort. 172. Gouan monsp. 423. Garid. 400. 401.

Lycium italicum. Dalech. 148, cop. in Park. theatr. 1009, \& Bauh. J. i. b. 59.

Spina infectoria pumila I. Clus. i. 111, (The fig. is R. catharticus.)

GRANA avenionensia. Berg. 151.

4. RHAMNUS theesans. Spines terminal. Leaves 
ovate, serrate at the margin. Branches divaricate. L. mant. 207.

RHAANNUS Thea. Osbeck traw. i. 375.

3. Calyx quinquefid. Petals and stamina 5.

5. RHAMNUS Frangula. Stigma 1. Flowers hermaphrodite. Leaves ovali-elliptic; margin entire, rcvolute. Seeds 2. Calyces glabrous. Obs. 4473 . Specimen gathered in a wood at Smethwick ncir Birmingham.-Hort. kew. i. 264. L. suec. n. 203; sp. 280. Bot. arrang. 210. Smith engl. bot. t. 250 ; brit. 262. Venten. tabl. if. 127. t. 22. f. 3. Gouan hort. 112. Near Montpclicr, wherc he says there is a variety with minutely scrratc leavcs.-Scop. carn. n. 263. Host 120. Fl. dan. t. 278. Asso n. 201. Silth. prodr. n. 553.

R. inermis, foliis annuis. .L. lapp. n.92.

Faulbaum. Trag. 981.

Aluus nigra'baccifera. Bauh. J. i. a.500. Raii hist. 1604 ; syn. 465.

Frangula. Cam. epit. 978. Matth. 1271, cop. in Dulech. 200. Toun. paris. 446. Vaill. paris. 56. Bocrh. ii. 231. Dod. 772, repr. in

Alnus nigra, sivc Frangula. Ger. by Johns. 1470, \& cop. in

Alnus nigra. Dalech. 97. Lob. obs. 594, repr. in ic. ii. 175, f. 1.'2, the inncr cop. in

Alnus nigra baccifera, seu Frangula. Park.theatr. 210.

Native of Europe.

FRANGULA. Pharm. suec.-Berg. 150, Dale 318. Krock. n. 350. Lew. i. 440. Linn. 78. Murr. iv. 5. Spiclm. 613. Vog. 294.

R. Frangula. Coste and Willcm. in med. comment. v. 298. 
Alnus nigra. AIill. Jos. 2t. Rutly 16. Alnus nigra baccifera. Chom. 22.

\section{ZIZYPHUS.}

Caly $x$ campanulate. Petals 5 and 4 , inserted into the calyx. Styles 2, or bifid. Drupe. Nut bilocular. Obs. 560s. and from L. a Willd. i. 1102.

Ziziphus. Juss, 380. Boerh. ii. 245.

$$
\text { 1. Aculeate. L. a W. }
$$

1. ZIZYPHUS lineatus. Leaves ovate, obliquely lineate. Aculei solitary, straight. From Lour.L. a Willd. i. 1102.

Rhamnus lineatus. Osb. trav. i. 553.t.7. L. sp. 281 ; mant. 341.

Rhamnus zeylanicus, folio subrotundo glabro, caulibus hirsutis, spinis exiguis ad ramorum et foliorum ortum exasperatus, flosculo spadiceo, bacca nigra. Burm. $J$. zeyl. 198, t. 88. Peduncles la. teral and terminal.

Acaciae forte cognatus e Maderaspatan, Pluk, alm. 4; phyt.t. 122. f. 4 .

RHAMNUS lineatus.' Lour. i. 197.

2. ZIZYPHUS soporifer. Leaves ribless, lanceolate. Aculei solitary, straight. Flowers solitary. From Rhamnus soporifer. Lour. i. 196.

VIDARA littorea. Rumph. ii. 119. t. 37.

3. ZIZYPHUS Jujuba. Style bifid. Aculei mostly solitary, recuryate. Peduncles aggregate. Leaves

$$
\text { F } f
$$


trinervose, subrotundo-oval, tomentose underneath. From L. a Willd. i. 1104,

Rhamnus Jujuba L. sp. 282, and Lour. i. 19ã. Hort. kew. i, 267.

Malum indicum. Rumph. ii. 117. t. 36, leaves represented as acute, but described as obtuse.

Perin-toddali, seı Jujube indica. Rheede iv. 85. $t$. 41. Raii hist. 1535.

Jujuba aculeata, nervosis foliis infra sericcis flavis. Burm. J. zcyl. 131.t. 61 .

Jujuba, sive Z. zejlanica rotundifolia crenata minor, foliis lanuginosis. Pluk. alm, 199 ; phyt.t. 197. f. 2.

Jujube-tree. Roxb. in limn. trans. yii. 48, t. 2. $\mathrm{f}$. 7. 8.

Jujuba indica. Raii hist. 1535.

Mala indica Acostac. Dalech. 1873, cop. in

Ber indịca fructn jujubino. Bauh.J. i. b. 44, \&

Mala indica, lusitanis Ber, et Ber Acostae. Park. theatr. 1636. Peduncles corymbose.

TUJUBA indica. Dale 306.

Rhamnus Jujuba. Bryant 261.

Boa Bidarra. Cook in Hawkesw. iv. 349.

4. ZIZYPHUS vulgaris. Stylcs 2. Prickles 2 togc。 ther, ane of which sometimes recurvate. Flowers aggregate, nẹarly sessile. Leaves oblongo-ovate, serrate; veins hirsutulous underneath. Obs. 5607. Specimen without fructifications gathered in the garden of Fothergill.-Obs. 5608. Specinien without prickles from Prof. Jos. F. Jacquin.-L. a Willd. i. 1105.

Rhamnus Zizyphus. L. a Murr. 235; sp. 282; mant. 342. Hort. kew. i. 267. Goun hort. 113. Near Montpclier.-Lour. i. 196. 
Zizyphus. Boerh. ii. 245. Dod. 795, repr. in Jujube arabum. Lob. obs. 597, \&.

Jujube arabum, sive Ziziphus Dodonaci. Ger. lyy Johns. 1501. \& repr. in

Ziziplra sativa et sylvestris. Bauh. J. i. b. 40, \&

Z. sive Jujuba nuajor. Park. theatr. 251. Raii hist. 1533. Near Tropea in Calabria.

Jujubae. Trag. 1023.

Z. punicea. Dalech. 356.

Lentes obtuse. Prickles 2, at the base of each petiole, distinct. Obs. 5607.-Stamina inserted into the margin of the nectarium. Obs. 5608 .

JUJUBA. Alst. ii. 291. Dale 306. Murr. iv. 7. Jujubae. Pharm. austriaco-prov. 43.-Berg. 151. Cartheus. ii. 188. Geoffr. ii. 307. Herm. 396. Lew. ii. 19; disp. by Rother. 181. Lim. 78. Mill. Jos. 247. Rutty 256. Spielm. 91. Vog. 272.

Rhamnus Zizyphus. Bryant 242.

Jujubes. Robinson in phil. trans, abr. by Jones $\mathrm{v}$. part ii. 143.

5. ZIZYPIUS africana.-Prickles in pairs, straight. Leaves ovate. L.-Mill. Ph. dict. n. 4, who received the seeds from Syria.

Rhamnus Napeca. Forsk. 204.

Rliamnus Spina christi. L. $s p$. 282, from seeds gathered by Hasselquist near Jerusalem.

Rhamnus aculeis geminatis rectis, foliis ovatis.- $\boldsymbol{L}$. cliff. 69, from seeds from the Cape of Good Hope. -Royjen 224, where for foliis rectis read foliis ovatis,

Jujube, sive $\boldsymbol{Z}$. africana, mucronatis foliis, spina gemella. Pluk. alm. 199.t. 197. f. 3. No fruc. tifications. 
Nabca, Paliurus Athenaci credita. Alpin。 aegypt. fol. 7. 8. $t$, cop, in

Nabca folio rhanni vel jujubac, Buuh. J. i. b. 39. $f .1$, cop. in

Napeci, Nabca, aut Oenoplia spinosa. Park. theatr. 1442.

Oenoplia spinosa. Bellus ap. Clus. kist. ii. 319. No fig.-Aculci in pairs.

OENOPLIA. Dale 306.

Rlamnus Nabeca. Forsk. xciii.

Nabbok. Pococte i. 122; ii. part i. 71.

Nebka. Sonnini ii. 195 .

\section{GOUANIA.}

Caly. $x$ supcrior, quinquefid. Petals 5 , inserted into the ealyx. Nectarium quinquangular. Stamina inserted into the margin of the nectarium, alternating with the angles of the nectarium. Style trifid, in the abortive flowers simple. Capsule with 3 cells, separating into 3 parts; cells monospermous. From Juss. 381, Swurts, and Roxb. i. $67 . t .98 .-L$.

1. GOUANIA glabriuscula, Angles of the capsules winged. Leaves ovate, acuminate, obtuscly serrate, nearly glabrous. Obs. 8682. Specimen ga: thered by Dr. Wright in Jamaica.

G. glabra. Jacq. amer. 264. t. [79. f. 40; a leaf and fruit; 8vo 339.

G. domingensis. Swartz. obs. 387. H. K. jii。 439. L. a Murr. 912; a Willd. iv. 999.

Gouana domingensis, L. sp. 1663. 


\section{Monogyna. 183: Ceanothis.}

Rhamnus sarmentosus, foliis ovatis venosis, capsilis trigonis racemosis. Browne 172.n. 4, but spoken of in 173 , as being his third species.

Paullinia. L. ups. 97.

Lupulus sylvestris americana, claviculis donata. Pluk. alm. 229; pkyt.t. 201. f. 4.

Coryli sive avellanae folio oblongo it acuminato frutex convolvulaceus capreolatus americanus. Pluk. alm. 229; phyt. t. 162. f. 3.

GOUANA domingensis. Wright in medi journ. viii. 257.

\section{CEÁNOTHUS.}

Calyx quinquefid. Petals 5, obovate; inserted into the calyx. Berry tricaccous; cells monospermous. Obs. 5616. 5618. L:

1. CEANOTHUS trinercis. Leaves serrate, trinervose. Obs. 5619. Specimen gathered by Dr. Cutler in New England.

C. amcricanus. L. sp. 284. Hort. kew. i. 270. Mill. Ph. dict. n: $1 ;$ ic. $t .86$.

Ceanothis: L. ups. 51: Gron: virg. 32.

Celastrus inermis, folliis ovatis serratis trincrviis, $\mathrm{ra}$ cemis $\mathrm{cx}$ summis alis longissimis̀. Royen 435. Gron. zirg. ed. i. 25.

Euonymus jujubinis foliis, carolinenisis, fructu parpa fere umbellato. Pluk. alm. 139. t. 28. f. 6 . Euonymus novi belgii; corni feminae foliis. Commét. horl. i. 167, t. 86 .

Pelals unguiculáte; laminàe concarie, vaulted. Style trificl. Stigmata erect, pressed to. Obs. 5619.

$$
\text { F } \mathrm{f} 3
$$


CEANOTIIUS. Lim. 78. Marsh. 27. Rushi. 31. Schocpf 27. Vog. 218.

C. americanus. Nonro, Don, sold. ii. 244. dimerican 'Ted. Cull. in amer. acad. i. 417.

\section{SCOPOLIA.}

Calyx quinquefid. Petals 5. Stigma capitate. Copsule baccatc, quinquelocular; cells monospermous. L. a Willd.-Smith.

Toddalia. Juss. 371 .

1. SCOPOLIA aculeata.-Stem aculeate. From $\boldsymbol{L}$. a Willd. i. 1115. Smith ic. herb. ii. n. 34.p. 3. Paullinia asiatica. L. sp. 524; a Murr. 379. Jacq. obs. iii. 11.t. 62. f. 1, a leaf, cop. from

Chamaelca trifolia aculeata, floribus spicatis. Burm. $J$. zeyl. 58. t. 24. Folioles entire at the margin, obovato-elliptic.

Kaka-Torldali malabarica ex oris Coromandel. Pluk. $a l m .202 . t .95 . f .5$. (The name engraved on $t$. 94.)

Frutex baccifer indicus spinosus trifolius, floribus spicatis, fructu plano-rotundo tricocco. Raii hist. 1612, from

KAKA-TODDALI. Rheede ษ. 81. t. 41. Folioles serrate.

\section{CELASTRUS.}

Culy. $x$ quinqueficl. Petals 5. Capsule with 3 cells, 3 and 2 valves, and 3 angles; cells monospermous, dispermous, and polyspermous. Obs. 5614. $L$. 
Monogyia. 157. Euonymus.

1. CELASTRUS edulis. Unarmed. Lenves opposite and alternate, elliptic, serrate. Cymes axillary, dichotonous. Vahl. symb. i. 21.

CATHA edulis. Forst. 63.

\section{NEUHOFIA.}

Caly $x$ quinquedentate; teeth deciduous. Petals 5. Capsule trilocular, trivalve, polyspermous. From Lour.

1. NEUHOFIA rosmarinifolia.

CEDRELA Rosmarinus. Lour. i. 199.

\section{EUONYMUS.}

Caly $x$ with 4 and 5 divisions. Petals 5 and A. Gera men immersed in an orbicular disc. Stamina 5 and 4 , inserted into the disc. Capsule pentacoco cous, and tetracoccous. Seeds arillate. Obs. 3735. $\boldsymbol{L}$.

1. EUONYMUS europacus. Peduncles compressed. Branches smooth. Stigmata subulate. Ols. 3736. Specimens gathered near Worcester.-Hort. kezw. i. 273. L. suec. n. 201; sp. 287. Bot. arrang. 241. Smith engl. t. 362; brit. 262.

Eunnymus. Cam. epit. 102. Dod. 771, repr. in E. Theophrasti. Ger. by Johns. 1468, \& cop. in E. vulgaris. Park. theatr, 241. Raii syn. 468. Scop. carn. n. 267.

E. multis, aliis 'Tetragonia. Bauk. J. i. b. 201. Tetragonia. Daleck. 272. 
Carpinus Theophrasti. Trag. 983.

(E. II. Clus. i. 57, is L. verrucosus.)

EUONYMUS. Dale 321.

'Tetragonia. Geofjir suile iii. 169.

\section{HOVENIA.}

C'alyx quinquepartite. Petals 5. Stigmata 3. Cap. sule trilocular, trivalve; cells monospermous. $L$. a Willd. i. 1141, from

1. HOVENIA dulcis. Thunb. jap. 101. SICKU. Kaempf. amoen. 808. t. 809.

\section{VIOLA.}

Calyx inferior, pentaphyllous. Corolla irregular; petals 5, one with a spur bchind. Antherae with an appendage at the end. Capsule with 1 cell, and 3 valves. Obs. 224. $\boldsymbol{L}$.

\section{With a scapus.}

1. VIOLA odorata. Leaves cordate, and reniformicordate, crenate, pubcsccnt. Shoots creeping. Obs. 223. On banks under hedges, gencrally next the south.-L. suec. n. 784; sp. 1324. Curt. lond. i. 63; mat. med. t. 13. Walc. t. F7. dan. t. 309. Woodv. ii. 225. t. 81. Bot. arrang. 954. Asso 12.881.

* riolacea. Corolla purplish bluc. Obs. 223. V. martia purpurea, flore simplici odoro. Boerh.i. 243. Magn. monsp. 278. In flowcr almost all the year,-Does it at Montpelier produce the forrers 


\section{Morogria. 189. Viola.}

with small petals which in England are alone succeeded by fruit :-Tourn. paris. 170. Vaill. paris. 203.

V. nigra, sive purpurea. Ger. by Johns. 850. Dod. 156, repr. in

V. flore albo. Ger. by Jokns. 850.

V. martia simplex. Park. parad. 282. t. 285. f. 1 , but the peduncles represented as growing on a stem.-Renealm. t. 140.

V. martia praecox, purpurea et alba, hortensis et campestris, odora, simplici flore. Lob. ic. i. 608, repr. in

V. nigra sive purpurea. Ger. by Johns. 850.

V. martia. T'rag. 558. Leaves too acute.

V. purpurea. Fuchs. 311, cop. in ed. 12 mo 308. c. $118, \&$

V. martia purpurea. Banh. J. iii. b. 542.

VIOLA. Violet. The fresh petals. Pharm. lond. -Alst. ii. 245. Berg. 705. Chom. 73. Dale 239. Geoffr. suile iii. 314. Herm. 585. Hill 440. Lew. ii. 452; disp. by IJunc. 392. Linn. 231. Murr. i. 517. Ploucq. bibl. i. 195. Rutty 543. Spielm. 349. Vog. 151.

叉. odorata. Coste \&. Willemet in med. comment. $\mathrm{v}$. 298. Murr. J. ii. 57.

V. martia. Mill. Jos. 452.

Violaria. Herm. 548. Linn. 231. Murr. i. 517. Vog. 89.

Violets. Fordyce G. fev. ii. 54 . Violicr. Chom. 706; suppl. 193.

2. With a stem. L.

2. VIOLA pulescens. Leaves cordate, acute, pubes= cent. Stipulae oblong, serrulate at the end. Stem 
crect, villose, terete, flattish on one side. From Hort. kcz. iii. 290.

VIOLA caule ereeto, foliis cordatis acuminatis. Cull. in amer. acad. i. 485.

3. With a stem. Stipulae cul or pinnaliful. Stigma urccolale.

3. VIOLA tricolor. Lower leaves roundish oval and oblong, the upper elliptic and lanceolate. Root fibrous. $O b$ s. 6322. On the side of the road between Fairfield and Tideswell in Derbyshire, on limestone, and more luxuriantly in an adjoiniug field of grass apparently newly laid down, and in similar fields between Norton and Sheffield on gritstone.-L. suec. n. 791, root annual;-p. 1326. Curt. lond. i. 65. t. Mill. Ph. dict. n. 9. An annual plant, whose roots decay after it has flowered and perfeeted its seeds.-Bot. arrang. 957. Hort. kew. iii. 291. Smith brit. 24S. Renealm. t. I40. Woodv. iv. 104. t. 252.

VIOLA tricolor. Berg. 708. Dale 239. Mill. Jos.453. Ploucq. bibl. i. 14. 297. 437. Strack, account from in med. journ. ii. 187.

Jacea. Lew. by Dunc. 349. Schlegel, account from in phys. journ. xiv. 431. Schrod. 605.

a caerulea. Corolla longer than the calyx, purplish blue, the lowermost petal yellow at the base. Obs. 2153. In sand near Kidderminster Worcestershire.

V. tricolor. IIuds. 380 \& Bot. arrang. 957 . Raii cat. ed. i. 317 ; ed. ii. 305 . In the mountainous parts of the north of England, as in Derbyshire and Yorkshire.- R. syn. 365, among corn, 
on mounds and ditch banks. An annual. $-F$ \% dan. t. 623. Smith engl. t. 1287.

V. tricolor with a pale blue flower. Lightf. 510 .

$V$. bicolor arvensis, flore cacrulco et luteo. Vaill. paris. 203.

Jacea bicolor, frugum et hortorum vitium Trago, flore caerulco et luteo. Banh. J. iii. 548. No fig.

Jaccea, sire Flos trinitatis. Camr. epil. 912.

Herba trinitatis sylvestris floribus caeruleis et luteis.

Trag. 563. No fig.

Root perennial, attenuate, with numerous fibres from the base and sides. Slems from the end of the root, hirsutulous, 3 to 5 inches long. Leaves obtusely serrate, hirsutulous, Stipulae pinnatifid; lateral segments linear, entire at the margin; the terminating one lanceolato-oblong, obsoletely and rarely crenate. Calyx hirsutulous, bluish at the base. Corolla 3 lowermost petals with purplish black lines. Obs. 6322.

\& trimaculata. Corolla longer than the calyx. Two uppermost petals" purple; lateral petals pale yellow, purple at the end; lowermost petal deep yellow and brownish purple at the end. Obs. 2856 . In a garden.

V. tricolor. L. B. Dod. 158, repr. in Ger. by Johns. 85t, \& cop. in

V. sylvestris tricolor. Park. theatr. 756.

V. tricolor major et vulgaris. Park. iheatr. 756.

V. tricolor with large flowers. Mill. Ph. dict.n. 9.

V. flammea sive tricolor. Park. par. 282. $t .285$. f. 3. The root perisheth every year.

V. tricolor, hortensis, repens. Vaill. paris. 204. In the sands between the farm and chateau of Rochefort. 
Herba trinitatis, Fuchs. 763. cd. 12mo, c. 310, in corn ficlds; cop. in

Jacea tricolor, sive trinitatis Flos. Bauh, J. iii. 546 , and abr. in

Herba trinitatis. Trag. 564. Calyx too long in proportion to the corolla. He says that the cultivated kind is sometimes preserved during the winter.

Peduncles triquetrous, inner angle canaliculate. Obs. 2856.

\section{Flowers erect. From L.}

4. VIOLA parviflora. Leaves ovate, serrate, petio. late, glabrous. Flowers erect, solitary, axillary. Stems diffuse, wcak, leafy. From $L$. fil. suppl. 396.

5. VIOLA Calceolaria. Stem simple, hirsute, herbaccous. Leaves lanccolate, pilose. Flowers solitary. L. $s p .1327$.

VIOLA Calceolaria. Decandolle, account from in edinb. journ. i. 103.

6. VIOLA Ipecacuanha. Leaves oval, pilose at the margin and underneath. The larger petal gibbous at the base, without a spur. From L. a Murr. 804; mant. 4S4, and Vandelli ap. L. fl. suppl. 397.

Ipecacuanha blanca. Pis. ind. 231; bras. 101. No fig.

IPECACUANHA alba. Berg. 7110. Geoffr. ii. 91. Limn. 239. Spielm. 616. Ipccacoanla alba. Cartheus. ii. 402. 
Monogria. 190. Impatiens.

V. Ipecacuanha. Decandolle, account from in edinb. journ. i. 103.

White Ipecacuanha. Douglass in phil. trans. abr. by Reid and Gray vi. part ii. 219; by IIult. vii. 357 ; and in Mihles ess. ii. 207.

White Ipecacoanha.' Neum. ii. 118,

Ipecacuanla blanc. Pomet i. 47.

\section{IMPATIENS.}

Caly $x$ diphyllous. Corolla irregular, petals 5 and 3, some with a spur. Capszile superior, with 5 valyes. Obs. 5896 . $L$.

\section{Peduncles with 1 flower. L.}

1. IMPATIENS Balsamina. Peduncles aggregate. Leaves lanceolate, the upper alternate. Lowermost petal shorter. L. sp. 1329. Hort. kew. iii. 292. Tilo-onapu, seu Notenga. Rheede ix. 101. t. 52. Balsamina foemina persicifolia, vel salicis folio. Bauh. J. ii. 909. No fig.

Iysimachia laevis. Bauk. J. ii. 907, (The name and description belong to another plant.) cop. from

Balsamina foemina. Fuchs. 189, c. 69. Park. parad. t. 279. f. 8. Besl. hort. aut. ord. 1. fol. A. t. f. 1. Ger. by Johns. 362. repr. from

Balsamina. Dod. 660.

LACCA herba. Rumph. v. 256. t. 90.

2. Peduncles with several flowers. L.

2. IMPATIENS Nolitangere. Peduncles solitary: 
Leaves ovate. Joints of the stem swoln. I. suec. 2.792 ; sp. 1329. Bot. arrang. 962. Fl. dan. t. 582. Smith brit. 244. Huds. 380. Near Rydall hall and elsewhere in Westnorland.Host 482.

Balsamina noli tangere. Scop. carn. n. 1101.

Impatiens. Riv. tetrap. $t .244$.

Balsamita altera, Noli me tangere. Col. ecphr. i. $t$. 150.

Balsamine lutea, sive Noli me tangere. Vaill. paris. 20. Boerh. i. 320. In Holland.-Dill. ap. Raii syn. 316. Found by Richardson near Bingley Yorkshire, and by Llwyd in Wales.

Persicaria siliquosa. Raii hist. 1328. On the banks of Winander mere near Ambleside, and on the sides of mountains near the Rhine;-syn. ed. ii. 282. Found by Lawson in Satherthwaite parislı Lan. cashire, and in many places in Westmorland.Ger. by Johns. 446, repr. from

Impatiens herba. Dod. 618, which cop. in

Mercurialis sylvestris, Noli nre tangere dicta, sive Persicaria siliquosa. Parli, thealr. 296.

Persicaria siliquosa, sive Noli me tangere. Lob. adv. 135, repr. in ic. i. 318, \& cop. in

Persicaria siliquata. Dalech. 1205.

Noli me tangere. Bauh. J. ii. 908.

Chrysaea. I)alech. 876.

Esula sylvestris. Trag. 295.

Corolla yellow, nearly an inch long. Obs. 5900.

In a garden.

IMPATIENS. Vog. 130.

I. Noli tangere. Cutl.485. Schoepf 129.

Noli me tangere. Geoffr. suite i. 195.

Persicaria siliquosa. Dale 268. 
Monogynia. 193. Mangifera.

191. VALKERA.-

Caly.x inferior, quinquepartite. Petals 5. Drupes 5, monospermous. Nuts reniform. L. a Willd. Walkera. L. a Schreb. n. 378.

1. VALKERA serrata.

Walkera serrata. L. a Willd. i. 1145.

Frutex baccifer malabaricus, fructu calyculato tea tracocco umbellato. Raii hist. 1572, from TSJOCATTI. Rheede v. 95. t. 48.

\section{ELAEODENDRUM.}

Calyx pentaphyllous. Petals 5. Drupe ovate. Nut bilocular. From $L$. a Willd. and $L$. a Schreb.

1. ELAEODENDRUM Argan. Branches spinose. Leaves ovate, obtuse. Retz. obs. vi. n. 29. Rhamnus pentaphyllus. L. a Murr. 233. Jacq. obs. ii. 17.

Rhamnus siculus. L. nat. iii. 229, where for quinatis read quinis.

Rhamnus siculus pentaphyllos. Boccon. sic. 43. $t$. 21. Raii hist. 1626.

ELAEODENDRUM Argan, Ret 。 ib.

\section{MANGIFERA.}

Calyx pentaphyllous. Petals 5. Stamina, 3 and 
4 of them barren. Drupe. Nut with loose fibres. Fram L. \& Vahl.

1. MANGIFERA indica. Leaves petiolate, lanceo. late. Panicles erect. Petals patulous at the end. Drupe somewhat reniform. From Vahl. cnum. i. 7. L. fil. suppl. 157. L. a Murr. 242; sp. 290. Brought. 477. Jacq. coll. iv. 96; ic. ii. t. 337. Mao, seu Mau, seu Manghas. Rheede iv. i. t. 1. 2.

Manga domestica. Rumph. i. 93.t.25.26.

Mangas, sive Amba. Bauh. J. i. a. 173.

Mangas Park. theatr. 1631.

Manga indica fructu magno reniformi. Raii hist. 1550.

MANGA. Dale 310.

M. indica. Bryant 254. Lour. i. 198.

Mango. Percival, Rob. ceyl. 312.

Manghas tree. Percival, Rob. ceyl. 331.

B excelsa. MANGA Pau. Rumph. i. 96.t. 26.

\% sylvestris. MANGA silvestris. Rumph. i. 97. t. 27. Drupe oyal.

2. MANGIFERA foetida. Leaves petiolate, lanceo. late. Petals reflex. From Vahl. enum. i. 7, \& MANGA foetida. Rumph. i. 98. t.28, who says "s stamina quorum unum altero longius," not reliquis longius as cited by Vahl. In the fig. they are equal. Drupe globular.

\section{RIBES.}

Petals 5, inserted into the calyx. Stamina inserted 
into the calyx. Style bifid. Berry inferior, with several sceds. $L$.

\section{Without prickiles. L.}

7. RIBES rubrum. Racemi of the flowers and fruit penduluus. Bracteale shorter than the pedicles. Petals cuneiform. Cillyces grlabrous. Obs. 2107. In a garden.-In a lane between Brewood Staffordshire and the mill which is half way between Brewood and the road leading to Wolverhampton. In Hurcott wood near Kidderminster but from an old pavillion being at no great distince I suspect it to have been originally planted there. But the white variety not having been foumd wild, I am inclined to believe the red to be a native and not in naturalised plant.-L. suec. n. 205; sp. 290.

a rulilum. Berries red. H. K. i. 279 .

R. rubrum. Lightf. 146. In the Isle of Isla amang. the brush wood on the banks of the sound. $-B o t$. arrang. 242. Walc. $t$. In hedges.-Roth germ. i. 107. In hedges throughout Germany. - Fl. dan. t. 967. Snith brit. 263; engl, t. 1289. Woodv. ii. 20\%. t. T任.

R. acidus ruber. L. lapp. n, 98 .

Grossularia, multiplici acino, sive non spinosa, hortensis, rubra, sive.R. officinarum. Vaill.paris. 95.

Grossularia rubra. Dalech. 132.

Ribes. Fuchs. 663, cop. in 635, ed. 12mo, \& Trag. 995.

R. vulgaris acidus ruber. Banh, J. ii. 97. In gardens.

R. frnctu rubrn. Parl. parad.t.559. f. 2.

R. fructu rubro majore. Park. theatr. 1562.

G $\mathrm{g}$ 
Ribesimn fructu rubro. Dod. 737, repr. in R. arabum. Lob.obs. 615, repr. in ic. ii. 202,

R. vulgaris fructu rubro. Ger. by Johns. 1593, \& R. vulgaris fructu dulci, Clus. list. i. 120. Bobert ap. Raii syn. ed. i. 236. Woods at Stanton in Leicestershire; ed. iii. 456. Found by Richardson near Settle Yorkshire.

R. fructu parvo. Dill. ap. Raii syn. 456. Found by Merret at Wimbleton and in Lancashire, and by James Sherard in Wimbleton Park.

RIBES rubrum. Red Currant. The fruit. Pharm. lond.-Bryani 166. Lew. disp. by Dunc. 295. Pearson, R. i. 68. Schoepf 28. Spielm. 78.

Ribesia rubra. Berg. 152. Krock. n. 354. Linn. 79. Murr. iii. 304.

Ribesium rubrum. Pharm. austriaco-prov. 61.

R. rubra. Monro iii. 236.

Ribesium. Herm. 511.

Ribesia. Cull. i. 253. Meberd. 3. 328. Leż. i. 443. Quarin animad. 198. Stoll med. iii. 129. 130. 287.

Ribes. Dale 293. Mill. Jos. 374. Quarin febr. 103. Stoll med. ii. 141.

Grossularia R. dicta. Geoffr. iii. 535.

Grossularia non spinosa. Cartheus. i. 435.

Grossularia multiplici acino, sive non spinosa, hortensis rubra, sive R. officinarum. Boecl. ap. I1 erm. 511. Chom. 818. Rutty 431.

Grossularia multiplici-acino, non spinosa hortensis rubra. Vog. 262.

Red Currants. Lew. in Neum. ii. 234.

Currants. Currie, $W$ account from in mcd. res. vi. 6t. Fordyce $W$. fev. 135. 143. 159. 167. 189. 220. Monro, Don. sold. ii. 185.

IR. vulgaire acide rouge. Tourn. i. 219. 
Grossularia hortensis, majore fructu rubro. Boecl. ap. Herm. 511.

$\beta$ rubescens. Berries pale red. In gardens.

y album. Berries white. $I$. K. i. $279 \beta$

R. inerme, floribus planiusculis, racemis pendulis. L. ups. 50.

R. vulgaris acidus, albas baccas ferens. Bauh. $J$. ii. 98. No fig. In the Stutgard garden.

R. fructu albo. Park, theatr. 1561. ('The fig. is $R$. nigrum.)

R. fructu nigro. Park, theatr. 1561. (The description is R. nigrum.)

R. alba. Park. parad. 55̃s. No fig. RIBESId alba. Rutty 431.

Ribes rubrum, varietas alba. Spielm. 78.

Grossularia hortensis, fructu margaritis simili. Boecl. ap. H $\mathrm{crm} .511$. Geoffr. iii. 536.

Grossularia hortensis, majore fructu albo. Boecl. ap. Herm. 511.

2. RIBES alpinum. Racemi of the flowers erect. Bracteae longer than the pedicles. Obs. 8071. In a hedge between Deerleap and Littlemore near Ashover Derbyshire, on gritstone, and in the hedge of a garden in a similar situation. $-L$. suec. n. 206; sp. 291. Lightf. 146. Fl. dan. t. 968. Jacq. austr. i. $t .47$, inner fig. a male plant; outer figures female planis.-Retzo obs. ii. 11, n. 17. $\alpha$ is probably a male plant; and $\beta$ a female plant. - Bot. arrang. 242. Roth germ. ii. 276, who describes the male and female flowers, and says that the female plants seldom produce ripe berries when a male plant is not near them.-Smith brit. 264; engl. t. 704. Gunn. n. 395. t.2. f. 1. 2. Fertile plants.

$$
\text { G g } 2
$$


R. aipinus dulcis. L. lapp. n. 97. Bauh. J. ii. 9S. Raii sym. 456. Found by Dodsworth in Yorkshire, and by Richardson in hedges near Bradford in Yorkshire.

R. minor, fruetu rabro. Besl. hort. wern. fol. 14. $t$.

Leaves above hirsutulous and dull, shining and nearly glabrous underneath, cordate, trilobate; segrments inciso-serrate. I'eduncle, pedicles and bracleae with glandular hairs. Calyx, segrments oval. Petals cuneiformi-rhombic, thrice as small as the semments of the calyx. Antherae rourdish, whitish, sessile, apparently without pollen, but all the flowers had been some time expanded. Receptacle green, flat, with globules of liquid on the surface. Style somewhat shorter than the calyx. Stigmata 2 , very short. Ous. 8071... Seeds 3, connected by threads to the rind of the berry. Qus, 5922. In Mr. Wilkinson's garden with no others growing near it. $-R a$. ceni of the fruit somewlat pendulous. Berries yellowish red, sweetish, but not at all grateful. Obs. 6458. 6459. Plants some in fruit, others with dead peduucles, in the garden of Mr. Sncyd who gathered them in the neighbourhood of Belmount Staffordshire, and who considered the fruitful plants as female and the barren ones as male.

RIBES alpinum. Lim. amoen. vi. 347.

3. RIBES nigrum. Raremi pilose. Flowers ublong, L. succ. u. 207; sp. 291. Fl. din.t. 556. Walc. t. Bot. arrang. 243. Smith brit. 265; engl. to 1291. Woodv. ii. 209. t. 75.

R. vulgaris, fructu nigro. L. lapp. $\varkappa_{0} 99$.

Grosșularia niggra. Dalech. 133.

Ribesium fruclu nigro. Dod. 737, repr. in 
R. nigra. Lob. ic. ii. 202, \&

R. fructu albo. Ger. by Johns. 1593, (the description is of R. rubrum $\beta$ ) and cop. in Park. theatr. 1562, (the description is of $R$. rubrum $\beta$ ) \&

R. nigrum vulgo dictum; folio olente. Bauh. $J$. ii. 99. Ruii syn. 456.

R. fructu nigro. Park. theali. 1562. (The fig. is R. rubrum $\beta$ )

RIBES nigrum. Blảck Currant: The fruit. Pharm. lond.-Berg. 154. Bryant 167. Cull. i. 253. Hill 512. Lew. disp. by Dunc. 295. Pearson, R. i. 68. Rutty 431. Schbepf 28. Spielm. 78. Vog. 136.

R. nigra. Dale 293. Monro iii. 236.

Ribesia nigra: Krock. n. 356. Linn. 79. Mitrr. iii. $30 \pi$.

Ribesium nigrum. Pliarm. austriaco-prov. 60.

Grossularia oleris, R. nigrum dicta: Geoffr: iii: 539. Grossularia non spinosa, fructu nigro. Vog. 262. Grossularia non spinosa, fructu nigro majore. Boecl. ap. Herm. 511.

Black Currants. Baker, H. in phil.: trans. äur. from in Mihles css. ii. 100. Cutl. in amer. acad. i; 421 .

2. Aculeate.

4. RIBES oxyucanthoides: Branches covered with aculci. L. sp. 291. Hort. kew. i. 281.

R. ramis undique aculeatis. L. ups. 51 . RIBES oxycanthoides. MIarsh. 132.

5. RIBES Grossularia. Prickles axillary. Flowers in pairs and solitary. Obs. 5915. 5916. In gardens.

$$
\text { G } 93
$$


Crossularia Uva. Scop.carn. n. 270.

Grossularia simplici acino, vel spinosa sylvestris. Tourn. paris. 464. In the woods of Saint Germain and Montmorency.-Vaill. paris. 95.

Grossularia alba. Dalech. 131.

Uva crispa. Fuchs. 186. c. 68. In thickets and liedges in Suabia.-Dod. 736, repr. in

Uva crispa. Ger. by Johns. 1324, \& cop. in

Uva crispa, sive Grossularia sylvestris. Park. theatr. 1560 .

Grossularia rubra et cacrulca. Park, theatr. 1560. Prickles triple, double, and single. Obs. 5915. Native of Germany, Switzerland, France, and the north of Italy.

GROSSULARIA. Berg. 157. Dale 293. Mill. Jos. 220. Rutty 224.

Uvae crispae. Spielm. 104.

Grossularia Uva crispa dicta. Geoffr. iii. 533.

Gooscberries. Dieudonne, account from in chir. rev. xi. part ii. 13. Fordyce TF. fev. 159. 167. 189. 206.

Grossularia simplici acino, vel spinosa. Chom. 818. a hirsuta. Berries lairy, Obs. 5915.

R. Grossularia. L.-Walc. $t$. In hedges-Bot. arrang. 243. On old buildings and church towers.

R. Uva crispa. Fl. dan. $t .546$. In hedges.-Smith engl. $t .1292$.

Grossularia aculcata. Parli. parad. t. 559. f. 5.

Grecne prickly Gooscberry. Park. parad. 561. The secd hereof hath produced bushes bearing berries, having few or no prickles upon them.

Ura crispa, sive Grossularia. Bauh. J. i. b. 47. RIBES Grossularia. Bryant 167. Krock. n. 358. Pearson, R. i. 6 . 
\& glabra. Berries glabrous. Obs. 5916. In a garden.

R. Uva crispa. L.-Relh. 9S. Woods and hedges. Sibth. ox. 84, who justly marks it as not indigea nous.

Grossularia vulgaris. Park. parad. t. 559. f. 3.

Grossularia fructu rubro. Park. parad. $t$. 559. $f$. 4.

RIBES Uva crispa. Krock.n. 357. Limn amoen. vi. 347.

\section{DARTUS.}

Calyx inferior, quinquefid. Corolla campanulate; tube globular. Berry unilocular, polyspermous, diaphanous. From Lour.

1. DARTUS Perlarins. Lour. i. 152.

\section{LEA.}

Corolla monopetalous. Nectarium monophyllous, inserted into the tube of the corolla, quinquefid, erect. Berry with 5 seeds, inferior. L. a Willd. i. $1177 . L$.

1. LEA bipinnata.-Stem sulcato-angular, glabrous. Leaves mostly bipinnate. Willd.

Leea sambucifolia. Salisb. R. allert. 144, repeated at 317.

Leca sambucina. L. a Willd. i. 1177.

Aquilicia sambucina. L. mant. 211.

Staphylea indica. Burm. N. ind. 75. t. 24. f. 2.

o g 4 
FRUTEX AGNOSUS femina. Rumph.iv. 103. t. 45 .

\section{9\%. ARGYREIA.}

Caly.x pentaphyllous. Corolla quinquepartite, plicate. Berry quadrilocular, monospermous and dispermous. From Lour.

1. ARGYREIA obtusifolia. Panicles mostly terminal. Irom Lour. i. 166.

2. ARGYREIA arborca. Racemi terminal. From Lour. i. 167.

\section{HEDERA.}

Calyx quinquedentate. Petals 5. Germen semi-inferior. Pomum with from 3 to 5 cells. Obs. 4176. L.

1. HEDERA diversifolia. Umbels erect. Obs. 4176. On trunks of trees, and against old walls.

II. Helix. L. suec. n. 209; sp. 292. Curt. lond. i. 16. t. Bot. arrang. 215. Dalech. 1419. Smith brit. 207 ; engl.t. 1267. Fl. den. t. 1027. Krock. n. 359. Dod. 408, repr. in Ger. by Johns. 858, \& cop. in Park. thealr. 679. Inchs. 414. c. 161, cop. in

H. communis minor. Bauh.J.ii. 111.

II. communis major et minor. Raii syn. 459.

H. foliis lobatis et ovatis. L. lapp.n.91.

II. arborca. Vaill. paris. 96. Dalech. 1418. 
Hedera. Brunsf. ii. 7. Trag. 801. Dod. 408, repr. in.

H. corymbosa. Ger. by Johns. 858.

H. nigra. Fuchs. 414. c. 161, cop. in

H. communis major. Bauh. J. ii. 111.

II. Dionysias. Dalech. 1419, cop. in

II. Dionysias, sive chrysocarpos. Park. theatr. 679.

Maur Epphew. Brunsf. ii. 6.

$P$ eduncles, pedicles, petioles, and caly.x tomentose; tomentum stellate. Obs. 4176.

HEIJERA. Chom. 76. Lew. i. 483. Vog. 322.

H. arborea. Pharm. austriaco-prov. 41.-Berg. 159. Cartheus. iii. 354. Chom. 655 ; suppl. 183. Dale 295. Gcoffr. ii. 535. Lew. disp. by Rother. 168. Linn. 80. Mill. Jos. 223. Mrurr. i. 307. Neum. ii. 46. Ploucq. bibl. i. 130. 139. Rutty 232. Spielm. 379. Vog. 103. 271.

\section{VITIS.}

Calyx quinquedentate. Petals 5. Germen superior, with 5 and 2 cells. Neciarium quinquedentate. Berry of 1 cell, with from 1 to 5 seeds. Obs. 6058. $L$.

1. VITIS indica. Leaves cordate, dentate, villose underneath. Cirrhi bearing racemi. L. sp. 293. Lour. i. 192.

Cevalchichiltic. IICrn. 128. No fig.

SCHEMBRA-VALLI. Rhe de vii. 11. t. 6.

Leares crenato-repandose.-Raii dendr. 67. 
2. VI'TIS Labrusca. Leaves cordate, dentate, angular, toinentose underneath. Obs. 2581: Specimen gathered by Broughton in Jamaica.-L. sp. 293. Ilort. licw. i. 282. Lour. i. 193.

V. indica. Sreartw. obs. 95.

V. silvestris, sarmentis late repentibus, uvis minoribus nigris. Browne 178.

V. foliis cordatis subtrilobis deutatis subtus tomento. sis. Gron. virg. 34.

V. foliis palınato-angulatis. Gron. virg. ed. i. 144. V. hederae folio serrato. Plum. a Burm. t. 259. $f$. I. Leaves angular.

V. vinifera sylvestris americana, foliis aversa parte densa lanugine tectis. Pluk, phyt. t. 249. f. 1. Leaves angular and trilobate.

Labrusca molucca. Rumph. v. 452. $t$. 167. Leaves lobate, angular, and dentate.

Leaves cordate, acuminate, dentate, angular, angles from 1 to 3, lanuginose above, tomentose underneath; teeth acute; tomentum ferrugineous. Cirrhi opposite to the leaves, dichotomous and simple. Racemi compound, just expanding. Obs. 2581.-Leares cordate, dentate, lanuginose above, tomentose underneath; tomentum whitish brown. Racemi compound, similar to those of $V$. vinifera, opposite to the leaves. Foung shoots ferrugineous. Obs. 86SI. Specimen gathered by Dr. Wright in Janaica.

VITIS fructu minore rubro acerbo, folio subrotundo minus laciniato subtus alba lanugine tecto. Sloane cat. 171; hist. ii. 104. t. 210. f. 4. Leaves angular, and dentate. No fructifications.

3. VITIS vinifera. Leaves cordate, lobate, and sinuate, crenate. Obs. 2580. In a garden.-Schmid. i. 32. t. 7. Dod. 410, repr. in Lob. ic. i. 699, 
and Ger. by Jolns. Si5, and cop. in Park. theatr. 1556. Bank. J. ii. 67. Dalech. 1402. Fuchs. S7. c. 29. Trag. 1056.

Vitis. Toum inst. $t$. 465, fruit; $t .466$, a branch and leaf.

$V$, vinifera, ex cujus uvis acerbis immaturis omplacium exprimitur. Boerh. ii. 232.

V. acinis albis dulcissimis, \&c. Garid. 492 to 517. VITIS. Pharm. lond.-Alst. ii. 306. Berg. 160. Dale 320. Geoffr. suite iii. 351. Linn. 80. Nilll. Jos. 456. Schoepf 28.

V. vinifera. Pharm. edin.-Bryant 216. Lew. disp. by Dunc. 392. Pearson, R. i. 69.

UVAE IMMATURAE. Ploucq. bibl. i. 525.

Urae recentes immaturae. Spielm. 98.

AGRESTA. Linn. 80. Mill. Jos. 458. Murr, i. 3I0. Spielm. 98.

UVAE. Quarin febr. 373.

Uvae recentes. Murr. i. 310. Spielm. 99.

Grapes. Clegh. 195. Currie, $W$. account from in med. rev. vi. 64. Fordyce G. fev. ii. 36; iii. 19t; W. fev. 135. 159. 167. 206. Nonro, Don. sold. i. 318; ii. 185. Rush v. 119.

PASSULAE MAJORES. Pharm. austriaco. prov. 55. suec.-Cull. i. 254. Herm. 400. Hill 481. Linn. 80, the name by an error of the press omitted. Spielm.98. Vog. 259.

Passulae, sive Uvae passae majores. Murr. i. 312. Passulae, Uvae passae, et Passulae majores. Alst. ii. 306.

Uvac passae majores. Lew. ii. 478. Mill. Jos. 457. Rutty 556.

Uvae passae, seu Passulae majores. Cartheus. ii. 187.

Uvae passac minores, seu vulgares. Geoffr. ii. 316. 
Tva paśsa major. Jalc 320.

Uva passa. Raisin. P'harm. lond. edin.-IIeberd. 325.

Raisins. Blane 302. Darw. ii. 274. Fordyce, $G$. fer. ii. 36.

UVAE PASSAE MAXIMAE, seu Passulae damascenae. Creoffr. ii. 316.

Passulite damascenac. Dale 320.

MUSTUM. Spiclm. 99.

VINACEA. Quarin anim. 284. Spielm. 99.

VINUM. Wine. Pharm. lond.-Bell, B. surg. i. 72. Boerh. aph. 11. 1402. Callisen in act. hanm. i. 74. 362. Cels. l. 4. c. 24. Colden in med. obs. i. 225. Cull. ii. 315. 432. Dale 320. Fordyce, G. pract. 169. 210; W. fragm. 44. 56. Heberd. 2. 8. 9. 48. 153.- 204. 214. 230. 233. 327. 357. 394. Hoffm. v. 342. 355. 341; vi. 469. Lew. ii. 450. Lim. 80. Mead mon. ii. 90. Murr. i. 314. Pearson, R. i. 104; ii. 202. Quarin febr. 80. 85. 146. 158. 183. 204. 346. 372. 431; animad. 101. 146. 296. Rutly 537. Sundiford in med. obs. iv. 317. Spielm. 100. Stoll med. ii. 202. 206; iii. 109. 272; aph. n. 501. 808. Trimman ap. Smellic thes. iii. 269. Willis. diatr. 238. Trintringh. in Mead mon. i. 220. 219.

Winc. Aillicn midi". 113. 12\%. 131. 134. 152. 206. Baylies in med. prop. 46. Bims in phys. journ. xv. 494. Bisset ess. 75. Jilane 122. 321. 324. 410. 495. Blizard, account from in med. rev. i. 330. Brce 294. Brozn, J. i. 9S. 150. 180. 198. 216; ii. 224. 230. 233. 265. 273. 274. 277. 306. 319. 347. 319. 350. 357 ; T. account from in chir. ros. x. 281. Chalm. i. 67. 81. 114.203; ii. 14. Chisholm 157. 171. 176. 17s. 193. Clart, 
Japies account from in ann. med. ii. 180, and chir. rev. iv. 2s9; J. long roy. 176. 187. 203; fev. 25. Clarkson in philat. coll. i. 69; and account from in med. conment dec. II. ix. 139. Clegh. 196. 219. Crateford, J. in Trotter ii. 93. Currie, $I F$. account from in med. comment. dec. II. x. 147, and med. rev. vi.64. Cull. pract. n. 219. 227. 576. 580. 623.62.t. Darw. ii. 65.66. 70. 74. 78. 99. 102. 111. 125. 132. 133. 160. 216. 217. 218. 222. 223. 226. 245. 248. 251. 274. 302. 304. 311. 336. 363. 485.487. 489. 524.678. 706. 716. 754. Denm. ii. 397. 471. Dewar, account from in chir. res. ix. 178. Dickinson 176. Ferguson, account from in med. rev. vii. 136. Fordyce, G. pract. 153. 297. 314; fev. iii. 251; iv. 44 ; vi. 33.40; W. fev. 160.168. 172. 220. Fothergill, $J$. in med. obs. vi. 130. Ilalls in med. comment. dec. II. x. 331. IIamilton, Rob. of Lym, account from in chir. rev. ix. 554; and med. rev. vii. 471. Hammick in contrib. 381. Home, F. clin. 89. Hosack, republ. in ann. med. iv. 389; \& phys. journ. iii. 569: Hoven, account from in med. rev. ii. 363. Hull phlegm. 221; caesar. 347. 349. Hunter jam. 112. 1<0. Jackson, Rob. account from in chir. rev. x. 437; fec. 261.290. 310. 330 ; jam. 236. 240. 278. 385. Kentish, E. account from in med. rev. v. 231. Kirliland apopl. 89. Kok, account from in med. rec. i. 569. Lempr. ii. 127. 160. 161. 162. 174. 179. 180. 190. 191. 192. 228. Lind hot. clim. 313 ; seam. 33. 147.261.275. 277. Longmore in ann. med. iii. 368. Macgregor ib. 313; and account from in chir. rev. xi. 50. Maclean 117. May 50. Mease 119; \& account from in pliys. journ: viii. 89, Monro, Don, sold. i. 211. 245, 
310 ; ii. 91. Mosclcy 222. 459. 489. Parler, account from in chir. rev. iv. 60. Percival, T' ii. 349. 349. Ploucy. lilul. i. 71. 355. 453. 455. 487. 494. 497. 501. 515. 517.610.670. Polidori account from in phys. journ. i. 104. Pringle 131. 283. 295. 314 ; app. p. cviii. Reilly in Trolt. ii. 129. Robcrlson fcv. 373. Rush in philnd. coll. i. 54; \& account from in mcd. comment. dec. II. ix. 136. Rush i. 113. 139. 196. 205. 211 ; if. 71.319; iii. 229. 288. 298. 299. 303; iv. 100 ; v. 142. 152. 180. Sandford, account from in med. rev. iii. 114. Sims, James 47. Smyth jail. dist. 122; \& accou..t from in ann. med. i. 99. Tainsh in phys. journ. v. 539; and chir. rev. viii. 86. Trotler, account from ib. x. 288. Underw. i. 228. 259. 264. 318; ii. 64. 107. 121. Voss, account from in chir. rev. iv. 85. Whately ulccrs 52. 105. 118. Willan lond. 93. 254. Wright in ann. mcd. ii. 357. 362.

Wines. Neum. ii. 247. Wright in med. facts vii. 11.

Tinum album ulyssopenense. Heberd 333.

White Wine. Underw. i. 11. 171.

Vinum austerum. Stoll med. iii. 103.

Vinum austriacum. Quarin. febr. 67. 94. 104. 111. 121. 207. 335. 383; animad. 176. 207.

Vinum canariense. Wintringh. in Mead mon. $\mathrm{i}$. 229.

Canary Wine. Brown, J. ii. 249. ATill. Jos. 456. Constantia Wine. Hawkesì. roy. iv. 414.

Vinum gallicum album. Pharm. suec.

Vinum gallicum rubrum. Pharm. suec.

Claret. Brown ii. 249. Chalm. i. 147. 153. 187; ii, 18. 98. 201. Sims, James 33. 
Vinum hispanicum. Pharm. suec.-Quarin anim. 295.

Vinum hungaricum. Quarin amimad. 157.

Vinum madererum. Aaskow in act. havm. i. 163.

Madeira. Brown, J. ii. 249. Kirkland apopl. 98.

Vinum mantanum. Wintringh, in Mead mon, i. 299.

Mountain Winc. Mrill. Jos. 456.

Sherry. Mill. Jos. 456.

White Port Wine. Mill. Jos. 456.

Vinum rhenanum. Pharm. suec.-Aaskow in act. haun. i. 163. Fordyce, W. fragm. 19. Mead mon. i. 32. Quarin febr. 67.94. 121. 207.348; amimad. 207. Wintringh. in Mead mon. i. 229.

Vinum rubrum. Aaskow in act. haun. i. 163. Quarin anim. 264. 265. 305; febr. 80.

Red Wine. Aitken midw. 136. Underw. iii. 138.

Red Oporto Wine. Chalm. i. 96. 222; ii. 125.

Red Port Wine. Chalm. i. 147. 153. 167. 187; ii. 18. S8. 98. 204. 208. Mill. Jos. 456. Underw. iii. 143 .

Vinum rubrum hungaricum. Quarin 183. 202.

Vinum tokainum. Quarin anim. 295.

Vinum tokaviense. Quurin febr. 399.

Vinous liquors. Brown, J. i. 107. Trotter, account from in edinb. journ. i. 75.

LORA. Spielm. 101.

TARTARUM. Pharm. lond-Hill 799. Lew. ii. A10. Pearson, R. i. 212. 237. Rutty 509.

Tartarus. Alst. ii. 483. Dale 320. Geoffr. ii. 758. Fordyce, G. pract. 207. Herm. 726. Spielm. 103.

Tartarus crudus. Pharm. suec.

Supertartris potassac impurus. Pharm. edin. $-L$ ew. disp. by Dunc. 314. 
Tartarus vini crudus. Carthcus. i. 424.

Tirtar. Clark J. long roy. 427. Fordyce, G. pract. 150 ; fev. ii. 54. Mill. Jos. 458. Monro i, 81.

Supcrtartris potassac. Pharm. cdin.-Lew. disp. by Dunc. 315. Murr. J. i. 359.

Tartari crystalli. Pharm. lond.-Calliscn in act. haun. i. 74.421. Fordyce, W. fragm. 27. 83. Quarin fcbr. 162. 382; animad. 260. Wintringh. in Mcad mon. i. 155. 250. 256.

Crystals of Tartar. Clark J. long roy. 187. 327. Cull. pract.n. 1448. 1685. Monro i. 116. Wright in ann. med. ii. 352 .

Cremor tartari. Aaskiow in act. haun. i. 197. 199. 202. Aitken midw. 121. Bang in act. haun. i. 19. 93. 274. 296; ii. 40. 49. Baylies in med. pap. 44. Callisen in act. hann. i. 416. Clegh. 202. 252. Fordyce, W. fragm. 48. Ploucq. bibl. i. 414. 655. Pringle 213. Quarin febr. 14. 28. 59. 144. 160. 219; animad. 46. 171. 188. 199. 223. 210. 267. Ranoe in act. haun. i. 35. Rogert in act. haun. i. 188. Stoll med. ii. 75. 100 ; iii. 158. 171. 192. 185. 303. 3!5. Underw. ii. 62. Wright in ann. med. ii. 361.

Cream of tartar. Blane 492. Chalm. ii. 90. Cull. pract. n. 1683. Darw. ii. 106. Ferriar i. 52. 87. 91; ii. 116. 162. Fordyce W. fev. 155. 160. II anmick in contrib. 382. Home $T$. clin. 326. Hume, J. in lctt. \& ess. 213. 217, Jackson, Rob. fev. 331. Lempr. ii. 159. Lind hot. clim. 260; scrum. 18. 36. 96. 262. Monto, Don. sold. ii. 186. Moseley 16. 17. 178. 442. 541. Rush i. 112; iii. 245. 302; iv. 89 ; v. 171. Sims, James 25. Undcrw. i. 304; ii. 121. Whitc, C. account from in chir. rco. viii. 59.

Creme of Tartar. Pringle 151. 
Imperiale. Fordyce, W. fev. 135. 167. 219.

KALI. Denm. i. 260. Heberd. 6. 80. 216. Mroodie in phys. journ. xi. 482. Stutz, account from ib. iii. 57. Underw. i. 28. 97. 108. 123. 127. 134. 164. 308. 355; ii. 16. 167 .

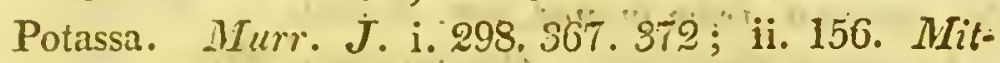
chill, account from in med. rev. i. $\$ 10$.

Lixivium. Home, Rob. in med. journ. iv. 384. Lame in med. facts iii. 127 ; and neẅ med. journ. i. 109.

Alcalià. Ploucq. bibl. i. 128. 4601.

Alkalies. Brickell, account from in phys. journ. xiv. 478. Darw. ii. 753. Grant fev. i. 258. Hàr gens, account from in plyys: journ. iv. 183, and med. rev. ii. 572. Lind hot clim. 248. Mitchill, account from in med. rev. vi. 239. Pajot, account from in phys. journ. iii. 168. Whyle ib. 233.

Kali praeparatum. Pharm. lond.-Heberd. 191. Pearson, R. ii. 216.

Carbonas potassae. Michaelis account from in ann. med. iv. 2i6. Wiedeman ib. 281.

Carbonate of potass. Claubry, account from in phys. journ. iv. 371. Guinot, niccount from ib. iii. 80. 165. 254. 363. Mascagni, account from ib. iv. 467. Mitchill, account from in phys. journ. i. 512.

Carbonate of potash. . Hull phlegm. 219.

Kali aëratum. Pearson, R. i. 234.

Alcali vegetabile. Cartheus. i. 436.

Vegetable Allkali. Blane in trans. improv. ii. 142. Monro i. 125. 148; iv. 231. Slutiz; account from in ann. med. v. 195. 206.

Alcali fixum. Auskow in act. haun. i. 320. Ploucq. bibl. i. 653 .

Fixed Alkali. Darzo. ii. 494. Gaitskicll in med. facts. iv. 66. 
Sal alcalinus. Meberd. 405. Pott ii. 218. Wintringh. in Mead mon. i. 248.

Alkaline salts. Chalm. i. 182. Cull. pract.n. 1206. Fothergill, $\dot{J}$. in med. obs. vi. 111. Hufeland, account from in med. rec. ii. 455.

Lixivium alcalinum. Quarin anim. 291.

Lixivial salts. Denm. i. 265. Monro, Don. sold. 287. Pringle 215. 216.

Alcali fixum vegetabile. Ploucq. bibl. i. 280.

Vegetable Fixed Alkali. Mitchill, account from in phys journ. i. 189 ; \& chir. rev. vi. 190.

Fixed Vegetable Alkali. Memminger, account from in phys. journ. ix. 176. Stuetz, account from in med. rev. v. 405 ; vi. 335.

Sal alkalinus fixus. Lew. ii. 291.

Fixed alkaline salt. Daniel in med. commun. $i_{0}$ 155.

Sal tartari. Bonhomme, account from in Underw. i. 342. Buchhave in act. haun. i. 325. Fordyce, W. fragm. 68. Hoffm. vi. 512. Mursinna, account from in phys. journ. vi. 280. Quarin animad. 172. 176. Stutz, account from in phys. journ. v. 473.557.

Salt of Tartar. Chalm. i. 220. Darw. ii. 45. Evans in phys. journ. iii. 535. Rush ii. 172.

Lixivium tartari. " Fordyce, $\boldsymbol{W}$. fragm. 50.

Oleum tartari per deliquium. Chalm. i. 215. Fordyce $W$. fragm. 93. Quarin febr.241.

Iixivium saponarium. Mead mon. ii. 62.

Caustic Lie. Home, F. clin. 443.

Sal aëratus. Holyolie, account from in phys. journ. i. 295.

FAEX VINI. Rutty 542.

ACETUM. Pharm. lond.-Callisen in act. med. haun. i. 301. Curthens. i, 415. Dale 920. Lew. 
i. 19. Linn. 80. Heberd. 150. 156. Méad mon. i. 37. 119. 266. Mertens obs. 172. Murr. i. 321. Pearson, R. i. 89. Ploucq. bibl. i. 123.451. 505. 515.594.637. Quarin febr. 15. 27. 28. 31. 36. 83. 103. 106. 120. 125. 133. 140. 142. 149. 150. 158. 162. 171. 204. 206. 219. 231. 276. 282. 288. 305. 307. 319. 328. 334. 345. 346. 381. 407. 421. 424.429; animad. 6. 54.131. 199. 227. 262. 265. Ranoe in act. haun. i. 387. Rutty 6. Stoll med. i. 8 ; ii. 41. 199. 326. 330. 332; iii. 26. 187. 183; aph. n. 495. 501. Swiet. iii. 572. Underw. i. 309. Wintringh. in Mead mon. i. 179.'230. 231. 241. 250. Worthington ap. Smell. thes. i. 217.

Acidum acetosum. Pharm. edin.-Fordyce, G. pract. 207. Murr. J. i. 358 ; ii. 51.

Acidun acetosum impurum. Lew. disp. by Dunc. 128.

Acctous acid. Bree 267. 289. 364.

Acetum vini. Pharm. succ-Aaskow in act. haun. i. 161. Bang. ib. i. 95. 106. 113. 114; ii. 52.

Acctum simplex. Spielm. 103.

Vinegar. Baylies in med. pap. 44. Biane 492.60. 302. Blizard, account from in med. rev. i. 391. 329. Brandreth in med. comment. dec. II. vi. 383. Bree 257. 258. 268. 282. 293. 251. Bromfield ii. 67. Chalm. i. 107. 122. 167. 221 ; ii. 90. 107. 114. 209. Clark, J. long roy. S37. Cleghorn, Dav. in red. Sacts ii. 120; and account of in new med. journ. i. 228. 291. Cooke in phys. journ. vii. 256. Cull. clin. 229; pract. n. 373. 921. 1207. 1625. Darz. ii. 59. 72. 73. 219. 230. 235. 245. 259. 457. 500. 682. 710. 721. Denm. ii. 331. Fordyce, $W$. fev. 160. 167. Grieve in Aitken midw. 182. IIalls in med. comment. dec. II. x. 32\%, Harrison, W. in med. soc. iv. 107. u $\mathrm{h} 2$ 
Sackson, Rob. jam. 407. Kok, account from in med. rer. i. 569. Leonissa in new med. journ. i. 113. Lind scam. 17. 18. 37. 96. 249. 259. 360. Med. rov. iii. 426. Mill. Jos. 458. Moises in phys. journ. vii. 337. Monro i. 114. 76. Moseley 23. Ncum. ii. 271. Percival, T. i. 69. 75. 105. Polt i. 27. 437. Pringle 127. 132. 135. 139. 143. 158. 305. 306. 310. Rush i. 125. 130; ii. 73. Schumacher, account from in phys. journ. vii. 81. Smyth jail dist. 179. Trotter, account from in chir. rev. ii. 50. Underw. i. 200; ii. 24. 120. 137. 151. 152. Wright in med. facts vii. 2. Willan lond. 234.284.

BRANDY. Bree 294. 298. Chalm. i. 220.222; ii. 88. 208. Clark, J. long voy. 327. Currie, $W$. account from in med. rev. vi. 63. Darw. ii. 17. 69. Fcriar iii. 90. Hunter, J. blood 412. Jackson, Rol. fev. 261. 290. 310. Lempr. ii. 162. 178. 179. 190. 191. Lettsom in med. soc. i. 163. Lind hot.clim. 313; seam. 17. Maclean 169. Mill. Jos. 458. Monro, Alex. sen. in med. ess. vi. 17. 19. Neum. ii. 258. Pringle 136. 210.283. Rush ii. 288; iii. 291 ; v. 120. 122. 184. Sandford, account from in med. rev. iii. 117. Underw. i. 123; ii. 39. 59. 101. 105. 107. Ware ophth. 51. Wright in med. facts vii. 11.

ALCOHOL dilutum. Pharm. edin.-Lew. disp. by Dunc. 130. Murr. J. i. 110.

Spiritus vinosus tenuior. Pharm. lond. spiritus vini gallicus. Pharm. suec.

Spiritus vini. Bang in act. haun. i. 109. Fordyce, IV. fragm. 24. Hebcrd. 2. 90. 150. 280. 314. -338. 353. Mlead mon. i. 137 ; ii. 90. Murr.i. 319. Pearson, R. i. 105 ; ii. 202. Ploucq. bib?. 
i. 314. 316. 313. 486. 521. Pott i. 27. 457. Ranoe in act. haun. i. 357. Quarin animad. 146. Underw. ii. 107. Ware ophthalm. 51.

Spiritus vinosus. Rutty 492.

Spirit of Wine. Darco. ii. 47. 57. 129. 263. 264. 336. Kentish, E. account from in chir. rev.'iv. 410; and med. rev. v. 231, Neum. ii. 261. Parkinson in med. soc. v. 62; and account of in med. rev. ii. 111. Underw. ii. 24.

ALCOHOL. Pharm. edin.-Darw. ii. 23, 61. 678. 682. 745. Fordyce, G. pract. 207. Hull phlegmat. 295. Lew. disp. by Dunc. 128. Murr. $J$. i. 110. Trotter, account from in phys. journ. xii. 86. Ward $i b$. ix. 40.

Spiritus vinosus rectificatus. Pharm. lond. Spirit. Aitken midw. 191. 206, Brown, J. i. 93. 150. 216. 268. 224. $361.364,286$; ii. 218. Underw. ii. 151.

Vinous Spirit.'Darw. ii. 128. 129. 682. 745.

Ardent Spírit. Aitken midw. 127. Cull. pract. $n$. 490. 576. 580. 1198. Monro ii. 209. Rush v. 143. 181; and account from in chir, rev. xii. part ii. 43.

Fermented Spirit. Brown, J. ii. 273. 362. 363. Spirituous liquors. Sims, James 34.

Spirits. Darw. ii. 274. 347. Fothergill, J. in med. obs. ví. 130. Lettsom in med. soc. i. 157. Monro, Alex. sen. in mẹed. esssị vị. 19. Pringle 210.

Distilled Spirits. Fordyce, G. fev. iii. 257.

* glabra. Leaves glabrous. In gardens. From memory.

V. vinifera. L. sp. 293. Hort. kew. i. '282. Woodv. 531. t. 195. Lour. i. 192. Jacq. vind. 39. In woods near the Danube;-coll. i, 160; ic.

H h 3 
5. . 50, On the banks of the Danube.-Sibth. prodr. $n .561$. In Greece on the banks of ripers.

Uvac. Merian surin. $34 . t ; 47 . t$.

B lanuginosa. Leaves lạnuginoso-villose. Obs. 2580.

V. Labrusca. Scop. carn. n. 272. In hedges about Duina and Gortz.-- Honck. n. 678.

V. folips lobatis sinuatis nudis. Kram. 58. On is: lands in the Danube.

V. sylvestris, Labrusca, Boerh. ii. 232. Garid. 492.

Cirrhi opposite to the leaves. Racemi compound, opposite to the leaves. Nectarium surrounding the base of the germen. Obs. 2580.

$\gamma$ apyrena. Berries without seeds. In a garden.L. sp. 293.

V. corinthiaca, sive apyrena. Bauh.J. ii. 72. No fig.-Garid. 492.

PASSULAE MINORES. Pharm. austriaco-prov. 55.-Alst. ii. 306. Cartheus. i. 431. Herm. 400. Lew. disp, by Dunc.349. Murr. i. 312. Vog. 259. Passulae corinthiacae. Linn. 80.

Passulae. Spielm. 97.

Uvae passac minores. Dale 321. Lew. ii. 479; disp. by Rother. 264. Mill. Jos. 457.

Uvae passae minimae. Geoffr. ii. 317.

4. VITIS quinquefolia. Loaves quinate; folioles 0. vate, serrate. Obs.6058. In a garden.

V. hederacea. L. "Willd. i. 1182. Ehrh.

V. hederacea indica Stap. 364.

Ampelopsis quinquefolia. Michau. i. 160.

Hedera quinquefolia. L. sp. 292 ; mant. 343. Ifork kew. i. 281.

Edera quinquefolia canariensis. Carn. 100 , t. a branch of which cop. in. 


\section{Monogyia. 201. Aegiceras.}

Hedera virginensis quinquefolia. Park. theatr. 679, inner fig. \&

V. seu potius Hedera virginensis. Park. par. 612. t. 609. $f .7$, with the addition of a racemus and separate leaf.

Calyx quinquedentate. Petals caducous, concave at the end. Germen ovate, bilocular, with 2 embryo seeds in each cell. Obs. 6058.

HEDERA. Schoepf 28 .

\section{BOTRIA.}

Calyx quinquecrenate. Pelals 5. Style none. Berry unilocular, monospermous. From Lour.

1. BOTRIA africana. Lour. i. 191.

\section{AEGICERAS.}

Calyx quinquefid. Petals 5. Capsule bowed, unilocular, univalve, monospermous, L. a Willd. Gaertn.

1. AEGICERAS majus. Leaves veined. Capsules cylindric. From L. a Willd. i. 1183. Gaertn. i. 216. t. 46. f. 1. Capsules acute.

Rhizophora corniculata. L. sp. 635.

(Mangium floridum. Rumph. iii. 125. $t .83$, is represented with capsules attenuate and very slightly curved, and with calyces as if minutely imbricate.) MIANGIUM fruticans corniculatum. 'Rumph. iii. 117.7 .77$.

$$
\text { H h } 4
$$


2. AEGICERAS minus. Leaves mostly witlout veins. Capsules attenuate. From L. a Willd. i. 1184, and Rumph.-Gaertn, i. 216.t.46. f. 1.

UMBRACULUM maris. Rumph. iii. 124. $t$. 82.

\section{LAGOECIA.}

Calyx superior, pentaphyllous. Petals with 2 horns. Seed 1. From L. \& Juss.

1. LAGOECIA cuminoides. L. sp. 294. Hort. kew. 1. 283. Sibth. prodr. n. 563.

Lagoecia. L. ups. 52:

Cuminoides vulgare. Boerh. i. 132.

Cuminum sylvestre Dioscoridis. Lob. adv. 330, cop. in ic. i. 743, \&.

Cuminum silvestre primum, valde odoratum, globulosum. Bauh.'J. iii : a. 23, and Lob. ic. repr. in Cuminum sylvestre. Dod. 298, and Ger. by Johns. 1067, \& cop. in Park. theatr. 372. Raii hist. 402, Cam. cpit. 518.

Cuminum sylvestre I. Dalcch. 697, AMMI vetcrum. Linn. 80.

'Cuminum sylvestric. Dale 112.

\section{MUZA.}

Calyx diphyllous; lower phyllum quinquedentate; upper entire. Berry trilocular. Obs. 5362. Obs. 8569, from M. coccinca.

Musa. L. Browne 364 . 
1. MUSA paradisiaca. Spadix nodding. Abortive flowers permancnt. L. sp. 1477. Hort. kew. iii. 421.

Musa fructu cucumerino longiori. Boerh, ii. 171.

Musa. Rumph. v. 125. t.60. Munt. phyt. 2.t.4.

5. Garcin in phil. trans. abr. by Reid and Gray vi. part ii. 235. t. 6. at p. 252. f. 75. n. 1. 2.3; and by Hutt. vii. 422. t. 11. f. 9. 10.11. Berry described and figured as trilocular.-Chus. exot. 299.

Musa caudice viridi, fructu longiore falcato anguloso. Sloane cat. 189 ; hist. ii. 141. Plaintain-tree.Trew. select. 3. $t$. 18. 19. 20.

Musa Serapionis, et Musa fructus. Lob. obs. 639, repr. in ic. ii, 236, and Ger. by Johns. 1515, cop. in

Musa arbor cum fructu. Dalech. 1839, and Bauk. $J$. i. a. 148; and the whole plant cop, in Musa arbor. Park, theatr. 1496. Raii hist. 1374. Musae fructus exactior icon. Ger. by Johns. 1516. cop. in

Musae arboris fructus. Park. theatr. 1496.

Ficus indica Linschottani. Baut. J. i. a. 151.

Muza. Stap. 352.

Bala. Rheede i. 17, t. 12. 13.

Plantine. Ligon 80.t.

Pacoeira. Marcgr. 137, repr. in Pis. ind. 154, with fruit added; \& in

Bacoba. Pis. bras. 75.

Musa, seu Ficus indica. Clus. exot. ed. ii. 283. No fig.

Musa arabum. Bosischen garten. 37. t.

Mauz, seu Musa. Alpin. aegypt. fol, 32. p. 2. $t_{\text {. }}$ 33. 
Stamina inserted into the receptacle, the 5 perfect ones at the base of the longer phyllum, the 6th barren one at the base of the shorter phyllum. Obs. 5362. Specimen gathered in the Gottingen garden. I suspect it will prove to be a variation of $M$. Bihai or some other wild plant, which from having been long cultivated by suckers has lost its power of producing perfect seeds.

MUSA. Dale 273.

Musa paradisiaca. Bryant 202. Clark, James in . med. facts vii. 305. Forst. G. escul. 28. Pearson, R. i. 64. Wright in med. journ. viii. 272.

Banana. Cook in Hawliesw. iv. 344. Graing. 40. 84.

2. MUZA sapientum. Spadix nodding. Abortive flowers deciduous. Spathae oblong, rather obtuse. Fruit clliptic. L. a Willd. iv. 894, from authors; sp. 1477. Hort. kew. iii. 421. Swartz. obs. 382.

Musa simiarum. Rumph.v. 138.t. 61?

Bananiera. Pis. ind. 154.

Bala. Rheede i. $t$. 14.

The Banana tree. Hughes 184. t. 16.

Bonano. Ligon 81. $t$. at p. 82.

Musa caudice maculato, fructu recto rotundo breviore odorato. Sloane cat. 192 ; hist. ii. 147. Trew select. 4. t. 21. 22. 23. Boerh. ii. 171.

BANANA, Dale 273. Raii hist. 1375.

Musa sapientum. Bryant 204. Pearson, R. i. 64. Wright in med. journ. viii. 272.

3. MUZA troglodytarum. Spadix erect. Spathae deciduous. L. sp. 1478; probably from IIUSA uranoscopos. Rumph. v. 137.t. 61. 
4. MUZA Bihai. Spadix erect. Spathae permanent. L. sp. 1477, probably from authors.

Musa spadice erecto, spathis rigidis amplexantibus distiche et alternatin sitis. Browne 364: Corolla as in M. paradisiaca. Stamina 5 , inserted into the lower part of the petal, with the rudiment of a sixth inserted into the nectarium. Stigma acute. Berry trilocular. Seeds solitary.-Hence I conclude the Wild Plantane-tree of Jamaica to be a species of Muza whatever was the plant intended by Linnaeus for Musa Bihai of sp. pl.

Musa humilior foliis minoribus nigricantibus, fructu minimo erecto. Sloane cat. 193.

Heliconia Bihai. H.K. i. 284, may be the plant, but it had not then flowered.-(L. mant. 211, if from the specimen whence the generic description at p. 147 was formed, must be a distinct plant.Swartz. obs. 96 cannot be the plant described by Browne though Browne is cited.)

MIUSA troglodytarum. Wright in med. journ. viii. 272.

\section{ILLECEBRUM.}

Calyx pentaphyllous. Corolla none. Stamina 5, united below, or inserted into the calyx. Style 1 . Capsule with 1 seed, with 5 valves. Obs. 6513. Juss. 88. $L$.

Those specics in which the stamina are inserted into the calyx, as $I$. Paronychia and capitatum, seem to be generically distinct, forming the link of connexion between Mllecebrum and Herniaria.

1. ILLECEBRUM sanguinolentum. Frutescent. Lcaves 
opposite. Spikes compound, compact. L. a Murr. 248.

Achyranthes sanguinolenta. ' $L$. sp. 294.

$V E R B E N A$ rubra. Rumph. vii. 60, t. 27. f. 2. In Java.

2. ILLECEBRUM sessile. Stems creeping, with a tomentose line on opposite sides. Leaves lanceo. late, nearly sessile: Heads oblong, glabrous. $\boldsymbol{L}$. a Murr. 249; sp. 300; mant. 345. H.K. i. 291.

Amaranthus humilis, folǐis oppositis, flosculis ex alis glomeratis. Burm. J. zeyl. 17.t. 4. f. 2.

Coluppa. Rheede $\times$. 21. $t .9$.

Amaranthoides humile maderaspatanum, capitulis candicantibus, folio molli. Pluk. alm. 27; plyyt. $t$. 133. $f$. 1, has some capitula on peduncles.

Calyx compressed; phylla 5, ovate, incumbent. Filaments united below, triangulari-subulate above, the distinct parts rather longer than the united part. Capsule compressed, obcordate, apparently valvular. Style very short. Seed 1, compressed; one of the lobes acute, the sinus uppermost. Obs. 6513. Spe. cimen gathered in the Paris garden.

OLUS SQUILLARUM. Rumph. vi. 37.t.15. f. 1 .

\section{POLIUM.}

Calyx decaphyllous: Corolla none. Capsule superior, unilocular, trivalve, polyspermous. Lour.

Polia. Lour. a name too similar in sound and ora thography to Pohlia and Pollia. 


\section{POLIUM arenarium.}

Achyranthes corymbosa. L. a Murr. 246; sp. 296;

a Willd. i. 1196.

Elichryso affinis herba indica polygonoides ramosior, foliolis caulium nodos ambientibus, coma paleacea, flore albo lituris aureis striato. Pluk. alm. 134; phyt. t. 86. f. 6.

Amaranthus folio tenuissimo incano mollugini aemulante. Boccon. mus. 44. t. 39.

(Paronychia foliis ad genicula confertis acutis, floribus umbellatis. Burm. J. zeyl. 184.t. 65. f.2, accords with the figures of Pluk. and Boccone, but is described as having a single triquetrous seed. The calyx is described as pentaphyllous, the corolla pentapetalous, and the petals as roundish and minute.)

POLIA arenaria. Lour. i. 204.

\section{HERNIARIA.}

Calyx quinquepartite. Corolla none. Stamina inserted into the calyx. Style very short, or none. Stigma 1 or 2. Arillus with 1 seed. Obs. 6518. L.

1. HERNIARIA glabra. Stem herbaceous, microscopically pubescent on one side; hairs decurvate. Obs. 7450. In Mr. Knowiton's garden.-L. $s p$. 317. Bot. arrang. 250. Smith engl. t. 206; brit. 271. Bauh. J. iii. 378. Fl. dan.t.529. Tourn. paris. 96. Vaill. paris. 101.

* glabrifolia. Leaves glabrous. Obs. 7451. Specimen gathered between Ostend and Paris.

Herniaria. Dod. 114, repr. in Ger. by Johns, 569. Raii syn, 160. On the Lizard point Cornwall. 
Leaves oblong, oval, and lanccolato-oblong, lower opposite, upper mostly alternate. Stipulae ovate, ciliate, membranaccous, whitish, 2 at the base of each petiole. Calyy, segments oblong, with 1 or 2 hairs at the end, with a filiform process from each sinus. Germen microscopically tuberculate. Style very short, emarginate. Arillus oval, somewhat longer than the calyx, inflated, whitish, semitransparent. Seed orbicular, rufons, vertical. Obs.6518. Spe. cimen gathered in the Paris garden.

IIERNIARIA glabra. Chom. 247; suppl. 83. Geoffr. iii. 5.58.

Herniaria. Berg. 174. Dale 78." Krock. n. 368. Linn. 83. Mill. Jos. 230. Murr. iv. 331. Spielm. 562. $\operatorname{Vog} .103$.

2. HERNIARIA hirsuta. Stem herbaceous, hirsute; hitirs horizontal. Obs. 7280. In Mr. Knowlton's garden.-L. sp. 317. Bot. arrang. 250. Bauh. J. ii. 379. Dill. ap: R. syn: 161, on the autliority of Buddle's herbarium.-Tourn. paris. 161. Vuill. paris. 101. Huds. 109. Colney-Hatch near Barnet.-Smith brit. 272; engl. t. 1379. Raii hist. 21., in Brabant, Germany, the south of France, and Italy.

Herba 'T'urca, H. multigrana serpilli facie. Lob. "dv. 180, cop. in

H. vulgaris. Park theatr. 447.

Calyj:x quinquefido-quinquepartite; segments oblong, unequal. Stamina 5, inserted into the calyx at the base of the segments, very sliort. Antherae roundish, buffcoloured. Germen superior, ovate, microscopically tuberculate. Style very short. Stignia simple, scurcely broader than the style. Obs. 6516. Specimen gathered in the garden of 
Monogrvia. 207. Achyranthes. 479

Pitcairn.-Calyx, no filiform processes between the segments. Style very short. Stigma simple. Arillus semitransparent, oval. Seed 1. Obs. 6520. Specimen gatthered in the Paris garden.-Root perennial. Slem perennial. Leaves oblongo-lanceolate. Stumina 3. Obs. 7280. -1 have never observed the leaves ovill.

HERNIARIA hirsuta. Chom. 247; suppl. 83. Geoffi: iii. 560.

Herniaria. Spielm. 563.

\section{ACHYRANTHES.}

Calyx pentaphyllous. Corolla quinquepartite, mi- nute. Slamina inserted into the sinuscs of the corolla. Style 1. Capsule with 1 seed. Ols. 6966. 6512. 6511. Juss. 88. L.

1. ACHYRANTHES ellipticifolia. Flowers deflex. Leaves elliptic, hirsutulous. Obs. 6512. Specimen gathered by Broughton in Jamaica?

Achiranthes foliis ovatis, floribus spicatis, appendicibus bisetis. Browne 180?

Spikes terminal. Flowers sulitary. Bracteae 9 , at the base of each flower. Caly.x, phylla 5, ovatolanceolate; ribs indistinct. Corolla quinquepartite, segments oblong, ciliate. Filaments inserted between the segments of the corolla. Style filiform. Stigma simple. Arillus monospermous. Obs. 6512.Legeres rhombeo-clliptic, and elliptic, ncarly glabrous. Calyx, plyylla 5, ovato-lanceolate, just sensibly shorter than those of 6512 , slightly unequal, the inner gradually shorter; ribs indistinct. Obs. 696 T. Specimen gatbered in the Paris garden. 
AURICULA CANIS mas. Rumph. vi. 27.t. 12. f. 1. Spike 1 and 2 feet long.

2. ACHYRANTHES obovatifolia. Flowers deflex. Leaves obovate. Obs. 6966 . In Mr. Shore's garden raised from seeds from the Calculta garden.

A. indica. Mill. Ph. dict. n. 2, who raised it from seeds received from Malabar.-Roth cat al. i. 40.

A. aspera indica. L. sp. 295; mant. 344. Hort. liew. i. 286.

A. aspera. L. a Murr. 246 ; a Willd. i. 1191.

A. caule erecto, foliis obverse ovatis undulatis, floribus reflexis. Mill. Ph. ic. S.t.11. f. 2.

Amaranthus spicatus zeylanicus, foliis obtusis, amarantho siculo Bocconi similis. Burm. J. zeyl. 16.t.5. f. 3 .

Stem villose, branched, erect. Branches patent, straight. Leaves opposite, sometimes in threes, with a slightly prominent angle at the end, pubescent, thin, entire at the margin. Petioles very short. Peduncles villose. Flowers sessile, deciduous. Bracteae 3, one third sliorter than the calyx, membranaceous, rigid, whitish, ending in subulate pinkcoloured spines, the innermost ovato-cuneiform, and remaining attached to the peduncle, the 2 outer ovate, the sides readily parting from the costa which is lengthened out into a spine, attatched to and falling off with the calyx: Caly $x$ always closed; plylla rigid, green, membranaceous and whitish at the margin, the outer rather broader. Corolla ininute, shorter than the breadth of the calyx, campanulate, quinquepartite, fleslicoloured white; very delicate; segments' oblong, ciliate, and pink at the end; ciliae white. Stamina 5, inserted into the sinuses of the corolla. Filaments subulate, half as long again as 
the segments of the corolla, purplish pink. Gcrmen turbinate, grecnish. Style filiform, erect, pink. Stigma roundish. Obs. 6966.

CADELARI. Rheedex. 155. t.78.

3. ACHYRANTHES prostrata: Stems prostrate, fruticose. Spikes oblong. Flowers 2 together, with a fisciculus of hooked bristles: $\quad L$. sp. 296; a Willd. i. 1194:

Cyathula geniculata. Lour. i. 124.

Scheru-cadelari. Rheede x. 157. t. 79 .

(Verbena indica. Bonit. 150, has spikes imbricated upwards.)

AURIS CANINA femina. Ruinph. vi. 26. $t$. 11.

4: ACHYRANTTHES luppácea: Stem fruticosse; diffuse. Lcaves nearly glabrous, ovatc; acute, attenuate at the base. Spike interrupted. The 2 lateral flowers with a componnd fasciculus of uncinate hairs on each side. Obs: 6511. Specimen gathered in Fothergill's garden.-L. a Willd. i. - 1192; sp. 295; a Murr. 246. Hort. kew. i. 286. -Achiranthes caule geniculato crecto, foliis ovatis oppositis, spicis terminatricibus, appendicibus multiset is. Browne 180.

Centaurium ciliare minıs, circeac fuliis firmioribus, spicatis floribus: Pluk. alm. 93; phyt. 1. 82. $f$. 2.

Blitum scandens, fructu lappacco. Burm. J. zeyl. 47. t. 18. f. 1, but stem and pedincle represented as aculcate.

Flowers 3 together. Bracteae ovate, 3 at the base of each fasciculus of flowers. Fusciculi of hooks compound, dichotonous and branched, each com- 
posed of from 2 to 4 fasciculi, with a bractea below the division into branches, somewhat analogous to the involucra of Cynosurus, and to be considered as a rachis in the lichotomy of which is placed a sessile flower. Calyx, phylla 5, slightly woolly on the outside, greenish, with 3 ribs, lanceolate. Stamince united below. Filaments triangulari-subulate, without any segment between each. Style as long as the germen. Stigma capitatc. Obs. 6511.

WELLIA.CODIVELI: Rheede x. I17. t. 59.

5. ACIYRANTHES muricata. Flowers patulous, remote, ovate. Leaves alternatc. Calyces squarrose. Stem fruticose, with patulous branclies. From L. sp. 295; mant. 344; a.Murr. 246. Hort. kew. i. 286.

BLITUM spinosum. Rumph. v. 234. t. 83. $f$. 2.

\section{CELOSIA.}

Caly $x$ pentaphyllous. Corolla semiquinquefid. Stamina terminating the alternate segments of the corolla. Capsule cut-round, with several seeds. Obs. 6507. Juss. 88. L.

1. CELOSIA argentea. Spikes scariose. Leaves lineari-lanccolatc. Stipulac subfalcate. From $\boldsymbol{L}$. a Willd. i. 1197; sp. 296, and Roycns-Hort. Kew. i. 287.

C. foliis lineari-lanceolatis. Royen 419. Tjeria-belutta-adeka-manjen. Rheede x, 7\%. t. 39. Spikes whitish and pale purplish. 
CELOSIA argentea. Lour. i. 203. Lcaves to. unentose underneatll.

2. CELOSIA margaritacea. Spikes scariose. Leaves lanceolate. Obs. 6507. Specimen gathered in the Paris garden.-L. sp. $29 \overline{7}$; mant. 344. Mill. Ph. dict. n. 1. From America.

C. foliis lanceolato-ovatis. $L$. cliff. 45 .

Amarantllus spica albescente habitiore Màrt.rar. 7. $t .7$.

Amaranthus spiontus argenteus americanus. Boerh. ii. 98.

Amaranthus spica longa candidissima, spicae foliis, maderaspatanus. Pluk. alm. 26; phyt. t. 118, f. 2 :

Belutta-adeca-manjen. Rheede x. 75. $t$. 38. Flowers whitish, and pale reddish purple.

Glabrous. Lieaves alternate, with young shoots in the axillae. Stipulae none. Spikes terminal, ovate, shining, whitish. Bracteae 3, at the base of each flower, scariose, one third slorter than the calyx, ovato-Ianceolate. Calyx scariose; phylla lanceolate, with 3 greenish ribs at the base. Stamina monadelphous. Filaments forming a quinquefid cup of an uniform texture, whitish, semitransparent, half as long as the calyx; segnients triangular, sibbulate above, with a short acumen in the middle of each sinus. Antherae oblong. Pistil somewhat shorter than the corolla. Germen ovate. Style filiform. Stigma roundish, depressed. Capsule cut-round, with several seeds. Obs. 6507.

CELOSIA margaritacea. Lour. i. 203. Leaves described as opposite, and the spikes tawny. 
3. CELOSIA cristata. Style simple. Leaves ovate and clliptic. Lateral bracteae with an arista from below the end. Obs. 6553. In a garden. $L$ L. -Mort. kew. i. 287. Mill. Ph. dict.n.2.

AMARANTHUS. Schrod. 531.

Arnarantus. Rumph.v. 236.

C. castrensis. Lour. i. 202.

a simplex. Spilies simple. From

Amaranthus simplici panicula. Bauh. Casp. phytop. 193; pin 121 .

Amaranthus. Malth. 1047. Lob."obs. 126, repr. in

Amaranthis purpureus saturo coccineo. Lob. ic. í. $250, \&$

Amarantlius purpureus. Ger. by Jolins. 329. Dalech. 871. Bauk. J. ii. 968, cop. from, \&

Circaea. Trag. 579, which repr. in

Amarantus purpureus. Cord. fol. 168. p. 1, imit. from Fuchs. fol. ed. 100. Dod. 185, repr. in

Amarantus purpurcus saturo cocci colore. Dod. 607; ed. ii. 618,

Amaranthus angustifolius simplici spicata panniculi. Lob. obs. 126; \&ic. i. 251, cop. in

Amaranthus angustifolius. Dalech. 871, and repr. in

Amaranthus coccincus. Ger. by Johns. 322.

a composila. Spike compound, terete, acuminate. From

Anrarantlus spicatus. Besl. hort, aut. ord. 2. fol. 8. $f .1$.

Amaranthis purpureus inajor. Tab. ic. 433 , repr. in

Amaranthus. Matth. a Casp. Bruh. 737. Cam. epit. 791.

$\gamma$ frstigiata. Spike compound, flatted, fastigiaten Obs. 6553. 
Amarantus vulgaris. Rumph. v. 238. t. 8t, who says he has been led to think that all the species of Amaranthus are only varieties.

Amiranthus cristatus. Besl. hort. aut. ord. 2. fol. S. f 2. Cam. epit. 792, cop. in

Amaranthus pannicula incurva. Mratth. a Casp. Bauh. 737. inner fig.-outer fig.-Bauh. Casp. phytop. 193; pin. 121.

Amaranthus holosericeis sanguincis reticulatis floribus, hilariore aspectu. Lob. obs. 126, repr. ir

Amaranthus holosericeis sanguincis reticulatis floribus. Lob. ic. i. 252, \&

Amaranthus pannicula incurva holosericea. Ger. by Johns. 323, \& cop. in Amaranthus bolosericeus. Dalech. 871, \&. Amaranthus coccineus. Park, parad. 371. t. 372, f. 4 .

Blitum indicum. Tab. ic. 432.

Stem 3 feet long, sulcate, below terete, upwards compressed, with lateral branches. Branches about as long as the leaves, shorter than the stem, terete, striate. Leaves ovate, acute. Racemi spikelike, terminal, rosecoloured, staining paper of a rosecolour, that terminating the stem compound, semicircular, compressed, from 1 to 4 inches broad; those terminating the branches oblong, acuminate, terete, the lower shorter than the peduncles, the uppermost near. Iy sessile. Pedicles very short. Bracteae 3 to each flower, lanceolato-ovate, acute, the lowermost at the base of the pedicle, the 2 lateral ones at the base of the calyx, one third shorter than the calyx; arista one fourth as long as the bracteac. Calyx, phylla lanceolato-oblong, with an acute point, 2 tenths of an inch long, fleshcoloured with a rosecoloured ștreak. 
along the middle. Stamina one fourth shorter than the calyx, whitish, united below into a decendentate cup, the altirnate teeth extenled into subulate filaments. Pollen whitc. Pistil a little longer than the calyx. Capsule polyspermous, Seeds shining, black. Obs, 6553 .

\section{GOMPHRENA.}

Calyx pentaphyllous. Stamina united below. Style bifid. Capsule cut-round, monospermous. Obs. 5135. Juss. 88. $L$.

1. GOMPHRENA giobosa. Heads solitary, with 2

- leaves. Leaves entire at the margin, lanceolate and oblong. Obs. 5135. Fron a garden. $-\boldsymbol{L}$. sp. 326; mant. 348. Hort. kew. i. 318.

Amarantho affinis indiae orientalis, floribus glomeratis, ocymoilis folio, Commelin. hort. i. 85, $t$. 45. Breyn. Jac. cent. 109. t. 51.

Wadapu. Rherde x. 73. t. 37.

bractene 3 to each flower, scariose, the lowermost ovate, acnte, shorter than the calyx; the 2 lateral ones lanceolate, carinate, twice as long as the calyx. Caly $x$ very woolly on the outside, rigid, closing on the seed; phylla lanceolate. Stamina united below into a tube; tube quinqueficl, investing the pistil; segrients bifid. Iilaments 5, very short, from the fissures of the segnents. Obs, 5135. FLOS GLOBOSUS. Rumph. v. 289. t. 100. f. 2 .

2. GOMPHRENA vermicularis. Stems creeping. Leuves nearly terete, fleshy. Heads solitary, ter- 
minal, oblong. Swartz. obs. 101. L. sp.ed. i. 224.

Illecebrum vermiculatum. L. sp. 300.

G. repens rufesnens, foliis linearibus crassiusculis, capitulis alaribus. Browne 184.

Amaranthoides humile curassavicum, ccpac foliis lucidis, capitulis albis. Herm. parad. 15. t, 15. Pluk. alm. 27; phyt.t.75. f. 9 .

PEREXXIL. Marcgr. 14, repr. in Caaponga I. Pis. ind. 243.

3. GOMPHRENA hispida. Stem erect. Heads with 2 leaves. Leaves crenate. L. sp. 326.

IIIN-ANGANI. Rheede ix. 141. $t .72$.

\section{CERATONIA.}

Calyx quinquefid. Corolla none. Filaments 5 to 7, much longer than the calyx. Germen surrounded by an orbicular gland. Legumen. Obs. 3275. $L$.

Flowers sometimes diecious with imperfect stamina or pistil. Juss.

1. CERATONIA inermis, Unarmed. From

C. Siliqua. L. a Gmel. ii. 431 ; sp, 1513.' Hort. kew. iii. 449.

Siliqua. Cam. epit. 139.

Ceratonia. Dod. 775, cop. in Dalech. 112, and repr. in

Ceratia siliqua, sive Ceratonia. Ger. by Johns. 1429, \& cop. in

Siliqua dulcis vulgatior. Park. theatr. 236.

\section{I i 4}


Siliquac arbor, sive Ceratia. Bauh.J.i. 6.413, the racemus and fruit cop. in

Flores et fructus Siliquac dulcis vulgaris. Park. theatr. 236.

Flowers hermaphrodite. Stamina 7, inserted into the calyx. Obs. 3275. Specinen from Prof. Jos. F. Jacquin.

CERATONIA Siliqua. Bryant 309.

Siliqua dulcis.-Pharm. austriaco-prov. 68.-Berg. 836. Cartheus. ii. 183. Dale 340. Herm. 404. Lew. disp. by Dunc. 340. Limn. 269. Mur. ii. 434. Vog. 263 .

Siliquac dulces. Spielm. 465.

Siliqua edulis. Rutty 485 .

Siliqua. Alst. ii. 317.

Carob. Neum. ii. 223.

\section{RAUVOLFIA.}

Drupe dispermous: Nuts bilocular. Corolla infun. dibuliform. From L. a Schreb. $L$.

1. RAUVOLFIA canescens. Leaves in fours, lanceoIate, pubescent above, tomentoso-villose underneath. Flowers corymbose. Obs. 8683. Specimen gathered by Broughton in Jamaica.-L. $s p$. 303 ; a Willd. i. 1218. J Jacq. amer. 8vo, 61.

R. subpubescens. L. mant. 345.

R. hirsuta. Jacq. amer. 47.

R. tetraphylla latifolia. Plum. a Burm. 232. $t$. 236. $f .2$.

Solani fructu fruticosa, foliis laurinis oblongis integris subtus hirsutis, flore minore purpureo. Sloane cat. 173; hist. ii. 107. t. 188. f. 1, no fructifica= 
Monogyina. 213. Carissa.

tions, leaves in fives; t.211. f. 1. Raii dendr. 75 , leaves opposite.

(Arbor sycophora jamaicensis, foliis minoribus.

Pluk. alm. 42; phyt. t. 213. f. 4, has alternate

leaves; - t. 266. $f .2$, has opposite leaves.)

RAUVOLFIA. Browne 180.

\section{PAEDERIA.}

One of the Contortae. Berry empty, brittle, with \& seeds. $L$.

1. PAEDERIA foetida, Stamina inclosed. L. a Willd. i. 1219 ; mant. 52. Rets. obs. i. 13. n, 23, who describes the flowers as sessile and yet race: mose!

CONVOLVULUS foetidus. Rumph.v. 436. $t$, 160.

\section{CARISSA.}

Calyx inferior, quinquepartite. Corolla infundibuliform; limb quinquepartite. Stigma simple, Berry bilocular; cells with from 2 to 4 seeds. From L. Roxb. \& Forsk.

\section{Spinose. L. a Willd.}

1. CARISSA Carandas. Leaves veined. Segments of the corolla lanceolate. From L. a Willd. i, 1219 ; a Murr. 251; mant. 52. 560; \& Ro.xb. corom. i. 55. t. 77. Lour. i. 153.

Lycium malabaricum, subrotundis pyrolae densioris 
bus foliis. Pluk. alm. 235; phyl. t. 305. f. 4. Corolla quadrifid.

CARANDAS. Garcias ap. Clus. exot.227. No fig. $-R u m p h$. vii. 57.t.25.

2. CARISSA edulis. Leaves veinless. Segments of the corolla lanceolate-linear. From Vahl. symb. i. 22.

ANTURA. Forsk.69; p. xciii.

\section{CERBERA.}

One of the Contortae. Drupe with 1 and 2 nuts. From $L$.

1. CERBERA linearifolia. Leaves lanceolato-linear, crowded. Obs. 8687. Specimen gathered by Broughton in Jamaica.

C. Thevetia. Jacq. amer. 48. t. 34. L. sp. 304. Mill. Ph. dict. n. 2. Swartz. obs. 102. Hort. kew. i. 293.

Thevetia. L. cliff. $76 \propto$

Plumeria arborescens, foliis lanceolatis, floribus fauce ampliatis subcampanulatis. Browne 181.

Nerio affinis angustifolia lactescens, flore lutco, americana. Pluk. alm. 263; (misprinted 253,) phyt. t. 207. $f .3$.

Ahovai nerii folio, flore luteo. Plum. a Burm. 10.

$t$. 18, the parts of fructification cop. in

Ahouai. Tourn. inst. t. 434.

CERBERA Thevetia. Jacq. amer. 8vo, 62.

2. CERBERA Manghas. Leaves Janceolate, with 
transverse ribs. L. sp. 303. Osb. trav. i. 138. Mill. Ph. dict. n. 3.

Arbor lactaria. Rumph. ii. 243. t. 81.

Odit lam. Rheede i. 71. . 39, a branch cop. in

Tavaracare mal barica, flore alho, folio nerii latiore. Pct. gaz. 24. t. 16. f. 4 .

Manga fructu venenato, ossiculo cordiformi nucleo gemino. Raii hist. 1552.

(Manghas lactescens, foliis nerii crassis venosis, jasmini flore, fructu persicae simili. venenato. Burm. J. zeyl. 150. t.70. f. 1, has a campanulate upright calyx four times shorter than the tube of the corolla.

Mangas Acostae. Dalech. 1870, has simple racemi.)

MANGAS bravas. Acostá ap. Clus, exot. 284.

3. CERBERA Ahovai: Leaves ovate, acute. L. a Willd. i. 1222, from authors;-sp. 303. Mill. Ph. dict. n. 1. Donn 51.

Thevetia. L. cliff. 75 .

Arbor america, foliis pomi, fructu triangulo. Bauk. Casp. pin. 434.

Ahovai Theveti. Raii hist. 1676. Clus. in Garc. ap. Clus. exot. 232, which repr. in

Ahouay Theveti. Lob. obs. 604; ic. ii. 186, and Ger. by Johns. 1545, and cop. in Tab. ic. 922, Dalech. 1844, \&

Ahovai, fructus venenatus. Bauh. J. i. a. 337, lower fig. the empty drupes.-Upper fig. a branch cop. from

A hovai. Dalech. 1843, in fruit.

$A H O A Y-G U A C U$. Pis, ind. 308, inner fig. cop. from Clus, - outer fig. in fruit;-bras. 49. No fig. 
4. CERBERA salutaris. Leaves oval. From Lour. i. 168.

LACTARIA salubris. Rumph. ii. 255. t. 84 .

\section{CANTHIUM.}

Germen inferior. Calyy quinquefid and quadrifid. Corolla infundibuliform, quinquefid and quadrifid. Stamina 5 and 4 , shorter than the corolla. Stigma capitate. Berry with 2 cells. Sceds solitary. From Lamarck in Juss. Roxb. \& Webera. L. a Schreb. 794.

Chomelia. L. gen. ed. ii. n. 167.

1. CANTHIUM corymbosum. - Without spines. Lcaves oblong, acute. Corymbus terminal. Willd. Webera corymbosa. L. a Willd. i. 1224.

Rondeletia asiatica. L. sp. 244.

Frutex indicus baccifcr, floribus umbellatis, fructu rotundo polyspermo. Ruii hist. 1494, from

CUPI. Rheede ii. 37.t. 23, is described as having berries containing 7 and 8 seeds,

2. CANTHIUM parriflorum. Spinose. Leaves ovate. From Roxb. corom. i. 39. t.51. Lamarck. Webera tetrandra. L. a Willd. i. 1224.

Lycium putatum indiae orientalis, capparis rotundioribus foliis, et aculeis adverso gemellis. Pluk. alm. 234; phyt. t. 97. f. 4. No fructifications.

Baccifera indica, flosculis ad foliorum extortum confertis, fructu dicocco. Raii hist. 1497; from TJEROU-KARA. Rheede v. 73. t. 37. Segments of the calyx and corolla, and stamina 5 . 


\section{GENIPA.}

Germen inferior. Calyx entire. Corolla infundibuliform. Antherae sessile, inserted into the tube of the corolla. Style clavate. Berry bilocular, polyspermous. From Tourn. Plum. and Juss. . L.

1. GENIPA americana. L. sp. 251.

Genipa. Plum. a Burm. 127.t. 136, the parts of fructification cop. in Tourn. inst. t. 436.

Gardenia Genipa. Swartz. obs. 84; prodr. 51. JANIPABA. Pis. bras. 38, repr. in ind. 138, and Marcgr. 92 ; and the descr. cop. in Raii hist. 1667.

\section{GARDENIA.}

Germen inferior. Calyx with 5 divisions. Corolla infundibuliform and hypocrateriform, with from 5 to 9 segments. Antherae sessile, inserted into the tube of the corolla. Style clavate. Berry dry, with 1, 2, or 4 cells, polyspermous. From L. fil. suppl. 23. 468, \& Juss. 201. L.-Hort. kะซึ. i. 293.

\section{Unarmed. L. a Murr.}

1. GARDENIA grandiflora. Corolla hypocrateriform. Leaves lanceolate. Segments of the calyx vertical, falcate, teflex. Berries oblong. From Lour. i. $18 \%$. 
2. GARDENIA forida. Corolla hypocrateriform. Leaves elliptic. Sigments of the calyx vertical, straight. Berries ovate. Ols, 7791. In Renishaw gardel1.-L. sp. 305. 1679; mant. 346; fil. suppl. 163. IIort kew. i. 293.

GARDENIA florida. Lour. i. 183.

* simplex. Corolla single. IIort. kezw, i. 293.

B plenu. Corolla double.-Hort. kew. i. 293.

Jasminum foliis lanceolatis oppositis integerrimis, calycibus acutioribus. Mill. Ph. ic. t. 180.

Jasminum ramo unifloro pleno, petalis coriaccis.

Ehret. t. 15, and another unpublished fig. in $\mathrm{Mr}$.

Knowlton's library.

Catsjopiyi. Rumph.vii. 26, t. 14. f. 2.

Leaves opposite, dark green obscurely mottled with pale green. Stipulae solitary, intrafoliaceous, vaginant, the lower half becoming a part of the bark. Flowers terminal, solitary, nearly sessile. Germen obpyramidal, green, with 6 prominent acute, angles. Calyx superior, cyathiform, sexpartite; segments subulate, compressed below, being extensions of the angles of the germen, trigonous at the end, patulous, somewhat longer than the germen; sinuses with 1 and 2 scariose triangular tcetl. Corolla buffcoloured white, very double, of a peculiar rich fragrance. Obs. 7791 .

3. GARDENIA appendiculata. Leaves elliptic. Co. rolla hypocrateriform. Calyx bursting on one side, with appendages. Front

G. Thunbergia. L. fil. suppl. 162, is liort. kicu. i. 294.

LA BERGKIAS. Somer, noun guin. 48. \&., 17. 18. 
2. Spinose. L. a Murr.

4. GARDENIA esculenta. Berry unilocular. Corolla rotate. Lcaves fasciculate, ovate, pilose. Flowers crowded. From

GENIPA esculenta. Lour. i. 185.

\section{ALLAMANDA.}

One of the Contortae. Capsule lentilshaped, unilo. cular, bivalve, erect, echinate, polyspermous. $\boldsymbol{L}$.

1. ALLAMANDA cathartica. L. mant. 214; fil. suppl. 165. Curt. mag. t. 338. Hort. kew. iii. 489.

ALLAMINDA. Linn. 81.

\section{VINCA.}

Corolla hypocrateriform; segments oblique. Follicles 2, erect. Sceds naked. Obs. 2705. L.

1. VINCA parviflora. Flowers pedunculate, in pairs. Leaves lanceolate. From Retz, obs. ii. 14. Hort. kew. i. 296.

V. pusilla. L. fil. suppl. 166.

CUPA-VEELA. Rheede ix. 61. t. 35.

2. VINCA ellipticifolia. Flowers on peduncles, solitary. Leaves glabrous, elliptic and oval. Obs. 2705. In a garden.

Y. minor. L.-Bot. arrang. 248, Found by Mr. Woodward near Hampstead and in Earshram wood. -Jacq. rind. 31. In mountains behind Grin- 
zirig.-Curt. lond. iii. 16. t. 172. Mlost. 125. In barren mountainous situations.-Walc. t. Asso 2. 213. Lighlf. 147, found by Parsons in Coryton woods. - Willd. berol. 84 , apparently spontancous.-Smilh bril. 270. On a bank near Itoningliam cluurch Norfolk, and in several lanes in that parish.-Rell. n. 171. Roth. germ. i. 95. Throughout Germany.-Siblh. prodr. n. 569.

Pervinca vulgaris angustifolia. Tourn. paris. 218: Garid. 358.

Pervinca vulgaris angustifulia, flore cacruleo. Vaill. paris. 159. In the forest of Montmorency and in the roods of the Capuchins de Meudon.-Boerh. i. 311 .

Clematis daphnoides. IJod. 401, repr. in Lob: obs. 360 ; ic. i. 635 , cop. in

V. pervinca vulgaris.' Parti. thecitr. 381, \&

Clematis daphnoides minor flore caerulco. Bauth. $J$. ii. 130, who observed it in the Euganean mountains, in Lombàdy, Switzcrland, and Burgundy; \& repr. in

V. Pervinca minor. Ger. by Johns. 891, who does not speak of it as growing wild.-Raii syn. 268. In hedges and on ditch banks but rare.

Clematis daphnoides, sive $V$. pervinca simplez minor. Park. parad. $3991, t .395 . \dot{f} .2$. In many woods and oichards by the hedge sides.

Y. Pervinoa, sive Clematis daphnoides. Lob. advo 282. In Germany, France, and Italy. Native of Greece, Italy, Spain, France, SwitzerIand, and Germany, and if of Britain of the more, southern counties. It is in general the outcast of gardens. 'Those who are acquainted with Coryton woods may best judge whether it is a native of Scota land. 
V̈INCA Pervinca. Berg. 170. Dale 179. Krock. n. 365، Linn. 81. Mill. Jos. 451. Murr. i. 540. Quctin animad. 84. Rutty 536. Spielm. 396. Vog. 140.

Pervinaa vulgaris: Geoffr. suite i. 365.

Pervinca vulgaris augustifolia: Chom. 568; suppl. 161.

3. VINCA ovatifolia. Flowers on peduncles, solitary. Leayes ciliate; ovate. Obs. 5729. Specimens gathered in the hedge of a cottage garden.

V. major. L. sp: 304. Bot. arrang. 249. Smith brit. 270; engl. t. 514. Relh. n. 172. Sibth.ox. 79. Magdalen College walks.-Curt. lond.'iv. 19. t. 222. Wale.t. Gouan hort. 119. About Montpelier.-Host 125. In Friuli in hedges.

Pervinca major. Scop. earn. n. 274. Lob. adv. 282. Near Narbonme in Languedoc.

Pervinca vulgaris, latifolia, flore caeruleo: Vaill. paris. 159. Boerh: i. 311. Garid. t. 81, at p. 386.

Clematis daphnoides major: Raii syn. 268, found by Plot between Wolverton and Yarnton; by Richardson near Colchester; and by James Sherard between Knowlton and Deal, and in a lane between Foots Gray and Roe hill; hist. 1091; exrop. 103. $\Lambda$ bout Montpelier.-Dod. 401 , repr. in

Clematis, sive Pervinca major. Lob. obs. 360 ; ic. i. 630 ;

Clematis daphnoides $y_{3}$ sive Pervinca major. Ger. by Johns. 891, \& cop. in

Clematis daphnoides latifolia, seu $\mathrm{V}$ : pervinca major. Park. theatr. 381.

Ciematis daphurides major flore cierulco. Bauh..T. k $k$ 
ii. 132. In many parts of Spain, and the south of France.

Native of Spain, Friuli, and the south of France, and said to have been found in Kent, Essex, and the isle of $\mathrm{W}$ ight.

PERVINCA latifolia. Geoffr. suite i. 368.

Pervinca vulgaris latifolia. Chom. 568.

Vinca. Dale 179.

\section{刃20. NERIUM.}

Corolla infundibuliform, with a double limb; inner - limb quinquepartite. Follicles 2, erect. Seeds plumose. Obs. 5913. L.

1. NERIUM Oleander. Leaves in threes. Phylla of the calyx squarrose. Segments of the inner limb of the corolla flat, trifid, Obs. 5913. In' a garden.-L. sp. 305. Hort. kew. i. 296. Mill. J. ill. i. $t .12$.

Leaves lanccolate. Obs. 5913.

a roseum. Corolla rosecoloured. Obs. 5914. Specimen gathered in the garden of Fothergill. $-H$. $K$. $\alpha$

N. floribus rubescentibus. Boerh. ii. 316.

N. sive Oleander. Raii hist. 1767. Ger. ly Johns. 1406 , repr. from

Rhododendrum. Dod. 839, which repr. in

Nerion. Kob. obs. 199, \&

Oleander, Laurus roséa. Lob. ic. ¿. 36t, and cop. in N. sive Rhododendron flore rubro. Bauh. J. ii. $140, \mathcal{E}$

Oleander flore rubro. Park. theatr. 1469. Raii curop. 189. On the side of mount Aetna. 
Monogynia. 220. Nerium.

\section{NERIUN. Dale 339.}

Nerion. Geoffr. suite i. 160.

Nerion floribus rubescentibus. Chom. 136.

2. NERIUM odorum. Leaves in threes. Phylla erect. Segments of the inner limb of the corolla multipartite; lacinulae filiform. $\boldsymbol{H} . \boldsymbol{K}$. i. 297.

OLEANDER sinicus. Rumph. vii. 15.t. 9. $f$. 1.

3. NERIUM coronarium. Leaves elliptic. Peduncles at the dichotomies of the branches, in pairs, biflorous. Hort. kew. i. 297. Jacq. coll. i. 138; ic. i. 5. t. 52.

Nandi-Ervatam minor. Rheede ii. 105. t. 55.

a plena. Corolla double. From

Nandi-Ervatam major. Rhecde ii. 105. $t .54$.

Jasminum zeylanicum folio oblongo, flore albo pleno odoratissimo. Burm. J. zeyl. 129. t. 59.

FLOS MANILIANUS. Rumph. iv. 87. t. 39,

4. NERIUM antidysentericum. Leaves oblongo-ovate. Panicles terminal. Hort. kew. i. 297. L. sp. 306; mant. 346. Lour. i. 142.

Nerium indicum, siliquis angustis erectis longis geminis. Burm. J. zeyl. 167. t. 77.

Codaga-pala. Raii hist. 1754, from Rheede i. 85, (where for 48 rear 47, ) $t .47$.

CODAGA PALA. Geoffr. ii. 208. Vog. 293.

Conessi. Lew̌. i. 361. Linn. 82, Monro iii. 77.

Frofluvii sive Conessi cortex. Murr. i. 541.

Conessi bark: Med. ess. iii. 30.

Tellicherry bark, Lind hot clim. 311. MIurra i. 552. 


\section{ECHITES.}

One of the Contartae. Follicles 2, long, straight. Seeds pappose. Corolla infundibuliform; throat barc. $L$.

1. LCHITES syphilitica. Leaves ovate, nearly sessile, slabrous, costate. Panicles dichotomous. Flowers in spikes. L. fil. suppl. 167.

2. ECHITES scholaris, Leaves mostly verticillate, oblong. Follicles filiform, very long. Umbels compound. L. mant. 53.

LIGNUM SCHOLARE. Rumph. ii. 246. $t_{\text {。 }}$ 82.

3. ECHITES umbellata. Peduncles umbellate. Leaves ovate, obtuse, mucronate. Stem twining. L. sp. 307. Hort. kew, i. 298. Jucq. amer. 30. t. 22, segments of the corolla represented as incumbent.

A pocynuin scandens majus, folio subrotundo. Sloane cat. 89 ; hist. i. 207. t. 131. f. 2, described and figured as having' a peduncle with a great many flowers.

Apocynum scandens foliis cordatis, flore albo. Catesh. i. t. 58.

Periploca alia, floribus amplis circinatis et crispis, radice bryoniae tuberosa. Plum. a Burm. t. 216. f. 2.

ECHITES. Browne 182,

4. ECHITES costata. Peduncles cymose. Leaves elliptico-lanceolate, acuminate. Forst. G. austral, 2. 123

KAMETTI-VALLI. Rheede ix.23. t. 14 . 


\section{PLUMERIA.}

Corolla infundibuliform; segments oblique. Follicles ventricose. Sceds with a nuembranaceous border. $-L$.

1. PLUMERIA'revolutifolia. Ieaves lanceolate, revolute at the margin. Pedicles bracteate. Obs. 8336," Specimen gathered by Dr. Wright in Jamaica.

P. alba, Jacq. amer: 36. $t, 174 . f .12$, a flower and follicle;-8vo, 46. L. sp. 306; a Murr. 254. Hort, kew, i. 299. Mill. Ph. dict. n. 3.

P. flore niveo, foliis longis angustis et acuminatis. Plum. cat. 20; a Burm. 227. t. 231.

(Apocynum americanum frutescens, longissimo folio, flore albo odoratissimo. Commel. hort. ii. 47. $t$. 24, with leaves not revolute, is rather P. obtusa, which is probably, as $J$. Burman conjectures, a white variety of $P$. rubra.)

Leaf lanceolato-nblong, petiolate. Peduncle longer than the leaf. Panicle terminal, compact, bracteate; primary branches very short; flowers aggregate; pedicles 6 times as long as the bracteae. Bracteae quadrato-ovate, shortly acuminatc. Caly $x$ superior, pentaphyllous, as long as the bracteae, twice as long as the germen, quadrato-ovate, carinate. Corolla twice and a half as long as the pedicles; tube slightly ventricose a little above the base, pubescent on the inside above the ventricose part; limb twice as long as the tube; segments oblongo-obovate, oblique. Stamina erect, inserted a little above the base of the tube, thrice as short as the tube of the corolla. Filaments very short. Antherae subulate, thrice as 
502 Pentandria. 223. Tabernaemontana.

long as the filaments. Pistil very short. Obs. 8336.

PLUMERIA alba. Linn. 82. Schoepf 29.

2. PLUMERIA rubra. Leaves ovali-clliptic. Pe. tioles with 2 glands. Obs, 8335. Specimen gathered by Dr. Wright in Jamaica.-L. sp. 306. Hort. kew. i. 298. Curt. mag. t. 279.

P. arborescens, ramulis crassis, foliis oblongo-ovatis, petiolis biglandulis, floribus geminatis per spicas terminales. Browne 181.

P. flore roseo odoratissimo. Catesb. ii. i. 92. Boerh. i. 315. Ehret t. 11. Trew. select. 11.t.41. Jasminum indicum. Merien surin 8. $t$. The tree Jessamin. Hughes 189. t. 17. Quauhtlepatli. Hernand. 67.

(Nerio affinis barbadensis arbor latifolia, flore purpureo jasmini odore. Pluk. plyyt. t. 207. f. 2, is a different plant as he himself suspected.)

NERIUM arboreum, folio maximo obiusiore, flore incarnato. Sloane cat. 154; hist. ii. 61. t. 185. 186. f. 1 .

\section{TABERNAEMONTANA.}

Follicles 2, horizontal. Seeds immersed in a pulp. Corolla contorted, infundibuliform. From $L$. and Obs. 7806.

1. TABERNAEMONTANA alternifolia. Leaves al ternate. Stem arborescent. L. sp. 308; mant. 346.

CURUTU-PALA. Raii hist. 175t, from Rheedc i. 83. t. 46, (misengraved 47.) 
Digynia. 225. Apocynum. 503

2. TABERNAEMONTANA bovina. Leaves opposite, lanceolate. Peduncles solitary, multiflorous. From Lour.

Capsicum silvestre. Rumph. iv. 133. t. 67.

TABERNAEMONTANA bovina. Lour. i. 145.

3. TABERNAEMONTANA bufalina. Leaves oppo. site, lanceolate. Peduncles in pairs, unillorous. From Lour. i. 145.

IND OF VOL. 1.

Birmingham, Printed by J. Belcher and Sor. 
$\therefore$

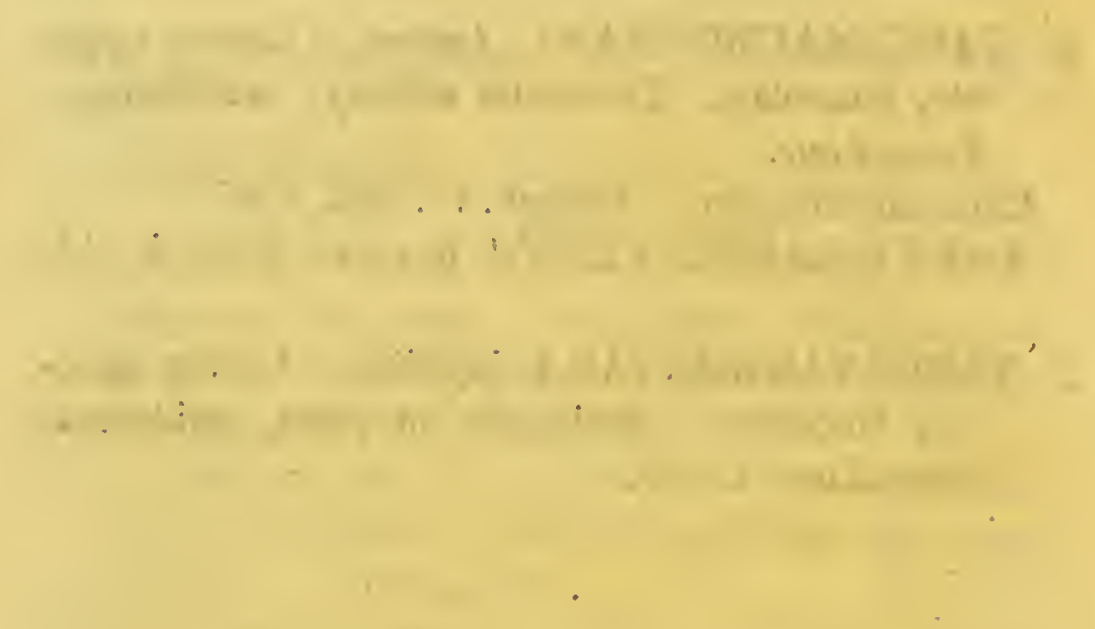

a 






$$
\text { . }
$$




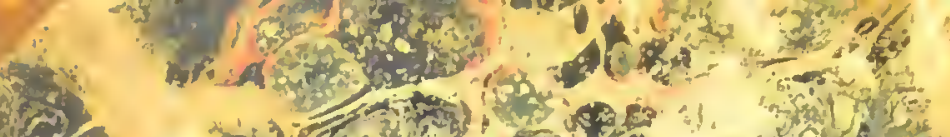

Wre

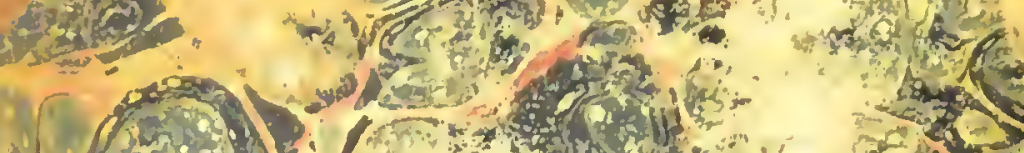
- (1)

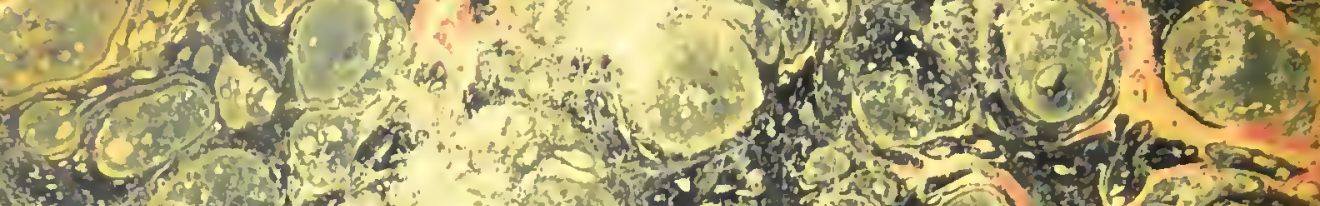

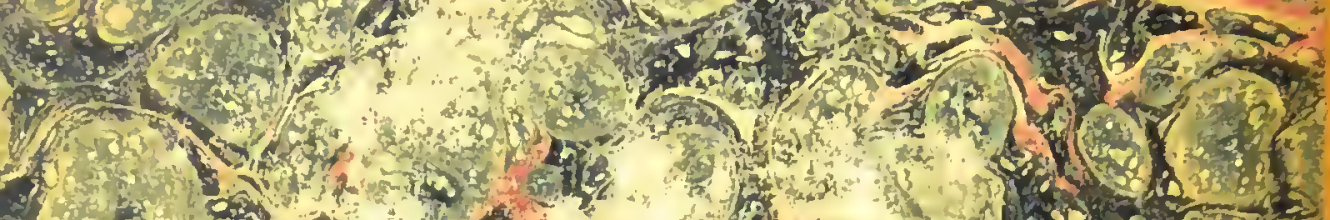

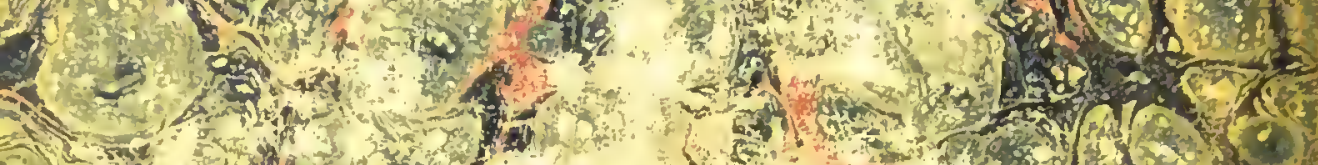

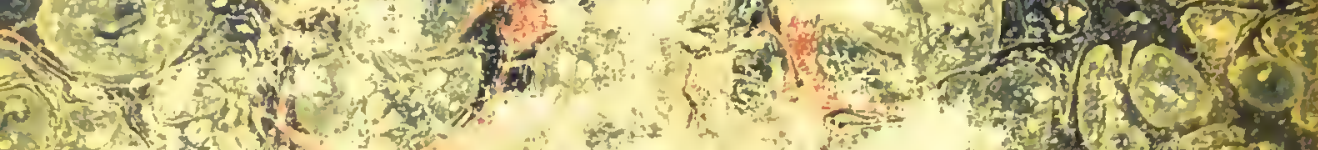

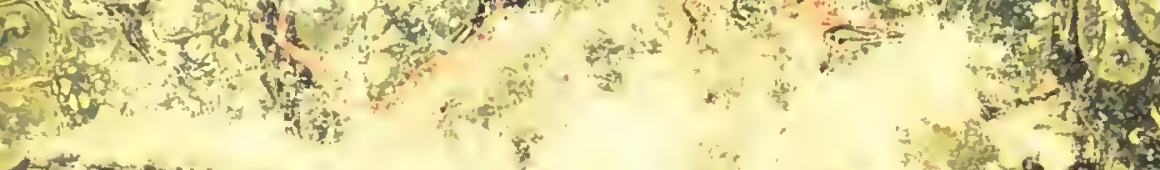

and

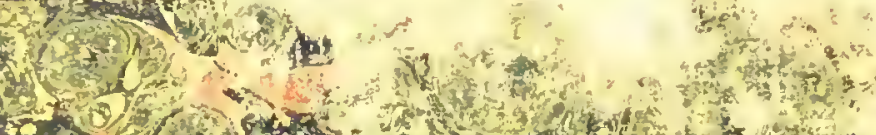

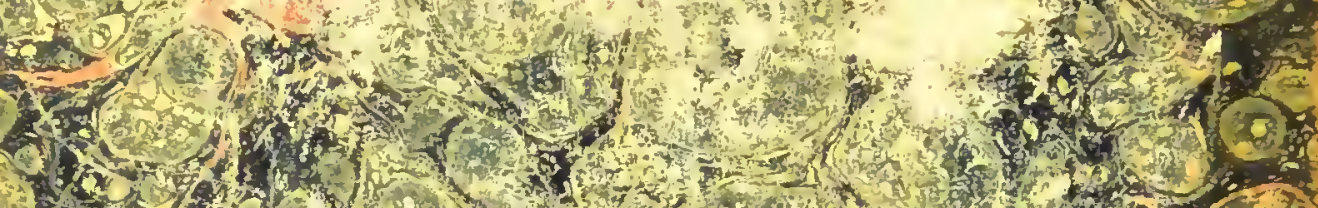

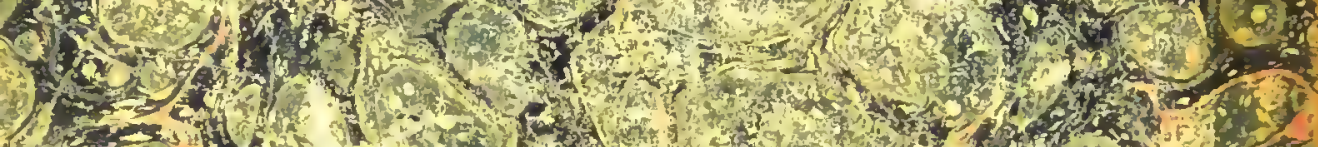

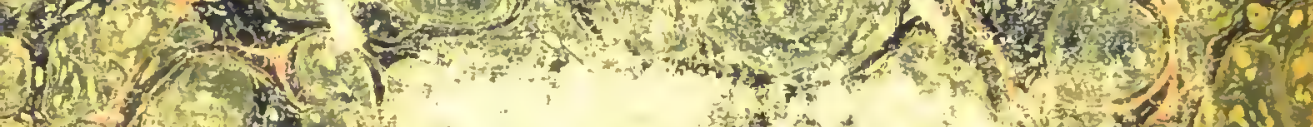

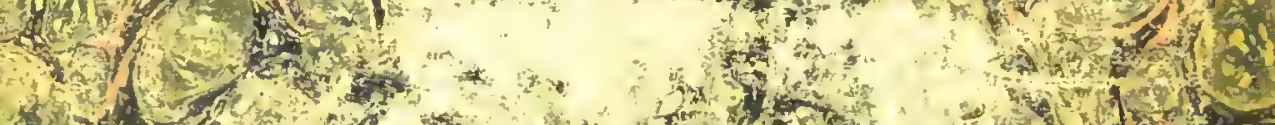

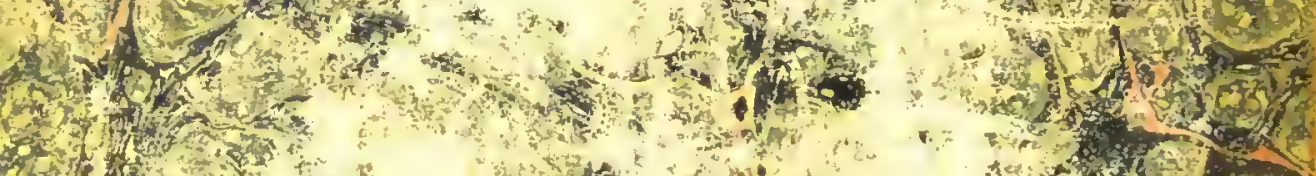
2.

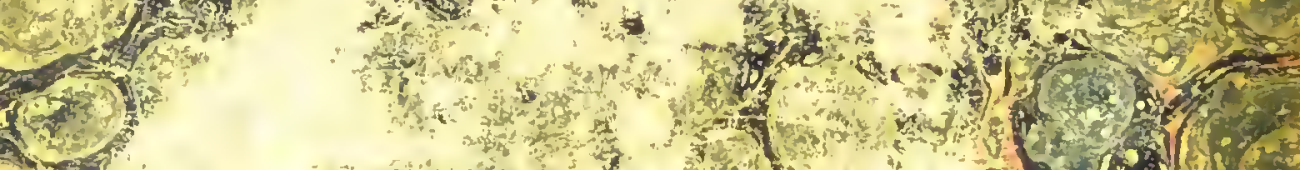
L. - n a

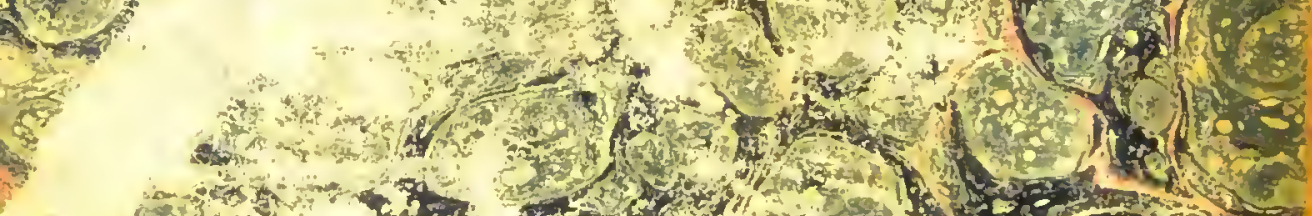

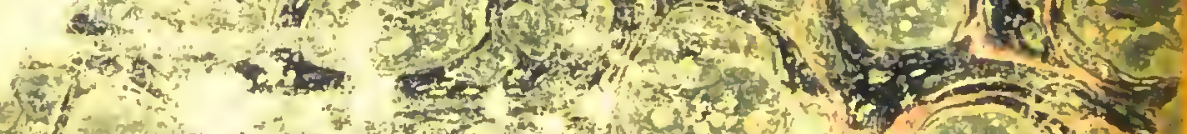

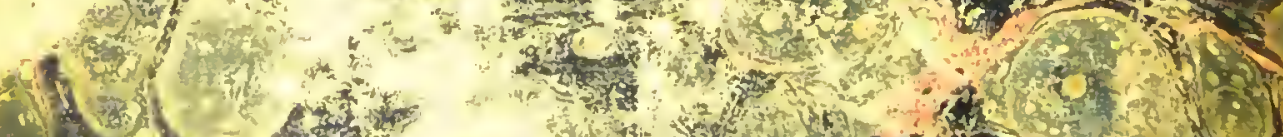

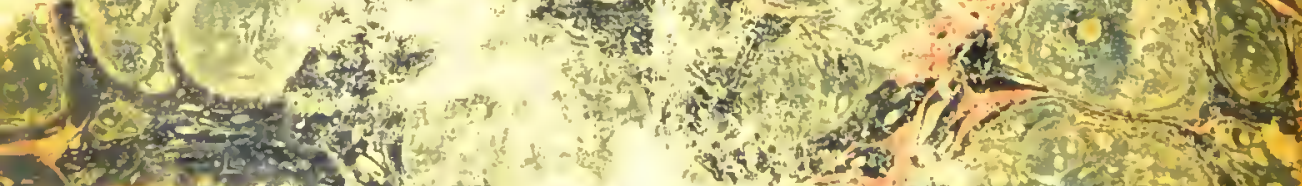

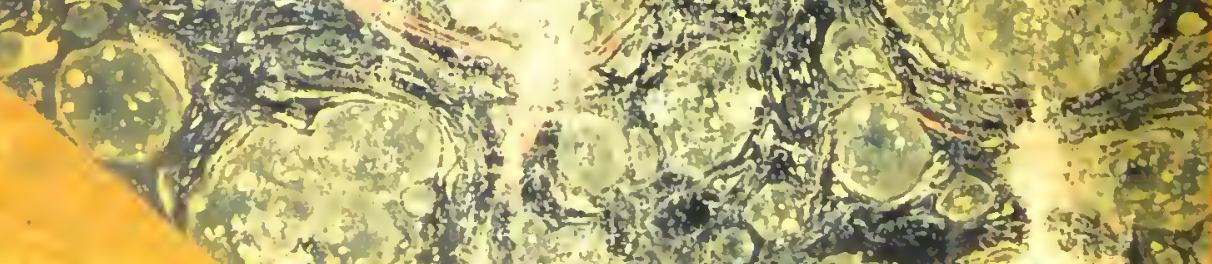

